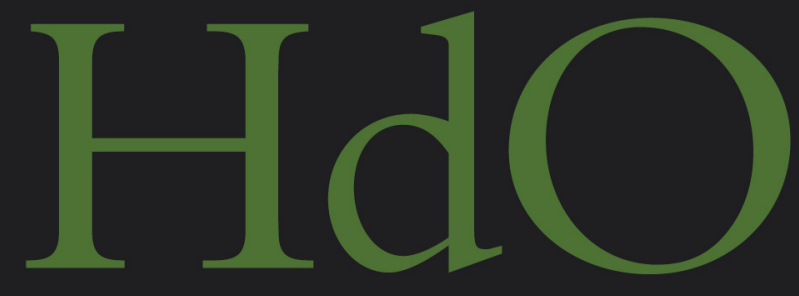

\title{
A Grammar of the Bedouin Dialects of Central and Southern Sinai
}

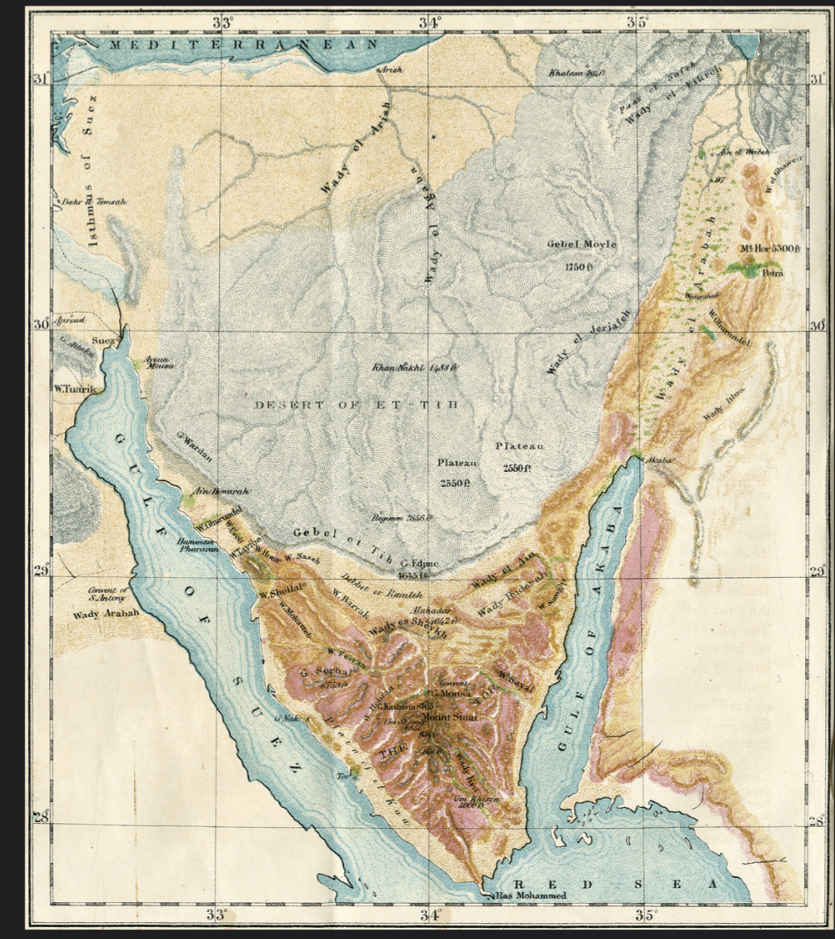

\section{by \\ Rudolf E. de Jong}




\section{A Grammar of the Bedouin Dialects of Central and Southern Sinai}




\section{Handbook of Oriental Studies Handbuch der Orientalistik}

Section 1, The Near and Middle East

Edited by

M. Şükrü-Hanioğlu

C.H.M. Versteegh

VOLUME 101 


\title{
A Grammar of the Bedouin Dialects of Central and Southern Sinai
}

\author{
By \\ Rudolf E. de Jong
}

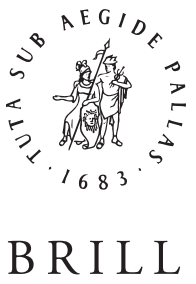

LEIDEN • BOSTON 
On the cover: Peninsula of Sinai. From: Stanley, Arthur Penrhyn. 1856. Sinai and Palestine in Connection with their History. London: John Murray of Albemarle Street. Reproduced by courtesy of the Leiden University Library.

This book is printed on acid-free paper.

Library of Congress Cataloging-in-Publication Data

Jong, Rudolf Erik de

A grammar of the Bedouin dialects of central and southern Sinai / by Rudolf E. de Jong.

p. cm. - (Handbuch der Orientalistik. Erste Abteilung, der Nahe und Mittlere

Osten, $0169-9423 ; 101$ Bd. = Handbook of Oriental studies. The Near and Middle East)

Includes bibliographical references and index.

ISBN 978-90-04-20101-9 (alk. paper)

1. Arabic language-Dialects-Egypt-Sinai. 2. Bedouins-Egypt-Sinai-Languages.

3. Arabic language-Social aspects-Egypt-Sinai. I. Title. II. Series.

PJ6799.S56J65 2011

492.7'709531- dc22

2011006129

ISSN 0169-9423

ISBN 9789004201019

Copyright 2011 by Koninklijke Brill NV, Leiden, The Netherlands.

Koninklijke Brill NV incorporates the imprints Brill, Hotei Publishing,

IDC Publishers, Martinus Nijhoff Publishers and VSP.

All rights reserved. No part of this publication may be reproduced, translated, stored in a retrieval system, or transmitted in any form or by any means, electronic, mechanical, photocopying, recording or otherwise, without prior written permission from the publisher.

Authorization to photocopy items for internal or personal use is granted by Koninklijke Brill NV provided that the appropriate fees are paid directly to The Copyright Clearance Center, 222 Rosewood Drive, Suite 910, Danvers, MA 01923, USA.

Fees are subject to change. 


\section{CONTENTS}

List of Illustrations ...................................................................................

Abbreviations and Symbols $\quad$.................................................................. $\quad \mathrm{xv}$

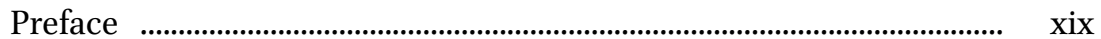

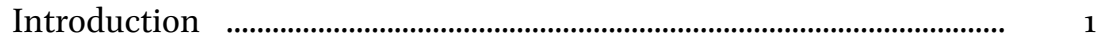

I. General ......................................................................................... 1

a. Central and Southern Sinai in Recent History $\ldots . . . . . . . . . . . . . . . . . . . \quad 1$

b. Cultural Background ................................................................... 2

c. Present-day Distribution of Bedouin Tribes in Central and Southern Sinai and Surrounding Regions $\quad$...................... $\quad 2$

d. Remarks on the Arrival of Bedouin Tribes in Central and Southern Sinai and some Remarks on their History $\quad$.... 3

e. Professional Activities of Bedouin in Central and Southern Sinai Today .................................................................. 8

f. Research Questions and Purpose of this Study .................... 9

II. Fieldwork Methodology ………………......................................... 10

a. Infrastructural Arrangements ................................................... 10

b. Selecting Targets for Field Research ......................................... $\quad 12$

c. Selecting Informants ................................................................... 13

d. Gathering Linguistic Material .................................................. 17

e. Difficulties during Field Research ............................................ 17

III. Presentation of the Data ................................................................. 18

a. Presentation of the Data and Selecting Criteria for Comparison ............................................................................... 18

b. Method of Description ................................................................ 19

Chapter One: A Description of the Dialects of the Ğbāliyyah, Awlād Sa'̄ì, Șawālḥah, Garāršah and Hamādah with Remarks on the Dialects of the Hanādwah and 'Lēgāt ..................................... 21

Introduction ….....................................................................................

1. Phonology ................................................................................................... 23

1.1. Consonants ...................................................................................... 23

1.2. Vowels .................................................................................... 27

2. Stress and Phonotactics …………….................................................... 39

2.1. Stress $\quad$............................................................................................... 39 
2.2. Phonotactics …...................................................................... 46

2.3. Anaptyxis ................................................................................ 48

2.4. Elision of Short Vowels ......................................................... 54

2.5. Assimilation ................................................................................ 55

3. Morphology …........................................................................................ 56

3.1. Nominal Morphology ............................................................. $\quad 5^{6}$

3.2. Verbal Morphology ................................................................... 79

4. Remarks on Phraseology .................................................................. 101

4.1. Nunation .............................................................................. 101

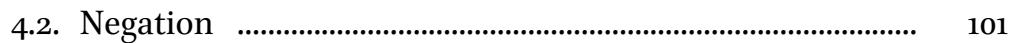

4.3. The $b$-imperfect ...................................................................... 102

4.4. Future Marker ............................................................................. 102

4.5. fih "there is / are" ..................................................................... 103

4.6. Some Conjunctions .................................................................... 103

4.7. Auxiliaries and Verbal Particles ............................................ 106

4.8. Presentative Particles .................................................................. 108

4.9. gayr ................................................................................................. $\quad 110$

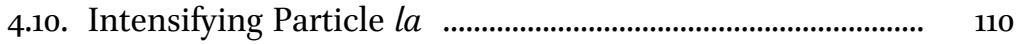

4.11. bidd or widd + pron. suffix .................................................... 110

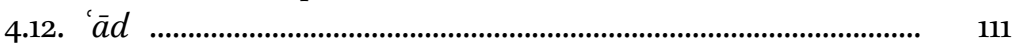

4.13. yabga ............................................................................................... 111

4.14. Characteristics of the Narrative Style …................................ 112

4.15. Pluralis paucitatis ....................................................................... 113

4.16. Concord .................................................................................. 113

5. A Sketchy Remark on Pitch ........................................................ 114

Chapter Two: A Description of the Dialects of the Mzēnah and

Baniy Wāṣil ................................................................................................. $\quad 115$

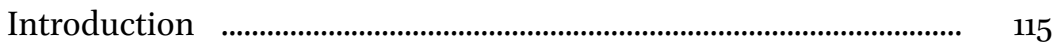

1. Phonology ....................................................................................... 116

1.1. Consonants _............................................................................ $\quad 116$

1.2. Vowels ................................................................................... 120

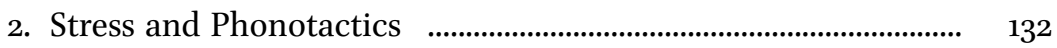

2.1. Stress ............................................................................................ 132

2.2. Phonotactics ........................................................................ 136

2.3. Anaptyxis ........................................................................................ 139

2.4. Elision of Short Vowels ............................................................ 144

2.5. Assimilation ......................................................................... 146

3. Morphology .............................................................................. $\quad 148$

3.1. Nominal Morphology .............................................................. 148

3.2. Verbal Morphology .............................................................. 162 
4. Remarks on Phraseology …………………………………………….. 182

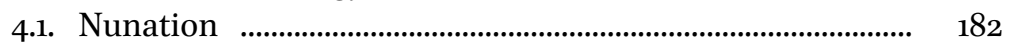

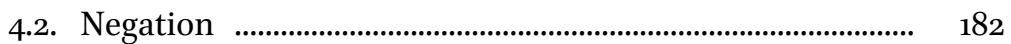

4.3. The $b$-imperfect $\quad$...................................................................... $\quad 183$

4.4. Future Marker ………………………………………………..... 183

4.5. fih "there is / are" ................................................................ 184

4.6. Some Conjunctions ...……………………………………….... 184

4.7. Auxiliaries and Verbal Particles $\quad$............................................ $\quad 187$

4.8. Presentative Particles ................................................................. 189

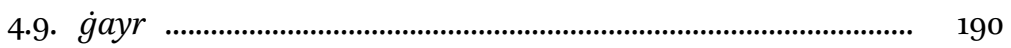

4.10. Intensifying Particle $l a \quad$............................................................ 190

4.11. bidd or widd + pron. suffix ..................................................... 190

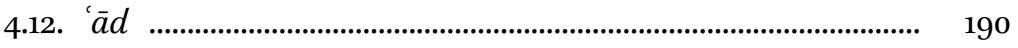

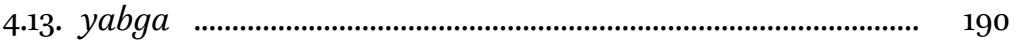

4.14. Characteristics of the Narrative Style $\quad$.................................. 191

4.15. Pluralis paucitatis ……………………………………………….. 192

4.16. Concord ............................................................................ 192

5. A Sketchy Remark on Pitch ...………………………………………. 192

Chapter Three: A Description of the Dialects of the Tarāāinn,

Ḥwẹtāat, Ǧarāğrah, Tayāha, Badārahah, Dbūr and Malālḥah .............. 193

Introduction …………………………………………………………... 193

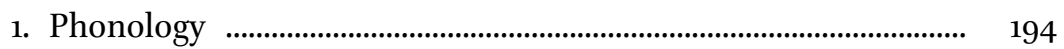

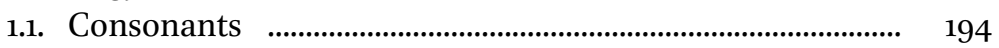

1.2. Vowels ………………………………………………...... 198

2. Stress and Phonotactics $\quad$............................................................... $\quad 215$

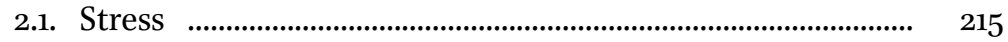

2.2. Phonotactics ……………………………………………….... 220

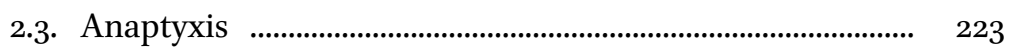

2.4. Elision of Short Vowels $\quad$........................................................ $\quad 226$

2.5. Assimilation ………………………………………………..... 228

3. Morphology ………………………………………………………... 228

3.1. Nominal Morphology ……………………………………….... $\quad 228$

3.2. Verbal Morphology ................................................................ 250

4. Remarks on Phraseology ...……………………………………... 272

4.1. Nunation ……………………………………………………….. 272

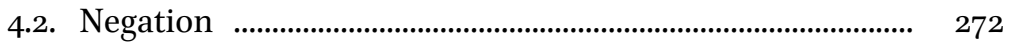

4.3. The $b$-imperfect ……………………………………………... $\quad 272$

4.4. Future Marker ………………………………………………..... 273

4.5. fih "there is / are" .................................................................. 273

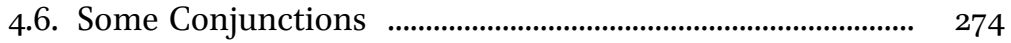


4.7. Auxiliaries and Verbal Particles ............................................ $\quad 277$

4.8. Presentative Particles .............................................................. $\quad 279$

4.9. ġayr ........................................................................................ $\quad 280$

4.10. Intensifying Particle $l a \quad$............................................................. $\quad 281$

4.11. bidd or widd + pron. suffix $\quad$.................................................... $\quad 281$

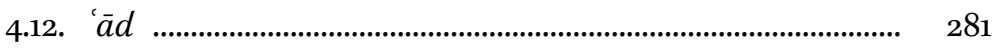

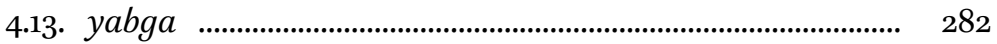

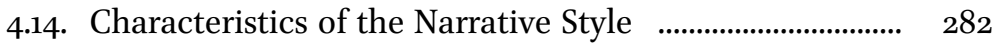

4.15. Pluralis paucitatis ................................................................. $\quad 284$

4.16. Concord ................................................................................... $\quad 284$

5. A Sketchy Remark on Pitch ...................................................... 284

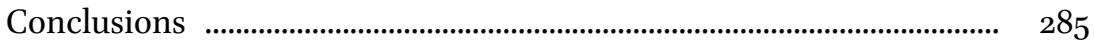

I. Comparing Dialects $\quad$..................................................................... $\quad 285$

a. Methods of Comparing Dialects …………............................ $\quad 285$

II. Remarks to the Maps in the Appendix ....................................... $\quad 287$

a. Criteria for Comparison from De Jong 2000 Producing Differences/Similarities in Central and Southern Sinai ..... $\quad 287$

b. Added Criteria for Comparison of Dialects in Central and Southern Sinai .................................................................. $\quad 298$

III. Isoglosses _.................................................................................... 299

a. The Identified Isoglosses in Central and Southern Sinai ..... 299

b. The Step Method to Calculate Relative Typological Distances between Dialects ..................................................... 309

c. A Continuum: From Group VII Through Group VIII Towards Group I .............................................................................. $\quad 312$

d. Multi-Dimensional Scaling ........................................................ 314

e. 'Bedouinness' vs 'Sedentariness' ............................................... 316

f. The Locations of Isogloss Bundles in Central and Southern Sinai

g. A 'Virtual' Isogloss Bundle, Number -39-: BWA and MzA

IV. Methods of Illustrating Dialect Differences $\quad$................................ 329

a. Some Remarks on Methods of Illustrating Typological Similarities/Differences of Dialects ......................................... 329

b. Multi-Dimensional Scaling in a Two-Dimensional Map $\quad . . \quad 331$

c. Other Results of the MDS Plot ................................................. $\quad 332$

d. Grouping Dialects Using a Dendrogram ................................ 334

e. What Informants Say .................................................................... 337 
V. A Comparison of the Dialect of the Hwêtāat of Southern Jordan and the Hịētāt of Sinai ................................................... 338

VI. Final Conclusions ........................................................................ 352

a. The Position of Sinai Dialects in Northwest Arabian Arabic (the NWA-group) ......................................................... 352

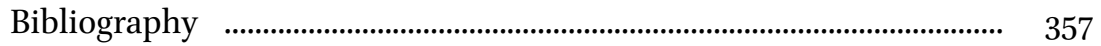

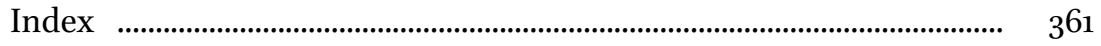

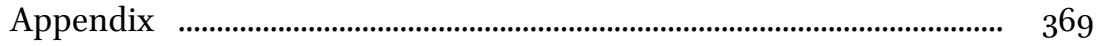





\section{LIST OF ILLUSTRATIONS}

Figure 1. Peninsula of Sinai. From: Stanley, Arthur Penrhyn. 1856. Sinai and Palestine in Connection with their History. London: John Murray of Albemarle Street. Reproduced by courtesy of the Leiden University Library

Figure 2. Approximate distribution of Bedouin tribes in Sinai and surrounding regions

Figure 3. Proxscal-Euclidian Binary MDS plot of dialects of Sinai

Figure 4. Proxscal-Squared Euclidian Binary MDS plot of dialects of Sinai

Figure 5. Alscal-Euclidian Binary MDS plot of dialects of Sinai

Figure 6. Dendrogram of dialects of Sinai

Figure 7. Binary Euclidean distances in a proximity matrix ........... $\quad 376$

Figure 8a. Dialect groups as clusters in similar shades of colours

Figure 8 b. Dialect groups as clusters in similar shades of colours

Figure 8c. Dialect groups as clusters in similar shades of colours

Map o. Isogloss bundles in central and southern Sinai 380

Map 1. $/ \mathrm{k} /$ and $/ \mathrm{k} /$ as separate phonemes in the phoneme inventory

Map 4. Velarization in kbār and ktāar 382

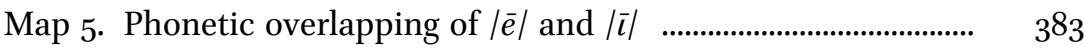

Map 7. Raising of $a$ in open syllable preceding $A \quad$.............................. $\quad 384$

Map 8. Raising of fem. morpheme $T$................................................. $\quad 385$

Map 9. Reflexes of $-\bar{a}($ ') in neutral environment ............................... 386

Map 10. Reflexes of final *-a( $\left.{ }^{\prime}\right) \quad$............................................................. $\quad 387$

Map 11. Diphthongs *ay and * $a w \quad$....................................................... 388

Map 14. Stress in $C \nu C \nu C$.................................................................... 389

Map 15. Stress in $\mathrm{CaCaCv}$................................................................. 390

Map 18. Stress in alCaCac .................................................................... 391

Map 20. Reflex of pattern ${ }^{*} \mathrm{CICaC}$........................................................ 392

Map 21. Raising of $a$ in $\mathrm{CaC} \iota \mathrm{C}(a h) \quad$......................................................... 393 
Map 22. Raising of $a$ in $\operatorname{CaCC} \bar{a} C(a h) \quad$................................................... 394

Map 23. Raising of $a$ in $\mathrm{CaC} \overline{\mathrm{u}} \mathrm{C}(\mathrm{ah}) \quad$.................................................. 395

Map 25. Article and relative pronoun ……………………………….... 396

Map 26. "mother" and "sister" .................................................................. 397

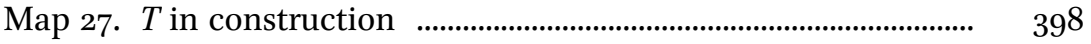

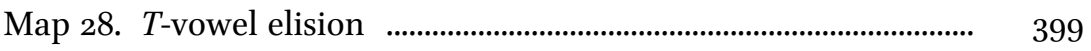

Map 29. Analytical genitive (genitive exponent) …………………... 400

Map 31. The independent personal pronominals of the 3 rd

p. sg. masc. and fem. ......................................................................... 401

Map 34. 3rd p. sg. masc. pron. suffix $\quad$ …………………………………... 402

Map 35. 3rd p. sg. fem. pron. suffix …………………………………... 403

Map 36. 2nd p. sg. masc. pron. suffix …………………………………... 404

Map 37. 2nd p. sg. fem. pron. suffix ..................................................... $\quad 405$

Map 39. sg. masc. demonstrative ……………………………………..... 406

Map 40. sg. fem. demonstrative .......................................................... 407

Map 42. Interrogative "who?" ................................................................. 408

Map 45. Shape of the adverb "there" ............................................... 409

Map 46. Shape of the adverb "here" ................................................... 410

Map 47. The preposition "to" + 3rd p. sg. masc. pron. ...................... 411

Map 48. The preposition "with" + 3rd p. sg. masc. suffix $\ldots . . . . . . . . . . . . . \quad 412$

Map 49. Numeral "one (fem.)" ............................................................ 413

Map 50. 3rd p. pl. masc. perfect ending ……………………………... 414

Map 52. Verb perfect $\mathrm{CaCiC} \quad$................................................................... 415

Map 54. 3rd p. pl. masc. imperf. ending …………………………….... $\quad 416$

Map 55. 3rd p. pl. fem. imperf. ending ……………………………...... 417

Map 57. Perfect of primae hamzah verbs …………………………... 418

Map 58. Imperfect vowel primae hamzah verbs …………………... $\quad 419$

Map 6o. Perfect forms of the verb "come" .......................................... 420

Map 61. 3rd p. sg. masc. and ist p. sg. com. imperfect of "come"

Map 62. Stress in anCaCaC / aCtaCaC (measures $n-1 / 1-t$ ) ............ 422

Map 68. Negation (predominantly) ………………………………….. $\quad 423$

Map 71. Occurrence of yōm, lōm for conjunction "when" ............... 424

Map 72. Marker of consequent action (unconjugated) gām .......... $\quad 425$

Map 73. Use of widd or bidd, "want, need" ....................................... $\quad 426$

Map 75. Raising of $a$ preceding $C C \bar{e} \quad$.................................................... $\quad 427$

Map 76. Raising of $a$ preceding $C \bar{e} \quad$....................................................... $\quad 428$

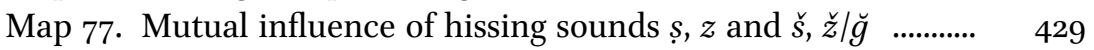

Map 78. The pl. masc. personal pronominal "they" .......................... 430 
Map 79. Negated personal pronominals

Map 8o. 2nd p. pl. masc. pronominal suffix

Map 81. Pl. com. demonstrative "these" ................................................ 433

Map 82. Interrogative "when?" ................................................................ 434

Map 83. Suffixed preposition "on him" .............................................. 435

Map 84. 2nd p. sg. masc. imperfect of mediae geminatae .............. $\quad 436$

Map 85. Sg. masc. imperative of mediae geminatae verbs ............. 437

Map 86. 3 rd p. sg. masc. perfect of tertiae $y \vec{a}^{\prime}$ verbs $\quad$......................... $\quad 438$

Map 87. The apocopated 2nd p. sg. masc. of tertiae infirmae imperfect

Map 88. Dialect groups in Sinai

For remarks on the absence of MAPS 2, 3, 6, 12, 13, 16, 17, 19, 24, 30, 32, 33, $38,41,43,44,51,53,56,59,63,64,65,66,67,69,70$ and 74 see Conclusions II. a. Criteria for comparison from De Jong 2000 producing differences/ similarities in central and southern Sinai (p. 287). 



\section{ABBREVIATIONS AND SYMBOLS}

\begin{tabular}{ll} 
B-form & Bedouinized form \\
com. & communis \\
cf. & confer \\
coll. & collective noun \\
constr. & construction \\
dem. & demonstrative \\
dim. & diminutive \\
fem. & feminine \\
gen. & genitive \\
ibid. & ibidem \\
imper. & imperative \\
imperf. & imperfect \\
I.P.A. & International Phonetic Alphabet \\
intrans. & intransitive \\
K-form & Koine form \\
lit. & (translated) literally \\
masc. & masculine \\
MDS & Multi-Dimensional Scaling \\
nom. & nominal \\
n.u. & nomen unitatis \\
obj. & object \\
p. & person \\
perf. & perfect \\
pl. & plural \\
pos. & possessive \\
pron. & pronominal \\
rel. & relative \\
sg. & singular \\
SPSS & Statistical Package for the Social Sciences \\
subj. & subject \\
suff. & suffix \\
trans. & transitive \\
\hline
\end{tabular}
A
stressed $a$ or $\bar{a}$
I
short high vowel $i$ or $u$ 
I $\quad$ stressed short or long high vowel (stressed $i, u, \bar{\imath}$ or $\bar{u}$ )

$\mathrm{T}$ feminine morpheme (t $\vec{a}$ marbüțah)

v any short vowel

$\mathrm{V} \quad$ any short or long vowel

$\overline{\mathrm{v}} \quad$ any long vowel

C any consonant; a following subscript number $(1,2,3$ or 4$)$ refers to the numbering of the radical in the root.

$\mathrm{X} \quad$ any back fricative $\left(x, \dot{g}, h,{ }^{\prime}, h\right)$

M any velarized consonant (primary or secondary emphatics)

[] phonetic representation between the square brackets

// phonemic representation between the slashes

|| representation of underlying base form

* precedes historical forms or phonemes, intermediate forms in illustrations of rule ordering, or follows a form with a remark given below

- $\quad$ precedes a form not heard in the dialect discussed and the form is deemed unlikely to occur in that dialect

$+\quad$ followed by...

$\emptyset \quad$ zero

$>\quad$ develops into (synchronically) or developed into (historically)

$<\quad$ develops from (synchronically) or developed from (historically)

$\neq \quad$ does not equal

$=\quad$ equals, is identical with

$\approx \quad$ is almost identical with

... any combination of $V \mathrm{~s}$ (vowels) and/or $C \mathrm{~s}$ (consonants) within word boundaries

co-occurs with

I co-occurs not in free variation with

\# speech pause

The list below shows abbreviations used for tribal varieties of Arabic (the asterisk "*' following the abbreviation indicates that the dialect has been described or partially treated in De Jong 2000). The tribes/non-tribal dialect communities are listed here more or less from north (-east) to west and then south (see map in Appendix 'Approximate distribution of Bedouin tribes in Sinai and surrounding regions'). Roman numbers indicate to which typological group the dialects have been concluded to belong. In brackets the names of the tribes follow in a classicized transcription: 
dialect

DA

$\mathrm{RA}^{*}$

$\mathrm{SA}^{*}$

MlA

'AA*

nTA*

$\mathrm{BaA}^{*}$

$\mathrm{DA}^{*}$

BA*

$\mathrm{AxA}^{*}$

$\mathrm{SaA}^{*}$

'AgA*

$\mathrm{MA}^{*}$

'AyA"

eŠA* near

HwA

HwJ

AḥA

TyA

DbA

TAS

ĞrA

TAN group

I

the dialect of the Dulläm (of the Negev Desert, not in Sinai), as described in Blanc 1970 (Zullām)

I Rmèliy, the dialect of the Rmèlāt (Rumaylāt)

I Swērkiy, the dialect of the Sawārkah (Sawārika)

I Mallāhiy, the dialect of the Malälhah (Malālina)

$\mathrm{V}$ 'Arāyšìy, the dialect of al'Arīš (not a tribe, but a town)

I Northern Turbanniy, the dialect of the northern Tarābin (Tarābinn)

I Balawiy, the dialect of Baliy (or Biliy) (Balī)

IV Dwégriy, the dialect of the Dawāgrah (Dawāgira)

III Bayya ạdiy, the dialect of the Bayyādiryyah (Bayyādīìa)

III Axrasiy, the dialect of the Axārsah ('Axārisa)

II Smêt niy, the dialect of the Samänah (Samã ina)

II 'Gèliy, the dialect of the 'Agāylah ('Aqāyila)

I Mas'üdiy, the dialect of the Masá'id (Masāi $\bar{\imath} d$ )

I 'Ayyādiy, the dialect of the 'Ayāydah ('Ayāyida)

III eastern Šarqāwiy, the dialect of the eastern Šarqiyya (a region in the eastern Nile Delta, not a tribe)

I Hwètiy, the dialect of the Hwèțāt (Huwaytạt)

I Hwètiy, the dialect of the Hwèțāt (Huwaytạt) in Jordan

I Ahaywiy, the dialect of the Ahaywāt ('Uhaywāt)

I Tìhiy, the dialect of the Tayāha (Tayāhā)

I Dibriy, the dialect of the Dbür (Dubūr)

I Turbāniy of Sadr, the dialect of the Tarābin of Rạs Sadr (Tarābin of Ra's Sudr)

I Ğarāğriy, the dialect of the Ğarāğrah (Ğarāğira)

I Turbāniy of $N w \bar{e} b i i^{i}$, the dialect of the Tarāain of Nwēbi (Tarābin of Nuwaybí) 
xviii

$\mathrm{BdA}$

'LA

HmA

SwA

GrA

ĞbA

ASA

$\mathrm{HnA}$

ȚwA

MzA

BWA

I Badriy, the dialect of the Badārah (Badāra or Badārā $)^{1}$

VIII 'Lègiy, the dialect of the 'Lēgāt ('Ulayqāt)

VII Hmèdiy, the dialect of the Hamādah (Hamāda)

VII Șälhizy, the dialect of the Șawālhah (Șawāliḥa)

VII Garrāšiy, the dialect of the Garāršah (Qarāriša)

VII Ğbāliy, the dialect of the Ğbäliyyah (Ǧibālīya)

VII Sa'idiy, the dialect of the Awlād Sa'id ('Awlād Sa $\left.{ }^{c} \bar{\imath} d\right)$

VII Hindiy, the dialect of the Hanādwah (a nonBedouin family in Wādiy aț-Ṭūr) (Hanādiwa)

VII Tuwara Arabic: in collective reference to the dialects of the Ğbaliyyah, Awlād Sa'ìd, Sawālhah, Garāršah and Hamādah (Tawara)

VI Mzèniy, the dialect of the Mzènah (Muzayna)

VI Wāṣliy, the dialect of the Baniy Wāșil (Banū Wāṣil)

\footnotetext{
${ }^{1}$ See remark ${ }^{*}$ in Introduction I.d.
} 


\section{PREFACE}

For too long our knowledge of the dialects of the central and southern Sinai had remained scanty, and many questions about the linguistic characteristics of these dialects remained unanswered, or at best guessed after. After completing A Grammar of Bedouin Dialects of the Northern Sinai Littoral (published in 200o) a logical next step was therefore to research the dialects of Bedouin tribes in the central and southern parts of Sinai as well.

In 2002 I submitted a research proposal to the Netherlands Organisation for Scientific Research (in Dutch Nederlandse Organisatie voor Wetenschappelijk Onderzoek, abbreviated as N.W.O.) to undertake such investigations. In the following year N.W.O. graciously made funds available for the execution of this linguistic research under their post-doctoral programme named VENI. The research proposal was submitted under the title 'The Bedouin Dialects of the Bedouin Tribes of Central and Southern Sinai; Testing and Adapting Models of Quantitative Comparison'.

The Amsterdam Center for Language and Communication (abbreviated as A.C.L.C.) at the University of Amsterdam acted as host for my research and provided institutional support. Manfred Woidich again allowed me to profit from his extraordinary expertise in the field of Arabic linguistics and dialectology, as well as to be inspired by his thoughts on a variety of topics. I owe N.W.O., A.C.L.C. and Manfred Woidich my gratitude.

To gather linguistic data I spent 8 periods of between 4 and 7 weeks in the area. I usually rented an apartment in Dahab for my stay. For always taking care of my local needs such as a reasonably priced apartment, for answering any questions local authorities might have about my activities, and for being a good friend, I wish to thank here 'Aliy Mḥammad al-'Āyiš, who is the owner and general manager of Mirage Village in Dahab and who is himself a member of the Biyyādiyyah in the north of Sinai. ${ }^{1}$ In the course of time, apart from being a superb host for his guests, which comes naturally to him, he has proven himself a true friend on numerous occasions.

The person without whom my research and interpreting the results would have been impossible — and much less entertaining in any case — and

\footnotetext{
1 The dialect of the Biyyāḍiyyah was described in De Jong 20oo:chapter III.
} 
to whom I am at least equally grateful, is 'Īd Silīm 'Īd 'Awdih al-Ațraš, known by many as 'I d at-Turbāniy. ${ }^{2} \mathrm{He}$ is a member of the Tarāāin of Raàs Ṣadr (where he was born and raised) and he has travelled the desert since he was seven years old, when as a young boy he would accompany his father on trips to nearly every corner of the Sinai peninsula and into Jordan. His experience in desert travel made him eminently suitable to act as a guide and he could at the same time introduce me to members of the different tribes (he knows virtually every wadi and almost everyone living there). His gentle nature and sense of humor make him an ideal travelling companion, and these qualities combined with his loyalty have made him a good friend for life. Not only did he travel with me, he also made recordings for me in my absence, and sat with me-for weeks on end - behind my desk to make sure I could write it all out, word by word. He would also explain to me many details of Bedouin life in Sinai often not available in books.

For his invaluable help in producing illustrations by means of various computer programs of the SPSS, processing of the data collected during the research for this study, and for his assistence in the interpretation of the outcomes of various calculated plotted maps, I owe my gratitude to Geer Hoppenbrouwers of Hogeschool Zuyd in the Netherlands (in the province of Limburg). In our at times very frequent e-mail contact, but also during our face-to-face meetings, he brought statistics to life, and showed me that it is far removed from the dullness that I had previously associated with this discipline.

Finally, my gratitude is due to all the people who have contributed to this research as informants. Telling stories or speaking about daily activities as subjects for my recordings, or answering questionnaires may not be everyone's favorite pastime, but my interviewees never gave me the feeling that I was overburdening them. I attribute this willingness to cooperate to the generosity of my 'victims' and at the same time often detected a sense of pride among them, that a westerner would come all the way from his homeland with the sole purpose of studying their speech.

Any shortcomings still remaining in this study are of course my own.

Amsterdam, 26 September 2010

${ }^{2}$ 'İd is of the Gṣār clan, for a tribal genealogy of the Tarāāinn see Bailey 1991:290. 


\section{INTRODUCTION}

\section{General}

\section{a. Central and Southern Sinai in Recent History}

Over the past twenty years the development of the tourist industry in the area has acquired such speed, that, as an arabist with a special interest in the dialects of Bedouin tribes, I could no longer sit idly by and watch these dialects slowly disappear. In less than two decades Šarm aš-Šēx and its surrounding areas on the southern tip of the peninsula has developed from a sleepy village of fishermen with only a few hotels from the times of Israeli occupation and catering for a few thousand visitors a year into a major attraction for literally hundreds and thousands of tourists from around the world, who go there for the favourable climate, ${ }^{1}$ water sports and for some of the world's most spectacular dive sites. This development started from Na'āmah Bay, which lies some 5 kilometres more or less to the east of the village Šarm. After this bay had been filled with hotels, more hotels and tourist villages were constructed between $\mathrm{Na}^{c}$ āmah Bay and Šarm, on the plateau between the village and the lighthouse, and farther east from the bay into the direction of the airport. Today there are more than 150 hotels and resorts in the area and more are under construction.

With the development of the tourist industry, thousands of mainland Egyptians flocked into the area to work in the newly built facilities, easily outnumbering the original inhabitants, most of whom are of the Mzēnah tribe. The Bedouin themselves usually work in jobs like driving taxis, guiding tourists on desert safaris, etc.

The numbers of members of Bedouin tribes in Sinai are not certain. Since, to the best of my knowledge, official numbers of Bedouin inhabitants do not appear in state publications, ${ }^{2}$ the numbers given here are estimates. ${ }^{3}$

\footnotetext{
1 Temperatures during the day vary from around (minimum) 18 or 19 degrees C. in winter to 40 degrees C. or more in summer, see www.holiday-weather.com (accessed 10-182010).

2 I have only seen total numbers of inhabitants published, which include 'immigrants' from the Egyptian mainland.

3 Von Sarnowski 2004:388 estimates the number of Bedouin in South Sinai at 19,00027,000. EEAA 2003:3 based on the population census of 1996 estimates the number of
} 


\section{b. Cultural Background}

The central part of Sinai, on the Tih plateau, is inhabited mainly by tribes who speak a group I dialect-type (see De Jong 2000:Chapter I). Tribes inhabiting the lower coastal areas on the Gulf of 'Aqaba and the Gulf of Suez are also speakers of this dialect-type. The higher mountains towards the south are inhabited by tribes who are often collectively referred to as Tawara (or Tiwara). Most of these tribes immigrated at different times in history coming from the Arabian Peninsula or (via) Palestine and (today's) Jordan. Of some of these tribes in Sinai today, relatives can still be found in the northern part of the Hiǧăa, across the Gulf of Aqaba, in present-day Saudi Arabia. Other tribes arrived in Sinai via the mainland of Egypt.

Like the Bedouin in northern Sinai, Bedouin in the centre and south of Sinai are culturally much more part of the larger area known as Arabia Petraea than of Egypt, to which Sinai belongs in a political and administrative sense, and as G.W. Murray (1935:256-257) remarks, "among themselves, they can distinguish each tribe and subtribe by their looks and dialects....".

\section{c. Present-day Distribution of Bedouin Tribes in Central and Southern Sinai and Surrounding Regions}

With an approximate north-south length of 380 kilometres and and eastwest width of about 210 kilometres, the surface area of Sinai is some 61,000 square kilometres.

The majority of Sinai's inhabitants (the total was estimated at 360,000 in 2007) ${ }^{5}$ are found along the Mediterranean coast in the north, who live more or less along the main road al-Ganțarah (on the Suez Canal in the west) - Rafah (on the border with the Gaza Strip in the east). Of this total, more than one third today live in North Sinai's capital city al-'Arī̌s.

Bailey 1985:23 and 2009:xvi show maps of the distribution of tribal confederations in Sinai in the early twentieth century. Interestingly, some

\footnotetext{
Bedouin in the Governorate of South Sinai to be in the range of 20,000 to 24,000 and their number is projected to reach 53,800 souls by the year 2017 (ibid.:6).

${ }^{4}$ For other general remarks on the cultural background of Sinai Bedouin, see also De Jong 2000:3-4.

${ }_{5}^{5}$ Some 300,000 in the north, 60,000 in the south. Numbers are quoted from the Executive Summary and Recommendations in Egypt's Sinai Question, Middle East./North Africa Report $N^{\circ} 61$ of 30 January 2007, International Crisis Group, see www.crisisgroup.org (accessed 10-18-2010).
} 
tribes $^{6}$ in present-day Saudi Arabia just across the Gulf of 'Aqabah and in Jordan are also indicated on these maps (these are also included in the map below): in the far north of the Hiğāz and in the south of Jordan we find Hwētạa (on Bailey's map spelled as Huwaytạat), with to their south (just east of the Tīinān islands in the mouth of the Gulf of 'Aqabah) the Masā̄ìd and (a little farther to the southeast, along the Arabian Peninsula's west coast) Bilī. These tribes are also found in Sinai today: the Masāīì live in and around the village of Ğilbānah in the northwest, Bilī (transcribed as Baliy on the map below) are found not far south from the main road al-Ganțarah-al-'Arīš, in an area named Garīf al-Ġizlān near ar-Rawḍah in the central northeast, and the Hwẹtāat live in the areas as indicated on the map below.

On the map below I have also indicated the presence of three (sub-) tribal collectives not indicated on the map in Bailey: the Ğarāğrah, whom I interviewed in the area near Wādiy as-Sīg named al-Malbad, the Dbūr, whom I found residing not far south from the road leading trhough the Mitla pass to Naxl, ${ }^{7}$ approximately forty kilometres to the west of Nixl, and also the Malālhah, who live near the border with Israel in the northeast of Sinai. Another name not indicated on Bailey's map is that of the Hanādwah, who are actually a family said to be of non-Bedouin origin ${ }^{8}$ living in Wādiy aț-Ṭūr inside the territory of the Awlād Sa'̄id.

\section{d. Remarks on the Arrival of Bedouin Tribes in Central and Southern Sinai and some Remarks on their History}

Most of the tribes of Sinai came to the area between the thirteenth and eighteenth centuries. ${ }^{9}$ The history reported for the Ğbāliyyah is undoubtedly one of the most sensational of the tribes in Sinai: ${ }^{10}$ one hundred men with their wives and children are said to have been recruited in $530 \mathrm{CE}$

6 The different communities are referred to here as 'tribes', although I am aware that in some cases 'tribal confederation', 'sub-confederation', 'sub-tribe' or 'clan' would be more appropriate terms.

7 My Turbāniy informant Eid told me that the name for the Mitla pass is actually derived from Uṃm Ițlah "(the region) with the tamarisk tree". Bailey (1991:344) gives the same etymology.

The town of Naxl in central Sinai is referred to among Sinai Bedouin as Nixl.

${ }^{8}$ Literally their name means "Indians, i.e. (originally) from India", but this could not be verified.

9 The dating is in this paragraph is quoted predominantly from Bailey 1985 .

${ }^{10}$ The quote in Bailey 1985:26 of the German geographer Carl Ritter is another example of a sensational claim: the "Azāzmah are claimed to be the "aboriginal inhabitants" of the Negev. 


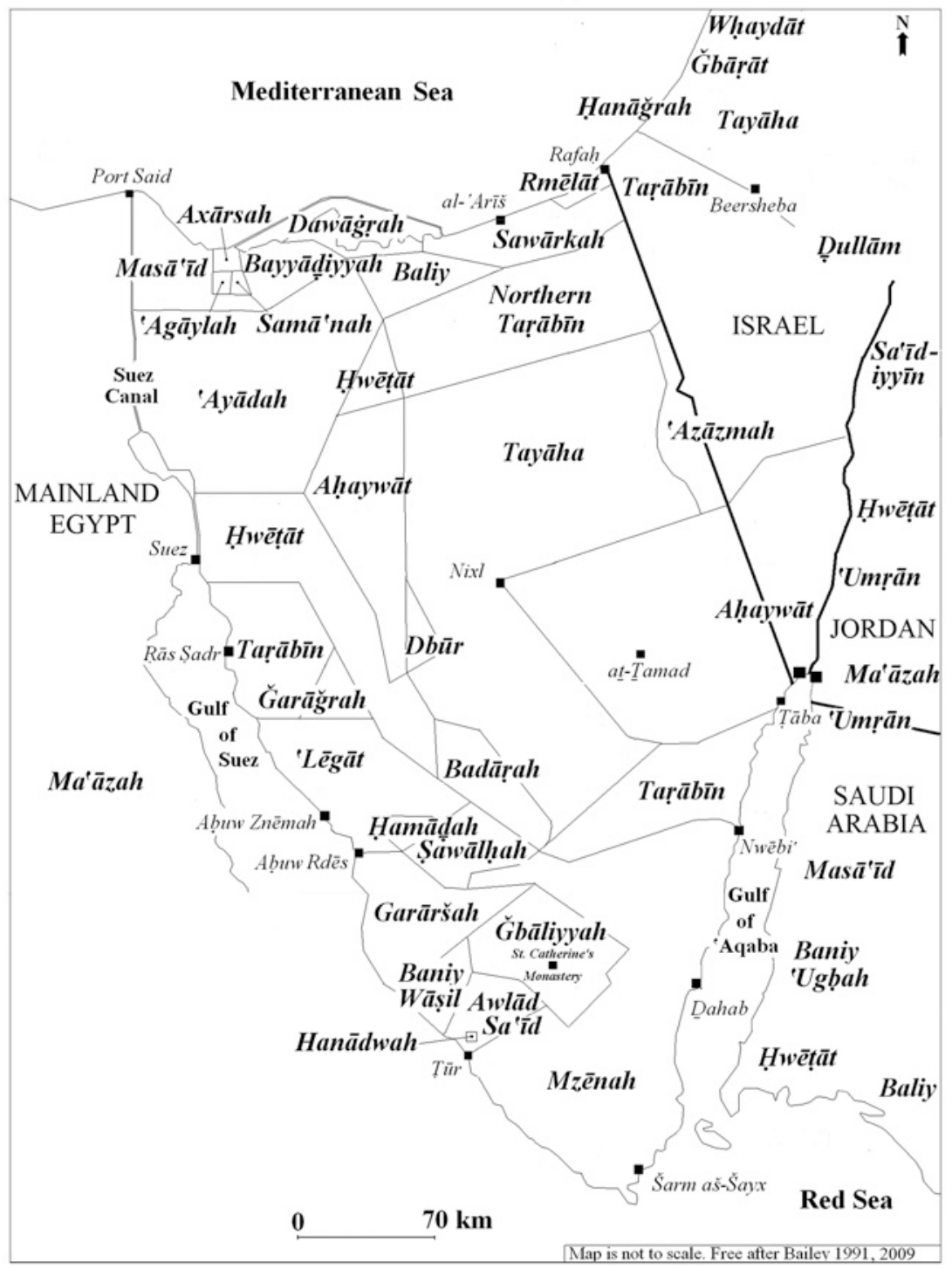

Approximate distribution of Bedouin tribes in Sinai and surrounding regions 
in the land of the Wallachians ${ }^{11}$ (another document mentions Byzantium (ar-Rūm) and Egypt) by the Emperor Justinian I (c. $482-565 \mathrm{CE}$ ) in the pre-islamic period to serve and protect St. Catherine's Monastery together with one hundred men with their wives and children who were sent to Sinai from Egypt. After about one thousand years almost the whole tribe had converted to islam. They remained, however, in the service of the Monastery. ${ }^{12}$

The estimated times of arrival of Bedouin tribes in central and southern Sinai appearing in this study are (as reported in Bailey $1985,{ }^{13}$ tribal names are given in my own transcription; ${ }^{14}$ in notes some details of their origins, histories, etc. will be given):

\begin{tabular}{|c|c|}
\hline Tribe & Estimated time of arrival \\
\hline 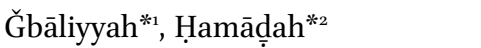 & pre-islamic period \\
\hline Badāṛah $^{*_{3}}$, Tayāha* ${ }^{*_{4}}$, Baniy Wāṣil ${ }^{*_{5}}$ & 10th (perhaps earlier) through $13^{\text {th }} \mathrm{c}$. \\
\hline \multicolumn{2}{|l|}{ 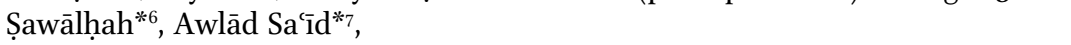 } \\
\hline 'Awārmah*6, 'Lēgāt*8 & 14th c. \\
\hline Tarāāīn*9, Garāršah" & 16th c. \\
\hline Hwēṭāt ${ }^{* 11}$, Mzēnah $^{*_{12}}$ & 17th c. (at the latest) \\
\hline
\end{tabular}

${ }^{*}$ For further information on the Ǧbāliyyah, see also aț-Ṭayyib 1993:621-622 and 639640 and Maiberger 1984:139-149. For an extensive account of their origins, history and present, Hobbs 1995 (especially 139-174) is recommended.

*2 For more background information on the history and origin of the Hamādah, see also at-Tayyib 1993:620. They are today a small tribe who are involved in mining activities in their mineral-rich area east of Aḅuw Znēmah, like in Wādiy aș-Ṣahaw. ${ }^{15}$ (see also remarks under ${ }^{*}$ ). Šuqayr 1916:107 writes that before the arrival of the Șawālhah they were in control of the region. After the Șawālhahah had arrived, the 'Lēgāt became their protectors.

${ }^{11}$ In present-day Romania the larger region around Bucharest, between the Transylvanian Alps and the Danube river.

${ }^{12}$ See Bailey 1985:33-35. Maiberger 1984:147-148 quotes Johann Ludwig Burckhardt writing that until well into the eighteenth century a few Ğbāliy families had remained Christians.

${ }^{13}$ See however Stewart 1991, where caution with regard to Bailey's conclusions is advised.

${ }^{14}$ For dates of arrival of tribes in northern Sinai, see Bailey 1985 and De Jong 2000:1415. For more information on the tribes of the central and south of Sinai, see also Šuqayr 1916:106-120.

${ }^{15}$ At-Tayyib 1997:290 lists them as one of the oldest tribes present in Sinai today. See also Šuqayr 1916:107, where also the presence of at-Tabanah, as the original inhabitants of the 'garden of Fērāan', and al-Mawāțrah is reported, and who in a distant past have their roots in the Hamādah. I have not heard the names of these former two groups mentioned during the research for this study. 
*3 Aț-Ṭayib 1993:620 actually spells their name as al-Badārā (برارى, with final 'alif maqșūrah, but it is spelled as بد in Šuqayr 1916:107). They are a very small tribe, who are reported to have moved from their earlier abode on Ğabal Iğmah (on the central Tīh plateau), where they lived together with (and were allies of) the Tayāha. When they fell out with the Tayāha, they allied with the Șafāyḥah (a sub-tribe of the Ahaywāt). ${ }^{16}$ Šuqayr (ibid.) suggests that perhaps the name 'Iğmah is derived from the word (from the same

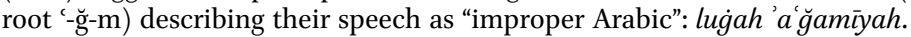

*4 The Tayāha are a relatively large tribe. Aț-Ṭayyib 1993:566 reports that they came to Sinai with the Banū Hilāl (of 'Adnānī origin) ${ }^{17}$ and that they were among the first tribes to 'settle' on the Tīh plateau. After the Tarābīn had arrived there, several wars were fought over control of the land. Sawārkah, Biliy, Rmēlāt, Samā'nah are mentioned as allies of the Tayāha in these wars. For some time they were also allied with the Hwèțāt against the Sawārkah. For further details on their history, presence in other countries etc., see ibid.:565-570 and also at-Tayyib 1997:227-233.

$*_{5}$ They are reported, also in at-Tayyib (see 1993:622 and 1997:292) ${ }^{18}$ to be one of the oldest tribes in Sinai. They are said there to have fought numerous wars against the Hamādah over territory and that both tribes severely weakened each other in the process. After these wars they agreed on a division of the land to the north and south of Wādiy Fērān, which was then later largely occupied by (the various sub-divisions of) the Șawālhah.

G.W. Murray 1935:243 writes that the original inhabitants of southern Sinai "are said to have been Beni Suleiman, and the Hamada and the Beni Wasil [in my own transcription: Baniy Slēmān, Hamāḍah and Baniy Wāșil]. Not long after the Arab conquest of Egypt, the Sawalha and the 'Aleiqat [in my own transcription: Șawālhạ and 'Lēgāt] were living in Sharqiya [...], from which they regularly raided south Sinai to carry off the dates of Feiran or to graze their camels wherever there had been rain. One year, these two tribes migrated en masse into the peninsula where they succeeded in conquering the Beni Suleiman and the rest, some of whom fled while others were absorbed into the conquerors [...] [T] he two tribes quarrelled and victory was inclining towards the Sawalha when there arrived from Arabia seven tents of the Muzeina [in my own transcription: Mzēnah], the remnant of a noble tribe flying from the results of a blood feud. These asked permission of the Sawalha to share their grazing. But this the Sawalha refused, unless the Muzeina paid them tribute. So the proud Muzeina went off to join the 'Aleiqat and both tribes together overcame the Sawalha in a battle fought in the Watia Pass [in my own transcription: Wātyah. The pass is located at appr. 28.41.40 North and 33.58.53 East, see Google Earth] on the main road to the Monastery. A sensible compromise then took place by which the three tribes divided the peninsula among them."

*6 In the map below I have indicated the Șawālhah as a separate entity positioned in the area where Bailey 1985:23 indicated the presence of the 'Awārmah. I have not met people who claimed to be members of the 'Awārmah' ${ }^{19}$ (see also the quote from G.W. Murray 1935 in the previous remark).

${ }^{16}$ At-Tayyib 1993:620 adds a footnote reporting that some Ahaywāt claim that the Badārah are originally of Ahaywiy origin. See also Aț-Ṭayyib 1997:290-291. Today they are found in ar-Ramlah near Ğabal Hmayyir, which is part of the 'Dividing Valleys' between the Tīh Plateau and the Sinai Massif, see Greenwood 1997:27 (figure 3-I), The geomorphic regions of Sinai.

${ }_{17}$ The Banū Hilāl were led by their legendary commander 'Amr ibn al-'Ạṣ when they conquered Egypt in the seventh century CE.

${ }_{18}$ Their origin is reported to be Qaḥțāniy, through Ǧudām and Banū 'Uqbah.

19 Aț-Tayyib 1993:642 actually mentions the 'Awārmah as one of the four sub-tribes of the Șawālḥah: al-'Awārimah, al-Maḥāsinah, ar-Raḍāwinah and an-Nawāṣirah (in my transcription: 'Awārmah, Maḥāsnah, Rạ̦āwnah and Nawāșrah). For the history and origin 
*7 At-Tayyib 1993:681-682 (see also 1997:36o-367) relates a story describing how the Awlād Sa'ìd joined the tribe of Șawālḥah during their days in the Hiğāz, after which they came to Sinai together. In ibid. it is also reported that a branch (named Awlād Sayf) of the Awlād Sa'īd are originally Masā'id.

*8 For a short history of the origin, present location(s) and activities of the 'Lēgāt in Sinai, ${ }^{20}$ see also at-Tayyib 1993:701-711 and 1997:475-489. At-Tayyib (1993:710 and 1997:487) however quotes Aḥmad Luțī as-Sayyid in his book qabä'il al-'arab fi mișr on the date of arrival of the 'Lēgāt in Sinai as being in the tenth century Hiğrah (i.e. appr. in the sixteenth century CE) (see also quote from G.W. Murray 1935 in remark ${ }^{*_{5}}$ above).

*9 The large tribe of at-Tarābīn ${ }^{21}$ in earlier times occupied land in central Sinai, but later, in the eighteenth century, expanded and moved into different directions at the expense of other tribes claiming their territories for themselves. ${ }^{22}$

$*_{10}$ The Garāršah are said to be a section of the Șawālhah (see Bailey 1985:33; I have heard the same from my own informants).

Bailey (1985:28-29) reports that the 'Awārmah, Awlād Sa'īd and Garāršah are 'jointly known as the Șawālhahah'. ${ }^{23}$

Bailey (1985:33) also reports a war that took place around 1600 between the Ṣawālhah and 'Lēgāt.

*11 The Hwẹtāāt in Sinai are only a small group, ${ }^{24}$ but large numbers of the Hwētāt live as an amalgam of sub-tribes or clans of various origins in southern Jordan and the far northwestern region of Saudi Arabia just south of the border with Jordan. According to Von Oppenheim, ${ }^{25}$ they occupy a special place among the Bedouin tribes in terms of genealogy. They are said to be offspring of an Egyptian man Huwayt, who traveled to 'Aqabah where he fell ill. He was then given shelter by a member of the Baniy 'Ațiyyah (who are still also today found in Jordan). When Huwayt had recovered from his illness, he stayed in 'Aqabah, and managed to guile the Baniy 'Ațiyyah out of their profitable business of

of the Șawālhạh see aț-Ṭayyib 1993:623-644. See also Maiberger 1984:141 (paraphrased:), where he mentions the 'Awāreme (who are said to be the sub-section of the Șawālhah who originally conquered the area), the Qarāreše (Garāršah in my transcription) (who-as owners of the best palm orchards in Wādiy Fērān-were the richest among the otherwise destitute Țawara), and the Awlād Sa'īd as sub-sections of the Șawālhahah. The name Șawālhạh derives from the prophet (an-nabiy) Șālih, from whom they claim descent. Together with the 'Lēgāt the Șawālhahah secured an income (in the form of bread paid by the monks) as 'Protectors' of pelgrims en route from Cairo to the monastery.

${ }^{20}$ They are for instance reported to be allies of the Mzēnah and Hamādahah and to have been in territorial disputes with the Șawālhạah.

${ }^{21}$ Their name Tarābīn is said to derive from their place of origin Wādiy at-Tarabah or the town of that name, located to the northwest of aț-Ṭāif in present day Saudi Arabia. Today sections of this tribe are also present in the Gaza area and the Negev Desert, see also aț-Ṭayib 1993:554-564.

Stewart 1991:106 also mentions that the Tarābīn were part of the Baniy 'Ațiyya.

${ }^{22}$ Bailey 1985:25 reports that they moved into 'Ayyādiy territory to their west (now Tarābīn of Rāās Ṣadr), the Mzēnah to their south (now Taṛābīn of Nwēbic) and Whaydāt, Ğbārāt (now found to the north of Gaza) and Rmēlāt (in my own transcription) to their north (now northern Tarābīn). In turn, they had their "own place in drought-ridden central Sinai taken over by the Ahaywāt, although not by conquest", see ibid. For more on the Tarābīn see also aț-Ṭayyib 1993:554-570 and aṭ-Ṭayyib 1997:210-226.

${ }^{23}$ I have treated them as separate entities, in conformity with how informants themselves defined their affiliations.

${ }^{24}$ See Von Oppenheim 1943:154-155.

${ }^{25}$ See Von Oppenheim 1943:291. 
protecting grain transports from Syria to pilgrimage stations. Only part of them became nomadic, and only at a later point in history. ${ }^{26}$

$*_{12}$ The Mzēnah are reported (see Bailey 1985:33) to be originally of 'Adnānī (northern Arabian tribes) origin, but they later (between the 14th and 16th centuries) joined the Qahțānī (southern Arabian) Harb. For a description of their origins, history, presence in Sinai and other locations, see also att-Tayyib 1993:687-700 and 1997:368-474. (See also the quote from G.W. Murray 1935 in remark ${ }^{*}$ above).

\section{e. Professional Activities of Bedouin in Central Southern Sinai Today}

Many of the Bedouin who live near or on the coast of the Gulf of 'Aqabah make a living in the tourist industry. The focal point of this industry is Šarm aš-Šayx, where hundreds of thousands of tourists come for sunshine and diving, every year generating billions of dollars of income for the Egyptian economy. Most of this money is, however, earned by mainland Egyptians and relatively very little trickles down to the local Bedouin population. Bedouin work mainly as taxi drivers, desert safari guides, and run small businesses like rental shops for diving equipment, cafeterias and small restaurants or sell souvenirs and camel rides. Only few Bedouin have seen opportunities to start their own hotel businesses or larger transport companies for tourists. ${ }^{27}$

About an hour's drive from the airport of Šarm aš-Šayx, Dahab also takes its share of tourism revenues, albeit a mere fraction of the money made in Šarm. Farther to the north in Nwēbic, which is about a two hours' drive from Šarm airport, and along the coast stretching towards Tāaba, much money has been invested to develop the tourism industry by (again predominantly) mainland Egyptians, but ever since the second intifā many of the tourists from or via Israel that would come to this area have stayed away. ${ }^{29}$ The result is a coastal area filled with half-finished concrete constructions, lying untouched while investors wait for better times. Only a limited number of hotels and a handful of holiday camps run by local Bedouin are open for the few tourists who do come.

\footnotetext{
${ }^{26}$ For a description and list of sub-sections of the Hwēțāt in Jordan and mainland Egypt, see Von Oppenheim 1943:291-308. For more information on their background and history, see Maulvi Al-Haq, Al-Huwaytat in: Encyclopaedic ethnography of Middle-East and Central Asia (Vol. I):287-289.

${ }^{27}$ Most of the larger tourism businesses are controlled by mainland Egyptians.

${ }^{28}$ The second intifädah started at the al-'Aqșā mosque in late September 2000.

${ }^{29}$ As part of the Camp David Accords, Israelis (and other tourists entering from Israel at Țāba) are allowed to travel into Sinai and visit the east coast of Sinai and its towns (including Šarm aš-Šayx and St Catherine's Monastery) on a 14-day permit available at the border. Israeli authorities (the Counter Terrorism Division) have however issued warnings to their citizens not to travel to Sinai due to the threat of terrorist attacks.
} 
On the coast of the Gulf of Suez more tourist facilities are being developed. The focal point for this business in this area is Rās Șadr (the name of the town is usually spelled 'Ras Sudr' on road signs) and the coast to its south. These facilities mainly cater for holiday makers from Cairo, Rāa Ṣadr being only a two and a half to three hours' drive away from the capital.

Other sources of income for Bedouin include fishing, herding small cattle, some modest crop farming in a karm, ${ }^{30}$ transporting fresh water from the mountains to hotels and also smuggling. ${ }^{31}$ Nowadays members of Bedouin tribes also find employment in development projects like the large scale South Sinai Regional Development Programme (SSRDP), which is funded by the European Union. ${ }^{32}$

\section{f. Research Questions and Purpose of this Study}

The volume in hand is the second on Bedouin dialects in Sinai after the first volume, which is on the Bedouin dialects of the northern Sinai littoral. The primary aim of this study is to give a synchronic description of the Bedouin dialects of central and southern Sinai and thus to complete the description of the Bedouin dialects of the Sinai Desert. ${ }^{33}$

This study is also aimed at testing the hypothesis that dialect-typological group of Northwestern Arabic dialects, as proposed by Palva 1991, continues farther south into Sinai, and to investigate the type of differences

\footnotetext{
${ }^{30}$ Lack of fresh water is one of the main problems in Sinai (in 2005 southern Sinai had been without any significant rainfall for fifteen years). Several kinds of fruits and vegetables are grown, as well as poppies and marihuana (in more isolated places) for the production of drugs. These crops are grown on ground water (delivered by means of drip irrigation), but due to the lack of rain and the large quantities which have already been trucked to Šarm aš-Šayx for the tourist industry, the ground water has already run out in several places. In some areas rain-fed agriculture is sometimes possible in sdüd (sg. sidd "dam"). See also fn 129, p. 104.

$3^{1}$ This is said to include drugs (I was told that in January 20081 kilo of marihuana cost LE 50.-, 1 wigiyyah (about 6 or 7 in a kilo) of opium LE 450.-, both locally grown in the central areas, and a kilo of heroine LE 70,000.-), and even women, who come on charter flights to Šarm (many from Russia and the Ukraine) to work in prostitution in Israel. Smuggling of fire arms and explosives is also said to take place.

$3^{2}$ A total of 64 million Euros has been allotted to this project by the European Union. For more information, see webpage http://www.eu-ssrdp.org/ (accessed 10-18-2010).

33 There are publications, however, which partially fill this gap: Nishio 1992 gives a basic vocabulary of the speech of the Ğbāliyyah, Stewart 1990 is a very valuable collection of texts (in transcription, and with translation in Stewart 1988) on customary law recorded mainly among the Ahaywāt, but also some of the other tribes. Stewart 1987 gives some texts and provides a sketch of the dialect of the Ahaywāt. Material presented by Stewart was incorporated into De Jong 2000. Material presented by Nishio will be referred to in descriptive chapter I below.
} 
which exist between the NWA dialects in this area. A similar related question is how far the Negev-type (the dialect of the Dulläm) can be concluded to stretch into Sinai. ${ }^{34}$

In northern Sinai a continuum of dialects with an east-west dimension was identified as constituting the transition of a largely Bedouin dialecttype (that of the Negev spoken by the Dullām as described in Blanc 1970, or the group I-type as described in De Jong 2000) towards the much more sedentary type as spoken in the eastern part of the Nile Delta, such as described in Abul Fadl 1961, Woidich 1979 and 1980 and in Behnstedt and Woidich 1985). ${ }^{35}$ The sedentary characteristics of the western dialects in the north, in particular those of group III (i.e. BA and AxA), are very likely to be due to dialect contact with sedentary dialects of the eastern Delta.

Another question to be investigated in this study is therefore whether similar sedentary influences can be traced in the dialects of the central and southern Sinai, which are geographically so much farther removed from sedentary dialects spoken on the Egyptian mainland than the dialects of group III.

In De Jong 2000:283 the pronominal suffixes ${ }^{-}{ }^{u} k$ for the 2 nd p. sg. masculine and $-k$ for the sg. fem. found in group II of the north were surmised to be a feature more typical of southern Sinai dialects. Another question is therefore whether this is indeed the case, and if so, how widespread this feature is.

A secondary purpose of this study is to apply the 'step' method introduced in De Jong 2000:614-621 to the dialects of central and southern Sinai and compare these to results of comparisons of the same dialects with the help of techniques of multi-dimensional scaling and clustering by generating a dendrogram.

\section{Fieldwork Methodology}

\section{a. Infrastructural Arrangements}

As a 'base' to work from for my field research I had chosen the small town of Dahab, situated on the east coast of Sinai and more or less half way between Šarm aš-Šayx and Nwēbic. The advantage of this town is that it

34 This question was already posed in Blanc 1970:2.

35 See De Jong 2000:621-627. 
was within reasonable travelling distance from the locations I wanted to visit for my recordings, while at the same time I was able to more or less 'mix in' with the numbers of tourists who come to spend a holiday in Dahab. ${ }^{3}$ On most of my visits I used a rented car from Cairo, while for recordings 'off the beaten track' I would sometimes rent a Toyota pick up truck, which handled remarkably well in sandy conditions. On other occasions I was able to bring a $4 \mathrm{X} 4$ vehicle (a Mitsubishi Pajero). With this vehicle I could visit Badārah in the area of ar-Ṛamlah and 'Lēgāt and Hamādah in other hard-to-access areas in the central western parts of southern Sinai.

In Dahab I would rent an apartment with a desk, where I could write out my recordings with my guide and main informant Eid and where I would also occasionally conduct recording sessions with informants. ${ }^{37}$

Recordings were made with digital recorders (2 Apple iPods and an Archos recorder) ${ }^{38}$ in MP-3 or WAVE format. To make sure speech was recorded properly, I always used extra cassette recorders making simultaneous recordings. ${ }^{39}$ The advantages of digital recordings are many: almost instant copies on computer become possible (without loss of sound quality), no wear and tear of audio tapes, and the recorders were easy to recharge with special cigarette lighter adaptors in a car. Other advantages are that recording of a speaker would not have to be interrupted to flip or change an audio tape, so that the speaker would be less actively reminded of the fact that he was being recorded. At 'home' in Dahab I would usually burn copies of these recordings on $\mathrm{CD}$, and work with these copies on $\mathrm{CD}$ players (with extra battery powered Sony speakers) to write the texts out on my computer with the help of my friend Eid. The computer I used was an Apple G4, on which I had installed the necessary fonts for transcription and which were created by Manfred Woidich.

After my experiences with chances for permission for my research in northern Sinai, I had decided not to apply for official permission to

\footnotetext{
${ }^{36}$ At the time of my field trips the town of Nwēbic had almost no tourists, and my chances to keep a low profile would have been much slimmer, while the town of Šarm aš-Šayx was too heavily infested with security personnel (the town regularly hosts international conferences and summit meetings) to remain relatively unnoticed.

${ }^{37}$ Most of the recordings were however conducted in situ.

${ }^{38}$ These were about the size of a pack of cigarettes.

${ }^{39}$ Although the sound quality was excellent when set to the maximum sampling rate, the Archos recorder I used (with an external Soundman 'Kopfmikrofon') was quite difficult to operate, especially in conditions without light. After pressing the wrong invisible button, this could result in loss of the recording. The iPods were much easier to handle with a Griffin iTalk click-on microphone.
} 
conduct my research in the centre and south, but to simply maintain as low a profile as possible. To remain friends with military or security personnel manning road blocks, a pack of cigarettes, or a bottle of water could work miracles. ${ }^{40}$

\section{b. Selecting Targets for Field Research}

During the research needed for this study the same assumption was made as for the previous research in northern Sinai: that the dialect of members of the same tribal collective will not be substantially different in different locations within the same dirah (or 'tribal area'). At the same time, some differences did show up in places inside the same dirah.

An example of such differences showing up among speakers of the same tribal collective is the treatment of 'original anaptyctics' in initial position in the suffixed preposition $m(i)^{\prime}$ " with" (see ${ }^{* 6}$ in chapter I, 3.1.16.) in different areas inside the dīrah of the Ğbāliyyah; speakers of Ğbāliy who live near the monastery tend to say e.g. for "with him" im 'úh (where $i$ is an anaptyctic vowel), while speakers of Ğbāliy in Mrēr (in Wādiy aš-Šèx) will more regularly stress the anaptyctic as in im uh (which leads to the conclusion that the morphophonemic base of the in the latter case is actually $\left.\left|\mathrm{im}^{\mathrm{c}}\right|\right)$. Another example are the genitive exponents in use for 'indirect annexation' among speakers of the Mzēnah. Speakers of Mzēniy living in Dahab and near to the coast will generally use šugl, while speakers of Mzēniy living more inland will more regularly use hagg (see chapter II, 3.1.11.). When such differences did show up among speakers of the same tribal collective, separate mention of this is made in the descriptive chapters.

To select the tribal communities to be approached for this study, I made an inventarisation based on the map in Bailey 1991 (also in Bailey 2009). I would then go out to the tribal areas where these collectives were to be found, and would try to conduct interviews with speakers after having been introduced to them by my guide and travelling companion Eid al-Ațraš. ${ }^{41}$ In the course of my research I would sometimes also hear

${ }^{40}$ If one passes through a road block three times a week, every time claiming a different purpose of the journey, such as Ğabal al-Banāt, St. Catherine's Monastery, the Blue Desert, or some other local attraction, one sometimes has to prop up one's credibility with a little present.

${ }^{41}$ The method of selecting informants, topics discussed during interviews, some of the difficulties associated with field research and the general methodological approach are described in De Jong 2000:20-21 and 23-30. 
names mentioned of tribal collectives not indicated (or known by another name) on the map in Bailey 1991, I would then go to the dirahs of these collectives to conduct interviews with speakers there as well. I would not attempt to subsume such collectives under a larger collective (like the Dbūr, of whom it is reported that they are a sub-section of the Hwêțāt, or the Badārah, of whom it is said that they are originally Ahaywāt, or in any case lived in close contact with a sub-section of the Ahaywāt for a considerable length of time), but I would simply accept the way speakers identified themselves, at face value, so to speak. ${ }^{42}$

I did however take note of the remarks I had heard about the origins of such smaller collectives, and at a later stage compared the typological position of such a sub-group with that of their original (usually) larger tribal collective with the help of Multi-Dimensional Scaling plots. Not surprisingly perhaps, such collectives show up relatively near each other in such Multi-Dimensional Scaling plots (see in the appendix below, where DbA is plotted in the immediate vicinity of HwA and BdA shows up very near AhA), which means that such tribal collectives show relatively few differences in a linguistic sense (for other remarks made by informants, see Conclusions, IV. e.).

\section{c. Selecting Informants}

Informants for interviews were-like so often in Arabic dialect researchselected on the basis of practical considerations: those who were prepared and able to be interviewed were invited to cooperate. Due to the conservative nature of Bedouin society, interviewing women was often not possible. Like in other areas of Sinai, women spend most of their time inside their homes or at a younger age herding goats and sheep. In towns like Dahab and Nwēbic younger girls can often be seen trying to sell locally produced souvenir trinkets like bracelets, purses, etc. to tourists. Approaching a woman who is alone-e.g. when she is out herding goats and sheep in the desert, or shopping in town - is regarded as extremely bad manners and is for Bedouin themselves even punishable under customary law (اقصاع الغرفي in Arabic).

There were a few exceptions: of the Tayāha I interviewed an elderly lady. This was possible because my guide and main informant Eid ('Īd) knew her personally, as he had spent time in prison with her son for more

\footnotetext{
${ }^{42}$ After all, if speakers do not identify themselves as belonging to a certain larger (or smaller) tribal group, or another group altogether, who am I to suggest that they should?
} 
than a year. ${ }^{43}$ I have also often spoken to the mother of my main informant Eid, a Turbāniyyih of appr. 65 years old.

Below the persons who were more or less formally interviewed ${ }^{44}$ during this research ${ }^{45}$ (their ages at times of recording follow in brackets) are listed. These interviewees are referred to by their first names only:

\section{Group I}

Tarābīn Nwēbic Šēx 'Šēš (47) (Nwēbic) + several Turbāniy visitors from around Nwēbi ' and Wādiy Watīr in his mag'ad. The abbreviation used here to refer to their dialect is TAN.

Tarābin Rậs Ṣadr 'Īd (33) (Ṛās Șadr) (+ 4 or 5 of his friends of appr. the same age in Rạa Ṣadr/Aḅuw Șwayrah, his mother, appr. 6o). The abbreviation used here to refer to their dialect is TAS.

Ğarāğrah Talāl (29) (born al-Bāğah/Wādiy as-Sīg); Swēlim (35) (born in Rāa asSīg); Ğamāl (appr. 32) (born in Wādiy as-Sīg); Mhammad (appr. 32) (born in Wādiy as-Sīg); Silmiy (53) (born in al-Malbad/Wādiy as-Sīg). The abbreviation used here to refer to their dialect is ĞrA.

Tayāha Mḥammad (34) (recorded in Abuw Șwayṛah); Slēm (49) (Ṛās aš-Šèțān, from Ṛās 'Bēd appr. 105 km south of al-'Arīš); Aṃm Xị̦r (appr. 65) (recorded near (northeast of) aț-Ṭarfa; ${ }^{6}$ ); Xid̦r (32) (northeast of aț-Ṭarfa). The abbreviation used here to refer to their dialect is TyA.

43 Many Bedouin men have spent time in prisons, often even without official charges.

44 "More or less formally" should be interpreted to mean that I conducted recording sessions with them. Often enough though, I met people during my travels with whom I chatted and on whose speech I would then later-immediately after the conversationtake notes if I was certain to which tribal groups they belonged, e.g. several Mzēnah in 'Ayn Hudrah, a couple of Hwēțāt on the main road through the Mitla pass, Hamādah on the way from the Ğabal Ḥmayyir area to Wādiy Lihyān, several 'Lēgāt near the area where I had interviewed Badārah (in the Ğabal Ḥmayyir area), Awlād Sa'īd near al-Buwayb, just south of Wādiy Fērān, Tarāāin in Dahab, etc.

45 Since I used to rent an apartment in Dahab during the several periods of my field research, I have spoken with and listened to many more individuals than those listed here. I would then also usually ask them about their tribal backgrounds. Many of these speakers were of course Mzēnah, but also members of other tribes of Sinai (including tribes from the north) can be found in this town.

${ }^{46}$ Appr. coordinates are 28.44.15 North and 33.58.48 East. 
Malālḥah Xị̣r (8o); Salmān (appr. 30); Zāyid (67); all three from al-Madfūnih/Nag' Šabānih, very near (appr. 300 metres) the border with Israel. The abbreviation used here to refer to their dialect is MlA.

Hweețāt Slēmān (46) (born and living in al-Ǧidy); Mhammad (born in al-Hammih, $20 \mathrm{~km}$ east of al-Ǧidy); 'Īd (28) (born and living in al-Ǧidy). The abbreviation used here to refer to their dialect is HwA.

Dbūr al-Ḥaǧğ Faráğ (62); 'Awdih (appr. 45, though claims to be 6o); Slēmān (appr. 35); Mhammad (appr. 40, born in Trayfih). The abbreviation used here to refer to their dialect is DbA.

Badārah 'Ațiyyih (6o) (born on the Tīh plateau); Silmān (55) (born on the Tīh plateau). Both from aṛ-Ṛamlah, near Ğabal Homayyir, some 10 to 12 kilometres almost due west from Ğabal Fōgah. ${ }^{47}$ The abbreviation used here to refer to their dialect is BdA.

\section{Group VI}

Mzēnah Hasan (54) (from Dahab); Mhạmmad (from Dahab/'Așalah) (appr. 28); 'Āyid (25) (from Dahab/ 'Așalah); 'Abdalḷah (appr. 34) (from Dahab); Frayğ (appr. 40) (on main road St Catherine's police post and appr. $30 \mathrm{~km}$ west of the police post at the intersection of the Nwebic/ Dahab road and the east-west route to St Catherine's monastery)..$^{48}$ The abbreviation used here to refer to their dialect is MzA.

Baniy Wāṣil Mḥammad (6o) (born in Wādiy Tammān, to the southeast of Wādiy aț-Ṭūr, about $30 \mathrm{~km}$ from the main road to Šarm); Sālim (25) (born in the mountains east southeast of aț-Tūr, near Wādiy Sli' ${ }^{49}$ The abbreviation used here to refer to their dialect is BWA.

\footnotetext{
47 Coordinates appr. 29.02.52 North and 33.33.38 East. I have also spoken to four other men of the Badārah, but could not make recordings on that occasion. When sufficiently zoomed in, their four or five tents are visible on Google Earth as white rectangles (the tents are nowadays made of flour sacks donated by USAID). Three more tents (white and brown) are visible at 29.02.36 North and 33.34.18 East.

${ }^{48}$ Coordinates are appr. 28.48.18 North and 34.17.56 East, see Google Earth.

49 Depending on dialect, this may also be pronounced as Wādiy Islah, Wādiy Aslah or Wādiy Sliy. See 1.2.4.4. and 3.1.5. in the descriptive chapters below. In Šuqayr 1916:69 the name is spelled in Arabic as Yll.
} 


\section{Group VII}

Hanādwah Ğimcih (29) (born in Wādiy Fērāan); Hamd (also known by his nickname Mundiy) (26) (born in Wādiy Fērāan); Slēmān (64) (born in Wādiy Fērāan). All were interviewed in Wādiy aț-Ṭūr, a few kilometres to the northeast of at-Tuur, Hamd was also recorded on several occasions in Dahab. The abbreviation used here to refer to their dialect is HnA.

Garāršah Mahmūd (24) (from il-Hișwah, Wādiy Fēṛān); Īd (22) (from il-Ḥișwah, Wādiy Fērāann); H̦sēn (54) (from il-Ḥiṣwah, Wādiy Fērạan); Ḥsēn

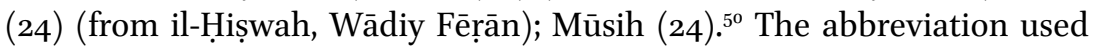
here to refer to their dialect is GrA.

Hamāḍah Maḥmūd (30) (born in Sēl Ba'bac):51 'Awwād (55) (Wādiy Liḥyān); Sa'ad (36) (Wādiy Liḥyān).52 The abbreviation used here to refer to their dialect is HmA.

Ğbāliyyah il-Ḥağğ Msallam (67) (from Brēgah, between Fērāan and Ḥișwah/Wādiy Fērān); Mūsa (28) (Wādiy iṛ-Ṛāḥah, appr. 3 km north of the monastery); 'Ațwah (30) (Wādiy iṛ-Ṛahhahah); Silēmān (27) (St Catherine village); Silēmān (36) (Mrēr, appr. $30 \mathrm{~km}$ into Wādiy aš-Šēx from the police post at St. Catherine's); Aḅuw Ḥmēd (38) (Mrēr). The abbreviation used here to refer to their dialect is ĞbA.

Awlād Sa' ìd 'Ōdah (35) (from Wādiy Ṣlāf. 2 years 'i'dādiy in Ṭūr); Nișsāâr (appr. 65) (from Wādiy Ṣlāf); Maḥmūd (appr. 6o) (from Wādiy ṣlāf). The abbreviation used here to refer to their dialect is ASA.

\footnotetext{
${ }^{50}$ Hiswah is in Wādiy Fēṛān, coordinates are appr. 28.43.13 North and 33.36.33 East, see Google Earth.

${ }^{51}$ The mouth of Wādiy Ba bac is just to the northeast of Abuw Rdēs and just to the northwest of Wādiy Maġārah. Coordinates are appr. 28.54 North and 33.15 East on Google Earth. The area of Umm Buğmah is well known among geologists for its manganese deposits. Already in pharaonic times, in the general area around Sarābīt alXādim and in Wādiy Magaārah turquoise was mined.

${ }^{52}$ Wādiy Lihyān (not indicated on Google Earth, but located appr. at 29.01 North and 33.25 East) is some kilometres (north) from Wādiy Mukattab, which is appr. at 28.50.58 North and 33.25.35 East and to the southwest Sarabịt alXādim. In this wadi there are several Nabataean and Byzantine rock inscriptions.
} 
Șawālhah Ḥsēn (38) (born in Xbayyir/Wādiy Fērān); Ğimcih (18) (born in Aḅuw Rdēs, lives in Xbayyir/Wādiy Fēṛān); 'Ațwah (36) (born in Xbayyir/ Wādiy Fērānn). The abbreviation used here to refer to their dialect is ȘwA.

\section{Group VIII}

'Lēgāt Sacád (appr. 40) (born in Sarābīṭ al-Xādim); Xid̄r (appr. 35) (from Sarābīt al-Xādim); Mḥammad (33) (from Sarābīt al-Xādim); Slēm (appr. 42) (from Sarābît al-Xādim). The abbreviation used here to refer to their dialect is 'LA.

\section{d. Gathering Linguistic Material}

In principle, the mode of operations described in De Jong 2000:23-30 was followed for this research as well.

\section{e. Difficulties during Field Research}

Problems connected to conducting research in Sinai have been referred to before, ${ }^{53}$ and since the times of my previous research in northern Sinai, matters in this respect have hardly changed for the better. If anything, local authorities have become all the more wary of foreigners who exhibit no particular interest in diving and/or sunshine.

At the same time, however, it seems that gradually the realisation has been sinking in that such foreigeners too come in a variety of shapes, and with a variety of interests, and that not all of them are out to smudge the reputation of Egypt, but may have a genuine academic interest.

Apart from the known difficulties associated with field research needed for dialect studies in Egypt, additional complications arose when tourist facilities in southern Sinai became the target of terrorist attacks.

Three simultaneous suicide bomb attacks took place in Dahab on the 24th of April 2006 (it was the early evening of the very day I had arrived there for more field work). Before these attacks, on the 7 th of October 2004, the Hilton hotel in Țāba, campsites north of Nwēbi ${ }^{{ }^{54}}$ / Ṛās aš-Šaytān had been targeted, which in turn came more than a year after on the 23 rd

\footnotetext{
${ }_{53}$ See also remarks in De Jong 2000:18.

${ }^{54}$ Although I transcribe Nwēbi', as a transliteration for Arabic on road signs, Dr Frank Stewart (in personal communication) advised me to correct this to read Nwēb'ih (as is his practice in several of his publications). I have chosen however to maintain my original transcription.
} 
of July 2005 bombs had exploded in Šarm aš-Šayx (of which one was a large car bomb driven into the reception area of the Ghazala Gardens Hotel). All in all, more than a hundred people lost their lives in these bombings, and hundreds more were wounded.

Since security forces almost immediately suspected Bedouin involvement in these attacks, thousands of Bedouin were rounded up and put under detention in al-'Arīs. Only after several months, when the involvement in the attacks of 2004 of a few members of one of the Bedouin tribes had become clear, three suspects were (within a matter of days) tracked down in the desert near the mountain range of Ṣadr al-Hayṭān (to the east of Raās Șadr) with the help of members of different Bedouin tribes, who had decided to assist authorities in their hunt to testify to their abhorrence for the terrorist acts ascribed to these three. The suspects died in the shootouts that ensued. Many of the estimated three thousand Bedouin who had been rounded up, however, remained in custody for a long time.

In the weeks following such attacks it was usually impossible to go out into the desert and look for informants to interview. On several occasions my regular informant Eid was taken from my car at one of the road blocks and locked up in prison or a police station, until some influential local tribesmen could be found to go there and seek his release. After a few of these incidents (he was arrested three times in the four weeks immediately after the Dahab bombings), we decided to work on recordings that we already had instead, and not to venture out of town until the situation had quieted down. This should in part explain why the average number of speakers is a little lower than during my previous research in northern Sinai. On the other hand, the number of Bedouin inhabitants of this southern region is also considerably smaller than in the north.

\section{Presentation of the Data}

\section{a. Presentation of the Data and Selecting Criteria for Comparison}

In this volume the data are presented in a manner similar to the method followed in De Jong 2000. As a very useful tool for linguistic description, the method used in Blanc 1970 is also followed here.

The emphasis again tends to be on differences between dialects, rather than shared characteristics. ${ }^{55} \mathrm{~A}$ selection of features which show up as dif-

\footnotetext{
55 For remarks on this issue, see De Jong 2000:31.
} 
ferences between dialects in the area is then represented in maps in the appendix of this volume. As parameters for comparison, the same features that were selected (from publications on surrounding dialects) to serve as criteria in De Jong 2000, have been used here. The purpose is to facilitate direct comparison with dialects of the northern littoral (described in De Jong 2000) and to this end the numbering of the paragraphs in the volume in hand runs parallel (with a few minor modifications) to the numbering used there.

This also implies that in some cases no information is given in some of the paragraphs due to the fact that such information was not available, or the situation is different in the dialects discussed in the volume in hand. For a discussion on the selection of criteria for comparison, see De Jong 2000:30-50.

In De Jong 2000 the identified area of transition (the 'continuum') between 'Bedouin' dialects of the type such as that spoken in the Negev (the dialect of the Dullām, described in Blanc 1970) was reflected in the gradual disappearance of certain 'Bedouin' dialectal features. The selection of criteria was in part also directed at illustrating the presence of such a continuum. For the sake of comparability, I have used the same criteria here, and although they do not produce the same or another type of transitional area of Bedouin vs non-Bedouin (or 'less Bedouin'), most of these criteria proved useful to illustrate differences in the central and southern area as well.

\section{b. Method of Description}

The methods and terminology used in this study are the same as those used in De Jong 2000. For a succinct description of these, see ibid.:50-54. 



\section{A DESCRIPTION OF THE DIALECTS OF THE ǦBĀLIYYAH, AWLĀD SA'ĪD, ȘAWĀLHAH, GARĀRŠAH AND ḤAMĀḌAH WITH REMARKS ON THE DIALECTS OF THE HANĀDWAH AND 'LĒGĀT}

\section{INTRODUCTION}

In 1992 Tetsuo Nishio published a basic vocabulary of the dialect of the Ğbāliyyah tribe in the central south of Sinai. More recently Roy Bernabela of the University of Leiden sent me his BA-thesis (2009) which contains four highly entertaining $\dot{g} u \bar{l}$-stories recorded from Ğbāliy speakers near St Catherine's monastery. Many references in this chapter will be made to Nishio 1992 and I have also included remarks on data found in Bernabela 2009. We shall see that many of the information listed there for ĞbA is corroborated by the findings of the research lying at the basis of this chapter. Where differences do turn up, many of these can be ascribed to differences in interpretation of the phonological system and therefore also in methods of transcription. To refer to forms listed in Nishio 1992 I shall use my own phonological transcription (such as $\check{g}$ for $\mathrm{j}$, ̌̌ for $\int$, $\underline{\mathrm{d}}$ for ð, etc., except where differences - mainly in representations for vowelsbetween Nishio's transcription and my own may be relevant for a variety reasons, e.g. final $-\varepsilon$ has not been replaced by (in my transcription) $-i\left({ }^{\prime}\right)$, $-e\left({ }^{\prime}\right)$ or $-a$ and the vowels e or ə have not been replaced by $a$ or $i$, etc. Where phonological implications are connected to adaptations in transcriptions, these are expounded in accompanying lines.

In this chapter I hope to shed some more light on the questions that may have arisen from Nishio 1992, and additional material is presented including material on neighbouring dialects: the dialects spoken by the Awlād Sa'̄ìd, Șawālḥah and Garāršah. With some reservation, I have also added the dialect of the Hamāḍah to this group, which I have numbered as VII. Although there are some differences, these dialects show a large number of similarities justifying their treatment as one typological group. In addition, the chapter contains remarks on the Hanādwah, who are one of the families said to be of non-Bedouin origin living in Wādiy aț-Ṭur (just to the northeast of the town of aț-Tuur). 
I have not made recordings in the town of aț-Ṭur, ${ }^{1}$ since it is a mixing bowl of various Egyptian dialects from the mainland. ${ }^{2}$

For the sake of brevity, the dialects of the Ǧbāliyyah, Awlād Sa'īd, Șawālḥah, Garāršah and Hamāḍah will be collectively referred to as TwA (Ṭuwara Arabic). The dialect of the 'Lēgāt is not included in Twa here, although often (in other publications) the tribe of the 'Lēgāt is also regarded as part of the Tuwara (i.e. tribes inhabiting the region known as aț-Tūur). ${ }^{3}$

The 'Lēgāt are a relatively large tribe, and live on the Gulf of Suez and farther inland as direct neighbours with the much smaller tribe of Hamād̆ah. Their neighbours to the north are the Tarābīn of Rās Șadr. ${ }^{4}$ In a dialect-typological sense, their dialect takes up a middle position between the dialects of TwA and HnA on the one hand, and group VI on the other (see MDS plots in the appendix). The dialect of the 'Lēgāt, which is concluded to be a separate group (VIII) in this study, will be referred to as 'LA.

The dialect of the Mzēnah and that of the Baniy Wāṣil are treated separately in chapter II (as group VI). ${ }^{5}$

\footnotetext{
${ }^{1}$ Being the capital of the governorate South Sinai, a large proportion of its inhabitants are mainland Egyptians, who work there as civil servants.

${ }^{2}$ This is not to say that the dialectal varieties found there, or whatever has resulted so far from contact between the different varieties, would be uninteresting. A description of the linguistic dynamics found in this town would however deserve much more space than can be afforded in this study.

${ }^{3}$ Von Oppenheim 1942:156 mentions the tribes of Șawālhahah, 'Lēgāt, Ğbāliyyah and Mzēnah as parts of the Tuwara. For a brief summary of their history, see Von Oppenheim 1942:156-166. See also Maiberger 1984:139-149 on the different tribal collectives that inhabit the region of southern Sinai. Ibid.:156-157 mentions Baniy Wāṣil as an off-shoot of Baniy 'Ugbah of the Hiǧāz and as one of the oldest tribes of the Țūr area, having arrived there after the Hamādah.

${ }^{4}$ Although the dīrah of the Tarāain of Șadr borders directly on that of the 'Lēgāt to their south, the majority of Tarāāin live in the northern part in and around Rạas Ṣadr and Abuw Șwayrah leaving the southern part of Turbāniy territory (along the coast on the Gulf of Suez) near 'Lēgiy territory virtually uninhabited.

${ }^{5}$ I have concluded on linguistic grounds that the dialects of the southern part of Sinai (i.e. excluding group I dialects) can be assigned to three different groups.
} 


\section{Phonology}

\subsection{Consonants}

\subsubsection{Inventory of consonants}

The inventory of consonantal phonemes of TwWA, HnA and 'LA is identical with that of group VI (described in chapter II):

\begin{tabular}{|c|c|c|c|c|c|c|c|c|c|c|c|c|c|}
\hline & $\begin{array}{l}\text { bilabial } \\
\text { vl vd }\end{array}$ & $\begin{array}{l}\text { labdent. } \\
\text { vl vd }\end{array}$ & $\begin{array}{c}\text { alv } \\
\text { vl }\end{array}$ & $\begin{array}{c}\text { eolar } \\
\text { vd }\end{array}$ & & $\begin{array}{l}\text { dent. } \\
\text { vd }\end{array}$ & $\begin{array}{l}\text { postalv. } \\
\text { vl vd }\end{array}$ & $\begin{array}{l}\text { palatal } \\
\text { vl vd }\end{array}$ & $\begin{array}{l}\text { velar } \\
\text { vl vc }\end{array}$ & $\begin{array}{l}\text { uvul. } \\
\text { vl vd }\end{array}$ & & $\begin{array}{l}\text { ar. } \\
\text { vd }\end{array}$ & $\begin{array}{l}\text { laryng. } \\
\text { vl vd }\end{array}$ \\
\hline plosive & $\mathrm{b}$ & & $\mathrm{t}$ & d & & & & & $\mathrm{k}$ & (q) & & & (') \\
\hline emph. & & & $\mathrm{t}$ & & & & & & $\mathrm{k}^{*_{1}}$ & & & & \\
\hline nasal & $\mathrm{m}$ & & $\mathrm{n}$ & & & & & & & & & & \\
\hline fricative & & f & $\mathrm{s}$ & $\mathrm{z}$ & $\underline{\mathrm{t}}$ & $\underline{\mathrm{d}}$ & $(\check{z})$ & & $\mathrm{x}$ & & ḥ & c & $\mathrm{h}$ \\
\hline $\begin{array}{l}\text { emph. } \\
\text { affricate }\end{array}$ & & & ș & (z) & & $\underset{d}{d}$ & & & & & & & \\
\hline trill & & & & $r$ & & & & $\mathrm{~g}$ & & & & & \\
\hline emph. & & & & $(\mathrm{r})$ & & & & & & & & & \\
\hline lateral & & & & l & & & & & & & & & \\
\hline emph. & & & & $!$ & & & & & & & & & \\
\hline glides & w & & & & & & & $\mathrm{y}$ & & & & & \\
\hline
\end{tabular}

$\mathrm{vd}=$ voiced, $\mathrm{vl}=$ voiceless, emph. $=$ emphatic/velarized

*1 The greatest difference with the phoneme inventory of group I is the presence of both phonemes $/ \mathrm{k} /$ and $/ \mathrm{k} /$, which is also a feature of group II in the north (see De Jong 2000:248, 282-285) and of dialects of group VI. Like in MzA (see chapter II), a minimal pair $b \bar{e} t^{u} k$ - be $\bar{t}^{i} k$ (i.e. a strictly phonological representation being $\left.|b \bar{e} t k|-\mid b \bar{e} t k /\right)$ "your (sg. masc.—sg. fem.) house" isolates $/ \mathrm{k} /$ and $/ \mathrm{k} /$ as phonemes in TwA and also in HnA and in 'LA. ${ }^{6}$

\subsubsection{Interdental fricatives $/ \underline{t} /, / \underline{d} /$ and $/ \underline{d} /$}

Like in almost all Sinai dialects, reflexes of * $\underline{t}$ and ${ }^{*} \underline{d}$ are interdentals $\underline{t}$ and $\underline{d}$ (I.P.A. [ $\theta]$ and [ð] respectively). Examples listed below can be heard in all dialects discussed here.

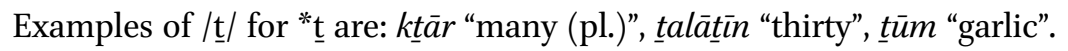

${ }^{6}$ The conclusion of vowelless personal pronominal suffixes is drawn form the fact that suffixation of these pronominals will result in consonant clusters, which then draw stress onto a directly preceding short vowel, e.g. wálad $+k>$ waládk "your (sg. masc.) son" and wálad $+k>$ waládk "your (sg. fem.) son" (see 2.1.1.1. and NOTE in 3.1.12.2.). This is in contrast to the pron. suffix $-k$ for the sg. masc. in the Nağdiy dialect of the Dawāgrah of the north, where a final cluster -Ck will not attract stress onto the directly preceding vowel, e.g. wáladk "your son", rabbna yikrimk "may our Lord have mercy on you" (see De Jong 2000:434-435 and 450-451). 


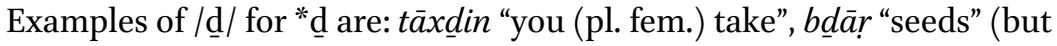
see remark below) and $\underline{d a} \bar{n}$ "ear".

There are also exceptions: "refrigerator" and "ice; snow" are with plosive $t$ (for * $\mathrm{t}$ ) in TwA and 'LA: tilläğah and talğ.

The reflex for * t may be $s$-mainly so in lexemes which must have been borrowed from or through a dialect whithout interdentals, like Cairene ${ }^{8}$ as in masalan "for instance", masal "(wise) saying", hădsih "accident", mêrūs "inherited" (see also remark in 1.2.4.1.), yisig bēhum "he trusts them",

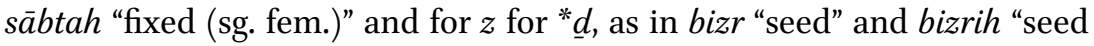
(n.u.)" (though pl. bdāâr! and budrah "seeds (like powder) from a palm tree" (the latter in HnA) and kaza "such and so".

Emphatic interdental $\underset{d}{d}$ (I.P.A. velarized [ə]) is the reflex of both *d and *d, e.g. (as the reflex of *d in) Ramadān "Ramadan", itnaddifhi" \# "you clean it (sg. fem.)", $\underline{d} \ddot{a} f$ "guest" and "úridha "its (sg. fem.) width" and (as a reflex for *d in) thäfid 'ilēh "you protect it" (but mahafüz!), xudriy "type of green tobacco", 'awad "compensation".

Like in group VI, $z$ is the current reflex in lexemes like mwazzaf "civil servant", zābit "officer", b-izzabt "precisely", binzabbit "we do a proper job", nizām "system". Some other examples are: btizhar "she becomes lucky", nazariytuk "your (critical) vision", biybawwizha "he ruins it (sg. fem.)", mazbüt "precise(ly)" and mahafüz "well-kept". 9

In TwA and HnA the sg. masc. demonstrative $(h \bar{a}-) \underline{d a} \sim \underline{d i}$ " "this (sg. masc.)" is not velarized. Also hā $\underline{d} a$ ( less frequent $\underline{d} a$ or $\left.\underline{d} i^{\prime}\right)$ in 'LA lacks velarization.

\subsubsection{Velar stops $/ k /$ and $/ g /$}

Like in all other dialects of Sinai, * $k$ and ${ }^{*} \mathrm{q}$ have unaffricated reflexes $k$ and $g$.

In TwA, HnA and also in 'LA $k$ and $k$ are heard and all have a minimal pair showing phonemic opposition $b \bar{e} t^{u} k$ "your (sg. masc.) house"- $b \bar{e} t t^{\prime} k$ "your (sg. fem.) house".

In HmA the suffix -kiy for the 2nd p. sg. fem. is also used (though not -ak for the sg. masc.!), but mainly when $\overline{\mathrm{v}}$ precedes, e.g. warākiy "behind you

\footnotetext{
7 For "freezer" I recorded flezzar in ȘwA.

${ }^{8}$ For the following examples in Cairene Arabic, see Hinds and Badawi 1986.

${ }^{9}$ For ĞbA Nishio 1992 reports d for * ${ }^{*}$ in bidr (p. 18 (III-16)), d in m(u)waddaf (p. $5^{8}$ (VIII-40) and hafad, yahafad (p. 96 (XIV-26)). The emphatic plosive de (pp. $5^{-6}$ (I-42)) is reported in ḍeḍi, ḍuụụ "breast" and in gaḍbān "angry" (p. 116 (XVI-22)).
} 
(sg. fem.)", fikiy "in you (sg. fem.)" and 'ilēkiy "on you (sg. fem)" (the latter $\sim$ 'ilik). In 'LA too this allomorph -kiy varies with $-k$ when $\overline{\mathrm{v}}$ precedes.

In the word "cigarette" we hear $g$ rather than $\check{g}$ (recorded in GrA, ǦbA and BWA): sgārah (pl. sagāyir).

\subsubsection{Post alveolar affricate /ğ/}

The fricative allophone $\check{z}$ (I.P.A. [3], i.e. without the initial full closure of [d]) for / $\check{g} /$ is very frequent in TwA. ${ }^{10}$ It was not heard in HnA or 'LA.

\subsubsection{Emphatic alveolar stop /t!/}

Glottalization of the emphatic $t$ was not noticed as a characteristic of TwA, HnA or 'LA.

\subsubsection{Glottal stop (hamzah)}

The reflex for * in the verb ask is ' in TwA, HnA and 'LA sa'al, yas 'al."

In * $r a$ 's "head", loss of ' is complemented by lengthening the preceding vowel rās in all dialects. The pl. is rūs in ĞbA, ȘwA, HnA and 'LA, but pl. ryūs in GrA, ASA and HmA.

Reflexes of the pl. pattern $\mathrm{CiCaC}$ (or $\mathrm{CuCaC}$ ) are often áCCaC in ȘwA, GrA, ASA and HnA (e.g. áhgan "injections", ášnat "suitcases", árkab "knees", ánxar "noses"). The hamzah that precedes this initial $a$ - (e.g. \# 'anxar) is dropped when it directly follows a consonant, e.g. (i)lášnat "the suitcases".

In ĞbA I have only recorded šnaț as in hāt iššnáț "get the suitcases!", (i)li náb "the grapes", (i)lihgán "the injections". ${ }^{22}$ Similar forms are current in LA.

${ }^{10}$ Bernabela 2009 transcribes $\check{z}$ throughout his texts for ĞbA.

1 Also reported for ĞbA in Nishio 1992:73-74 (X-9).

${ }^{12}$ For ǦbA Nishio 1992:38 (V-35) recorded (šanțāt ) šonaț as pl. for šanța. Similarly (p. $36(\mathrm{~V}-25)$ ) plurals are (šōkāt ) šowak, (p. 34 (V-9) (pl. of golle) golal "water jars", (pl. of ḥoṣa) (ḥōṣāt ) ḥowaṣ, (p. 34 (V-9)) (known in other parts of Sinai as xūṣah) "knife", (pl. of ḥalle) (ḥallāt ) helal (p. 34 (V-10) "cooking pot", nogaṭ (pl. of nogṭa) (p. 143 (XX-11)) "point, dot" etc., but lōda "room" (with (originally) the article incorporated in the stem as a first radical!) and the pl. form coined on the pattern aCCaC alwad (p. 26 (IV-6)). Of these pl. forms only the last strikes me as proper ĞbA. The other plurals of the pattern CICaC are likely to be K-forms; such plurals are also current in e.g. Cairene. 


\subsubsection{Secondary velarization}

There is a clear lack of velarization in ASA, ȘwA, GrA and HnA forms rikbih, árkab (pl. rkab in ḤmA and ĞbA) "knee(s)". All dialects discussed in this chapter have a pl. demonstrative dill (-ih) "these" (although $\sim \underline{d u m}$ for pl. masc.) and also the sg. masc. demonstrative is without velarization: $(h \bar{a}-) \underline{d a} \sim \underline{d i}$ " this".

Velarization spreads into the long $\bar{a}$ in kuḅba $\bar{a}$ ih in all dialects, except in ĞbA and HnA (there kubbāyih) and in all dialects, except 'LA, the pl. forms of kitīir "much, many" and kibir "big; old" both lack velarization: forms are $k \underline{t a} \bar{r}$ and $k b \bar{a} r\left(\bar{a}\right.$ is just below I.P.A. [ $\left.\left.\varepsilon^{\star}\right]\right)$ and also kamān "also" is not velarized. In 'LA, however, the pl. for kibir is velarized, while the pl. for kititr is not: 'LA forms are kbạạr (I.P.A. [kbarr]) and ktä̈r (I.P.A. [kӨærr]).

Imperatives of the verbs "eat" and "take" are clearly velarized, i.e. and $(u) k u l,(u) k l i y$, etc. and similarly so in 'LA, but there without the initial $u$-.

Imperfect forms vary (per dialect) in degree of velarization, but all dialects (though in ASA yākul yākil) have $u$ as a base vowel: yāxud, yākul. In 'LA velarization is clear in yậkul and yạxụd (but also yākil and yāxid were recorded there).

The other forms listed for group VI may also be heard in TwA and HnA. Some additional examples for TwA and HnA are: ištágal "he worked", yištáğluw "they work", salaxnāh "we slaughtered it", gāl "say", ramlah "sand", gal ḅān "poor, wretched", burdugāl "orange[s]" and xālı "my uncle". In 'LA there are forms like gāl, ygū! "say", xa!l āha "he let her", txa!l hin "you let them (fem.)", arRamlah "the Sands (area south of the Tìh escarpment)", gabil "before", naxál "palm trees", gaḷ̣̣̂ah "thick (sg. fem.)", šug "genitive marker".

\subsubsection{Liquids ! and ?}

Generally, like in group I, the sequence $\bar{a} r$ will be velarized (I.P.A. [a:r]), unless $i$ follows within morpheme boundaries (see also De Jong 2000:6567 ). An exception is the pl. forms for kițir "many" and kibïr "big; old" which are unvelarized $k t \underline{\ddot{a} r}$ and $k b \bar{a} r$ in TwwA and HnA (i.e. ending in I.P.A. [a:r]), but (unvelarized) kt $\underline{\ddot{a} r}$ and (velarized) $k b \bar{a} \bar{r}$ in 'LA.

Examples with velarized $\bar{a} r$ listed for group VI may also be heard in TwA and HnA. Some additional examples are: 'fār "dust", zwārah "(annual) visit to the tomb of a wiliy", zyārah "visit", dāruh "his house", fār "rats; mice" and ǧizzār "butcher", sgārah "cigarette". Some "LA examples are fār, dār, 
Badārah "name of a neighbouring tribe", 'amār "enough (said to politely refuse tea or coffee)", nār "fire", nahār "daytime".

Like in group VI, velarization is prevented by (even when elided) $i$ following an $\bar{a} r$ sequence within morpheme boundaries, e.g.: wārid "having watered" and wārdih "having watered (sg. fem.)", šārib, (pl.) šuwārib "lip", imbārih "yesterday”, bārdih "cold (sg. fem.)", bikāriğ "coffee pots”. Examples in 'LA are: sārih "having taken the small cattle out to graze, 'ārif "knowing”, hạarit "ploughing", šārib "lip" and taǧārib "experiences".

Also sequences $r \bar{a}$ are generally not velarized when (vanished) $i$ follows in the next syllable within morpheme boundaries or precedes. Examples listed for group VI are also heard in TwA and HnA. More examples are: farāšḷ̆ "loaves of bread baked on the šāz (= șāğ)", zrā'ah "agriculture", darāhim "money", $\underline{d} \bar{r}^{c}$ (< $\left.\left.{ }^{*} \underline{d} i r \bar{a}\right)^{c}\right)$ "arm", mifțirät or mifiträ̀ "having eaten breakfast (pl. fem.)" and also (in ASA) zērān, pl. of zōr "throat". Examples in 'LA are: iğrān "feet", ${ }^{13}$ răìy "herdsman", Garārših "name of tribe".

\subsubsection{Nasal $n$}

No remarks.

\subsubsection{Devoicing of final voiced stops, liquids and nasals in pause}

Devoicing of final voiced stops liquids and nasals in pause is regular in TwA, HnA and 'LA.

\subsection{Vowels}

\subsubsection{Inventory of vowel phonemes}

The inventory for vowel phonemes in TwA, HnA and 'LA contains three short vowels and five long vowels:

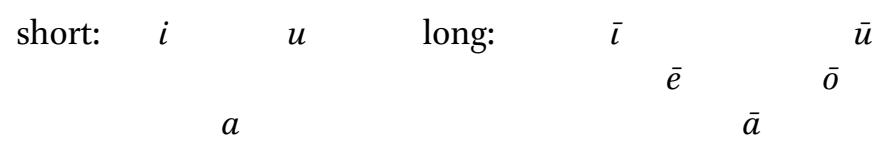

\footnotetext{
${ }^{13} i g ̆ r$, pl. iğrān "foot". The root '-ğ-r is also current for "foot" in dialects of the Šām, see e.g. Hava 1982.
} 


\subsubsection{Long vowels}

\subsubsection{Allophones of long vowels $\overline{\mathrm{e}}$ and $\overline{\mathrm{i}}$}

Unlike in group I dialects, and like in group VI, phonetic overlapping of $/ \overline{\mathrm{e}} /$ and $/ \overline{\mathbf{l}} /$ is rare in TwA, HnA and 'LA.

The phonemic status of $/ \overline{\mathrm{e}} /$ and $/ \overline{\mathrm{i}} /$ can be established with the same minimal pairs as in group VI.

A difference with group VI is that diphthong *ay has also been monophthongized to $/ \overline{\mathrm{e}} /$, even in positions preceded by emphatics or back spirants (see also 1.2.4.).

The risk of homophonic clash of low reflexes of *ay and high realizations of /ā/ is largely avoided; ${ }^{14}$ low realizations of / $/ \bar{e} /$ occur after emphatics or back spirants and are then near I.P.A. [ $\left.\varepsilon_{\Sigma}\right]$ (indicated here as $\bar{a}$, e.g. xär "good", hätt "walls"), but realizations of /ā/ following emphatics tend to be near $[\mathrm{a}$ ] $]$ and $/ \overline{\mathrm{a}} /$ following back spirants (if not velarized, like in e.g. $x \bar{a} f$ [xa:f] "he feared" and $\dot{g} \bar{a} b$ [ya:b] "he was absent") are nearer to [a:], e.g. hâal "state" and 'àm "he floated".

\subsubsection{Allophones of long vowels $\overline{\mathrm{o}}$ and $\overline{\mathrm{u}}$}

Like diphthong *ay, diphthong *aw has been monopghthongized to $/ \overline{0} /$, even when it is preceded by emphatics or back spirants, (see also 1.2.4.).

The minimal pairs for group VI also isolate phonemes in TwA, HnA and 'LA.

In positions influenced by velarization, $/ \overline{\mathrm{u}} /$ is realized relatively low, near I.P.A. [o:], but / $\overline{\mathbf{o}} /$ is realized even lower: in that case $/ \overline{\mathbf{o}} /$ tends to be lowered to near I.P.A. [э:], e.g. xo:f "fear" and ho:l "year".

In verbs with $w \bar{a} w$ as $\mathrm{C}_{1}$ the diphthong $a w$ has usually been monophthongized, as is illustrated in e.g. nōgaf "we stand" and also tōgid "you light" (both in TwA, HnA and 'LA). In all dialects discussed here the imperative of $w^{\text {' }-y}$ "pay attention, take heed" has an initial diphthong: aw' in rūskin/ ryūskin "mind (pl. fem.) your heads!".

\subsubsection{Allophones of long vowel ā}

The long vowel $\bar{a}$ may have a realization as high as somewhere between I.P.A. [æ:] and [ع:]. This occurs in neutral positions and is not dependant on following by $i$ or $\bar{\imath}$ in the next syllable (but within morpheme boundaries), e.g. firšăhah "loaf of bread from a șăğ" and also the realization of /ā/ in zimān "in the past", iyyām "days", hayāh "life" and siyāl (raised $a$ in

\footnotetext{
${ }^{14}$ The word 'avoided' is not intended to imply a conscious choice by speakers.
} 
sayāl) "acacia tree". Realizations of /ā/ are not noticeably different when $i$ follows in the next syllable (within morpheme boundaries), as in ysābig "he races".

$\bar{a}$ in velarized environments is realized near I.P.A. [a:], as in $r \bar{a} s \bar{s}$ "my head", dārī "my house" and ǧărī "my neighbour".

The difference in realizations of $\bar{a}$ in $r \bar{a} s \bar{\imath}$ and rāsiy may be explained by recognizing either $/ \bar{a} /$ and velarized $/ \bar{a} /$ as separate phonemes, or $/ \mathrm{r} /$ and velarized $/ \mathrm{r} /$ as separate phonemes. A similar difference in the realization of $\bar{a}$ (and $r$ ) is found in e.g. the pair fāris (I.P.A. ['fæ:rıs]) "knight" - fār (I.P.A. [fa:r] "mouse; rat". ${ }^{15}$

\subsubsection{Shortening of long vowels}

Like in group I dialects, shortening of unstressed long vowels is a characteristic of allegro style of speech in TwA, HnA and 'LA as well.

\subsubsection{Short vowels}

\subsubsection{Isolating phonemes $/ i /, / u /$ and $/ a /$}

Minimal pairs producing the phonemes $/ \mathrm{i} /, \mathrm{u} / \mathrm{and} / \mathrm{a} / \mathrm{in} \mathrm{TwA}, \mathrm{HnA}$ and 'LA are listed below. In a number of (near) minimal pairs /i/ and / $\mathrm{u} / \mathrm{can}$ be isolated as phonemes, but these are only found in closed syllables:

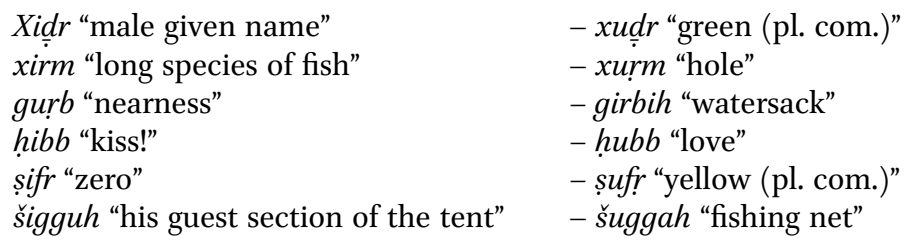

Minimal pairs to isolate /a/ on the one hand, and /i/ or / $/ \mathrm{l}$ on the other hand are much easier to find, e.g.:
habb "grain"
- hubb "love"
hatt "he placed"
- hutt "place!"
šadd "he pulled"
- šidd! "pull!"

An additional minimal pair is (verbal measure 4) yin im "bestow favours"(verbal measure 1) yun'um "become soft".

15 Bernabela 2009:13 gives IPA [ $\left.\varepsilon^{\star}\right]$ in neutral environments, [a:] following ' and $h$, and [a: $]$ in velarized environments. 


\subsubsection{Phonetic factors influencing the quality of I}

In principle, distribution of short high vowels $i$ and $u$ is governed by the same rules as described for group I in De Jong 2000:70-74: a short high vowel tends to be $u$ in velarized and/or labial environment, otherwise $i$.

In the pl. com. forms for colours and physical defects all dialects show $\mathrm{C}_{1} \mathrm{uC}_{2} \mathrm{C}_{3}$ as the pattern, i.e. like in MzA of group VI. Only in ĞbA both 'imy and 'umy were recorded for "blind". ${ }^{6}$

All dialects of group VII (except ASA and HmA, see 3.2.2.3.) have only $u$ as imperfect vowel of primae hamzah verbs: $y \bar{a} x u \underline{d}$ and $y \bar{a} k u l$ "he takes" and "he eats". In 'LA imperfect forms both with $i$ as well as $u$ were heard.

Also $u$ in the sg. masc. imperative: $k u l$ and $x u d$ "eat!" and "take!" (resp.) and clear velarization, caused by the 'vanished' $u:{ }^{17} x$ diy and $k$ liy (sg. fem.), $x \underline{d u w}$ and $k l u w$ (pl. masc.) and $x \underline{\text { din }}$ and klin (pl. fem.).

Imperfect forms of mediae geminatae verbs recorded in group VII corroborate the rule formulated in De Jong 2000:72-73: $u$ appears near primary and (potentially) secondary emphatics, while $i$ appears in neutral environments.

Examples listed for group VI may be heard with the same high vowels in TwA and HnA. Some additional examples are: ( $u$ in) yruṣs "pile up", yrugg "flatten", ybuxx "spit", yxurr? "leak water", yhukk "rub" and ( $i$ in) ydizz "push", yhiğğ "run away", y ǧizz "shear (wool of sheep)", yǧiss "test", y izz "ala "hurt", yšinn "sizzle (in hot oil)", yhill "be haläl", yğiff "become dry" and yšigg "split". ${ }^{8}$

\subsubsection{Morphological conditioning of the short high vowel}

Morphological conditioning of the high vowel is like in group VI.

The exception to morphological conditioning noticed in group VI is also in group VII found in some forms coloured by the extreme velarization caused by the pronominal suffix $-k$ or $-u k$. Examples in group VII are (a measure 1 medial geminate verb) wala yhumminu “don't let it bother

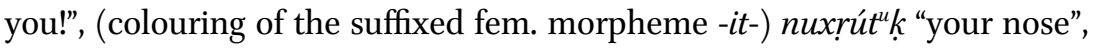
šug $l^{u} t^{u} k$ "yours (sg. fem.)", and (colouring of $i$ in the act. participle of measure 3) ana mkāwúnk. "I'm fighting you".

${ }_{16}$ Nishio 1992:2 (I-9) reports ' $m \bar{i}$ (which must be a misprint for $m^{\text {c}} \overline{1}$ ) for ĞbA.

${ }_{17}$ See remarks in Blanc 1970:127-128.

${ }^{18}$ It is not clear why ydugg "punch", ylugg "hit" is usually with $u$, while yšigg is with $i$, but similar variation was noticed for the high vowel in the contiguity of $k$ (e.g. $y$ fikk and yfukk "untie", but in different dialects) see De Jong 2000:73-74. Cf. also the verb katt, and the imperfect is then ykitt or ykutt "go downstream in a wadi", as reported for group I dialects in Chapter III, 1.2.3.2. 


\subsubsection{Allophones of short vowels}

Allophones of short vowels do not differ much from what was described for group I in De Jong 2000:74-77, although some allophones, notably of /a/, may appear in environments different-or are more frequent, or less frequent-from those in group $\mathrm{I}$.

\subsection{Allophones of /i/}

Allophones of /i/ are like those described for group VI.

\subsection{Allophones of $/ u /$}

Allophones of /u/ are like those described for group VI.

\subsection{Allophones of $/ a /$}

1.2.3.4.3.1. /a/ in non-raised positions

Allophones of /a/ in non-raised positions are like those described for group VI.

\subsection{Raising of $\left({ }^{*}\right) / \mathrm{a} /$ preceding long stressed vowels}

Like in group VI, $a$ is raised in a great number of stress-preceding positions in TwA, HnA and also 'LA:

- preceding stressed Cì: ǧirìd "palm leaves”, midīnih "town”, digìg "dough”, xifíf "light", 'irīs "bridegroom", hịìd "parrot fish", and also 'Ilíy "male given name *'Alı̈" and verb forms nisit "I forgot", ligit "I found" and even 1st p. sg. com. imperfect forms of mediae $y \bar{a}^{\prime}$ verbs išll "I carry" irìd "I want" (see remark * below).

Such raising is not inhibited by any phonetic factors, but is optional, as may be concluded from many examples which show $a$ in such positions as well, e.g. kațīr "much, many", kabìr "big; old", taxīn "thick", tawīl "long, tall", dagīg "dough", xamis "Thursday", hadìd "iron".

- no instances were recorded of raised a preceding stressed CCī: batțīx "watermelon", sakkinah "knife", barmil "drum", Katrin "(St.) Catherine" and also garnit "octopus" (similarly in 'LA).

- (preceding stressed Cē): 'ilèḳum "on you (pl. masc.)", ligēnāh "we found him", mišèt "he walked", fidèt "I sacrificed". In 'LA raising of $a$ preceding $\bar{e}$ in the suffixed preposition 'ala was not observed: 'aleha "on her" (but there was raising in 'ilúh, see remark ${ }^{* 4}$ in 3.1.16.).

- (preceding CCē) middèt "I stretched", suwwēt "I did/made" and istamirrēna "we continued", ista iddèt "I prepared". 9

19 Such raising is not consistently reported for ĞbA in Nishio 1992. Among isolated examples there, however, is: səwwēt "I made" (p. 99 (XIV-37). 
- (preceding stressed Cā): midāris "schools", misāfih "distance", filāyik ișsêd "(small) fishing boats (with sails)", bihāyim "cattle (pl.)", dibāyih "animals for slaughter", digāyig "minutes". In 'LA such raising also takes place (but is less frequent than in TwA and HnA): gibayyil "tribes", but manātig "regions", mašāyix "sheikhs" and ğawālig "carpets".

- (preceding stressed CCā): niğğăr "carpenter", tillāğah "fridge", zihgānīn "fed up (pl. masc.)", šigrā "white (sg. fem.)", turmā "gap-toothed (sg. fem.)", In 'LA such raising occurs mainly in neutral environments: kislān "lazy", wiğ ān "suffering pain" and suwwāg "driver", but 'ațšān "thirsty", galțān "wrong", galbān "poor, destitute", fallāh "farmer" and also (but without apparent phonetic factors inhibiting raising) ša 's ān "having eaten one's fill". ${ }^{20}$

- (preceding stressed $\bar{u}$ ): buxūr "incense", xurūf "lamb", ğinūb ğunūb "south" and (with initial *hamzah) ubüy "my father" and uxüy "my brother", and also 1st p. sg. com. imperfect forms of mediae $w \bar{a} w$ verbs ugūm "I get up", ugūl "I say" (see remark * below). Similar examples in 'LA are gu 'üd "young male camel", fuțūr "breakfast", lugūḥ "pregnant (of a camel)", ubūh "his father".

Like raising of $a$ preceding $\bar{l}$, raising of $a$ preceding $\bar{u}$ is optional; forms like 'ağuzz "old lady", ğanūb "south", yahūd "Jews" may also be heard. In 'LA: rasūl "Prophet", hamūlah "animal led to a party for slaughter as a present".

- (preceding stressed a): ma tihatkúm̧š "not under you", ma tị̆áthiš "not under her", 'iláy "on me", ğimál"k, "your camel" and in 'LA ğimál "camel".

- (preceding stressed u): uxušš "I enter", uguș̣ "I follow tracks" and in 'LA "ilúh "on him" (see remark ${ }^{* 4}$ in 3.1.16.).

- (preceding stressed $i$, verb forms) išidd "I pull", iliff "I wrap" (see remark * below).

In TwA and HnA stress in perfect forms of verbal measures $n-1$ and $1-t$ is inwákal, ittáfag, etc. (see 2.1.1.1.). The article is not stressed in a sequence $\mathrm{ilCvCv}(+)$ (see 2.1.1.).

${ }^{20}$ Some examples of such raising reported for ĞbA in Nishio 1992 are: rijjāl "man" (p. 48 (VII-11)), fillāh "peasant, farmer" (p. 59 (VIII-44)), keslān "lazy" (p. 110 (XV-31)), defyān "warm" (p. 123 (XVII-32)), telfān "slender" (p. 125 (XX-25)) and wusxān "dirty" (p. $15^{2}$ (XXI-3o)), but no raising in hallāg "barber", najjār "carpenter", ḥaddād "smith" (p. $5^{8}$ (VIII-37, 38, 39)), țayyāra "aeroplane", barrād "teapot" (p. 99 (XIV-37)), gaḍ̂ān "angry" (with ḍ!) (p. 116 (XVI-22)) and makkār "cunning" (p. 148 (XXI-8). 
In 'LA stress in verbal measures $n-1$ and 1- $t$ is like in group TwA and HnA: inwákal, ittáfag, but in 'LA the article-like in groups I and VI-is stressable in a sequence $\operatorname{alCvCv}(+)$, e.g. álğimal "the camel" and áddawa "the medicine".

Again like in groups I and VI, when $a$ follows stressed $i$ in closed syllable, it is raised in TwA, HnA and 'LA, as in imperfects of measures $n-1$ and 1-t: yíndirib "he is beaten", yíttifig "he agrees". ${ }^{21}$

* Forms like axušš, aḥuțt, ašidd, aliff etc. may also be heard in ȚwA, $\mathrm{HnA}$ and 'LA, but it is not possible to conclude here whether raising of $a$ (> uhutt, išidd, etc.) is optional, or whether forms without raising are actually loans from a dialect where such raising does not take place (like e.g. Cairene). The same holds for variation in forms like ugūm-agūm "I rise" and išll-ašll "I carry".

1.2.3.4.3.3. Raising of the feminine morpheme $(\mathrm{T})$

The $a$ of the fem. morpheme is regularly raised in neutral environments and reaches a phonetic value near I.P.A. [lh]. ${ }^{22}$

Such raising is basically a pausal phenomenon. Examples are: . ilká akah diy bya'ağinha 'ağin mazbūt xāliṣ "(for) this ka'akah he kneads the dough extremely well", tíšluh šwayyah nihā w šwayyah nihä bitkūn il'arid̄... suxnat "you take it out, a bit here and a bit here (i.e. there) and the ground will have become hot".

Examples with raising in pause hilwah hilwah bitnadd filmi dih ... "good, good, it (sg. fem.) cleans the stomach" and lamma btínhišiy tamiṛ ... bingūl 'alēha šannih "when it is stuffed with dates ... we call it a basket". Examples

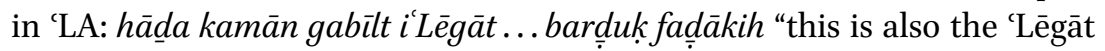
tribe... there too" and 'irf aḍ that the guest came from far, that he had come from another land."

In velarized environments such raising does not take place, e.g. ' $a$ lhäțah \# "on the wall”, nğạrah \# "carpentry". txal!̣ha galịdah \# "you make (lit. let be) it (sg. fem.) thick", nafs ilgișah \# "the same story".

\footnotetext{
${ }^{21}$ And like in group VI, in the verb forms yíndirib and yittifig, the raised $a$ will again 'surface' as $a$ when in closed syllables, e.g. yindárb́bu and yittáfguw, see also 3.2.3.1.1.

${ }^{22}$ Nishio 1992:XV reports 'imālah up to I.P.A. $[\varepsilon]$ in ĞbA. My impression was that it could reach up to $[1]$ in ĞbA, and often with a following glottal stop when final $[\varepsilon]$ represented final $-\bar{a}$ or $-\bar{a}^{3}$.
} 
In TwA and HnA raising is not inhibited by the pharyngeals 'and $h$, , e.g. wās ih \# "wide (sg. fem.)", sab'ih \# "seven", ilFāthị \# "the Fātihaha sūrah", dibihinih "animal for slaughter".

\subsubsection{Prosodic lengthening of short vowels}

To express extra emphasis, such as on long durations of time, long distances, great quantities and the like, speakers often prosodically lengthen short vowels. Examples are: la ha:dd sanah xamsih "(I was in school all the time) until the fifth year" and iysallūh 'ala nnār kidiy lamma: yanšaf "they cook it over the fire like this (all the time) until it dries".

\subsubsection{Long vowels and diphthongs}

\subsubsection{Monophthongization of diphthongs *ay and *aw}

In positions not influenced by velarization, or preceded by $\mathrm{X}$, older diphthongs *ay and *aw have in most cases become monophthongal $\bar{e}$ and $\bar{o}$ with realizations near I.P.A. [e:] and [o:].

Examples of /ē/ for *ay are: itnēn "two", bēn "between", lèlih "evening", sēl "flood", ğwēl (dim. of $\check{g} \bar{a} l)$ "little side" and examples for $\bar{o}$ for *aw are mōt "death", yōm "day", fōg "above”, sōdíy "black (sg. fem.)", gōṃah "(manner of) standing up".

When *ay and *aw are preceded by $\mathrm{X}$ or velarized consonants, they have been monophthongized to be $/ \overline{\mathrm{e}} /$ and $/ \overline{\mathrm{o}} /$ as well, but are usually realized a little lower than I.P.A. [e:] and [o:], just above [ع:] and [o:].

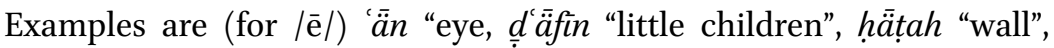
$x \bar{a} r$ "good", șä d "hunting", d̦ä́f "guest", țär "birds", and verbs hatțǟna "we placed" and ištaränna "we bought" and (for /ō/) hos:l "year", 's:dah "male given name 'Ōdah", xo:f "fear", șott "sound; voice", though when $h$ precedes, $/ \overline{\mathrm{e}} /$ or $/ \overline{\mathrm{o}} /$, it is near I.P.A. [e:] and [o:] (resp.), as in Abuw Hēb "name of a snake charmer (of the Awlād Sa'̄ì)" and hōdağ "camel litter (formerly used for the bride in a wedding procession)".

In a few cases the diphthong *aw has a /ē/ reflex: mēğùd (though mawğ $\bar{u} d$, root $w$ - $\breve{g}-d$ ) "present", mērūs "inherited" (root $w$-r-te , see remark in 1.1.2.) and also mẹrakah (root $w$-r-k) "leather riding cushion supporting the lower leg".

In some cases monophthongization in neutral environments has not taken place, mawğūd "present (adj.)", aw'a "watch out!" ${ }^{23}$ and also taybis

${ }^{23}$ In SwA, ASA and HnA aw'a is conjugated: aw'a tans!, aw'iy tansiy!, etc. "don't you forget!" In the other dialects it was left unconjugated for number and gender, e.g. aw'a tansin "don't you (pl. fem.) forget". 
"drying". The advantage is that arrangement of root consonants in the various morphological patterns has remained transparent.

In 'LA the form zraygān "dark-coloured thoroughbred camel" was recorded, which is probably a loan from group I type dialects. ${ }^{24}$

The suffixed preposition lay "to me" and also bay "with me" are actually better interpreted as lay $+y$ and bay $+y$.

\subsubsection{Isolating long vowels $/ \bar{\imath} /, / \bar{u} /, / \bar{a} /, / \bar{e} /$ and $/ \bar{o} /$ as phonemes}

Phonetic overlapping of $/ \overline{\mathrm{e}} /$ and $/ \overline{\mathrm{l}} /$ in neutral environments is not characteristic of TwA, HnA or 'LA.

Minimal pairs to isolate phonemes in group VI also work here:

dèr "monastery" - dìr "turn (trans.)!"—dūr "turn (intrans.)!"-dōr "floor (in a building)" - dār "house"

ǧībuh "bring it!"—ğèbuh "his pocket"—ǧābuh "he brought it" gōm "enemy tribe"—gūm "get up!"

Suffixed prepositions lay "to me", 'alay "on me" and fay "in me" are actually better interpreted as final $a y+y$; fayy must have been formed in analogy to the former two forms.

In law "if" and aw "or" the diphthong has remained intact.

\subsubsection{Allophones of $\bar{a}$}

Like in the dialect of the Tarābīn of group I, $\bar{a}$ in neutral surroundings is realized as near I.P.A. [E:]. Unlike Turbāniy, however, $\bar{a}$ in open syllable and neutral surroundings does not need Ci following within morpheme boundaries for such I.P.A. values to be reached.

In $\mathrm{MzA}$ this $\left[\varepsilon^{*}\right]$ for $\bar{a}$ is reached also when āC is morpheme-final, e.g.

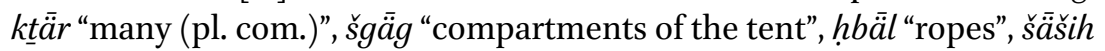
"screen" and also wäḥid "one", särhih "out grazing (goats and sheep)", nä gti "my she-camel".

\subsubsection{Reflexes of final *-ā'(')}

Like in group VI, the reflex of final ${ }^{*}-\bar{a}$ in neutral environments in TwA and HnA is often $-i$. Like in group VI, stress will be on the vowel of a heavy sequence that precedes, but in in group VII this inludes vowels that were originally anaptyctics and which have become part of the morphophonemic base.

\footnotetext{
${ }^{24}$ See Stewart 1990:286 (glossary). A wạahạn is a light-coloured thoroughbred hecamel, see ibid. 276. A clue for these forms to be of group I origin is the hypochoristic -ān suffix in these names, see De Jong 2000:153.
} 
Another difference is stress in a sequence $\mathrm{CaCa}(\mathrm{C})$ : $\mathrm{Cá} \mathrm{Ca}(\mathrm{C})$ in $\mathrm{VI}$ and CaCá(C) in VII. Examples of such differences in stress are:

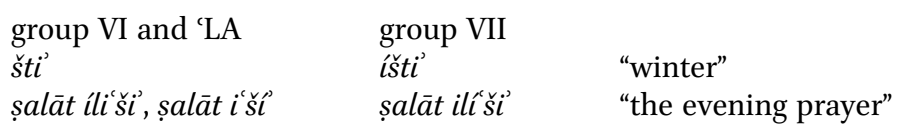

Group VI 'iší', group VII and 'LA 'áši * "dinner"

* When $a$ directly precedes the reflex of final * $-\bar{a}\left({ }^{\prime}\right)$ in open syllable, it is usually not raised. ${ }^{25}$ More often, forms are like il'áša', ilgáda'. Forms with raising 'áši', gáde' were recorded in pause and only in GrA and ȘwA. Unraised forms ǵáda' and 'áša' were heard in sandhi.

Other recorded examples with raised reflexes of final $-\bar{a}\left({ }^{\prime}\right)$ are: if ' $i$ ' "viper", Wādiy Ísli' (stressed on initial I-) "Wādiy Isla" ǧi "he came", ilbunn di ' "these coffeebeans", tižibhi' "you get it (sg. fem.)", 'ala gadd ḥâlni' "as much as we can afford", ifțarni' "we had breakfast". Comparable examples in 'LA are: gri', (i)líf 'ih and also (i)líf 'iy "the viper", álwalad di "this boy", ğambhi' "next to her", biddni' "we want" and ilikrih "the wages".

Reflexes of final ${ }^{*}-\bar{a}\left({ }^{\prime}\right)$ preceded by velarized consonants are not raised, have remained long and are often cut off-especially in pause-by a glottal stop. Examples are: (sg. fem. forms of colours) xaḍa $r\left({ }^{\prime}\right)$ "green", $b \bar{e} \underline{d} \bar{a}($ ') "white" and (optionally) raised $a$ in syllable preceding final $\bar{a}$ in the examples zirgā(') "black (lit. blue)", himrāa(') "red" and șifrā(') "yellow". Similarly, sg. fem. forms of physical defects are hamg $\bar{a}($ (') "stupid", tarmā(') "gap-toothed". Such examples are also available for 'LA.

When no phonetic factors interfere, raising of final ${ }^{*}-\bar{a}(')$ in sg. fem. forms of colours and physical defects will reach (stressed) -íy, as in e.g. (colours) sōdíy "black; bad", šaḥabíy "sand-coloured", gabšíy "dark" and (physical defects) ḥolíy "cross-eyed", hablíy "dim-witted”, 'arž́xy "limping (sg. fem.)", 'amyíy "blind" and šōlíy "left-handed". Such examples are also found in 'LA.

N.B. "here" is nihā(') or nihāniy in TwA, HnA and 'LA, but also híniy was recorded in ȘwA, ASA, HnA, (only once in) ḤmA and K-form hina or hínih in all dialects.

\footnotetext{
${ }^{25}$ In group I raising of final $-\bar{a}\left({ }^{\prime}\right)$ is also prevented by $a$ directly preceding in open syllable, see Blanc 1970:124 (13) and De Jong 2000:82.
} 
In dialects of group I raising (there to final -iy) is inhibited by (underlying) $a$ preceding in open syllable. ${ }^{26}$ In group VII raising to $-i$ tends to be prevented by $a$ preceding in open syllable (see remark * above in 1.2.4.4.). Examples are: iddáwa' "the medicine", issáma" "the sky", (verb forms) fáda" "he sacrificed", máša' "he walked", sáwa' "together", istáwa' "it became cooked" and also ána' "I".

In 'LA some examples are: áddawa "the medicine", ál'aša "the dinner", máša' and ána.

The forms with raised final ${ }^{*}-\bar{a}(>-i)$ do not only occur in pause, but also in sentence-medial positions. Such raising is therefore concluded to have led to morphological restructuring, e.g. ịna ittaṣalni buh "we contacted him", hatta lif 'i ma tagdarš tuktulhi' "even the viper you cannot kill".

The (often unreleased) glottal stop following the final vowel is not only regular when this vowel is stressed, but occurs also when it is unstressed.

When suffixed, raising in the verb form ğ $i$ ' "he came" will be absent, e.g. law $g ̌ \bar{a}^{u} k$ dixil "if somebody comes to you as a daxil". ${ }^{27}$ Similarly, when $k r i$ ' is suffixed, final $-i$ ' will be $-\bar{a}+$, e.g. $k r a \bar{h}$ "his wages" and $k r \bar{a}^{u} k$ "your wages" (example from 'LA).

\subsubsection{Allophones of long vowels $\overline{\mathrm{e}}, \overline{\mathrm{l}}, \overline{\mathrm{o}}$, and $\overline{\mathrm{u}}$}

\subsection{Lowering effect of preceding emphatics on $\overline{\mathrm{l}}$ and $\overline{\mathrm{u}}$}

Primary and secondary emphatics will lower the phonetic value of following $\overline{\mathrm{l}}$ and $\overline{\mathrm{u}}$ towards (resp.) I.P.A. [e:] and [o:] and like in group VI such lowering is clearer in the case of following $\overline{\mathrm{u}}$; with following $\overline{\mathrm{i}}$ it is less clear, but an on-glide is clearly audible.

Reflexes of *ay and *aw, also when following velarized consonants, have been monophthongized to be $/ \overline{\mathrm{e}} /$ and $/ \overline{\mathrm{o}} /$, but their realizations tend to be lower: nearer to I.P.A. [ $\varepsilon:]$ and [o:].

\subsection{Off-glide in $\overline{\mathrm{e}}$ and $\overline{\mathrm{1}}$}

The same type of off-glides in $/ \overline{\mathrm{e}} /$ and $/ \overline{\mathbf{l}} /$, as described for group VI, may also be heard in TwA, HnA and 'LA.

\footnotetext{
${ }^{26}$ See Blanc 1970:124 (13) and De Jong 2000:82.

${ }^{27}$ A daxil is someone who seeks refuge (e.g. after having commited a crime) in the house of someone else. The 'host' is then obliged to take care (lodge him, and if necessary, defend him) of his daxil for three days (and one third of a day) and seek legal assistance to have the problem of his daxil resolved.
} 


\subsection{Off-glide in $\overline{\mathrm{o}}$ and $\overline{\mathrm{u}}$}

The same type of off-glides in $/ \overline{\mathrm{o}} /$ and $/ \overline{\mathrm{u}} /$, as described for group VI, may also be heard in TwA, HnA and 'LA.

\subsubsection{Diphthongs}

TwA, HnA and 'LA have two diphthongs: $i y$ and $u w$. Older diphthongs *ay and ${ }^{*} a w$ have been monophthongized as $/ \overline{\mathrm{e}} /$ and $/ \overline{\mathrm{o}} /$.

1.2.4.6.1. Reflexes of *ay and *aw

1.2.4.6.1.1. Reflexes of *ay and *aw in neutral environments

In positions not preceded by or velarized consonants *ay and *aw have usually become $\bar{e}$ and $\bar{o}$, cf. 1.2.4.1.

1.2.4.6.1.2. Reflexes of *ay and * $a w$ in non-neutral environments

1.2.4.6.1.2.1. Reflexes of *ay and *aw preceded by X.

Cf. 1.2.4.1

1.2.4.6.1.2.2. Diphthongs *ay and *aw preceded by velarized consonants.

Cf. 1.2.4.1

1.2.4.6.2. Diphthongs -iy and -uw

1.2.4.6.2.1. Reflexes of final $* \bar{\imath}$ and $* \bar{u}$

Final diphthongs $-i y$ and $-u w$, which in part reflect older ${ }^{*}-\bar{\imath}$ and ${ }^{*}-\bar{u}$ are best heard in lento speech and occur both in sentence medial as well as in sentence final positions. In allegro forms these diphthongs tend to be reduced to $-i$ and $-u$ (I.P.A. [i] and $[u]$, i.e. not lowered [l] and [v]).

The reinterpretation of morpheme boundaries, as described for group VI, has not taken place in TwA, HnA or 'LA.

Examples of diphthongs $i y$ and $u w$ created by anaptyxis are: mašiy \# "walking" and \# iyxăf "he fears" and hašuw \# "filling, stuffing", xațuwtēn "two steps" and \# uwlād "children". In the latter three instances, one may also hear the diphthong $i w$.

Instances of final $-i y$ as reflexes of ${ }^{*}-\bar{\imath}$ are like those reported for group VI.

Like in group VI, many final $y \vec{a}$ 'verbs with an $i$-type conjugation in the perfect have adopted - though often only partially - an $a$-type perfect in ȚA and HnA. Examples are maša "he walked" (but mišyit "she walked"), nása and násat (but also nisyit) and also lígiy laga "he found", ligyit lagat "she found", etc. (for further detail, see 3.2.2.5.1.). In 'LA maša was recorded with a regular paradigm of the $a$-type and ligiy with a regular $i$-type paradigm. 
Final -iy may also reflect older final ${ }^{*}-\vec{a}$ in the pattern ${ }^{*} \mathrm{CaCCa}{ }^{\prime}$ for physical defects: 'arğíy "limping (sg. fem.)", hablíy "simple-minded (sg. fem.)", 'amyíy "blind" and the sg. fem. pattern for colours (also *CaCCā') sōdíy "black", šahabíy "sand-coloured". ${ }^{28}$

Apart from nihā (-niy) for "here", the form hiniy is also often heard (though not recorded in 'LA).

Final $-i y$ reflects final * $\vec{\imath}$ in bíriy "innocent", final *-iy in șábiy "boy", gáwiy "strong" and nibiy "prophet", *-ay' in šiy "thing" and also the nisbahending for the sg. masc., e.g. Su'üdiy "Saudi".

1.2.4.7. Prosodic lengthening of long vowels and diphthongs

Examples of long vowels being lengthened:(expressing great surprise) yā salā:m "my goodness!", (expressing an extreme degree) hayāh și bah xā:liṣ "a very difficult life" and in 'LA ḍalla nāyim "he remained asleep (for a long time)".

\section{Stress AND Phonotactics}

\subsection{Stress}

\subsubsection{Rules for word-stress}

Stress in TwA and HnA is of the máktabah-type. Rule order is the same as in group VI.

Verbal gahawah-forms of the $i$-type imperfect, like yáhartuw "they plough", receive special treatment (see 2.1.2.4.).

The rules for TwA and HnA are (for ĞBA there are exceptions like íššti "the winter"):

1. Like in group VI.

2. The domain of stress is formed by either:

a. the last two syllables of a word, also if this includes the article $i l$ - as the penultimate syllable,

b. or the last four syllables, when these are without article, or verbal pre- or infixes, but including suffixes,

c. or, in the presence of a verbal in- or prefix, the last three syllables including the vowel of the syllable preceding the in- or prefix, but only when the verb form is an imperfect or a participle. When the verb form is perfect, the vowel of the prefix or the vowel preceding the infix is not stressable.

\footnotetext{
${ }^{28}$ Also in ĞbA 1992, see ?arji (sic.) (a misprint for-in my own transcription—'arǧı́y) on p. 7 (I-61).
} 
3. Stress is placed according to the criterion of quantity, i.e. vowels of heavy sequences are stressed.

4. The following types of 'heavy' sequences occur: vCC $(C)$ and $\bar{v} C(C)$ (including $\overline{\mathrm{v}}(\mathrm{h})$ ).

5. The vowel of the first heavy sequence from the right is stressed (see examples in 2.1.1.1.)

6. In the absence of a heavy syllable, stress the vowel in the first syllable from the left.

The exception made for resyllabification of $\mathrm{CaCaCaCv}(\mathrm{C})$ sequences in MzA of group VI is not necessary for TwA, HnA or 'LA, since such sequences are not resyllabified.

In HmA the presumably older stress system is being replaced by the system described above. The older stress system - much (but not totally) like that described for group I-is characterized by the following forms: wálad, náxal, kátab, kátabat, rágabah, náxalah, yáhariț, yáhartuw, álwalad, ál'aša', íli 'ši', šnaț, áššnaț, ánġasal, yíngisil, inġásaluw, áštaġal, yíštigil, ištágaluw, kátabatuh, rágabatuh and yáaraguw.

In 'LA the article is a stressable unit (e.g. álğamal, but forms like ilğámal were also heard, though less regularly), but unlike other dialects that may stress the article, 'LA does not allow stressing of initial vowels in the perfect of measures $n-1$ and 1-t. 'LA is thus the only dialect in Sinai with a stressable article, but which does not allow stress on initial vowels in the perfect verbal of measures $n-1$ and $1-t$.

2.1.1.1. Stress in words with heavy sequences

Examples of stress in words with 'heavy' sequences are in TwA and HnA: iššti "the winter" (ĞbA), il'áša" "the dinner, ilíf 'i "the viper" (second $i$ is originally anaptyctic), șalāt ilí śi "evening prayer", ilálab "the tins", mádrasah "school", ištágal "he worked", ittáfag "he agreed", inġásal "he was washed", ilbáṣal "the onions", ilwálad "the boy/son", ittáfaguw "they agreed", ingásaluw "they were washed", hsşiy "rocks", ${ }^{29}$ šolíy "left-handed (sg. fem.)" and šahabíy "sand-coloured (sg. fem.)".

As far as stress in reflexes of ${ }^{*} \mathrm{CiCa}(\mathrm{C})$ is concerned, 'LA appears to be in a process of transition; when the first $\mathrm{C}$ is not a sunletter, an anaptyctic vowel will separate this $C$ and $l$ of the article, when the article precedes. Although stress rules specify that the vowel of the article should then

\footnotetext{
${ }^{29}$ In 'LA the form ílihși' "the rocks" was also recorded.
} 
be stressed (being the vowel in the 'underlying' heavy sequence vlCC), the anaptyctic may receive stress instead (see scenario 1 below). When the first $C$ is a 'sunletter' no anaptyctic appears, since the $l$ of the article assimilates to this 'sunletter'. The vowel of the article is then stressed (see scenario 2 below). Schematically:

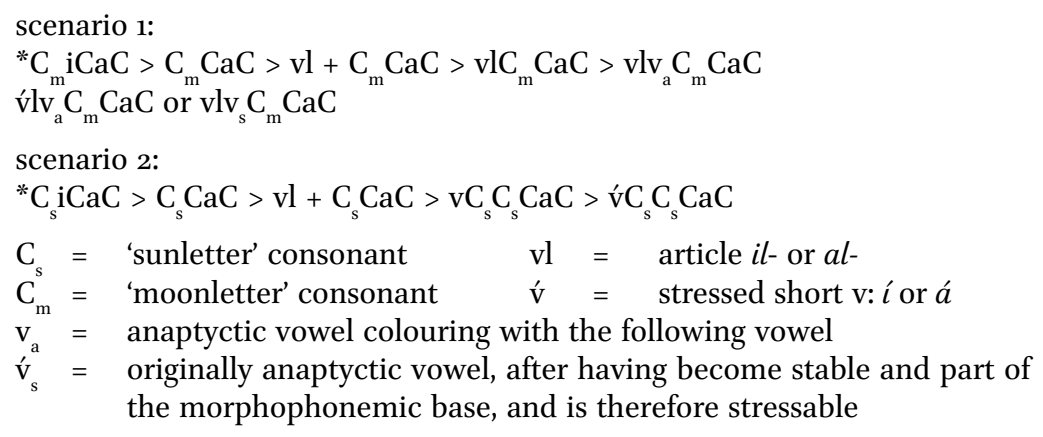

When anaptyctics preceding forms with initial $\mathrm{C}_{\mathrm{m}}$ have become stable and the anaptyctic has become part of the morphophonemic base as the initial vowel, this new initial vowel will be stressed if it is part of a heavy sequence.

A next, or parallel step in this development is anaptyctics becoming stable base vowels where they precede CC; a cluster \# CC or C CC needs to be resolved, so that an anaptyctic will be inserted preceding the last CC of such a cluster. The anaptyctic-colouring with the base vowel of the following noun ${ }^{30}$ — can thus become stable, and therefore become part of the morphophonemic base and be stressed,,$^{31}$ e.g.

$$
\begin{array}{lllll}
\text { origin } & \text { elision } & \text { cluster } & \text { anaptyxis } & \text { stress } \\
* \text { durah } & >\text { drah } & >C+\underline{d} r a h & >C v_{a} \underline{d} r a h & >a \underline{d} r a h\left(v_{s} d r a h\right)
\end{array}
$$

When the article is then prefixed, the resulting form will be aládrah "the sorghum", since the new base vowel prevents the prerequisite of contact of $l$ and the 'sunletter' $\underline{d}$ for assimilation to take place. Another example is alángar "the potholes".

\footnotetext{
$3^{3}$ Such colouring of the anaptyctic was also reported for group II in the north, see De Jong 2000:270.

${ }^{31}$ In fact, this development is also a more rigorous application of the rule that base forms can only have initial C- or (') v-; there is a phonotactic constraint barring initial CC.
} 
Forms in 'LA are: íšstì, ál'aša', ilif'ih, íli ši ilíšì', áligrab "the watersacks" (but alángar "the potholes"), álabar "the needles" and also aládrah "the sorghum".

Other forms with heavy sequences in TwA, HnA and 'LA: tilína "we rose", waládk “your (sg. masc.) son", waládk "your (sg. fem.) son”, úṃmuk "your mother", štì "winter", zèn "good", zēnih "good (sg. fem.)", zēnīn "good (pl. masc.)".

2.1.1.2. Examples of stress in words without heavy sequences

2.1.1.2.1. Stress in $\operatorname{cv} C \nu C(v)$

Stress in $(\mathrm{C}) \mathrm{v}_{1} \mathrm{Cv}(\mathrm{C}):^{32}$

(') ${ }_{1} \mathrm{CvC}$ : úḳul "eat!", úgum "stand up!", ísil "carry!", ánam "go to sleep!", ábar "needles" ("I come" is ìǧiy). 'LA forms are: kul, gūl, gūm, šll, nām. ${ }^{33}$

$\mathrm{Cv}_{1} \mathrm{Cv}($ ()): 'áša' "dinner", máša' "he walked", dáwa' "medicine" ("stick" was recorded as 'așa ). The same forms are found in 'LA.

Cv ${ }_{1}$ CvC: ǧámal "camels", šáğar "trees", gáțas "he dived”; wágaf "he stood up", wárag "paper" and șábiy "boy", bíriy "innocent", țáriy "moist; soft" ("he goes" is yı̌ğiy, also in 'LA). In 'LA both types of stress are heard: walád or wálad, although the latter stress type is more current.

2.1.1.2.2. Stress in $(C) v C v C v(C)$ and $(C) v C v C v C v(C)$

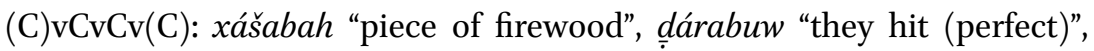
báladuh "his country", násatuh "she forgot him", ma násatuš "she did not forget him" (the latter two not in 'LA), and gahawah-forms áhamar "red", náağih "ewe", áarag "I sweat", áhariț "I plough", gáhawah "coffee". ${ }^{44}$

$(\mathrm{C}) \mathrm{vCvCvCv}(\mathrm{C})$ : dárabatuh "she hit him", ma dárabatuš "she did not hit him", rágabatuh "his neck" and gahawah-forms gáhawatuh "his coffee", táaragin "you (pl. fem.) sweat".

ilxášabah "the piece of firewood", ilbádawiy "the Bedouin (sg.)", (gahawah-form) innáxalah "the palm tree", ibtáhafruw "they dig", ištágalat "she worked", inbáșațuw "they rejoiced", ittáfagat "she agreed", tağáwwazat "she got married", takállamuw "they spoke".

\footnotetext{
${ }^{32}$ When $\mathrm{v}_{1}$ in this pattern is not preceded by $\mathrm{C}$, it is underlying $|\mathrm{a}|$.

33 Forms of the mediae infirmae verbs like gum / úgum or gum / úgum were checked, but were rejected as not proper 'LA.

${ }_{34}$ Stress reported for ĞbA in Nishio 1992 is the same, see p. 146 (XX-3o and 33). However, ibid. p. 7 (I-61) reports (in my transcription) a'rağ "lame" (without gahawah-vowel).
} 


\subsubsection{Exceptions to the stress rule}

\subsubsection{Stress on reflexes of ${ }^{*}-\bar{a}^{\prime}$ and ${ }^{*}-\bar{a}$}

Like in group VI (and also in group IV, see De Jong 2000:428), reflexes of ${ }^{*}-\vec{a}$, which have not been raised due to phonetic factors described in 1.2.4.4., will be stressed, when they have remained long and thus form a heavy sequence, e.g. $x a \underline{d} r \bar{a}\left({ }^{\prime}\right)$ "green (sg. fem.)", șifra $\bar{a}($ ') "yellow (sg. fem.)",

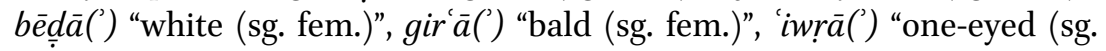
fem.)". Such stressing is regular in TwA, HnA and 'LA. ${ }^{35}$

In phonetically neutral surroundings, final $-\vec{a}$ of sg. fem. forms of colours and physical defects is raised to -iy (see 1.2.4.4.). Such raised -iy reflexes are then stressed, even if (other) heavy sequences precede, e.g. sōdíy "black (sg. fem.)", šadf'y "left-handed (sg. fem.)”, hawliy "cross-eyed (sg. fem.)". Notice however stress in híniy "here", although more regular for "here" is nihā. Also in a gahawah-form, in which the gahawah-vowel has resolved the cluster forming the heavy sequence, the reflex of $-\vec{a}$ ' receives stress: (šahba $\vec{a}>$ ) šahabíy "sand-coloured (sg. fem.)". These forms are current in TwA, HnA and 'LA.

Reflexes of final * $-\bar{a}\left({ }^{\prime}\right)$ that are short $-a^{\prime}$ or $-i$ are stressed in conformity with the rules in 2.1.1.2. When no heavy sequences precede, e.g. (forms in TwwA and HnA) (il)'áša' "(the) dinner", (il)ǵgada' "(the) lunch", (is)sáma' "the sky", ${ }^{6}$ but with heavy sequences available: iššti' "the winter", șalät

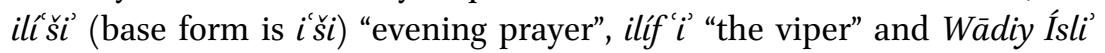
(stress on initial I) "Wadi Islah".

Note: there is variation, however: (only) in ĞbA and HmA forms with stress on the final vowel like șalāt ili ‘šl "evening prayer", ilif " $i$ "the viper", wagt iššti" "the winter time" and Ğabal iGni" "the mountain of canals/ water ducts (situated in the Magāạah area)" were also heard.

Since heavy sequences always precede within word boundaries, raised reflexes of pronominal suffixes will not be stressed, e.g. mnākulhi' "we eat it (sg. fem.)", šuftti (< šuft + ha) "I saw her". Verbal endings that developed from *-a also remain unstressed, e.g. šufni' "we saw" and máša' "he walked". The reflex of final *- $\bar{a}($ ') will only be stressed if it is the only vowel available, e.g. ilwálad dì "this boy", ǧi" "he came".

\footnotetext{
35 Nishio 1992 reports the same in terms of stress and raising for ĞbA, see p. 16 (XX-30 to XX-35), e.g. (in Nishio's transcription) hamrā and sūdī.

${ }^{36}$ Nishio 1992 reports the same type of stress in ĞbA, see e.g. p. 119 (XVII-1) sáma, but does not indicate stress in gad $\varepsilon$ and 'aš $\varepsilon$.

${ }^{37}$ In Tuṛbāniy dialect this mountain is referred to as Ǧibál iGníy; gniy is a pl. form $<{ }^{*}$ qinä.
} 


\subsubsection{Stress on final nominal ${ }^{*}-\bar{y}$ reflexes in * CaCìy}

In TwA and HnA, reflexes of the pattern CaCìy are CaCiy or (after raising the short vowel $a$ ) CiCiy are stressed on the penultimate, which is in conformity with the rules formulated in 2.1.1.2.

2.1.2.3. Stress in al/il $+{ }^{*}$ CaCìy

Prefixing an article to a CaCiy sequence has no consequences for the assignment of stress in TwA and HnA, e.g. inníbiy or innábiy "the Prophet" and ișsábiy "the boy". In ḦmA ánnibiy was recorded and in ĞbA ínnibiy.

șabiy (pl. șibyān) "boy" with suffixes: șabíyyuk "your boy", șabiyyī "my boy", șabiyyhum "their boy".

\subsubsection{Stress in suffixed gahawah-forms}

In TwA, HnA and 'LA stress in gahawah-forms is like in group VI (naxálha "her date palms", gáhawatuh "his coffee" and ( $i$ - and $u$-type gahawahimperfect verb forms) yá ağnuh "he kneads it" and táxabțin "you (pl. fem.) knock". ${ }^{8}$

Resyllabication of sequences CaCaCatv (> CaCCitv) is not a characteristic of TwA, HnA or 'LA.

\subsubsection{Stress in $v C C I C v$}

Like in group VI, a short high vowel is not dropped from a sequence $\mathrm{vC}_{\mathrm{a}} \mathrm{C}_{\mathrm{a}}$ $\mathrm{IC}_{\mathrm{a}} \mathrm{v}$ and stress is placed according to rules in 2.1.1.2., e.g. bitǵázzizuh "you sow it (of watermellon seed, by inserting each seed into its own hole in the soil)". In this example reduction of the geminate is clearly audible.

An example in 'LA is biyballilüha "they make it (sg. fem.) wet". For active participles of the verb ta aknan "be irritated", see 2.4.4.

\subsubsection{Stress units}

2.1.3.1. Stress in combinations with preposition min and negated personal pronominals

Like in group I, the preposition min may form one stress unit with the following word, as in mín-tahat "from below", mín-kidiy "from this" and mín-ihniy "from here" (the latter BWA).

In negated pronominals stress is as follows (recorded in HnA, ȘwA, ǦbA, ASA):

${ }^{38}$ Nishio 1992 lists many gahawah-forms for ĞbA as well, e.g. (p. 19 (III-31) gahawe, (p. 28 (IV-25)) faham "charcoal" and verbs: (p. 101-102) (XIV-54)) yaxalat "mix", (p. 102 (XIV-55)) yahafer "dig" and (p. 115 (XVI-19) yahazen "be sad", etc. 


$\begin{array}{llll} & & \text { sg. } & \text { pl. } \\ \text { 3. } & \text { masc. } & \text { mahūš } & \text { mahíň̌ } \\ & \text { fem. } & \text { mahǐš } & \text { mahúmš } \\ \text { 2. } & \text { masc. } & \text { mántiš } & \text { mantūš } \\ & \text { fem. } & \text { mantīš } & \text { mantínš } \\ \text { 1. } & \text { com. } & \text { manǐš } & \text { máhnišš }\end{array}$

Negated pronominals recorded in ḤmA are: $m \bar{a} h \bar{u}, m \bar{a} h \bar{\imath}$, mintih, mintiy, mānī, miḥna, mintuw, mintin, māhuṃ, māhin.

In GrA direct elicitation yielded the following forms: ${ }^{39} m \bar{a} h \bar{u}, m \bar{a} h \bar{\imath}$, mantih, mantiy, mānī, māhum, māhin, mantum, mantin, mahna.

In 'LA the single negation with preceding $m \bar{a}$ is current. Elicited forms are: māhū, māhì, mantah, mantiy, mānī, māhum, māhin, mantuw / mantum, mantin, mahna.

\subsubsection{Enclitically suffixed prepositions $\mathrm{l}$ and $\mathrm{b}$}

\subsection{Enclisis of the suffixed preposition 1}

Enclitic suffixation of the suffixed preposition l occurs regularly. Examples are: yug úd-luh šaharän talātih "it stays (for itself) two or three months" (GrA). ibyāxúd -luh btāe sāe tēn "he spends about two hours" (ĞbA), biyṝhūūluh "they go to him" (ȘwA), arawwíh-luh giddām ilmīēà ib yōm aw yōmēn "I go to him one or two days before the appointment" (ASA) and nahafírluh "we dig (a hole) for it" (HmA).

Such enclitic suffixing was found to be especially current in HnA, e.g.: ibyibgā-luh mōsim "there is a season for it" (HnA), innās bitgūm tahaš̄̄ luh ... hašiy "people then stuff it (properly)" (HnA), imwazzaf byāxud-luh talațīyt iğnēh "a civil servant gets (for himself) three hundred pounds" (HnA).

An example in 'LA is: biytallí-luh "he gets out for him".

\subsection{Enclisis of the suffixed preposition $\mathrm{b}$}

Enclisis of suffixed preposition $b$ is less current than that of suffixed 1 , but does take place, e.g. mistahtír-buh "making fun of him" (ASA), w inġammísbuh "and we dip (food) with it", timš̄i-buh "you go with him" (HnA), ibyihtimmū-buh htimām ğāmid "they attach great importance to it" (HnA). In 'LA it was not recorded.

\footnotetext{
${ }_{39}$ Negation in GrA is usually constructed with single $m \bar{a}$, without $-\check{s}(i)$, see also 3.1.12.3. and 4.2.
} 


\subsection{Phonotactics}

\subsubsection{The gahawah-syndrome}

2.2.1.1. The gahawah-syndrome: a-insertion in *aXC sequences

Like in many dialects of Sinai, the gahawah-syndrome is active in TwA and HnA. Some of many examples are: šáhar "month", șalāt ilmaġarib "prayer at sunset", bá ad "after", byaxațibha "he gets engaged to her", ahabal "stupid", ahawal "cross-eyed", šahabíy "sand-coloured", tahat "under".40

In 'LA we see similar forms, but stress may be on the vowel of the second syllable, e.g. naxál "palm trees", Sa ád "male given name",

\subsubsection{Morphological categories showing variation}

The gahawah-syndrome is active in forms of the past participle (i.e. where $\mathrm{C}_{1}=\mathrm{X}: \operatorname{maXC}_{2} \overline{\mathrm{u}} \mathrm{C}_{3}$ ) like mahafūr "dug", maxarūm "pierced", mahabūs "imprisoned", maḥațūt "placed" and ma agū! "reasonable", ma'adūd "few, countable" and mag்așūb "forced, compelled", but also maxzūn "stored", Mahmmūd "male given name" and maxțūbah "engaged (sg. fem.)".

Exceptions are also found with the pattern $\operatorname{maXC}_{2} \mathrm{vC}_{3}(\mathrm{ah})$ : magarib "time of sunset", máxazan "storage place, but also magrib, maxzan and mahğar "stone quarry".

Examples in 'LA: ma'arüfin "known (pl. masc.)", maxarūm "pierced", maxațūbah "engaged (sg. fem.)", magarib "time of sunset", but also mahțūt "placed".

\subsubsection{Morphological categories in which the gahawah-syndrome is not active}

In TwA, HnA and 'LA the gahawah-syndrome is not active in derived verbal measures. Examples are like those listed for group VI.

Examples of the absence of the gahawah-syndrome in elatives are: ahsan "better/best", aḥla "more/more beautiful, sweeter/sweetest", ag lab

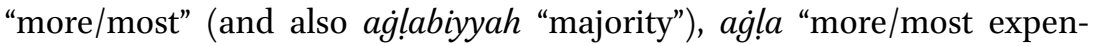
sive" and the name Ahmad.

\footnotetext{
${ }^{40}$ Nishio 1992 cites numerous instances of the gahawah-syndrome for ĞbA too, but there are also exceptions, such as a'rağ "lame" (p. 7 (I-61)), ta'bān "tired" (p. 41 (VI-9)), lağwe "language" (p. 72 (X-1)), rag̉we "bubble, foam" (p. 125 (XVII-48)), wahlə "mud" (p. 127 (XVII-64)) and verbs like 'awağ, ya wağ "bend" (p. 99 (XIV-41)) and xiliṣ, yaxlaș "end" (p. $103(\mathrm{XV}-4))$ and other forms. N.B. the imperfect of a (there measure 1) verb like 'ața, ya'ți "give" listed on p. 82 (XII-1) is best interpreted as an $i$-type, with here $a$ as transcription of the allophonic realisation of $i$ under influence of the 'ayn (in my own transcription this would be yi țiy). A similar example is (also measure 1) 'azam, ya'zim "invite" (p. 90 (XIII-21)), which in my own transcription would be 'azam, yi zim.
} 
The gahawah-syndrome also usually remains absent in loans from Standard Arabic like ya niy "that is, it means", yahșal "it happens" and another measure 1 verb ya 'mal "he makes, does".

The fem. morpheme in construct state becomes -at when it follows XaC (also where $a$ is a gahawah-vowel), so that the sequence CaXaCat is the result. When such a sequence is directly suffixed with a vowel-initial suffix, the resulting CaXaCatv sequence is not resyllabified (contrast possible resyllabification in MzA of group VI). Examples are naxalatī "my palm tree" and gáhawatuh "his coffee".

2.2.2. Articulatory delay in the realization of alveolar sonorants (liquids l, $r$ and $n$ )

2.2.2.1. Articulatory delay in the realization of $\mathrm{r}$ : the bukara-syndrome Examples of bukara-vowels are (underlined): azarag "dark brown", tagara IFāthịh "you recite the Fātihah", dugigiriy "straight ahead, right away", tzagịiriț "she ululates", ygōțirin "they (fem.) go", xudiririy "type of cheap green tobacco (smoked in rolled cigarettes)".

Examples of the bukara-syndrome inhibiting the elision of a preceding high vowel are laxi in innahār "until the end of the day" and indawwi ilğamal "we look for the camel".

Examples of the 'greater' or 'expanded' bukara-syndrome creating vowels: $f i$ lgașín $^{42}$ ibtaxazin-luk "in the storage you store it for yourself" and fi lgidị ib hâluh "all of it in the pot" and in "LA Șadir ilHêțān "name of a mountain range, south of Umm Itlah ${ }^{43}$ pass".

\subsubsection{Influence of 1}

Like $r, l$ may also be involved in inhibiting elision of the short vowel. Examples are (preserved vowels underlined) ibyinzil isSwēs "he goes down to Suez", hādiy btākil ilğarbū' "this one (fem.) eats jerboa" (though also ibtākl itweer "it (fem.) eats small birds") and f-awwil ilwagt "in the beginning". An example in 'LA is gâl ya rağil ilmasal dii' "he said 'oh man, this saying...' ".

Examples of 'expanded' or 'greater' bukara-vowels preceding $l$ in sandhi (where the vowel is not a cluster-resolving anaptyctic as described in

\footnotetext{
${ }^{41}$ Much more current for "make, do" is the measure 2 verb sawwa, ysawwiy.

${ }^{42}$ gașr, pl. gṣūr: a small cave-like hollow in the side of a mountain or katarah (a clay mound) used as a safe storage for goods (esp. foodstuffs).

43 The 'Umm 'Itlah pass, on the main road from the Ahmad Hamdi tunnel near Suez to Nixl, is usually indicated on maps as 'Mitla pass', see fn 7, p. 3 .
} 
2.3.2.) are ('greater' bukaṛa-vowels underlined): $w$ il'akil iyyāmha kamān și ib "food was also difficult (to get) in those days" and ithutțh fi ssi in iw yug úd-luh yōm "and you put it in the goat skin and it sits (there for itself) for a day".

\subsection{The high vowel preceding l in *ibil and *rağil}

The form bil or ibil was not recorded.

raǧil for "man" was only recorded once in HmA and once in 'LA, but

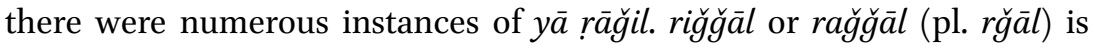
current for "man".

\subsubsection{Articulatory delay in the realization of $\mathrm{n}$}

Non-elision of short high vowels preceding $n$ in otherwise eligible positions is quite regular, e.g. (here underlined) yōmin iygassim "when he allots" and iygūminn anniswān yáhalbịn adduwābb (i.e. not *iygūmn anniswān yáhalibn adduwābb) "the women then (get up and) milk the animals".

Also, an anaptyctic vowel in sandhi is often inserted in positions not covered by the anaptyxis rule (see 2.3. below). Examples are: assamin aššl̆hiy "the wormwood ghee", and ibyanfa' l albațin iw fih šiǧár l așșadir iw fih šiğár l iddišbih "it is good for the stomach and there are plants (i.e. herbs) for the chest and there are plants for (treating) a cold" ${ }^{44}$

\subsubsection{Articulatory delay of 'ayn following geminates}

Articulatory delay of 'ayn following geminates was not noticed as a regular feature.

\subsection{Anaptyxis}

Rules formulated for group VI are also valid for TwA, HnA and 'LA. For ĞbA Nishio reports several instances of schwa resolving a consonant cluster $\mathrm{C}_{\mathrm{a}} \mathrm{C}_{\mathrm{a}} \mathrm{C}_{\mathrm{b}}$ (where $\mathrm{C}_{\mathrm{a}} \mathrm{C}_{\mathrm{a}}$ is a geminate), e.g. (p. 196) hī biddəhe timši "she wishes to leave (or walk)", biddəne "we wish" and biddəken "you (pl. fem.) wish" and also (p. 56 (VIII-9)) non-elision of high vowels in mdarrəse and mdarrəsīn for (respectively) "teacher (fem.)" and "teachers".

\footnotetext{
${ }^{44}$ dišbih is used for common cold (with coughing), a more severe cold with flu-like symptoms is usually referred to as habșah. Bailey 2009:343 (glossary) lists dishba as "the flu".
} 


\subsubsection{Word-medial anaptyxis}

Word-medial clusters (in bold print below) resulting from high vowel elision are usually-depending on the relative sonority of the consonants involved ${ }^{45}$ - resolved by inserting an anaptyctic vowel preceding the last two consonants of the cluster, e.g.

$$
\begin{array}{lll}
\text { yiktib }+u w & >\text { *yiktbuw } & \text { > yíkitbuw "they write" } \\
\text { yug } u d+u w & >\text { *yugduw } & >\text { yúgu'duw "they sit"46 }
\end{array}
$$

Also when suffixation results in a cluster, this cluster is resolved, e.g.:

$$
\text { tisg }^{*_{1}}+\text { ha } \quad>\text { *tisgha > tísigha "you water it" }
$$

$*_{1}$ tisg: an apocopated imperfect of 2 nd p. sg. masc. (root $\left.s-q-y\right)$.

\subsubsection{Anaptyxis in sandhi}

2.3.2.1. Anaptyxis in clusters resulting from 'colliding' morphological base forms

Examples of sandhi clusters of four consonants. caused by the collision of morphological base forms, which are resolved by insertion of an anaptyctic preceding the last two consonant (clusters are in bold print, clusterresolving anaptyctics are underlined):

$s a b^{c} \operatorname{snin}^{47}>$ sab' isnīn "seven years".

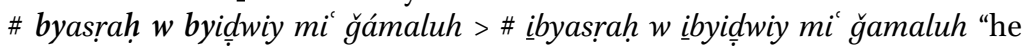
goes away and comes back at sunset with his camel".

\subsubsection{Anaptyxis in \#CC and CC\#}

\begin{tabular}{|c|c|c|c|}
\hline \#CC & $>$ & \# $\mathrm{iCC}:$ & \# byasrạ > \# ibyasrạ \\
\hline CC\# & $>$ & $\mathrm{CiC} \#:$ & b irriğl \# > b irriğịl \# \\
\hline
\end{tabular}

When speech pause directly precedes or follows CC, the resulting cluster \#CC or CC\# is resolved (anaptyctics underlined), e.g.:

${ }^{45}$ For the role of relative sonority, see remarks in De Jong 2000:125-26.

${ }^{46}$ Nishio 1992 gives numerous instances in which word-medial with subsequent anaptyxis does not take place, e.g. imperatives of "write" (sg. fem.) iktibi, (pl. masc.) iktibu and (pl. fem.) iktiben (p. 76 (X-27), imperfect forms (pl. masc.) yod̦robu, (pl. fem.) yod̦roben, etc. (p. 88 (XIII-11) and also imperf. forms (pl. masc.) yinzəlu and (pl. fem.), yinzəlen, etc.

${ }_{47}$ The base form is with initial consonant, which may be concluded from forms preceded by the article (its $l$ assimilates to the first consonant), e.g.: iș̣gayyyir, isSwēs and also issnīn (not (i)lișgayyir, (i)liSwēe or (i)lisnīn). 
An example in 'LA is: matrah ma timis, iris "wherever you are in the evening, spend the night there (lit. throw out your anchor)" (a saying advising not to travel by night); tims is an apocopated imperfect (root $m-s-y)$, irs is an apocopated imperative (root $r-s-y)$.

\subsubsection{Consonant clusters resulting from I-elision in sandhi, with subsequent anaptyxis}

Some examples of clusters in sandhi after I-elision, eliminated by anaptyxis from TwA, HnA (intermediate forms with clusters are marked *):

(base forms, high vowel eligible for elision underlined, stress has already been placed)

sámnit il'anz >

(after elision of unstressed high vowel, cluster in bold print)

* sámnt il'anz >

(after stress and anaptyxis, anaptyctic underlined: surface forms)

sámint il'anz "the ghee of the goats"

Another example is:

(base forms, high vowel eligible for elision underlined, stress has already been placed)

nílhịg iššă $z>$

(after elision of unstressed high vowel, cluster in bold print)

* nilhg iššā $z>$

(after anaptyxis, anaptyctic underlined: surface forms)

nilinhg iššă "we put the șāğ (on the fire)"

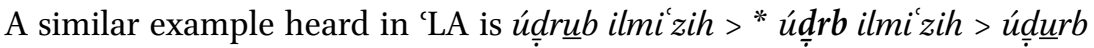
ilmi zih "hit the goat".

\subsubsection{Resyllabication of word-medial CVCCICV, and of CVCCIC VC} sequences in sandhi

Resyllabication of a word-medial sequence CVCCICV > CVCICCV (e.g. yikitbuw) is compulsary, while resyllabication of a sandhi sequence CVCCIC VC > CVCICC VC (e.g. níliḥ iššāz) is optional.

\subsubsection{Exceptions to the anaptyxis rule}

\subsubsection{Unresolved consonant clusters}

Like in group I, not all clusters are eliminated. Especially clusters of which the first consonant is nasal or a liquid followed by a voiceless second consonant (predominantly stops), ${ }^{48}$ e.g.: kalthi' "I ate it (sg. fem.)", talgha "you will find her", kāwantn̄ "you fought me", fihimt? \# "did you understand?"

\footnotetext{
${ }^{48}$ For similar phonetic conditioning, see De Jong 2000:123-128.
} 
Clusters may be left unresolved in sandhi as well, e.g. gult hēhū dii! "I said 'there he is!" and 'ind bètuh "near his house".

When assimilation between the first and second consonant takes place, the cluster will remain intact as well, e.g. (in sandhi) xatt bāluk "you see?".

These and other similar examples were recorded in TwA, HnA and 'LA.

2.3.3.2. The role of sonority of consonants invloved in unresolved clusters See remarks in De Jong 2000:125-126.

\subsubsection{Some special cases with regard to anaptyxis}

\subsection{Consonant clusters with initial geminates}

When the first two consonants of a three-consonant cluster form a geminate, this geminate is usually (partially) reduced, e.g. (word-medial) biddha "she wants, needs". Examples listed for group VI may be heard in TwA, HnA and 'LA as well.

\subsection{Preposition ind $+C$}

The suffixed preposition ind takes vowel-initial allomorphs of the pronominal suffixes, e.g. 'índaha ('índihi') "with her", 'induk "with you (sg. masc.)", indik "with you (sg. fem.)", 'induhuw "with them (pl. masc.)", 'indihin "with them (pl. fem.)", 'índukum ( - -ukuw) "with you (pl. masc.)", 'índikin "with you (pl. fem.)" and "índina "with us". The same forms are heard in 'LA.

Clusters in sandhi are left intact, however, e.g.: 'ind wāhid "with someone" and in "LA 'ind 'arbānuh "with his family".

2.3.3.3.3. The 2nd p. sg. masc. and fem. pronominal suffixes in consonant clusters

In TwA, HnA and 'LA (like in group VI) the pronominal suffixes of the and p. sg. masc. and fem. $-\mathrm{k}$ and $-\mathrm{k}$ (resp.) are vowelless when preceded by one consonant. This may be concluded from stress assignment, but it is difficult to conclude whether an anaptyctic is present or not; especially with a voiceless consonant preceding and a vowel following $\mathrm{k}$ (in sandhi), there may be a voiceless anaptyctic or none at all.

Examples are arkábuk ibyōğinnuk "your knees hurt you (sg. masc.)". arkáb ${ }^{i} k$ ibyōğinnik "your knees hurt you (sg. fem.)”. In 'LA law arwáḥ"k ibyunguz min 'induh "if he smells you he jumps from his place".

When more than one consonant precedes the personal- pronominal suffixes take allomorphic shapes - $u k$ (for sg. masc.) and -ik (for sg. fem.) e.g. xallukgāid "remain seated", 'induk "with you”. ${ }^{49}$

49 Nishio 1992:178 (XXV-6) reports $\mathrm{ku} \sim$ ok and adds that "in rapid speech the last vowel $/ \mathrm{u} /$ is reduced to schwa, or often inaudible, in which case the redundant phonetic feature 


\subsubsection{Phonetic quality of the anaptyctic}

\subsubsection{Phonetic quality of word-medial anaptyctics}

The phonetic quality of the word-medial anaptyctic vowel is a lax and centralized [1], towards [ə], in front environments and a lax and centralized $[\mathrm{v}]$, towards a moderately rounded [ə], in back environments..$^{\circ}$

\subsection{Phonetic quality of word-medial anaptyxis in clusters form "colliding"} base forms

The situation in TwA, HnA and 'LA is like in group VI.

2.3.4.1.2. Phonetic quality of anaptyctics in clusters after I-elision

The situation in TwA, HnA and 'LA is like in group VI.

2.3.4.1.3. Anaptyctics in clusters resulting from elision of $\mathrm{i}$ from $T$ The situation in TwA, HnA and 'LA is like in group VI.

\subsubsection{Phonetic quality of anaptyctics in sandhi}

2.3.4.2.1. Phonetic quality of word-initial anaptyctics in sandhi

Word-initial anaptyctics tend to have a phonetic value of near a lax and centralized [1].

Examples listed for group VI also illustrate the situation in TwA, HnA and 'LA.

In TwwA, HnA imperatives of the verbs xád "take" and kál "eat" are úḳul,

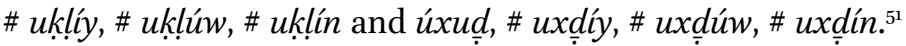

In 'LA the sg. masc. is $k u l$ and (velarized) $x u \underline{d}$, but the other imperatives are the same.

\subsection{Phonetic quality of word-final anaptyctics}

Anaptyctics resolving word-final clusters have a phonetic quality near I.P.A. [v] in labial and/or velarized environments. Anaptyctics in neutral environments will be near (centralized) [1]. Examples listed for group VI can also be heard in TwA, HnA and 'LA.

\footnotetext{
of aspiration might become relevant". I did not notice any relevant degree of aspiration. For the conclusion drawn here of $/ \mathrm{k} /$ and $/ \mathrm{k} /$ as separate phonemes see 1.1.1. and 3.1.12.3.1.

${ }^{50}$ This is the same as described for group I in De Jong 2000:128.

${ }^{51}$ Nishio 1992:91 (XIV-2) lists oxod $\sim$ xod, oxodi $\sim$ xodid, oxodu $\sim$ xodu, oxoden $\sim$ xoden, but okul $\sim$ kul. okli, oklu and oklen for ĞbA. In the majority of cases Nishio indicates non-elision of the short high vowel reflexes of CiCaC, e.g. zubab "penises" (p. 7 (I-54)), kusas "vulvas" (p. 7 (I-56)), šowak "ploughs (p. $36(\mathrm{~V}-25)$ ), šonat "bags" (p. 38 (V-35)), turab "graves" (p. 44 (VI-29)), sikak "roads" (p. 69-70 (IX-24)), geșaș "stories" (p. 74 (X-14)), nogaț "points" (p. 143 (XX-11)), hețat "places" (p. 154 (XXII-1)), nimar "numbers" (p. 173 (XXIV-48)) and also dora (p. 17 (III-11)), gora "villages" (p. 55 VIII-1)).
} 


\subsubsection{Stressed original anaptyctics}

In the reflex of the pattern $\mathrm{CICaC}$ (i.e. $\mathrm{CuCaC}$ or $\mathrm{CiCaC}$ ) in TwA (except ĞbA) and HnA originally anaptyctic vowels have become part of the morphophonemic base. Stress is then placed in conformity with rules described in 2.1.1. In most cases the phonetic value of the vowel is coloured in by the vowel already present in the pattern.

Examples are (for the pattern *CICaC) (with initial $a$-) árkab "knees", ášnat "suitcases, bags", áštal "seedlings", áhgan "injections", ánxar "noses", áwraš "workshops", ángar "pits, álmad "lamps (sg. lambah), ágrab "water skins", álab "tins; packets", áșwar "pictures", áxșa' "testicles" and (with

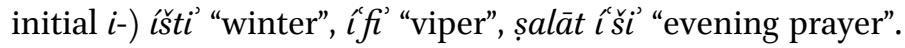

Forms recorded in ĞbA are more like those heard in group I (apart from the fact that the article is not stressed in ĞbA) e.g. hät iligráb "bring the waterskins", (i)lihgán "the injections", iššnát "the suitcases, bags" and comparable stressing in the form șalāt ili ši "the evening prayer" (though also ilí ši was heard). ${ }^{52}$

In 'LA there is a development in progress; in some cases the new pattern aCCaC has already come into use (e.g. áhgan, ángar), in other cases the pattern $\mathrm{CCaC}$ is still being used (see also remarks in 2.1.1.1.), e.g. álgrab "the waterskins" (not (a)lágrab).

See also stress patterns in imperative forms of the verbs (3.2.2.3.) "eat" and "take".

Notice that the development of original anaptyctics becoming stressable and colouring with the base vowel has taken place in dialects of the Samā'nah and 'Agāylah in the north of Sinai (group II) as well, see De Jong 2000:270-271.

Examples of plurals with *' as the first radical are (')ábar "needles"53 and ( )áwad "rooms".

Plurals ending in *-iy have reflexes -iy like in: gniy "bunches of dates", ${ }^{54}$ hṣiy "rocks", 55 rhìy "hand mills" and ș̣iy "sticks".

${ }^{5^{2}}$ See also remarks in 1.2.4.4. above.

${ }^{53}$ See also Nishio 1992:16.

${ }^{54}$ From the context it is clear that the pl. of "date bunches" is meant here. Compare also differences in stress and pronunciation in Bìr iGní / Bìr iGníy / Bìr Ignah (the latter stressed on I) (located at appr. 28.51.51 North and 33.43.35 East). Compare this to the different pronunciations of Wādiy Sli', Wādiy Sliy, or Wādiy Islah / Aslah (cf. 1.2.4.4. and 3.1.5.).

${ }_{55}$ In 'LA a form ílihși' was recorded, which must reflect the coll. hașan (root $h-s-y$ ). I do not have an explanation for the raising of final $-\bar{a}$ preceded by the emphatic șād. 
In ȚwA (however, for remarks on ǦbA see 3.1.16.) and HnA the preposition $m(i)^{c}$ followed by a vowel-initial suffix will be stressed as follows, e.g. ím 'uh, ím $u k$, ím $i k$, except stress is on the final (long) vowel in im'i. Negated forms are stressed má-m'uš, ma míkuš, ma míkiš and (more predictably) $m a$ m' $i s$.

In 'LA the suffixed preposition $m$ ' will be stressed on the vowel of a vowel-initial suffix, e.g. múk "with you" and m'úh "with him" (for more remarks on stress in suffixed prepositions see 3.1.16.).

\subsection{Elision of Short Vowels}

TwA, HnA and 'LA are 'différentiels' in terms of short vowel elision. ${ }^{6}$ The rule is like that already formulated for group VI. The rules for morphophonemic elision are compulsary.

\subsubsection{Morphophonemic I-elision}

Rules given for group VI are valid here as well.

\subsubsection{I-elision in sandhi}

Like in group VI, morphophonemic elisions of short high vowels $i$ and $u$ are compulsary, but comparable elisions in sandhi are optional.

\subsubsection{Cyclic anaptyxis rule in sandhi}

The optional I-elision rule in sandhi may be applied after the execution of the anaptyxis rule, e.g. (the cluster is underlined and in bold print, the anaptyctics are in bold print and the high vowel eligible for sandhi-elision is underlined):

1) bitțalli' + 'yūn > bitțalli_ 'yūn > bitțallí í ${ }^{\prime} y \bar{u} n>$ bitțall' i'yūn "it (sg. fem.) grows flower buds".

In this first example the cluster " $y$ is resolved, after which the high vowel $i$ preceding it lands in open syllable (thus becoming eligible for elision) and is dropped.

Like in group VI, the I-elision rule may also be re-applied after execution of the rule for anaptyxis, as in the example: urbut hzamuk > urbut

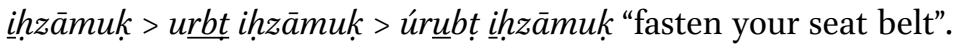

\footnotetext{
${ }^{5}$ See Cantineau 1936:49.
} 
In this second example the cluster thz is resolved, after which the high vowel $u$ preceding $t$ is in open syllable (thus becoming eligible for elision) and is dropped, creating a new cluster $r b t$, which is then eliminated by insertion of another anaptyctic $u$.

Such examples are also found in 'LA.

\subsubsection{Exceptions to the I-elision rule}

When $\mathrm{C}_{\mathrm{a}}$ and $\mathrm{C}_{\mathrm{b}}$ in $\mathrm{C}_{\mathrm{a}} \mathrm{C}_{\mathrm{a}} \mathrm{IC}_{\mathrm{b}}$ are phonetically close or identical, I is not dropped. An example is bitgázzizuh "you sow it (of watermellon seed, by inserting each seed into its own hole in the soil)".

Another exception to the high vowel elision rule was found through direct elicitation in SwA, H.mA and HnA with the act. participles (sg. fem.) mta'ákninih, (pl. masc.) mta'akninìn and (pl. fem.) mta'aknināt "irritated". In ASA the $i$-elision does take place (with immediate subsequent anaptyxis) mta'akinnih, -in, -ät and in ĞbA and 'LA both mta'ákninih and mta'ákinnih (and mit'akninīn / mit'akinnìn, mit'aknināt / mit'akinnāt) were recorded.

\subsection{Assimilation}

Three types of contact assimilations can be identified: regressive (partial or total), progressive (partial or total) and reciprocal (total). ${ }^{57}$

Apart from contact assimilations of $l$ of the article $i l$ - or al- to 'sunletters', $l$ is also - more regularly so than in group VI-assimilated to following ğ, as in iğğild "the skin", iǧğizzār "the butcher", iğğism "the body" and iğğamr "the live embers" and iğǧim 'ah ğğāyih "the next Friday". This type of assimilation may be regularly heard in ȚWA, HnA and 'LA. Assimilation of $l$ to initial $k$ was not recorded.

Assimilations listed for group VI are current in TwA, HnA and 'LA as well. Some additional examples are:

Regressive total:

$\begin{array}{lll}t+s & >s s & s s \bar{u} g \text { "you drive" } \\ t+s \underline{s s} & >\underline{s} \underline{\underline{d}} & \text { bill "you pray" } \\ t+\underline{d} \underline{d} & >\underline{d} & \text { "you stay/keep on" }\end{array}$

An example of regressive total assimilation with reduction of the preceding geminate is (recorded in 'LA):

\footnotetext{
${ }^{57}$ For remarks on contact assimilation involving the spread of velarization cf. 1.1.7.
} 
$l l+n>n n n$ (I.P.A. [n:]) xannī "let me"

Instances of regressive partial assimilation were also recorded in TwA, $\mathrm{HnA}$ and 'LA.

Progressive total assimilation of initial $h$ - of pronominal suffixes to preceding voiceless consonants is regular in TwA, HnA and LA, as well as reciprocal total assimilations of the type reported for group VI, e.g. 'arìssa "her bridegroom", mașlahatta "her department", taslaxxa "you skin it (sg. fem.)".

In a number of instances the mutual influence of hissing sounds has resulted in a metathesis. Examples in the dialects discussed here are șāg (or șāž) > šāz "iron baking sheet", siğih (or sǐzih) > šczih "game of sĭğah". In ĞbA I heard both šizn and siğn "prison" and bitsağǧil and bitšazzil "you record", but in ASA I heard only basaǧğil "I record".

Another example of the mutual influence of hissing sounds in all dialects is: šamš "sun", but in all dialects šağar "trees" is current.

\section{Morphology}

\subsection{Nominal Morphology}

\subsubsection{Raising of a}

\subsubsection{Raising of * $a$ in $C_{1} a C_{2} \bar{i} C_{3}(a h)$}

Raising of $a$ in the nominal pattern $\mathrm{C}_{1} \mathrm{aC}_{2} \mathrm{C}_{3}(\mathrm{ah})$ occurs regularly, but is optional. Although such raising is much less regular when $\mathrm{X}$ precedes or follows $a$, it does take place in such positions. The high vowel that results from such raising is not elided..$^{8}$

To illustrate, some forms that were recorded with and without raising in ȚwA, HnA and 'LA are: kațīr kițīr "many; much", kabìr $\sim$ kibìr "big; old", garīb girīb "relative (related person)", gadìm gidìm "old", dagìg

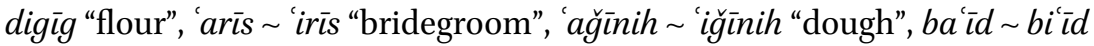
"far", taxin $\sim$ tixin "thick, fat", xafif $\sim$ xifif "light (in weight)", xamis $\sim$ ximis

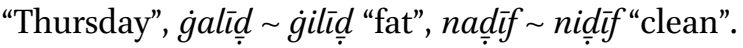

\footnotetext{
$5^{8}$ This situation is the same as what was described for group II in the north, see De Jong 2000:272-273. Nishio 1992, however, lists several instances of elisions of this vowel, as in e.g. tgīl "heavy" (p. 176 (XXIV-74), ktīr "many, much" (p. 176 (XXIV-74), etc. See also remark ${ }^{*}$ on (non-) elision of 'underlying a' in 3.2.2.1. and in verbs like nisiy and ligiy in 3.2.2.5.1.
} 
Some forms recorded only without raising are: hadìd "iron", dalïl "list (of persons)", țarìg "road", gațīrah "boat", șaḥịh "correct", raxīṣ "cheap", la'ìm "mean person", (')akìd "certain".

Some forms recorded only with raising are: midinih "town", yimin "right (direction)", mi 'iz "goat", sirīr "bed", fisix "salted fish".

3.1.1.1.2. Raising of a in * CaCiy $\left(C_{3}=y\right)$

Raising of a preceding ${ }^{*} \mathrm{CaCiy}\left(\mathrm{C}_{3}=\mathrm{y}\right)$ occurs often, but variation is still heard as well. Examples are: bíriy "innocent", gúwiy "strong”, țíriy "moist; soft", wíliy wáliy "saint", 'Iliy 'Aliy "name" and níbiy nábiy "Prophet". A form recorded in 'LA is guwíy.

\subsubsection{Raising of a in open syllable preceding stressed í}

No remarks for TwA and HnA.

\subsubsection{Raising of a in $\mathrm{CaCC} \bar{C}(-a h)$}

Raising of a in CaCCīC(-ah) was not recorded, e.g. batțīx "watermelon", kabrït "matches", barmïl "drum", Katrīn "(St.) Catherine”, zambïl "basket for sand", sakkinah "knife" and garnit "octopus". Also verbal nouns of measure 2 do not show such raising, e.g. tağlīb "throwing out (of a line, fishing)" and ("LA) tašnīn "taking aim".

\subsubsection{Raising of a in $\mathrm{CaCC} \bar{a} \mathrm{C}$}

Raising of a in the pattern CaCCāC in ĞbA and GrA is almost without exception when it concerns patterns $\mathrm{C}_{1} \mathrm{aC}_{2} \mathrm{C}_{2} \overline{\mathrm{a}} \mathrm{C}_{3}$ and $\mathrm{C}_{1} \mathrm{aC}_{2} \mathrm{C}_{3} \overline{\mathrm{a}}$. These patterns have been morphologically restructured as $\mathrm{C}_{1} \mathrm{iC}_{2} \mathrm{C}_{2} \bar{a} \mathrm{C}_{3}$ and $\mathrm{C}_{1} \mathrm{iC}_{2} \mathrm{C}_{3} \bar{a}$.

Examples in TwA and HnA: šig̀g் $l^{59}$ "busy, functioning", riǧğğăl "man", siyyāl "acacia tree", millāḥ "salty type of herb", niǧğḡr "carpenter", tillāğah "fridge", willā'ah "lighter", hissās "sensitive”, hiğǧḡāriy "pickaxe”, milyān "full", siyyārah "car", giltțān "mistaken", diblān "wrinkled (of skin of fruit)", although also galțān and rağğ $\bar{a} l$ were recorded. ${ }^{60}$

In 'LA comparable forms show that morphological restructuring has not taken place, but that raising is optional: šab 'ān "satiated", raddāhah "roast pit", raggāṣah “dancer (fem.)", 'ațšān "thirsty", galțān "mistaken",

59 In ǦbA $\dot{g} \dot{g}$ in $\check{s} a \dot{g} \dot{g} a \bar{l}$ was several times pronounced with very little friction, and sounded more like velarized $g g$.

${ }^{60}$ Nishio 1992 also lists several instances of such raising in ǦbA, but mainly in neutral environments, e.g. tilfān "thin, lean" (p. 41 (VI-8)), wuğcān "ill” (p. 41 (VI-11)), riğğāl “(adult) man" (p. 48 (VII-11)), but also nağğār "carpenter" (p. $5^{8}$ (VIII-38)) and kaslān "lazy" (p. 149 (XXI-9)). Nishio usually transcribes a in positions influenced by emphatics or back spirants, e.g. bațțāniye "blanket" (p. 29 (IV-35)), nad̦d̦āra "glasses" (p. 33 (V-3)), 'aryān "naked" (p. 13 (II-4)), d̦amyān and 'aț̌sān (both) "thirsty" (p. 23 (III-53)), šağgaāl "servant" (p. 53 (VII-43)) and ălso ğa'ān "hungry" (root ğ-w-') (p. 23 (IIII-53)). 
ġalbān "poor, destitute", fallāh "farmer", Sallām "male given name", rawyān "well-watered" and (raising in) kislān "lazy", wiğ ān "suffering pain", siyyāl "acacia", suwwāg "driver", tillāğah "fridge", burṛād "kettle" and wayyāh wiyyāh "with him".

Also in other patterns $a$ is often raised in TwA and HnA when it precedes CCā, e.g.: hibbāyāt "corns, seeds", mirrrāt "times" and also in the pattern for sg. fem. adjectives of colours and physical defects $\left({ }^{*} \mathrm{CaCCa} \bar{a}^{\prime}\right)$, as in tirma' "gap-toothed (sg. fem.)", gir '‘ $\bar{a}$ ' "bald (sg. fem.)", 'iwr $\vec{a}$ ' "one-eyed (sg. fem.)", gilbā' "stupid (sg. fem.)" and himṛā' "red (sg. fem.)", șifṛà "yellow (sg. fem.)", zirga ' "black (lit. blue, sg. fem.)" and also xiḍrä "green (sg. fem.)". Though forms like $x a d r a \bar{a}$ ' and hamra $\vec{a}$ ' were also recorded. In 'LA

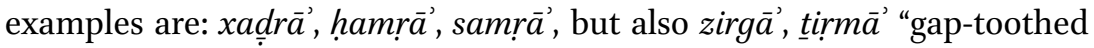
(sg. fem.)".

Notice that raising of $a$ in the pattern for sg. fem. for colours and physical defects may only take place when final $-\bar{a}\left({ }^{\prime}\right)$ has not been raised to -íy, e.g. 'arğı́y "limping (sg. fem.)", and also the gahawah-form šahabíy "light coloured (sg. fem.)".

In ASA, ȘwA, HmA and HnA similar raising may take place, but there it is optional and X preceding $a$ usually constitutes an inhibiting factor, e.g.

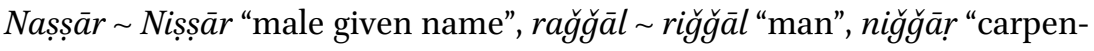
ter", Silmān "male given name", șiyyād "fisherman" (but șayyādiyyah "dish with fish"), bitțāniyyah "blanket", kislān "lazy", wiğ àn "suffering pain", šib'ān "sated, full", zihgānīn "fed up (pl. masc.)".

Variation or no raising in galțān "mistaken", galbān "poor, wretched", 'ayyān "ill", ta 'bān "tired", malyān "full", 'ițšān 'ațšân "thirsty" and in sg. fem. adjectives for colours and physical defects: zirga' $\sim$ zarga' "black (lit. blue, sg. fem.)", himra $\vec{a}$ hamrāà red (sg. fem.)", raddāḥah riddāḥah "trap net (used to catch birds)", safrä "yellow (sg. fem.)", hamg $\bar{a}^{\prime}$ "stupid, silly (sg. fem.)", marrāt "times", habbàt "corns, bits" and mi nāt + "the meaning of".

The conclusion for HmA, ȘwA, ASA and HnA is that, just like in 'LA, such raising has not led to morphological restructuring, but is optional in neutral environments.

3.1.1.5. Raising of a in ...CaCāC...

Raising of $a$ preceding Cā is current, but is concluded to be optional, since it is often absent in more careful speech.

Some of many examples are: gināyāt "small water courses", ǧināyin "gardens", zimān "in the past", gizāz "glass", timānīn "eighty", midāris "schools", misāfih "distance", mišākil "problems", filāyik iṣṣed "(small) fishing boats (with sails)", bihāyim "cattle (pl.)", dibāyiḥ "animals for slaughter", digāyig 
"minutes", šimāl "north", kimān "also", dirāhim "money", ma mišāš "he did not go", ilifä‘iy "the vipers". ${ }^{61}$

In labial environments, raising of $a$ may als be towards [u], as in šuwārib "lips", muwā̄in "receptacles", fuwākih "(different types of) fruit" and kumān "also".

Examples without raising are: kamān "also", banāt "girls", tamām "excellent", makān "place", kabābiy "cups", ganāh "small water course”, šamāl "north", tamātim "tomatoes".

Here too, raising occurs less when $l$ or $r$ follows $a$, or X precedes, e.g. malāyīn "millions", șalāh "prayer", țalātah "three", xalāṣ "ready", salām "peace", Garāršah "name if tribe", farāšç "thin loaves of bread baked on a šāz (i.e. a șāğ)", marākib "boats", farā̄nnah "Faraos", and 'ašān "because", hasạah "rock", xawāğih "foreigner", Hamādah "name of tribe", hayāh "life", $\dot{g} a z \bar{a} l$ "gazelle". Also when 'precedes, raising is not regular, e.g. (')amākin "places", (')aṣābi "fingers; toes". Such examples may also be heard in 'LA.

This raising of $a$ in open syllable directly preceding stressed $\bar{a}$ was found to be much less current in the dialect of the Șawālḥah (ȘwA) than in the other TwA dialects.

3.1.1.6. Raising of a in ...CaCá...

Given the different rules for stress in groups VI and VII (CaCáC and CáCaC resp.), $a$ in open syllable preceding stressed $a ́$ is not as regular as in group VI. However, when $a$ is found in this position and in neutral environments, raising may occur like in group VI, but only optionally so, e.g. 'iláy "on me", ǧimál"ḳ "your camel”, tiháthi" "under her", ma tiháthiš "not under her".

Such raising only occurs on a limited scale, however; examples of nonraising are numerous, e.g.: dabáḥtuh "I slaughtered it", ragabát ${ }^{u} \underline{\text { ch }}$ "your neck", katábt "I wrote" and also gahawátkum "your (pl. masc.) coffee".

Since the stress pattern CaCáC is current in 'LA, many more instances were to be expected of this type of raising. Its occurrence is, however, limited. Examples are: ğimál "camel", ğibál "mountain" and muṭár "rain".

3.1.1.7. Raising of a in open syllable preceding stressed $A$

Like in group II of the north, raising of $a$ towards I.P.A. [1] preceding Cā is current, but similar raising of $a$ preceding stressed Cá is not regular in TwA and HnA, although in 'LA a limited number of instances of such raising were recorded.

\footnotetext{
${ }^{61}$ Compare C.A. $a f^{c} a^{n}$, pl. $a f a \bar{a}^{c} i^{n}\left(\operatorname{root} f^{-}-y\right)$.
} 


\subsubsection{Raising of a in $\mathrm{CaCu} C(a h)$}

Like raising of $a$ towards I.P.A. [1] in open syllable preceding $\mathrm{C} \overline{\mathbf{1}}, a$ in open syllable is also often raised — usually towards I.P.A. [v]—when it precedes Cū. Examples are: buxūr "incense", xurūf "lamb", ğinūb ǧunūb "south", gumūs "food dip", 'urūs "bridegroom", fuțūr "breakfast", yuhūd "Jews" and (with initial hamzah) ubūy "my father" and uxūy "my brother", and also ist p. sg. com. imperfect forms of mediae wāw verbs ugūm "I get up", ugūl "I say". These forms may be heard in TwA, HnA and also in "LA. Some additional 'LA examples are lugūh "pregnant (of a she-camel)" and gu'ùd "young male camel".

Like raising of $a$ preceding $\bar{\iota}$, raising of $a$ preceding $\bar{u}$ is optional; forms like 'aǧuzz "old lady", ğanūb "south", 'arūsah "bride", hamūlih "animal led to a party to be slaughtered", yahūd "Jews" may also be heard. Such forms were recorded in TwA, HnA and 'LA.

Notice also the form (in HnA) 'abūr in the name madrasat il'Abūr "the Crossing $^{62}$ School". Since $u$ of the first syllable in the MSA loan 'ubūr is not dropped in pronunciation, which would result in 'būr (compare e.g. 'yūn < 'uyūn for "eyes", see 3.1.5.), it appears to be interpreted as raised $a$ (which is not dropped in such positions) and the base form is concluded to be 'abür. Since raising of $a$ in such positions is however only optional, one may also hear a form like 'abūr. Similar reasoning would lie behind the form (also loaned from MSA) hakūmah "government".

Notice also that some surface forms of the type $\mathrm{CaCu} C$ are actually underlying $\mathrm{Ca} C \overline{\mathrm{u}} \mathrm{C}$, with reduced $\bar{a}$; such shortened $a$ for $\bar{a}$ is not raised, examples are $m \bar{a}$ ùu (ma'ūn) "container", nāmüsiyyih (namūsiyyih) "mosquito net".

A gahawah-vowel in open syllable preceding $\mathrm{C} \overline{\mathrm{u}}$ is not raised, e.g.

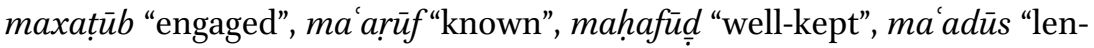
til soup" (such forms were recorded in ȚwA, HnA and 'LA).

3.1.1.9. Raising of a in open syllable preceding stressed $\mathrm{u}$

$a$ in open syllable preceding stressed $u$ is found much less often in group VII than in group VI. Although this may be partly due to differences in stress patterns (Cv́CvC in TwA and HnA as opposed to CvCv́C), such 'LA forms (which also stresses CvCv́C) are few.

${ }^{62}$ The 'crossing', C.A. 'ubūr, refers to the crossing of the Suez Canal of the Eyptian army into Sinai during the 1973 Arab-Israeli War (also referred to as Ramadan War, October War or Yom Kippur War). 
Some instances of $u$-type verbal perfects are $\dot{g} u l u \underline{d} t$ "I grew fat", $\dot{g} u l u \underline{d} t i n$ "you (pl. fem.) grew fat".

A form quite typical for 'LA (i.e. it was only heard sporadically in HmA and not in the other dialects discussed here) is 'ilúh, which also appears without raising as 'alúh "on him" (see remark ${ }^{* 4}$ in 3.1.16.). Notice here that in the absence of velarization or labialization, raising is towards $i$, even though the stressed vowel following is $u$.

3.1.1.10. a-raising rules combined

Combining the rules for raising of $a$ described in te paragraphs above, we may summerize as follows:

$$
\mathrm{a}>\mathrm{I} / \mathrm{C}_{\mathrm{a}}-\mathrm{C}_{\mathrm{b}} \overline{\mathrm{I}} \mathrm{C}
$$

$\overline{\mathrm{I}} \quad=$ long vowel $\overline{\mathrm{u}}$ or $\overline{\mathbf{i}}$

I $\quad=$ short high vowel $\mathrm{u}$ if $\overline{\mathrm{I}}$ is $\overline{\mathrm{u}}$; short high vowel $\mathrm{i}$ if $\overline{\mathrm{I}}$ is $\overline{\mathrm{i}}$

$\mathrm{C}_{\mathrm{b}} \quad$ = consonant capable of carrying velarization in case of raising to $\mathrm{u}$

Notice the difference with the rule formulated in De Jong 2000:150; the provision of $\mathrm{C}_{\mathrm{a}} \neq{ }^{*}$ made for the group I dialects described there is not made here, i.e. preceding "*hamzah" does not inhibit such raising in the dialects described here.

\subsubsection{Reflexes of ${ }^{*} \mathrm{C}_{1} a C_{2} C_{3}(a h)$}

For reflexes of $\mathrm{CaCC}(-\mathrm{ah})$ the following forms were recorded in TwA: badw "Bedouin", táḥat "under" (also 'LA), fáḥam "coal”, waḥdah ( wiḥdih in ĞbA, ḤmA and 'LA) "one (sg. fem.)", nahyih "direction”, șáab "difficult", šakl "shape”, șáḥan "dish, plate” (also 'LA), ğady "kid goat” (also 'LA), șadr "chest", waḳl "food" (also 'LA), karš "(fat) belly", kalb "dog” and ǧidd "grandfather" (also 'LA) and ǧifn "eyelid".

\subsubsection{Reflexes of ${ }^{*} \mathrm{CaCiC}(\mathrm{ah})$}

wirk "thigh", ${ }_{3}$ kitf "shoulder", kilmih "word", širkih "company".

\subsubsection{Reflexes of $\mathrm{C}_{1} u \mathrm{C}_{2} \mathrm{C}_{3}(\mathrm{ah})$}

Some reflexes of $\mathrm{C}_{1} \mathrm{uC}_{2} \mathrm{C}_{3}(\mathrm{ah})$ are: bunn "coffee beans", rizz "rice", kull "all; every" (also 'LA), uṃm "mother" (also 'LA), uxt "sister" (also 'LA), Ǧim ih "male given name" (also 'LA), muddih "period", hurmah "woman" (also

\footnotetext{
${ }^{63}$ For ĞbA wilk, wlāk is reported in Nishio 1992:7 (I-58).
} 
'LA), zibdih "butter" (also 'LA), rikbih "knee", hinnih "they (fem.)" (also 'LA), šuggah "a woven length of a tent (about $1 \mathrm{~m}$. wide)".

\subsubsection{Absence of I in open syllables preceding stress}

As is the case in all dialects of Sinai, a high vowel $i$ or $u$ in open initial syllables of the type $\mathrm{CIC}(\mathrm{V})$ preceding stress $($ on $\mathrm{V}$ ) is dropped.

When $\mathrm{V}$ is a long vowel, an initial CC cluster is the result, e.g.: snin "years", 'yūn "eyes" and ğnēh "pound (money)", ğbāl "mountains", gṣayyir "short". Such forms are regular in TwA, HnA and 'LA.

When $\mathrm{V}$ is a short vowel, the anaptyctic vowel which precedes the CC cluster 'on the surface' has become part of the morphological base. ${ }^{64}$ The phonetic value of this anaptyctic is steered by the vowel that was already part of the base. Examples with short vowels are: árkab "knees", áhgan "injections", if ' $i$ ' "viper", is $t i$ ' "winter". Such forms are regular in ȚAA and HnA, but in 'LA forms like hgan, šnat "suitcases" and "nab "grapes" are predominant, although also forms if 'iy if ' ih are heard.

Exceptions to such elisions are often found in MSA loans, e.g.: nizām (all dialects) "system", bidāyithi" "its (sg. fem.) beginning", xumūl "tiredness" (ĞbA), nihä'iy "final" (ĞbA), siyāhah "tourism" (ḤA), 'ibārah 'an "consisting of" (ȘWA) and gizāz "glass" (although perhaps better interpreted as underlying |gazāz|) ('LA).

Verb forms listed for group VI are also current in TwA and HnA. The verb "come" however has imperfect forms with a long base vowel $\bar{l}$, e.g. yiğiy "he comes", which is again like forms in group II of the north (see De Jong 2000:307, contrast with groups I and VI, see 3.2.2.6.1.).

\subsubsection{Diminutive patterns}

The usual diminutives expressing 'littleness', 'shortness', 'narrowness' etc. were recorded as e.g. grayyib "near", sggayyir "small; young", rfayyi "narrow", d'ayyfih "weak (sg. fem.)", glayyil "few; little", kwayyis "good", šwayyih "a bit" and (as a common dim. used to euphemistically refer to women) hrayyim "women".

${ }^{64}$ The implication of such elisions is that stress was CICáC, and that it must have shifted in the course of time. 
In ȘwA the viper (ilif' $i$ ) was also referred to as swèd illeel, lit. "the (little) blackness of night". Other diminutives are: rišrēšs mațar ${ }^{65}$ "a few drops of rain", ibtākl ițwerr "it (sg. fem.) eats small birds", zrēgān "darkcoloured thoroughbred camel", yā-ḅuw șhayybī "my little friend (as a form of address)".

Except in the form zrēgān, the hypochoristic - $\bar{a} n$ suffix, which was recorded in some of the dialects of group $\mathrm{I}^{66}$ was not heard in TwA and HnA.

\subsubsection{Pattern $a C_{1} C_{2} a C_{3}$}

The pattern used for colours and physical (and sometimes mental) defects is (for sg. masc.) $\mathrm{aC}_{1} \mathrm{C}_{2} \mathrm{aC}_{3}$ (e.g. abyad ) and $\mathrm{aC}_{1} \mathrm{aC}_{2} \mathrm{aC}_{3}$ (e.g. áhamar, stressed on the first syllable) where $\mathrm{C}_{1}=\mathrm{X}$. Other examples are like those listed for group VI.

The sg. fem. forms have a $\mathrm{C}_{1} \mathrm{aC}_{2} \mathrm{C}_{3} \overline{\mathrm{a}}$ pattern, with a final $-\bar{a}$ that has remained long and which is often in pause followed by an unreleased glottal stop (e.g. $b \bar{e} d \bar{a}$, hamra ${ }^{2}$ ). There is an additional $a$ following $\mathrm{C}_{2}$ when it is $\mathrm{X}$ and final $-\bar{a}$ is raised to $-\dot{y} y$ when $\mathrm{C}_{3}$ is neutral (e.g. šahabiy). Other examples are like those listed for group VI.

In the pl. com. forms for coulours and physical defects all dialects (including 'LA) show $\mathrm{C}_{1} \mathrm{uC}_{2} \mathrm{C}_{3}$ as the pattern, i.e. like in MzA of group VI. Only in ĞbA both "imy and 'umy for "blind" were heard.

Plural forms for "black" and "white" are sūd $\left(\mathrm{C}_{2}=w \bar{a} w\right)$ and bị̀ $\left(\mathrm{C}_{2}=y \bar{a}^{\prime}\right)$.

3.1.8. The elative patterns $a C_{1} C_{2} a C_{3} a C_{1} a C_{2} C_{3}$ and $a C_{1} C_{2} a$

The elative patterns are like in group $\mathrm{VI}: \mathrm{aC}_{1} \mathrm{C}_{2} \mathrm{aC}_{3}$, e.g. aktar "more; most", $\mathrm{aC}_{1} \mathrm{aC}_{2} \mathrm{C}_{3}$, e.g. agal! "less; least" and $\mathrm{aC}_{1} \mathrm{C}_{2} \mathrm{a}$ (without gahawah-vowel), e.g. ahla "sweeter; sweetest".

\footnotetext{
${ }_{5}$ Notice reduplication of the biconsonantal root $r$-šs-š with its general meaning of "spray, spatter, splash" to express. See also EALL 2009 (Vol IV):50-53.

${ }_{66}$ See De Jong 2000:153.
} 


\subsubsection{Initial a}

\subsubsection{The article and the relative pronoun}

The article is il- in all dialects and the relative pronoun is illiy. The article is not a stressable unit (see 2.1.1.), except in HmA, where the (stressable) article $a l$ - is used parallel to the (unstressable) article il-. Examples in HmA are ál'aši il'áša' "the dinner", álġada" ilǵáda' "the lunch", álġanam ilgánam "the sheep".

Examples in other dialects of ȚwA are: ilğámal "the camel", táağn il'ağinah diyyih "you knead this dough".

The relative pronoun is illiy. Examples are: fih amākin ġațs hilwah nihā fi Dáhab.w illiy biy rawwh Ubuw LHōl $^{67}$ "there are beautiful dive sites here in Dahab. And there are those (lit. sg.) who go to the Blue Hole" and hasab kimmìt illaban illiy 'induk 'àd "depending on how much milk you have, of course".

An example of how il- and al- may appear side by side in HmA: nasrạ b ilǵánam w ị̣na șǵayyrīn. ingōțir ilbaṛ̣ yā salām iyțubb álmuțar..."we used to roam around with the small cattle when we were young, we used to go to the desert, oh my gooodness, and (then) the rain would fall...".

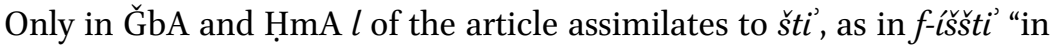
(the) winter". In other dialects one will hear fi lišti. Similarly (in ḦA) hāt áššnat "go get the bags!", where the other dialects have ilášnaț. ${ }^{68}$ An example from ASA is hatígib iláswar walla tánam 'ilèhin "are you going to bring the photos or keep them (fem.) for yourself (lit. sleep on them)?".

'Specifying' ha- was heard used only in adverbial halhin "now", e.g. fih bu'rāan bitxăf halḥin law nizilt iššāri', bitxậf mi l'arabiyyih "there are camels that are afraid, if you would now go out on the street, they would be afraid of a car".

In 'LA the preference is for al- and alliy, but il- and illiy have also been recorded. The article $i l$ - (with initial $i$ ) is heard mainly when preceding a noun with a high vowel, as in e.g. șalät ilmigrib "the sunset prayer", ilíkri(') "the wages", but also álfaras ilfáras "the horse". When the article is stressed, the vowel is usually a (e.g. álgada' "lunch", ál'aša' "dinner",

\footnotetext{
${ }^{67}$ A buw lHōl-literally "the Sfinx" - is the local name for the dive site known in English as (almost homophonic) the "Blue Hole". The dive site is located at approximately 28.34.20 North and 34.32.13 East, see Google Earth.

${ }^{68}$ For differences in stress inside ĞbA (i.e. spoken near the monastery or in Wādiy aš-Šēx near aț-Ṭarfa) see remarks below in 3.1.16.
} 
álgrab "the watersacks"), but sometimes colours with the vowel of the noun, as in șalāt íli 'šì "evening prayer" and ilihṣị "the rocks".

3.1.9.2. Other instances of initial a

Forms in TwA and HnA are: uṃm "mother", uxt "sister", ihna "we", (')ábar "needles" and (')áwad "rooms". Forms recorded in 'LA are umpm, uxt, álabar and álawad.

For $a$-initial plurals for the *CICaC pattern (e.g. ágrab "water skins" and áșwar "pictures"; in 'LA álgrab was heard), see 2.3.5.

3.1.10. The feminine morpheme (T) in genitive construction

$\mathrm{T}$ in genitive construction is treated like in the dialect of the Samā'nah of group II in the north: ${ }^{69} \mathrm{~T}$ preceded by any sequence $-\mathrm{CaC}$ (including $\mathrm{C}+$ gahawah-vowel $\mathrm{a}+\mathrm{C}$ ) in genitive construction becomes -CaCat. The rule is:

$\mathrm{C}=$ any consonant

$$
\mathrm{T}>\text { at } / \ldots \mathrm{CaC}_{-}+\text {gen. }
$$

$\mathrm{a}=$ any $\mathrm{a}$, including a produced by the gahawah-syndrome

Nishio 1992:XV, however, describes a situation for ĞbA in which the phonetic quality of the T-vowel is basically phonetically conditioned: "[t]he reflex of the Classical Arabic feminine ending $-a h(t \bar{a}$ marbūta) is $-\varepsilon$ (cf. in the possessive construction, $[-\varepsilon t] \sim[-$ et $] \sim[-t]$ except when after the emphatic consonants, or $/ \mathrm{r} /,|\mathrm{x} /,| \dot{\mathrm{g}} /,|\mathrm{h} /| \$,$% ."$

3.1.10.1. T in genitive construction preceded by a in open syllable

Like in group VI, the feminine morpheme $-a h \sim-i h$ in construct state becomes -at when aC directly precedes. Examples of aCT + suffix: (dual) sanatēn "two years" and ragabatuh "his neck".

Notice that resyllabication of a sequence CaCaCTv does not take place in TwA or HnA (contrast MzA of group VI), whether these are suffixed verbals or nominals, e.g. rágabatuh "his neck" and also verb form dárabatuh "she hit him".

3.1.10.2. The rule for $T$ not directly preceded by aC or $\bar{v}$

Like in group VI when not preceded by $\mathrm{aC}$, the fem. morpheme -ah becomes -it (or $-t$ when a long vowel $\overline{\mathrm{v}}$ directly precedes, see 3.1.10.4.) in construct state.

\footnotetext{
${ }^{69}$ See De Jong 2000:279-281.
} 
The $i$ of the ending -it may then be subject to the rule for high vowel elision, after which often an anaptyctic is inserted. Examples listed for group VI may also illustrate the situation in TwA and HnA.

\subsubsection{T preceded by the gahawah-vowel a}

Forms in which a gahawah-vowel $a$ directly precedes $\mathrm{T}$ in open syllable are treated in the same way as forms in which such a preceding $a$ is 'historical'..$^{\circ}$ Examples are: gahawatī "my coffee", gáhawatuh "his coffee", gahawát "k "your coffee" and naxalatī "my date palm", naxaláthum "their date palm" and naxalát ${ }^{i} k$ "your (sg. fem.) date palm", etc.

\subsubsection{T following $\overline{\mathrm{a}}$}

T preceded by $\bar{a}$ yields $-\bar{a} h$, e.g. șalāh "prayer" and when in construction, $\mathrm{T}>-t$, as in șalät ilí ši "the evening prayer".

3.1.10.5. Nominal ending -it in construction vs. verbal $3 r d p$. sg. perf. ending -at The high vowel $i$ of the nominal ending -it is dropped when it is in open unstressed syllable, e.g. nāgtuh "his she-camel".

The low vowel $a$ in verbal forms of the 3 rd p. sg. perf. is not dropped, e.g. šăfatuh "she saw him" and ma šăfatuš "she did not see him".

\subsubsection{Genitive marker}

The genitive marker is šuğl, but in ǦbA also h̆agg was recorded in spontaneous text. Informants who claimed (when asked) that hagg was used in their dialects too were speakers of ASA and HnA. hagg does not appear to be current in GrA, ȘwA and HmA.

Apart from šuğl and hagg, K-form $b t \bar{a}$ is often used..$^{11}$

The paradigms for $\check{s} u \dot{g} !$ and hagg are like those listed for group VI, except the 3 rd and 2nd p. pl. masc. suffixes, which are -huw and -kuw in group VI: see 3.1.12. for the suffixes in TwA and HnA. ${ }^{72}$

A preference for the construct state instead of indirect annexation could not be concluded from the available data.

\footnotetext{
${ }^{70}$ For a different situation in group I, see De Jong 2000:158-16o.

${ }^{71}$ Nishio 1992:192-194 (XXVII-8) reports the same three possibilities for ĞbA.

${ }^{72}$ In Nishio 1992:192-194 (XVII-8) transcribes a as T vowel in closed syllables in šoġlat $+\mathrm{C}$ and haggat $+\mathrm{C}$ (e.g. šog̉latne and haggatne "our") and ət for T in open syllables: (with T-vowel not elided!) šugləti and haggəti "my" (though elision of the ə is given as an option in e.g. marr(ə)tēn "twice" (p. 173 (XXIV-49)), but e in e.g. bta'etne "ours" and the T-vowel elided in open syllables, e.g. in bta'ti "my".
} 


\subsubsection{Personal pronominals}

\subsubsection{Independent pronominals}

In TwA and HnA the following independent pronominals are used:

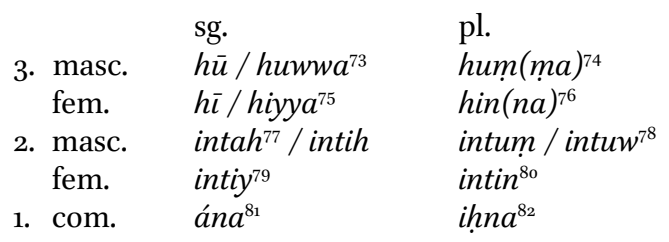

In ṢwA, HnA, ĞbA and ASA the following negated pronominals are used:

\begin{tabular}{|c|c|c|}
\hline \multicolumn{3}{|c|}{ negated* } \\
\hline & $\begin{array}{l}\text { sg. } \\
\text { mahī̌s }\end{array}$ & $\begin{array}{l}\text { pl. } \\
\text { mahúmš }\end{array}$ \\
\hline fem. & mahūš & mahínš \\
\hline 2. masc. & mántiš & mantūš \\
\hline $\begin{array}{l}\text { tem. } \\
\text { 1. com. }\end{array}$ & $\begin{array}{l}\text { mantišs } \\
\text { manīss }\end{array}$ & $\begin{array}{l}\text { mantíns } \\
\text { máhnniš }\end{array}$ \\
\hline
\end{tabular}

* In GrA direct elicitation yielded: māhū, māhī, mantih, mantiy, mana, māhum, māhin, mantum, mantin and mahnna.

In ḤmA and (additional forms in) ĞbA the forms recorded are: mānī, mintih, mintiy, māhū, māhì, mị̣na, mintuw / mintum, mintin, māhum, māhin.

\subsubsection{Pronominal suffixes}

In TwA, HnA and 'LA the following pronominal suffixes are used:

$\begin{array}{lll} & \text { sg. } & \text { pl. } \\ \text { 3. masc. } & (\mathrm{C}) \mathrm{C}-u(h), \overline{\mathrm{v}}-(h)^{*_{1}} & -h u m^{*_{5}} \\ \text { fem. } & -h a /-h i\left({ }^{\prime}\right)^{* 2} & -h \text { n }^{*_{5}}\end{array}$

\footnotetext{
${ }^{73}$ Nishio 1992:179 (XXV-13) gives "hū ( hūwa cf. < Cl.A or Cairene Ar.)".

${ }^{74}$ Nishio 1992:180 (XXV-17) gives "hummo ( humma cf. < Cairene Ar. Young people prefer this form.)" for ĞbA.

${ }^{75}$ Nishio 1992:179 (XXV-15) gives "hī ( hīye hīya < Cl.A or Cairene Ar.)" for ĞbA.

${ }^{76}$ Nishio 1992:180 (XXV-19) gives "henne" for ĞbA.

77 Nishio 1992:178 (XXV-3) only gives inta for ĞbA.

${ }^{78}$ Nishio 1992:179 (XXV-9) only reports the form "intu ( intow cf. [intów])", without final -m.

${ }^{79}$ Nishio 1992:178 (XXV-5) gives "inti ( intey cf. [intéy])" for ĞbA.

${ }^{80}$ Nishio 1992:179 (XXV-11) gives inten for ĞbA.

${ }^{81}$ Nishio 1992:178 (XXV-1) also gives ana for ĞbA.

${ }^{82}$ Nishio 1992:178 (XXV-3) also gives ihna for ĞbA.
} 


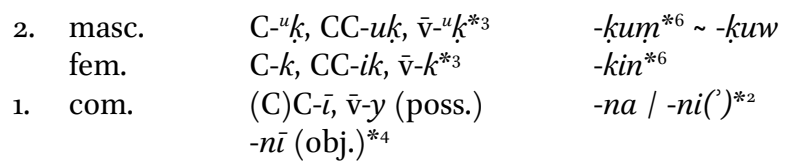

Initial $h$ of the suffixes (in 3 rd sg. fem and 3rd pl. masc. and fem.) often assimilates to a voiceless preceding consonant, e.g. bêttum "their house". ${ }^{83}$

For allomorphs used with the preposition 'ind, see below 3.1.16.

*1 Like in group VI, TwA, HnA and 'LA have the $-u(h)$ suffix for the 3 rd p. sg. masc. (contrast with -ah/-ih in group I, see De Jong 2000:164-165).

Some examples are: țá amuh hiluw "its taste is sweet", udugguh "I pound it", salaxnāh "we skinned it". ${ }^{4}$

${ }^{*}$ Endings in $-i$ ' occur mainly in pause and in neutral environments. ${ }^{85}$

${ }^{*}{ }_{3}$ For remarks on the use of superscript ${ }^{u}$, see remark ${ }^{*_{2}}$ of 3.1.12.2. of group VI in chapter II. For a likely development of these suffixes see the note below these remarks.

${ }^{*} 4$ Suffixes $-\bar{\imath}$ and $-n \bar{\imath}$ for the 1st p. sg. com. are stressed. Unstressed $-i$ and $-n i$ also occur. ${ }^{86}$

$*_{5}$ Parallel to independent pronominals, the 3 rd p. pl. masc. suffix is formed with $-m$, rather than with $-w$ (the latter being characteristic of group VI). ${ }^{87}$

${ }^{* 6}$ Like in the speech of older men of the Samānnah of group II of the north (see De Jong 2000:282-286), final - $m$ is regular for the 2 nd p. pl. masc. ${ }^{88}$

See also verbal endings in $-m$ in 3.2.1.1. and 3.2.1.2. below.

\section{NOTE}

The suffixes $-k$ and $-k$ as pronominal suffixes for the second person sg. (resp.) masc. and fem. are likely to have developed in the following manner:

\footnotetext{
${ }^{83}$ Such assimilations are also reported for ĞbA, see Nishio 1992:180.

${ }^{84}$ For ĞbA Nishio 1992:179 (XXV-14) gives consonant + o and long vowel $\overline{\mathrm{v}}+(\mathrm{h})$.

${ }^{85}$ Nishio 1992:178-179 (XXV-4 and 16) only gives he for the 3 rd p. sg. fem. And ne for the ist p. pl.com. in ĞbA.

${ }^{86}$ These stressed and unstressed forms are also reported in Nishio 1992:178 (XXV-2) for ĞbA.

${ }^{87}$ Nishio 1992:178-179 (XXV-8) gives $\mathrm{k} \sim$ ek for the 2nd p. sg. fem. and ken for the 2 nd p. pl. fem.

${ }^{88}$ Nishio 1992:179 (XXV-10) for ĞbA also lists final -m in kom. For the pl. fem. form Nishio 1992:179 (XXV-12) gives ken.
} 
In the verbal system of these dialects the endings - uw and -in are current for the pl. forms for masc. and fem. (resp.). This is the case in both the second person and the third person, e.g. (for the third p. pl.) (imperf.)

$y$-ikitb-uw and $y$-ikitb-in and (perf.) katab-uw and katab-in, and (for the second p. pl.) (imperf.) $t$-ikitb-uw and t-ikitb-in and (perf.) katab-t-uw and katab-t-in.

In the forms above I have 'split' the endings of the second person pl. in the perfect forms into two separate morphemes, since we are dealing here with a reinterpretation of morpheme boundaries in which - $u w$ signals 'pl. masc.' and -in signals 'pl. fem.'. Logically then, the - $t$ - preceding these pl. morphemes, just like in sg. forms, signals 'second person' (apart from the fact that sg. com. also has $-t$ ).

Parallel to this reinterpretation the pronominal system was reinterpreted as -uw signalling 'pl. masc.' and -in signalling 'pl. fem.'. The $-h$ - of the third person was then interpreted as signalling 'third person' (masc. $-h$-uw and fem. $-h-i n$ ), while $-k$ - was taken to be signalling 'second person' in the pronominal system, like $-t$ - in the plural suffixes of the perfect in the verbal system.

This reinterpretation could take place only after velarization/ pharyngealization of the preceding $k$ (due to the influence of following - $u w$ on this $-k$-) had become stable, which resulted in the second person endings pl. masc. -kuw and pl. fem. -kin. 'Subtracting' the reinterpreted new pl. morphemes - $u w$ and -in (just like in the verbal system) then resulted in second person pronominal suffixes to be used for the sg.: (masc.) $-k$ and (fem.) $-k$.

In dialects of group VI this reasoning by analogy (though presumably not a conscious process) was taken a step further; since $-h$ - signals 'third' person, adding pl. suffixes $-u w$ and $-i n$ resulted in the pronominal suffixes for the pl. (masc.) - $h$-uw and (fem.) $-h$-in. ${ }^{89}$

Since the reinterpretation of morpheme boundaries resulted in a pronominal system that is internally quite logical,,$^{90}$ even dialects that use a different system may copy this new logical system — wholly or partiallyinto their own systems.

Notice that in dialects of group VII where we have pronominal suffixes -hum and -hin and verbal second person pl. suffixes -tum and -tin (if these are indeed 'original' verbal endings of the second p. pl.) comparable

\footnotetext{
${ }^{89}$ See also De Jong 2000: 169 , remark ${ }^{* 3)}$.

${ }^{90}$ If we accept that 'internal logic' of a system significantly contributes to chances of this system to be copied by speakers of dialects with a different system.
} 
reasoning by analogy has resulted in verbal perfect and imperfect endings -um (or -um) and -in, as in perfect (masc.) katab-um and (fem.) katab-in, and imperfect (masc.) y-ikitb-um and (fem.) y-ikitb-in. One of my 'Lēgiy informants explained that the -um endings are used in more formal settings, such as court sessions.

\subsubsection{Pronominal suffixes and negation}

When forms with pronominal suffixes are negated with the compound negation $m a \ldots . . . s$, we have the following forms:

"want need"91

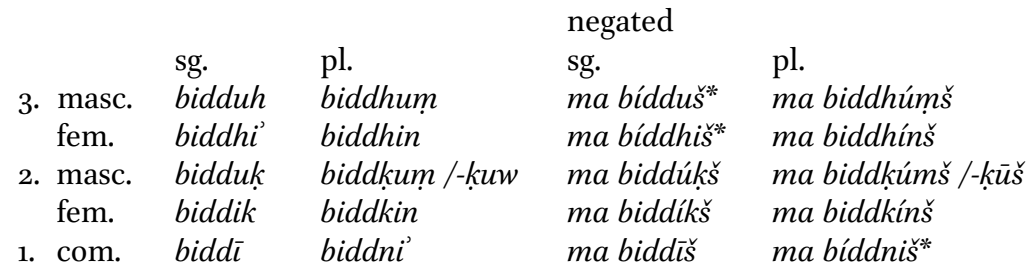

* Notice that negated forms do not show lengthened vowels and stress does not shift (like in e.g. Cairene Arabic: ma šuftūš "I did not see him", ma šuftahāšs "I did not see her", ma šuftināšs "you did not see us"), and that the $-s$ is simply affixed to the final vowel, even if this vowel has been raised. For this reason (i.e. the absence of lengthening), it seems fair to assume that -kum is the 'original' pron. suffix rather than -kuw, since one would not expect lengthening of a final vowel $(-* \bar{u}<-u(w))$ with affixed $-\check{s}($ i.e. $-\bar{u} s$ as in $-k \bar{u} \check{s})$ in a system where other vowels are not lengthened when they precede affixed $-\check{s}$. A form comparable to the unlengthened forms in $m a$ bídduš, ma bíddhiš and ma bíddniš would have been 'ma bíddkuš.

Some examples of negated verb forms are:

$\begin{array}{lll}\text { kátabatuh } & \text { "she wrote it (sg. masc.)" } & \text { negated } \\ \text { katabátti } & \text { "she wrote it (sg. fem.)" } & \text { ma katabáttiš } \\ \text { katábtuh } & \text { "I wrote it (sg. masc.)" } & \text { ma katábtuš } \\ \text { katábtti } & \text { "I wrote it (sg. fem.)" } & \text { ma katabttiš }\end{array}$

${ }^{91}$ Nishio 1992:196-197 (XXVII-21) also lists bidd, but indicates with a schwa that a cluster $\mathrm{dd}+\mathrm{C}$ is resolved, as in e.g. hī biddəhย timši "she wishes to leave (or walk)" and biddəne "we wish". Also in verb forms the high vowel tends not to be dropped when preceded by a geminate but is reduced to schwa ("in rapid speech") in Nishio's material on ĞbA, it seems, e.g. Nishio 1992:96 (XIV-27) ydawwəru, ydawwəren "they (masc., fem.) search", etc. Such forms were not heard in my recordings. 


$\begin{array}{ll}\text { i'iṭni yyāh } & \text { "give it (sg. masc.) to me" } \\ \text { ițūni yyāh } & \text { "give (pl. masc.) it to me" } \\ \text { i'țīhi yyāh } & \text { "give (sg. fem.) it (fem.) to her" } \\ \text { i'țūha } & \text { "give (pl. masc.) it to her" } \\ \text { iținhi } & \text { "give (pl. fem.) it to her" } \\ \text { i'țínnuh } & \text { "give (pl. fem.) it to him" }\end{array}$

ma ti iṭniš iyyāh ma ti țūniš iyyāh ma ti țīhiš iyyāh ma ti țūhaš iyyāh* ma tițínhiš iyyāh* ma títínnuš iyyāh

* Notice the difference in phonetic quality of the vowels preceding $-\check{s}$; the (originally) pausal vowel is directly suffixed with -š.

Other such examples are: ukúlhi' "eat (sg. masc.) it (sg. gem.)", (negated) ma tākúlhiš "don't eat (sg. masc.) it (sg. fem.)", uḳ̂̄ihi "eat (sg. fem.) it (sg. fem.)" is negated as ma tāḳlīhiš “don't eat (sg. fem.) it (sg. fem.)", but uḳ̂ūha "eat (pl. masc.) it (sg. fem.)" is negated as ma tāklūhaš “don’t (pl. masc.) eat it (sg. fem.)".

išllhi' "take it (sg. fem.) away"

išluh "take it (sg. masc.) away"

(i) šllūha "take (pl. masc.) it (sg. fem.) away"

(i) šllinnuh "take (pl. fem.) it away"

(i)šllūh "take (pl. masc.) it (sg. masc.) away" negated

ma tišilhiš / ma tšllhiš

ma tíšluš / ma tš̄luš

ma tšilūhaš

ma tšillínnuš

ma tšll $\bar{u} \varsigma^{*}$

* Notice that this form is homophonic with the negation of unsuffixed (i.e. without object suffixes) forms:

$$
\begin{array}{ll}
\text { (i)šlluw "take (pl. masc.) away" } & \text { negated as } \\
\text { ma tšillūš }
\end{array}
$$

Other such examples are:

uxdīh "take (sg. fem.) it"

úx diy "take (sg. fem.)"

and

$$
u x \underline{d u} h \text { "take (pl. masc.) it" }
$$$$
\text { úx } \underline{\text { duw }} \text { "take (pl. masc.)" }
$$

both negated as

ma tāx $\underline{d} \bar{i} s$

Similarly, the vowel in the pronominal suffix -na is not lengthened when it is in turn suffixed with -šs, e.g. šăfni' "he saw us", (negated) ma šāfniš "he did not see us" and šâlūni' "they carried us", (negated) ma šālūniš "they did not carry us".

N.B.

This treatment of the pl. com. pronominal suffix -na differs from treatment of the verbal suffix -na: in contrast to the vowel of the pronominal suffix, the vowel of the verbal suffix is lengthened before -̌s, e.g. šufna "we 
saw" is negated as ma šufnāš "we did not see", and also suffixed šufnāh "we saw him" is negated as (homophonous) ma šufnāš "we did not see him". Similarly, the negated 3 rd p. sg. masc. form of the verb "come" is ma ğ $\bar{a} s$ "he did not come", not •ma ğiš (cf. 3.2.2.6. below).

These remarks do not apply to 'LA, since 'LA hardly uses compound negation; negating suffixed verbs in 'LA is done with preceding $m \bar{a}$, e.g. $m \bar{a}$ byahašūh "they do not stuff it (sg.fem.) (i.e. of food)" and mā yākilha "he does not eat it" and mā byibnūh "they do not build it" (see also remarks in 3.1.16. and 4.2. of this chapter).

\subsubsection{Demonstratives}

\subsubsection{Near and far deixis}

Near deixis ${ }^{* 1}$ :

$\begin{array}{lll} & \text { sg. } & \text { pl. }{ }^{*_{3}} \\ \text { masc. } & (h \bar{a}-) \underline{d a h} h^{*_{2}} & (h \bar{a}-) \underline{d i l l}(-i h)^{*_{4}} \\ \text { fem. } & (h \bar{a}-) \underline{d} i y & \end{array}$

$*_{1}$ Forms without initial $h \bar{a}$ - are much more regular than in group I. In dialects other than HmA, the forms with initial $h \bar{a}$ - occur mainly in the sg.

$*_{2}$ In pause, and at times also sentence-medially often $\underline{d i}$ or $\underline{d i h}$.

*3 In HnA the pl. forms (masc.) innās $\underline{d u w}$ and (fem.) ilihrayyim dinn(-ih) were also recorded.

*4 In ḦmA also hâd $\bar{o} l(-a h)$ can be heard. Forms with prefixed $h \bar{a}$ - (also in far deixis) are more regular in HmA..$^{22}$

In 'LA the form $\underline{\text { dum }}(\sim \underline{\text { dillih}})$ was also elicited (but a conceivable $\cdot \underline{d i n}$ for the pl. fem was rejected when suggested).

Nishio 1992:181 (XXV-24) gives dell $\sim$ dōl (the latter being more used among younger speakers) and dellet for the fem. in ĞbA.

Notice the absence of velarization in these pl. demonstrative forms. These forms are strongly reminiscent of forms hadella and hadelle reported by Bergsträßer ${ }^{93}$ for the 'Amārīn near Wādiy Mūsa.

Far deixis*

$\begin{array}{lll} & \text { sg. } & \text { pl. } \\ \text { masc. } & \underline{d} \bar{a} k(-a h)^{*_{2}} & \underline{d a l l a ~} \hat{a}(-a h)^{*_{2}} \\ \text { fem. } & \underline{d} \hat{\imath} k(-i h) & \end{array}$

\footnotetext{
${ }^{92}$ Bernabela 2009:27 reports several instances of $\underline{d} \bar{o} l$ for the pl. masc. and one instance of dillah for the pl. fem.

${ }_{93}$ Cf. Bergsträßer 1915. Cf. also the remark in Palva 1991:164.
} 
*1 $_{1}$ Like in near deixis, also in far deixis HmA tends to have forms with

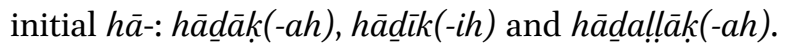

For ĞbA Nishio 1992:181-182 (XVV-25 and 26) lists d̄āka had̄āka for sg. masc., dīke $\sim$ hadīike for sg. fem. and dallāka for pl. masc. and dallāket for pl. fem. and adds that in the pl. the masc. form is often used "when used as subject".

$*_{2}$ Velarization present in the forms for far deixis, but absent in the forms for near deixis, is likely to be the result of spreading from velarized $k$.

Like in group VI, "there he/she is (lit.: has come)" or "there they are (masc./ fem.) (lit. have come)" is hēhü ǧi', hēhì ğàt, hēhuṃ(ma) ǧuw and hēhin(na) ǧin.

In ĞbA also the following forms were elicited:

$$
\begin{aligned}
& \text { ilihrummah hikín(nih) "those women (there)" } \\
& \text { innās hukúm(ṃa) "those people (there)" } \\
& \text { ilwálad hukúw(wah) "that boy (there)" } \\
& \text { ilbint hikíy(yih) "that girl (there)" }
\end{aligned}
$$

The $k$ may also be doubled. Forms recorded in ǦbA and ASA are:

hukkū ği' "there he has come", hikkī ğāt "there she has come", hukkuṃ(mah) ğuw "there they have come", hikkin(nah) ğin "there they (fem.) have come".

The origin of these presentatives is probably $h \bar{a} k+h \bar{u}$ or huwwa, after which $k+h$ was assimilated to $k k$ and $\bar{a}$ of $h \bar{a} k$ was shortened and harmonized with the vowel of the suffixed pronominal.

3.1.13.2. Specifying ha-

Specifying ha- was heard only in halhìn "now".

\subsubsection{Interrogatives}

Interrogatives for 1) "who?", 2 ) "what?", 3 ) "why?", 4) “when?", 5$)$ "where?", 6) “which?”, 7) "how?”, 8) "how much?”, 9) "how many/much?”.

1) min, 2) ès / èh, 3) lès / lēh, 4) (i)mtēh (mtēn in ḤmA and ASA and (i)mtēn mitēn in ĞbA) and wagtēš (less regular wagtēh), 5) wèn, 6) iyyāt + sg., 7) kêf* 8) kam + sg. "how many?", kutrǟ̌š / kutrēěs "how much?", 9) gaddēš / giddēš.

Nishio 1992 lists the following forms for ĞbA: 1) min (p. $183(\mathrm{XXV}-30))$, 2) ēš ē (p. 183-184 (XXV-31)), 3) lēš lē (p. $184(X X V 35)), 4)$ mitēn ( imta from Cairene Arabic) (p. $184(\mathrm{XXV}-36)), 5)$ wēn ( fēn from Cairene Arabic) (p. $184(\mathrm{XXV}-34)), 6)$ ayyu (p. $\left.\left.184\left(\mathrm{XXV}-3^{2}\right)\right), 7\right)$ kēf $(\sim$ izzay from Cairene 
Arabic) (p. 184 (XXV-33)), bkam (p. $185(\mathrm{XXV}-38))$, 9) kam (XXV-37)) and translates gaddēš $\sim$ gadrēš as "how far" (p. $185(\mathrm{XXV}, 39))$.

* Bernabela 2009:21 (and in also his texts) reports several instances in ĞbA of $i z z \bar{a} y$ or $i z z a y y$ azzayy (no instances of kēf or kīf) which I attribute to adaptation by the speaker to the speech of the interviewer (who spoke Cairene).

\subsubsection{Adverbs}

3.1.15.1. Adverbs: "there”, "over there (far away)", "here", "thus", "now", "still", "afterwards, after that"

"Here" is nih $\bar{a}\left(\right.$ (') or nihāniy ${ }^{*_{1}}$ ( $f i \underline{d} i$ is also used) K-form hínih also appears and perhaps the original form is híniy, "there" is hnütiy or hnōtiy" ( $f$ $\underline{d} \bar{a} k(-a h)$ is also used, hnuh occurs less), $\dot{g} \bar{a} d$, sometimes $\dot{g} \bar{a} d i y$ (both with open $\bar{a}$ ) is used for "over there (far away)" (the opposite being $\check{g} \bar{a} y$ "nearby"). "Thus" is kídiy or kidiyyih, "now" is halhìn, "still" is lissā (and K-form lissa) and "afterwards, after that" is baiadenn.

* nihāniy was not heard in ĞbA. Like in group VI, when the preposition min precedes niha $\bar{a}$, one syllable is haplologically dropped, e.g. mi-nhā(') or mi-nhāniy "from here; this way (in this direction)". Bernabela 2009:28 reports hnit and nihiniy and a shortened form nihiy for ĞbA. Nishio 1992:182 (XXV-28), however, does report nhāni and (as a form from Cairene?) heni $(\sim$ hena) for ĞbA.

As a possible origin for the locative adverb niha, one could think of *hinā or *hunā followed by the (postpositioned, see 3.1.9.1. of chapter III) deictic element $h \bar{a}$, producing *hināhā or *hunāhā (stressed on final syllable), after which $\bar{a}$ of the second syllable was shortened (> hinaha or *hunahā, see 1.2.24.), the resulting short $a$ was raised (> ${ }^{*}$ hiniha or *hunihā, see 3.1.1.5.) and the first syllable was dropped. On the historical order of these developments it can only be stated with relative certainty that shortening of $\bar{a}$ and consequent raising of the resulting $a$ must have taken place in that order.

*2 Nishio 1992:182 (XXV-28) reports henōt (i.e. without final -i(y)) and (as a form from Cairene?) hnāk ( henāk) for ĞbA.

3.1.15.2. "maybe"

For "maybe" no forms based on the root $x$-w- $f$ (e.g. xōf allah) or k-w-d (e.g. $k \bar{u} d$ ) were recorded, but only yimkin "maybe, possibly". 
3.1.15.3. bilhēe "at all"

bilhẹel "very, extremely" was heard in ĞbA only in combination with a negation in the meaning of "at all": bațla 'mašiy 'ana. bass b ilğamal ma țili tiš. b iṣṣarăḥah, miš b ilhêl ilbu ṛān ma barīdhinš "I go out on foot, but I have not gone out with a camel. Frankly, I don't like camels at all”. Another example is rawwaḥt iddēr, iw fataḥna șșubiḥ. issuwwāḥ māš ilǧim'ah suwwāḥ b ilhèel "I went to the monastery, and we opened up (i.e. their souvenir shop) in the morning. There are no tourists, on Friday there are no tourists at all".

3.1.15.4. bišwēš "slowly, carefully"

Adverbial bišwěš was not recorded in ȚA, nor in HnA or 'LA. Instead, a construction like šwayyih šwayyih "bit by bit" is used.

3.1.15.5. $\min x \overline{\text { f }}$ "lest"

min $x \bar{o} f$ in the sense of "lest" (see De Jong 2000:179) was not recorded.

Instead, a construction with ahsan was recorded in HnA: bitsawwha, mumkin itxallha galīdah, bass in tabga rffayy'ah tabga ēh? ahsan ibtístiwiy "you make it, you could make it thick, but if it is thin it what? Otherwise (lest) it becomes cooked".

\subsubsection{Prepositions + pers. pronominal suffixes}

Suffixed prepositions recorded in TwA, HnA and 'LA (unless explicitely stated otherwise) are: (suffixes - $h a$ and $-n a$ are usually - $h i$ ' and $-n i$ in neutral environments and in 'LA 2nd p. pl. masc. final $-u w$ varies with final $-u m$ )

\begin{tabular}{|c|c|c|c|c|c|c|}
\hline \multirow{7}{*}{$\begin{array}{l}\text { 3. masc. } \\
\text { fem. } \\
\text { 2. masc. } \\
\text { fem. } \\
\text { 1. com. }\end{array}$} & \multicolumn{2}{|l|}{$l t^{* 1}$} & \multicolumn{2}{|l|}{ 'ala+ ${ }^{* 4}$} & \multicolumn{2}{|c|}{ (i) $m(i)^{c}+{ }^{* 6}$} \\
\hline & sg. & pl. & sg. & pl. & sg. & pl. \\
\hline & luh & lēhuṃ & 'ilēh & 'ilèhhum & imiuh & miḥhuum \\
\hline & lēha & lēhin & 'ilēha & 'ilēhin & miḥha & miḥhin \\
\hline & $l u k^{*_{2}}$ & lée $\bar{e}^{u} u m$ & 'ile $e^{u} k$ & 'ilēeu kum & ím'uk & miḳuṃ \\
\hline & $l i k^{* 2}$ & lèkin & 'ilēk & 'ilēkin & ímik & mikin \\
\hline & $l \imath^{* 3}$ & lèna & 'aláy $(y)^{* 5}$ & ‘ilēna & $i m^{\prime} \bar{\imath}$ & mina \\
\hline
\end{tabular}

$*_{1}$ The preposition $l+$ suffix may in turn again be enclitically suffixed, e.g. biytallí-luh "he takes out for himself". This was however only observed with a suffix $-u h .^{94}$

*2 In HimA lée $\bar{e}^{u}$ and lēk or lēkiy.

${ }^{94}$ In forms like $g \bar{a} !$ luk or $g \bar{a} !$ luh it is not possible to conclude enclitic suffixing; 'proof' of such enclisis would be stress shift or lengthening of a directly preceding vowel, as in e.g. Cairene gibtū-luh "I brought it for him" or 'alit-lu "she said to him". Examples of such vowel lengthening or stress shift were not recorded in these dialects. 
$*_{3}$ In ASA and 'LA lay.

*4 In 'LA direct elicitation yielded (sg.) 'luh, ' lèha, 'luk, 'lik, 'lay and (pl.) 'lèhum, 'lèhin, 'lèkum / -uw, 'lēkin, 'lèna but in spontaneous texts only forms like 'alúh 'ilúh (and also 'alēh), 'alēha, 'alēkuw / -um etc. occurred. In ḦmA both 'alēh 'ilèh and less regularly 'alúh 'ilúh can be heard.

*5 In ĞbA both 'aláy and 'ilèy (compare ìdèy "my hands") were recorded.

*6 In GrA full paradigmatic levelling has produced variant forms (for consonant-initial suffixes) ími'ha, ími'hum, imi'hin, ími kum, ími kin and imina, leading to the conclusion that the underlying morphological base is $\left|\operatorname{im}^{\prime}\right|$ in this case.

In ĞbA near the monastery and in 'LA forms without stressed original anaptyctic are current: (sg.) $m^{\prime} u h, m^{\prime} u k, m^{\prime} i k$ and $m^{\prime} \iota$. In Mrēr (in Wādiy aš-Šèx) ĞbA forms are like those listed in the paradigm above (im 'uh, etc.).

In HmA 3 rd p. sg. masc. was recorded as $m^{\prime} u h$, and 2 nd p. sg. masc. and fem. as $m i^{\prime} u k$ and $m i^{\prime i} k$ resp.

\begin{tabular}{|c|c|c|c|c|c|c|}
\hline & $f i+$ & & $f o ̄ g+* 3$ & & $\min +$ & \\
\hline & sg. & pl. & sg. & pl. & sg. & pl. \\
\hline 3. masc. & fih & fihum & föguh & fōghum & minnuh & minhum \\
\hline fem. & fiha & fihin & fögha & fōghin & minha & minhin \\
\hline 2. masc. & $f i k$ & fi kum & fóguk ${ }^{* 4}$ & fögḳum & minnuk ${ }^{* 5}$ & minḳum \\
\hline & $f i k^{* 1}$ & fikin & fógik & fōgkin & minnik $^{* 5}$ & minkin \\
\hline com. & $f i^{*_{2}}$ & fina & $f \bar{o} g \bar{\imath}$ & fōgna & minnī & minna \\
\hline
\end{tabular}

*1 In 'LA fikiy.

$*_{2}$ In ASA, ĞbA and 'LA fini.

*3 For "above" also min hard+ pron. suffix is used: min hardī, min harduk etc.

*4 Since in negated forms (see below) the high vowels $i$ and $u$ are stressed, I have not interpreted these as anaptyctic vowels, but as morphophonemically present vowels (hence their notation is not superscript).

$*_{5}$ Notice doubling of the $n$ here indicating that the suffixes are vowelinitial in these cases: $-u k$ and $-i k$.

\begin{tabular}{|c|c|c|c|c|}
\hline & wara+ & & ind+ & \\
\hline & & pl. & sg. & pl. \\
\hline 3. masc. & warāh & warāhuṃ & induh & 'induhum \\
\hline fem. & warāha ${ }^{*_{1}}$ & warāhin & 'índaha" & 'índihin \\
\hline 2. masc. & wara $\bar{a}^{u} k^{* 2}$ & warāḳum & ‘induḳ & 'induḳum \\
\hline fem. & $w a r a \bar{a} k^{* 2}$ & warākin & 'indik & 'indikin \\
\hline 1. com. & warāāy*3 & warāna $^{* 4}$ & ‘indī & 'índina \\
\hline
\end{tabular}


In the following notes below a few remarks follow on negated suffixed forms. These remarks do not apply to 'LA, since 'LA does not use compound negation; negating suffixed prepositions in 'LA is done with preceding $m \bar{a}$, e.g. $m \bar{a}$ warāha, $m \bar{a}$ 'indī, etc. (see also remarks in 3.1.12.3. and 4.2.).

*11 In ASA warāha (negated ma warāhaš), but in ĞbA warahi and (negated ma warāhiš).

$*_{2}$ Negated forms in ȘwA were recorded as (sg. masc.) ma waṛă $\bar{a}^{u} \underline{s}$ and (sg. fem.) ma warākšs. Other dialects have negated forms (sg. masc.) ma wară $\bar{a}^{u} k u s ̌$ and (sg. fem.) ma warākiš (compare negated 'ala+ below).

*3 Negated ma warāyys.

*4 Negated ma warāniš.

$*_{5}$ When the final vowel is raised, the vowel preceding $h$ will be raised as well: 'indihi.

Other examples of negated suffixed prepositions in TwA and HnA are (not in 'LA):

negated:

\begin{tabular}{|c|c|c|c|c|}
\hline & 'ala $+^{*_{1}}$ & & $f \bar{g} g+$ & \\
\hline & sg. & pl. & sg. & pl. \\
\hline 3. masc. & ma ilēes & ma ‘ilēhúṃš & ma fōguš & ma fōghúmšs \\
\hline & ma ìlēhiš & ma ilēhínš & ma fōghiš & ma fōghínš \\
\hline 2. masc. & $m a{ }^{c} i \bar{e}^{u} k ̣ u s^{*_{2}}$ & $m a$ 'ilēukúmšs & ma fōgúḳšs* & ma fōgḳumš \\
\hline fem. & 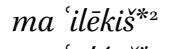 & ma ilēkínš & ma fōgíkš ${ }^{*} 4$ & ma fōgkínš \\
\hline 1. com. & ma 'aláyš*3 & ma ilēniš & ma fōgīš & ma fōgniš \\
\hline
\end{tabular}

${ }^{*_{1}}$ Like in group VI, raising of short $a$ to $i$ in open syllables preceding stressed $\bar{e}$ (as indicated here) is optional, but very regular.

As independent prepositions both 'al $a$ and ' $a$ (not only when preceding the article) are current, e.g. ' $a$ ğamb "aside".

*2 In ȘwA negated forms are $m a$ 'alēu $k s ̌$ and $m a$ 'alēkš.

*3 In ǦbA ma ilēyš was also recorded.

$*_{4}$ On the status of high vowels $i$ and $u$ in these forms, see remark ${ }^{*_{4}}$ to paradigm $f \bar{g} g+$ above.

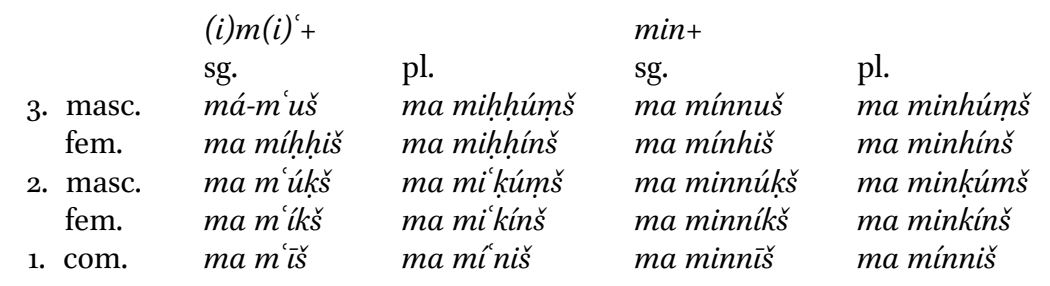




\subsubsection{Numerals and counted plurals}

\subsubsection{Cardinal numbers 1-10}

Independent cardinal numbers in TwA, HnA and 'LA are (forms that precede counted nouns follow in brackets):95 wähid / wihdih ${ }^{*_{1}}$, thēen / tintēn ${ }^{*_{2}}$, talātih (tálat), arba'ah (arba'), xamsih (xams), sittih (sitt), sab'ih (sab'), tamānyih (táman), tis ih (tis'), 'ašarah ('ašar).

*1 wāhid and wihdih may follow the counted noun as adjectives for extra emphasis, e.g. walad wāhid "one boy" and bint wihdih "one girl".

*2 tnèn and tintēn may follow the counted dual form of the noun as adjectives for extra emphasis, e.g. waladēn ițnèn "two boys" and idèy ițtintēn or idèy tintēnhin "my two hands".

Some plural forms of nouns are counted with proclitic $t$ - (a remnant of the fem. morpheme in construct state), e.g. 'ašar t-infār "ten people", talat t-iyyām "three days".

\subsubsection{Ordinal numbers 1-10}

Only three ordinals were recorded in TwA, HnA and 'LA: awwil, țāniy, tālit.

\subsubsection{Numerals: 11 and up}

Numerals recorded in TwA, HnA and 'LA are:

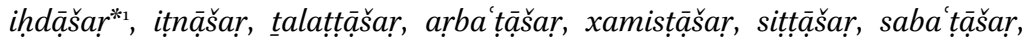

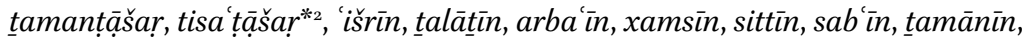
tis'in, miyyih, miyytēn, tulitmiyyih, rubi'miyyih, xumismiyyih, suttmiyyih, subi'miyyih, tuminmiyyih, tusimiyyih, alf, alfēn, talat t-älāf, xamis t-ālāf,

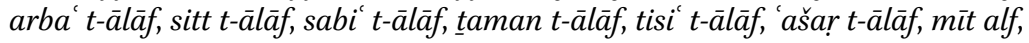
miyytēn alf, milyōn ${ }^{* 3}$ (and țalat malāyìn).

*1 In 'LA hidāšar

*2 Forms recorded in HnA have endings in -ạšir. In ȘwA also shorter forms

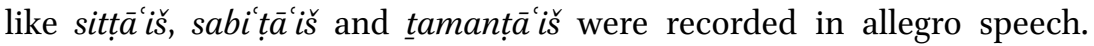
Informants for ASA claimed endings in $-\bar{a} c i s ̌$ are more current than those ending in -ạšir or -āšar.

*3 In HnA and 'LA malyōn.

Some plurals recorded with proclitic $t$ - are: talat $t$-iškāl "three shapes", talat $t$-ālāf "three thousand", 'ašar t-iyyām "ten days", xamis $t$-ušhur "six

\footnotetext{
95 For numerals recorded in ǦbA in Nishio 1992 see pp. $169-175$ (XXIV-2 to XXIV-71).
} 
months", arba' t-írbi "four descent groups (of a tribe)", taman t-infār "eight persons".

Months are usually referred to by numbers, but in ȘwA also šahar Imšı̃r was mentioned (the Coptic month of Amshir, 6th month of the Coptic calender).

\subsubsection{The dual}

Suffixing -ēn (or -änn) to the sg. form of a noun forms the dual, e.g. nușșän "two halves", šaharǟn "two months", marrtēn "two times", xațiwtēn "two steps".

Older forms of the dual are used in expressions for body parts, e.g. riğlèy "my (two) legs", riğlè k "my (two) hands" and ìdèy "my (two) hands" and $\bar{\imath} d \bar{e}^{u} k$ "your (two) hands".*

* In ĞbA forms with initial $a$ - were recorded: adēy and $a d \bar{e}^{u} k$ and also adèhum "their hands" (pl. adēn). ${ }^{96}$

\subsection{Verbal Morphology}

In the dialects of the Hamāḍah (HmA) and 'Lēgāt ('LA) several instances of -um $(\sim-u w)$ endings in perfect and imperfect for the 2nd and 3 rd p. pl. masc. were recorded. The remarks on perfect and imperfect forms in 3.2.1.1. and 3.2.1.2. should be extrapolated for the entire verb system.

\subsubsection{Regular verbs}

\subsubsection{Regular verbs perfect}

In HmA and also 'LA the verbal ending of the 2nd p. ending -tum is also often heard as a variant.

In some, but fewer instances, the ending -um was also heard being used as a variant to the ending $-u w$ for the 3 rd p. pl. masc., both in the perfect and in the imperfect. Such verbal endings are reminiscent of verbal endings recorded in the dialect of the Samā'nah of group II in the north. ${ }^{97}$

The final $-m$ is also heard in the 2 nd p. pl. masc. pronominals intum and the suffix -kum, and these pronominals are also current-though

\footnotetext{
${ }_{96}^{6}$ Nishio 1992:5 (I-36) gives sg. yīd and pl. yīdēn/yidēn, e.g. xamsع yidēn.

${ }_{97}$ See De Jong 2000:297-298.
} 
co-occurring with intuw and -kuw-in surrounding dialects of group VII GrA, ȘwA, ĞbA, ASA and HnA..$^{98}$

Of the two variant verbal endings of the perfect -tuw and -tum the latter appears to be losing ground to the former, while $-u m$ as a variant for $-u w$ has almost entirely disappeared.

Like in group VI, the 2nd and $3 \mathrm{rd}$ p. pl. fem. ending is -in (including the $a$ - and $i$-types of the tertiae infirmae). The perfect ending of the 3 rd p. sg. fem. may be -at or -it, depending on the vowel-type of the perfect (contrast group VI in chapter II).

Perfects of measure 1 verbs come in three types: $\mathrm{C}_{1} \mathrm{aC}_{2} \mathrm{aC}_{3}, \mathrm{C}_{1} \mathrm{iC}_{2} \mathrm{iC}_{3}$ and $\mathrm{C}_{1} \mathrm{uC}_{2} \mathrm{uC}_{3}$. The paradigms are:

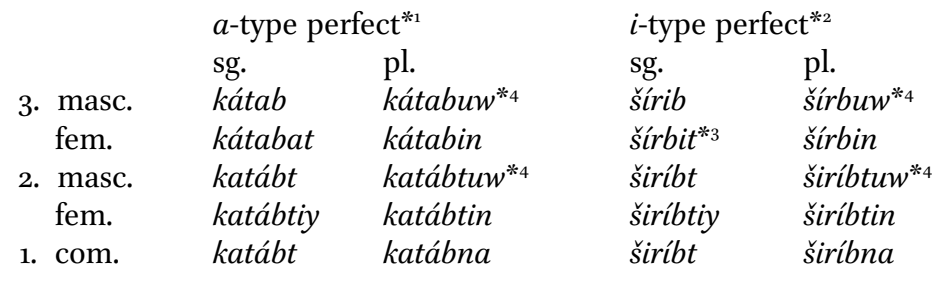

${ }^{*_{1}} a$ may be raised to $i$ in pre-stress syllables, e.g. kitábtiy, but such raising is less regular than in group VI.

*2 The short high vowel $i$ of the first syllable is actually underlying $|\mathrm{a}|$ and is therefore not dropped in open unstressed syllables (so e.g. not šribt, šribtiy, etc.).

Nishio 1992, however, almost invariably indicates instances of such high vowel elision from the unstressed first syllable in ĞbA, e.g. smi't "I heard" (p. 11 (I-76)), lbist "I got dressed" (p. 13 (II-2)), šribt "I drank" (p. 21 (III-46)) and also ğrit "I ran" (p. 67 (IX-17)) as a form used by younger speakers, lgit "I found" (p. 96-97b (XIV-28)), etc.

*3 Notice the ending -it instead of -at used in group VI.

*4 In HmA (and also in 'LA) often katabtum and siribtum. Notice that similar forms were recorded in the dialect of the Samā'nah in northern Sinai (see De Jong 2000:298). -um endings in the 3rd p. pl. masc. perfect forms were also recorded in $\mathrm{HmA}$ (like the situation in SaA), but were rarer, e.g. hatțum "they placed", ištárum "they bought", lāgum "they found". Notice that also in the dialect of Cairo both katabu katabum and katabtu

${ }_{98}^{8}$ The same verbal endings were recorded in the speech of older members of the Samā'nah of group II in the north, see De Jong 2000:296-301. In this dialect of group II, older speakers also used the ending -um for and and 3 rd pl. masc. forms in the imperfect, see remarks in 3.2.1.2. below. 
katabtum can be heard, of which the forms in $-m$ are characterized as "sub-standard" (see Woidich 2006:75) (see also remarks on imperfect forms in 3.2.1.2. below).

\subsubsection{Regular verbs imperfect}

Like in many dialects in Sinai, the imperfect is characterized by vowel harmony in the verbal prefixes. Like in group VI, this vowel harmony is also found in the 1st. p. sg. com. of $i$ - and $u$-type imperfects (contrast e.g. group I, where we have initial $a$ - for 1st p. sg. com. in all (three) vowel types, see De Jong 2000:299). ${ }^{99}$

There are three imperfect patterns: yaC $\mathrm{C}_{2} \mathrm{CaC}_{3}$, yuC $\mathrm{C}_{2} \mathrm{CuC}_{3}$ and yiC $\mathrm{C}_{2} \mathrm{iC}$. The paradigms for TwA, HnA and 'LA are identical to those listed for group VI, but for HmA and LA the following remarks should be added:

For HmA several (spontaneously produced) instances of -um (but $\sim-u w$ ) were recorded for the 3 rd and 2 nd p. pl. masc., e.g. yhuttum "they place", thutțum "you (pl. masc.) place", yíštirum "they buy", yafdum "they sacrifice", tafdum "you (pl. masc.) sacrifice", yridum "they want", trìdum "you (pl. masc.) want". When such forms were checked separately (i.e. on another occasion with another speaker), they were rejected, and forms with - uw endings were accepted only.

Also in 'LA some instances (but less regularly than in HmA) of -um endings for 2nd and $3 \mathrm{rd} \mathrm{pl.} \mathrm{masc.} \mathrm{imperfect} \mathrm{forms} \mathrm{were} \mathrm{heard.} \mathrm{One} \mathrm{'Lēgiy}$ informant explained that - $u w$ endings were used in 'faster' speech, while -um endings would be used in more formal speech, e.g. by a gādịy "judge". Notice that similar forms were also recorded in the dialect of the Samāenah in the Gatyah oasis in the north (cf. De Jong 2000:296-309 and map 54 in the appendix). See also NOTE in 3.1.12.2.

Measure 1 verbs $i$-type (e.g. yaharit) and $a$-type (e.g. ya arag) with $\mathrm{C}_{1}=$ $\mathrm{X}$ have the same paradigms as group VI. Perfects and participles of these verbs hárat and 'írig are like kátab and šírib (see 3.2.1.1.).

3.2.1.3. Reflexes of older ${ }^{*} C_{1} a C_{2} u C_{3} * y^{*} C_{1} C_{2} u C_{3}$

$u$-type perfect ${ }^{*}$

"grow fat"

$\begin{array}{lll} & \text { sg. } & \text { pl. } \\ \text { 3. masc. } & \dot{g} u \dot{l u d} & \dot{g} u l \underline{d} u w \\ \text { fem. } & \dot{g} u l \underline{\dot{d}} i t & \dot{g} u \underline{\dot{d}} \text { in }\end{array}$

${ }_{99}$ Nishio 1992 reports the possibility of vowel harmony for the first person sg. com. in $i$ - and $u$-type imperfects in ĞbA too, e.g. ad̦rob oḍrob "I hit" (p. 88 (XIII-11)) and enzil "I descend" (p. 107 (XV-15)). 

2. masc.
$\dot{g} u l u \underline{d} t$
$\dot{g} u l u d t u w$
fem.
guludtiy
guludtin
1. com.
$\dot{g} u l u \underline{d} t$
$\dot{g} u l u \underline{d n}$ a

The Classical Arabic 'Eigenschafts' verb-type (which expresses a certain personal characteristic) may have $\mathrm{C}_{1} \mathrm{uC}_{2} \mathrm{uC}_{3}, \mathrm{yuC}_{1} \mathrm{C}_{2} \mathrm{uC}_{3}$ reflexes (imperfect paradigm is like that of yúdrub in MzA and BWA, see 3.2.1.2. in chapter II). This appears to be the case when the perfect is velarized. When velarization is absent, the perfect tends to be $\mathrm{C}_{1} \mathrm{iC}_{2} \mathrm{iC}_{3}$ and the imperfect then $\mathrm{yaC}_{1} \mathrm{C}_{2} \mathrm{aC}_{3}$.

A paradigm elicited in ASA is: (sg.) túxun, túxnit, tuxínt, tuxíntiy, tuxint and (pl.) túxnuw, túxnin, tuxíntuw, tuxíntin, tuxínna. The imperfect is yutxun.

In ĞbA, ȘwA, HmA, GrA and HnA also gulud ( gilid in ĞbA) (and imperf. yugilud, in 'LA giliẹ, yugigud), but tíxin (imperfect yatxan) and kibir (imperfect yakbar).

The short vowel of the first syllable in the perfect may be $i$ or $u$, but it is not dropped, and is therefore best interpreted as underlying $|a|$.

\subsubsection{Regular verbs participles}

Like in group VI, active participles in TwA, HnA and 'LA are formed with the patterns $\mathrm{C}_{1} \overline{\mathrm{a}}_{2} \mathrm{iC}_{3^{\prime}}, \mathrm{C}_{1} \overline{\mathrm{a}} \mathrm{C}_{2} \mathrm{C}_{3} \mathrm{ah} /$-ih (sg. fem.), $\mathrm{C}_{1} \overline{\mathrm{a}} \mathrm{C}_{2} \mathrm{C}_{3} \overline{\mathrm{in}}$ (pl. masc.), $\mathrm{C}_{1} \overline{\mathrm{a}} \mathrm{C}_{2} \mathrm{C}_{3} \overline{\mathrm{a}} \mathrm{t}(\mathrm{pl}$. fem.).

When the sg. fem. participle is suffixed with an object, it is in construct state with this suffix. Examples are: 'äwiztuh "she wants/loves him" and (in 'LA) rāyidtuh "she wants him". In HnA a form 'äriftha "she knows her" was recorded several times, instead of expected 'ärfitha.

\subsubsection{Regular verbs imperatives}

Imperatives of regular verbs in TwA, HnA and 'LA are like in group VI, e.g. áftah, áftahiy, áftaḩw, áftahin "open!", úg'ud, úgu'diy, úgu'duw, úgu'din "sit down!" and inzil, inzliy, inzluw, inzlin "come down!".

\subsubsection{Irregular and other verbs}

\subsubsection{Verbs $C_{1}=\mathrm{w}$ (primae wāw)}

Imperfect, perfect, and imperative paradigms for measure 1 verbs $\mathrm{C}_{1}=w$ are like in group VI, e.g. yōrid and yōgaf.

In H.mA "stand" was recorded with an $i$-type imperfect:yōgif "he stands", yōgfuw "they stand", etc.

In two instances in ASA verbs without the wāw, i.e. with an initial short vowel, were recorded: tálid "she gives birth" and yísig bēhum "he trusts 
them". The latter of these is probably a loan, of which $s$ for * $\underline{t}(\operatorname{root} w-\underline{t}-q)$ is indicative (see 1.1.2.).

$a w^{\prime} a$ may in some dialects be left unconjugated and be used more as a general particle of warning, e.g. (in GrA) aw'a tans, aw'a tansiy, aw'a tansuw and aw'a tansin "don't you forget! (for sg. masc., sg. fem., pl. masc. and pl. fem. resp.)".

But imperative forms were also recorded in TwA, HnA and 'LA: $a w^{\prime} a$ rāsuk, aw'iy răsik, aw'uw ryūskum, and aw'in ryüskin (although the pl. of $r \bar{a} s$ in HnA and 'LA is rūs).

In ĞbA: aw'a rạasuk, aw'a rāasik, aw'a rūsḳum, aw'a rūuskin.

In ȘwA a particle $a w^{\prime}$ was also recorded with pronominal suffixes for the person addressed: aw'uk tans, aw'ik tansiy, áwu'kum tansuw, áwi kin tansin (notice also the insertion of anaptyctics in the last two examples). ${ }^{100}$

\section{Participles:}

Active participles have a $\mathrm{C}_{1} \overline{\mathrm{a}} \mathrm{C}_{2} \mathrm{iC}$ pattern, e.g. (with velarized first syllables) wārid, wardih, wārdīn, wärdāt "having watered".

The passive participle for the root $w-\check{g}-d$ was recorded as mawğ $\bar{u} d$ in all dialects, but in ĞbA and ȘwA the form mēğ $\bar{d}$ was also heard, and in ĞbA also the form mērūs "inherited" (see remark on root $w$-r-te above). ${ }^{101}$

3.2.2.2. Verbs $C_{1}=\mathrm{y}$ (primae yâ')

Like in group VI, the only verb recorded with $\mathrm{C}_{1}=y$ is yibis, yeebas "dry (intransitive)" in TwA, HnA and 'LA.

\subsubsection{Verbs $C_{1}={ }^{* \prime}$ (primae hamzah)}

The two verbs "eat" and "take" have similar conjugations. Both have a limited, but clear degree of velarization in the imperfect and all dialects have $u$ as the imperfect vowel, as in $y \bar{a} k \hat{k} u$ and $y \bar{a} x u \underline{d})$, but in HmA also

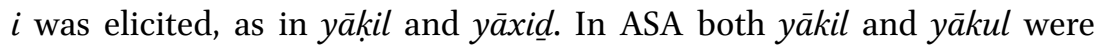
recorded, but the base vowel $u$ appeared to be conditioned by its phonetic environment; $u$ only appeared when $l u k$ "for you" followed, as in (several

${ }^{100}$ These anaptyctic vowels also cause the $w$ to become vowel-initial in the surface form. In these cases the diphthong $a w$ is clearly not treated like its product of monophthongization $\bar{o}$. For an interesting discussion on the topic of mono- or poly-phonemicity of diphthongs ay and $a w$ in Old Arabic and in the modern Arabic dialects, see Fischer 1967.

${ }_{101}$ Compare also the form miğ $\bar{u} d$ reported in Blanc 1970:25, fn 42 and the form mayğ $\bar{u} d$ heard in the dialect of the Masāî̀ in the north of Sinai (see De Jong 2000:194). Henkin in EALL 2008:362 also reports mawlūd maylūd "born" in Negev Arabic. 
instances of) yākul luk "he eats for you" (an instance of the ethical dative, see 4.14.3.). The perfect forms are all without initial $a$-: kal and $x a d$.

The sg. masc. imperative may be with initial stressed $\dot{u}$ - in all dialects except HmA and 'LA as in úkul and úxud, but was also recorded as $k u l$ and $x u \underline{d}$ in all dialects, except in ȘAA and ASA (compare with the sg. masc. imperatives of mediae geminatae in 3.2.2.4.2.).

The sg. fem. appears with initial stressed ú (úkliy) in ȘwA, GrA, ASA and HnA. In ĞbA it is kliy or úkliy and in H.

Similarly, plural forms are úkluw (masc.) and úklin (fem.) in ȘwA, GrA, ASA and HnA. In ĞbA co-occurring forms are ḳluw, klin and úkluw and $u ́ k l i{ }^{102}$ and in HimA forms are only without initial $u$-: kluw and klin. Like

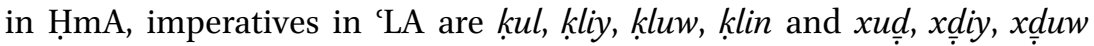
and $x$ din.

Compare this to the occurrence of stressed original anaptyctics (in 2.3.5.) and the absence of a stressed original anaptyctic in the suffixed preposition $m(i)^{c}$ as opposed to its presence in other dialects of this group (see 3.1.16.).

Active participles in TwA, HnA and 'LA are with initial $m$-: māxid, māx dih, māxdīn, māxdāt and mākil, māklih, māklīn and māklāt.

The verbal noun in TwA and HnA is wakl "eating" (also "food") and the passive verb "be eaten" is inwákal, yínwikil, but in ĞbA also intákal, yintikil was recorded.

\subsubsection{Verbs $C_{2}=\mathrm{w}$ or y (mediae infirmae)}

3.2.2.4.1. Verbs $C_{2}=\mathrm{w}$ or y (mediae infirmae) perf. and imperf.

Like in group VI, in TwA and HnA a short base vowel is characteristic for the 2nd p. sg. masc. imperfect and imperative forms of mediae infirmae verbs, although forms with long base vowels may also be heard.

The perfect and imperfect paradigms are like in group VI (except for the ending -tum, see above in 3.2.1.1.), but instead of sg. masc. imperfect forms $t(u)$ gúm tgūm heard in group VI, in ṬwA and HnA we hear túgum / tgūm and also tišil / tšil and tánam / tnām.

However, during direct elicitation, my ḦmA informants rejected suggested forms like túgum and tánam and only accepted the form tísil with difficulty. Some of my ĞbA informants rejected tánam, but forms like tísil,

${ }^{102}$ Nishio 1992:91 (XIV-2) lists oxod $\sim$ xod, oxodi $\sim$ xodid, oxodu $\sim$ xodu, oxoden $\sim$ xoden, but (p. 20-21 (III-43)) okul kul. okli, oklu and oklen for ĞbA. 
túgul, túgum were produced spontaneously, e.g. túgum tíğib illaban "you then (get up) and get the milk".

When such shorter 2nd p. sg. masc. imperfect forms are suffixed, we get forms like e.g. tišluh "you carry it (sg. masc.)", ma tišluš "don't carry it!", ma tišilhiš "don't carry it (sg. fem.)", bitǧíbha "you bring her" and btu 'úzha "you want it (sg. fem.)".

N.B. Imperfect and imperative forms for the end p. sg. masc. with a short base vowel are not characteristic of 'LA. If 'LA speakers use such forms, this is attributed (by other 'LA speakers) to the influence of speakers of other dialects. Forms claimed as proper 'LA are (imperfect) ť̌̀l, tnām, tgūl and (imperative) $\bar{s} \bar{l} l, n \bar{a} m, g \bar{u} l$. Sg. fem. and pl. masc. and fem. forms are

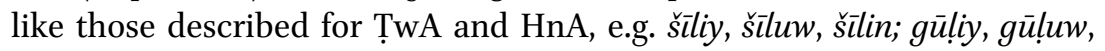
gūlin and also nāmiy, nāmuw, namin.

Participles in ȚA, HnA and 'LA are like in group VI, e.g. šāyil, šāylih, šāylīn, šâylāt.

The perfect of the verb šăf, yšüf was recorded in TwwA and HnA with short vowel $u$ only: šuft "I saw" (not recorded in 'LA).

Verbs $\mathrm{C}_{2}=y$ are like in group VI as well, e.g. šăl, yšll (and šilt) (for a remark on originally measure 4 verb rāad, yrïd, see 3.2.3.7.2.).

\subsection{Verbs $C_{2}=\mathrm{w}$ or $\mathrm{y}$ (mediae infirmae) imperatives}

Like in the imperfect, imperatives of the 2nd p. sg. masc. often have short base vowels. They may also have an initial short vowel (recorded in ĞbA) šil ísil "carry!", gul úgul "say!" and also nam ánam "go to sleep!" ${ }^{103}$ In ĞbA the sg. masc. imperative with a short base vowel may or may not have an initial vowel as well (contrast with other dialects in this group, see below). This is concomitant with comparable imperative forms of primae hamzah verbs in ĞbA, see 3.2.2.3.

The other imperatives (for sg. fem, pl. masc. and pl. fem. resp.) are: šilliy, šiluw, šllin; gūliy, gūluw, gūlin and nāmiy, nāmuw, nāmin.104

When the forms for the sg. masc. are suffixed, resulting forms are like: šlluh (ĞbA), išluh and (i)šllhi. Dialects that have initial $u$ - in imperative

\footnotetext{
${ }^{103}$ For ĞbA Nishio 1992:30 (IV-37) for "sleep" gives nām, nām (sic.), nāmu and nāmen and for "say" (p. 72-73 (X-6)) ogol gol gūl, gūli, gūlu and gūlen.

${ }^{104}$ For ĞbA Nishio 1992:31 (IV-41) gives gom $\sim$ gūm $\sim$ ugūm, gūmi ugūmi, but for the pl. only gūmu and gūmen.
} 
forms for "eat" and "take" (see 3.2.2.3.), also have initial short vowels in imperatives of mediae infirmae verbs.

In some dialects, the initial short vowel spread through the whole paradigm (paradigmatic levelling): in ȘwA, for instance išl iššwāl "carry the sacks!", išìlīhi šìlīhi "carry (sg. fem.) them (sg. fem.)!", išìlūha šllūha” "carry (pl. masc.) them (sg. fem.)!" and išllinnuh šillinnuh "carry (pl. fem.) it (sg. masc.)". In GrA, ASA and HnA imperative forms recorded were úgum or gūm, ugūmiy, ugūmuw, ugūmin for "stand up!". In these dialects (i.e. GrA, ȘwA, ASA and HnA) a short base vowel does not appear after an initial vowel (compare this to sg. masc. imperatives in ȘwA and GrA of primae hamzah verbs in 3.2.2.3.). In HmA the sg. masc. does not have an initial vowel, but the form is gum or güm.

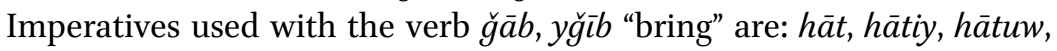
hātin.

For a remark on the absence of shortened long base vowels in the 2nd p. sg. masc. imperfect and imperative forms in 'LA, see 3.2.2.4.1. above.

3.2.2.4.3. Verbs $C_{2}=\mathrm{w}$ or y (mediae infirmae) participles

Active participles of measure 1 in TwA, HnA and 'LA are formed with the

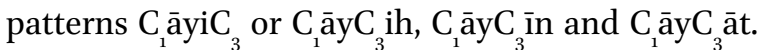

A passive partiple recorded for $g \bar{a} l, y g \bar{u} l$ is magyū! "said, spoken" (in ASA and ȘwA) and for rāad, yrīd is maryūd "wanted" (ASA).

3.2.2.5. Verbs $C_{3}=\mathrm{y}$ (tertiae infirmae)

3.2.2.5.1. Verbs $C_{3}=\mathrm{y}$ (tertiae infirmae) perfect

Many informants for TwA and HnA produced mixed paradigms for the perfect of tertiae infirmae verbs.

In 'LA informants kept the $a$-type and $i$-type perfects apart better.

Unmixed paradigms for the $a$ - and $i$-type perfects are:

perfect

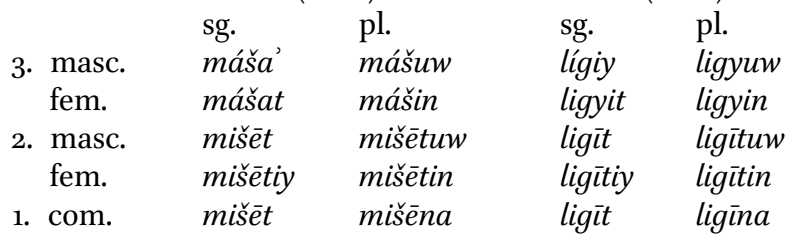

* $_{1}$ The same paradigms were recorded in ȘwA and 'LA (maša is also $a$-type perfect there). 
Raising of $a$ preceding $\bar{e}$, as is reflected in the paradigm above, is current in the $a$-type perfect, e.g. mišēt < mašêt. Such raising is however optional..$^{105}$

*2 Similar paradigms were recorded for yansa, nisiy "forget", and these were also recorded in 'LA.

The high vowel $i$ of the first syllable is to be interpreted as a raised 'underlying' $a$, since it is not dropped in unstressed positions. Such raising of $a$ presumably began in positions preceding stressed $\bar{l}$, after which the resulting $i$ became stable-i.e. such raising was no longer optional-and then spread through the paradigm (paradigmatic levelling) to replace $a$ in all positions.

A mixed paradigm for the perfect of the verb "forget" was recorded in ASA:

$\begin{array}{lll}\text { perfect } & & \\ & \text { "forget" (ASA) } & \\ & \text { sg. } & \text { pl. } \\ \text { 3. masc. } & \text { nása' } & \text { nisyuw } \\ \text { fem. } & \text { násat/nisyit } & \text { nisyin } \\ \text { 2. masc. } & \text { nisīt } & \text { nisìtuw } \\ \text { fem. } & \text { nisītiy } & \text { nisītin } \\ \text { 1. com. } & \text { nisìt } & \text { nisìna }\end{array}$

One of the GrA informants had similar difficulties with the perfect of the verbs máša' / mísiiy. The paradigm he produced was: (sg.) miśsiy / máša, mášat, mišēt, mišêtiy, mišēt and (pl.) mišyuw / mášuw, mášyin / mášin, mišêtuw, mišētin, mišēna. He also produced a mixed paradigm for lígiy "find" (forms were: (sg.) lígiy, lígyit, ligitt, ligïtiy, ligït and (pl.) lígyuw, lígyin, ligètuw / ligìtuw, ligìtin, ligēena).

Also in HnA forms of both the $i$-type and of the $a$-type may be heard used for the perfect in verbs like laga / ligiy and nisiy / nasa. The verb maša is, however, clearly $a$-type in HnA (for a remark on measure 1 verbs, which were originally measure 4 verbs in $\mathrm{HnA}$, see 3.2.3.7.1).

Paradigms for "find" recorded in ASA and HmA were exactly like those listed for ĞbA (above) ${ }^{106}$ Also nisiy and mišiy are clearly $i$-types in ḤmA.

\footnotetext{
${ }^{105}$ Nishio 1992:66 (IX-16) gives final $-\varepsilon$ (as in maš $\varepsilon$ ) in the 3 rd p. sg. masc., does not indicate glottalization of final $-a$ in this position nor raising of $a$ in open syllable preceding stressed $\bar{e}$.

${ }^{106}$ Nishio 1992:112 (XVI-5) lists nisi "forget" as an $i$-type perfect.
} 
Notice that perfect conjugations in which $a$ - and $i$-types have mixed also occur in groups I and VI.

Nishio 1992, however, does list many forms with such elision in ĞbA, see remark ${ }^{* 2}$ in 3.2.1.1. above. This was not observed in ĞbA by myself ${ }^{107}$ (cf. also remark in fn to 3.1.1.1. on (non-) elision of 'underlying' a in $\mathrm{CaCīC}$ ).

N.B. Although 2nd p. sg. masc. imperfects and imperatives with shortened long base vowels (of mediae infirmae verbs) are absent from 'LA (see 3.2.2.4.1.), apocopated imperfect and imperative forms for the $2 \mathrm{nd} \mathrm{p}$. sg. masc. of tertiae infirmae verbs are current in 'LA. 'LA thus occupies a middle position between group VII dialects (which show both base vowel shortening and apocopation of tertiae infirmae) and TAṢ (Tuṛbāniy of Rāàs Șadr) (which shows none of these).

3.2.2.5.2. Verbs $C_{3}=\mathrm{y}$ (tertiae infirmae) imperfect

Tertiae infirmae verbs in TwA, HnA and 'LA are:

imperfect

$\begin{array}{lllll} & \text { "find"*1 } & & \text { "walk" } \\ & \text { sg. } & \text { pl. } & \text { sg. } & \text { pl. } \\ \text { 3. masc. } & \text { yalga } & \text { yalguw } & \text { yimšiy } & \text { yimšuw } \\ \text { fem. } & \text { talga } & \text { yalgin } & \text { timšiy } & \text { yimšin } \\ \text { 2. masc. } & \text { talg*2 } & \text { talguw } & \text { timš š } & \text { timšuw } \\ \text { fem. } & \text { talgiy } & \text { talgin } & \text { timšiy } & \text { timšin } \\ \text { 1. com. } & \text { alga } & \text { nalga } & \text { imšiy } & \text { nimšiy }\end{array}$

*1 $_{1}$ The type of raising of final - $a$ (e.g. yansi') heard in group VI is not current here.

${ }^{*}$ Apocopated imperfects for the 2 nd p. sg. masc. are very regular. ${ }^{108}$

Suffixed examples recorded in TwA, HnA and 'LA are: $\operatorname{alg} \bar{a}^{u} k$ "I find you", (apocopated) talgnī "you find me", hayalgūnī "they will find me", hayalgūk. "they will find you", hayalginnuk "they (fem.) will find you". In the latter example, $i$ of the verbal ending may colour (towards I.P.A. [u]) with velarization of the pronominal suffix, i.e. yalgunnuk "they (fem.) find you". Forms with measure 1: (apocopated) hatalghi' "you (sg. masc.) will find

${ }^{107}$ Bernabela 2009 heard ligēt "I found" (p. 66), ligīhum "he found them" (p.79) and also maligitš "I did not find". He recognizes that ligēt is probably an $a$-type (with raised $a$ in the first syllable). The paradigm of the $i$-type without elision of the first vowel is listed on p. $5^{0 .}$

${ }_{108}$ Also reported for ǦbA in Nishio 1992, e.g. tagr "you read" (p. 76 (X-28)), tiğr "you run” (p. 66-67 (IX-17)). 
her", hatilgāhi' (with prefix vowel $a$ raised $>i$ ) "she will find her", hatalgīhi" "you (sg. fem.) will find her" (for suffixed measure 3 forms, see 3.2.3.6.1.).

3.2.2.5.3. Verbs $C_{3}=y$ (tertiae infirmae) imperatives

Like apocopated imperfect forms for the and p. sg. masc., apocopated imperative forms for sg. masc. are currrent in TwA, HnA and 'LA, e.g. irm (írim \#) "throw", irmuh "throw it (away)" and imš "walk; go!". The other forms are irmiy / imšiy, irmuw / ímšuw and írmin / ímšin. ${ }^{109}$

3.2.2.5.4. Verbs $C_{3}=\mathrm{y}$ (tertiae infirmae) participles

Active participles have the patterns $\mathrm{C}_{1} \overline{\mathrm{a}} \mathrm{C}_{2} \mathrm{iy}, \mathrm{C}_{1} \overline{\mathrm{a}} \mathrm{C}_{2}$ yih, $\mathrm{C}_{1} \overline{\mathrm{a}} \mathrm{C}_{2} \mathrm{yin}$ and $\mathrm{C}_{1} \bar{a} \mathrm{C}_{2}$ yāt. Examples are fādiy, fādyih, fādyīn, fādyāt "having sacrificed".

3.2.2.5.5. Verbs $C_{3}=\mathrm{y}$ (tertiae infirmae) verbal nouns

A verbal noun of a verb $C_{3}=y$ (tertiae infirmae) is mašy.

3.2.2.6. The verb "come"

\subsection{The verb "come" perfect and imperfect}

The verb "come" was recorded in HmA as (differences with paradigms for the other dialects are given in notes; apart from these differences, paradigms for this verb are the same in TwA, HnA and 'LA) :

\begin{tabular}{|c|c|c|c|c|}
\hline & perfe & & imper & \\
\hline & sg. & pl. & sg. & pl. \\
\hline 3. masc. & $\check{g} i^{* * 1}$ & $\grave{g} u m^{* 2}$ & yiğiy & yı̈ğuw \\
\hline fem. & $\check{g} \bar{a} t$ & ğin ${ }^{* 3}$ & tiğiy & yı̆ğin ${ }^{* 3}$ \\
\hline 2. masc. & ğìt & ğitum $^{*_{2}}$ & tìğiy ${ }^{* 4}$ & tīğuw \\
\hline fem. & ǧitiy & ğititin ${ }^{* 3}$ & tiğiy & tĭǧin ${ }^{* 3}$ \\
\hline 1. com. & ğit & ğina & ïgù & nüğiy \\
\hline
\end{tabular}

${ }^{*}$ When suffixes follow, final $-i$ will be $\bar{a}$ as in $\check{g} \bar{a}^{u} k$ "he came to you" and ma $\check{g} \bar{a} \breve{s}$ "he did not come" (see also remark N.B. in 3.1.12.3.).

$*_{2}$ Instead of final $-m$ of HmA, other TwA dialects and HnA have final $-w$ : ğuw and ğituw (which are also parallel forms in ḤmA).

In 'LA only ğuw was heard, but given the several instances of 3 rd p. pl. masc. perfect forms with final -m (e.g. kátabum "they wrote"), it seems safe to assume that the form ğum will also be heard in 'LA, just as ğttuw co-occurs with ğttum (see also remarks in 3.2.1.1. and 3.2.1.2. above). For a remark on the development of the verbal suffix -um see NOTE in 3.1.12.2.

Notice that the form gum is also current in Cairene Arabic.

\footnotetext{
${ }^{109}$ Also reported in ĞbA by Nishio 1992, e.g. er "see” (p. 9 (I-73)), ağr "run” (p. 76 (X-28)), but only imši "go" (p. 66 (IX-16)) and "run" eğri (p. 67-67 (IX-17)).
} 
*3 When suffixed with consonant-initial suffixes, the final $-n$ is doubled, e.g. ğitinnuh "you (pl. fem.) came to him", (and examples for TwA and 'LA) ma ǧinnuš "they (fem.) did not come to him" and ma tï̌́innuš "don't (pl. fem.) go to him!".

*4 Notice the long vowel $\bar{\iota}$ in the imperfect paradigm. In ĞbA both long vowel

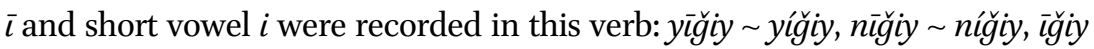
$\sim$ iğiy, but only tiğ as the apocopated form for the 2 nd p. sg. masc. ${ }^{110}$

GrA, Swa, ASA and HnA have long $\imath$ in the imperfect, except in GrA, SwA and ASA, where also tiğ occurs as the shortened and apocopated form. In $\mathrm{HnA}$ and 'LA only the apocopated form tīg was heard.

\subsection{The verb "come" imperatives}

Imperatives used with the verb "come" are: ta'āl, ta'āliy, ta āluw and ta ālin." ${ }^{11}$ In one instance in ḤmA ta āluw ǐğuw "come (pl. masc.)” was recorded.

In 'LA the 2nd p. sg. masc. imperative was recorded as (without final $-l$ ) $\operatorname{ta}^{\prime} \bar{a}$ (other forms in 'LA are like those listed above).

\subsection{The verb "come" participles}

Participles of the verb "come” are: ǧāy, ğāyih, ǧāyīn, ğāyāt in TwA, HnA and 'LA.

\subsubsection{Verbs $C_{2}=C_{3}$ (mediae geminatae)}

\subsection{Verbs $C_{2}=C_{3}$ (mediae geminatae) perfect and imperfect}

Mediae geminatae verbs in TwA, HnA and 'LA have the following paradigms:

\begin{tabular}{|c|c|c|c|c|}
\hline \multirow{6}{*}{$\begin{array}{l}\text { 3. masc. } \\
\text { fem. } \\
\text { 2. masc. } \\
\text { fem. }\end{array}$} & \multicolumn{2}{|l|}{ perfect $^{*_{1}}$} & \multicolumn{2}{|c|}{ imperfect } \\
\hline & sg. & pl. & sg. & pl. \\
\hline & 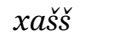 & xaššuw & yxušš & yxuššsw \\
\hline & xaššat & xaššin & txušš & yxuššin \\
\hline & xiššèt & xiššētuw & txušš & txuššuw ${ }^{* 2}$ \\
\hline & $\begin{array}{l}\text { xiššètiy } \\
\text { xiššèt }\end{array}$ & $\begin{array}{l}\text { xiššēêtin } \\
\text { xiššēena }\end{array}$ & $\begin{array}{l}\text { txuššì } \\
\text { uxuššs }\end{array}$ & $\begin{array}{l}\text { txuššin } \\
\text { nxušš }\end{array}$ \\
\hline
\end{tabular}

*1 Raising of $a$ preceding $\bar{e}$ is regular in TwA, HnA and 'LA (like in group VI and in the dialect of Biliy in the north, see De Jong 2000:205) and is not

\footnotetext{
${ }^{110}$ The same paradigms for perfect and imperfect (but only with long base vowel ī) are reported for ĞbA in Nishio 1992:62 (IX-2), but parallel to ğum the forms jū and jow are also listed, and parallel to the 2nd p. sg. masc. imperfect form tiji the apocopated form listed there is tìj. The end p. pl. masc. perfect form listed there is without final -m: jītu.

${ }^{11}$ The same forms are listed for ĞbA in Nishio 1992:62 (IX-2).
} 
prevented by preceding $x$, although such raising does not take place when $a$ is preceded by $h$ (see remark below). ${ }^{112}$

When the geminate is velarized, the $\bar{e}$ of the ending is lowered (indicated here as $\bar{a}$, near I.P.A. [ $\left.\varepsilon_{\Sigma}\right]$ ), but not diphthongal ay. E.g. hatțǟt "I placed" and in HmA hatțum "they placed" and hatțätum "you (pl. masc.) placed" (notice that $a$ is not raised, so not •hițtät or •hutțät, or something similar). In 'LA hatțätum was elicited.

${ }^{*_{2}}$ Forms elicited in H. HA are (pl. masc.) yhutțum and thuțtum. In 'LA thutțum was elicited.

3.2.2.7.2. Verbs $C_{2}=C_{3}$ (mediae geminatae) imperatives

Imperatives of mediae geminatae verbs in TwA, HnA and 'LA are like in group VI, e.g. limm, limmiy, limmuw, limmin "gather!" and with base vowel u: xušš, xuššiy, xuššuw, xuššin “enter!".

3.2.2.7.3. Verbs $C_{2}=C_{3}$ (mediae geminatae)

Active participles of medial geminate verbs in TwA, HnA and 'LA are e.g.: lāmm, lāmmih, lāmmīn, lāmmāt "having gathered".

Passive participles may be subject to the gahawah-rule when $\mathrm{C}_{1}=\mathrm{X}$, e.g. mahațūt "placed", maxarūm "pierced", ma arüfah "known (sg. fem.)", etc.

\subsubsection{Derived measures}

\subsubsection{Measure n-1}

\subsection{Measure n-1 sound roots}

In TwA, HnA and 'LA the vowel in the preformative of measure n-1 is not stressable in the perfect, but may be stressed in the imperfect. The underlying patterns are: (i) $\mathrm{nC}_{1} \mathrm{aC}_{2} \mathrm{aC}_{3}, \mathrm{yinC}_{1} \mathrm{aC}_{2} \mathrm{iC}$. The a in the imperfect is raised to $\mathrm{i}$ in open syllables, but 'reappears' in closed syllables. Paradigms are:

"be beaten"

perfect

sg.

3. masc. fem.

2. masc. fem.

1. com. (i)ndárab

(i)ndárabat

(i)ndarábt

(i)ndarábtiy

(i)ndarábt pl.

(i)ndárabuw

(i)ndárabin

(i)ndarábtuw

(i)ndarábtin

(i) nḍarabna imperfect

sg. $\quad$ pl. yíndirib yindárbuw tíndirib yindárbin tíndirib tindárbuw tindِárbiy tind̄árbin inḍirib níndirib

${ }^{112}$ Nishio 1992 does not report comparable raising for ĞbA, e.g. laffēt "I turned around" (p. 65 (IX-10)), addēt "I gave" (p. 82 (XII-1)), zaggēt "I pushed" (p. 94 (XIV-13)), lammēt "I gathered" (p. 98 (XIV-36)), etc. 
Participles are: mínḍirib, minḍ̂́rbih, minḍarbīn, minḍarbāt.

3.2.3.1.2. Measure n-1 $C_{2}=C_{3}$ (mediae geminatae)

Patterns for perfect and imperfect of measure n-1 of medial geminate verbs in Twa, $\mathrm{HnA}$ and ' $\mathrm{LA}$ are: $(\mathrm{i}) \mathrm{nC}_{1} \mathrm{aC}_{2} \mathrm{C}_{2}$ and yinC $\mathrm{aC}_{2} \mathrm{C}_{2}$, e.g. inhațt, yinhațt "be placed".

\subsection{Measure $\mathrm{n}-1 C_{2}=\mathrm{y}$ or $\mathrm{w}$ (mediae infirmae)}

The patterns for perfect and imperfect of measure n-1 of medial weak verbs are: $\mathrm{inC}_{1} \mathrm{a}_{3}$ and yinC $\mathrm{a}_{1} \mathrm{C}_{3}$. Paradigms in TwA, HnA and 'LA are like those listed for group VI, e.g. inšāl, yinšāl "be carried (away)".

3.2.3.1.4. Measure $\mathrm{n}-1 C_{2}=\mathrm{y}$ or $\mathrm{w}$ (mediae infirmae) participles

Participles are shaped on the pattern $\operatorname{minC}_{1} \bar{a}_{3}$ and are like those listed for group VI.

\subsubsection{Measure t-1}

Only one instance of measure $t$-1 was recorded in ȘwA: tithirig "it (sg. fem.) is burnt".

\subsubsection{Measure 1-t}

\subsection{Measure 1-t sound roots}

Underlying patterns for measure $1-t$ are: $(i) \mathrm{C}_{1} \operatorname{taC}_{2} \mathrm{aC}_{3} \mathrm{yiC}_{1} \mathrm{taC}_{2} \mathrm{iC}_{3}$, with a of the imperfect being raised to $\mathrm{i}$ in open syllables (e.g. níğtimi " "we gather"), but 'reappearing' as a in closed syllables (e.g. yiğtam 'uw "they gather")."13 Like in measure $n-1$, raised a is found in the unstressed syllables of the surface form for the imperfect, e.g.: (i)štáġal, yíštigìil "work", (i)ttáfag, yíttifig "agree" and (i)stáwa, yístiwiy "ripen; be cooked (of food)".

Paradigms in TwA, HnA and 'LA are:

\begin{tabular}{|c|c|c|c|c|}
\hline & sg. & pl. & sg. & $\mathrm{pl}$. \\
\hline 3. masc. & yíštiriy & yíštiruw ${ }^{* 2}$ & ištára & ištáruw ${ }^{* 2}$ \\
\hline fem. & tiśstiriy & tíštirin & ištárat & ištáran \\
\hline 2. masc. & tíštir ${ }^{*_{1}}$ & tíštiruw $^{* 2}$ & ištarǟt & ištarätuw ${ }^{*_{2}}$ \\
\hline $\begin{array}{l}\text { fem. } \\
\text { 1. com. }\end{array}$ & $\begin{array}{l}\text { tíštiriy } \\
\text { ištiriy }\end{array}$ & $\begin{array}{l}\text { tíštirin } \\
\text { níštiriy }\end{array}$ & $\begin{array}{l}\text { ištaräätiy } \\
\text { ištarät }\end{array}$ & $\begin{array}{l}\text { ištarätin } \\
\text { ištaräna }\end{array}$ \\
\hline
\end{tabular}

${ }^{*}$ Notice again the apocopated form, also reported for ĞbA in Nishio 1992:83-84 (XII-4).

${ }^{113}$ Nishio 1992 does not report such 'reappearing' $a$ in closed syllables in ĞbA, e.g. (p. 105 (XV-11) yijtim'u "they gather". 
$*_{2}$ In HmA also forms (imperfect) yíštirum and tíštirum and (perfect) ištárum and ištarä̈tum were recorded.

Participles are: mištiriy, mištaryih, mištaryīn, mištaryāt.

Imperatives are: ištir (apocopated), ${ }^{114}$ ištiriy, ištiruw, išstirin

3.2.3.3.2. Measure 1-t $C_{2}=\mathrm{w}$ or y (mediae infirmae)

An example of a medial weak measure 1-t verb is ištāg, yištāg (l) "long (for)". ${ }^{115}$

\subsection{Measure 1-t $C_{2}=C_{3}$ (mediae geminatae)}

Examples of medial geminate measure 1-t verbs are iltamm, yiltamm "gather, assemble (of people)" and imtadd, yimtadd "stretch out (in surface)".

\subsection{Measure 1-t participles}

Patterns for measure 1-t participles in TwA, $\mathrm{HnA}$ and ' $\mathrm{LA}$ are $\mathrm{miC}_{1} \mathrm{tiC}_{2} \mathrm{iC}_{3}$ (underlying $\mathrm{miC}_{1} \operatorname{taC}_{2} \mathrm{iC}_{3}$ ) $\mathrm{miC}_{1} \operatorname{taC}_{2} \mathrm{C}_{3} \mathrm{ah} / \mathrm{ih}, \mathrm{miC}_{1} \operatorname{taC}_{2} \mathrm{C}_{3} \overline{\mathrm{n}}, \mathrm{miC}_{1} \operatorname{taC}_{2} \mathrm{C}_{3} \bar{a} \mathrm{t}$.

Examples are: mištig̈il "working", miftarsih "predatory (of animals)", misstiriy "having bought (sg. masc.)", mištaryih "having bought (sg. fem.)", míttifig "agreed (sg. masc.)", mittafgāt "agreed (pl. fem.)".

Examples of participles of medial geminate and medial weak verbs are: mištāg lēha "longing for her", miltammin "having gathered (pl. masc.)", mimtaddih "stretching out (in surface) (sg. fem.)".

\subsubsection{Measure ista-1}

\subsection{Measure ista-1 sound roots}

Like measure 2, measure ista-1 has alternating short vowels: a in the perfect and $\mathrm{i}$ in the imperfect. The paradigms in TwA, HnA and 'LA are like those listed for group VI. ${ }^{116}$

3.2.3.4.2. Measure ista-1 $C_{2}=\mathrm{y}$ (mediae infirmae)

No perfect or imperfect forms of measure ista-1 verbs of medial weak roots were recorded.

\footnotetext{
${ }^{114}$ Also reported for ĞbA in Nishio 1992:83-84 (XII-4) (there: eštir).

${ }^{115}$ Nishio 1992:109 (XV-24) reports e.g. xtāt (sic.), yixtār "choose, select".

${ }_{116}$ Alternating vowels are also reported for ĞbA in Nishio 1992, e.g. p. $109(\mathrm{XV}-27)$ and p. 113 (XVI-11) and p. 95 (XIV-22) sta'mal yista'mel "use", but not in e.g. (p. 22 (III-50) stafrağ, yistafrag "vomit".
} 


\subsection{Measure ista-1 $C_{3}=\mathrm{y}$ (tertiae infirmae)}

Measure ista-1 verbs of final weak roots were not recorded in TwA or HnA. In 'LA a verb istagda (1st p. sg. com. istagdēt), yistagdiy (3rd p. pl. masc. yistagduw) "take up a new habit by following an example" was recorded.

3.2.3.4.4. Measure ista-1 verbs $C_{2}=C_{3}$ (mediae geminatae)

Patterns for medial geminate measure ista-1 verbs are: istaC $\mathrm{aC}_{2} \mathrm{C}_{2}$, yistaC $\mathrm{iC}_{2} \mathrm{C}_{2}$, e.g. (i)sta'add, yista idd "prepare oneself". ${ }^{117}$ Forms (reflecting optional raising of a preceding stressed ē) recorded in 'LA are: (sg.) ista'add, ista 'addat, isti iddēt, isti iddētiy, ista iddēt and (pl.) ista 'adduw, ista 'addin, ista iddētuw, ista iddētin isti'iddēne', see also remark in 3.2.2.7.1.

\subsection{Measure ista-1 participles}

Participles of measure ista-1 verbs have the pattern mistaC $\mathrm{C}_{2} \mathrm{iC}_{3}$, e.g. mistagrib "finding strange".

For measure ista-1 verbs of medial weak roots the pattern is $\operatorname{mistaC}_{1} \mathrm{iC}_{3}$ : mistahill "impossible, absurd" and (a clear MSA loan) mistaqimih "straight".

For mediae geminatae the pattern is mistaC $_{1} \mathrm{iC}_{2} \mathrm{C}_{2}$ : mista idd "having prepared oneself, ready".

\subsubsection{Measures 2 and $\mathrm{t}-2$}

In TwA, HnA and 'LA the patterns for measure 2 are: (perfect) $\mathrm{C}_{1} \mathrm{aC}_{2} \mathrm{C}_{2} \mathrm{aC}_{3}$, (imperfect) $\mathrm{yC}_{1} \mathrm{aC}_{2} \mathrm{C}_{2} \mathrm{iC}_{3}$.

Measure $t$-2 has morphologically fixed $a$. The patterns are (perfect) taC $\mathrm{aC}_{2} \mathrm{C}_{2} \mathrm{aC}_{3}$, (imperfect) $\mathrm{ytaC}_{1} \mathrm{aC}_{2} \mathrm{C}_{2} \mathrm{aC}_{3}$.

\subsection{Examples of measure 2 sound roots}

Like in other groups, the high vowel i of imperfect measure 2 may be elided in open syllables. The inital geminate of the resulting cluster may then be reduced. Examples of morphophonemic elisions are: biyfaḥmuw "they make charcoal", biyhammsuh 'a nnār "he roasts it on the fire", txazznuh "you store it".

Examples of sandhi elisions: twall innār "you light the fire" and bittall" ìyūn "it (sg. fem.) grows buds (of a plant)".

$r$ following the high vowel $i$ may inhibit its morphophonemic elision, e.g. imwaxxirih "pushing back (sg. fem.)" and an example in sandhi biykabbir il'adim "the bones grow". Examples with $l$ in a similar elision-inhibiting role were not recorded.

\footnotetext{
${ }^{117}$ For ĞbA Nishio 1992:104 (XV-6) reports e.g. stamarr, yistimirr "continue".
} 
When $\mathrm{C}_{2}=\mathrm{C}_{3}$, the elision of $i$ does not take place, but the geminate may be reduced, e.g. bitgázzizuh "you sow it (of watermellon seed, by inserting each seed into its own hole in the soil". A similar example from 'LA is biyballilūha "they moisten it (sg. fem.)".

\subsection{Measure 2 tertiae infirmae}

Paradigms for measure 2 tertiae infirmae verbs in TwA, HnA and 'LA are like those listed for group VI.

\begin{tabular}{|c|c|c|c|c|}
\hline & perfect & & imperfect & \\
\hline & sg. & pl. & sg. & pl. \\
\hline 3. masc. & sawwa & sawwuw & ysawwiy & ysawwux \\
\hline fem. & sawwat & sawwin & tsawwiy & ysawwin \\
\hline 2. masc. & suwwēt & suwwētuw ${ }^{*_{1}}$ & $t s a w w^{* 2} /-i y$ & tsawwuw \\
\hline fem. & suwwētiy & suwwētin & tsawwiy & tsawwin \\
\hline 1. com. & suwwēt & suwwēna & asawwiy & nsawwiy \\
\hline
\end{tabular}

$*_{1}$ In HmA and 'LA -tum. Suggested perfect forms sawwum and imperfect ysawwum for the 3 rd p. pl. masc. were not accepted in HmA (not checked in 'LA).

*2 An example of suffixation of an apocopated form is twarrha-yyāh "you show it (sg. fem.) to her". For ĞbA Nishio 1992 also reports apocopation, e.g. twarr "you show" (p. 97 (XIV-29)).

\subsection{Examples of measure 2 primae hamzah}

The verb "feed" is wakkal, ywakkil "give food", e.g. itwakkl ilgánam "you feed the sheep" (in 'LA itwakkl álganam) and wadda, ywaddiy "bring, take to", e.g. ywaddūh Mașir "they take him to Egypt (i.e. the mainland)".

\subsection{Measure t-2 imperfect and perfect}

In measure $\mathrm{t}-2$ the vowel $\mathrm{a}$ is morphologically fixed for the perfect and imperfect. Patterns in TwA, $\mathrm{HnA}$ and $\mathrm{LA}$ are $\operatorname{taC}_{1} \mathrm{aC}_{2} \mathrm{C}_{2} \mathrm{aC}_{3}$, $\mathrm{ytaC}_{1} \mathrm{aC}_{2} \mathrm{C}_{2} \mathrm{aC}$.

Like in group VI, the $t a$ - prefix in the perfect and imperfect of measure $t-2$ is stable and is only rarely reduced to $(i) t-.^{118}$

Reduction of initial $t t a$ - $>t a$ - in the imperfect is regular like in group VI. ${ }^{119}$ The paradigms are:

\footnotetext{
${ }^{118}$ Nishio 1992:105 (XV-8) however lists many instances of such reduction for ĞbA, e.g. p. 105 (XV-8) tharrak, yitharrak "move, be in motion", p. 72 (X-3) tharraf, yitharraf (mac) "speak with" and tballal, yitballal "be(come) wet".

${ }^{119}$ Nishio 1992 does not report such reduction in ĞbA (see also preceding fn), e.g. on p. 113 (XVI-8) tit'allam.
} 
"have dinner"

\begin{tabular}{|c|c|c|c|c|}
\hline & perfect & & imperfect & \\
\hline & & pl. & sg. & pl. \\
\hline 3. masc. & ta'ašša & ta'aššuw & yta'ašša & yta'aššuw \\
\hline fem. & ta'aššat & ta'aššin & ta'ašša & yta'aššin \\
\hline 2. masc. & ta'aššèt & ta'aššētuw & táa $a \check{s} s$ & ta'aššuw \\
\hline fem. & ta'aššētiy & ta'aššētin & ta'aššiy & ta'aššin \\
\hline 1. com. & ta'aššēt & ta'aššēna & ata'ašša & nta'ašša \\
\hline
\end{tabular}

Like in group VI, unstressed $a$ of the preformative $t a$-preceding stress may be raised, e.g. ti aššèt.

\subsection{Measures 2 and $\mathrm{t}-2$ verbal nouns}

Verbal nouns for measure 2 have a $\operatorname{taC}_{1} \mathrm{C}_{2} \mathrm{iC}_{3}$ pattern, e.g. (MSA loan) ta'ǧil "postponement", ta lìg "hanging up" and a gahawah-form ta'awīr "wounding" and a form tašnīn "taking aim" in 'LA.

$\mathrm{A} \mathrm{C}_{3}=y$ verbal noun was not recorded, nor a verbal noun for measure $t-2$.

\subsection{Measures 2 and $\mathrm{t}-2$ participles}

In TwA, HnA and 'LA active participles of measure 2 have a $\mathrm{mC}_{1} \mathrm{aC}_{2} \mathrm{C}_{2} \mathrm{iC}_{3}$ (-ih/ -ah, -īn, -āt) pattern. Passive participles have a $\operatorname{mC}_{1} \mathrm{aC}_{2} \mathrm{C}_{2} \mathrm{aC}_{3}(-\mathrm{ih} /-\mathrm{ah}$, -īn, -āt) pattern. Examples are like those listed for group VI.

Like in group VI, the $t a$ - preformative of measure $t$-2 is often reduced to $t$ - in participles in TwA and HnA (though less so in 'LA!), so that both patterns for $t$-2 active participles $\operatorname{mtaC}_{1} \mathrm{aC}_{2} \mathrm{C}_{2} \mathrm{iC}_{3}$ (-ih/-ah, -īn, -āt) and mit$\mathrm{C}_{1} \mathrm{aC}_{2} \mathrm{C}_{2} \mathrm{iC}_{3}$ (-ih/-ah, -īn, -āt) occur, e.g. mtağawwiz mitğawwiz "married" and for $\mathrm{C}_{3}=$ y) mtagaddiy $\sim$ mitgaddiy "having eaten lunch".

\subsubsection{Measures 3 and $\mathrm{t}-3$}

Measure 3 has morphologically alternating vowels in TwA, HnA and 'LA: $i$ in the imperfect and $a$ in the perfect. Patterns for measure 3 are: $\mathrm{C}_{1} \bar{a}_{2} \mathrm{aC}_{3}$, $\mathrm{yC}_{1} \overline{\mathrm{a}} \mathrm{C}_{2} \mathrm{iC}$.

Also in TwA, HnA and 'LA, measure t-3 has morphologically fixed $a$ in the perfect and imperfect, and like in measure $t$-2, reduction of the $t a$-preformative to $t$ - does occur, but is not very regular. Patterns for measure $t-3$ are: $\operatorname{taC}_{1} \bar{a} C_{2} a_{3}, y t_{1} C_{1} \bar{a}_{2} i_{3}$. Like in measure $t$-2, intitial $t$ - in the imperfect is reduced to $t$ - (see examples in 3.2.3.6.1.). ${ }^{120}$

\subsection{Examples of measures 3 and $t-3$}

Paradigms for measure 3 are like those listed for group VI. Also paradigms for a measure $3 \mathrm{C}_{3}=\mathrm{y}$ verb are like those listed for group VI.

\footnotetext{
${ }^{120}$ Nishio 1992:3 (I-23) lists tatāwab, ytatāāwab "yawn" without reduction of the $t a$ - preformative.
} 
Examples of apocopated imperfects of tertiae infirmae verbs are: $b$ il'arabiyyah twät 'ilēh "with the car you go down on it (to crush it, i.e. a snake)". Another example is: tlāg ilwalad, itlāguh "you find the boy, you find him" (the latter example also in 'LA). ${ }^{121}$

The verb lāga, ylägiy is often used alongside ligiy, yalga, without apparent difference in meaning: hanlägīhi' or hanilgāhi' "we'll find her" and hatläghin or hatalghin "you (sg. masc.) will find them (fem.)". Other forms recorded through direct elicitation are: (measure 3) hatlāgīh "you (sg. fem.) will find him", hatläginhin "you (pl. fem.) will find them (fem.)", hatlāgūhum "you (pl. masc.) will find them (masc.)" (for suffixed measure 1 examples, see 3.2.2.5.2.).

Examples for measure $t-3$ are: iytašāgaluw ššwāl "they throw the sacks together", tad̄āyag "he became angry", tanāwaš (< ttanāwaš) "you pick (of fruit from a tree)", tașāfa (< ttașāfa) Imayyah mn illaban "the water becomes cleared from the milk".

An example in 'LA is biytadāwalūh "they exchange it (among themselves)".

\subsection{Measures 3 and $\mathrm{t}-3$ participles}

Active participles of measure 3 have the pattern $\mathrm{mC}_{1} \mathrm{aC}_{2} \mathrm{iC}_{3}(-\mathrm{ih} / \mathrm{ah}$, -īn, -āt), e.g. mwāfig "agreeing", mlāgyih "having found (sg. fem.)", mkāwnīn "fighting (pl. masc.)" and in 'LA m âwid "returning" and mlāgīu "finding/ meeting (sg. masc.) you".

A passive participle (pattern $\mathrm{mC}_{1} \mathrm{a}_{2} \mathrm{aC}_{3}$ ) is the origin for the loan mwāṣalät "public transport".

Active participles of measure $t-3$ have the pattern $\mathrm{mtaC}_{1} \mathrm{aC}_{2} \mathrm{iC}_{3}$ or mitC ${ }_{1} \overline{C_{2}} \mathrm{iC}_{3}$ (-ih / ah, -īn, -āt). Not enough instances of participles of measure $t-3$ were recorded to draw conclusions on reduction of the $t a$ - preformative, i.e. initial $m t a->$ mit-. An elicited example is mitkāwnin "fighting (pl. masc.)".

\subsection{Measures 3 and $\mathrm{t}-3$ verbal nouns}

A verbal noun for measure 3 that was recorded is mmārasat ilhayāh "experience in life". Verbal nouns of the type $\mathrm{tC}_{1} \mathrm{e}_{2} \mathrm{iC}_{3}$ were not recorded.

\subsubsection{Measure 4}

\subsection{Measure 4 sound roots perfect and imperfect}

Like in many Bedouin dialects of Sinai, measure 4 is active in TwA, HnA and 'LA as well.

\footnotetext{
${ }^{121}$ Similar apocopation in ĞbA.
} 
In $\mathrm{HnA}$, however, several originally measure 4 verbs have joined measure 1 , or co-occur as measure 1 with measure 4, e.g. a'ta 'ața, yi țiy (and participles mi'țiy 'àțiy, mí ityih 'àtyih, etc.) "give”. Examples of its use as measure 1 are 'ațuw "they gave" and hinnih 'aținnuh "they (fem.) gave him". The paradigm for the perfect 'ața is thus a measure $1 a$-type, i.e. like maša in HnA: (sg.) 'áta, 'áțat, 'ațāt, 'ațätiy, 'ațät and (pl.) 'áțw, 'áțin, 'ațätuw, 'ațätin, 'ațäna. In 'LA the verb is still full measure 4: a'ța (1st. p. sg. com. a'țät), yi țíy and participles mi țiy, mí ityih, mi ityīn, mi ityāt.

Other verbs are fátar, yifțir "have breakfast" (paradigms like kátab, yiktib, see 3.2.1.1.) and dáwa, yị̂wiy "return home before sunset with goats and sheep". The measure 1 participles of these verbs co-occur with measure 4 participles: fāțir $\sim$ mifțir and $\underline{d} \bar{a} w i y \sim$ miḍwiy. ${ }^{122}$ In 'LA these verbs are (measure 1) $\underline{d}$ awa, yid wiy with participle $\underline{\underline{d}} \bar{a} w i y$, and (measure 4) aftar, yifțir and participle mifțir.

The patterns are $\mathrm{aC}_{1} \mathrm{C}_{2} \mathrm{aC}_{3}$ for the perfect and $\mathrm{yiC}_{1} \mathrm{C}_{2} \mathrm{iC}_{3}$. The paradigms are like those listed for group VI, including raising of unstressed initial $a>i$, e.g. ifțárt "I had breakfast". Such raising of unstressed initial $a$ is also heard in 'LA, e.g. i'țät "I gave".

The imperfect paradigm for yifțir is like that of yiktib, see 3.2.1.2.

\subsection{Measure ${ }_{4} C_{2}=\mathrm{w}$ or $\mathrm{y}$ (mediae infirmae) perfect and imperfect}

In all dialects described here the verb "want" has become measure 1 . This is to be concluded from the shape of the participles: rāayid, rāaydih, rāàdīn, rāydāt and passive participles maryūd, -ih, -īn and -āt, e.g. ('LA) iza māhī rāyidtuh ibtušrud 'innuh “if she doesn't want (to marry) him, she flees from him".

Only one instance of a participle of a media infirma measure 4 verb was recorded (in ASA): $m \dot{g} \ddot{\imath} r$ "running fast".

\subsection{Measure ${ }_{4} C_{3}=\mathrm{y}$ (tertiae infirmae) perfect and imperfect}

Like in group VI, a ța, yi tịy is a measure 4 verb in most dialects (in ASA, GrA, ȘwA and HmA). In HnA only measure 1 'ața was recorded (see remark above) and in ĞbA only idda, yiddiy was heard for "give", e.g. biddik tiddīnī lmiftāh "you (sg. fem.) need to give me the key" and (apocopated) bidduk tiddnī lmiftāh "you (sg. masc.) need to give me the key".

The perfect and imperfect paradigms for a'ta, yi țiy are:

${ }^{122}$ In e.g. the dialect of the Tarāain of group I, these verbs are all clearly measure 4: a'ta, yi țiy, afțar, yifțir and adwa, yid̦wiy with matching participles mi țiy, mifțir and mid̦wiy. Also

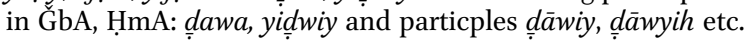


"give"

\begin{tabular}{|c|c|c|c|c|}
\hline & perfect & & imperfect & \\
\hline & sg. & pl. & sg. & pl. \\
\hline 3. masc. & áța & áțuw & yițiy & yi țuw \\
\hline fem. & áțat & áțin & tițiy & yițin \\
\hline $\begin{array}{l}\text { 2. masc. } \\
\text { fem. }\end{array}$ & $\begin{array}{l}\text { a'țāät } \\
\text { ațätiy }\end{array}$ & $\begin{array}{l}\text { a'tāätuw } \\
\text { a'țätin }\end{array}$ & $\begin{array}{l}t i t^{*} /-i y \\
\text { titiy }\end{array}$ & $\begin{array}{l}\text { tițuw } \\
\text { titin }\end{array}$ \\
\hline 1. com. & $a \dot{c} t \bar{a} t$ & àțäna & ițiy & nițtiy \\
\hline
\end{tabular}

* Notice the presence of the apocopated 2 nd p. sg. masc. forms in measure 4 as well.

3.2.3.7.4. Measure ${ }_{4} C_{1}=\mathrm{w}$ (primae $\left.\mathrm{wāw}\right)$ perfect and imperfect

A measure 4 prima wāw (and also tertia yâ’) verb recorded in ĞbA is awfa yūfiy, as in gaḅil ma yūfiy ilaṛba sā āt "before 4 hours have (fully) passed". ${ }^{123}$

3.2.3.7.5. Measure ${ }_{4} C_{2}=C_{3}$ (mediae geminatae) perfect and imperfect

Verb forms of measure $4 \mathrm{C}_{2}=\mathrm{C}_{3}$ (mediae geminatae) were not recorded, or not recognized as such.

Examples of imperatives for measure 4 sound roots are like imperatives for the $i$-type imperfect (see: 3.2.1.5.).

Imperatives of $\mathrm{C}_{3}=y$ roots are: (apocopated) it t, it tiy, it tuw, it tin.

Suffixed examples are: îith-iyyāha "give it (sg. fem.) to her", ițuh luh "give it to him".

\subsection{Measure 4 participles}

The particples for sound roots have a $\operatorname{miC}_{1} \mathrm{C}_{2} \mathrm{iC}_{3}$ pattern, e.g. mifțir, mífitrih, mifițrin, mifițrāt "having eaten breakfast".

For mediae infirmae there are participles of the type $\mathrm{mC}_{1} \mathrm{i}_{3}$, like $m \dot{g} \bar{i} r$, -ih, -in, - $\bar{a} t$ "running fast".

\subsubsection{Measure 9}

Paradigms for measure 9 in TwA, HnA and 'LA are the same as for group VI, except the diphthong ay in the endings of the perfect are monophthongal $\bar{e}$ (with velarized consonants preceding $\bar{e}$ is lowered to $\bar{a}$, i.e. I.P.A. $\left[\varepsilon^{\star}\right]$ ) in group VII, e.g. ihmarrrätuw "you (pl. masc.) turned red", participles are mihmarr, $-a h,-\bar{\imath} n,-\bar{a} t$.

\footnotetext{
${ }^{123}$ The verb awfa, yūfiy was also recorded in group I in the north, see De Jong 2000:219.
} 


\subsubsection{Quadriliteral verbs}

Like measure 2, quadriliteral verbs have morphologically alternating vowels in the imperfect (vowel $i$ ) and perfect (vowel $a$ ). ${ }^{124}$ The paradigms listed for group VI zagrat, yzagrit "ululate" are the same in group VII. Other examples are: biykarikmūh "they add curcumin to it", bitgáribluh "she sieves it".

The typically Bedouin verb type with inserted $w \bar{a} w$ between $\mathrm{C}_{1}$ and $\mathrm{C}_{2}$ : $\mathrm{C}_{1} \overline{\mathrm{o}} \mathrm{C}_{2} \mathrm{aC}_{3}, \mathrm{yC}_{1} \overline{\mathrm{o}} \mathrm{C}_{2} \mathrm{iC}_{3}$ has the following paradigms:

\begin{tabular}{|c|c|c|c|c|}
\hline & \multicolumn{2}{|l|}{ perfect } & \multicolumn{2}{|c|}{ imperfect* } \\
\hline & sg. & pl. & sg. & pl. \\
\hline 3. masc. & gōtar & gōtaruw & ygōttir & ygōt $t^{u} r u w$ \\
\hline fem. & gōțart & gōtarin & tgōṭir & ygōțrin \\
\hline $\begin{array}{l}\text { 2. masc. } \\
\text { fem. }\end{array}$ & $\begin{array}{l}\text { gōtart } \\
\text { gōțartiy }\end{array}$ & $\begin{array}{l}\text { gōtartuw } \\
\text { gōțartin }\end{array}$ & $\begin{array}{l}\text { tgōttir } \\
\text { tgōțiriy }\end{array}$ & $\begin{array}{l}\text { tgōtu } t^{u} r u w \\
\text { tgōtirin }\end{array}$ \\
\hline 1. com. & gōțart & gōțarna & agōțir & ngōṭir \\
\hline
\end{tabular}

* The superscript vowels in this paradigm are bukara- vowels.

An example of such a verb recorded in 'LA is (with diphthong!) biyrawb 'uw nnās "people perform the marbū'ah". ${ }^{125}$

Quadriliteral verbs may also have a $t a$ - preformative. The stem vowel of the perfect and imperfect is then fixed $a$.

"be irritated, annoyed" perfect

sg. pl.

3. masc. ta'aknan fem. ta'aknanat

ta'aknanuw

ta'aknanin

imperfect

masc. ta'aknant

ta'aknantum/-uw

sg.

pl.

fem. ta'aknantiy

ta'aknantin

yta'aknan

yta'aknanuw

ta'aknan yta'aknanin

1. com. ta'aknant

ta'aknanna

ta'aknan

ta'aknanuw

ta'aknaniy ta'aknanin

ata'aknan nta'aknan

Participles:mta'aknin,mta'akninih,mta'akninīn/mta'akinnīn,mta'aknināt/ mtaiakinnāt. Notice that elision of the the short high vowel $i$ does not necessarily take place (compare this to the non-elision of high vowels in measure 2 verbs of mediae geminatae, see 2.1.2.5. and 3.2.3.5.1.).

For the verbal noun $t^{i} i$ nin $^{126}$ was recorded.

${ }^{124}$ Nishio 1992, however, reports a number of instances with 'fixed' a in perfect and imperfect, e.g. (p. 62 (IX-1) gōțar, ygōṭar "leave", and also (p. 72 (X-3) dardaš, ydardaš "debate".

${ }^{125}$ During night time festivities older men stand in a square (marbǘah) and improvise verse to each other.

${ }^{126}$ See remark in Stewart 1990:8 (text 1), fn 55 on the form tširrit formed on a pattern for verbal nouns used for both measure 2 and $t$-2 verbs. See also Abul Fadl 1961:286 on 
A quadriliteral verb with $\mathrm{C}_{4}=y$ is tagahwa, ytagahwa and has the following paradigms:

"drink coffee/tea"

$$
\text { perfect }
$$

sg. $\quad \mathrm{pl}$

3. masc. tagahwa

fem. tagahwat

2. masc. tagahwēt

fem. tagahwētiy

1. com. tagahwèt pl.

tagahwuw

tagahwin

tagahwētuw

tagahwētin

tagahwēna imperfect

sg. pl.

ytagahwa ytagahwuw

tagahwa ytagahwin

tagahw* tagahwuw

tagahwiy tagahwin

atagahwa ntagahwa

* When in pause, tagáhuw \#.

An apocopated imperative for the sg. masc. is tagahw "drink tea / coffee!". Participles are mtagahwiy, mtagáhiwyih, mtagahiwyīn, mtagahiwyāt.

\section{Remarks on Phraseology}

\subsection{Nunation}

Tanwīn is not a feature of TwA, HnA and 'LA, but in loans from MSA and in poetry nunation does occur. Recorded examples are: (all loans from MSA) tab'an "of course", masalan "for instance", 'àmmatan "in general", dāyman "always" (< MSA dā'iman), hạaliyyan "currently", ahyyānan "now and then" and tagrīban "approximately".

\subsection{Negation}

In TwA and HnA a verb is usually negated with compound $m \bar{a}+$ verb form + -š. Examples are dawwir dawwir iza mā ligìtiš 'arǧác-luh țāniy "keep looking (for it), (and) if you don't find any, go back to him", ma bingațtí iš siyyāl "we don't cut down acacia trees", ma farašáttiš (< ma farašat + hi + $\check{s}$ ) "she did not spread it out", ma na aráfhaš "we don't know her" (for more detail on negated pronominals and negated verb forms with pronominal suffixes, see 3.1.12).

A negated suffixed preposition is ma lukšs da'awah "it is no concern of yours". For more detail on negation of suffixed prepositions, see 3.1.16.

A single negation with only $m \bar{a}$ preceding the verb form may also be heard, but is much less frequent, and seems to be reserved for more emphatic

verbal nouns of measure $t$-2 tuhussun "Besserung", tu'uhhud "Verpflichtung" and tukubbur "Hochmut". 
negation, often accompanied by $x \bar{a}$ liṣ "at all". Examples are $w$ All āh mā ğāni "By God, he did not come to us" and bidd dakkirna la hāăḡàt mā na'ariffa "you remind us of things we don't know (i.e. had forgotten about)".

In 'LA verbs are regularly negated with single preceding $m \bar{a}$ (the compound negation is the exception in 'LA). Also negated pronominals, prepositions etc. are negated with preceding $m \bar{a}$. Examples in 'LA are: mā țallágithe' "I had not divorced her", fih nās halhīn ibyākl-álbalah iw hü țazzah mā byahašūh "there are people now who eat the dates while they're fresh (and who) don't stuff them", iza mā 'induh haläl "if he doesn't have small cattle (for slaughter)", gāl abuw lbint 'māhì maxațūbāh' "the father of the girl said 'she is not engaged".

\subsection{The b-imperfect}

The originally sedentary feature of the $b$-imperfect to express the habitual present tense is also current in TwA, HnA and 'LA. Some examples in TwA are āywah biyhutțūh f-ágrab "yes, they put it in goat skins", ma bingatți š siyyāl "we don't cut down acacia trees", innāgah biysībūha ...ibtimšiy l wahadha fi șṣahara. iw kull šahar aw šahrēn wāhid bišüffi" "the she-camel, they let her go... she goes alone in the desert. And every month or two months somebody sees her". yōm akbar, mumkin iykūn 'induh sanah biyğĭbuh... 'induh fi lbēt iw huwwa ēš? biyțabb'uh. ya niy biyrabbih "when it is older, it could be a year old, (then) he gets it... (and keeps it) with him in his house, while he what? He trains it, that is, he raises it".

Two examples from 'LA are: ba adēnubūh ... biyrawwih larriğğăl ... aḅuw lbint ... iw biyxarrfuh "after that his father... goes to the man ... the father of the girl... and speaks to him", biyšūf bint ibtí iğbuh "he sees a girl that he likes".

\subsection{Future Marker}

To express "volition" or "need" bidd + pron. suffix may be used in TwA, $\mathrm{HnA}$ and also in 'LA.

Often not only volition or need is expressed, but also a sense of futurity of the action expressed in the following verb. Examples are: (futurity/volition) biddī-gūl luk 'ala hạağih [...] ilgașalah dìy...halhịn xallēt Mahmūd iyğawwiz bintī ... "I want to/shall tell you something ... this twig.... I have now (agreed to) let Mahmūd marry my daughter".

To express futurity. the imperfect form may also have prefixed $h a-$, e.g. hantașarraf lèha fi lgamūs... "we'll make do with it in the (preparation of) food dip" and iw ba'ad kidiy btágasluh ... gasīl ğāmid xāliṣ. hatlāgīh tirìy "and after that you wash it thoroughly, and you'll find it is dry...". 
In these and other instances there was less emphasis on 'inevitability' than was noticeable in examples for group VI.

The future may however also be expressed with the simple imperfect, as in ássalag yizg்atte ... ${ }^{127}$ lamma yulguțha'. mā yākilha lamma yğìbha la șâhbuh. iygūm șāḥbuh dābihḥe. "the hunting dog runs after it... until it catches it (fem.). He will not eat it (fem.) until he brings it to its master. His master then slaughters it".

\section{5. fih "there is / are"}

fih is used to express existence or availability of something, e.g. fih wāhid șāhibna nihāniy mumkin nāxud minnuh l'arabiyyah nkutt bèha lwādiy "there is a friend of ours here whose car we can take with which we go down the wadi" and ('LA) fih nās biyšüfa" "there are people who see her".

The negation is usually ma fišs, also in 'LA (!), e.g. w Allah ġār rišrēěs mațar mā fiš "by God, except for a few drops there hasn't been any rain" and ("LA) aza mā fiš hurmah fạdyah lèhin "if there is not a woman free for them (i.e. to take care of the anmimals)".

Also māš may be used for negation: issuwwāḥ māš ilǧim'ah suwwāḥ $b$ ilhẹel "the tourist, on Friday(s) there are no tourists at all". māš was not heard in 'LA.

\subsection{Some Conjunctions}

\subsubsection{Conjunctions lamma and yōm}

Like in many dialects of Sinai, conjunctions lamma and yōm, or variant forms based on these, are used for "when".

4.6.1.1. yōm

\subsubsection{1. yōm used independently}

yōm may be used meaning "when", e.g. il'anz yōm taḥalibha kiḍiy w ithutțuh fi ssi in kimān... illaban "the goat, when you milk it like, and you put it in the goatskin ${ }^{128}$ also... the milk", țab'an illaban yōm iykūn kitīr binhutțuh fīh ēh? "of course, when there is a lot of milk we put it in what?”, ilmațar illiy nāzil dii', yōm yinzil 'ala gizāz l'arabiyyah ... țīn "this rain that falls, when it comes down on the glass of the car...it is mud" and (from 'LA) yōm rawwah 'ind húrumtuh bidduh ynām ğambhi' "when

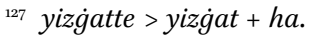

${ }_{128}$ A sin is a leather bag made of goatskin in which butter is churned.
} 
he came to his wife he wanted to go asleep beside her" and yōm assaddah rawyānah byațla "when the dam ${ }^{129}$ is watered it grows".

4.6.1.1.2. yōm in combination with in

4.6.1.1.2.1. yōmin used independently

yōmin may also be used for "when", like in the following examples: yōmin ligihi "when he found her..." and (from 'LA) așsubih yōmin ma yiğì l alfaxx iw lannha malgütah "when he comes to the trap in the morning, there she is, caught".

4.6.1.1.2.2. yōmin + obj. suffix as subject of the clause

There is an example of yomin suffixed with a dummy subject (-uh); the subject is "I": ba'adēn hawwalthum híniy yōminnuh ițtarrēt ǐğiy wara li'yāl 'ašān ilmidāris "after that I moved them here, when I was forced to come with (lit. after) the children because of the schools" (țt in itțarrēt is assimilated $<\underline{d} t)$. No such example in 'LA.

4.6.1.1.2.3. $\min$ yōm

min yōm(in) is often used for "as soon as" or "from the moment that", e.g. min yōm ana-ddèt ilgașalah ${ }^{130}$ xalās "from the moment that I give the twig, it's done" and ('LA) min yōm a ț̣̄h algașalah xalāṣ 'irif hādiy húrumtuh, ib sinnt Allăh $w$ rasūl-a'tūh ... ${ }^{131}$ gásalatuh "from the moment that they have (i.e. the father of the bride) has given him the twig, xalās, he knows that she (lit. this) is his wife... according to the tradition of God and his Prophet they have given him... his twig".

4.6.1.1.2.4. min yōm in combination with ma

A combinations of min yōm and ma was only recorded in 'LA: min yōm ma 'āyzah tušrud, marrrah marṛtēn țalātah xalāṣ lāzim iyțalligha ...xalāṣ māhi ' $\bar{a} y i z t u h$ "from the moment that she wants to flee, once, twice, three times, that's it, he has to divorce her (i.e. grant her her wish for a divorce), (because) she does not want him".

${ }^{129}$ The 'dam' is actually the soil behind a dam on which water collects.

${ }^{130}$ A gașalah "twig" is given to the groom by the father of the prospective bride in betrothal ceremonies. See also Bailey 2009:350 (glossary).

${ }^{131}$ rasūl-ațūh: rasūluh + ațūh. The phrase $b$ sinnt Allăh $w$ rasūluh is often added to descriptions of practices whose islamic origin(s) are doubtful. See also remark in $\mathrm{fn} 430$, De Jong 2000:219 and Šuqayr 1916:387-388. 


\subsubsection{2. lamma and lumma}

lamma is often used for "when" and "until". Also a form like lam was recorded (variants lumma or lum were not heard).

\subsubsection{1. lamma "when" used independently}

Examples of lamma used for "when": tiğb il'anz, iw tísigha mayyah lamma tkūn 'ațšānah walla hạāgih, iw ba'ad ma tašaṛab. timsikha, wāḥid ibyimsíkluḳ iw wāḥid ibyad dbaḥ. bitgūl bismillāh Aḷ̂āhu 'akbar iw tad̆bah "you get the goat, and you give it water when it is thirsty or something. And after it drinks you take hold of it, someone holds it for you and someone (else) slaughters. You say 'in the name of God, God is great', and you slaughter".

Another example is: lamma nnās ibyasma'uw xabit illibbah kidiy, ilkull ibyá arf inn fíh wāḥid ži ... "when people hear such knocking on the loaf, ${ }^{122}$ everybody knows that someone has come (as a visitor)...". An example in "LA is (both in the meaning of "until" and "when") bitsawwiy zzibdeh, iw

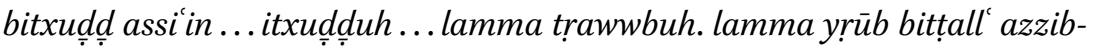
dah minnuh "she makes butter, and she churns the goat skin ... she churns it ... until she causes it to curdle. When it curdles, she takes the butter out of it (i.e. from the goat skin)".

Another form recorded in GrA is ānāt, which is used for "when": ānāt ma yístiwiy biykūn tamir layyin șār "when it matures it will have become tender (soft) dates".

\subsubsection{2. lamma + in}

The only recorded example (in ASA) of lamma + in (lumma + in was not recorded) is budxul 'ād 'ind innās illiy baṛra, [kididi] fị̣māyithuṃ ... lamman inšūf ilmúškilih diy, iw taxlaṣ "so I take refuge with people who are outside (i.e. outside my own community), like that in their protection... until we see (look into) this problem, and it is resolved".

\subsubsection{3. lamma and lumma "until"}

lamma (lumma was not recorded) maybe used in combination with lagāàit for "until", e.g. bitduggha dagg fi lhōn ... lagāàyat lamma yun um kidiy "you crush it (sg. fem.) in the mortar... until it becomes soft" and biyğīb miṣwāt kidِiy xašab, iw byuḍrubha bēha barḍuh āh? lagāàyat lamma tağadiy... zayy izzibdah fi ba aḍha "he takes a wooden spoon, like, and stirs it (sg. fem.) with it (sg. fem.) and also what? until it becomes ... like butter mixed together".

${ }^{132}$ The libbah is a loaf of bread baked in live embers and hot sand. When it is done, the loaf is beaten to get rid of the dust and ashes. 
An example of lamma used as "until" without lajḡait is tíğib ilhațab di', imn issiyyāl, $w$ itwall innār lamma èh yáhaǧim yágadiy ǧamir "you get this firewood, from the acacia, and you light the fire (and let it burn) until what? The flames die down (and) it becomes glowing embers".

An example in 'LA: ana xannni-țawwil bālì lamma șsabāh yațlac...w arawwh ilmag'ad wanām fì "(addressing himself) let me be patient until the morning comes... and let me go back to the mag'ad ${ }^{133}$ and sleep there".

4.6.1.3. $\operatorname{lōm}(+$ in)

An example of min lom in the meaning of "from the moment that" (in ASA): biyrawwi 'ind' ${ }^{34}$ ilAhẹewāt biyrawwi 'ind ilGirārših biyrawwi' 'ind iliMzēnih, ana min lōm biyrawwih kidiy mā-garrib luh "he goes to the Ahaywāt, he goes to the Garāršah, he goes to the Mzēnah, from the moment that he goes (like this), I didn't go near him". Another example is min lōm hü ğawwazha "from the moment he married her" and from 'LA lōm tiğ talgha lannha $x \bar{a} \underline{d} \underline{d}$ it issi in, $w$ imsawwyah libbah $w$ fättìtta 135 "when you come you find her and (lo!) there she has churned the goat skin, and she has made libbah and she has made fattah of it (sg. fem.)".

4.6.2. hatta

4.6.2.1. hatta "until", "so that"

hatta was not recorded in the meaning of "until" or "so that".

\subsection{Auxiliaries and Verbal Particles}

4.7.1. gām

gām used as a 'marker of consequent action' was recorded only in 'LA: ${ }^{136}$ iw hạal...gām xallāha $w$ 'ugub sanatēn...zabbat álhațab, iw ğāb addabāyiḥ, iw ğāb ibyūt ášša ar "and in case... he has then left her and

${ }^{133}$ A mag ad is a place where men meet and a host receives his guests, and where they drink coffee or tea and exchange stories and news.

${ }^{134} h+$ + often assimilates to ", also in sandhi: biyrawwih 'ind > biyrawwi "ind.

${ }^{135}$ fattìtta $=($ fättah $)$ fāttìt + ha "having made it (sg. fem.) into fattah". When suffixing the obj. pron. suffix to the sg. fem. act. participle the fem. morpheme becomes -it here, instead of -it. This appears to be typical of 'LA (as I was told by a Turbāniy informant). Another example (provided by the same Turbāniy informant) is māklītha "having (sg. fem.) eaten it (sg. fem.)". For such suffixation as a trait of fellāhi dialects in Transjordan and Hōōān, see Cantineau 1946:22-225 and Palva 2008a:61. See also EALL 2006 (Vol. I):263 (Rosenhouse: Bedouin Arabic).

${ }^{136}$ The three instances recorded in 'LA showed a 3 rd p. sg. masc. subject. 'Unconjugated' can therefore not be concluded. 
after two years... he has prepared the firewood, and brought the animals for slaughter, and has brought the tents".

4.7.2. rִāḥ

Examples of the use of rāh used as an auxiliary were recorded only in HmA: lamma rāạh karrrarha winha manganīz [...] manganiz nimrah wāhid ... ğì gāl

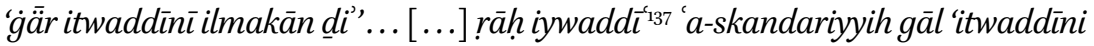
makānuh' "when he then (went and) analyzed it, lo it was (i.e. turned out to be) manganese $[\ldots]$ top quality manganese. ${ }^{138} \mathrm{He}$ came and said 'you have to take me to this place'... [...] he was going to send it to (a laboratory in) Alexandria, he said 'take me to its place' (i.e. where you found it)".

\subsubsection{Conditional particles}

\subsubsection{Variations on kān as a conditional particle}

4.7.3.1.1. in + kān

An example of in + kān "if" in Ṭ̂A and HnA: iw šūfuw-nkān talguw lē"kụu bu rạān 'induh "and look if you find camels of yours with him", w inguṣs inkān ğựrt ilbu rạān fihi "and we follow the tracks if the camel tracks are in it" and in 'LA w alfuțūr ba adīytta ${ }^{139}$ nkān 'āwz itsawwha bitsawwha "and (the breakfast) after this (lit. it (sg. fem.) if you want to prepare it (sg. fem.), you prepare it (sg. fem.)".

\subsection{Suffixed inkān}

Instances of suffixed kān or inkān were not recorded in any of the dialects discussed here.

4.7.3.1.3. il + kān

Instances of il + kān were not recorded.

4.7.3.1.4. kān preceded by $C A$ loans iz or iza

The following example of kān preceded by iz is not very coherent: izkān... șāhbuh-lliy yğībuh... ārif nimrah-zkān nimṛit bațāgtuh...w á arfuh bass "if... its owner who brings him... you know the number, if

${ }^{137}$ ywaddī ' $a$ is assimilated < ywaddīh ' $a$.

${ }_{138}$ In the area of Uṃm Buğmah manganese deposits have been found. A Google search on the internet with search criteria "Um Bogma" or "Oleikat" (i.e. 'Lēgāt) will yield references to geological reports on these deposits. Google Earth indicates Umm Bugma as being located at appr. 29.00.43 North and 33.20.28 East, which is the area of Sēl Bacba' (Wadi Baba").

See also Greenwood 1997:35 (figure 3-6) (there transcribed as Um Bogma).

139 See remark in fn 135, p. 106. 
the number of his I.D., I just want to know him (i.e. who he is)". A more coherent sentence is: iw ba'ad kididy xamis 'ašar digāyig xamisțāšar digīgih bințalliḥha-z kān ğamị hịiluw "and after like five, ten minutes, fifteen minutes we take it out if it is (a fire of) good embers" and izkān wāhid 'ayyān walla hạăgah biyğībūh luh "if someone is ill or something, they bring it to him."

Instances of $i z(a)+k \bar{a} n$ were not recorded in 'LA. Instead, several instances of $i z a$ or $i z$, and even more regularly $a z(a)$ were heard as independent conditionals, e.g. iza mā 'induh halāl "if he does not have small cattle (for slaughter)", iz fatt alfattah mazbūt xālis "if he has prepared the fattah very well..." and aza gāluw 'la' läzim tuskun 'indina "if they say 'No, you have to live with us' ...", aza lugūh, bitxallhe' ... imšammalah "if she is pregnant (i.e. the she-camel), you make sure she gets a šamlah." ${ }^{140}$

\subsubsection{5. kān as an independent conditional}

kān used independently as conditional "if" was recorded often, but an example is: kān im 'úk dirāhim "if you have money". No such examples were recorded in 'LA.

4.7.3.1.6. kān, inkān or ilkān introducing alternatives

kān may introduce alternatives: iddaxil kān Šarim, aw issyāḥah ‘āmmatan fi liblād diy "an income is (i.e. can be made in) Sharm, or (in) tourism in general in this land". No such examples were recorded in 'LA.

\subsubsection{Absence of a conditional particle}

Conditional sentences are often not introduced by a particle. An example is: huṃma kānuw... huṃma rrğāl 'āyzìn yúgu'duw sáwa', fì makān... ilmağma' barra "they were... if they are men who want to sit together, there is a place ... the meeting place is outside". Another example from 'LA is: māhì lugūh, bitbarrik 'alēha țāniy "if she is not pregnant (i.e. the she-camel), you have her covered (i.e. to be impregnated) again".

\subsection{Presentative Particles}

4.8.1. ir or ar

Presentatives ir' or ar were not recorded in TwA or HnA, nor in 'LA.

${ }^{140}$ A šamlah is a piece of cloth covering the vagina of the she-camel. This is used to make sure that she can only have been impregnated by a thoroughbred camel. 
4.8.2. hē + suffix

The presentative particle $h \bar{e}$ followed by a personal pronominal to draw the listeners attention to something or someone is current, e.g. hēhù ği'! "there he has come!", hēhì ğàt "there she has come!", hēhuwwa ğuw "there they (masc.) have come!", hēhinnah ğin "there they (fem.) have come!”. In 'LA an example is: $w$ lin ği hêhuwwih "and there he came".

This presentative $h \bar{e}$ must have developed from $h \bar{a} y$, which shortens to hay in unstressed positions. ${ }^{141}$

Another possibility recorded in ASA is $h v k$ (in which $v$ is the short high vowel colouring with the following vowel) followed by a pronominal of which initial $h$ assimitaes to $k$, e.g. hukkuwwa or hukkü "there you have him", hikkiyyih "there you have her", hukkummma "there you have them", hikkinnih "there you have them (fem.)".

This presentative element $h v k$ or must have developed from a presentative $h \bar{a} k^{142}(<h \bar{a}+k)$ of which the long vowel was shortened, due to its unstresed position in forms like hāk + hummma or hāk + hiyya, after which the resulting short $a$ (e.g. as in assumed intermediate forms *hakkummịa and *hakkiyya) could assume the colour of the following vowel: > hukkuṃma and hikkiyya.

\subsubsection{Particle wlin wilin, win}

The particle wlin is mainly used to present a sudden or unexpected turn in a narration. Although in the first example below, like also in examples for group VI, the development referred to is hardly unexpected or sudden:

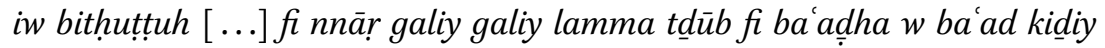
bitḥuț̣aw innha samin šĭhiy "and you put it on (lit. in) the fire to boil and boil until it melts together, and there you have wormwood ghee".

Another example is ndawwir iNmēr iw linn ğurṛit ğamal hēhì giddāmna himrā' "we went to Nmēr and there were the tracks of a camel and there she was in front of us, red (colour)" and ba'ad talat sā àt kidiy w linnī $b$ $x \bar{e}$. ana banabbit tanbit fi lblād "after three hours or so I was alright again. (and) I was jumping about on the ground".

In ASA a similar iw lannuh hū b nafsuh "and there he was himself" was also recorded (see remark in next paragraph).

\footnotetext{
${ }^{141}$ For remarks on hāy and hay $(<h \bar{a}+y)$ see De Jong 2000:235-236.

${ }^{142}$ On the difference in deictic function between hay or hāy and hāk, see De Jong 2000:236.
} 
$w$ lin / lan was also recorded in 'LA, often in combination with $h \bar{a}$ - or $h \bar{e}-+$ pron. suffix and not necessarily with preceding $w$ : lan hāhu lfaras "there was the horse", iw lan hêhū issēl ğa $\bar{a} y$ "and there is the flood coming" and a suffixed example yōm yĭğiy luh linnuh, linnuh lägiṭha' "when he comes to it, there it (i.e. the trap)..., there it has caught her (i.e. an animal)".

\subsubsection{Particle wlā +}

An example of the presentative particle $w l \bar{a}$ is probably $w$ lannuh (see preceding paragraph 4.8.3.) consisting of the elements $w+l \bar{a}+i n n+u h$.

In 'LA the presentative lan co-occurs with lin, of which the former is probably the result of $l \bar{a}+$ in (see examples in 4.8.3.).

\section{9. gayr}

$\dot{g} \bar{a} r(<\dot{g} a y r)$ may be used preceding imperfect forms to express the neces-

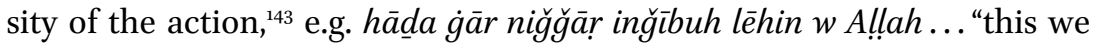
have to get a carpenter for them (pl. fem.), by God...".

Also in 'LA several examples of $\dot{g} \bar{e} r$ were heard, e.g.: gāl hū $\dot{g} \bar{e} r$ iğìb issēf $w$ agta 'rágabatuh "he said 'I have to get the sword and decapitate him". Instances of reduced gayr were recorded as ir, e.g.: law kalat ${ }^{u} k$ bidduk, ir kān daktūr walla bidduk, iza f-albaṛ kamān mā hāwwală ${ }^{u} k$ daktūr ir kān insān ḩāwiy "if it bites you (i.e. a snake) you need, it should be a doctor, or you need, if you're in the desert and also there is no doctor near (lit. around) you, it must be a person (who is) a snake charmer" and ibyidirsuw b álğimal, iw g̈är insān 'ärif iysawwīh "they thresh with the camel, and it should be someone who knows how to do it".

\subsection{Intensifying Particle la}

The particle la intensifying the 1st p. sg. com. was not recorded in any of the dialects discussed here.

$$
\text { 4.11. bidd or widd + pron. suffix }
$$

To express "want" or "need" speakers of TwA and HnA use suffixed bidd ( suffixed badd in ĞbA), but in ḤmA suffixed widd was also heard. Exam-

\footnotetext{
${ }^{143}$ See Hopkins 1990.
} 
ples for "need" or "want" are: biddna nkutt fi lwādiy "we want to go down the wadi", bidduh ygōtir "he wants to go (away)".

An example of bidd expressing futurity, rather than "want" or "need" is ihnna zayy ibtā țalat marrạat biddna nḍ $\bar{\imath}^{c}$ fi lbahar "something like three times we were going to get lost at sea" (HnA).

bidd is also used in 'LA, e.g. ịnna biddni' ... nirsiy 'ädiy "so we'll anchor (here) (i.e. make camp for the night)" and ana biddītagaddam ... māšì "I shall / want to continue walking".

\subsection{2. 'àd}

The particle ' $\bar{a} d$ is current to express "so, thus, then". Examples are: bitmaddid fi liblād. iw btațla batțixxah ... id 'ayyfah kidiy ssā', 'awwil ma yațla', iw byakbar iw ba'ád-ma yakbar, túkun itḥāfị̣ 'ilēh 'ād intih ... 'an ḍarb iššamš ilguwiyyih." It grows out over the soil, and a watermelon grows ... still a bit weak, when it comes up, and it grows, and after it grows, you should then be protecting it... from the strong radiation (lit. beating) of the sun". Another example is hā $\underline{d}$ a biykad dib ' $\bar{a} d$ "so this man is lying".

An example of ' $\bar{a} d$ in 'LA is iw 'ugub kidiy ' $\bar{a} d$ waddāha dāruh "so after that he took her home", but often the forms 'ádiy or 'ádīyit also occur: $h \bar{u}$

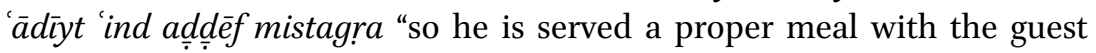
(i.e. who actually received the invitation and through whose company he is also invited for the meal)" ${ }^{144}$

$$
\text { 4.13. yabga }
$$

Like in group VI, yabga is not very current in TwA, HnA or 'LA, but may be heard at times meaning "so, then", as in w itta am illiy fiha bardagān. yabga șārat bitğı̆b xêr akțar "and its taste is oranges, so then it brings more good (i.e. it is even better)".

${ }^{144}$ A proper meal fit to be served to a respected guest is called grá' (n.u. garwah) and usually consists of rice and meat. Other ingredients instead of meat are also acceptable, if the host is unable to serve meat. Compare also Stewart 1990:222 (glossary), root $g-r-y, 4$ th measure (agra, yigriy) "to entertain, feed guests" and griy "hospitality, the food etc. that is given to a guest". See also Bailey 2004:173 (entry 449). In a similar context I have also heard ilxubiz mā byigriy "bread is not a proper meal". See however also fn 36, p. 208 for griy as a pl. form for garyih. 


\subsection{Characteristics of the Narrative Style}

4.14.1. Imperative of narration

Instances of the narrative imperative were not recorded in TwA, HnA or 'LA. ${ }^{145}$

\subsection{2. kān as a temporal marker}

Unconjugated $k \bar{a} n$ used as a marker to indicate the past is current in TwA and HnA, e.g. kān inğìb ilMansiy min Aḅuw Rdēs "we used to get ilMansiy from Abuw Rdēs", kān binhutț ġèr izzētūn "we used to plant olive trees only".

However, kān was more frequently used as a verb and conjugated as such, e.g. kānat iliğnēnah dìy kullha kānat milyānih. kān milyān ēh? bațāțis

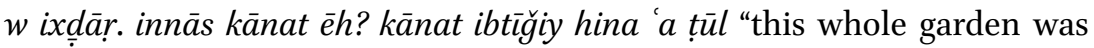
full. It was full with what? Potatoes and vegetables. People used to what? They used to come here directly".

Findings for 'LA were similar.

\subsubsection{Dativus ethicus}

Some instances of the ethical dative are: $w$ itwiğğ innār minnuh w iyșīr luḳ. tamām $x \bar{a}$ liṣ "and you light the fire with it (i.e. firewood) and it becomes perfect for you", iw ba'ad kidiy bitğīb mașfa 'imāmah-w ayyi hạăǧih, iw bitșaff 'ilèh iw bitțall' izzèt iw bitsaww luk imraggagah 'ilēh aw bissaww luk ayyi hăğih "and after that you get the cloth-sieve or anything, and you sieve with it and you get the oil out and you make mraggagah ${ }^{146}$ for yourself with it or you make anything for yourself" and mumkin yākul luk fațisih, yākul luk bahimah mayytih, yākul luk ayyi hăăghah xalāṣ "he could eat for you (meat of) a corpse", he could eat for you (meat of) dead livestock, he could eat anything at all for you". ${ }^{147}$

${ }^{145}$ This should not be taken to mean that these dialects lack this feature; it is simply not present in my material.

${ }^{146}$ mraggagah is like fattah: a dish with torn pieces of flat bread in oil and herbs.

${ }^{147}$ The translation with 'could' reflects that the person in question (a boy who has been chosen to grow up to be a snake charmer) should avoid eating what is mentioned, and that people should take extra care with his food. It is believed that the wrong food-anything harāam-will ruin his special gift. 
An example in 'LA is: gậl luk hāda krāk 'indī b xamisțāšar sanah "he says (lit. said) to you, here is your pay ${ }^{148}$ that I owe you for fifteen years (of work)".

\subsection{Pluralis paucitatis}

For limited or countable numbers often the healthy plural form is used, instead of the broken plural. Examples are: $x u \underline{d}$ rawāt - x $\underline{d a} r$ "vegetables" (HnA), nuxrāt-ánxar "noses" (GrA), banāt-bnittih "girls", šuggāt$\check{s} g \bar{a} g$ "woven lengths of a tent", habbāt-ḥbūb "grains; pills" (both ASA), šwālät—šwilih "sacks (for grain)" (ȘwA).

\subsection{Concord}

Limited or countable numbers of things tend to be referred to in the pl. fem. Examples are: (A) 'āwzìn irṛakkb iššabābìk $w$ ilbībān ... (B) là lā dillih šug̣lithin dill țawìlah 'ilēne ... (A) walla nğīb lēna niǧğār? (B) hāda $\dot{g} \bar{a} r$ niğğă inğ $\bar{l} b u h$ lèhin $w$ Allah "(A) we want to fit the windows and the doors (B) No, no, the work on these things is too much for us (to handle). (A) or shall we get ourselves a carpenter? (B) (for) This (is something), we have to get a carpenter for them, by God". Another example is illiy žāb luh sittīn išwāl walla ḥāğah biywaddīhin ilmațhanih, lākin išwāl wāhid biywaddīh ilbèt ibyațhan 'a rrḥa ... "he who has harvested (lit. brought) sixty sacks or something for himself, takes them to the mill, but (if it is just) one sack he takes (it) home and grinds (it) on the hand mill" and fih amākin igṣūr ${ }^{149}$ innās imsawwyinhin zamān, fa biytaxazzan fihin "there are places for storage that people made in the old days, so they store (goods) in them".

The following is a reference to a pl. of animals (here camels): $w$ Allah

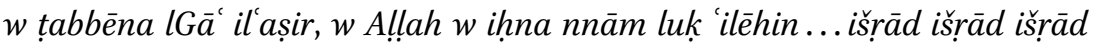
išrâd lamma ğina Bōr Mūs-Aḅuw 'Ațwa "By God, and we went to ilG $\bar{a}^{\mathrm{r} 5^{0}}$ in the afternoon, by God, while we lay flat on them (for you), ${ }^{151}$ fleeing, fleeing, fleeing, fleeing until we came to Bīr Mūsa Aḅuw 'Ațwa”.

Some examples in 'LA are: fih igṣūr iligșūr dill biyhutțuw algirbah fihin "there are storage caves. They put the girbah (a goat skin sack) in these

\footnotetext{
${ }^{148}$ Root k-r-y, I have also recorded íkrih and krāh "his pay".

${ }^{149}$ gșūr (sg. gașr), see fn 42, p. 47.

${ }^{150}$ The (largely empty) sandy coastal plain near at-Tūr. See also fn 1, Chapter Two below.

${ }^{151}$ luk "for you" is an instance of the ethical dative, see 4.14.3.
} 
storage caves", (talking about animals) alġizlān dillah mā biyțịhin fi lwātịy,

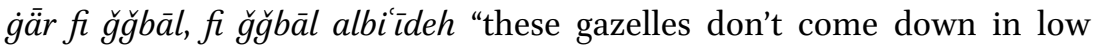
areas, (you'll find them) only in the mountains, in the far mountains" and ibtasrah ib bi rạnuk, iw tīğiy 'a nayyt álg̀ada ... itgayyidhin w itxall hin ... $f i$ ğàl 'an alhaläl "you go out grazing with your camels, and you come by lunch time, you hobble them and leave them ... away (lit. aside) from the small cattle".

\section{A Sketchy Remark on Pitch}

The type of pitch heard in group I predominantly among older men in the northeast was not heard in TwA or HnA, nor in 'LA. 


\section{A DESCRIPTION OF THE DIALECTS OF THE MZĒNAH AND BANIY WĀṢIL}

\section{INTRODUCTION}

The largest tribe of the central, south and southeastern Sinai are the Mzēnah (or Muzaynah). The much smaller tribe of Baniy Wāṣil live near the town of at-Ṭur and towards the east of it and in the western part of the massif of the central south of Sinai, where they are neighbours of the Awlād Sa'ī $\mathrm{d}^{1}$ and the Garāršah, who live to their north. The dialects of Mzēnah (MzA) and Baniy Wāṣil (BWA) share some important characteristics, and are therefore treated in one chapter. Originally, however, the dialect of the Baniy Wāṣil must have been more like the dialect-type of group I, with which it still shares a number of features not found in Mzēniy. Some of these features actually occur parallel to features also heard in Mzēniy, while other characteristics are still uniquely (inside Sinai, that is) found in group I. Wāṣliy is therefore treated here together with Mzēniy, partly for contrastive purposes and partly because it must have developed towards Mzēniy.

On the location of Baniy Wāșil, as it appears on the maps in this study, the following must be taken into account: although their territory does not directly border on the territory of the Mzēnah, in practice the Awlād Sa $\overline{1} \mathrm{i} d$, whose territory is indicated to lie between that of the Baniy Wāṣil and that of the Mzēnah, actually live more inland, i.e. in and around Wādiy Șlāf in the central mountain massif,² where they are direct neighbours of the Ğbāliyyah. The coastal plain of the dīrah of the Awlād Sa'īd is in fact empty land (the sandy coastal plain al-Gāe), and hence the Baniy Wāṣil are-more or less_-direct neighbours of the Mzēnah.

\footnotetext{
${ }^{1}$ Although the dīrah of Awlād Sa'ìd is indicated on the map as bordering the Gulf of Suez, members of this tribe actually do not live in this deserted coastal plain (known as $G \bar{a}^{c} a \check{s} \breve{S} a r m$ or simply $\left.a l G \bar{a}\right)$, but are found more up in the mountains to the east. In effect, the Mzēnah and Baniy Wāșil (who do inhabit the coastal area on the Gulf of Suez near aț-Ṭur) are direct neighbours.

${ }_{2}^{2}$ The coordinates are appr. 28.32.35 North and 33.43.55 East, see Google Earth.
} 
In the following chapter a decription of the characteristics of both dialects is given, unless explicitly stated otherwise.

\section{Phonology}

\subsection{Consonants}

1.1.1. Inventory of consonants

The inventory of consonantal phonemes of MzA and BWA is:

\begin{tabular}{|c|c|c|c|c|c|c|c|c|c|c|c|}
\hline & $\begin{array}{l}\text { bilabial } \\
\text { vl vd }\end{array}$ & $\begin{array}{l}\text { labdent. } \\
\text { vl vd }\end{array}$ & $\begin{array}{c}\text { alveo } \\
\text { vl }\end{array}$ & $\begin{array}{l}\text { olar } \\
\text { vd }\end{array}$ & $\begin{array}{l}\text { intdent. } \\
\text { vl vd }\end{array}$ & $\begin{array}{l}\text { postalv. } \\
\text { vl vd }\end{array}$ & $\begin{array}{l}\text { palatal } \\
\text { vl vd }\end{array}$ & $\begin{array}{l}\text { velar } \\
\text { vl vd }\end{array}$ & $\begin{array}{l}\text { uvul. } \\
\text { vl vd }\end{array}$ & $\begin{array}{l}\text { phar. } \\
\text { vl vd }\end{array}$ & $\begin{array}{l}\text { laryng. } \\
\text { vl vd }\end{array}$ \\
\hline plosive & b & & $\mathrm{t}$ & d & & & & k $\mathrm{g}$ & (q) & & (') \\
\hline emph. & & & $t$ & & & & & & & & \\
\hline nasal & $\mathrm{m}$ & & & $\mathrm{n}$ & & & & & & & \\
\hline fricative & & f & $\mathrm{s}$ & $\mathrm{z}$ & $\underline{\mathrm{t}} \quad \underline{\mathrm{d}}$ & $\check{S} \quad(\check{z})$ & & $\begin{array}{ll}\mathrm{x} & \dot{\mathrm{g}}\end{array}$ & & h & $\mathrm{h}$ \\
\hline emph. & & & ș & (z) & $\underset{d}{\mathrm{~d}}$ & & & & & & \\
\hline affricate & & & & & & & $\check{g}$ & & & & \\
\hline trill & & & & $r$ & & & & & & & \\
\hline emph. & & & & $(\mathrm{r})$ & & & & & & & \\
\hline lateral & & & & l & & & & & & & \\
\hline emph. & & & & 1 & & & & & & & \\
\hline glides & $\mathrm{w}$ & & & & & & $\mathrm{y}$ & & & & \\
\hline
\end{tabular}

$\mathrm{vd}=$ voiced, $\mathrm{vl}=$ voiceless, $\mathrm{emph} .=$ emphatic/velarized

The greatest difference with the inventory of group I is the presence of both $/ \mathrm{k} /$ and $/ \mathrm{k} /$, which is also a feature of group II in the north and of dialects of groups VII and VIII. A minimal pair xud bāluk-xdiy bālik (though $\sim b \bar{a} l k i y$ in BWA) "pay attention (sg. masc. - sg. fem.)" isolates $/ \mathrm{k} /$ and $/ \mathrm{k} /$ as phonemes.

$*_{1}$ See remarks in 1.1.3. below.

\subsubsection{Interdental fricatives $/ \underline{t} /, / d /$ and $/ \underline{d} /$}

The reflexes of * $\underline{t}$ and ${ }^{*} \underline{d}$ are interdentals $\underline{t}$ and $\underline{d}$ (I.P.A. $[\theta]$ and $[\gamma]$ respectively).

Examples for *ț are: naharit "we plough" (MzA), tāniy "second" (both), tyāb "clothes" (BWA), (')atarhuw "their tracks" (BWA).

For *d: nāxid "we take" (both), migdāaf "oar" (MzA), mnadbaḥuh "we slaughter him" (MzA), idn "ear" (MzA), dikr "mention" (BWA), dimimih "ugly" (BWA), xud bāluk "pay attention, mind you" (BWA).

There are also exceptions: "refrigerator" and "ice; snow" are with $t$ in both dialects: tillāğah and tal̆̆. 
In some loans from MSA (presumably via speakers of Cairene) the reflex for *t is $s$, e.g. hadīs "modern" (BWA) and also haras (!) ${ }^{3}$ "he ploughed" (BWA), masalan "for instance" (both) and for *d it is sometimes $z$, as in bizr "seed" (BWA) and kizâluk ${ }^{4}$ "as well".

Emphatic d (I.P.A. velarized [ð]) is the interdental reflex of *d and * $\underline{\underline{d}}$, e.g. (as reflex of *d in) raw $\underline{d}$ (pl. rị $\underline{d} \bar{a} n$ ) "small wadi between low moun-

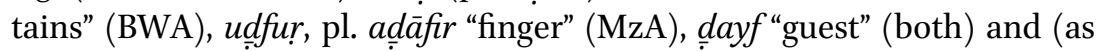

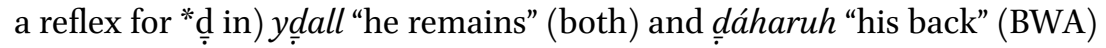
and álgada" "(the) inferior type of firewood" (BWA).

In a number of lexemes $z$ (usually loans from MSA or Egyptian Arabic) is the current reflex, like in mwazzafin "civil servants", zubbāt "officers" (both BWA), b-izzabt "precisely" (both), binzabbit "we do a proper job", nizām "system" (both MzA), etc.

In both dialects the sg. masc. demonstrative $(h \bar{a}-) \underline{d a}$ "this (sg. masc.)" is without velarization.

\subsubsection{Velar stops $/ k /$ and $/ g /$}

Like in the other dialects of Sinai, *k and * $\mathrm{q}$ have unaffricated reflexes $k$ and $g$.

Although in both dialects $k$ and $k$ are heard, only in MzA we find a true phonemic opposition in a minimal pair like ìduk "your (sg. masc.) hand"idik "your (sg. fem.) hand"; in BWA (sg. fem.) pronominal suffixes -ik and -kiy are used as parallel forms ${ }^{5}$ (i.e. $\bar{\imath} d i k$, as well as $\bar{\imath} d k i y$, the latter of which is the original BWA form and which is normally used). A true phonemic opposition between $/ \mathrm{k} /$ and $/ \mathrm{k} /{ }^{6}$ such as that existing in MzA, appears to be developing in BWA.

Similarly we find the (sg. masc.) pron. suffix C-ak (and its allomorph $\overline{\mathrm{v}}-k$ ) parallel to the (sg. masc.) pronominal suffix $-k$ in BWA.

In MzA "cigarette" is sigạrah (not like in many other dialects siğārah).

3 A sibilant $s$ for interdental $\underline{t}$ in the verb harat, yaharit "plough" is usually (i.e. in other dialects of Sinai) not one of the exceptions.

4 Compare MSA ka-dālik, of which morpheme boundaries were reinterpreted as kad̄al-ik, after which $l$-ik "to you (sg. fem.)" was adapted as $l$-uk (for sg. masc.).

${ }^{5}$ For the notion of 'parallel forms' as a characteristic of a transitional stage in dialect change due to dialect contact, see Trudgill 1983:chapter 5 and remarks in De Jong 2000:28, 596-597.

6 'True' in the sense that the two phonemes can be isolated in a minimal pair. 


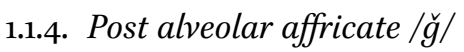

The allophone $\check{z}$ (I.P.A. [3]) for / $\check{g} /$ is particularly frequent in MzA. It was not recorded in BWA.

\subsubsection{Emphatic alveolar stop /ț/}

In all dialects of group I of the south, and also in group VI, a measure of glottalization in the realisation of / $t /$ may occur. Often the glottal release, which coincides with the release of the $t$, is not very clear. What is clear, is the lack of aspiration in the release of $t$, and the immediate onset of a following vowel.

\subsubsection{Glottal stop (hamzah)}

Like in many dialects of Sinai, the reflex for *' in the verb ask is ': sa' al, yas'al.

In * $r a$ 's "head", loss of 'is complemented by lengthening the preceding vowel > rās (pl. rūus).

\subsubsection{Secondary velarization}

What strikes the ear first of all when one hears MzA is the lack of velarization in positions where neighbouring group I dialects in Sinai appear to have it almost as a matter of natural fact. It is a feature of which one of my Mzēniy informants was quite aware; when asked to mention a few differences of his own dialect with that of the Tarābīn (who are their neighbours to the north), he mentioned kibbäyih "(drinking) glass", pl. kibäbiy, where a Turḅāniy would say kuḅbāayih and kuḅāḅiy. MzA rikbih (pl. rkab) "knee" is pronounced rukḅah (pl. rḳab) in TAN, and MzA siwwāg "driver" is sawwāg in TAN.

The imperfects of "eat" and "take" are not (or at best only minimally) velarized, whereas the imperatives are: (imperfects) yāxid and yākil, but velarization is heard in (imperative forms) $k u l$ and $x u \underline{d}$.

Compared to TAN, long $\bar{a}$ in MzA is also noticeably higher in positions

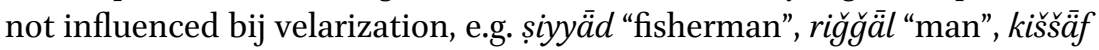
"flashlight", 'ițšän "thirsty" ( $\bar{a}$ is used here to indicate a phonetic value between I.P.A. [æ:] and [ع:]). In TAN the long $\bar{a}$ is considerably lower (nearer to I.P.A. [a:]): șiyyād, raǧğāl, kaššāf, 'aț̌̌̄an.

Another difference with TAN is MzA and BWA demonstrative hä $\underline{d} a$

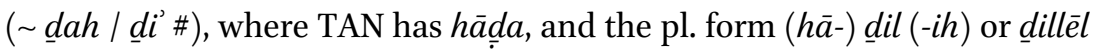
$(-i h)(\sim h \bar{a} \underline{d} \bar{o} l$ in BWA) where group I dialects have heavily velarized forms 


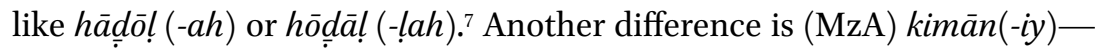
(TAN) kumịān "also".

\subsubsection{Liquids l and $\mathrm{r}$}

On the other hand, MzA and BWA, like many dialects in Sinai (including TAN), have strong velarization ${ }^{8}$ in $x \bar{a} f$ "he feared" (and also $x \bar{a} y i f$ "afraid" in MzA), $\dot{g} \bar{a} b$ "he was absent", rug்fạn "loaves (of bread)", (in the first syllable of ) xfạyyif "light", nār "fire", xyār "gherkins" and (i)nfār "persons" and himrāa "red (sg. fem.)”, 'iwrāa "one eyed (sg. fem.)”, bi '̣ān "camels” and rāās "head" (but no velarization in frāš "blanket").

Uvulars followed by $l$ or $r$ are especially prone to become velarized as an accompanying phonetic feature, ${ }^{9}$ e.g. ag்labiyyah "majority", šu $\dot{g} !$ "genitive exponent", naxa! "palm trees", xa!l "let! (imperative)", nuxrah (pl. nxar) "nose", baxarrif "I speak", nugrah (pl. ngar) "pit, pothole", bagra "I read (i.e. study)", garār "decision", grayyib "near", ga!̣ "heart", gālat "she said", glayyil "few, little" (g!ạ! "few (pl.)" and aga!l "less") and Rās Aḅuw Gallūm "name of a cape between Dahab and Nwēbi".

Generally, like in group I, the combination $\bar{a} r$ will be velarized, unless $i$ follows within morpheme boundaries (see also De Jong 2000:65-67). An exception is the pl. for kițir "many", which is kt $\underline{\ddot{a} r}$ in MzA and BWA (with a long $\bar{a}$ almost as high up as I.P.A. [ $\left.\varepsilon^{\Sigma}\right]$ ), but velarized $k \underline{t} \bar{a} r$ in TAN, whereas groups I and VI both have velarized kbār as the pl. for kibir "old, big". There are many examples of velarized $\bar{a} r$, of which some are: mitmārah "(cylindrically shaped) grain silo", ${ }^{10}$ xyār "gherkins" (BWA), sinnārah "fishing hook", nār "fire", nahār "day (-light)". Also: sigārah "cigarrette", xuwwāar "inferior type of camel, raised for its meat", byār "wells", Badārah "name of the tribe Badārah".

Notice, however, how following (either 'vanished' $i$ within morpheme boundaries blocks such velarization, e.g.: mizāri "lands for cultivation", midāris "schools", šāri "street" and 'ārif "knowing (sg. masc.)".

\footnotetext{
7 See De Jong 2000:170-172.

${ }^{8}$ Combinations of a velar $(g, x$ or $\dot{g})$ with $l, r$ or $b$ will often produce velarization, especiallly with $u, \bar{u}$ or $a, \bar{a}$ in their vicinity.

9 The articulation of uvulars involves some raising of the back of the tongue (towards the uvula). The process of velarization also involves a degree of raising of the back of the tongue.

${ }^{10}$ mițmärah is also used for "pit for storing grain or belongings", see Bailey 2009:347 (glossary). The rocky mountains, more or less shaped like grain silos and located appr. at 28.51.46 North and 34.27.31 East, are also locally known as Ğabal Mațāmìr.
} 
Also sequences $r \bar{a}$ are generally not velarized when (vanished) $i$ precedes, or follows in the next syllable within morpheme boundaries, e.g. marākib "boats", grāyah (cf. MSA qiräah) "studying (lit. reading)", frāš "blanket" (cf. MSA firāš), Garāršah "name of tribe" (compare with MSA Qarārišah) and rākib "riding (sg. masc.)", but there is velarization in forms like rās "head", barrāad "teapot" and harāạah "heat".

\subsubsection{Nasaln}

No remarks.

\subsubsection{Devoicing of final voiced stops, liquids and nasals in pause}

Devoicing of voiced stops, liquids and nasals in pause is regular in MzA and BWA.

One of my informants claimed that one feature of MzA is the type of glottalization of $\bar{a}$ in a final sequence $-\bar{a} C$ in pause, by which the final consonant is no longer produced (compare the situation described in remarks on TyA in 1.1.10. of chapter III). I have not been able to verify his claim.

\subsection{Vowels}

1.2.1. Inventory of vowel phonemes

The inventory for vowel phonemes contains three short vowels and five long vowels:

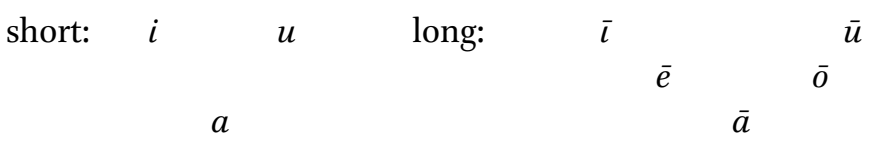

\subsubsection{Long vowels}

1.2.2.1. Allophones of long vowels $\overline{\mathrm{e}}$ and $\overline{\mathrm{l}}$

Unlike in group I dialects, phonetic overlapping of $/ \overline{\mathrm{e}} /$ and $/ \overline{\mathbf{l}} /$ is rare in group VI dialects.

The phonemic status of $/ \overline{\mathrm{e}} /$ and $/ \overline{\mathbf{l}} /$ can be established with a minimal pair like: šèn "bad"—š̌n "name of letter š", and /â/ may be isolated by pairing either of these with $(\min )$ šān "because of".

In MzA imperfect forms of the verb "dry" (root $y$ - $b$-s) monophthongization takes place, e.g. yēbas (< *yaybas) "he dries (intrans.)". 


\subsubsection{Allophones of long vowels $\overline{\mathrm{o}}$ and $\overline{\mathrm{u}}$}

In neutral environments, i.e. in the absence of velarization and without preceding back spirants, older diphthongs * ay and * $a w$ have been monophthongized as $\bar{e}$ and $\bar{o}$. As long vowels, the phonemic status of $/ \overline{\mathrm{u}} /$ and $/ \overline{\mathbf{o}} /$ can be established through minimal pairs like:

rūḥ "go! (imperative sg. masc.)"—rōḥ "soul"

$g \bar{u} l$ "say! (imperative sg. masc.)" - gōl "speaking".

In positions influenced by velarization, $/ \overline{\mathrm{u}} /$ is realized relatively low, near I.P.A. [O:].

In verbs with $w \bar{a} w$ as $\mathrm{C}_{1}$ the diphthong aw has usually been monophthongized, as is illustrated in e.g. nōgaf "we stand" and also tōgid "you light" (both in MzA and BWA). In both dialects the imperative of $w^{-}$' $y$ "pay attention, take heed" has an initial diphthong: aw in rūskin "mind (pl. fem.) your heads!"."

\subsubsection{Allophones of long vowel $\bar{a}$}

Allophones of the long vowel / $\bar{a} /$ are ruled by the same principles as in group VII.

\subsubsection{Shortening of long vowels}

Like in group I dialects, shortening of unstressed long vowels is a characteristic of allegro style of speech in group VI dialects as well.

\subsubsection{Short vowels}

1.2.3.1. Isolating phonemes /i/, /u/ and /a/

Minimal pairs listed for groups VII and VIII also produce the phonemes /i/, /u/ and /a/ in MzA and BWA.

\subsubsection{Phonetic factors influencing the quality of $\mathrm{I}$}

In principle, distribution of short high vowels $i$ and $u$ is governed by the same rules as described for group I in De Jong 2000:70-74: a short high vowel tends to be $u$ (i.e. near I.P.A. [v]) in velarized and/or labial environment, otherwise $i$ (i.e. near I.P.A. [1]).

The pl. com. of ašdaf "left-handed" was recorded as šidf in BWA, but as šudf in MzA. Similarly, the pl. com. of a'arağ "lame, limping" has the high

${ }^{11}$ The imperative $a w^{\prime} a$ is often not inflected for number or gender, e.g. aw'a rūskuw! or aw'a rāsik! (instead of aw'uw and aw'iy respectively). Apocopated imperative forms of this verb have not been recorded, thus e.g. aw'a tans! "don't you forget!". 
vowel $i$ in 'irğ in BWA, but $u$ in 'urğ in MzA and that of a'ama "blind" is 'imy in BWA, but 'umy in MzA. Other pl. com. forms of the pattern $\mathrm{aC}_{1} \mathrm{C}_{2} \mathrm{aC}_{3}$, used for colours and physical defects, recorded in both dialects have a $\mathrm{C}_{1} \mathrm{uC}_{2} \mathrm{C}_{3}$ pattern (most have some degree of velarization), e.g. (sg. masc. ahamar) humr "red", (sg. masc. azrag) zurg "black", ${ }^{12}$ (sg. masc. axadar) ${ }^{13}$ xudr "green", (sg. masc. asfar) șufr "yellow" and (sg. masc. ahabal) hubl "dim-witted" (where labialization of the $b$ triggers the appearance of $u$ ), (sg. masc. agra ${ }^{\dagger}$ ) gur "bald", turm (sg. masc. atram) "gap-toothed".

Both dialects have $i$ in the imperfect of primae hamzah verbs: $y \bar{a} x i \underline{d}$ and $y \bar{a}$ kil "he takes" and "he eats", but $u$ in the sg. masc. imperative: $k u l$ and xud "eat!" and "take!" (resp.) and clear velarization, caused by the 'van-

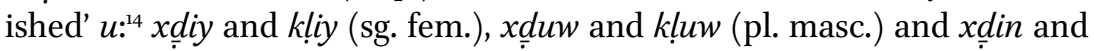
klin (pl. fem.).

Imperfect forms of mediae geminatae verbs recorded in group VI corroborate the rule formulated in De Jong 2000:72-73: $u$ appears near primary and (potentially) secondary emphatics, while $i$ appears in neutral environments. Examples are:

MzA: yhuttt "place", yrudd "answer", ydugg "inject (with a needle)",

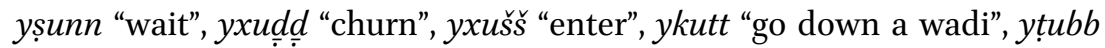
"go on a journey to", ylugg "hit", ${ }^{5}$ y "loosen", ywišs "swing a fishing net over one's head", ${ }^{16}$ ymidd "stretch", ytiff "spit", yliff "wrap", y idd "count", yfitt "prepare fatittah".

\subsubsection{Morphological conditioning of the short high vowel}

So far we have seen that often a velarized or labial environment triggers the appearance of $u$. Morphology, however, will over-rule this phonetic feature, as far as distribution of short high vowels is concerned. For instance, measures 2, 3 and 4 will have $i$ in the imperfect forms, such as $\mathrm{yC}_{1} \mathrm{aC}_{2} \mathrm{C}_{2} \mathrm{iC}_{3}$ (measure 2), $\mathrm{yC}_{1} \overline{\mathrm{a}} \mathrm{C}_{2} \mathrm{iC}_{3}$ (measure 3), yiC $\mathrm{C}_{2} \mathrm{iC}_{3}$ (measure 4),

${ }^{12}$ azrag lit. "blue" is often used euphemistically for "black".

${ }^{13}$ In MzA axadar was also recorded in the meaning of "wet", as in iw hü yğ́y migir kidiyyih b ídāduh ... iw ğilduh 'ilēh, l issā' axadar hü "and he comes running like this with his (diving) gear ... with his diving suit (lit. skin) on, still wet he was...".

${ }^{14}$ See remarks in Blanc 1970:16 [127]!

${ }^{15}$ lagg, ylugg is listed as "snatch, grab" in Stewart 1990:245 (glossary), but my recording calls for a translation like "hit, strike", as in [alğarrah byirikdūha èh?] $f$ ššamš, itlugg fiha ššams "[they place the earthenware pot where?] in the sun, [where] the sun hits (i.e. shines on) it" as a method to let milk ferment to produce rāayib.

${ }^{16}$ The verb wašš, ywi ${ }^{2} \check{s}$ is onomatopaeic. 
yinC $\mathrm{iC}_{2} \mathrm{iC}_{3}$ (measure $n-1$ ) and $\mathrm{yiC}_{1} \mathrm{tiC}_{2} \mathrm{iC}_{3}{ }^{17}$ (measure $1-t$ ) and yistaC $\mathrm{C}_{2} \mathrm{iC}_{3}$ (measure $i s t a-1)$. Other examples are the active participles of the measures: $\mathrm{C}_{1} \overline{\mathrm{a}} \mathrm{C}_{2} \mathrm{iC}_{3}$ (measure 1), $\mathrm{mC}_{1} \mathrm{aC}_{2} \mathrm{C}_{2} \mathrm{iC}_{3}$ (measure 2), $\mathrm{mC}_{1} \overline{\mathrm{a}} \mathrm{C}_{2} \mathrm{iC} \mathrm{C}_{3}$ (measure 3) and $\operatorname{miC}_{1} \mathrm{C}_{2} \mathrm{iC}_{3}$ (measure 4), $\operatorname{mtaC}_{1} \mathrm{aC}_{2} \mathrm{C}_{2} \mathrm{iC}_{3}$ (measure ta-2), mtaC $\bar{a}_{2} \mathrm{iC}_{3}$ (measure $t a-3$ ), minC $\mathrm{iC}_{2} \mathrm{iC}_{3}$ (measure $\left.n-1\right), \operatorname{miC}_{1} \mathrm{tiC}_{2} \mathrm{iC}_{3}$ (measure $\left.1-t\right)^{18}$ and mistaC $_{1} \mathrm{C}_{2} \mathrm{iC}_{3}$ (measure ista-1).

An exception to such morphological conditioning is found in forms coloured by the strong velarization caused by the pronominal suffix $-k$ or $-u k$, as in tušǵúlk "she occupies you/keeps you busy" and also the vowel of the fem. morpheme in construct state may be affected, as in nuxrút $t^{u} k$ "your (sg. masc.) nose", contrasting with nuxrít'k "your (sg. fem.) nose".

\subsubsection{Allophones of short vowels}

Allophones of short vowels do not differ much from what was described for group I in De Jong 2000:74-77, although some allophones, notably of /a/, may appear in environments different-or are more frequent, or less frequent-from those in group I.

\subsection{Allophones of /i/}

When in stressed and neutral positions, short high vowel /i/ will be realized near I.P.A. [1] and slightly higher nearer to [i] when it precedes $y$, e.g. židd [3ıd:] "grandfather", nirmiy ['nırmi' ${ }^{y}$ "we throw" and dišbih ['dıfbli ${ }^{\mathrm{h}}$ " cold (disease)".

When in velarized positions, backing and centralizing takes place, resulting in [ $\mathbf{t}$, e.g. tibb "(practicing) medicine" [tłb:].

When laryngeals precede, they usually have a lowering effect on /i/, resulting in [e] or slightly higher, e.g. hiluw \# ['heluw ] "beautiful, sweet", xirm [xerm] "large species of fish".

\subsection{Allophones of $/ u$ /}

In neutral positions short high vowel /u/ will be realized near I.P.A. [v], and slightly higher [u] when it precedes $w$, e.g. yuskun ['joskon] "he lives (inhabits)", nāmuw "they slept" ['næ:mu'] ${ }^{19}$

When velarized consonants or laryngeals precede, lowering tends to take place, resulting in a realization near I.P.A. [o], e.g. gumsih ['yomsi ${ }^{\mathrm{h}}$ ] "food dip", hurmah ['horma $\left.{ }^{\mathrm{h}}\right]$ "woman", xutwah ['xotwa ${ }^{\mathrm{h}}$ "step".

\footnotetext{
${ }_{17}$ See following fn.

${ }_{18}$ When in closed syllable, the vowel preceding $\mathrm{C}_{2}$ will be $a$ in measures $n-1$ and $1-t$ (or VII and VIII resp.), e.g. yindarbuw "they are beaten" and mindarbah "having been beaten (sg. fem.)" and yištaglin "they (fem.) work" and mištag்lìn "working (pl. masc.)".

19 On the articulatory position of [æ] see remark in De Jong 2000:59-6o, fn 10.
} 


\subsection{Allophones of $/ a /$}

1.2.3.4.3.1. /a/ in non-raised positions.

The realization of short low vowel /a/ in neutral environments will be near I.P.A. [e], e.g. tánam ['tenem] "you sleep", maddat ['med:et] "she stretched out".

Where pharyngeals precede, /a/ has a realization near open and front I.P.A. [a], e.g. harìm [ha'ri:m] "womenfolk", 'arǧ́́y [ 'ar'dziy] "lame, limping (sg. fem.)" and also with $h$ preceding, as in šahabíy [ Jaha'biy] "graycoloured (sg. fem.)".

In velarized environments, /a/ is realized near I.P.A. [a], e.g. bahar ['baћar] "sea" and nugțah ['nogłah] "police post" and habșah ['habsah] "severe cold (disease)".

1.2.3.4.3.2. Raising of $\left(^{*}\right) / \mathrm{a} /$ preceding long stressed vowels

The short vowel /a/ is raised in a variety of positions preceding stress:

- preceding stressed Cī: kibīr "large; old", šidìd "strong", gilị̀ "fat, thick", xifíf "light", 'irīs "bridegroom", hirìd "parrot fish", and also 'Ilíy "male given name * $A l \bar{\imath}$ " and verb forms nisit "I forgot", ligit "I found". Instances of $a$ preceding stressed CCī were not recorded: batțīx "watermelon", sab'in "seventy".

- (preceding stressed Cē): 'ilēh "on him", ligèna "we found", mišèt "I walked", bidēna "we started", (preceding CCē) middèt "I stretched", suwwèt "I did/made" and istinnēni(\#) "we waited" (but istanna "he waited").

- (preceding stressed Cā): 'isākir "soldiers", zimān "in the old days (used as adverb)", timānyih "eight"; (preceding stressed CCā): riǧğ $\bar{a} l$ "man", siyyād "fisherman", kiššā $f$ "search light", biț̣āriyyih "flashlight", zirgā "blue (sg. fem.)". mirṛāt "times", mi nāt (hâăgih) "the meaning (of sth)".

- (preceding stressed $\bar{u})$ : 'urūs "groom", isSu'ūdiyyih "Saudi Arabia", šu'ūr "emperor (fish species)". ${ }^{20}$

- (preceding stressed a): ǧimál "camels", gi adna "we sat down", xubár "information", nihábuk, "he plundered you".

- (preceding stressed u): kubúr "he grew", gulúd "he grew fat".

- (preceding stressed i): širíb "he drank", biríy "innocent", guwíy "strong”.

${ }^{20}$ Of the Lethrinidae: the longnosed emperor is Lethrinus olivaceus. 
Raising of $a$ also takes place following stressed $a$, as in ánwikal "it was eaten", áttifag "he agreed", háwǧisat "she improvised song", ánnixal "the palmtrees", álhiwi "the wind", ál 'iši "the dinner" and ádduwa" "the medicine".

Also when $a$ follows stressed $i$ in closed syllable, it is raised, as in yíndirib "he is beaten", yíttifig "he agrees". ${ }^{21}$

1.2.3.4.3.3. Raising of the feminine morpheme $(\mathrm{T})$

The $a$ of the fem. morpheme is regularly raised in neutral environments and reaches a phonetic value near I.P.A. [lh]. This is not only a pausal phenomenon, but occurs sentence-medial as well. Examples are kull wāhid 'induh xurrāâfah hilwih biyğibhi' "everyone has a nice story which he tells", lamma llēlih gōtarat "until the evening has passed", țalla gișídih $f i$ wihdih rāayidhi" "he recited a poem on a girl with whom he was in love".

In velarized environments such raising does not take place, e.g. gāmat ḥuṛ̣ah \# "a woman stood up", (a mock rhyme) binğīb lēna fạxxah siminih, iw līhiy siminih bi lmarrah "we get for ourselves a fat chicken, but it is not fat at all". Other examples are: bisițah "simple", gilì ¿igāmah "snake-like species of sea fish", ramlah "sand".

Raising is not inhibited by the pharyngeals "and $h$, e.g. rfayy ih "thin", sām ih "hearing (sg. fem.)", Șuwālhị "name of a tribe", mirḡẹḥih "swing", safịih "cannister (of 20 litres)".

1.2.3.5. Prosodic lengthening of short vowels

To express extra emphasis, such as on long durations of time, long distances or great quantities, speakers often prosodically lengthen short (but also long, see 1.2.4.7.) vowels. Examples are bti'gluh 'ala lmayyih "you boil it (for a long time) in water", iw bingațtiy lhațab buh ku:llïtuh "we cover a:ll the firewood with it".

\subsubsection{Long vowels and diphthongs}

\subsubsection{Monophthongization of diphthongs *ay and *aw}

In positions not influenced by velarization, or preceded by $\mathrm{X}$, older diphthongs *ay and *aw have in most cases become monophthongal $\bar{e}$ and $\bar{o}$.

${ }^{21}$ In verb forms like hawǧisat and yíndirib and yíttifig, the raised $a$ will again surface as $a$ when it is in closed syllables, e.g. hawğast "I improvised song", yindarbuw "they are beaten" and yittafguw "they agree" (see also 3.2.3.1.1. and 3.2.3.3.1.). 
Examples for *ay are: ithnēn "two", bēn "between", lēlih "evening", sēl "flood", ğwēl (dim. to ǧăl) "little side" and examples for $\bar{o}: m \bar{t} t$ "death", yōm "day", fōg "above”, sōdíy "black (sg. fem.)", gōmah “(manner of) standing up".

In some cases such monophthongization in neutral environments has not taken place, mawğūd "present (adj.)", aw'a "watch out!"22 and also taybis "drying".

In forms like b'aytarāan velarization has also spread backwards, preserving ay as a diphthong. Diphtongal * $a w$ is preserved by spread of velarization as aw or ow in e.g. gowtaruw "they went".

In MzA (of 'Ayn Hud ${ }^{2} a h^{23}$ and of a family in Wādiy 'Arāadah) forms like $m \bar{e} g \bar{u} d$ "present" and $m \bar{e} l \bar{u} d$ "born" have also been recorded.

\subsubsection{Isolating long vowels $/ \bar{\imath} /, / \bar{u} /, / \bar{a} /, / \bar{e} /$ and $/ \bar{o} /$ as phonemes}

In many dialects of group I phonetic overlapping of $/ \overline{\mathrm{e}} /$ and $/ \overline{\mathrm{i}} /$ in neutral environments occurs. Such is not the case in MzA and BWA. Finding (near) minimal pairs to isolate these phonemes is not a problem:

$d \bar{e} r$ "monastery" — dīr "turn (trans.)!"—dūr "turn (intrans.)!" — dōr "floor (in a building)"-dār "house"

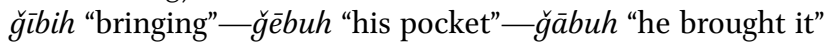
gōm "enemy tribe"—gūm "get up!"

Suffixed prepositions lay "to me", 'aláy "on me" and fay "in me" are actually better interpreted as final $-a y+y$.

\subsubsection{Allophones of $\overline{\mathrm{a}}$}

Like in the dialect of the Tarābīn of group I, $\bar{a}$ in neutral surroundings is realized as near I.P.A. [ع:]. Unlike Turbāniy, however, $\bar{a}$ in open syllable and neutral surroundings does not need $\mathrm{Ci}$ following within morpheme boundaries for such I.P.A. values to be reached.

In MzA this [ $\left.\varepsilon^{\prime}\right]$ for $\bar{a}$ is reached also when $\overline{\mathrm{a}} \mathrm{C}$ is morpheme-final, e.g. kțärr "many (pl. com.)", šgäg "compartments of the tent", ḩbä́l "ropes", šäših "screen" and also wäḥid "one", särḥih "out grazing (goats and sheep) (sg. fem.)", nä̈gtī "my she-camel”.

\footnotetext{
${ }^{22} a w^{\prime} a$ is often left unconjugated, and has thus developed into a general particle of warning or admonition, as in aw'a tans! "don't you forget!"

${ }^{23}$ Von Oppenheim 1942:159 mentions 'Ayn Ḥựrah as 'Lēgiy territory (in his transcription: 'Olēkāât). Today this oasis is inhabited by members of the Mzēnah.
} 


\subsubsection{Reflexes of final *āa( $\left.{ }^{2}\right)$}

Like in the dialect of Biliy in the north, ${ }^{24}$ the reflex of final ${ }^{*}-\bar{a}$ in neutral environments in MzA and BWA is often - $\imath$. Examples are: Wādiy Sli" "Wadi

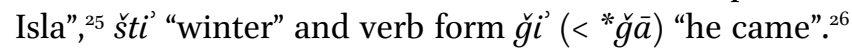

Final $-i$ ' will be unstressed when a heavy sequence precedes. The vowel of the heavy sequence is then stressed. E.g. áššifi "the curing", (wāhid) mínni "(one) of us", táfdi" "you sacrifice" and yánsi" "he forgets".

However, in sg. fem. forms (cf. MSA CaCCā') that come with the (sg. masc.) aCCaC pattern for physical defects and colours, we do find raising like in group I, e.g.: šadf’́y "left-handed (sg. fem.)", hawlíy "cross-eyed" and habliy "stupid", unless such raising is prevented by phonetic factors, such as velarization, as in e.g. (colours) samrā "brown", xadrā "green", hamrāa "red", zargā "black; blue” and (physical defects) 'iwrā "one-eyed”, gir' $\bar{a}$ "bald" and dorā "absent minded". The final stressed $-\bar{a}$ may be cut off in pause by a flottal stop, e.g. xadră \#.

\section{N.B. "here" is niha $\bar{a}($ ') in MzA and BWA.}

In dialects of group I raising (there to final -íy) is inhibited by (underlying) $a$ preceding in open syllable. ${ }^{27}$ Such is not the case in MzA and BWA, e.g. hiwi "wind", 'iši "dinner", diwi "medicine" (in MzA), simì "heaven" and also verb forms like mišì (< *mašā) "he went", ligi" (< *lagā) "he found" and tawaffi" "he died".

When (secondary) emphatics precede, final ${ }^{*}-\bar{a}\left({ }^{\prime}\right)$ is not raised, while reflexes of ${ }^{*}-\bar{a}^{3}$ have remained long and reflexes of ${ }^{*}-\bar{a}$ are short. Examples

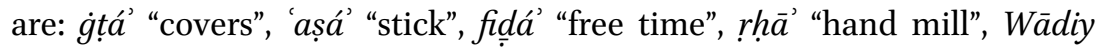

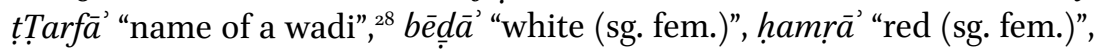

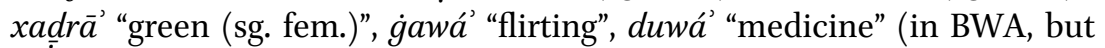
in MzA diwi'), ragt tă "speckled (sg. fem.)", zarga $\vec{a}^{\prime}$ "black; blue; dark coloured (sg. fem.)", samrā' "brown (sg. fem.)".

In BWA álma(') "the water" and in MzA álmi were recorded for "the water" ( in both with much more frequent mayyih).

\footnotetext{
${ }^{24}$ See De Jong 2000:81.

${ }_{25}$ My Turbāniy informant pronounced Wādiy Sliy. The name of this wadi is often spelled ' Isla ' on maps (cf. 1.2.4.4. and 3.1.5.). The wadi is located somewhat to the southeast of at-Ṭur, where it disappears into the south-western high mountains.

${ }^{26}$ Like in the dialect of Biliy in the north, see De Jong 2000:83.

${ }_{27}$ See Blanc 1970:12 [123] and De Jong 2000:82.

${ }_{28}$ The wadi is situated at the far high end of Wādiy Fērān in central Sinai and is Ǧbāliy territory bordering on Mzēniy territory.
} 
Final * $-\bar{a}$ is not raised in the elative aḥla "sweeter; more beautiful".

Several of the preceding examples also show raising of final $-\bar{a}$, although preceded by $a$ in open syllable, does take place, ${ }^{29}$ e.g. duwá or diwi $\iota^{\prime}$ and verb forms like miší and ligí.

The forms with raised final ${ }^{*}-\bar{a}(>-i)$ do not only occur in pause, but also in sentence-medial positions. Such raising is therefore concluded to have led to morphological restructuring.

The-usually unreleased-glottal stop following the final vowel is not only highly regular when this vowel is stressed, but also when it is unstressed.

In MzA forms like ğ $\bar{a} n \bar{i}$ "he came to me" were heard, but also forms with lengthened [1] , as in $h \bar{u} g{ }_{g} i^{u} k$ "he came to you (sg. masc.)": not with IPA [i: ], but with lengthened [1]: [dzir $\left.{ }^{\mathrm{u}} \mathrm{k}\right]$ ) "he came to you (sg. masc.)" and also $h \bar{u}$ ği:k (IPA [dzı:k]) "he came to you (sg. fem.)". In BWA such lengthened [1:] was not heard.

\subsubsection{Allophones of long vowels $\overline{\mathrm{e}}, \overline{\mathrm{i}}, \overline{\mathrm{o}}$, and $\overline{\mathrm{u}}$}

\subsection{Lowering effect of preceding emphatics on $\overline{\mathrm{i}}$ and $\overline{\mathrm{u}}$}

Like in group I (see De Jong 2000:85), primary and secondary emphatics will lower the phonetic value of following $\bar{l}$ and $\bar{u}$ towards (resp.) I.P.A. [e:] and [o:]. Such lowering is clearer in the case of following $\bar{u}$; with following $\bar{\imath}$ it is less clear, but an on-glide is apparent.

Like in group I, reflexes of *ay and *aw following emphatics have remained diphthongal, which prevents homophonic clash with lowered $\bar{\imath}$ and $\bar{u}$ in positions preceded by emphatics.

\subsection{Off-glide in $\overline{\mathrm{e}}$ and $\overline{\mathrm{l}}$}

An off-glide in the realisation of $\bar{e}$ and $\bar{l}$ is often audible, when these are followed by an emphatic. Examples are (from both dialects) gēd (I.P.A. [ge: ${ }^{a} \oslash$ ] "chain", (a less clearly audible off-glide in) Fērāan [fe: ${ }^{a^{\prime}}$ ra:n] "Wadi

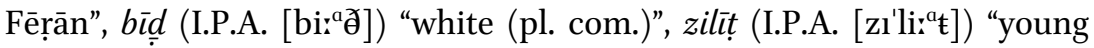
goat or gazelle" and mšêtah [\# Pəm' $\int \mathrm{e}^{\mathrm{a}^{\mathrm{a}}} \mathrm{ta}^{\mathrm{h}}$ ] "type of herb".

Comparable off-glides, but then towards I.P.A. [a], are heard when $h$ or "follow $\bar{e}$ or $\bar{\imath}$, e.g. ğinnēhhih I.P.A. [dzı'ne:ahe ${ }^{\mathrm{h}}$ ] "brown surgeonfish", ${ }^{30} b \bar{e}^{-\mathrm{c}}$

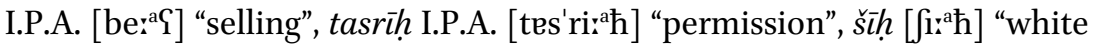

\footnotetext{
${ }^{29}$ Which is also the case in the dialect of Biliy, see De Jong 2000:82 (1.2.4.4.3.2.).
}

${ }^{30}$ Lat. Acanthurus nigrofuscus. 


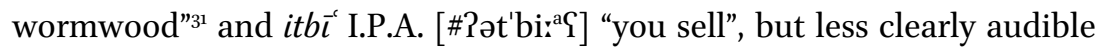

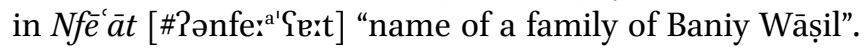

\subsection{Off-glide in $\overline{\mathrm{o}}$ and $\overline{\mathrm{u}}$}

Like in group I off-glides towards I.P.A. [a] are audible in $\bar{o}$ and $\bar{u}$ when these are followed by emphatics, e.g. gōtarat ['go: "tarat] "she went".

Off-glides in $\bar{o}$ and $\bar{u}$ towards I.P.A. [a] are clear when 'or $h$ follow, e.g.

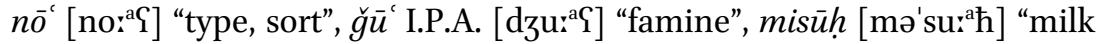
camel" (there were no instances recorded with $\bar{o}$ followed by $h$, but e.g. lōh "(wooden) board, panel" would thus be [lo: $\mathrm{a}]$ ).

\subsubsection{Diphthongs}

MzA and BWA have four diphthongs: $a y, a w, i y$ and $u w$.

1.2.4.6.1. Reflexes of *ay and *aw

1.2.4.6.1.1. Reflexes of *ay and *aw in neutral environments

In positions not preceded by or velarized consonants *aw and *ay have usually become $\bar{o}$ and $\bar{e}$.

1.2.4.6.1.2. Reflexes of *ay and *aw in non-neutral environments

1.2.4.6.1.2.1. Reflexes of *ay and *aw preceded by X

Like in group I, MzA and BWA have phonologically conditioned diphthongs for * $a w$ and *ay in positions preceded by back spirants $X$ (i.e. $x, \dot{g}, h$, ' and $h$. For the latter, see remark below). In some instances, a diphthong is audible without being attributable to phonetic conditioning, as in sanatayn "two years" (MzA).

Examples with $X$ preceding *ay are: xayt "thread", gayrī "(someone) other than I", $b$ ilhayl "very", 'ayn "eye", but the only form with preceding $h$ recorded is nhe dih "a type of herb (used to treat kidney disease)".$^{2}$

Examples with $X$ preceding *aw are: xawf "fear", hawl "year", 'Awdih "male given name" and a Bedouin verb ${ }^{33}$ hawğas, yhawğis "improvise singing", hawmal, yhawmil "bring a hamülah ${ }^{34}$ for a feast".

\footnotetext{
$3^{11}$ Lat. Artemisia herba-alba, used to prepare samn šịiy "ghee".

$3^{2}$ Perhaps the reference was to the Eyptian desert weed Cymbopogon proximus.

33 Verbs of the type CawCaC, yCawCiC (with inserted $w \bar{a} w$ ) are considered to be typically Bedouin, see Palva 1991:155.

${ }^{34}$ A hamūlah is an "animal led to a party to be slaughtered as a present".
} 
1.2.4.6.1.2.2. Diphthongs *ay and *aw preceded by velarized consonants Examples of *ay with a velarized consonant preceding: sayf "summer", dayf "guest", hatțayt "I put (perfect)". Examples with the secondarily velarized consonants preceding are: ištarayt "I bought", ihmarrayt "I turned red", taharrayna $\bar{a}^{u} k$ "we waited for you", kitrayš? "how much?", $\underline{\text { dall }}$ layna "we remained" and also șannayt ${ }^{35}$ "I kept quiet", dawayt $^{36}$ "I returned home at sunset (with goats and sheep)" and tarabayzih "table". ${ }^{37}$

Examples of * aw with a velarized consonant preceding are fewer: șawm "fasting", țawr (pl. tị̣̂ān) "overhanging cliff" and rawd (pl. rị̂̀āan) "small wadi".

1.2.4.6.1.2.3. Reduction of diphthongs ay and aw

The diphthong in $\dot{g} a y r$ is often reduced to $a$ and then complementary lengthened. Examples are: $\dot{g} \bar{a} r$ ánnaxal, mā fih izrā'ah zamān "only palm trees, there was no agriculture in the past" and 'ašān law daggat wāhid minni', $\dot{g} \bar{a} r$ kān iyrawwih l ittaktūr ${ }^{3}{ }^{8}$ "because if it would sting one of us, he would have to go to the doctor".

Diphthongs are much less regularly than in group I reduced to $a$ or $\bar{a}$.

'Systemzwang' has preserved diphthongs in e.g. taybīs "drying (measure 2 verbal noun)" (but not in the imperfect form of measure 1 yébas "it (masc.) dries"), šawliy "left-handed (sg. fem.)" and mawğūd "present (adj.)". Another instance may be aw'a "beware, watch out!" (other imperatives of primae $w \bar{a} w$ verbs are with initial $\bar{o}: \bar{o} g a f !$ "stand still!", ôrid! “fetch water!").

\subsection{Diphthongs -iy and -uw}

\subsection{Reflexes of final *-ī and *-ù}

Final diphthongs $-i y$ and $-u w$, which in part reflect older final ${ }^{*}-\bar{\imath}$ and ${ }^{*}-\bar{u}$ are best heard in lento speech and occur both in sentence medial as well as in sentence final positions.

In verbs the ending $-u w$ has developed as a morpheme signalling pl. masc., but also in pronominal suffixes. Examples are: (verbal perfect)

35 In this example, velarization caused by șād is carried through the word by $n n$, which then causes the dipthongal realization in the final syllable.

${ }^{36}$ dawá, yidwiy is a measure 1 verb in MzA and BWA. In several group I dialects it is measure 4 ad $w a$, yiḍwiy.

${ }_{37}$ The latter does not reflect Older Arabic ay, but is a loan-perhaps via Cairene-from Greek $\tau \rho \alpha \dot{\pi} \varepsilon \zeta \alpha$. In e.g. TAS the diphthong is not present: there tarabēzah.

${ }^{8}{ }^{8}$ taktūr "doctor" (cf. Cairene daktūr, see Hinds and Badawi 1986) was also recorded in TyA, see Shawarbah 2007:419. A comparable example there is taftar "notebook" (cf. Cairene daftar, see Hinds and Badawi 1986). 
katab-uw "they wrote", katabt-uw "you (pl. masc.) wrote", (verbal imperfect) yikitb-uw "they (pl. masc.) write", tíkitb-uw "you (pl. masc.) write" and in pronominal suffixes bēth-uw "their (pl. masc.) house" and bētk-uw "your (pl. masc.) house". ${ }^{39}$

Anaptyxis may also create final - $u w$ to eliminate final -CC clusters, e.g. hiluw \# "pretty, beautiful" (morphological base hilw) and daluw \# "pail" (morphological base dalw).

Instances of final -iy are much more numerous. Examples of verbal endings are (perfect) katabt-iy "you (sg. fem.) wrote" and (imperfect) tíkitb-iy "you (sg. fem.) write". In verbs where $\mathrm{C}_{3}=y$ (imperfect) yimšiy "he walks", ysawwiy "he makes" and yiğ́y "he comes", etc.

In MzA and BWA an -iy ending in the 3 rd p. sg. masc. of $i$-type perfects is rare. Instead, final $y$ verbs nearly all have an $a$-type perfect e.g. nisi" "he forgot" ${ }^{40}$ Final $-i y$ may also reflect older final * $-\vec{a}$, as in (MzA) miy "water", (reflecting the sg. fem. pattern *CaCCā' for physical defects) 'arğ́y "limping (sg. fem.)", habliy "simple-minded (sg. fem.)", 'amyíy "blind" and the sg. fem. pattern for colours (also *CaCCā') sawdíy "black", šahabíy "sand-coloured". Although a regular reflex for final ${ }^{*}-\bar{a}$ is stressed $-i \bar{i},-i y$ reflects ${ }^{*}-\bar{a}$ in hniy ${ }^{41}$ "here" (in BWA only; "here" is nih $\bar{a}(-n i y)$ in MzA). Final -iy reflects final * $\vec{\imath}$ in biríy "innocent", final *--y in șibíy "boy", *-ay' in šiy "thing" and is of course also the nisba ending for the sg. masc., e.g. Mașriy "Egyptian".

Anaptyxis may also create final (but unstressed) -iy sequences, as in e.g. ‘miy \# "(pl. com.) blind" (morphological base ‘my) and ğidiy \# "billy goat" (morphological base ğidy).

\subsubsection{Prosodic lengthening of long vowels and diphthongs}

The first element of the diphthong ay is often lengthened, ${ }^{42}$ e.g. 'aryš "bread", 'a:yb "disgraceful act", xa:ytni' "our (fishing) line". Such lengthening of diphthongs is also heard in some of the dialects of group I (TAN, TAṢ, HwA, ĞrA and BdA, see chapter III) and also takes place without an apparent intention to express extra emphasis. ${ }^{43}$

\footnotetext{
39 For further detail on the development of $-u w$ in pronominal suffixes, see 3.1.12.2.

${ }^{40}$ Although labelling the form nisí as an $a$-type perfect may look like a contradiction, the interpretation of nisi" < *nas $\bar{a}$ (after applying the rule described for raising of final ${ }^{*}-\bar{a}$, and subsequently the rule for raising of short $a$ in open pre-stress syllable) is plausible (see remark ${ }^{*_{1}}$ in $3 \cdot 2.2 \cdot 5 \cdot 1$.).

${ }_{41}$ Final stressed $-i y$ for $* \bar{a}$ is regular in group I. In the dialect of Biliy, however, the same $-i$ reflex was recorded for ${ }^{*}-\bar{a}$ and also ${ }^{*}-\vec{a}$, see De Jong 2000:89.

42 This was not observed with the diphthong aw, but this may be due to the fact that $a w$ occurs much less frequently than $a y$.

43 Lengthening of diphthongs was also reported to be a feature of the dialect of the Dawāğrah in northern Sinai, see De Jong 2000:420-421.
} 


\section{Stress AND Phonotactics}

\subsection{Stress}

\subsubsection{Rules for word-stress}

In terms of rule order, the rule for word stress follows the rule for elision, but precedes the rule for anaptyxis. Stress is of the máktabah-type. Verbal gahawah-forms of the $i$-type imperfect, like yáhartuw "they plough", receive special treatment (see 2.1.2.4.).

Rules for word-stress are:

1) Speech pause does not have the function of a consonant for the stress rule.

2) The domain of stress is formed by:

a.) either the last three syllables of a word, including the article $a l$ - or $i l$ - and the verbal an- prefix of measure $n$ - 1 and the syllable preceding the $t$-infix of measure 1 - $t$ and suffixes, if these are part of the last three syllables,

b.) or, in the absence of an article, infix or prefix, the last four syllables.

3) Stress is placed according to the criterion of quantity, i.e. vowels of heavy sequences are stressed.

4) The following types of 'heavy' sequences occur: vCC $(C)$ and $\bar{v} C(C)$ (including $\overline{\mathrm{v}}(\mathrm{h})$ ).

5) The vowel of the first heavy sequence from the right is stressed (see examples in 2.1.1.1.).

6) In the absence of a heavy syllable, stress the vowel in the first syllable from the left if more than two syllables are available, otherwise stress the last syllable.

An exception may be made when of four syllables the first three syllables are open and contain $a$, and the last syllable is not heavy, i.e. $\mathrm{CaCaCaCv}(\mathrm{C})$. In that case the sequence maybe resyllabified as $\operatorname{CaCCiCv}(\mathrm{C})$ and is stressed on the first syllable: $\operatorname{CáCCiCv}(\mathrm{C})$, e.g. dárbituh "she hit him" and rágbituh "his neck". This type of resyllabification was recorded in MzA, but not in BWA.

Also if resyllabification is absent, the first syllable is stressed: $\mathrm{CáCaCaCv}(\mathrm{C})$, e.g. dárabatuh and rágabatuh.

2.1.1.1. Stress in words with heavy sequences

Examples of stress in words with 'heavy' sequences are: mádrasih "school", áštaġal "he worked”, áttifag "he agreed”, ánġasal "he was washed”, álbuṣal 
"the onions", álwalad "the boy/son", iššti "the winter", il 'iši "the dinner", ${ }^{44}$ árrkab "the knees", áligṃam "the Moray eels", álibkal"45 "the jerrycans", ilihssily "the rocks" (in the latter two examples anaptyctics are underlined) and šawlíy "left-handed (sg. fem.)", šahabíy "sand-coloured (sg. fem.)", țilína "we rose", waládk "your (sg. masc.) son", waládk "your (sg. fem.) son", áṃmuk "your mother" (MzA), štì "winter", zèn "good”, zēnih "good (sg. fem.)", zēnin "good (pl. masc.)".

2.1.1.2. Examples of stress in words without heavy sequences

\subsection{Stress in $\operatorname{Cv} C v C(v)$}

Stress in $(\mathrm{C}) \mathrm{v} \mathrm{Cv}(\mathrm{C})^{46}$ is placed thus:

(') ${ }_{1}$ CvC: akál "he ate", axád "he took", ugúm "stand up!", iğíy "I come" $\mathrm{Cv}_{1} \operatorname{Cv}\left({ }^{\prime}\right)$ : 'așá "stick", 'iší "dinner", mišì "he walked”, duwá "medicine" $(\sim$ diwi $)$.

Cv CvC: ǧimál "camels", šiǧár "trees", gitạ́s "he dived"; wugáf "he stood up", warág "paper" and yiǧíy "he goes", șibíy "boy", biríy "innocent", țiríy "moist; soft".

\subsection{Stress in $(C) v C v C v(C)$ and $(C) v C v C v C v(C)$}

Examples of stress in $(\mathrm{C}) \mathrm{vCvCv}(\mathrm{C})$ sequences are:

(C) $\operatorname{vCv} \mathrm{Cv}(\mathrm{C})$ : ákalat "she ate", (gahawah-form) áhamar "red", xášabih "piece of firewood", dárabuw "they hit (perfect)", báladuh "his country", násatuh "she forgot him" and gahawah-forms gáhawah "coffee", náaǧih "ewe", áhariț "I plough" and yágațis "he dives".

(C) $\mathrm{vCv} \operatorname{cv} \mathrm{Cv}(\mathrm{C})$ : ákalatuh "she ate it" (or MzA áklituh), ḍárabatuh "she hit him" (or MzA ḍárbituh), fárašatuh "she spread it (sg. masc.) out" (or MzA fáršituh), rágabatuh "his neck" (or MzA rágbituh) and gahawah-forms gáhawatuh "his coffee" (or MzA gáhwituh), láhamatuh "his (piece of) meat" (or MzA láḥmituh), tá aragin "you (pl. fem.) sweat", yáa araguw "they sweat".

alxášabih "the piece of firewood", albádawiy "the Bedouin (sg.)", (gahawahform) annáxalah "the palm tree", (gahawah-form) ibtáhafruw "they dig", ištágalat "she worked", inbásațuw "they rejoiced", ittáfagat "she agreed", tiǧáwwazat "she got married", takállamuw "they spoke".

\footnotetext{
44 But notice $a$ in the article in áššifi "the healing".

45 The word buklah (pl. bkal) is used for a plastic jerrycan in MzA.

${ }^{46}$ When $v_{1}$ in this pattern is not preceded by $C$, it is underlying $|a|$.
} 


\subsubsection{Exceptions to the stress rule}

\subsubsection{Stress on reflexes of ${ }^{*}-\vec{a}^{\prime}$ and ${ }^{*}-\bar{a}$}

Reflexes of ${ }^{*}-\vec{a}$, which have not been raised (see 1.2.4.4. above), will be stressed, when they have remained long and thus form a heavy sequence, e.g. $x a \underline{d} r \bar{a}$ "green (sg. fem.)", șifrā "yellow (sg. fem.)", bẹ $\underline{d} \bar{a}$ "white (sg. fem.)", gir'ā "bald (sg. fem.)", 'iwrā "one-eyed (sg. fem.)".

In positions not influenced by velarization, $-\vec{a}$ is raised to $-i y$ (see 1.2.4.4.) Such raised -iy reflexes are then stressed, even if (other) heavy sequences precede, e.g. sōdíy "black (sg. fem.)", šadfiy "left-handed (sg. fem.)", hawliy "cross-eyed (sg. fem.)" and hniy "here" (only in BWA), although more regular for "here" is nihā.

Also in a gahawah-form, in which the gahawah-vowel has resolved the cluster forming the heavy sequence, the reflex of $-\vec{a}$ receives stress: $\left(\check{s} a h b b \vec{a}^{\prime}>\right)$ šạabíy "sand coloured (sg. fem.)".

Reflexes of final * $-\bar{a}$ in neutral environments are final $-i$. The resulting forms are then stressed in conformity to the rules in 2.1.1.2. Examples are šti "winter; rain", mi "water", wādiy Sli' "wadi Isla", simì "sky", diwì "medicine", 'iší "lunch", sifi "healing”, mášti "winter".

Examples of pronominal suffixes *-hā and *-nā are tanshi! "forget her!", gițah minhi' "a piece of it (sg. fem.)", ğdūdni "our forefathers", ba 'adni "(we) each other" and of the sg. masc. demonstrative álwalad di "this boy". When velarization has spread, $a$ in pronominal suffixes is not raised, e.g. uxūha' "her brother", binzabbițha' "we do it (sg. fem.) properly".

Examples of such raising in verb forms in which $\mathrm{C}_{3}=y$ are (perfect) mišì "he walked", ligi" "he found", sawwi "he did" and ǧi "he came". Examples of imperfect forms are yansi' "he forgets", ytagaddi" "he has lunch".

Examples of reflexes of ${ }^{*}-\bar{a}$ preceded by velarized consonants are álga ${ }^{\prime} a^{\prime}$ "type of wood (does not burn like embers)", barrra' "outside", verb forms (imperfect) yarḍa" "he agrees happily" and șa!lla" "he prayed".

2.1.2.2. Stress on final nominal *-iy reflexes in *CaCiy

In MzA and BWA, reflexes of the pattern CaCiy are CaCiy or (after raising the short vowel $a$ ) CiCiy and are stressed on the ultimate, which is in conformity with the rules formulated in 2.1.1.2.

2.1.2.3. Stress in $\mathrm{al} / \mathrm{il}+{ }^{*} \mathrm{CaC} \bar{y}$

When the article precedes a reflex of CaCìy, the resulting cluster will draw stress onto its directly preceding vowel, e.g. innibiy "the Prophet" and isșsibiy "the boy". 


\subsubsection{Stress in suffixed gahawah-forms}

In forms with consonant-initial suffixes closing the syllable with the gahawah-vowel, this vowel is stressed, e.g. ba ádhin "each other (pl. fem.)", sahánha "her plate".

With the fem. morpheme becoming -at in construct state, stress is placed according to rules described in 2.1.1.2., e.g. gáhawatuh "his coffee".

In verb forms of $i$ - or $u$-type imperfects, the gahawah-vowel is dropped when vowel-initial suffixes are appended, but stress is not placed on the gahawah-vowel, which then directly precedes the resulting consonant cluster, e.g. yáharțuw "they plough", táağnuh "you knead it (sg. masc.)", yáxabtuw "they knock".

Resyllabified MzA forms of the type CaCaCatv > CaCCitv are stressed on the first syllable; resyllabification of such forms cancels the high-vowel elision rule and the resulting form is stressed according to rules described in 2.1.1.2., e.g. xášbituh ${ }^{8}$ "his piece of wood" (contrast e.g. wákiltuh "eating it (sg. masc.)" and ríkibtuh "his knee").

\subsubsection{Stress in $v C C I C v$}

A short high vowel is not dropped from a sequence in which the consonant preceding it is phonetically close to, or identical with the consonant following it and stress is placed according to rules in 2.1.1.2., e.g. thálliluh "you analyze it", ǧidditī "my grandmother".

\subsubsection{Stress units}

\subsubsection{Stress in combinations with preposition min and negated personal} pronominals

Like in group I, the preposition min may form one stress unit with the following word, as in mín-tahat "from below", min-kidiy "from this" and min-ihniy "from here" (the latter BWA).

For stress in negated personal pronominals, see 3.1.12.1. of this chapter.

\subsubsection{Enclitically suffixed prepositions $\mathrm{l}$ and $\mathrm{b}$}

\subsection{Enclisis of the suffixed preposition 1}

Enclitic suffixation of the preposition $l$ occurs only sporadically. ${ }^{49}$ The examples (all from MzA) are ğă-luk "he came to you", gult-ilhi' "I said to

\footnotetext{
47 I hear $\sin$, rather than șād.

${ }^{48}$ Notice also that the high vowel elision rule is not applied after stress placement, hence xášbituh, not xášibtuh (contrasting with a form like 'ilibtuh "his packet").

49 In as far as such may be concluded; it is not possible to conclude enclitic suffixing
} 
her" (notice that the form is not lēha), ahsál-luk "it is best for you" (assimilated ahsan+luk) and a'míl-luk "I'll make for you". ${ }^{\circ}$

2.1.3.2.2. Enclisis of the suffixed preposition $\mathrm{b}$

Instances of enclitic suffixation of the preposition $b$ were not recorded.

\subsection{Phonotactics}

\subsubsection{The gahawah-syndrome}

2.2.1.1. The gahawah-syndrome: a-insertion in *aXC sequences

The gahawah-syndrome is active in MzA and BWA; $a$ is inserted in a sequence $\mathrm{XC}$ when this sequence is preceded by $a$. The rule is:

$$
\varnothing>\mathrm{a} /(\mathrm{C}) \mathrm{aX} \_\mathrm{C}(\mathrm{V})
$$

$\mathrm{X}=$ any of the back spirants $h, h,{ }^{\prime}, x, \dot{g}$

The resulting vowel may be stressed according to rules described in 2.1.1.2. Exceptions to these rules with regard to stress in gahawah-forms are described in 2.1.2.4. Examples of gahawah-forms are: ("naxl) naxál "palm trees", ( ${ }^{*}$ sahl) sahál "easy", ( *axdar) áxaḍar "green", ( ahțal) áhațal "stu-

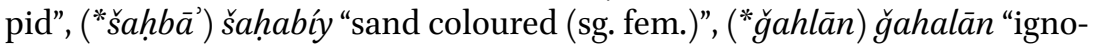
rant", ("mahmūl) mahamūl "neglected", ("maxrūm) maxarūm "pierced", ( "mahțūt) mahațūt "placed", ( maxfiy) máxafiy "hidden" and verb forms ( "yaxțib) yáxațib "he proposes (for marriage)", ( "yaḥšūh) yahašūh "they fill it", ("ta'raguw) ta'araguw "you (pl. masc.) sweat".

\subsubsection{Morphological categories showing variation}

Although the gahawah-syndrome is active in forms of the past participle (i.e. where $\mathrm{C}_{1}=\mathrm{X}: \operatorname{maXC}_{2} \overline{\mathrm{u}} \mathrm{C}_{3}$ ) like maxarūm "pierced", mahamūl "neglegted" and ma agū! "reasonable", it was not recorded in maxṣūṣ "specialized" and mahsūb 'ala "reckoned with".

Exceptions are also found with the pattern $\operatorname{maXC}_{2} \mathrm{aC}_{3}(\mathrm{ah})$ : ma'rakah "battle", mahkamah "court of justice", magrib "time of sunset".

from a form gult+luh, since stress does not shift (as in e.g. gälát-luh) and no vowel is lengthened (as in e.g. gă

${ }^{50}$ The verb form must be a loan (an indication is also the initial vowel: a mil instead of i $m i l)$, see also remark in following fn. 
2.2.1.3. Morphological categories in which the gahawah-syndrome is not active

The gahawah-syndrome is not active in derived verbal measures, e.g. (measure 4) a ța "he gave", (measure ista-1) istahmal, yistahmil "bear, endure", istagrab, yistagrib "wonder, be amazed", ista mal, yista mil "use". Quadriliteral verbs gahwa, yigahwiy "serve coffee or tea to", zagrat, yzagrit "ululate" and a passive participle mgatal "handicapped in the legs" and ta-quadriliteral tagahwa, ytagahwa "be served coffee or tea".

Examples of elatives are ahsan "better", ahla "more beautiful, sweetest", axțar "most dangerous", but ágalad "thicker".

In loans from Standard Arabic (or Cairene Arabic) like mahkamah (see above) the syndrome is not active. Other examples are: ragma 'ann "although", ag̣labiyya "majority", tahliyyih "analysis", mayyah ma daniyyih "mineral water", ya 'niy "that is, it means", yahșal "it happens" and another measure 1 verb ya'mal ${ }^{51}$ "he makes, does".

The fem. morpheme in construct state becomes -at, also when it follows $\mathrm{XaC}$ (i.e. where $a$ is a gahawah-vowel), so that the sequence CaXaCat is the result. When such a sequence is directly suffixed with a vowel-initial suffix, the CaXaCatv sequence-like any other sequence of the type CaCaCatv-tends to be resyllabified as CaXCitv in MzA.

Examples are naxlitī "my palm tree" and gáhwituh "his coffee". When such resyllabification does not take place, the resulting forms are of the type CaXaCatv, as in e.g. lahamati "my piece of meat" and dáxanatuh "its (sg. masc.) smoke" (for further details, see 2.1.1.).

2.2.2. Articulatory delay in the realization of alveolar sonorants (liquids $l, r$ and $n$ )

2.2.2.1. Articulatory delay in the realization of $\mathrm{r}$ : the bukara-syndrome Often the 'simple' bukara-syndrome ${ }^{52}$ creates an intrusive vowel in a sequence $C r v$. The vowel created is inserted between $C$ and $r$ and is in phonetic quality guided by the vowel following $r$. A summary of the rule is:

$$
\begin{aligned}
& \varnothing>\mathrm{v}_{\mathrm{b}} /-\mathrm{C}_{-} \mathrm{Rv}_{\mathrm{a}} \\
& \mathrm{v}_{\mathrm{b}}=\mathrm{v}_{\mathrm{a}} \text { or } \mathrm{v}_{\mathrm{b}} \approx \mathrm{v}_{\mathrm{a}} \\
& \mathrm{R}=r \text { or } r \\
& \mathrm{C}=\text { any consonant }
\end{aligned}
$$

${ }^{51}$ Much more current for "make, do" is sawwa, ysawwiy.

$5^{2}$ See also EALL 2006 (Vol. II):320-322. 
Examples of bukara-vowels are (underlined): zağarațat "she ululated", tzagigirit "she ululates", tušurud "she flees", gațarah "drop (noun)", kuburuw "they grew old", tufurukha "you rub it (sg. fem.)".

Examples of the bukara-syndrome inhibiting the elision of a preceding high vowel are: tkassiri isnūn"k. "it (sg. fem.) breaks your teeth", miš gädir iy ğ $b$ "he is not able to bring".

Examples of the 'greater' or 'expanded' bukara-syndrome creating vowels: mitị iw nuṣs "a meter and a half", ğamir issiyyāl "the embers of the acacia tree".

\subsubsection{Influence of 1}

Like $r, I$ may also be involved in inhibiting elision of the short vowel. Examples are (preserved vowels underlined) tākil imn álbahạ "you eat from the sea", yinzil išwayyih "it comes down a little", 'ayyil ișgayyir "a young child", biyhawmil alhamāyil "he brings the animals to be slaughtered (to a wedding party)".

Examples of 'expanded' or 'greater' bukara-vowels preceding $l$ in sandhi (where the vowel is not a cluster-resolving anaptyctic as described in 2.3.2.) are ('greater' bukara-vowels underlined): šuguul iğdūdna "of our fore-

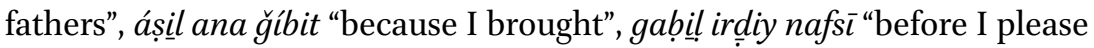
myself", gabịl il 'Utmāniyyinn "before the Ottomans".

2.2.2.2.1. The high vowel preceding $\mathrm{l}$ in *ibil and *rağil

One of the forms for she-camels is bil, and with article álbil (BWA, not recorded in MzA). rağil for "man" was only recorded once in BWA (and

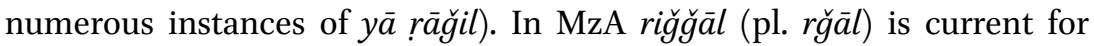
"man".

2.2.2.3. Articulatory delay in the realization of $\mathrm{n}$

The realization of $n$ is often delayed, which leads to an intrusive vowel being realized with an I.P.A. value around [ə], e.g. (here indicated in superscript) fōg ${ }^{\supset} n a$ "above us", ittafag ${ }^{2} n a$ "we agreed", axád ${ }^{2} n i$ " "we took", yib nih "he builds it". An instance in sandhi is in e.g. (vowel underlined) bithuttuh $f i$ ssi in iw bitxudduh "you put it in the goat skin and you churn it".

\subsubsection{Articulatory delay of 'ayn following geminates}

In isolated instances an articulatory delay of 'ayn following a geminate can be heard, e.g. binhutț ${ }^{\circ}$ 'alēh "we put on it". 


\subsection{Anaptyxis}

In terms of rule order, the anaptyxis rule follows the rules for elision and stress.

The rules are:

1.) In the anaptyxis rule speech pause has the same function as a consonant.

2.) Clusters of three or four consonants are usually resolved by inserting an anaptyctic vowel preceding the last two consonants of the cluster. The rule for anaptyxis is:

$\mathrm{I}=$ anapyctic vowel

$$
\varnothing>\mathrm{I} /\left(\mathrm{C}_{\mathrm{a}}\right) \mathrm{C}_{\mathrm{b}-}-\mathrm{C}_{\mathrm{c}} \mathrm{C}_{\mathrm{d}}
$$

The rule holds for word-medial clusters, as well as sandhi clusters.

\subsubsection{Word-medial anaptyxis}

Like in other dialect groups in Sinai, word-medial clusters (in bold print below) resulting from high vowel elision are resolved by inserting an anaptyctic vowel (underlined below) preceding the last two consonants of the cluster, e.g.

$$
\begin{array}{lll}
\text { yurbutt }+u w & >\text { *yurbțww } & >\text { yúrubtuw "they tie" } \\
\text { tudrub }+ \text { uh } & >\text { *tuḍrbuh } & >\text { túdurbuh "she hits him". }
\end{array}
$$

\subsubsection{Anaptyxis in sandhi}

2.3.2.1. Anaptyxis in clusters resulting from 'colliding' morphological base forms

Examples of sandhi clusters of four consonants caused by the collision of morphological base forms, which are resolved by insertion of an anaptyctic preceding the last two consonants: (the first cluster is four consonants, the second is three (both in bold print, anaptyctics are underlined):

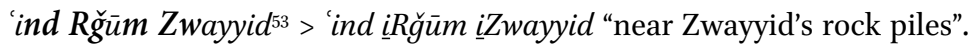

\footnotetext{
53 rǧūm, sg. riğm is a pile of small rocks alongside a path or track to indicate its direction, see Bailey 1991:438 and Holes and Abu Athera 2009:246 (glossary).
} 
Another example of (word-medial) collision of base forms is:

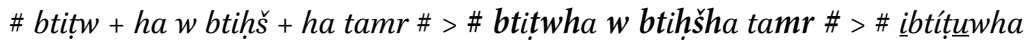
$w$ ibtíhišsha tamir \# "you fold it (sg. fem.) and stuff it (sg. fem.) with dates" (both verb forms are apocopated imperfects).

\subsubsection{Anaptyxis in \#CC and CC\#}

When speech pause directly precedes or follows CC, the resulting cluster \#CC or CC\# is resolved, e.g. (clusters are bold, anaptyctics are underlined):

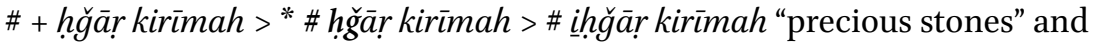
Maṣr + \# > Mașr \# > Mașir \# "Egypt (the mainland), Cairo".

\subsubsection{Consonant clusters resulting from I-elision in sandhi, with} subsequent anaptyxis

Some examples of clusters in sandhi after I-elision, eliminated by anaptyxis (intermediate forms with clusters are marked with *):

(base forms, high vowel eligible for elision underlined) w btilhig iddagig $w$ bta'ağnuh > (after elision of high vowel, clusters in bold print)

* $w$ btilhg iddagìg $w$ bta'ağnuh > (after stress and anaptyxis, anaptyctics underlined: surface forms) w íbtílihg iddagig w íbtáa ğnuh "and you take the dough and knead it".

Another example is:

(base forms, high vowel eligible for elision underlined)

yimsîk alfanāğül >

(after elision of high vowel, cluster in bold print)

* yimsk alfanāăg̈l >

(after stress and anaptyxis, anaptyctic underlined: surface forms) yímisk alfanāğ

2.3.2.4. Resyllabication of word-medial CVCCICV, and of CVCCIC VC sequences in sandhi

The resyllabication of a word-medial sequence CVCCICV > CVCICCV (e.g. yikitbuw) is compulsary, while resyllabication of a sandhi sequence CVCCIC VC > CVCICC VC (e.g. yimisk alfanāğ

\subsubsection{Exceptions to the anaptyxis rule}

\subsubsection{Unresolved consonant clusters}

Like in group I, not all clusters are eliminated. Especially clusters of which the first consonant is a semi-vowel, a nasal or a liquid followed by a voice- 
less second consonant, ${ }^{44}$ e.g.: ilhalb hāda "this milking", alGlā iyyih "location where water from šarafat ilGā' flows into Wādiy Fēṛān", 'amaltha "I did it (sg. fem.)", álgrab "the water skins", tušǵúlk \#55 "it (sg. fem.) occupies you", tanshi' "forget her!", fihimt lay kēh? "do you understand what I mean?" and (with semi vowels) mīyt kïluh "a hundred kilometres", ištaraytha "I bought it (sg. fem.)". But in some cases, also when the second consonant is voiced, the cluster is left intact, as in ǧildha "her skin" (where $d$ is homorganic with $l$ ) and yinzluw "they go down".

Examples of other sandhi clusters left intact are: int 'ärif "you know", yā bint! \# "hey, girl!" and 'ind Biniy Wāṣil "with the Baniy Wāṣil" (see 2.3.3.3.2.) and gult lèhuw "I said to them".

When assimilation between the first and second consonant takes place, the cluster will remain intact as well, e.g. (axadtha >) axattha "I took it (sg. fem.)".

2.3.3.2. The role of sonority of consonants involved in unresolved clusters See remarks in De Jong 2000:125-126.

\subsubsection{Some special cases with regard to anaptyxis}

\subsection{Consonant clusters with initial geminates}

When the first two consonants of a three-consonant cluster form a geminate, this geminate is usually (partially) reduced, e.g. (word-medial) biddna "we want, need", nmiddhin "we stretch them (fem.) out", thutțha "you place it (fem.)" ithammṣ ilbunn "you roast the coffeebeans", tğammr išwayyih "it (sg. fem.) becomes glowing embers a little". Sandhi examples are: nxušš $f i$ "we

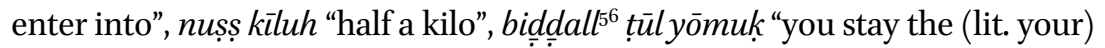
whole day", sinn \# "tooth" and hatț \# "he placed", nšidd \# "we pull tight".

When a cluster contains a geminate and two other consonants, it is resolved, e.g. bass igrūš "but sharks", țābb iNwēbi "going to (sg. masc.) Nwēbi", sitt išhūr "six months".

\subsection{Preposition ind $+C$}

The suffixed preposition 'ind takes vowel-initial allomorphs of the pronominal suffixes, e.g. 'indaha "with her", induk "with you (sg. masc.)", "indik "with you (sg. fem.)", 'induhuw "with them (pl. masc.)", 'indihin "with them (pl. fem.)", 'indukuw "with you (pl. masc.)", 'indikin "with you (pl. fem.)" and "indina "with us".

\footnotetext{
54 For similar phonetic conditioning, see De Jong 2000:123-128.

55 Velarization spread through the whole word, colouring the vowels $i$ (of measure 4, as in yišgil) to $u$.

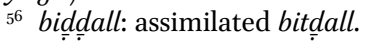


Clusters in sandhi are left unresolved, e.g. (underlined): 'ind Biniy Wāṣil "with the Baniy Wāșil", la 'ind șulbuk "(submerged in water) up to your waist", 'ind ǧidditī rḥa "my grandmother has a hand mill".

2.3.3.3.3. The 2nd p. sg. masc. and fem. pronominal suffixes in consonant clusters

Like in group II of the north (the dialects of Samā'nah and 'Agāylah), the pronominal suffixes of the 2nd p. sg. masc. and fem. $-k$ and $-k$ (resp.), are vowelless when preceded by one consonant. This may be concluded from stress assignment, but it is difficult to decide whether an anptyctic is present or not; especially with a voiceless consonant preceding and a vowel following $k$ (in sandhi), there may be a vowelless anaptyctic, or none at all, as in e.g. illiy yațla min dimmitk i itnī yyāh "whatever comes out of your goodness, give it to me". Other examples are: hurmít u $^{u}$ "your wife", awșúf ${ }^{u}$ \# \# "I'll describe to you". nāgít"k "your (sg. masc.) she-camel",

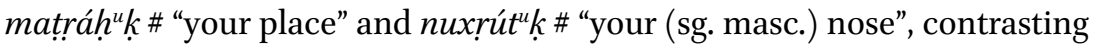
with nuxrít'k \# "your (sg. fem.) nose".

When assimilation takes place, an anaptyctic is absent, e.g. sarákk $(<s a r a ́ g+k)$ "he robbed you".

When more than one consonant directly precede, the personal pronominal suffixes take allomorphs $-u k$ (for sg. masc.) and -ik (for sg. fem.) e.g. xalluk gāid "remain seated", 'induk "with you", șadruk "your chest", nafsuk "yourself", 'umruk "your age" and (doubling of $n$ in he preposition min) minnuk "from you". The latter example is actually a strong indication that we are dealing with a vowel-initial allomorph; $n$ of the preposition min is only doubled in such cases (i.e. the suffixed form is not ${ }^{*} \min k$ or ${ }^{*} \min ^{u} k$ ).

\subsubsection{Phonetic quality of the anaptyctic}

\subsubsection{Phonetic quality of word-medial anaptyctics}

The phonetic quality of the word-medial anaptyctic vowel is a lax and centralized [1], towards [ə], in front environments and a lax and centralized $[\mathrm{v}]$, towards a moderately rounded [ə], in back environments. ${ }^{57}$

2.3.4.1.1. Phonetic quality of word-medial anaptyxis in clusters form "colliding" base forms

Examples of the phonetic quality of word-medial anaptyxis in clusters form "colliding" base forms are:

57 This is the same as what was described for group I in De Jong 2000:128. 
irm + ha $>$ *irmha $>$ írimha "throw it (sg. fem.)"

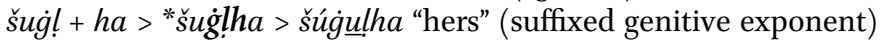

\subsection{Phonetic quality of anaptyctics in clusters after I-elision}

The phonetic quality of the anaptyctic resolving a cluster resulting from high vowel elision is the same as (or near to) that of the vowel from whose elision the cluster resulted (anaptyctic vowels underlined).

Example with $i$ :

$$
\begin{array}{ccc}
\text { base form elision } & \text { anaptyxis } \\
\text { yisrig }+u w & >^{*} \text { yisriguw } & >^{*} \text { yisrguw }>\text { yísirguw "they steal" }
\end{array}
$$

Example with $u$ :

$$
\text { tuktul+uw >*tuktuluw >*tuktluw >túkutluw "you (pl. masc.) hit" }
$$

2.3.4.1.3. Anaptyctics in clusters resulting from elision of $\mathrm{i}$ from $T$

Anaptyctics eliminating clusters resulting from high vowel elision from -it (the fem. morpheme in construct state) are phonetically conditioned by the phonetic value of surrounding consonants: $i$ in neutral environments and $u$ in velarized environments (anaptyctic vowels are underlined) (examples of $i$ ): xíligtuh "his ugly mug", 'ilibtuh "his packet" and (examples of $u$ ) húrumtuh "his wife" and šug $\underline{u}$ ltt "mine (suffixed genitive exponent)".

\subsubsection{Phonetic quality of anaptyctics in sandhi}

\subsection{Phonetic quality of word-initial anaptyctics in sandhi}

Word-initial anaptyctics tend to have a phonetic value of around a lax and centralized [1].

Examples of word-initial anaptyctics (underlined): \# ítkūn írfayy'ih "it (sg. fem.) will be thin", zilìt iṣgayyir "a young goat or gazelle", \# iymūṣ íšwayyih "it becomes a little soft/moist", ahád ịmn ịş̧ābuk \# "one of your friends".

Imperatives of the verbs axád "take" and akál "eat" are kul, \# uḳlíy, \#

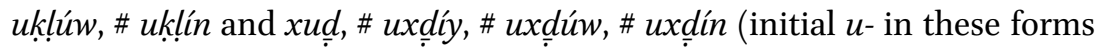
is an anaptyctic resolving a cluster \# CC).

\subsection{Phonetic quality of word-final anaptyctics}

Anaptyctics resolving word-final clusters have a phonetic quality near I.P.A. [v] in labial and/or velarized environments.

Examples are: baduw \# "Bedouin", hiluw \# "sweet, beautiful", daluw \# "pail”, šugu \# "of (genitive exponent)", țhur \# "circumcision”, ḥumur "red (pl. com.)”, zurug "black (pl. com.; lit. "blue”)", iduk \# “your (sg. masc.) 
hand", bētuk \# "your (sg. masc.) house", min gabul \# ( min gabil \#) "before (adv.)", ğamur \# ( ğamir \#) "live embers", rubu \# ( rubi \#) "quarter".

Anaptyctics in neutral environments will be near (centralized) [1], e.g. și ib \# "difficult", mitir \# "metre", giriš \# "shark", Șadir \# "Ṛās Șadr", wagit \# "time", xašim \# "long nose".

\subsubsection{Stressed original anaptyctics}

Instances of stressed original anaptyctics - like those found in intitial positions in other dialects such as írkab or árḳab "knees", íhna "here" etc. ${ }^{8}$ - were not recorded in MzA and BWA..$^{9}$

In BWA stress in the preposition / with a consonant-initial suffix will be on the vowel of the suffix, e.g.; \# ilhá or \# ilhi" "to her", \# ilkúw "to you (pl. masc.)", \# ilkín "to you (pl. fem.)", etc. Forms in MzA are lēha or lēhi', lēḳuw and lèkin.

In MzA and BWA the preposition $m(i)^{c}$ followed by a vowel-initial suffix will be stressed on the vowel of that suffix, e.g. m'úh, m'úk, m'ík and also $m i$ (contrast with forms in some dialects of group VII of the type im'uh, where the original anaptyctic is stressed). However, forms of the type ma'áh, ma'úk and ma'ík ( ma'kiy) were also recorded in BWA (through direct elicitation).

\subsection{Elision of Short Vowels}

High short vowels $i$ and $u$ are dropped in open syllables. Short $a$ in comparable positions is not dropped (with an exception, see below), which makes BWA and MzA 'différentiels' in Cantineau's terminology. ${ }^{60}$ The high-vowel elision rule comes before the stress rule in terms of rule ordering. The rule is:

$$
\begin{aligned}
& \mathrm{I}>\varnothing /(\mathrm{V}) \mathrm{C}_{\mathrm{a}}\left(\mathrm{C}_{\mathrm{b}}\right)_{-} \mathrm{C}_{\mathrm{c}} \mathrm{V} \\
& \mathrm{I}=\text { short high vowel } i \text { or } u \\
& \mathrm{C}=\text { any consonant }
\end{aligned}
$$

The morphophonemic elision rules are compulsary.

\footnotetext{
${ }^{8}$ Such forms are, for instance, found in groups II and III of the north (see De Jong 2000:270-271 and 355, and in group VII in the south (see Chapter I, 1.1.6.).

59 The regular reflex for the pl. pattern ${ }^{*} \mathrm{CICaC}$ in MzA and BWA is CCaC. Examples are: gmam "Morray eels", rkab "knees" (MzA), etc, cf. 3.1.9.2.

6o See Cantineau 1936:49.
} 


\subsubsection{Morphophonemic I-elision}

The rule for elision of unstressed I in open syllable preceded by only one consonant:

$$
\mathrm{I}>\varnothing / \mathrm{VC}_{\mathrm{a}}-\mathrm{C}_{\mathrm{b}} \mathrm{V}
$$

Examples are (high vowel eligible for elision in bold print): nizil $+u w>$ *niziluw > nizluw "they descended", simi + at > "simiat > sim'at "she heard", kubur + at > *kuburat > kubrat "she grew older", tāxid + in > *tāxidin > tāxdin "you (pl. fem.) take", mištigil (= underlying $\mid$ mištağil $\mid)+$ ah > *mištagilih > mištáglih "working (sg. fem.)" and taharit + uw > *taharituw > táhartuw "you (pl. masc.) plough".

The rule for elision of unstressed I in open syllable preceded by two consonants is:

$$
\mathrm{I}>\varnothing / \mathrm{VC}_{\mathrm{a}} \mathrm{C}_{\mathrm{b}}-\mathrm{C}_{\mathrm{c}} \mathrm{V}
$$

Examples of immediate elimination of a cluster resulting from high vowel elision: tufruš $+i y>$ *tufrušiy > túfuršiy "you (sg. fem.) spread out", yiktib + in > *yiktibin > yikitbin "they (pl. fem.) write".

When an unstressed high vowel follows a geminate, it is dropped and the geminate is reduced. The rule is:

$$
\mathrm{VC}_{\mathrm{a}} \mathrm{C}_{\mathrm{a}}=\text { geminate }
$$

$$
\mathrm{I}>\varnothing / \mathrm{VC}_{\mathrm{a}} \mathrm{C}_{\mathrm{a}}-\mathrm{C}_{\mathrm{b}} \mathrm{V}
$$

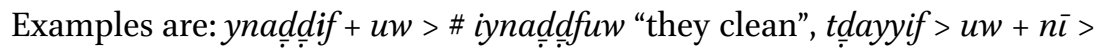

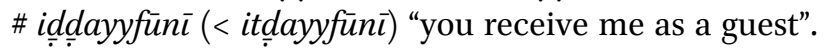

\subsubsection{I-elision in sandhi}

I-elision in sandhi may take place like morphophonemic elisions described above, but such sandhi-elisions are optional, examples are (high vowels eligible for elision are in bold print): btílhig iddagig > btillhg iddagìg > \# ibtilihg iddagig "you take the dough", byimsik issi'n > byimsk issi' $n$ > \# ibyimisk issi in \# "he takes the goatskin (used for churning butter)".

\subsubsection{Cyclic anaptyxis rule in sandhi}

The optional I-elision rule in sandhi may be applied after the execution of the anaptyxis rule, e.g. (the cluster is underlined and in bold print, the anaptyctics are in bold print and the high vowel eligible for sandhi-elision is underlined): 
1) twakkil + 'yälk $>$ twakkil $y a \bar{a} l k>t w a k k i l$ i $y a ̈ l k>$ (including word-initial and word-final anaptyxis) \# itwakkl i yāluk \# "you feed your children".

In this first example the cluster $l y$ is resolved, after which the high vowel preceding it lands in open syllable (thus becoming eligible for elision) and is dropped.

The rule for anaptyxis may also be re-applied after execution of the rule for anaptyxis, ${ }^{61}$ as in the example:

2) nílbis + ğlüdni' > nílbis ğglūdni > nilbis i iğlūdni > nílbs iğlūdni > nílibs iğlūdni' "we put on our diving suits (lit. our skins)".

In this second example the cluster sggl is resolved, after which the high vowel preceding it lands in open syllable (thus becoming eligible for elision) and is dropped, creating a new cluster $l b s$, which is then eliminated by insertion of another anaptyctic vowel.

\subsubsection{Exceptions to the I-elision rule}

When $\mathrm{C}_{\mathrm{a}}$ and $\mathrm{C}_{\mathrm{b}}$ in $\mathrm{C}_{\mathrm{a}} \mathrm{C}_{\mathrm{a}} \mathrm{IC}_{\mathrm{b}}$ are phonetically close or identical, I (underlined in the examples below) is not dropped, and the geminate may be reduced. Examples are: ǧidditī "my grandmother", thálliluh "you analyze it (sg. masc.)".

\subsection{Assimilation}

Three types of contact assimilations can be identified: regressive (partial or total), progressive (partial or total) and reciprocal (total) assimilation (instances of contact assimilation involving the spread of velarization are treated in 1.1.7.).

Apart from contact assimilations of $l$ of the article $i l$ - or $a l$ - to 'sunletters', $l$ is also sometimes - this is by no means regular-assimilated to following ğ or $k$, as in iğğibneh "the cheese". alxayt b áğğ lab "the line with the hooks (used for fishing)" and also ikkis "the bag".

${ }^{61}$ The example in De Jong 2000:134-135 only illustrates the application of the I-elision rule after the execution of the anaptyxis rule (like the first example here). The second example here clearly illustrates re-application and cyclicity of the I-elision rule. 
Instances of regressive total assimilation are:

$\begin{array}{lll}n+r & >r r & \text { birraǧğid "we pile" } \\ t+\check{s} & >t \check{s} & \text { ššlliy "you carry" } \\ t+z & >z z & \text { zzìd "it (sg. fem.) increases" } \\ t+d & >d d & \text { ddīr "you turn (fem.)" } \\ d+t & >t t & \text { axatt "I took" } \\ t+\check{s} & >\check{s} \check{s} & \text { šsidd "you pull" }\end{array}$

Instances of regressive partial assimilation are:

\begin{tabular}{|c|c|c|}
\hline$t+z$ & $>d z$ & $d z \bar{\imath} d$ "it (sg. fem.) increases" \\
\hline$t+\check{g}$ & $>d \check{g}$ & dğīb "you bring" \\
\hline$b+n$ & $>m n$ & mnadbahuh "we slaughter him" \\
\hline+ & $>\eta g$ & maygad "fireplace" \\
\hline
\end{tabular}

progressive total:

Initial $h$ - of pronominal suffixes often totally assimilates to preceding voiceless consonants, e.g.

$$
\begin{aligned}
& \text { aǵlabiyyit }+ \text { hin } \quad>\text { a } \\
& \text { ğimā at + huw > ǧimā áttuw "their group of people" } \\
& \text { tuṭux }+ \text { ha > tuṭbúxxa "you cook it (sg. fem.)" } \\
& \text { naftah + ha > naftáḥha "we open it (sg. fem.)" }
\end{aligned}
$$

Other instances of progressive total assimilation are:

$$
\text { zagrat + tiy > zagrátțiy “you (sg. fem.) ululated" }
$$

Instances of reciprocal total assimilations are:

$$
\begin{array}{ll}
\text { baraǧği }+ \text { ha } & >\text { barağíhhe "I return it (sg. fem.)" } \\
\text { mablag }+ \text { hin } & >\text { mibláxxin "their (fem.) price" }
\end{array}
$$

In a number of instances the mutual influence of hissing sounds has resulted in a metathesis. An example in both dialects is siğih (or sižih)

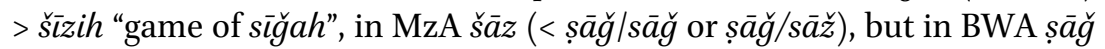
"iron baking sheet". Additional examples in MzA are šizn (< siğn or sižn) "prison", mšazzil (> saǧğil or sažžil) "recorder" and našz (> nasğ or naš̌) "weaving", but in BWA siğn and tasğı̆l "recording".

Another example of the mutual influence of hissing sounds is MzA is šamš (> šams) "sun", but BWA šams, and in both dialects šağar "trees" is current. 


\section{MoRPhOLOGY}

\subsection{Nominal Morphology}

\subsubsection{Raising of a}

3.1.1.1. Raising of a in $C_{1} a C_{2} i C_{3}(a h)$

Raising of $a$ in the nominal pattern $\mathrm{C}_{1} \mathrm{aC}_{2} \mathrm{IC}_{3}(\mathrm{ah})$ occurs regularly, but is optional. Such raising is not inhibited by phonetic factors.

Examples are: šidìd "intense, strong", kițīr "many, much", kibïr "large, old", gilì "fat, thick", 'ifı́g, 'irìs "groom", xifíf "light". But also forms without raising have been recorded: katīir, kabìr, 'afı̈g, xafîf, etc.

\subsubsection{Raising of a in open syllable preceding stressed í}

For instances of raising of $a$ in the $i$-type perfect (with underlying pattern $\mathrm{CaCiC}$ ) of verbs, see 3.2.1.1. below.

\subsubsection{Raising of a in $\mathrm{CaCCiC}(-a h)$}

Raising of $a$ in $\mathrm{CaCC} \overline{\mathrm{i}} \mathrm{C}(-\mathrm{ah})$ was not recorded, e.g. batțix "water melon", xamsin "fifty", sab'in "seventy" and a verbal noun tağlīb "throwing out (of a fishing line)".

\subsubsection{Raising of a in $\mathrm{CaCC} \overline{\mathrm{C}} \mathrm{C}$}

Raising of a in $\mathrm{CaCC} \overline{\mathrm{C}}(+)$ is regular. Examples are: riğǧāl "man", șiyyād "fisherman", siyyāl $l^{62}$ "acacia tree", kiššā $f$ "search light", bitțāriyyih "flashlight", zirgā "blue (sg. fem.)", șif̣ā "yellow (sg. fem.)", himrā "red (sg. fem.)", gir 'a "bald (sg. fem.)", mirrrāt "times", mi nàt (hāàgih) "the meaning (of sth)", Wādiy Wirdān "Wadi Wardān".

3.1.1.5. Raising of a in ...CaCāC...

When not followed by $l$ or $r$ and not preceded by', unstressed $a$ preceding $\bar{a}$ may be raised to $i$ or $u$. Examples are: ( $i$ in) gizāyiz "bottles", mišāyix "sheikhs", digāyig "minutes", dināgìy "small boats" (BWA), gibāyil "tribes", tikātrih "doctors" and (u in) Șuwālḥih "name of tribe Șawālhah", buwāṣiy

\footnotetext{
${ }^{62}$ sayyāl is likely to be a folk etymology for sayāl. The connotation must be with 'a tree growing by a sēl ("flood, watercourse")'.

${ }_{63}$ The sg. dingiy is a loan from English dingy, which must have come through one of the Egyptian dialects where the reflex for * ğ is $g$ and where the English [dz] was replaced by [g]. Compare this to an opposite development of $g$ in Egyptian ginēh (a loan from English guinea), where [g] was replaced by [dz] by speakers of ǧim-speaking dialects, who pronounce $\breve{g}(i) n \bar{e} h$. Other such examples are siggärah "cigarette" and grām "gram", which became sĭğạrah and ğrām in many ğìm-speaking dialects (though in MzA sigārah is current).
} 
"a type of fish (pl. form)", min muwālīd Daháb "born in Dahab" and also (as an exception) durāhim "money" (but see remark below) and verb forms nisāh "he forgot him" and ligāh "he found him".

Such raising is however optional, since there are also many instances in which it is absent, e.g. masākinhuw "their dwellings", 'Azāzmih "name of a tribe (living partly in Sinai and partly in the Negev)", Hamā a tribe", zamān "in the past", gabāyil "tribes" and also verb forms ytawāğad "it (sg. masc.) exists" and yta álağ "he receives medical treatment".

When $a$ is followed by $l$ or $r$ or preceded by ' or X, this type of raising is much less regular, e.g.: talätih "three", Tarāāin "name of a tribe", wara $\bar{a}^{u} k$ "behind you", marākib "boats" and (with 'preceding) 'asāsāthuw "their origins". 'ažānib "foreigners", 'așābi "fingers" and 'aḍ̂âfirk "your (sg. fem.) nails". Examples in which X precedes $a$ are: 'ašàn "because", hawāliy "about, approximately", harārah "heat", xalāṣ "that's it!", ġazāl "gazelle" and hawä $\bar{a}^{u}$ "your desire".

3.1.1.6. Raising of a in ...CaCá...

$a$ in open syllable preceding stressed $a$ is often-but only optionally soraised to I in neutral environments, ${ }^{64}$ e.g.: sináh "year", šiǧár "trees", libán "milk", ǧimál "camel”, fiḍa "free time", Diháb "name of the town Dahab", a gahawah-form šihár "month" and verb forms ligát "she found", kitáb "he wrote".

Raising towards [u] is heard in the examples: $m \bar{a}$ m'uk duwá "medicine", wurág "paper" (though more regularly warág).

Such raising is (usually) absent when 'or X precedes, e.g.: (')ahád "anyone" and verb forms (')akál "he ate" and (')axád "he took" and (with X preceding) hațáb "firewood", ganám "small cattle", 'adád "number", 'arág "sweat" and xalág "He created", but also gitás "he dived" and mā miuk xubár "you have no clue/idea".

\subsubsection{Raising of a in open syllable preceding stressed $A$}

Both types of a-raising described in 3.1.1.5. and 3.1.1.6. can be combined in one rule (see also De Jong 2000:147):

$$
\begin{array}{lll}
\mathrm{C}_{\mathrm{a}} \neq * \text { or } \mathrm{X} & \mathrm{a}>\mathrm{I} / \mathrm{C}_{\mathrm{a}-\mathrm{C}_{\mathrm{b}} \mathrm{A}} \\
\mathrm{C}_{\mathrm{b}} \neq l . & \mathrm{A}=\text { stressed } a \text { or } \bar{a} \\
\mathrm{I}=\text { high short vowel } i \text { or } u
\end{array}
$$

\footnotetext{
${ }^{64}$ See the rule in De Jong 2000:145 is: $\mathrm{a}>\mathrm{I} / \mathrm{C}_{\mathrm{a}}-\mathrm{C}_{\mathrm{b}} a$, where $C_{\mathrm{a}} \neq{ }^{*}$ or $\mathrm{X}$ and $\mathrm{C}_{\mathrm{b}} \neq l$.
} 
And like in group I, stress of A does not have to be primary for such raising to take place. Instances where stress on A is secondary are, e.g.: ğibābil "mountains", min muwālìd Diháb "born in Dahab", mikānī "my place" and ánwikal "it was eaten", háwğisat "she improvised song", ánnixal "the palmtrees" and also in forms with final raised reflexes of $-\bar{a}\left({ }^{\prime}\right)$, such as áddiwi "the medicine" and ássimi "the sky".

\subsubsection{Raising of a in $\mathrm{CaCu} C(a h)$}

Like in the pattern $\mathrm{CaCi}^{-1}(\mathrm{ah}), a$ is often raised to I in the pattern $\mathrm{CaCu} \mathrm{C}(\mathrm{ah})$, but instances of absence of such raising were also recorded. Examples are lugūnih "a child with keen intelligence", ${ }^{6}$ yuhüd "Jews", Su'üdiyyih Sa'ūdiyyih "Saudi Arabia", gu'ūd "young male camel", ġumūs "food dip", xurūf "lamb", but also ğanūb "south", 'ağüz "old woman", 'arūs 'urūs "bridegroom", ša ūr šu úur "emperor (fish species)" and also hakūmah "government". 66

Also when (') precedes, such raising often takes place: (')ubüy "my father", (')uxūh "his brother" and also in verb forms (')ugüm "I get up, (')ušüf"I see"..$^{67}$

\subsubsection{Raising of $\mathrm{a}$ in open syllable preceding stressed $\mathrm{u}$}

Like raising of $a$ in open syllable preceding stressed $i, a$ in similar positions preceding stressed $u$ is also raised, e.g.: kubúr "he grew", gulúd "he grew fat".

3.1.1.10. a-raising rules combined

If we combine the different possibilities of raising in one rule, this rule is:

$$
\begin{aligned}
& \mathrm{a}>\mathrm{I} / \mathrm{C} \_\mathrm{CI}(\mathrm{C}) \\
& \mathrm{I}=\operatorname{short~high~vowel~} u \text { if } \mathrm{I}=\dot{u} \text { or } \bar{u}, i \text { if } \hat{\mathrm{I}}=\boldsymbol{i} \text { or } \bar{\imath} \\
& \mathrm{C}=\text { any consonant }
\end{aligned}
$$

Notice that the rule is more general than the (second) one formulated in De Jong 2000:15o, since we do not need to make a provision here for the first $\mathrm{C}$ not being hamzah.

\footnotetext{
${ }^{65}$ The word was used in reference to a child, who is recognized at an early age to have a keen intelligence, and is therefore raised to become a häwiy "snake charmer". It is related to the root $l-q-n$ "learn; have keen intelligence" and must mean "endowed with intelligence" and/or "(to be) taught through instruction".

${ }^{66}$ See also fn 18, Chapter Two in De Jong 2000:149.

${ }^{67}$ Such raising following' is not current in group I (see De Jong 2000:147-149).
} 


\subsubsection{Reflexes of ${ }^{*} \mathrm{CaC}_{1} \mathrm{C}_{3}(a h)$}

Examples of reflexes of ${ }^{*} \mathrm{C}_{1} \mathrm{aC}_{2} \mathrm{C}_{3}(\mathrm{ah})$ are: $b a d w$ "Bedouin (pl.)", ğady (BWA) "kid goat", tahát tihát "under", fahám "coal", šikl "shape", șahán șihán "dish", kalb "dog".

Also: wiğh "face", wiḥdih "one (fem.)", nahyih "direction", și b șa b (the latter perhaps a K-form; notice the absence of a gahawah-vowel), șadr "chest", wakl "food" and ǧidd "grandfather".

\subsubsection{Reflexes of ${ }^{*} \mathrm{CaCiC}(a h)$}

Examples of reflexes of * $\mathrm{CaCiC}(\mathrm{ah})$ are: kilmih "word", širkih "company", kitf "shoulder".

\subsubsection{Reflexes of $\mathrm{C}_{1} u \mathrm{C}_{2} \mathrm{C}_{3}(a h)$}

Examples of reflexes of ${ }^{*} \mathrm{C}_{1} \mathrm{uC}_{2} \mathrm{C}_{3}(\mathrm{ah})$ are: bunn "coffee beans", rizz ( ruzz in MzA) "rice", kull "all; every", aṃm "mother" ( uṃm in BWA), uxt "sister". Also: Ğim ih "male given name", sinnih "usage" (BWA), middih "period", hinnih "they (pl. fem.)", zibdih "butter".

Forms with sufficient backing show $u$, as in šuggah "fishing net" (MzA), xutwah "step", nugțah "police checkpoint", gumsih "food dip", rukbah "knee" (BWA) (but rikbih (MzA)), hurmah "woman".

\subsubsection{Absence of I in open syllables preceding stress}

Like in all dialects of Sinai, a high vowel $i$ or $u$ in open initial syllables of the type $\mathrm{CIC}(\mathrm{V})$ preceding stress (on V) is dropped, resulting in initial CC clusters. Examples are: ǧlūd "skins", 'yūn̄̄ "my eyes", xšěšāt "little huts", Hmēed "male given name", byèt ša ár "little tent", blād "land", ǧbāl "mountains", snìn "years", glayyil "little; few", g!̣̆l "few (pl.)" and štiy "winter". Examples with stressed short vowels are: gmam "Morray eels", rkab "knees" (MzA).

Exceptions to such elisions are (loans from MSA) šu'ūn iğtimāiyyih "social affairs", nizām "system". ${ }^{6}$ Another exception is șayd furūsiyyih "hunting on horseback" (in BWA), where the influence of $r$ may have prevented elision of $u$ in furūsiyyih (if it is not a loan from MSA altogether). For other 'surface' forms with initial sequences of the type CiCā... or

\footnotetext{
${ }^{68}$ Notice also $z$ here instead of more regularly expected emphatic interdental $\underline{d}$.
} 
CuCā..., $\mathrm{CiCi}_{1} \ldots$ or $\mathrm{CuCī} \ldots$ and $\mathrm{CuCū \ldots or} \mathrm{CiCu} \ldots$ see 3.1.1.7.-3.1.1.10. above.

Also in verb forms a short high vowel in open unstressed syllable is not found, e.g. ygūl "he says", tšll "you carry", tnām "you sleep", nhuuțt "we place", tšiddiy "you (sg. fem.) pull tight", ygōtruw "they go". Notice, however, that in the verb "come" the vowel of the first syllable is not dropped, e.g. tiğı́y "you come”, yiğı́y "he comes" (contrast with forms tğiy and y̌ğiy heard in group I). ${ }^{69}$

\subsubsection{Diminutive patterns}

A number of diminutive forms were recorded in MzA and BWA. Apart from the usual forms such as glayyil "few", gsayyir "short", rfayyi "thin", șgayyir "small; young", kwayyis "good" and šwayyih "a bit", etc., other recorded examples are: sraybih "small group (of people)", byēt ša ár "little tent", xšěšāt "little huts", bnayyih "little girl", wlèd "little boy" and also a very regular (i.e. in Sinai) hrayyim "women".

The hypochoristic - $\bar{a} n$ suffix, which was recorded in some of the dialects of group I (especially dialects in the east like AhA), was not heard in MzA or BWA.

\subsubsection{Pattern $a C_{1} C_{2} a C_{3}$}

The pattern used for colours and physical (and sometimes mental) defects is $\mathrm{aC}_{1} \mathrm{C}_{2} \mathrm{aC}_{3}$ and $\mathrm{aC}_{1} \mathrm{aC}_{2} \mathrm{aC}_{3}$ (stressed on the first syllable) where $\mathrm{C}_{1}=\mathrm{X}$. Examples are: abyad "white", azrag (euphemistically; the word aswad is avoided) "black; dark coloured", ašhab "light coloured, pale" (and with $\mathrm{C}_{1}=\mathrm{X}$ ) áhamar "red", áxạ̣ar "green", áhawal "cross-eyed", áhabal "stupid", áama "blind" and áxaraṣ "mute", á arağ "limping".

The sg. fem. forms have a CaCCā pattern, with a final $-\bar{a}$ that has remained long and which is often in pause followed by an unreleased glottal stop, e.g. be $\underline{d} \bar{a} \bar{a}^{\prime}, h a m r \vec{a}$. There is an added $a$ following $\mathrm{C}_{2}$ when it is $\mathrm{X}$ and final $\bar{a}$ is raised (to - $-y)$ when $\mathrm{C}_{3}$ is neutral, e.g. 'arǧ́y and šahabíy.

Most pl. com. forms have a $\mathrm{C}_{1} \mathrm{uC}_{2}^{3} \mathrm{C}_{3}$ pattern, e.g. zurg, sumr, $x u \underline{d} \dot{d}$, humr and $h u b l$, but some forms that lack velarization were recorded with a $\mathrm{C}_{1} \mathrm{iC}_{2} \mathrm{C}_{3}$ pattern, e.g. 'irğ, šị̣b. Plural forms for "black" and "white" are sūd $\left(\mathrm{C}_{2}=w \bar{a} w\right)$ and $b \bar{c} \underline{d}\left(\mathrm{C}_{2}=y \bar{a}\right)$.

\footnotetext{
${ }^{69}$ See De Jong 2000:203-204.
} 
3.1.8. The elative patterns $a C_{1} C_{2} a C_{3} a C_{1} a C_{2} C_{3}$ and $a C_{1} C_{2} a$

The elative pattern is $\mathrm{aC}_{1} \mathrm{C}_{2} \mathrm{aC}_{3}$, e.g. aktar "more/most", akbar "bigger/biggest; older/oldest", ashal "easier/easiest", aṣ 'ab "more difficult/most difficult".

In MzA forms ahla "sweeter/sweetest; better/best" and ahsan "better/ best" were recorded several times without a gahawah-vowel (similarly ag̣labiyyih "majority"), but a gahawah-vowel was heard in axațar "more dangerous/most dangerous" (though also axtar). agalad "thicker" and also ahala in BWA.

Elatives of geminate roots have a pattern $\mathrm{aC}_{1} \mathrm{aC}_{2} \mathrm{C}_{3}$ (where $\mathrm{C}_{2}=\mathrm{C}_{3}$ ), e.g. aga!! "less/least" and ahamm "more important/most important".

\subsubsection{Initial a}

\subsubsection{The article and the relative pronoun}

The article may be $a l$ - or il-; al-is mainly used when the following nominal has $\mathrm{Ca}$ as its initial sequence, but this is in no way regularly so. When the article is stressed, however, the article tends to be ál- when (underlying) $\mathrm{Ca}$ or $\mathrm{CCaC}$ follows, and il- when other sequences follow. Examples with (underlying) Ca following are: álbahar "the sea", álğimal "the camel", áddiwi "the medicine", ássimi" "the sky", áșṣahan "the plate", but (when preceding sequences other than Ca) ilihșiy "the rocks" and ilif ' $i$ " the viper", iššti "the winter", but isșibiy "the boy" (underlying form is |ṣabiy|). With CCaC following: árrkab "the knees", ánnxar "the noses", áll'af "the bait (pl.)", áššnat "the suitcases".

When $\bar{\imath}$ or $i y$ precedes the article $a l$-, it is dropped, as in, e.g.f-ațiür "in aț-Ṭū" and f-awwalha w hatta f-āxirha "in its (sg. fem.) beginning and even in its (sg. fem.) end".

In some cases in BWA the possessive suffix $-\bar{\imath}$ was not dropped against initial $a$ - of a following verb, but an intrusive (voiced?) $h$ was inserted instead, e.g. widd $\bar{\imath}$ - $h$-aṣalliy "I want / am going to pray", widdī-h-anām "I want to (go to) sleep". This not only occurred with following initial $a$-, but also in directly elicited instances like widdī-h-udrub "I want to hit", widdī-

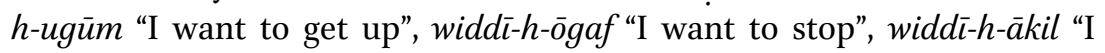
want to eat" and also with initial $i$-following, as in widdi-h-ǐšll "I want to carry".

The relative pronoun is illiy, e.g. illiy 'āyiz luh kìlu, $w$ illiy 'āyiz luh nuṣs kilu "(there are) those who want a kilo and others who want half a kilo".

'Specifying' ha- was heard used only in adverbial halhìn (often halhinit in MzA) "now". 


\subsubsection{Other instances of initial a}

Another instance of initial $a$ is amm "mother" (in MzA, in BWA uṃm ), "we" is ihna, "sister" is uxt.

Like in group I, plural forms reflecting older * $\mathrm{CICaC}$ have a $\mathrm{CCaC}$ pattern, e.g. gmam "Morray eels", rkab "knees" (MzA), rxaṣ "licences", 'nab "grapes" (BWA), hgan "injections", šnaț "suitcases", l'af "bait (pl.)”, although the pl. for (')ibrih is (')abár "needles".

\subsubsection{The feminine morpheme $(T)$ in genitive construction}

\subsubsection{T in genitive construction preceded by a in open syllable}

The feminine morpheme - $a h \sim-i h$ in construct state becomes -at when aC directly precedes. Examples of aCT + suffix: máratuh "his wife", sánatuh

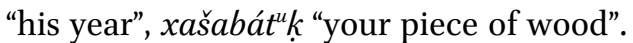

In the case of $\mathrm{CaCaCT}+\mathrm{v}(\mathrm{C})$ sequences in $\mathrm{MzA}$, a special provision needs to be made for $a$-elision in the rule for short vowel elision, which in terms of rule ordering precedes the rule for $\mathrm{T}$. This should explain why $\mathrm{T}$ becomes -it in such cases: since $a$ has been dropped from CaCaCTv (resulting in CaCCTv), $\mathrm{T}$ is no longer directly preceded by aC, but by CC. Therefore $\mathrm{T}>\mathrm{it}$, resulting in a sequence CaCCitv. Since the rule for short vowel elision has already been executed (and this rule is not cyclic!), such CaCCitv sequences will not be resyllabified to (after applying stress and anaptyxis rules) become CáCiCtv, but the sequence is stressed and appears on the surface as CáCCitv. Examples of such sequences are rágbituh "his neck", xášbituh "his piece of wood".

Verbal forms of the 3 rd p. sg. fem. $a$-type perfect + vowel are resyllabified analogous to the suffixed nominals; the rule was generalized to cover all (including verbal) sequences: CaCaCat $+\mathrm{v}>\mathrm{CaCCitv}$, e.g. ( farašat $+u h>$ ) fáršituh "she spread it out" and katabat + uh >) kátbituh "she wrote it".

The advantage of fitting the extra provision with regard to elision of $a$ into the ordering of rules is that the T-rule, which holds in almost all Sinai dialects, does not have to be customized to fit the situation in MzA.

Also, an advantage of this rule-generalization is that no separate rule is needed for the sudden appearance of -it in the case of the 3 rd p. sg. fem. of $a$-type perfects when vowel-initial suffixes are appended. $7^{0}$

$7^{0}$ From the point of view of historical development, such a rule would be highly unlikely, since the verbal ending is -at under all other circumstances, see verbal morphology in 3.2 . 


\subsubsection{The rule for $T$ not directly preceded by $a C$ or $\bar{v}$}

When not preceded by aC, the fem. morpheme - $a$ h becomes -it (or - $t$ when a long vowel $\overline{\mathrm{v}}$ directly precedes, see 3.1.10.4.) in construct state.

The $i$ of the ending -it may then be subject to the rule for high vowel elision, after which often an anaptyctic vowel is inserted (underlined in following examples), e.g.: 'ílibtuh "his packet", 'ilbít"k "your packet", fátrit $a r b a^{\prime} \sin$ (with sandhi elision and anaptyxis >) fátirt arba ísnīn "a period of four years", nāgtuh "his she-camel", nāgituk "your (sg. masc.) she-camel". In strongly velarized environments T may be realized as -ut, as in nuxrút $t^{u} k$ "your (sg. masc.) nose", contrasting with nuxrít'k "your (sg. fem.) nose".

\subsubsection{T preceded by the gahawah-vowel a}

Forms in which a gahawah-vowel $a$ is in open syllable directly preceding $\mathrm{T}$ are treated the same way as forms in which such a preceding $a$ is 'historical'. Almost paradoxically so, the forms gahwitī and gáhwitu (and similar forms like laḥmitì and láhmituh) show that the gahawah-syndrome has created fully-fledged syllables in these nominals, for if the gahawahvowel $a$ would have been a mere anaptyctic vowel (i.e. more like in verb forms, cf. 2.1.2.4.), one might have expected forms like gahawtī and gáhawtu. The fact that the gahawah-vowel $a$ is dropped from (intermediate) forms like *gahawati and *gahawatuh thus illustrates that we are dealing with a full short vowel $a$ (produced by the gahawah-syndrome), since only $\mathrm{CaCaCT}+\mathrm{v}$ sequences are affected by the special provision made in the short vowel elision rule (as described above).

\subsubsection{T following $\bar{a}$}

T preceded by $\bar{a}$ yields -āh, e.g. hamātuh "his mother-in-law",

In one instance *mainā (spelled in Arabic with 'alif maqșūrah: معنى) was interpreted as T-final (as occurs more often in other dialects as well): mi nät ilkilmih "the meaning of the word".

3.1.10.5. Nominal ending -it in construction vs. verbal $3 r d p$. sg. perf. ending -at The high vowel $i$ of the nominal ending -it is dropped when it is in open unstressed syllable, e.g. nāgtuh "his she-camel", gatțāytuh "its (sg. masc.) cover".

The low vowel $a$ in verbal forms of the 3 rd p. sg. perf. is not dropped, e.g. šăfatuh "she saw him" and lāgatuh "she found him", kāwanatuh "she fought him". 


\subsubsection{Genitive marker}

The genitive marker is $\check{s} u \dot{g} !$, but in more isolated areas (away from the coast) hagg is more current in MzA. In BWA šuğl is the current form, although hagg may also be heard. Though not as regularly as šugl, the K-form $b t \bar{a}{ }^{c}$ may also be heard. The form taba' was heard only once in $\mathrm{MzA}$.

The paradigms for suffixed $\check{s} u \dot{g} !(a h)$ and $h a g g(a h)$ are as follows:

\begin{tabular}{|c|c|c|c|c|}
\hline e.g. & ilbēt + & & il'ilbih + & \\
\hline & & pl. & sg. & pl. \\
\hline $\begin{array}{l}\text { 3. masc. } \\
\text { fem. }\end{array}$ & $\begin{array}{l}\text { šug்tuh } \\
\text { šúg்ulha }\end{array}$ & $\begin{array}{l}\text { šúg்ulhuw } \\
\text { šúg்uḷin }\end{array}$ & $\begin{array}{l}\text { šúg்ultuh } \\
\text { šúglítha }\end{array}$ & $\begin{array}{l}\text { šuǵlíthuw } \\
\text { šuglíthin }\end{array}$ \\
\hline 2. masc. & šuğtuk & šúg்uḷkuw & šug̣lít ${ }^{u} k$ & šuġlítkuw \\
\hline fem. & šug̣lik & šúg்uḷin & šug lit $^{i} k$ & šug̣littkin \\
\hline l. com. & šug & šúg்uḷa & šuguultī & šuġlítna \\
\hline
\end{tabular}

Pl. forms used for humans are šug̣līn and šug̣lāt: e.g. iliwlād šuğlīn ilmádrasih "the boys of the school" and ilbanāt šug̣tàt ilmádrasih "the girls of the school". Also for smaller or numbers the pl. fem. is used: ittalātah ǧinēhāt dillih šug $\underline{g}^{a} t^{u} k$ "these three pounds are yours".

$\begin{array}{lllll}\text { e.g. } & \text { ilbēt }+ & & \text { il'ilbih }+ & \\ & \text { sg. } & \text { pl. } & \text { sg. } & \text { pl. } \\ \text { 3. masc. } & \text { hagguh } & \text { hagghuw } & \text { haggtuh } & \text { haggithuw } \\ \text { fem. } & \text { haggha } & \text { hagghin } & \text { haggitha } & \text { haggithin } \\ \text { 2. masc. } & \text { hagguk } & \text { haggkuw } & \text { haggit }{ }^{\prime} \text { ha } & \text { haggitkuw } \\ \text { fem. } & \text { haggik } & \text { haggkin } & \text { haggit'k } & \text { haggítkin } \\ \text { 1. com. } & \text { haggi } & \text { haggna } & \text { haggti } & \text { haggítna }\end{array}$

Pl. forms for humans are haggīn and haggàt: e.g. iliwlād haggìn ilmádrasih and ilbanāt haggāt ilmádrasih. Like in the case of šug̣tāt, the pl. fem. haggāt is often used for smaller numbers: ițtalātah ğinēhāt dillih haggāt ${ }^{u}$ k.

A preference for the construct state instead of indirect annexation could not be concluded from the available data.

\subsubsection{Personal pronominals}

3.1.12.1. Independent pronominals

In MzA the following independent pronominals are used: 


\begin{tabular}{|c|c|c|c|c|}
\hline & & & negated: & \\
\hline & sg. & pl. & sg. & pl. \\
\hline 3. masc. & $h \bar{u}$ & huwwa $(h)$ & $m \bar{u} h \bar{u}^{*}$ & mūhuwwa $(h)$ \\
\hline fem. & $h \bar{\imath}$ & hinnah & $m \bar{\imath} h \bar{\imath}^{*}$ & minhinnih \\
\hline 2. masc. & $\operatorname{int}(a h)$ & intuw & $\operatorname{mint}(a h)$ & mintuw \\
\hline fem. & intiy & intin & mintiy & mintin \\
\hline 1. com. & ana & iḥna & $m \bar{a} n \bar{\imath}^{*}$ & míhna \\
\hline
\end{tabular}

Direct elicitation yielded the following negated forms in BWA: $m \bar{a} h \bar{u}^{*}$, māh $\imath^{*}$, mintah, mintìy, mānn $\imath^{*}$, māhumma, māhinnah, mintuw, mintin, mihna.

* In these forms stress is on the vowel of the first syllable.

For a likely development of the pl. masc. form huwwa - in which reinterpretation of morpheme boundaries must have played an important rolesee 3.1.12.2. in the preceding chapter and also De Jong 2000:163.

3.1.12.2. Pronominal suffixes

In MzA the following pronominal suffixes are used:

\begin{tabular}{|c|c|c|}
\hline & $\begin{array}{l}\text { sg. } \\
(\mathrm{C}) \mathrm{C}-u(h)^{*_{1}}, \overline{\mathrm{v}}-(h)\end{array}$ & $\begin{array}{l}\text { pl. } \\
-h u w^{*}\end{array}$ \\
\hline fem. & $-h a$ & -hin \\
\hline 2. masc. & C- ${ }^{u} k$, CC- $u k, \bar{v}^{-}{ }^{u} k^{* 2}$ & $-k u w$ \\
\hline fem. & $\mathrm{C}-{ }^{i} k, \mathrm{CC}-i k, \overline{\mathrm{v}}-k^{* 2}$ & $-k i n$ \\
\hline 1. com. & $\begin{array}{l}\text { (C)C- } \bar{\imath}, \overline{\mathrm{v}}-y \text { (poss.) } \\
-n \bar{\iota}(\text { obj. })^{*_{3}}\end{array}$ & $-n a$ \\
\hline
\end{tabular}

For allomorphs used with the preposition 'ind, see below 3.1.16.

${ }^{* 1}$ Notice the $-u(h)$ suffix for the 3 rd p. sg. masc., instead of $-a h /-i h$ which we find in group I.

${ }^{*_{2}}$ The superscript vowel ${ }^{u}$ serves to indicate a considerable degree of velarization (accompanied by lip rounding); it is not to be interpreted as a vowel, which may be concluded from stress placement and (lack of) short high vowel elisions in forms like hurmit " $k$ "your (sg. masc.) wife" and $n \bar{a} i^{\prime} t^{\prime} k$ "your (sg. masc.) she-camel". Contrast this with forms followed by 2nd p. sg. fem. suffixes: 'ilbit'k "your (sg. fem.) pack", nāgit'k.

When ${ }^{u} k$ is suffixed to $\overline{\mathrm{v}}$, the long vowel colours strongly towards $[\mathrm{u}]$ before $k$ is released, e.g.: 'ile $e^{u} k$ "on you", $f i^{u} k$ "in you", gif $\bar{a}^{u} k$ "your neck". Contrast these with forms followed by and p. sg. fem. suffixes: 'ilekk, fik and gifäk.

When lip-rounding is already present, there appears to be a slight difference in the pronunciation of $u b \bar{u} k$. "your (sg. masc.) father" and $u b \bar{u} k$ 
"your (sg. fem.) father"; the long vowel $\bar{u}$ preceding $k$ is more tense than $\bar{u}$ preceding $k .^{7^{1}}$

*3 Like most in Bedouin dialects of Sinai ${ }^{2}$ we find stressed suffixes $-\bar{\imath}$ and $-n \bar{\imath}$ for the 1 st p. sg. com. Unstressed $-i$ and $-n i$ also occur.

*4 Parallel to independent pronominals, the 3 rd p. pl. masc. suffix is formed with $-w$, rather than with $-m$ (although a few instances with final $-m$ were recorded).

For the development of second person pronominal suffixes $-k$ and $-k$ see NOTE in 3.1.12.2. in the preceding chapter.

\subsubsection{Demonstratives}

3.1.13.1. Near and far deixis

Near deixis*2:

$\begin{array}{lll} & \text { sg. } & \text { pl. } \\ \text { masc. } & (h \bar{a}) \underline{d} a h^{*_{1}} & (h \bar{a}) \underline{\text { dill }(i h)^{*_{2}}} \\ \text { fem. } & (h \bar{a}) \underline{d} \dot{i} y & (h \bar{a}) \underline{\text { dillih }} / \underline{\operatorname{dill}} \bar{e} l(i h)^{*_{2}}\end{array}$

Forms without initial $h \bar{a}$ - are much more regular than in group I.

Far deixis*2:

$\begin{array}{lll} & \text { sg. } & \text { pl. } \\ \text { masc. } & (h \bar{a}) \underline{d} \bar{a} k(a h) & (h \bar{a}) \underline{d a ́} \text { ll } a k(a h)^{*_{2}} \\ \text { fem. } & (h \bar{a}) \underline{d} \bar{k} k(a h) & \end{array}$

*1 In pause often $\underline{\text { dih }}$ or $\underline{d i}$.

$*_{2}$ The forms listed here with initial $h \bar{a}$ are current in BWA, but occur only sporadically in MzA. Another pl. form recorded in MzA was hädēlah. For presence / absence of velarization in these forms, see remarks ${ }^{*_{2}}$ and ${ }^{*_{4}}$ in chapter I, 3.1.13.1.

To express "there he/she is (lit.: has come)" or "there they are (masc./fem.) (lit. have come)" a prefix $h \bar{e}$ - precedes the personal pronominals, as in hèhū ği !' "there he is!", hēhì ğàt "there she is!", hēhuwwa ğuw "there they (masc.) are!", hēhinnah ğin "there they (fem.) are!".

${ }^{71}$ These remarks are based on mere impressions, not on precise machine-aided measurements.

$7^{2}$ See De Jong (2000:3.1.12.2. of ch. I-III) and (2003:163). 
3.1.13.2. Specifying ha-

Specifying $h a-$, which is especially current in group I dialects (see De Jong 2000:172-173), was heard only in halhin ( halhinit in MzA) "now" and once in halyōm "today" (the latter only recorded in BWA).

\subsubsection{Interrogatives}

min is used independently for "who?", but another possibility to enquire after someone's identity is $\min$ (with a short vowel) in combination with a pron. suff., as in $\min h \bar{u}$-h-intih? "who are you?".

"What?" is ès? ( much less often $\bar{e} h)$; "why?" is lēh? (both in sentenceinitial, as well as sentence-final position); "where?" is wēn?; "when?" is mitēh? or wagtēš?; "how?" is kēf?; "how much?" is gaddēš?; kam + sg.? is "how many?", yāt bèt "which house?" and yāt bint "which girl?".

\subsubsection{Adverbs}

3.1.15.1. Adverbs: "there", "over there (far away)", "here", "thus", "now", "still", "afterwards, after that"

"Here" is nihāa(') or nihāniy* in MzA and hniy in BWA ( $f$ h hāda is also used),

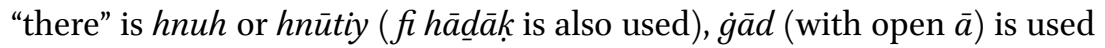
for "over there (far away)". "Thus" is kídiy or often kidiyyih (and less often kidiyyāniy), "now" is halhīn ( halhīnit in MzA), "still" is l issā' and "afterwards, after that" is ba'adèn.

* When min precedes nih $\bar{a}^{\prime}$, one syllable is haplologically dropped, e.g. imšin mi-nhä or mi-nhāniy "go away (pl. fem.) from here!".

\subsubsection{2. "maybe"}

For "maybe" no forms based on the root $x-w-f$ (for undesirable possibilities, e.g. $x \bar{a} f a ! l l a h$, see De Jong 2000:177) or $k$-w-d (for positive possibilities, kūd see ibid. 178) were recorded, but only yimkin.

3.1.15.3. bilhayl "very, extremely"

b ilhayl "very, extremely" is often used in BWA to qualify an adjective, e.g.

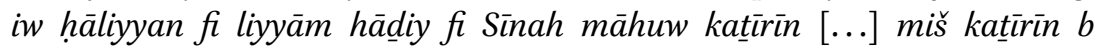
ilhayl..."And now, these days, they are not many in Sinai [...] They are not very many...". Another example is [...] iw zayy kidiy $b \bar{\imath} d \bar{e}^{u} k$, bitgatți ...alkáakih $w$ tuf ưukha $w$ bithuțt 'ālēha lèha... issamin iwlāha hilwih $b$ ilhayl..." and like this with your hands you break the cookie to pieces and crumble it. And you add, put ghee on it, and (then) it is extremely tasty...”. 
3.1.15.4. bišwēš "slowly, carefully"

The adverb bišwēš was not recorded in MzA or BWA. Instead, a construction like šwayyih šwayyih is current.

3.1.15.5. min xawf "lest"

min $x a w f$ in the sense of "lest" (see De Jong 2000:179) was not recorded.

\subsubsection{Prepositions + pers. pronominal suffixes}

In BWA the pron. suffix for the 2nd p. sg. fem. $-k$ co-occurs with -kiy, e.g. fik fikiy "in you (sg. fem)". and also lik lkiy "to you (sg. fem.)".

In direct elicitation, the -ak suffix was also recorded for the 2 nd p. sg. masc., though in spontaneous texts only - ${ }^{u} k$ or $-u k$ was heard.

Suffixed prepositions in MzA are:

\begin{tabular}{|c|c|c|c|c|c|}
\hline$l i+*_{1}$ & & 'ala $+*_{2}$ & & $m(i)^{c}+*_{3}$ & \\
\hline luh & lēhuw & 'ilēh & 'ilēhuw & $m^{\prime} u h$ & miḥhuw \\
\hline lèha & lēhin & ílēha & 'ilēhin & miḥha & miḥhin \\
\hline luḳ & $l \bar{e}^{u} k \underline{w} w$ & ílēe $e^{u}$ & ‘ilēe k़uw & $m i u k$ & mikuw \\
\hline lik & lēkin & ‘ilēk & ilēekin & mik & mikin \\
\hline $\operatorname{lay}(y)^{* 4}$ & lèna & $\operatorname{alay}(y)^{* 4}$ & ‘ilèna & $m^{c} \bar{\imath}$ & mina \\
\hline
\end{tabular}

$*_{1}$ The paradigm is mixed; forms like $l \bar{e} u k$ and $l \bar{e} h$ are much less frequently used than luk and luh. A similar paradigm is used for $b+$. The suffixed proposition $l+$ may be enclitically suffixed, e.g. ğâluk "he came to you", gultilhi' "I said to her" (notice that the form is not lèha), ahsál-luk. "it is best for you" (assimilated ahsan + luk), but this is not always the case, as may be concluded from stress in e.g. gălat luh "she said to him", tfakkir luh "you look at him" (i.e. these examples are not stressed gālát-luh and tfakkir-luh, which would be the forms in case of enclitic suffixing).

In BWA the short base instead of the forms with $\bar{e}$ is more current: Iha, lhuw, lhin, lkuw, lkin and lna.

*2 Raising of short $a$ to $i$ in open syllables preceding stressed $\bar{e}$ (as indicated here) is optional, but very regular.

BWA forms are the same, though raising of $a$ in these positions is much less regular than in MzA.

As independent prepositions both 'ala and ' $a$ (not only when preceding the article) are current.

*3 The short vowel $i$ is dropped when vowel-initial suffixes follow (including $-u k$ and $-i k)$, but stressed when consonant-initial suffixes are involved and ' and $h$ reciprocally assimilate to become $h h$.

* For a remark on lay and 'aláy, see 1.2.4.1. 
In BWA forms are the same.

\begin{tabular}{|c|c|c|c|c|c|}
\hline$f i+$ & & $f \bar{o} g+^{*_{1}}$ & & $\min { }^{* 2}$ & \\
\hline fih & fihuw & föguh & fōghuw & minnuh & minhuw \\
\hline fiha & fihin & fögha & föghin & minha & minhin \\
\hline$f \iota^{u} k$ & $f_{i}^{u} k u w$ & fōgu $g^{u}$ & fōgḳuw & minnuk & minḳuw \\
\hline fik & fikin & $f o \bar{g} g^{i} k$ & fōgkin & minnik & minkin \\
\hline $\operatorname{fay}(y)^{* 3}$ & fina & $f \bar{g} g \bar{\imath}$ & fögna & $\operatorname{minn} \bar{\imath}$ & minna \\
\hline
\end{tabular}

*1 Alternatively one can say min hardī "above me" min ḥarduk "above you (sg. masc.)", etc. ${ }^{73}$

$*_{2}$ Notice here that the $n$ is doubled preceding the short vowels in the suffixes $-u k$ and-ik, which indicates that the vowels of these allomorphs are not merely anaptyctic vowels.

*3 fay must have developed in analogy to lay and 'aláy, see remark above.

The preposition min is usually stressed in the compounds mín-tahat "from below", min-kidiy "from this".

\begin{tabular}{|c|c|c|c|}
\hline $\begin{array}{l}\text { wara + } \\
\text { warāh }\end{array}$ & warāhuw & $\begin{array}{l}\text { 'ind }+ \\
\text { 'induh }\end{array}$ & 'induhuw"*2 \\
\hline warāha & warāhin & indaha ${ }^{* 2}$ & "indihin ${ }^{* 2}$ \\
\hline wara $\bar{a}^{u} k$ & warāḳuw & ‘nduk & 'indukuw" \\
\hline $\operatorname{wara} k^{*_{1}}$ & warākin $^{*_{1}}$ & ‘indik & 'indikin" \\
\hline warāāy & warāna & 'indī & 'indina*2 \\
\hline
\end{tabular}

$*_{1}$ In the forms for the 2 nd p. fem. the velarization created by the preceding $r$ is gradually lost during articulation of the following $\bar{a}$. Thus an opposition between $w a r \bar{a}^{u} k$ and warāk is maintained.

$*_{2}$ Notice that the allomorphs used with this preposition are all vowel-initial.

\subsubsection{Numerals and counted plurals}

3.1.17.1. Cardinal numbers 1-10

Independent cardinal numbers are (forms that precede counted nouns

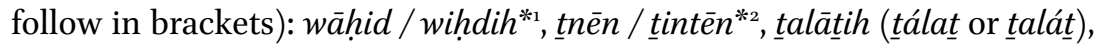
arba'ah (arba'), xamsih (xams), sittih (sitt), sab'ih (sab'), tamānyih (táman or tamán), tis ih (tis'), 'ašarah ('ašaṛ).

73 Šuqayr (1916:341), however, lists hard in the meaning of bi ğănib "beside". 
* wăhid and wihdih may follow the counted noun as adjectives for extra emphasis, e.g. walad wāhid "one boy" and bint wiḥdih "one girl".

*2 tnên and tintèn may follow the counted dual form of the noun as adjectives for extra emphasis, e.g. waladēn ițnèn "two boys" and ìdèy ițtintēn or idèy tintēnhin "my two hands".

Some plural forms of nouns are counted with proclitic $t$ - (a remnant of the fem. morpheme in construct state), e.g. 'ašar t-infär "ten people", talat t-iyyam "three days".

\subsubsection{Ordinal numbers 1-10}

Only three ordinals were recorded: awwil, țāniy, țâlit.

3.1.17.3. Numerals: 11 and up

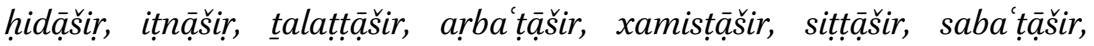

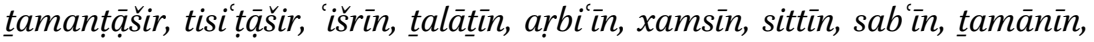
tis'in, miyyih, miyytèn, tultmiyyih, rubimiyyih, xumsmiyyih, suttmiyyih, subimiyyih, tuminmiyyih, tusimiyyih, alf, alfēen, talat t-äläf, xamis t-älāf,

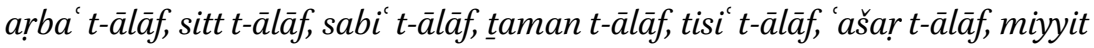
alf, miyytēn alf, malyūn.

\subsubsection{The dual}

Suffixing -èn or -ayn to the sg. form of a noun forms the dual, e.g. šaharayn "two months", sbü'ayn "two weeks", nō'ayn "two kinds" and -èn (in neutral environments) 'arabiyytēn "two cars", miyytēn "two hundred", rikibtēn "two knees", sanatēn "two years", bintēen "two girls".

Older forms of the dual are used in expressions for body parts, e.g. riğlēy "my (two) legs" and riǧlē" k "my (two) hands" and ìdèy "my (two) hands" and $\bar{i} d \bar{e}^{u} k$ " your (two) hands".

\subsection{Verbal Morphology}

3.2.1. Regular verbs

\subsubsection{Regular verbs perfect}

In all vowel-types of the perfect and imperfect, the end and 3rd p. pl. masc. ending is $-u w$, the and and $3 \mathrm{rd} \mathrm{p}$. pl. fem. ending is -in (including the $a$ - and $i$ - types of the tertiae infirmae) and the ending of the 3 rd p. sg. fem. is -at (except in the verb 'come', see below) ${ }^{74}$

${ }^{74}$ These are differences with group I dialects (see De Jong 20oo: several paragraphs under 3.2. in chapter I. 
Perfects of measure 1 verbs come in three types: $\mathrm{C}_{1} \mathrm{aC}_{2} \mathrm{aC}_{3}, \mathrm{C}_{1} \mathrm{iC}_{2} \mathrm{iC}_{3}$ and $\mathrm{C}_{1} \mathrm{uC}_{2} \mathrm{uC}_{3}$. The paradigms are:

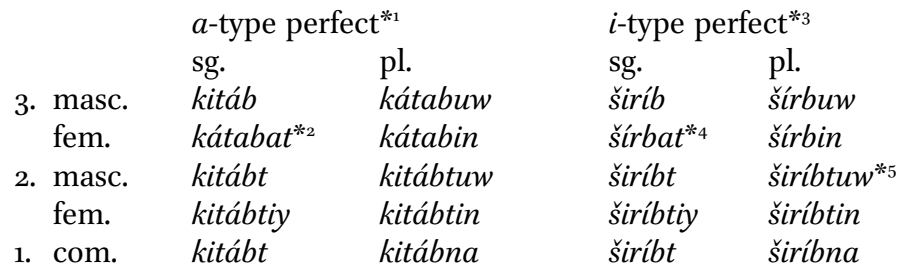

*1 Notice that $a$ (in the first syllable) is raised to $i$ in pre-stress syllables. In a labial environment raising of unstressed $a$ in the first syllable tends to be towards $u$, as in wugáft "I stopped" and wugáftin "you (pl. fem.) stopped", but wágafat "she stopped" and wágafin "they (pl. fem.) stopped". *2 When suffixed with a vowel-initial suffix forms are: kátbitu or kátabatu "she wrote it (sg. masc.)". The latter form may be due to influence from one of the neighbouring dialects (such as TAN), where the form is not resyllabified.

*3 The short high vowel $i$ of the first syllable is actually underlying $|\mathrm{a}|$ and is therefore not dropped in open pre-stress syllables. This underlying $|a|$ does not 'reappear' in closed syllables (in contrast with reappearing $|\mathrm{a}|$ in some -not all- of the dialects of group I).

*4 Notice that the ending here is -at in the $i$-type perfect, not -it (contrasting with surrounding dialect groups).

*5 'Almost' širíbtum: one of my informants had a tendency to almost close his lips (approximating I.P.A. [m]) when articulating $w$ of pl. verbal endings; one had to look carefully to see that he was not actually producing $m$, because it often sounded as such, also because of the high degree of nasalisation which accompanied his realisation of such final $w \bar{a} w^{75}$ (see also remarks on the situation in HmA (of group VII) and 'LA (group VIII) in 3.2.1.1. of the preceding chapter).

\subsubsection{Regular verbs imperfect}

Like in many dialects in Sinai, the imperfect is characterized by vowel harmony in the verbal prefixes. Another interesting feature is that this vowel harmony has spread through the entire paradigm and that it includes the 1st. p. com. sg. This accounts for the absence of initial $a$ - in

75 This is reminiscent of verbal endings in group II of northern Sinai, see De Jong (2000:3.2. of chapter II). See also remarks in 3.2. above. 
the 1st. p. sg. com. of $i$ - and $u$-type imperfects, which we do find in many other dialect groups (see 3.2.1.2. of the various chapters).

There are three imperfect patterns: $\mathrm{yaC}_{1} \mathrm{C}_{2} \mathrm{CaC}_{3}, \mathrm{yuC}_{1} \mathrm{C}_{2} \mathrm{CuC}_{3}$ and $\mathrm{yiC}_{1} \mathrm{C}_{2} \mathrm{iC}_{3}$, all of which are characterized by vowel harmony in the prefixes:

\begin{tabular}{|c|c|c|c|c|}
\hline & \multicolumn{2}{|c|}{$a$-type imperfect ${ }^{* 1}$} & \multicolumn{2}{|c|}{$i$-type imperfect } \\
\hline & sg. & pl. & sg. & \\
\hline 3. masc. & yášṛab & yášṛabuw & yiktib & yíkitbuw \\
\hline fem. & tášrrab & yášrabin & tiktib & yíkitbin \\
\hline 2. masc. & tášrab & tášrabuw & tiktib & tíkitbuw \\
\hline fem. & tášrabiy & tášrabin & tíkitbiy & tíkitbin \\
\hline 1. com. & ášrab & nášrab & iktib & niktib \\
\hline & $u$-type in & rfect $^{*_{2}}$ & & \\
\hline & sg. & pl. & & \\
\hline 3. masc. & yudrub & yúdurbuw & & \\
\hline fem. & tud $\operatorname{drub}$ & yúdurbin & & \\
\hline 2. masc. & tud & túdurbuw & & \\
\hline fem. & túdurbiy & túḍurbin & & \\
\hline 1. com. & $u \underline{d} r u b$ & nùdrub & & \\
\hline
\end{tabular}

$*_{1}$ Notice the lack of vowel harmony in the endings of 2 sg. fem., 2 pl. masc. and fem. and $3 \mathrm{pl}$. masc. and fem. (in contrast with group I). ${ }^{76}$

$*_{2}$ In the $u$-type-provided velarization is lacking - the anaptyctic vowel in the imperfect forms tends to vary, i.e. either $i$ or $u$. One may hear e.g. túgu'duw as well as túgi duw for "you (pl. masc.) sit”, but in velarized forms the anaptyctic $u$ is regular, like in the paradigm listed here.

Measure 1 verbs with $C_{1}=X$ have the following paradigms:

\begin{tabular}{|c|c|c|c|c|}
\hline \multirow{7}{*}{$\begin{array}{l}\text { 3. masc. } \\
\text { fem. } \\
\text { 2. masc. } \\
\text { fem. } \\
\text { 1. com. }\end{array}$} & \multicolumn{2}{|c|}{$i$-type ${ }^{*_{1}}$ imperfect $^{* 2}$} & \multicolumn{2}{|c|}{$a$-type imperfect ${ }^{* 2}$} \\
\hline & sg. & pl. & sg. & pl. \\
\hline & yáharit & yáhartuw & yáarag & yáaraguw \\
\hline & táhariț & yáḥartin & táarag & yáaragin \\
\hline & táḥarit & táḥartuw & táarag & táaraguw \\
\hline & $\begin{array}{l}\text { táharțiy } \\
\text { áharit }\end{array}$ & táḥartin & táaragiy & táaragin \\
\hline & ạhariț & nạharit & a arag & na arag \\
\hline
\end{tabular}

*1 Notice that the lack of vowel harmony in $i$-type imperfects like yaharit implies that, from a historical perspective, the gahawah-rule must be understood to ante-date the rule for vowel harmony (hence forms like e.g. yihrit are not heard in these dialects).

${ }^{76}$ See De Jong 2000:190-191. 
*2 Perfect harát like katáb (see 3.2.1.1.). My BWA informant articulated sinn instead of $\underline{t} \bar{a}^{\prime}$, e.g. yáharis and yáharsuw, etc.

*3 Perfect 'iríg like simí (see 3.2.1.1.).

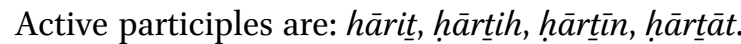

Active participles of the type $\mathrm{C}_{1} \overline{\mathrm{a}} \mathrm{C}_{2} \mathrm{iC}$ (etc.) for the verb iríg, yáarag are not really used, instead for "sweating" one may hear: 'argān, 'argānih, 'argānīn, 'argānāt.

3.2.1.3. Reflexes of older ${ }^{*} \mathrm{C}_{1} a C_{2} u C_{3},{ }^{*} \mathrm{yaC}_{1} \mathrm{C}_{2} u C_{3}$

$u$-type perfect ${ }^{* 1}$

3. masc. kubur kubruw

fem. $\quad$ kubrat $^{*_{2}} \quad$ kubrun $^{*_{3}}$

2. masc. kuburt kuburtuw

fem. kuburtiy kuburtin

1. com. kuburt kuburna

*1 The Classical Arabic 'Eigenschafts' verb-type (which expresses a certain characteristic) $\mathrm{C}_{1} \mathrm{aC}_{2} \mathrm{uC}_{3} \mathrm{a}, \mathrm{yaC}_{1} \mathrm{C}_{2} \mathrm{uC}_{3} \mathrm{u}$ has $\mathrm{C}_{1} \mathrm{uC}_{2} \mathrm{uC}_{3}, \mathrm{yuC}_{1} \mathrm{C}_{2} \mathrm{uC}_{3}$ reflexes (imperfect paradigm like $y u d \underline{d} u b$, see 3.2.1.2.). Notice that, like in reflexes of C.A. ${ }^{*} \mathrm{C}_{1} \mathrm{aC}_{2} \mathrm{iC}_{3}$ a (such as, e.g., širib), the high vowel of the first syllable of the perfect is not dropped in unstressed positions (so not e.g. $k b u r t$ for "I grew"). We may conclude therefore that also in the case of $\mathrm{C}_{1} \mathrm{uC}_{2} \mathrm{uC}_{3}$ perfects, the $u$ of the first syllable is actually underlying aa (i.e. like $i$ in the first syllable of $\mathrm{C}_{1} \mathrm{iC}_{2} \mathrm{iC}_{3}$ perfects, see ${ }^{* 3}$ in 3.2.1.1.).

Other $u$-type perfects are: tuxunt "I became fat", hì $\dot{g} u l \underline{\text { dat }}$ "she became fat", hinnih guldin "they (fem.) became fat", iddinyah suxu $n a t$ "the weather became hot" (for superscript ", see 2.2.2.3.) and innās kutruw "people became many".

$*_{2}$ Notice the ending -at here, cf. remark ${ }^{*} 4$ in 3.2.1.1. above.

$*_{3}$ Notice that the vowel of the ending -in colours with the preceding vowels $(>-$ un $) \cdot{ }^{77}$

3.2.1.4. Regular verbs participles

Active participles are formed with the patterns $\mathrm{C}_{1} \overline{\mathrm{a}} \mathrm{C}_{2} \mathrm{iC}$ (sg. masc.) $\mathrm{C}_{1} \overline{\mathrm{a}} \mathrm{C}_{2} \mathrm{C}_{3} \mathrm{ah} /$-ih (sg. fem.), $\mathrm{C}_{1} \overline{\mathrm{a}} \mathrm{C}_{2} \mathrm{C}_{3} \overline{\mathrm{i}}$ (pl. masc.) $\mathrm{C}_{1} \overline{\mathrm{a}} \mathrm{C}_{2} \mathrm{C}_{3} \bar{a} \mathrm{t}$ (pl. fem.).

77 Similar colouring was noticed in the imperfect form yukburun, recorded in the dialect of the Rmēlāt in the north, see De Jong:2000:191. 
When the sg. fem. participle is suffixed with an object, it is in construct state with this suffix. Examples are: bānīytuh "having built it (sg. masc.)", hì mìhì 'àyiztuh "she does not want/love him".

\subsubsection{Regular verbs imperatives}

Imperatives of regular verbs have a harmonized initial vowel, while endings are like those in the imperfect paradigm, e.g. ásma', ásma iy, ásma'uw, ásma in "listen!", údrub, údurbiy, ụdurbuw, údurbin "hit!" and íktib, íkitbiy, ikitbuw, íkitbin "write!".

\subsubsection{Irregular and other verbs}

3.2.2.1. Verbs $C_{1}=\mathrm{w}$ (primae wāw)

Imperfect paradigms of verbs with $w \bar{a} w$ as $C_{1}$ are:

$\begin{array}{lllll} & \text { i-type* } & & \text { a-type } & \\ & \text { sg. } & \text { pl. } & \text { sg. } & \text { pl. } \\ \text { 3. masc. } & \text { yōrid } & \text { yōrduw } & \text { yōgaf } & \text { yōgafuw } \\ \text { fem. } & \text { tōrid } & \text { yōrdin } & \text { tōgaf } & \text { yōgafin } \\ \text { 2. masc. } & \text { tōrid } & \text { tōrduw } & \text { tōgaf } & \text { tōgafuw } \\ \text { fem. } & \text { tōrdiy } & \text { tōrdin } & \text { tōgafiy } & \text { tōgafin } \\ \text { 1. com. } & \bar{o} \text { rid } & \text { nōrid } & \bar{o} \text { gaf } & \text { nōgaf }\end{array}$

* The $\bar{o}$ in this paradigm reflects older $a$ in the preformatives of $i$-type imperfects as well, as in e.g. *yawrid, and these are presumably older than the forms with harmonized vowels like e.g. yiktib. Diphthongal preformatives were not recorded.

The imperfect of the verb "light, kindle" was recorded as yog gid. The perfects of prima $w \bar{a} w$ verbs are $\mathrm{C}_{1} \mathrm{iC}_{2} \mathrm{iC}_{3}$ or $\mathrm{C}_{1} \mathrm{aC}_{2} \mathrm{aC}_{3}$ (see above). The imperatives are:

$\begin{array}{lllll} & \text { sg. } & \text { pl. } & \text { sg. } & \text { pl. } \\ \text { masc. } & \overline{\text { orid }} & \overline{\text { orduw }} & \overline{\text { ogaf }} & \overline{\text { ogafuw }} \\ \text { fem. } & \overline{\text { ordiy }} & \overline{\text { ordin }} & \overline{\text { ogafiy }} & \overline{\text { ogafin }}\end{array}$

The imperative áw'a was said to occur in that form only (i.e. uninflected for number or gender): "mind your head(s)!" is thus:

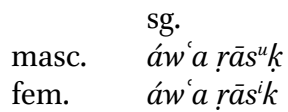
pl.
áw'a rūsḳuw
áw'a rüskin

\section{Participles:}

Active participles have a $\mathrm{C}_{1} \overline{\mathrm{a}} \mathrm{C}_{2} \mathrm{iC}_{3}$ pattern, e.g. (with velarized first syllables) wạgif, wāgfih, wạgfin, wạgfăt "standing". 
The passive participle for the root $w$ - $\check{g}$-d was recorded as maw $\check{g} \bar{u} d$ (see 1.2.4.1.).

3.2.2.2. Verbs $C_{1}=\mathrm{y}$ (primae yä)

The only verb recorded with $\mathrm{C}_{1}=y$ is yibis, yēbas "dry (intrans.)".

3.2.2.3. Verbs $C_{1}=$ ' (primae hamzah)

The two verbs "eat" and "take" have similar conjugations. The perfect and imperfect paradigms for "eat" are:

\begin{tabular}{lllll} 
& perfect & & \multicolumn{2}{c}{ imperfect } \\
& sg. & pl. & sg. & pl. \\
3. masc. & akál & ákaluw & yākil & yākluw \\
fem. & ákalat & ákalin & tākil & yāklin \\
2. masc. & akalt & akaltuw & tākil & tākluw \\
fem. & akaltiy & akaltin & tākliy & tāklin \\
1. com. & akalt & akalne & $\bar{a} k i l$ & nākil
\end{tabular}

Active participles are: mākil, māklih, māklīn, māklāt. Past participles are $m \bar{a} x \bar{u} \underline{d},-a h,-\bar{a} t,-\bar{n}$, which is also used meaning "daft".

Imperatives are (these forms are considerably velarized): $x \underline{u} \underline{\underline{d}}, x \underline{\underline{d}} \underline{\mathrm{y}} \mathrm{y}$, $x \underline{d} \underline{w} w$ and $x \underline{d i n}$. Also kul, kliy, kluw, klin. Notice the absence of stressed initial $u$-in these forms; an unstressed $u$ - may precede in forms like (here in superscript) " $x$ diy and ${ }^{u}$ k $l u w$, but is then-as should be concluded from its lack of stress - a mere anaptyctic vowel.

The verbal nominal is wakl "eating" and the passive verb "be eaten" is ánwikal, yínwikil.

3.2.2.4. Verbs $C_{2}=\mathrm{w}$ or $\mathrm{y}$ (mediae infirmae)

A characteristic of southern dialects is the short base vowel in the 2nd p. sg. masc. imperfect and imperative forms. In MzA and BWA these cooccur with forms with a long base vowel, but in BWA forms with the long base vowel are more current than those with a short vowel.

Perfect and imperfect forms of mediae infirmae are:

$$
\begin{aligned}
& \mathrm{C}_{2}=w \\
& \text { "get up" } \\
& \text { perfect imperfect } \\
& \begin{array}{lllll} 
& \text { sg. } & \text { pl. } & \text { sg. } & \text { pl. } \\
\text { 3. masc. } & \text { gām } & \text { gāmuw } & \text { ygūm } & \text { ygūmưw }
\end{array} \\
& \text { fem. gäṃat gämin tgūṃ ygūṃin } \\
& \text { 2. masc. guṃt guṃtuw tgūị /tulugúm tgūṃuw } \\
& \text { fem. guṃtiy guṃtin tgüṃiy tgūmin } \\
& \text { 1. com. guṃt guṃna ugūṃ ngūm }
\end{aligned}
$$


Participles are: gāyim, gāymih, gāymin, gāymāt (no velarization).

The verb $\check{s} \bar{a} f, y s ̌ \bar{u} f$ was recorded in MzA with short vowel $u$, as in šuft, as well as with $i$, as in šift "I saw".

\begin{tabular}{lllll}
\multicolumn{2}{c}{ "sleep" } & & \\
& perfect* & & imperfect & \\
& sg. & pl. & sg. & pl. \\
3. masc. & nām & nāmuw & ynām & ynāmuw \\
fem. & nāmat & nāmin & tnām & ynāmin \\
2. masc. & nimt & nimtuw & tnām / t(a)nám & tnāmuw \\
fem. & nimtiy & nimtin & tnāmiy & tnāmin \\
1. com. & nimt & nimne & anām & nnām
\end{tabular}

Participles: nāyim, nāymih, nāymīn, nāymāt.

$$
\mathrm{C}_{2}=y
$$$$
\text { "carry" }
$$$$
\text { perfect imperfect }
$$

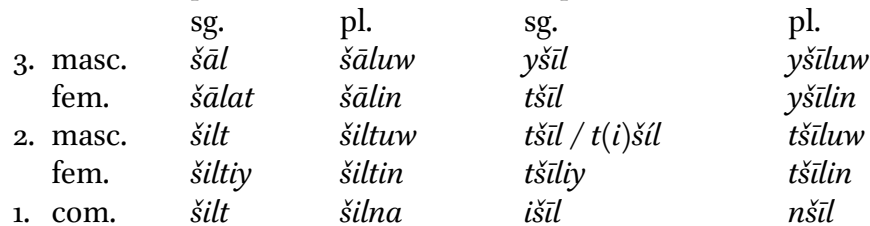

N.B. Where there is variation in group I dialects between the 3 rd p. sg. masc. forms biyšll and bišll, both meaning "he carries" (see De Jong 2000:199), in group VI a form like bišll "he carries" (after reduction of the diphthong $i y>i$ ) has become homophonous with the form for the 1st p. sg. com. "I carry".

3.2.2.4.2. Verbs $C_{2}=\mathrm{w}$ or $\mathrm{y}$ (mediae infirmae) imperatives

Like in the imperfect, imperatives of the 2nd p. sg. masc. often have short base vowels and may have a short vowel preceding, as in šil "carry!", ugúm "get up!". Examples are: nām, nāmiy, nāmuw, nāmin, gūm / ugúm, gūmịiy, gūmuww, gūminin.

Imperatives used with the verb ǧăb, yğìb are: hāt, hātiy, hātuw, hātin.

3.2.2.4.3. Verbs $C_{2}=\mathrm{w}$ or y (mediae infirmae) participles

Active participles of measure 1 are formed with the patterns $\mathrm{C}_{1}$ āyiC ${ }_{3}$, $\mathrm{C}_{1}$ āyC $\mathrm{ih}_{3}, \mathrm{C}_{1} \bar{a} \mathrm{y} \mathrm{C}_{3} \mathrm{in}$ and $\mathrm{C}_{1}$ āyC $\mathrm{C}_{3} \mathrm{a}$.

A passive partiple is mašyu $\bar{u}$ etc. 


\subsubsection{Verbs $C_{3}=\mathrm{y}$ (tertiae infirmae)}

\subsection{Verbs $C_{3}=\mathrm{y}$ (tertiae infirmae) perfect}

Below two paradigms are listed of perfects of tertiae infirma verbs that are actually mixed; some forms originate from the $a$-type perfect, while other forms in the same paradigm are originally $i$-type forms:

In MzA the following paradigms were elicited:

\begin{tabular}{|c|c|c|c|c|}
\hline & $\begin{array}{l}\text { rrget" } \\
i \text {-type } \mathrm{p}\end{array}$ & & $\begin{array}{r}\text { go, walk" } \\
a \text {-type }\end{array}$ & $\mathrm{fect}^{*_{2}}$ \\
\hline & sg. & pl. & sg. & pl. \\
\hline 3. masc. & nisi" & nisyuw $w^{* 1}$ & mišì & mišyuw \\
\hline fem. & nisyat $^{* 1}$ & nisyin $^{* 1}$ & mišyat & mišyin \\
\hline . masc. & nisìt & nisītuw & mišèt & mišētuw \\
\hline fem. & nisitity & nisītin & mišētiy & mišètin \\
\hline com. & nisìt & nisina & mišēt & mišēna \\
\hline
\end{tabular}

$*_{1}$ Another informant, however, claimed that forms like ligyuw and ligyin are not MzA. According to him, proper MzA forms are ligúw (< *laguw) (a suffixed example is ligūh) and ligín (<* lagin) (a suffixed example is ligínnuh) and by analogy one would then also expect ligát for the 3 rd p. sg. fem. (< $<$ lagat). The 3 rd p. sg. masc. form nisi $\left(<{ }^{*}\right.$ nasa $)$-instead of nisíy-must then have crossed over from the $a$-type perfect (compare miši ', see remark below). for the paradigm of the $i$-type elicited in BWA, see below.

$*_{2}$ The verb is listed here as an $a$-type perfect, since miši" must have developed from *maš $\bar{a}$, and endings in $-\bar{e}+$ clearly belong to the $a$-type (for raising of the $a$ preceding the stressed $\bar{e}$ see 1.2.3.4.3.2.), but the endings of the 3 rd p. pl. and 3 rd p. sg. fem. (i.e. those with $y$ ) are identical with the $i$-type endings. For similar $a$-type forms recorded in the dialect of Biliy of group I in northern Sinai, see De Jong 2000:201. The forms of the $a$-type perfect in BWA are the same as in MzA.

Suffixed forms are, e.g.: nisītuh "I forgot him" and nisināh "we forgot him", which are quite straight forward $i$-type, but forms like nisäh "he forgot him" and ligāh "he found him" point to the a-type. Similarly: hì nísyituh or násatuh "she forgot him" and ligyituh or (less current) lágatuh "she found him". Other examples (with doubling of $n$ ) in nisitinnuh "you (pl. fem.) forgot him" and nisyinnuh or (alternatively) nisinnuh "they (f.) forgot him" and alternatives like ligyūh / lagūh (after raising ligūh) "they found him".

Imperatives of tertiae $y \vec{a}$ verbs are apocopated in the sg. masc., e.g. the verbs yirmiy "throw" and yimšiy: 


$\begin{array}{lll} & \text { sg. } & \text { pl. } \\ \text { masc. } & \text { irm* / imš } & \text { irmuw / imšuw } \\ \text { fem. } & \text { írmiy / imšì } & \text { irmin / imšin }\end{array}$

* When followed by a pause or a consonant, an anaptyctic vowel appears, e.g. (underlined): írim \#! "throw!" and írimha "throw it (fem.) away!".

The paradigm of the $i$-type perfect recorded from BWA informants is almost identical to that of group I, however (De Jong 2000:201).

\begin{tabular}{|c|c|c|}
\hline \multicolumn{3}{|c|}{ "forget" } \\
\hline & perfect & \\
\hline & sg. & pl. \\
\hline 3. masc. & nisíy & nisyuw \\
\hline fem. & nisyat & nisyin \\
\hline 2. masc. & nisīt & nisītuw \\
\hline fem. & nisītiy & nisītin \\
\hline . com. & nisıt & nısına \\
\hline
\end{tabular}

N.B. $i$ in the first syllable of these verbs is not elided.

3.2.2.5.2. Verbs $C_{3}=\mathrm{y}($ tertiae infirmae) imperfect

\begin{tabular}{lllll}
\multicolumn{3}{c}{ "forget" } & \multicolumn{3}{c}{ "go, walk" } \\
& \multicolumn{2}{c}{ a-type imperfect* } & \multicolumn{2}{c}{ i-type imperfect } \\
& sg. & pl. & SG & PL \\
3. masc. & yansi & yansuw & yimšiy & yimšuw \\
fem. & tansi & yansin & timšiy & yimšin \\
2. masc. & tans & tansuw & timš /-iy & timšuw \\
fem. & tansiy & tansin & timšiy & timšin \\
1. com. & ansi & nansi & imšiy & nimšiy
\end{tabular}

* Verb forms are listed here in their unsuffixed shapes; when suffixed, $i>\bar{a}$, as in e.g. yansāhi "he forgets her" (contrast with remark in ${ }^{* 2}$ on treatment of final $-i$ ' in ğ $i$ ' "he came" in 3.2.2.6.1.).

N.B. Apocopated tertiae infirmae 2nd p. sg. masc. imperfect forms are very regular in group VI. Other examples are ag!labiyyah lliy btalghuw sakanuw fi wiǧih gibil așȘa ¿d "the majority of those you find settled down in the south in Upper Egypt", hatläguh "you'll find him", aw'a tans! "don't you forget!" and iw biti: $\dot{g} l u h$ "and you boil it (a long time)".

3.2.2.5.3. Verbs $C_{3}=\mathrm{y}$ (tertiae infirmae) imperatives

Like apocopated imperfect forms for the 2nd p. sg. masc., apocopated imperative forms for sg. masc. are currrent, e.g. írimhi' "throw it (sg. fem.) away!", ansuh "forget him!". 
3.2.2.5.4. Verbs $C_{3}=\mathrm{y}$ (tertiae infirmae) participles

Active participles have the patterns $C_{1} \bar{a} C_{2} i y, C_{1} \bar{a} C_{2} y i h, C_{1} \bar{a} C_{2} y \bar{n}$ and $\mathrm{C}_{1} \overline{\mathrm{a}} \mathrm{C}_{2} \mathrm{yāt}$. E.g. lāgiy, lāgyih, lāgyìn, lāgyāt "having found".

3.2.2.5.5. Verbs $C_{3}=\mathrm{y}$ (tertiae infirmae) verbal nouns

No instances of verbal nouns of tertiae infirmae were recorded.

3.2.2.6. The verb "come"

3.2.2.6.1. The verb "come" perfect and imperfect

\begin{tabular}{|c|c|c|c|c|}
\hline \multirow{2}{*}{ "come" } & \multicolumn{2}{|l|}{ perfect ${ }^{*_{1}}$} & \multicolumn{2}{|l|}{ imperfect ${ }^{* 1}$} \\
\hline & sg. & pl. & sg. & pl. \\
\hline 3. masc. & $\check{g} i^{* *_{2}}$ & ğuw & yiǧı́ $y^{*}$ & yiǧúw \\
\hline fem. & $\check{g} \bar{a} t$ & $\check{g}^{\prime}$ *n $^{* 3}$ & tiğı́y & yiǧín \\
\hline 2. masc. & ğìt & ǧituw & $t_{i g} *_{5}$ & tiğúw \\
\hline fem. & ǧiticy & ğittin ${ }^{* 3}$ & tiǧíy & tiǧín \\
\hline 1. com. & ğìt & ğine’ & iğ'́y & niǧíy \\
\hline
\end{tabular}

${ }^{*}$ Apart from stress in the imperfect paradigm, these forms are reminiscent of forms heard in the dialect of Biliy (see De Jong 2000:204).

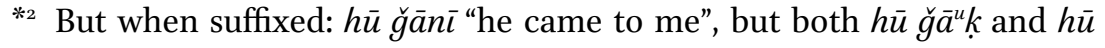
$\check{g}^{\prime}{ }^{u} k$ (i.e. not with IPA [ir], but with lengthened [i]: [dzis $\left.{ }^{\mathrm{u}} \mathrm{k}\right]$ ) were heard for "he came to you (sg. masc.)" and also hü ǧi:k (IPA [dzık ]) "he came to you (sg. fem.)".

${ }^{*} n$ is doubled when followed by a vowel-initial pronominal suffix, as in tiğínnu fi dāruh and ğitínnu fi dāruh, and also doubling of the $n$ when followed by a consonant-initial suffix, including those of the 2nd p. sg.: ğinnuk / ğinnik "they (fem.) came to you sg. masc. / sg. fem.".

*4 In rapid speech byiǧry may be realized as biǧı́y, making it homophonous with the form for ist p. sg. com., e.g. fi șșayf biğ́y rịh kițìr, iw fìh $f i$ Imašti byiǧcy rịh kițīr "in summer a lot of wind comes, and there are (times also) in winter that a lot of wind comes".

$*_{5}$ Notice the apocopated imperfect form for the 2nd. p. sg. masc., which is in complete conformity with the treatment of tertia yā' verbs.

*6 The form ağíy came out through direct elicitation in MzA, but the form iǧ́y is more logical and was indeed recorded regularly in MzA and also in BWA.

3.2.2.6.2. The verb "come" imperatives

Imperatives used with the verb "come" are: ta'āl, ta'äliy, ta'äluw, ta'älin. 
3.2.2.6.3. The verb "come" participles

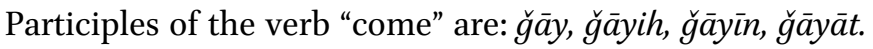

3.2.2.7. Verbs $C_{2}=C_{3}$ (mediae geminatae)

3.2.2.7.1. Verbs $C_{2}=C_{3}$ (mediae geminatae) perfect and imperfect

"stretch"

$$
\text { perfect* imperfect }
$$

$\begin{array}{llll}\text { sg. } & \text { pl. } & \text { sg. } & \text { pl. }\end{array}$

3. masc. madd madduw ymidd ymidduw

fem. maddat maddin tmidd ymiddin

2. masc. middèt middètuw tmidd tmidduw

fem. middētiy middētin tmiddiy tmiddin

1. com. middēt middēna imidd nmidd

* Raising of $a$ in closed syllable preceding stressed $\bar{e}$ is regular (like in the dialect of Biliy of group I in the north and also in groups $\mathrm{II}^{78}$ and VII. See also remark to the perfect paradigm in $3.2 .3 \cdot 5.2$.

When the geminate is velarized, the $\bar{e}$ of the ending is diphthongal $a y$, as in e.g. hattayt "I placed". $a$ in closed syllable preceding ay is not raised. When the geminate is velarized, the imperfect usually has $u$ as a base vowel, e.g. yhutț "place".

3.2.2.7.2. Verbs $C_{2}=C_{3}$ (mediae geminatae) imperatives

Imperatives of mediae geminate verbs are e.g. šidd, šiddiy, šidduw, šiddin "pull!" and with base vowel u: ḥuțt, hutțiy, huutțtuw, huuțtin "place!".

3.2.2.7.3. Verbs $C_{2}=C_{3}$ (mediae geminatae)

Active participles geminate verbs are e.g.: mādd, māddih, māddīn, māddāt.

Passive participles may be subject to the gahawah-rule when $C_{1}=X$, e.g. mahațūt "placed", but this was not heard in maxṣūṣ "special".

\subsubsection{Derived measures}

\subsubsection{Measure n-1}

\subsection{Measure n-1 sound roots}

Measure $n-1$ is used to express the passive. The underlying patterns are anC $\mathrm{aC}_{2} \mathrm{aC}_{3}$, yinC $\mathrm{aC}_{2} \mathrm{iC}$. The vowel of the preformative (in both perfect and imperfect) may be stressed in positions eligible for stress and surface

\footnotetext{
${ }^{78}$ For the dialect of Biliy, see De Jong 2000:205. For group II, see ibid.:309.
} 
forms often show raised $a$, e.g. ángița', yíngiți "be cut", ánwikal, yínwikil "be eaten". The paradigms are:

\begin{tabular}{|c|c|c|c|c|}
\hline & perfect & & imperfect* & \\
\hline & & pl. & sg. & pl. \\
\hline 3. masc. & ánbiṣaț & inbáșațuw & yínbișit & yinbáștuw \\
\hline fem. & inbáṣaṭat & inbáșațin & tínbișit & yinbáșțin \\
\hline 2. masc. & inbașáțt & inbașáțtuw & tínbișiț & tinbáșțuw \\
\hline $\begin{array}{l}\text { fem. } \\
\text { com. }\end{array}$ & $\begin{array}{l}\text { inbașátttiy } \\
\text { inbasátt }\end{array}$ & inbașáțtin & tinbáșțiy & tinbáșțin \\
\hline & ınbașațt & inbașáța & inbișiț & ninbișiț \\
\hline
\end{tabular}

* In the imperfect forms the underlying $|\mathrm{a}|$ 'reappears' in syllables closed by $\mathrm{C}_{2}$ (here $s$ ) after elision of $i$ preceding $\mathrm{C}_{3}$ (here $t$ ). The fact that the $i$ preceding $s$ is actually underlying $|\mathrm{a}|$ can also be concluded from the fact that it is not elided from forms like yinbișit (i.e. the form is not yin(i)bșit; a form which would be analogous in terms of elision and anaptyxis to a form like yikitbuw). In a similar manner, the participles are formed using the underlying pattern $\operatorname{minC}_{1} \mathrm{aC}_{2} \mathrm{iC}_{3}$, e.g. mínbișiț, minbașțah, minbașțin, minbaștāt "rejoicing".

The inflectional base of the verb has been reinterpreted as underlying |inbașiț|, instead of |nbașiț|; verbal prefixes are then vowelless (i.e. $y$-, $t$ - and $n$-) and for the ist p. sg. com. the prefix is $\varnothing$ (see also below inša $\bar{l}$ in 3.2.3.1.3.).

\subsection{Measure n-1 $C_{2}=C_{3}$ (mediae geminatae)}

Patterns for perfect and imperfect of measure $n$-1 of medial geminate verbs are: $\operatorname{inC}_{1} \mathrm{aC}_{2} \mathrm{C}_{3}$ and yinC $\mathrm{aC}_{2} \mathrm{C}_{3}$, e.g. inhatt, yinhatt "be placed" and inșabb, yinșabb "be poured". ${ }^{79}$

\subsection{Measure $\mathrm{n}-1 C_{2}=\mathrm{y}$ or $\mathrm{w}$ (mediae infirmae)}

The patterns for perfect and imperfect of measure $n-1$ of medial weak verbs are: $\operatorname{inC}_{1} \bar{a} C_{3}$ and yinC $\bar{a}_{1} C_{3}$, e.g.

"be carried"

\begin{tabular}{|c|c|c|c|c|}
\hline & perfect & & imperfe & \\
\hline & & pl. & sg. & pl. \\
\hline 3. masc. & inšăl & inšāluw & yinšāal & yinšāluw \\
\hline fem. & inšālat & inšālin & tinšāl & yinšālin \\
\hline 2. masc. & inšilt & inšiltuw & tinšāl & tinšāluw \\
\hline $\begin{array}{l}\text { fem. } \\
\text { 1. com. }\end{array}$ & $\begin{array}{l}\text { inšiltiy } \\
\text { inšilt }\end{array}$ & $\begin{array}{l}\text { inšiltin } \\
\text { inšilne }\end{array}$ & $\begin{array}{l}\text { tinšāliy } \\
\text { inšă } \bar{l} l^{*}\end{array}$ & $\begin{array}{l}\text { tinšālin } \\
\text { ninšāl }\end{array}$ \\
\hline
\end{tabular}

* Notice the absence of vowel harmony, and the paradigmatically fixed intital $i$ -

${ }^{79}$ It is unsure whether the initial vowel of the perfect is $a$ - (i.e. anhatt) or $i$-. 
3.2.3.1.4. Measure n-1 $C_{2}=\mathrm{y}$ or $\mathrm{w}$ (mediae infirmae) participles

Participles are shaped on the pattern $\operatorname{minC}_{1} \overline{\mathrm{a}} \mathrm{C}_{3}:$ minšăl, minšālah, minšā $\bar{l} \bar{n}$, minšālāt "carried away, removed".

\subsubsection{Measure t-1}

No instances of measure $t$-1 were recorded in these dialects.

\subsubsection{Measure 1-t}

\subsection{Measure 1-t sound roots}

Underlying patterns for measure $1-t$ are: $\mathrm{aC}_{1} \operatorname{taC}_{2} \mathrm{aC}_{3} \mathrm{yiC}_{1} \operatorname{taC}_{2} \mathrm{iC}_{3}$. Like in measure $n-1$, raised $a$ is found in unstressed syllables of the surface forms, e.g.: áštigal, yíštigil "work", áttifag, yíttifig "agree" and ástuwa, yístiwiy "ripen; be cooked (of food)". Paradigms for $\mathrm{C}_{3}=y$ are:

\begin{tabular}{|c|c|c|c|c|}
\hline \multirow{2}{*}{ “buy” } & \multicolumn{2}{|l|}{ perfect } & \multicolumn{2}{|c|}{ imperfect } \\
\hline & & pl. & sg. & pl. \\
\hline 3. masc. & áštara & áštaruw & yíštiriy & yištiruw \\
\hline & áštarat & áštarin & tiśtiriy & y'šstirin \\
\hline 2. masc. & ištarayt & ištaraytuw & tíštiriy & tíštiruw \\
\hline fem. & ištaraytiy & ištaraytin & tištiriy & tíštirin \\
\hline 1. com. & ištarayt & ištarayna & ištiriy & ništiriy \\
\hline
\end{tabular}

3.2.3.3.2. Measure 1-t $C_{2}=\mathrm{w}$ or y (mediae infirmae)

An example of a medial weak measure 1-t verb is $i h t \bar{a} g$, yiḥtāğ "need".

3.2.3.3.3. Measure 1-t $C_{2}=C_{3}$ (mediae geminatae)

An example of a medial geminate measure 1-t verb is itazz, yitazz (bi) "be proud (of)".

\subsection{Measure 1-t participles}

Patterns for measure 1- $t$ participles are $\mathrm{miC}_{1} \mathrm{tiC}_{2} \mathrm{iC}_{3}$ (underlying $\mathrm{miC}_{1} \mathrm{taC}_{2} \mathrm{iC}_{3}$ ), $\operatorname{miC}_{1} \operatorname{taC}_{2} \mathrm{C}_{3} \mathrm{ah} / \mathrm{ih}, \mathrm{miC}_{1} \operatorname{taC}_{2} \mathrm{C}_{3} \overline{\mathrm{n}}, \mathrm{miC}_{1} \operatorname{taC}_{2} \mathrm{C}_{3} \overline{\mathrm{a}} \mathrm{t}$.

Examples are: míśtigil "working", miftársih "predatory (of animals)", mistiwiy "ripe, cooked (sg. masc.)", mistáwyih "ripe cooked (sg. fem.)". mittifig "agreed (sg. masc.)", mittafgāt "agreed (pl. fem.)" and mítiniy "taking care of, providing for".

Examples of participles of medial geminate and medial weak verbs are: miḥtāğ "in need", miltammin "having gathered (pl. masc.)".

One example of a passive 1-t participle is mittahamin "accused (pl. masc.)" (cf. C.A. root $w-h-m)$. 


\subsubsection{Measure ista-1}

\subsection{Measure ista-1 sound roots}

Like measure 2, measure ista-1 has morphologically alternating short vowels: $a$ in the perfect and $i$ in the imperfect. The paradigms are:

$\begin{array}{lllll} & \text { "ask for information" } & & \\ & \text { perfect } & & \text { imperfect } & \\ & \text { sg. } & \text { pl. } & \text { sg. } & \text { pl. } \\ \text { 3. masc. } & \text { istafham } & \text { istafhamuw } & \text { yistafhim } & \text { yistáfihmuw } \\ \text { fem. } & \text { istafhamat } & \text { istafhamin } & \text { tistafhim } & \text { yistáfihmin } \\ \text { 2. masc. } & \text { istafhamt } & \text { istafhamtuw } & \text { tistafhim } & \text { tistáfihmuw } \\ \text { fem. } & \text { istafhamtiy } & \text { istafhamtin } & \text { tistáfihmiy } & \text { tistáfihmin } \\ \text { 1. com. } & \text { istafhamt } & \text { istafhamna } & \text { astafhim } & \text { nistafhim }\end{array}$

3.2.3.4.2. Measure ista-1 $C_{2}=\mathrm{y}$ (mediae infirmae)

Measure $i s t a-1$ verbs of medial weak roots were not recorded.

3.2.3.4.3. Measure ista-1 $C_{3}=\mathrm{y}$ (tertiae infirmae)

Measure ista-1 verbs of final weak roots were not recorded.

3.2.3.4.4. Measure ista-1 verbs $C_{2}=C_{3}$ (mediae geminatae)

Patterns for medial geminate measure ista-1 verbs are: istaC $\mathrm{aC}_{2} \mathrm{C}_{3}$, yistaC $\mathrm{iC}_{2} \mathrm{C}_{3}$, an example is $(i)$ sta 'add, yista idd "prepare oneself".

Short $a$ in the perfect preceding stressed $\bar{e}$ may be raised (e.g. ista $a d d \bar{e} t$ $>$ ista iddèt), see also remarks in 3.2.2.7.1. and 3.2.3.5.2.

\subsection{Measure ista-1 participles}

Participles of measure ista-1 verbs have the pattern mistaC $\mathrm{C}_{2} \mathrm{iC}_{3}$, e.g. mista ǧil "in a hurry".

For mediae geminatae the pattern is mistaC $_{1} \mathrm{iC}_{2} \mathrm{C}_{3}$ : mista idd "having prepared, ready".

\subsubsection{Measures 2 and $\mathrm{t}-2$}

Measure 2 has morphologically alternating short vowels: $a$ in the perfect and $i$ in the imperfect. The patterns are: $\mathrm{C}_{1} \mathrm{aC}_{2} \mathrm{C}_{2} \mathrm{aC}_{3}, \mathrm{yC}_{1} \mathrm{aC}_{2} \mathrm{C}_{2} \mathrm{iC}_{3}$.

Measure $t$-2 has morphologically fixed $a$. The patterns are $\operatorname{taC}_{1} a_{2} C_{2} a_{3}$, $\operatorname{ytaC}_{1} \mathrm{aC}_{2} \mathrm{C}_{2} \mathrm{aC}$. $_{3}$

\subsection{Examples of measure 2 sound roots}

Like in group I, the high vowel $i$ of imperfect measure 2 may be elided in open syllables. The inital geminate of the resulting cluster may then be reduced. Examples are: yzabbțuw "they do a proper job", bitțall'uw gișāyid "you (pl. masc.) recite (lit. bring up) poems", biybarrkuw 'așill "they let a throughbred cover", the latter in I.P.A. [bi ${ }^{\mathrm{j}^{\prime}}$ barkow $\left.\mathrm{Pa}^{\mathrm{e}} \mathrm{s}^{\mathrm{e}} \mathrm{i} \mathrm{l}\right]$. 
Similar elisions may take place in sandhi, as in thamms ilbunn "you roast the coffee beans" and $w$ itxalliy tğammr išwayyih "and you let it (burn) a little (to) become glowing embers".

$r$ or $l$ following the high vowel $i$ may inhibit its morphophonemic elision, e.g. itfassiruh "you explain it" and biy'assirin im 'úk išwayyih "they (pl. fem.) have some influence on you".

When $\mathrm{C}_{2}=\mathrm{C}_{3}$, the elision of $i$ does not take place, but the geminate may be reduced, e.g. thálliluh "you analyze it" (I.P.A. [ət'halıl $\left.\mho^{\mathrm{h}}\right]$ ).

3.2.3.5.2. Measure 2 tertiae infirmae

Paradigms for measure 2 tertiae infirmae verbs are:

$\begin{array}{lllll} & \text { perfect }{ }^{*_{1}} & & \text { imperfect } & \\ & \text { sg. } & \text { pl. } & \text { sg. } & \text { pl. } \\ \text { 3. masc. } & \text { sawwi } *_{2} & \text { sawwuw } & \text { ysawwiy } & \text { ysawwuw } \\ \text { fem. } & \text { sawwat } & \text { sawwin } & \text { tsawwiy } & \text { ysawwin } \\ \text { 2. masc. } & \text { suwwēt } & \text { suwwētuw } & \text { tsaww/-iy } & \text { tsawwuw } \\ \text { fem. } & \text { suwwētiy } & \text { suwwētin } & \text { tsawwiy } & \text { tsawwin } \\ \text { 1. com. } & \text { suwwēt } & \text { suwwēni } & \text { asawwiy } & \text { nsawwiy }\end{array}$

${ }^{* 1}$ For raising of $a$ in closed syllable preceding stressed $\bar{e}$ see remark in 3.2.2.7.1.

$*_{2}$ Like in forms of the imperfect (see remark * in 3.2.2.5.2.) final $-i>-\bar{a}$ when suffixed, e.g. sawwāh "he did it".

\subsection{Examples of measure 2 primae hamzah}

The verb "feed" is wakkal, ywakkil, e.g. hatta mā ywakklūne \# "so that they wouldn't give us food", gi adna šaharayn, fi lğbāl hādiy binḥūm. innās kānat bitxāf itwakkilne "we stayed two months in these mountains as we moved around. People were afraid to give us food".

\subsection{Measure t-2 imperfect and perfect}

In measure $t$-2 the vowel $a$ is morphologically fixed for the perfect and imperfect. Patterns are $\operatorname{taC}_{1} \mathrm{aC}_{2} \mathrm{C}_{2} \mathrm{aC}, \mathrm{ytaC}_{1} \mathrm{aC}_{2} \mathrm{C}_{2} \mathrm{aC}$.

Unlike the situation in group I dialects (especially so in those of the Rmēlāt and Sawārkah, see De Jong 2000:212), the ta- prefix in the perfect and imperfect of measure $t-2$ is stable and is hardly ever reduced to $(i) t$ -

When the imperfect preformative $t$ - of the 3 rd p. sg. fem. and of the 2 nd. p. sg. and pl. masc. and fem. precedes, the resulting sequence tta- is reduced to $t a-.^{80}$ For tertiae infirmae $t-2$ verbs the paradigms are:

\footnotetext{
${ }^{80}$ I have referred to this before as a haplological drop of the verbal prefix $t a$ - (from an initial sequence ${ }^{*}$ tata-). This interpretation however pre-supposes verbal imperfect pre-
} 
"have lunch"

\begin{tabular}{|c|c|c|c|c|}
\hline & perfect $^{* 1}$ & & imperfect* & \\
\hline & sg. & pl. & sg. & pl. \\
\hline 3. masc. & tag்addi & tag்adduw & ytag்addi & ytag்adduw \\
\hline fem. & tag்addat & tag்addin & tajaddi & ytag்addin \\
\hline 2. masc. & tagaddēt & tag்addētuw & tag்add $^{* 2}$ & tagadduw \\
\hline fem. & tågaddētiy & tag்addētin & tag்addiy & tag்addin \\
\hline 1. com. & tagiaddēt & tag்addēni' & atag்addi' & ntag்addi' \\
\hline
\end{tabular}

*1 With a verb like ta'ašša, yta'ašša "have dinner" raising of $a$ in the $t a-$

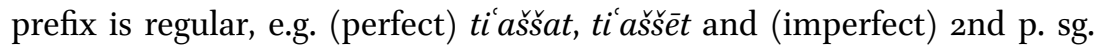
masc. ti aššs.

Notice that the 3 rd. p. pl. masc. and fem. of the perfect have become homophonic with the 2nd p. pl. masc. and fem. (respectively) of the imperfect. And the 3 rd p. sg. masc. of the perfect is homophonic with the 3rd. p. sg. fem. of the imperfect.

Raising of final * $-\bar{a}$ is indicated here as $-i \dot{ }$, but phonetic values may also be slightly lower (i.e. nearer to I.P.A. $\left[\mathrm{e}^{\text {? }}\right]$ ).

$*_{2}$ Notice also apocopation.

\subsection{Measures 2 and $\mathrm{t}-2$ verbal nouns}

Verbal nouns for measure 2 have a taC $\mathrm{C}_{2} \mathrm{C}_{3}$ pattern, e.g. tağlīb "throwing out (of a fish line)", taybīs "drying (trans.)", tadrīb "training (trans.)" and a gahawah-form tahadīr "coming down".

$\mathrm{A}_{3}=y$ verbal noun is found in tirbàt álǧimal "training the camel".

Verbal nouns for measure $t$-2 were not recorded. For the quadriliteral verb ta'aknan, yta'aknan "be annoyed", however, the verbal noun tiknin was recorded.

\subsection{Measures 2 and t-2 participles}

Active participles of measure 2 have a $\mathrm{mC}_{1} \mathrm{aC}_{2} \mathrm{C}_{2} \mathrm{iC}_{3}$ (-ih/-ah, -īn, -āt) pattern, e.g. m'aggid "travelling", m'allig "keeping suspended", for $\mathrm{C}_{3}=y$ msawwiy, msawwyih etc., "making, doing" and for $\mathrm{C}_{2}=\mathrm{C}_{3}$ mğaddid, mğaddidih (without elision of the short vowel $i$ ), etc. "renewing".

The pattern for the passive measure 2 participle is $\mathrm{mC}_{1} \mathrm{aC}_{2} \mathrm{C}_{2} \mathrm{aC}_{3}$ (-ih/-ah, -īn, -āt), e.g.: mlawwan "coloured", mnaššaf "dried, hardened" and mtallal "piled up", for $\mathrm{C}_{3}=y$ msawwa, msawwayih etc., "made, done" and for $\mathrm{C}_{2}=\mathrm{C}_{3}$ mğaddad, mğaddadih etc. "renewed".

fixes like $t a-, y a$-, and $n a$-, whereas these are actually $t$-, $y$ - and $n$ - (the latter two implying the first). The interpretation of reduction of the initial geminate is therefore preferred here. 
The pattern for measure $t$-2 active participles is $\operatorname{maC}_{1} \mathrm{aC}_{2} \mathrm{C}_{2} \mathrm{iC}_{3}$ (-ih/-ah, -īn, -āt), but in participles often the $t a$ - prefix has been reduced to $t$ - (pattern mitC $\mathrm{aC}_{2} \mathrm{C}_{2} \mathrm{iC}_{3}$ (-ih/-ah, -īn, -āt), e.g. mit'așșil "deep-rooted", mithaddir ( min) "originating (from)", mitğawwiz "married" and for $\mathrm{C}_{3}=y$ ) mtagaddiy, mtagaddyih etc. "having eaten lunch" and also mitharriy, mitharryih etc. "striving for, aspiring".

\subsubsection{Measures 3 and $\mathrm{t}-3$}

Like measure 2, measure 3 has morphologically alternating vowels: $i$ in the imperfect and $a$ in the perfect. Patterns for measure 3 are: $\mathrm{C}_{1} \bar{a} \mathrm{C}_{2} \mathrm{aC}_{3}$, $\mathrm{yC}_{1} \overline{\mathrm{a}} \mathrm{C}_{2} \mathrm{iC}$.

Measure $t-3$ has morphologically fixed $a$ in the perfect and imperfect, and like in measure $t$-2, the $t a$-preformative is not often reduced to $t$-. Patterns for measure $t-3$ are: $\operatorname{taC}_{1} \bar{a} C_{2} a_{3}, y \operatorname{taC}_{1} \bar{a} C_{2} i C_{3}$.

Also like in measure $t-2$, the $t a$ - preformative of measure $t-3$ in the perfect is usually not reduced to $(i) t$ -

3.2.3.6.1. Examples of measures 3 and $\mathrm{t}-3$

Paradigms for measure 3 are:

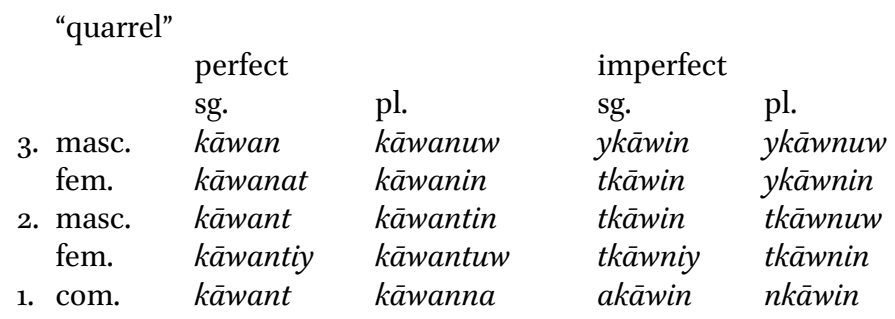

Some suffixed examples are: suffixed: kāwanatuh (stressed on first syllable) "she quarrelled with him", kāwannāh "we quarrelled with him", kāwantinnuh "you (pl. fem.) quarrelled with him" and (imperfect) tkāwnīh "you (sg. fem.) quarrel with him", ykāwninnuh "they (fem.) quarrel with him", $y k \bar{a} w n \bar{u} h$ "they (masc.) quarrel with him".

$\mathrm{A}_{3}=y$ verb has the following paradigms:

\begin{tabular}{|c|c|c|c|c|}
\hline \multirow{4}{*}{$\begin{array}{l}\text { 3. masc. } \\
\text { fem. }\end{array}$} & perfect & & imperfect & \\
\hline & & pl. & sg. & pl. \\
\hline & lāga & lāguw ${ }^{*_{1}}$ & ylāgiy & ylāguw \\
\hline & lāgat & lāgin ${ }^{* 1}$ & tlāgiy & ylāgin \\
\hline 2. masc. & lāgēt & lāgētuw & $t \operatorname{ta} g^{* 2} /-i y$ & tlāguw \\
\hline fem. & lāgētiy & lāgētin & tlāgiy & tlāgin \\
\hline 1. com. & lāgēt & lāgēna & alāgiy & nlāgiy \\
\hline
\end{tabular}


$*_{1}$ Notice the absence of vowel harmony in the endings: - $u w$ and -in instead of -aw and -an current in group I.

$*_{2}$ Apocopated 2nd p. sg. masc. imperfect forms also occur in measure 3.

Some examples of suffixed forms are: hū lāgāh "he met/found him", hì lāgát"k "she met/found you (sg. masc.)", hì lāgatuh "she met/found him" (cf. 3.1.10.5.) and hinnah biyläginnuk/-innik "they meet/find you (sg. masc./fem.)".

Examples for measure $t-3$ are: [kān] bintarāfag iw bintasābag "we used to travel together and race together" and (for $\mathrm{C}_{3}=y$ ) bukrah hantalāga "tomorrow we'll meet", huwwa ytalāguw "they meet", intin talāgin (like in measure $t$-2, initial $t t a$ - is reduced to $t a-$, cf. 3.2.3.5.4.) "you (pl. fem.) meet". The vowel $a$ preceding stress may be raised, as in the example yti $\bar{a} l a g$ "he receives medical treatment" and the perfect tihâlafuw "they became allies".

Notice again the absence of vowel harmony in the 3 rd and 2nd p. pl. masc. and sg.: $-u w$ and -in, contrasting with -aw or -ow and -an in group I.

\subsection{Measures 3 and $\mathrm{t}-3$ participles}

Active participles of measure 3 have the pattern $\mathrm{mC}_{1} \bar{a}_{2} \mathrm{iC}_{3}(-\mathrm{ih} /-\mathrm{ah}$, -inn, -āt), e.g. mğăhdīn "fighting (pl. masc.) in a ğihàd", $m k \bar{a} f^{\prime}{ }^{\prime}{ }^{2}$ "compensating (sg. fem.)".

A passive participle (pattern $\mathrm{mC}_{1} \overline{\mathrm{a}} \mathrm{C}_{2} \mathrm{aC}_{3}$ ) is mtāaradin "having been pushed back (in a fight)".

Active participles of measure $t$-3 have the pattern $\operatorname{mtaC}_{1} \bar{a} C_{2} i_{3}$ or mitC $_{1} \bar{a}_{2} \mathrm{iC}_{3}(-\mathrm{ih} /$-ah, -īn, -āt); like in participles of measure $t$-2 (cf. 3.2.3.5.6.), the $t a$ - preformative is often reduced to $(i) t$-. Both mtawāğdih and mitwāğdih "present (sg. fem.)" were recorded and also mithāyig lay "it seems to me" (cf. MSA root h-y-').

\subsection{Measures 3 and $\mathrm{t}-3$ verbal nouns}

A verbal noun for measure 3 that was recorded is ǧihād "war against unbelievers" and another is $m s \bar{a}$ 'adah "help, assistance". Verbal nouns of the type $\mathrm{tC}_{1} \mathrm{e} \mathrm{C}_{2} \mathrm{iC}$ were not recorded. ${ }^{81}$

\subsubsection{Measure 4}

\subsection{Measure 4 sound roots perfect and imperfect}

Like in many Bedouin dialects of Sinai, verbal measure 4 is found in group VI as well.

\footnotetext{
${ }^{81}$ Such as they have been reported for the dialect of the Ahaywāt of group I, see Stewart 1990: 186 (text 69) and 118 (text 37).
} 
The patterns are $\mathrm{aC}_{1} \mathrm{C}_{2} \mathrm{aC}_{3}$ for the perfect and $\mathrm{yiC}_{1} \mathrm{C}_{2} \mathrm{iC}_{3}$. The paradigms are:

\begin{tabular}{|c|c|c|c|c|}
\hline \multirow{6}{*}{$\begin{array}{l}\text { 3. masc. } \\
\text { fem. } \\
\text { 2. masc. } \\
\text { fem. }\end{array}$} & \multicolumn{2}{|l|}{ perfect } & \multicolumn{2}{|c|}{ imperfect $^{*_{2}}$} \\
\hline & sg. & pl. & sg. & pl. \\
\hline & áfțar & áfțaruw ${ }^{* 1}$ & yifțir & yíftetrux \\
\hline & áftarat & áfțarin ${ }^{* 1}$ & tifțir & yífitrin \\
\hline & ifțart & ifțartuw & tifțir & tíftitruw \\
\hline & ifțartiy & ifțartin & tífitriy & tíftẹin \\
\hline 1. com. & ifțtart & ifțarna & ifțir & nifțir \\
\hline
\end{tabular}

*1 Notice again the absence of vowel harmony in the endings

$*_{2}$ The anaptyctic vowel in forms like (here underlined) tifitruw and $y$ ffitrin is voiceless and therefore barely audible.

3.2.3.7.2. Measure ${ }_{4} C_{2}=\mathrm{w}$ or $\mathrm{y}$ (mediae infirmae) perfect and imperfect Patterns for measure 4 mediae infirmae are: $\mathrm{C}_{1} \overline{\mathrm{a}} \mathrm{C}_{3}\left(\mathrm{C}_{1} \mathrm{iC} \mathrm{t}_{3}\right) \mathrm{yC}_{1} \overline{\mathrm{1}} \mathrm{C}_{3}$, e.g. ra $\bar{a} d$ "he wanted", ridt (I.P.A. [rit:]) "I wanted", yrid "he wants". The paradigms are like those of $\check{s} \bar{a} l, y \check{s} \breve{l}$ (

Some examples of suffixed forms are: rādatih "she wanted him", ridnāh "we wanted him", intuw ridtūh "you (pl. masc.) wanted him", intin ridtinnuh "you (pl. fem.) wanted him" and rādinnuh "they (fem.) wanted him".

3.2.3.7.3. Measure $4 C_{3}=\mathrm{y}$ (tertiae infirmae) perfect and imperfect The patterns for measure $4 \mathrm{C}_{3}=y$ (tertiae infirmae) are $\mathrm{aC}_{1} \mathrm{C}_{2} \mathrm{a}$ (perfect) and $\mathrm{yiC}_{1} \mathrm{C}_{2}$ iy (imperfect). The paradigms are:

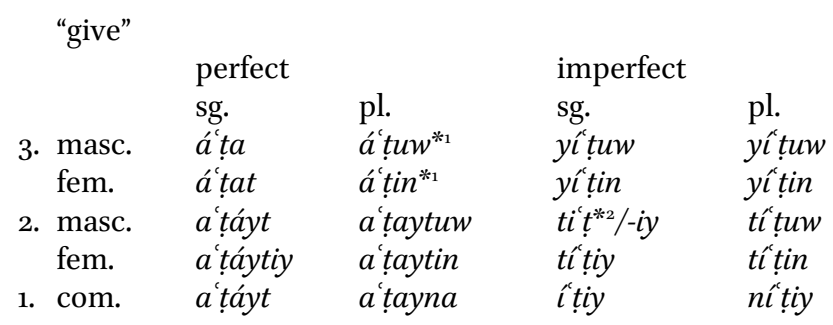

*1 Notice the absence of vowel harmony in the endings in tertiae yầ perfects as well: $-u w$ and -in instead of -aw and -an current in group I.

${ }^{*}$ Notice the presence of the apocopated 2 nd p. sg. masc. forms in measure 4 as well.

Some suffixed examples are: hinnah a ținnuh "they (fem.) gave him" and hinnah a'ținnuh iyyāh "they (fem.) gave it to him". 
3.2.3.7.4. Measure ${ }_{4} C_{1}=\mathrm{w}$ (primae wāw) perfect and imperfect

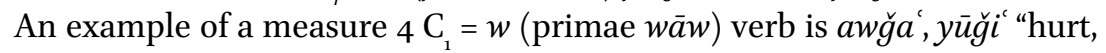
cause pain to", e.g. ibtūğ uh "it (sg. fem.) hurts him" and 'idnī awğa 'atnī "my ear hurt me".

3.2.3.7.5. Measure ${ }_{4} C_{2}=C_{3}$ (mediae geminatae) perfect and imperfect Verb forms of measure $4 \mathrm{C}_{2}=\mathrm{C}_{3}$ (mediae geminatae) were not recorded, or not recognized as such.

\subsection{Measure 4 imperatives}

Examples of imperatives for measure 4 sound roots are like imperatives for the $i$-type imperfect (see 3.2.1.5.).

Imperatives of $\mathrm{C}_{3}=y$ roots are: $i^{\prime} t$ (apocopated), it tiy, it tuw, it tin. Suffixed examples are: i'ițh-iyyāha "give it (sg. fem.) to her", ițuh luh "give it to him".

\subsection{Measure 4 participles}

The participles for sound roots have a miCCiC pattern, e.g. mifțir, mifftrih, mifițīn, mifitrāt "having eaten breakfast".

For mediae infirmae there are participles of the type $m r \bar{\imath} d,-i h,-\bar{\imath} n,-\bar{a} t$ "wanting". ${ }^{82}$ Another example is $m \dot{g} \bar{\imath}$ " "running".

3.2.3.8. Measure 9

Paradigms for measure 9 are:

\begin{tabular}{|c|c|c|c|c|}
\hline & perfect & & imperfect & \\
\hline & sg. & pl. & sg. & pl. \\
\hline 3. masc. & iḥmarr & iḥmaṛruw & yihmart? & yihmmarruw \\
\hline fem. & ihmmarrat & iḥmarṛin & tihmmaṛ & yihmarrrin \\
\hline 2. masc. & ihmarrayt & ihmarrraytuw & tihmarr & tiḥmarruw \\
\hline $\begin{array}{l}\text { fem. } \\
\text { 1. com. }\end{array}$ & $\begin{array}{l}\text { ihmarraytiy } \\
\text { ihmarrayt }\end{array}$ & $\begin{array}{l}\text { ihmarraytin } \\
\text { ihmarrayne }\end{array}$ & $\begin{array}{l}\text { tihmarrịy } \\
\text { ahmarrr }\end{array}$ & $\begin{array}{l}\text { tihmarrin } \\
\text { nihmarr }\end{array}$ \\
\hline
\end{tabular}

Particples are: miḥmaṛ, $-a h,-\bar{\imath} n, \bar{a} t$.

3.2.3.9. Quadriliteral verbs

Like measure 2, quadriliteral verbs have morphologically alternating vowels in the imperfect $(i)$ and perfect $(a)$.

\footnotetext{
${ }^{82}$ Though for the verb rād, yrīd measure 1 participles rāyid, -ih etc. were also accepted by my informants.
} 


\begin{tabular}{|c|c|c|c|c|}
\hline & perfect ${ }^{* 1}$ & & imperfec & \\
\hline & sg. & pl. & sg. & pl. \\
\hline 3. masc. & zagrat & zág்rațuw & yzaġrit & yzágirțuw \\
\hline fem. & zágrațat & zaġrațin & tzaġrit & yzágierțin \\
\hline 2. masc. & zagirațt & zaǵrațtuw & tzagriț & tzágiirțuw \\
\hline fem. & zaġrațtiy & zaǵrattin & tzágirțiy & tzáġirțin \\
\hline 1. com. & zag்rațt & zagrațe & azagriț & nzagrriț \\
\hline
\end{tabular}

${ }^{* 1} t t$ is assimilated to $t \underline{t}$, e.g. zagrattiy.

*2 Initial $t z$ is assimilated to $d z$ or $z z$, e.g. (partially) \# idzagriṭ or (totally) \# izzagriț.

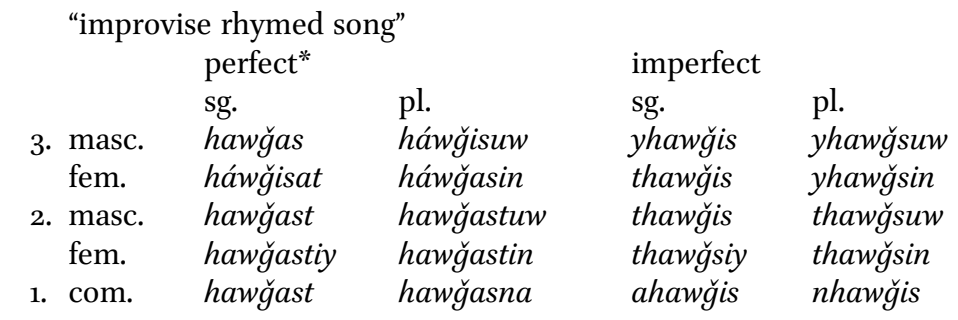

* Forms like hawğisat and hawğisuw show raising of $a>i$ (see 3.1.1.7.).

The verbal noun is hǧèsiy or thĭğis. Similarly, the verb hawğan, yhawğin "improvise rhymed song in public" has verbal nouns hğèniy or thïğin.

\section{Remarks on Phraseology}

\subsection{Nunation}

Tanwin is not a feature of MzA or BWA.

Of course, there are the loans from MSA, which may have come via other dialects, such as masalan "for instance"; the $s$ for *t (in a tā'-speaking dialect!) is a clue that this loan came via a dialect in which interdentals are not part of the phoneme inventory, such as Cairene.

Other examples of such MSA loans with nunation are: tab an "of course", tagrïban "approximately", 'așlan "in origin", filan "indeed, actually" and hâaliyyan "currently".

\subsection{Negation}

Negating a verb is done with $m \bar{a}$ preceding the verb form, although bipartite $m \bar{a}+$ verb form $+\check{s}$ is also used. Of my informants, one speaker 
used $m \bar{a}+$ verb form for more emphatic negation (almost always in combination with $x \bar{a} l i s ̣$ "at all") and the compound negation for 'normal' negation. Another informant, who actually speaks the 'original' dialect better, used the single negation, and only the compound negation by way of exception.

Examples are iw biytaraǧğuw Imašāyix illiy kān ḥinha mawğūdīn mā ywaddūhuw Falaștīn iywaddūhuw Mașir \# "and they asked the sheikhs, who were there at that time, not to send them to Palestine, (but) to send them to Egypt..." and hād-illiy yainiy btākluh, law mā lihág daktūr aw hāwiy biymūt "and this (person) that he (i.e. a snake) bites, if he doesn't (quickly) get to a doctor or a snake charmer, he dies".

\subsection{The b-imperfect}

The originally sedentary feature of the $b$-imperfect to express the habitual present tense is widespread in Sinai. ${ }^{83}$

Some examples are iw biddugg bi 'ìd ilhōn ingūl 'alēh 'ìd ilhōn, iw ba'ad kidiyyih ... ilbarrāad hü ibyiğtiy binhuuțt èh? "and you pound it with the pestle, we call it the pestle, and after that... (when the water in) the teapot is boiling and we put what?" and hù mūhū fāhim kidiy, hü mūhu 'ärif ...innha mā bitrìduh "he did not understand this, he did not know ... that she did not want him" w Allah btug ud kidiyyih w bitgahwiy $n n \bar{a} s^{84}$ iw btaxarrafa iw bitğīb ... bithawğis ilkalām illiy zimān "By God, you sit down like this and you give the people coffee (or tea ${ }^{85}$ and you talk and you get ... you improvise the type of talk of old times".

See also remark in $3 \cdot 2.2 .4$. on reduction of the diphthong in a form like biyšll > bišll.

\subsection{Future Marker}

To express "volition" or "need" MzA uses bidd + pron. suffix (see also 4.11.). ${ }^{86}$

Often not only volition or need is expressed, but also a sense of futurity of the action expressed in the following verb. Examples are: (futurity)

\footnotetext{
${ }^{83}$ It is current in all dialects of Sinai, except in that of the Dawāgrah, see De Jong 200o: 224-226, 318-319, 394, 478, 527 and 691 (map 69).

${ }^{84}$ bitgahwiy nnās or bitgahw innās (the latter with apocopation); these two sequences are homophonous.

${ }_{5}$ The verb gahwa, ygahwiy is used for "serve a hot drink", i.e. either coffee or tea.

${ }^{86}$ In contrast, widd is current in group I, see De Jong 2000:238-239.
} 
halhinit bidd-āxd iššuggah $w$ uxušš... w unšur "now I shall take the net and go in (i.e. into the water), and spread it".

To express futurity. the imperfect form may also have prefixed $h a-$, e.g. ya'niy halhīnit álwalad il'așill illiy hü 'indina nihä'...hatlāguh ibyasma' kilamm ubūh "that is, the true son that we have here with us, you will find that he listens to what his father says". In the instances recorded, this hawas invariably used to express inevitability connected to stating a general truth. law istagduw 'a lhikāyah diy, hayagța'-áššiğar, ${ }^{87}$ hayagța'ūh "if they would seek to imitate this (story), they would cut down the trees, they would cut them down".

In the many cases, however, the future is expressed with the simple imperfect, as in intah law ga'att bukrah hinih, ašüfluk wähid iygülluk èh? 'al-êh? 'ala ttadrïb dih. "If you stay here tomorrow, I'll get you someone who will tell you what? About what? About this training (of camels)".

\section{5. fih "there is / are"}

fih is used to express existence or availability of something, ${ }^{88}$ e.g. iw fih $i$ 'ša $a$ fi lbarr bitdāwiy ssukkar "and there are herbs in the desert which cure diabetes".

The negation is usually $m \bar{a}$ fih (or K-form ma fišs), e.g. $\dot{g} \bar{a} r$ ánnaxal, $m \bar{a}$ fih izrä ah zamān "there were only palm trees, in the old times there was no agriculture".

Also māš may be used for negation (but was only heard in BWA): gab! ilfașil kān ya niy ḥ̂ēl alfèn ițtalā ... ya niy māš kațīr "before the seperation there was, that is, around two thousand, three...that is, there was not much" and $w$ Allāhiy māš isdūd fihe ... iblādna hädiy "By God, there are no dams in it... (in) (this) our land".

\subsection{Some Conjunctions}

4.6.1. Conjunctions lamma and yōm

Like in many dialects of Sinai, conjunctions lamma and yōm, or variant forms based on these, are used for "when". ${ }^{89}$

\footnotetext{
${ }_{7}^{8}$ hayagța'uw + aššiğar.

${ }^{88} \mathrm{fih}$ 'functions as a prepositional predicate of a nominal sentence', cf. Grotzfeld 1964:87.

${ }^{89}$ For use of yōm in dialects of northern Sinai, see De Jong 2000:692 (map 71).
} 
4.6.1.1. yōm

\subsubsection{1. yōm used independently}

yōm may be used meaning "when", e.g. yōm lihguw war-álbil, șār ilkōn...yōm șār ilkōn gāmuw gasamuw mi iZwayyid innuṣṣ "when they had caught up with the (tribe who had stolen their) camels, there was a fight. When the fight was over they then ${ }^{90}$ divided (the camels) equally with (Sheikh) Zwayyid". Another example is ya niy kïlu ... ițnēn kïlu yōm ma fiš hawa xăliṣ "(we catch) like a kilo, two kilos when there is no wind at all” and fìh mayyih, halhīn ilğbāl yōm tiğhi', subhāan Alḷāh rabbna mí tiniy kull šiy "there is water. If you come to the mountains now-God be praised-our Lord takes care of everything".

4.6.1.1.2. yōm in combination with in

\subsection{1. yōmin used independently}

yōmin may also be used for "when", like in the following example: ya'niy kunna šabāb 'ala zzamil w intasābag w insābig yōmin nğ-ál'arab, ${ }^{91}$ fihimt lay $k \bar{e} f$ ? "that is, we were young lads riding camels, and we'd race each other and we'd race and when we'd come to the village, you see what I mean?"

yōmin was only recorded in BWA.

4.6.1.1.2.2. yōmin + obj. suffix as subject of the clause

There were no instances of direct suffixing of yōmin.

\subsection{3. $\min$ yōm}

min yōm(in) is often used for "as soon as" or "from the moment that", e.g. kunt fi Mațariyyih sākin, bass bašūf ilǧbālāt hādōlah 'ala 'yūn̄̄ $w$ aná $f i$ Mațariyyih law-ddūnì min yōmin fakkat Sīnih, law kull yōm alf iğnēh mānì $g \bar{a} i d$ "I was living in Mațariyya, ${ }^{92}$ but I kept seeing these mountains on my retina (lit. my eyes) while I was in Mațariyya. (even) If they, ever since Sinai was liberated, would have given me a thousand pounds for every day, I would not have stayed (in Mațariyya)".

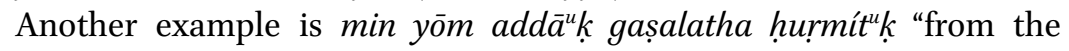
moment that they have given you her twig,93 she's your wife".

${ }^{90}$ gāmuww (lit. "the stood up") is here translated as "then", i.e. like unconjugated gām, which is often used in narrating a chain of events that took place in the past, see De Jong 2000:231.

${ }_{91}^{1}$ nğì + ál-'arab.

${ }_{92}$ Many members of Bedouin tribes in Sinai spent the years of the Israeli occupation of Sinai (following the 1967 war) as refugees in the Egyptian Nile Delta.

${ }^{93}$ A twig is traditionally given to the groom in betrothal ceremonies as a token of the girl's engagement to him. 
4.6.1.1.2.4. min yōm in combination with ma

4.6.1.2. lamma and lumma

Both lamma and its variant lumma (probably a hybrid form of lamma and yōm ma) are often used for "when" and "until".

4.6.1.2.1. lamma and lumma "when" used independently

Examples of lamma used for "when": alhinit lamma bigūl luk intah min wèn? bitgūl luh ana Mzèniy "now, when he says to you 'Where are you from?' You say to him 'I am a Mzēniy”, inhum gōtaruw hnúh aṣil lamma tfakkir Sìna zamān alblād hèdiy mahál "they went there because when you would see (as it was) before this land was dry".

An example of lumma (current in MzA, but not in BWA) inta lhin

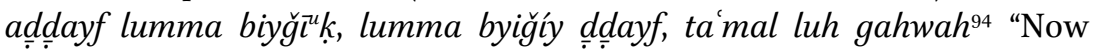
when the guest comes to you, when the guest comes, you make coffee for him".

4.6.1.2.2. lamma + in. lamma or lumma + in was not recorded

4.6.1.2.3. lamma and lumma "until"

lumma (see also remark below in 4.6.1.3.) or lamma may be used in combination with la $\dot{g} \bar{a} y i t$ for "until", e.g. (prosodically lengthened $a$ in the first syllable) la: $\dot{g} \bar{a} y i t$ lumma ddaxanah btabga bẹ $\bar{d} \bar{a}$ " "until (when) the smoke becomes white". But also without laḡayit, as in iw byinhațt luh šwayyih zayy ma tgūl fi ššmis lamma yrūb "and it is placed in the sun a bit, as you say, until it curdles" and bithuțt...ğamir issiyyāl nār lamma táhağam "you put... coal of the acacia tree in the fire (and wait) until it becomes coal". ${ }^{95}$

4.6.1.3. $\operatorname{lōm}(+$ in $)$

An example of lōm + ma was recorded in MzA: iw ğina Diháb nihāniy lōmma midāris fátahin ... "and we came to Dahab here when schools (were) opened". lumma of the preceding paragraph is to be interpreted as shortened lōm+ma.

lòm was not heard in BWA.

\footnotetext{
${ }_{94}$ The last part of the sentence shows Koine influences; instead of ta mal luh gahwah, proper MzA would be more something like itsaww luh gáhawah or tgahwīh.

95 "Become coal" is a gloss from my informant. I could not find a dictionary which lists this verb, but I suppose that the root $h-\check{g}-m$ is in some way related to the root $\breve{g}-m-r$, as in ğamriyyih "glowing ember".
} 
4.6.2. hatta

\subsubsection{1. hatta "until", "so that"}

hatta "until" was recorded in bitdugguh iw biti: $\dot{g} l u h^{96}$ 'ala lmayyih aw mā hatta tiğluh 'a lmayyih "you pound it and boil it in water or water until you boil it in water".

hatta was also recorded meaning "so that": yainiy halhịnit álwalad il'aṣil illiy hū 'índina nihà'... hatlāguh ibyasma' kilām aḅūh. ibyarḍa' ...ya'niy

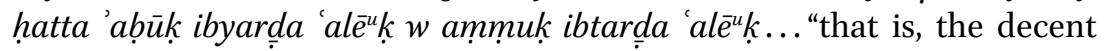
son that we have here (in our community)...you'll find that he listens to (the words of) his father. He is pleased.... that is, so that your father is pleased with you and your mother is pleased with you".

\subsection{Auxiliaries and Verbal Particles}

4.7.1. gām

Unconjugated gām used as a 'marker of consequent action' was not recorded in these dialects. In only one instance (but conjugated) gāmuw was used in a narration of events: yōm șār ilkōn gāmuw yōm liḥguw warálbil, șār ilkōn ... yōm șār ilkōn gāmuww gasamuw mi iZwayyid innuṣṣ "when they had caught up with the (tribe who had stolen their) camels, there was a fight. When the fight was over they then divided (the camels) equally with (Sheikh) Zwayyid".

4.7.2. rāạ

rāh was not recorded as an auxiliary or particle in MzA or BWA.

\subsubsection{Conditional particles}

\subsubsection{Variations on kān as a conditional particle}

4.7·3.1.1. in + kān

An example of in + kān "if": min zilìt iṣgayyir zayy zilìt șaryd aw zilìt ġanám mā y young animal like a young gazelle or a young goat, it is not bad, but if it is from the young gazelle, it is better for the 'ukkah". ${ }^{97}$

\footnotetext{
${ }^{9}$ Prosodic lengthening is here used to express long duration of time, see also 1.2.3.5.

97 A 'ukkah is like a watersack (girbih) made from animal skin, but smaller and made from the skin of a young animal, making the leather smoother.
} 
4·7·3.1.2. Suffixed inkān

Instances of suffixed $k \bar{a} n$ were not recorded.

4.7·3.1.3. il + kān

Instances of $i l+k \bar{a} n$ were not recorded.

4.7.3.1.4. kān preceded by CA loans iz or iza

An example of kān preceded by iz or iza meaning "if": (a line of poetry) $w$ izkān intuw bitliffūh 'ala miyyih "and if you're going to be around here a hundred (counts)" and ra'āníy[yih]...alimsimmih diyyih. diy iz kān nilgāha fi šgāgni' ... ġār nagța aššuggah kidìy ...w ințuššhi' "a scorpion fish, this venemous one. If we find this in our nets, we have to cut the net like this... and throw it away".

\subsubsection{5. kān as an independent conditional}

An example of kān used independently as conditional "if": iḥna bniftixir bèha hatta kān biygūluw waddiy w hätiy "we are proud of it (sg. fem.) even if they treat us like slaves (lit. they say "bring (this), get (that)!")".

Another example is: law žin ib tafkìr, kān iddarāhim dillih...masalan alḥinit 'ašar $t$-ālāf . . ixlāl arba' $t$-ušhur xamis $t$-ušhur ... il'ašar $t$-alāf dillih talghin 'išrin alf "if it (i.e. the money) came (to you) by brainwork, if this money...for instance it is ten thousand now...over four or five months...you'll find that these ten thousand pounds have become twenty thousand".

4.7·3.1.6. kān, inkān or ilkān introducing alternatives

kān may introduce alternatives, like in hakamuw 'alēhuw b sinih țarid ... min Sìnih b ilmarrrah ḥatta mā ywakklüne ... kān wālidtī w uxtī w uxūyw ...yainiynāsī..."they sentenced them to a year of total exile ... from Sinai, so that they would not (be able to) feed us, be it my mother and my sister and my brother and... (all) my family, that is".

Another example is: $w$ inḥutțuh fiha. kān giliệ aw irfayyi lāzm iykūn miš ya'niy nō'ayn "and we put it in there. Be it thick or thin, it shouldn't be two kinds (mixed), that is".

4.7.3.2. Absence of a conditional particle

Often conditional sentences are not introduced by a particle, e.g. il...alhìn ákalat ib sínnaha, hū ytiff kidiy f-ìdu, iw yaxabața kidiy "the... now if it has bitten with its tooth, he (i.e. the snake charmer) spits in his hand, like this, and slaps it (sg. fem. i.e. the place of the bite)" and ligațāh fi lxēt. iw mnä ... mnimšiy šwayyah zayy 'ašarah mitir, iw binunšur țāniy "if we have 
caught it in the net, (and) then we what? We walk a little farther, like ten metres, and we throw out (our net) again"..$^{8}$

\subsection{Presentative Particles}

4.8.1. ir ${ }^{\mathrm{c}}$ or ar $^{\mathrm{c}}$

Presentatives ir' or $a r^{\prime}$ were not recorded.

4.8.2. hē + suffix

To draw the listener's attention to something or someone, a presentative particle $h \bar{e}$ may be used followed by a personal pronominal, e.g. hēhū ği' "there he is!", hēhī ğàt "there she is!", hēhuwwa ǧuw "there they (masc.) are!", hēhinnah ğin "there they (fem.) are!" (lit. "has/have come").

\subsubsection{Particle wlin $\sim$ wilin, win}

The particle wlin is used mainly to present a sudden or unexpected turn in a narration, ${ }^{99}$ but in the following example the development referred to is hardly unexpected or sudden: 'ašar dagāyig iw tiglibha ma fiš dig ... kam digìgih $w$ tiglibha 'a lğâl ițtāniy $w$ linnhī yōm ástuwat ... bitțalliḥha "ten minutes and you flip it over after less than a min ... a few minutes and you turn it on its other side and there it is, when it has become cooked...you take it out".

Another example is with the variant particle ilin + suffix: $w$ fi lxarrāfah diyyih ... ilinnih irkāb ğin ${ }^{100}$ "and in this story ... there they were, the riding animals came" (recorded in MzA).

\subsubsection{Particle wlā +}

An example of the presentative particle $w l \bar{a}$ (used more or less like $w l i n$ ): w ibtalhagha 'a ș̣āăg galibtēn talātih wlāha mistawyih "and you put it on the șāğ and flip it two or three times, and there it is: cooked!" (recorded in BWA).

${ }_{98}^{8}$ The fishing technique described is with nets (sg. šuggah, pl. šgāg) on a line (xayt; here $x \bar{e} t$ ) while the fishermen stand on the edge of the coral reef by the deep water ('ala harf ilbāhah) and throw out their nets on the deep side.

99 See Blanc 1970:34 (145).

${ }^{100} r k a \bar{b} b$ is pl. (of small numbers) of irkābih. Notice that the reference is in the pl. fem., see 'concord' in 4.16. 


\section{9. ġayr}

$\dot{g} \bar{a} r(<\dot{g} a y r)$ may be used preceding imperfect forms to express the necessity of the action, e.g. ilimhilliy gär iyxaddim 'a dd d̦ayf "the host should serve the guest" and rawwahna luh, ana gult èh? ġär arawwih luh. awaddìh lalhurmah diy, yimkin áššifi' 'al-îdhi "we went to him, [and] I said what? I need to go to him. I'll take him to this woman, maybe she can cure him (lit. the cure is by her hand)".

\subsection{Intensifying Particle la}

The particle la intensifying the 1st p. sg. com. was not recorded.

$$
\text { 4.11. bidd } \text { or widd + pron. suffix }
$$

To express "want" or "need" speakers of BWA use bidd and widd side by side (the latter is heard more inland, the former nearer to the coast). In MzA only suffixed bidd is common. ${ }^{101}$ Examples for "need" or "want" are: widdna nlaggiy Wãdiy Sli"102 "we want to go to Wadiy Islah" (BWA), ēš bidduk? "what do you want?", bidduh yāxid šiǧár mi-nhāniy iỵhállituh "he wants to take plants from here to analyze them (sg. masc.)".

Like in other dialects as well, often not only volition is expressed, but also a sense of futurity of the action expressed in the following verb, e.g. halhinit bidd-āxd iššuggah w uxušš...w unšur "now I shall take the net and go in (i.e. into the water), and spread (it) out".

\subsection{2. ‘̄àd}

The particle ' $\bar{a} d$ is current to express "so, thus, then". Examples are: ' $\bar{a} d$ yōm tišrif 'ala šarafat ilGā ibyinșabb ġād fi sēl Wādiy Fērāan "so when you look out at the highest point of alGā' it flows there into the flood course of Wadi Fērānn" and 'âd wèn lagga? "so where did he go?".

\subsection{3. yabga}

yabga is not very current, but may be heard at times meaning "so, then", as in yabga táámhin hiluw "so their (pl. fem.) taste is sweet".

\footnotetext{
${ }^{101}$ In group I widd is current.

${ }^{102}$ Wãdiy Isla (as it is usually indicated on maps) runs from almost due east of aț-Ṭur into the mountains. In group I the name of this wadi is pronounced Sliy (cf. 1.2.4.4. and 3.1.5.).
} 


\subsection{Characteristics of the Narrative Style}

\subsubsection{Imperative of narration}

The narrative imperative is one of the characteristics of the narrative style. An example is $w$ ashabuw syūf. zimān ġār b isyūf. [...] iw taxx taxx taxx $w$ asla'uw kitif wāḥid, iw hū yušurud, úšurduw rawwḥuw tTarāāin..."and they drew (their) swords. In the old days it was only with swords [...] And they hit and hit and hit, and they wounded somebody's shoulder, while he was fleeing, they fled and went to the Tarābīn". Another example is (after somebody had stepped on a mine) innās ğuw 'ilēh dammuh kulluh $f i$ ddag'ah, nāzil ... zayy ssēl. limmūh $w$ ahānuw dammuh, iw hutțuw 'a lbi' ìr iw yimšuw "people came to him, all his blood had run on the ground ... like a flood. They gathered it together and buried his blood and put him on a camel and they went away".

\subsection{2. kān as a temporal marker}

As another characteristic of the narrative style, unconjugated kān can be used as a marker to indicate the past, e.g. bass zimān fi sSu'üdiyyah hnütiy kān innās mā btalga tākil "but in the past in Saudi Arabia over there people could not find (anything) to eat", ilmayyah kān bitganniy fi lwādiy hā $\underline{d} a$ "water used to flow through (narrow) canals in this wadi". In most cases, however, kān is conjugated for number and gender.

\subsubsection{Dativus ethicus}

Several instances of the ethical dative were recorded. Examples are: kān 'indin-ayw-marākib ... marāāib bass iṣgayyrāt yainiy ... iṣggayyrāt ...tálātah mitir aw arbá ah mitir ya'niy timšiy bēhin min ba'ad ášša'ab timš luk itnēn bēha "yes, we used to have boats...boats, but small, that is...small ones ...three or four meters (in length), that is, you go with them beyond the reef, you go for yourself two (kilometers) with them". Another exam-

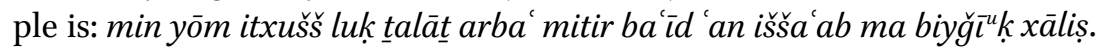
lākin law mišèt 'á-šša'ab byimšiy warăa ḳ "when you go (for yourself) in (into the sea) three or four metres, far away from the reef, it (i.e. the Morray eel) will not come to you at all. But if you walk on the (edge of the) reef, it will come after you". 


\subsection{Pluralis paucitatis}

For limited or countable numbers often the healthy plural form is used, instead of the broken plural. Examples are: tamān fațīāt 'ašar fațīrāt "eight loaves, ten loaves". Another pl. form, used for greater or unspecified numbers is the broken pl. fațāyir.

Similarly, a pl. is used in designations of quantity like $w$ ithutț 'alèhin èh? gadd 'ašar iğrāmāt minhin "and you put what on them? About (the quantity of ) ten grams of these (lit. them (pl. fem.)" (see remark in fn 63, p. 148) and 'ašar kìlāt ( 'ašarah kìlu) "ten kilos".

\subsection{Concord}

Limited or countable numbers of things are referred to in the pl. fem. and so are plurals of animals. Examples are: binğīb arruǵfận iw birrağǧidhin f-áșahan "we bring the loaves of bread and we pile them up on a plate" and il'ašar t-aläf dillih talghin 'išrin alf"these ten thousand (pounds), you'll find them (to have increased to) twenty thousand". Other examples are: halḥin ilwidyān ...ağlabīyttin la Biniy Wāṣil...ka milkiyyih, tawğad lēhin warág fi ddēr, tawğad lèhin warág kidìy...yainiy...ag̉!abìyt ilwidyān inNabig...išŠarim ... "nowadays most of the wadis belong to the Baniy Wāṣil... as property, you'll find a piece of paper on them in the monastery, you'll find a piece of paper on them like that ... that is ... most of the wadis near Nabg, Šarm...". Also plurals of animals are referred to in pl. fem., e.g. iw fìh huūt kițīr f-álbiḥar iw fìh igrūš, bass igrūš dìy mā-ḥadd yainiy mā-hadd ibyākilhin.bass ya niy ibniștādhin barḍh b ilxayt biyğín fi lxayt barduh "and there is a lot of fish in the sea, and there are sharks, but these sharks, that is, nobody eats them. But, that is, we fish for them also with a line, they also come on a line".

\section{A Sketchy Remark on Pitch}

The type of pitch often heard in the speech of (predominantly older) men of group I was not heard in MzA or BWA. ${ }^{103}$

\footnotetext{
${ }^{103}$ I merely conclude the absence of this feature in my material. I do not exclude the
} possibility of its existence in this group. 
CHAPTER THREE

\section{A DESCRIPTION OF THE DIALECTS OF THE TARĀB̄īN, HWWĒṬĀT, ĞARĀĞRAH, TAYĀHA, BADĀRAH, DBŪR AND MALĀLHAH}

\section{INTRODUCTION}

In this chapter the Bedouin dialects of the Tarābīn' (of Rạas Ṣadr on the Gulf of Suez, abbreviated as TAȘ, and of Nwēbi' on the Gulf of 'Aqabah, abbreviated as TAN), Hwētāat (of Ǧidy in Sinai, ${ }^{2}$ abbreviated as HwA), Ğarāğrah (of Malbad, some $40 \mathrm{~km}$ to the southeast of Rāa Ṣadr, ${ }^{3}$ abbreviated as ĞrA), Tayāha (on the Tīh plateau of central Sinai, abbreviated as TyA), Badārah (in ar-Ramlah, ${ }^{4}$ abbreviated as BdA), Dbūr (some kilometres south of Qal'at al-Ğindiy, ${ }^{5}$ abbreviated as DbA) and Malālhah (on the border with Israel, not far from al-Gșaymah, ${ }^{6}$ abbreviated as MlA) are described as forming the southern continuation of group I.7 This is also the dialect type spoken in the northern Sinai by the tribes Rmēlāt, Sawārkah, Biliy, Masāīìd, 'Ayāydah, (farther into eastern central Sinai) Ahaywāt (as it appears in Stewart 1987 and 1990) and the Tarābīn of the north. This type, which was earlier described in De Jong 2000:Chapter 1, links up to the dialect spoken by the Dullām in the Negev Desert, described in Blanc:1970. The same dialect type is spoken by branches of the Bedouin

${ }^{1}$ The Tarābīn claim descent from the Bugūm of the southern Hị̌ãz (see Holes and Abu Athera 2009:62 [fn 4] and 66 [fn 67]).

${ }^{2}$ Geographical coordinates of Ğabal al-Ğidy are appr. 30.10.00 North and 33.09.0o East, see Google Earth (there spelled Jabal al Jiddī).

${ }^{3}$ Geographical coordinates of nearby Ğabal al-Malbad are appr. 29.29.41 North and 33.05.55 East, see Google Earth.

4 Badārah were recorded in a small settlement located at appr. 29.02.50 North and 33.33.39 East, see Google Earth. Another recording sesion was conducted farther towards the east a few kilometres south of Ğabal Fōgah or Fawga, coordinates appr. 29.01.26 North and 33.40.22 East. and 29.02.35 North and 33.34.18 East, see Google Earth.

${ }_{5}$ Geographical coordinates of Qal'at al-Ǧindy are appr. 29.51.00 North and 33.07.50 East, see Google Earth. If my memory serves me well, it is the settlement visible on Google Earth around the coordinates 29.48.30 North and 33.07.30 East.

${ }^{6}$ Al-Gșaymah is at appr. 30.40.08 North and 34.22.00 East, see Google Earth (there spelled Quseima).

7 The Malālhah are actually on the border with Israel in the northeast of Sinai. They were included here, since their dialect was not discussed in De Jong 2000. 
tribes Tayāha, Tarābīn and 'Azāzmah living in the Negev Desert, and has been succinctly described in Henkin 2008. The dialects of the same group I (or Negev-) type, but spoken more toward the central parts of Sinai (HwA, ${ }^{8}$ DbA, BdA, TyA, ĞrA, TAȘ, TAN and MlA $)^{9}$ will be collectively referred to here as 'southern group I dialects'.

\section{Phonology}

\subsection{Consonants}

\subsubsection{Inventory of consonants}

The inventory of consonantal phonemes of Ḥw, DbA, BdA, TyA, ĞrA, TAȘ, TAN and MlA (in the northeast) is identical to that of group I in De Jong 2000: ${ }^{10}$

\begin{tabular}{|c|c|c|c|c|c|c|c|c|c|c|c|}
\hline & $\begin{array}{c}\text { bilabial } \\
\text { vl vd }\end{array}$ & $\begin{array}{l}\text { labdent. } \\
\text { vl vd }\end{array}$ & $\begin{array}{c}\text { alvec } \\
\text { vl }\end{array}$ & $\begin{array}{c}\text { olar } \\
\text { vd }\end{array}$ & $\begin{array}{l}\text { intdent. } \\
\text { vl vd }\end{array}$ & $\begin{array}{l}\text { postalv. } \\
\text { vl vd }\end{array}$ & $\begin{array}{l}\text { palatal } \\
\text { vl vd }\end{array}$ & $\begin{array}{l}\text { velar } \\
\text { vl vd }\end{array}$ & $\begin{array}{l}\text { uvul. } \\
\text { vl vd }\end{array}$ & $\begin{array}{l}\text { phar. } \\
\text { vl vd }\end{array}$ & $\begin{array}{l}\text { laryng. } \\
\text { vl vd }\end{array}$ \\
\hline plosive & b & & $\mathrm{t}$ & $\mathrm{d}$ & & & & k g & (q) & & (') \\
\hline emph. & & & $t$ & & & & & & & & \\
\hline nasal & $\mathrm{m}$ & & & $\mathrm{n}$ & & & & & & & \\
\hline fricative & & $\mathrm{f}$ & $\mathrm{s}$ & $\mathrm{z}$ & $\underline{\mathrm{t}} \quad \underline{\mathrm{d}}$ & $\check{s} \quad(\check{z})$ & & $\mathrm{x} \quad \dot{\mathrm{g}}$ & & h c & $\mathrm{h}$ \\
\hline emph. & & & ș & $(\mathrm{z})$ & $\underline{d}$ & & & & & & \\
\hline affricate & & & & & & & $\stackrel{\check{g}}{ }$ & & & & \\
\hline trill & & & & $\mathrm{r}$ & & & & & & & \\
\hline emph. & & & & $(\mathrm{r})$ & & & & & & & \\
\hline lateral & & & & li & & & & & & & \\
\hline emph. & & & & 1 & & & & & & & \\
\hline glides & $\mathrm{w}$ & & & & & & $\mathrm{y}$ & & & & \\
\hline
\end{tabular}

$\mathrm{vd}=$ voiced, $\mathrm{vl}=$ voiceless, emph. $=$ emphatic $/$ velarized

Of consonants listed here, those in brackets are heard in loans, such as q and 'in the word qur'ān "Koran". They are marginal as a phoneme, such as $z$ in zabbat, yzabbit "do properly", or are allophone, such as $\check{z}$ for ğ; in

${ }^{8}$ The triangular area in the central north of Sinai which is indicated on the map as Hweețiy territory (between the dīrahs of 'AyA, nTA and AhA) was not visited during this research. For the maps in the appendix I have simply followed the findings for HwA as spoken by Hwèțāt to the southwest of this area to colour in this area as well.

9 See remark in fn 7 , p. 193.

${ }^{10}$ Cf. De Jong 2000:59. 
some of the dialects ž is highly regular, while in other dialects it is rare. The phonemic status of $r$ is sometimes disputed, and therefore $r$ is bracketed in this inventory. ${ }^{11}$

\subsubsection{Interdental fricatives $/ \underline{t} /, / \underline{d} /$ and $/ \underline{d} /$}

Reflexes of ${ }^{*} \underline{t}$ and ${ }^{*} \underline{d}$ are interdentals t $\underline{t}$ and $\underline{d}$ (I.P.A. [ $\left.\theta\right]$ and [ð] respectively. Emphatic d (I.P.A. velarized [ð]) is the interdental reflex of both *d and *d, e.g. (as reflex of *d in) raw between low mountains" (DbA), hâmid "sour" (BdA), dayf "guest” (TyA) and (as a reflex for *d in) y $\underline{\underline{d}}$ all "he remains" (TAN) and $\underline{\underline{d}}$ aharah "his back" and $\underline{\text { dimy }}$ "thirst" (both ĞrA).

In a number of lexemes $z$ (usually loans from MSA or Egyptian Arabic) is the current reflex, like in zāabit "officer", b azzabt "precisely", mazbūt "correct", muhāfiz "governor", nizām "system", zurūf "circumstances" (TyA) (notice that in the latter three examples short high vowels have not been dropped from the open initial syllables, which is another indication of

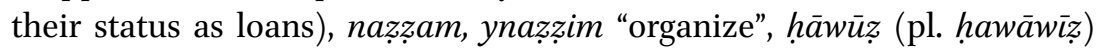
"large storage tank for oil" (in ḤwA and TAṢ), ḥāğih fižı ah "a disgusting thing" (DbA), etc. ${ }^{12}$

In all dialects both $h \bar{a} \underline{d} a$ and velarized $h \bar{a} \underline{\underline{d}} a$ "this (sg. masc.)" may be heard, except in HwA, where such velarization as in the latter form is not current.

The reflexes for ${ }^{*} \underline{t}$ and ${ }^{*} \underline{\mathrm{d}}$ are interdentals $\underline{t}$ and $\underline{d}$. Examples for ${ }^{*} \underline{t}$ are: nahariț "we plough" (ĞrA), țillāğah "refrigerator" (BdA and țallāğah and talğ "ice, snow" in TAȘ), ${ }^{13}$ biytannuw lha "they come back to her" (HwA).

For *d: nubdur "we sow" (HwA), kidb "lying" (BdA) and adbaḥah "I slaughter it (masc.)" and midrāh" "winnowing fork" (both ĞrA).

There are also exceptions: in HwA *t in "refrigerator" and "ice; snow" has a reflex $t:^{15}$ tillāğah, talğ and also haddūtih "story; fairy tale" (BdA, TAȘ).

In some loans from MSA (presumably via speakers of Cairene) the reflex for *t is $s$, e.g. ta'sìr "influence" (TAN), bit' assir 'alèh "it (fem.) has an

\footnotetext{
${ }^{11}$ For remarks on the notation of $\mathrm{r}$ or $\mathrm{r}$, see De Jong 2000:65-67.

${ }_{12}$ Additional examples may be found in De Jong 2000:60. In TAN mhāafid with emphatic interdental as final consonant was also recorded.

${ }_{13}$ In winter temperatures below zero are not uncommon in the higher parts of the mountainous region of southern Sinai.

${ }^{14}$ I was told that the 'older' word for "winnowing fork" in ǦrA is actually digrān, a term I also heard used by speakers of HwA.

${ }^{15} t$ for * ${ }^{*}$ in lexemes talğ and tilläğah is also regular in dialects of groups VI and VII in 1.1.2. of chapters I and II.
} 
influence on him" (TyA), turās "legacy" (HwA), hâadsih "accident", bi hays (cf. MSA bi haytu) "so as to..." (TAȘ) and masalan "for instance" (all dialects), and for *d it is $z$, as in zakālak" "likewise" (DbA) or kazālak (TAȘ), bala m'āxza "no offense intended" (DbA) and bizr "seed" and bizrih "seed (n.u.)", but hū byubdur ibdār "he sows seeds" (TAṢ).

\subsubsection{Velar stops $/ k /$ and $/ g /$}

Like in other group I dialects ${ }^{*} k$ and ${ }^{*} q$ have unaffricated reflexes $k$ (I.P.A. $[\mathrm{k}])$ and $g$ (I.P.A. [g]). These group I dialects do not have a separate phoneme / $\mathbf{k} /$ (contrast groups II, VI, VII and VIII).

\subsubsection{Post alveolar affricate / $\check{g} /$}

A regular realisation of $/ \check{g} /$ in southern group I dialects is [dz] (with varying degrees of the plosive onset [d] of this affricate; also [ $\left.{ }^{\mathrm{d}} 3\right]$ ). The fricative allophone $\check{z}$ (I.P.A. [3]) for $/ \check{g} /$ is more regular in southern group I dialects than in those of the north and it is particularly frequent in HwA.

\subsubsection{Emphatic alveolar stop /t!/}

In all southern dialects of group I a measure of glottalization in the realisation of / $t /$ may occur. Often the glottal release, which coincides with the release of the $t$, is not very clear. Much more clearly audible is the complete lack of aspiration in the release of $t$-resulting from the total closure of the vocal cords - and the immediate onset of voicing for the following vowel, which coincides with the release of $t$.

In one case the reflex for *t was t: ti mih "bait", which must be related to the root $t-^{-}-m$ (DbA). The form tal'ah "(a usually rocky) watercourse between two mountains used to climb through (i.e. a pass)" is presumably related to the root $t-l_{-}^{-}$" ascend" (TASS).

\subsubsection{Glottal stop (hamzah)}

Like in many other groups in Sinai, the reflex for *' in the verb "ask" is 's sa'al, yas 'al. Also the presentative ar' or ir "behold!" shows 'for *' (< root $\left.{ }^{*}{ }^{\prime}-{ }^{\prime}-y\right) \cdot{ }^{17}$

${ }^{16}$ Compare MSA ka-da âlik, after metathesis > dakālik, and after reinterpreting morpheme boundaries of $\underline{d} a-k \bar{a} l i k$ as $\underline{d} a k \bar{a}$-lik, after which -lik could be interpreted as the suffixed preposition l used as a presentative. See also remark on kizāluk in fn 4, p. 117.

${ }^{17}$ Also reported for TyA of the Negev, see Shawarbah 2007:418. 
In *ra's "head", loss of 'is complemented by lengthening the preceding vowel $r \bar{a} s$ in all dialects. The pl. is r rūs in TyA, HwA, DbA, BdA, ĞrA, but pl. ryūs in TAS and TAN.

Reflexes of the pl. pattern ${ }^{*} \mathrm{CiCaC}$ (or ${ }^{*} \mathrm{CuCaC}$ ) are often $\mathrm{CCaC}$ in these group I dialects, e.g. rkab "knees", šnaț "suitcases", hgan "injections", nxar "noses", etc.

\subsubsection{Secondary velarization}

Like in dialects of group I in the north (see De Jong 2000:63-65), secondary velarization is a feature typical of southern group I dialects as well. In many cases a combination of a velar $(g, x$ or $\dot{g})$ with $l, r$ or $b$ wil produce velarization, especiallly with $u, \bar{u}$ or $a, \bar{a}$ in its vicinity. Some of many examples are: $x$ ullah, (pl.) $x$ la! "screened off private section of a tent" (TAȘ), mxa!lla! "pickled" (ĞrA), ánnaxa! "the palm tree" (ǦrA), ġrāb "crow"

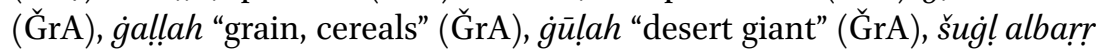
"of the desert" (ĞrA), 'ugḅah "after him" (DbA), ga!̣̣ "heart” (DbA), gábiḷha "before her" (ĞrA), xa!lāhum "he let them" and xa!lah ytaga!la "let him go free" (both BdA), glayyil "little", aga!l "less; least" (both TAṢ).

Notice the phonemic difference in this respect between gullah, pl. glal "pitcher, jug" and gillih "lack, paucity". ${ }^{18}$

\subsubsection{Liquids ! and $r$}

In HwA there is a phonemic opposition between $/ \mathrm{r} /$ and $/ \mathrm{r} /$ in the minimal pair drās "threshing" and $d r \bar{a} s$ "the hard remains of the stems after threshing (thrown away as refuse)". In TyA a near minimal pair dāriy "knowing (sg. masc.)"—dārì "my house" (though stress differs) may be used to isolate $/ \mathrm{r} /$ and $/ \mathrm{r} /$ as phonemes as well.

Generally, the combination $\bar{a} r$ will be velarized, unless $i$ follows within morpheme boundaries (see also De Jong 2000:65-67). There are many examples, of which some are: mițmārah "storage for grain", škārah "sack

${ }^{18}$ There is a phonemic difference, but to identify the different phonemes causing this difference in meaning is problematic.

A gullah "waterjar" (pl. gla!) is referred to as bittiyyih (pl. batātiy) in TAṢ, while older people refer to the waterjug as zimzimiyyih (which reflects underlying $a$ in the second syllable, hence not •zimizmiyyih), cf. the well Zamzam in Mecca. The word gullah is also used in metaphorical reference to a shell fired by a tank. karniffah (pl. karānīf), originally refers to the thick part of the palm leaf where it attaches to the stem, but is now also used metaphorically for the head of a tank-fired shell. 
for grain" (HwA), faxxār "pottery", nār "fire", nahār "day(-light)", ğrạr "jar (pl.)" and kțār "many (pl. com.)", kbār "old (pl. com.)". Also: mixšăr "large wooden fork used to stir food", zwärah "visit to (the tomb of) a saint" (DbA), xuwwār "inferior type of camel, bred for meat", byār "wells", Badārah "name of the tribe Badārah", ḥwār "one-year-old camel" (all TyA).

Notice, however, how following (either present or elided) $i$ within morpheme boundaries blocks such velarization, e.g.: albārih "yesterday", šārib "lip; having drunk (sg. masc.)", 'agārib "scorpions", sārih "taking the goats and sheep out to graze (sg. masc.)" and (elided) 'ārfin "knowing (pl.)", Bšāriy "of the tribe Bišăriyyah (referring to a type of camel)", šări "street, xarārīf "stories" and tärīx "history".

Another illustration is the difference in velarization (i.e. its presence or absence) in bindārğih mdārağih "we take it (in travel) in stages" and in the plural form in Sèl liXbār "the Wādiy (lit. Stream) of the fields", but the other pl. form xibāriy "agricultural (plots of) land fed by rainwater".

\subsubsection{Nasaln}

No remarks.

\subsubsection{Devoicing of final voiced stops, liquids and nasals in pause}

A feature noticed in TyA is the glottalization of (especially) the $\bar{a}$ in an ending $-\bar{a} C$ in pause $>-\vec{a}$, after which the $\mathrm{C}$ (in all recorded instances this was an alveolar) is no longer pronounced. Examples are (the dropped final consonant is indicated in square brackets): Fêr $\bar{a}$ \# [ $n]$ "Wādiy Fērān", kattä \# [l] "killer", Nșayra ă \# [t] "(a sub tribe) Nșayrāt", blä \# [d] "land".

\subsection{Vowels}

\subsubsection{Inventory of vowel phonemes}

Like northern group I dialects, southern group I dialects have three short vowels and five long vowels:

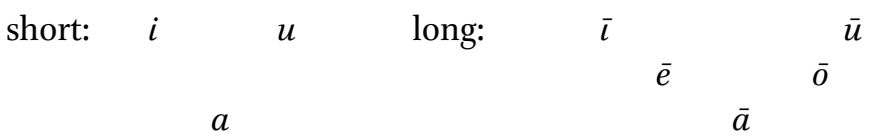




\subsubsection{Long vowels}

\subsubsection{Allophones of long vowels $\overline{\mathrm{e}}$ and $\overline{\mathrm{i}}$}

Like in group I dialects of the north, phonetic overlapping of $/ \overline{\mathrm{e}} /$ and $/ \overline{\mathbf{l}} /$ occurs in most southern group I dialects as well. However, in TAȘ, ĞrA and TAN this feature was found to be less regular than in the other group I dialects. Examples are siff "sword" (TyA), zinn "good" (TyA).

Not withstanding such phonetic overlapping, the phonemic status of phonemes $/ \overline{\mathrm{e}} /$ and $/ \overline{\mathbf{l}} /$ can be established with a minimal pair like šên "bad"-šin "name of letter $\check{s} "$.

In several dialects of group I imperfect forms of the verb "dry" (root $y$ - $b$-s) monophthongization has remained absent, keeping the morphological pattern transparent, e.g. yaybas "he dries (intrans.)" (recorded in HwA, ĞrA, TyA, TAṢ).

\subsubsection{Allophones of long vowels $\overline{\mathrm{o}}$ and $\overline{\mathrm{u}}$}

In neutral environments, i.e. in the absence of velarization and without preceding back spirants, older diphthongs *ay and * $a w$ have been monophthongized as $\bar{e}$ and $\bar{o}$. As long vowels, the phonemic status of $/ \overline{\mathrm{u}} /$ and $/ \overline{\mathbf{o}} /$ can be established through a minimal pair like: rūḥ "go! (imperative sg. masc.)"—rōḥ "soul".

In positions influenced by velarization, $/ \overline{\mathrm{u}} /$ is realized relatively low, near I.P.A. [o:], but phonemic clash with reflexes of * $a w$ is avoided, since ${ }^{*} a w$ tends to be realized as a diphthong aw in such positions.

In verbs with $w \bar{a} w$ as their first radical, the diphthong aw has often not been monophthongized, which keeps verb forms morphologically transparent, e.g. nawgaf "we stand" as opposed to monopthongization in togid "you light" (both in DbA and HwA) and tawșafni "you describe to me" and tōzin "you weigh" (both in TAṢ). But in TyA both yawșal "he arrives" and yawrid "he gives water" have diphthongs. In ĞrA there appears to be a tendency to monophthongize aw in closed syllables, e.g. yawrid "he waters", but yōrduw "they water". Examples in BdA: yowgaf "he stands" and yōkinha "he ties it (fem.) closed".

Some $\mathrm{C}_{1}=w$ verbs in HwA also have imperfect forms occurring without incorporated $w \bar{a} w{ }^{19}$ e.g. tigif "she stands", tagfin "they (pl. fem.) stand", yirid "he waters" and tardiy "you (sg. fem.) water", but a form like tizín for "you weigh" was not accepted during direct elicitation.

\footnotetext{
19 Shawarbah 2007:432 also reports yír(i)d and yișil for TyA.
} 
Notice that in the forms tigif and yirid the vowel of the first syllable is actually underlying $a$, hence it is not dropped in open unstressed syllable (which would have resulted in forms like •tgif and •yrid) and 'reappears' as $a$ in closed syllables (cf. the sg. fem. forms quoted).

\subsubsection{Allophones of long vowel $\bar{a}$}

The long vowel $\bar{a}$ may have a realization as high as I.P.A. [ $\varepsilon:]$, mainly in neutral positions and when followed by $i$ or $\bar{l}$ in the next syllable (but within morpheme boundaries), as in nāsiy "having forgotten (act. part. sg. masc.)". nāyim "asleep (act. part. sg. masc.)", rāsiy "anchored (act. part. sg. masc.)", dāriy "knowing (act. part. sg. masc.)" and ǧāriy "running (act. part. sg. masc.)".

But $\bar{a}$ is realized nearer to I.P.A. [a:] in positions like $n \bar{a} s$ "people", and also in nāsī "my people" (contrast nāsiy above).

Also in HwA the phonetic difference between $\bar{a}$ in mākil "having (sg. masc.) eaten" and nāyim "sleeping (sg. masc.)" (both near I.P.A. [ع:]) and in nākil "we eat" and nām "he slept" (both nearer to I.P.A. [a:]) is clear. Another example is /ā/ (near I.P.A. [a:]) in šâl "he carried" and šçyil "carrying", where $/ \bar{a} /$ is nearer to I.P.A. $[\varepsilon:]$.

In velarized environments, $\bar{a}$ is realized near I.P.A. [a:], as in $r \bar{a} s \bar{\imath}$ "my head", dārì "my house" and ǧârị "my neighbour".

The difference in realizations of $\bar{a}$ in $r \bar{a} s \bar{\iota}$ and $r a \bar{s} i y$ may be explained by recognizing either $/ \bar{a} /$ and velarized $/ \bar{a} /$, or $/ \mathrm{r} /$ and velarized $/ \underline{\mathrm{r}} /$ as separate phonemes. In the case of differences in a near minimal pair like nāsiy and $n \bar{a} s \bar{\imath}$, absence or presence of velarization is irrelevant. We could isolate / $\varepsilon$ :/ and $/ \bar{a} /$ as separate phonemes. ${ }^{20}$

However, since nāsi is stressed on the final syllable, whereas nāsiy is stressed on the first, concluding stress as being phonemic would be equally justified, if we would choose to regard $\left[\varepsilon^{*}\right]$ and $[\mathrm{a}:]$ as allomorphs of $/ \bar{a} /$.

\subsubsection{Shortening of long vowels}

Like in northern group I dialects, shortening of unstressed long vowels is a feature of allegro style in southern group I dialects as well. ${ }^{21}$

\footnotetext{
${ }^{20}$ The problem of identifying phonemes in cases such as described here was discussed before in De Jong 2000:65-67.

${ }^{21}$ Shawarbah 2007:421 reports for TyA of the Negev that shortening of long vowels in unstressed positions only occurs in open syllables; in closed syllables their length is retained.
} 


\subsubsection{Short vowels}

\subsubsection{Isolating phonemes $/ i /, / u /$ and $/ a /$}

In a number of minimal pairs short high vowels $/ \mathrm{i} /$ and $/ \mathrm{u} / \mathrm{can}$ be isolated as phonemes:

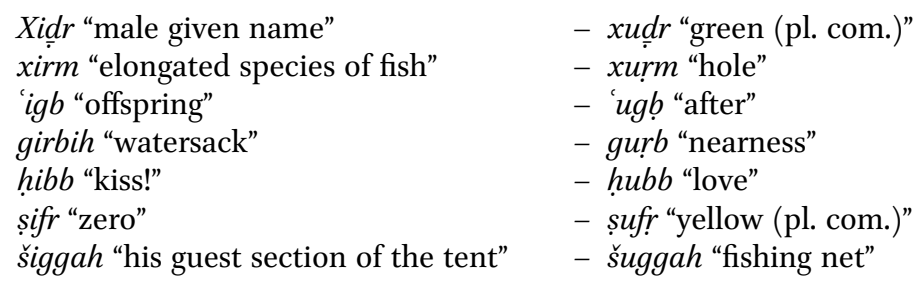

Minimal pairs to isolate /a/ on the one hand, and /i/ or / $/ \mathrm{l}$ on the other hand are much easier to find, e.g.:
habb "grain"
- hubb "love"
hatt "he placed"
- hutt!! "place!"
šadd "he pulled"
- šidd! "pull!"

1.2.3.2. Phonetic factors influencing the quality of $\mathrm{I}$

The subject of phonetic factors influencing the phonetic quality of $I$ has been discussed at some length in De Jong 2000:70-74.

In the pl. com. form for colours or physical defects $i$ tends to show up in neutral environments, and $u$ in velarized or labial environments, but different dialects show different short vowels. Forms recorded are:

šidf in ĞrA, TyA, HwA, BdA, DbA, but šudf in TAṢ "left-handed (pl. com.)"; 'imy in ĞrA, Ḥw, BdA, DbA, but 'umy in TyA and TAṢ "blind (pl. com.)"; 'irğ in ĞrA and BdA, but 'urğ in TyA, HwA and TAṢ "limping (pl. com.)"; zirg in ĞrA, TyA and HwwA, but zurg in TAṢ, BdA and DbA "blue; black (pl. com.)"; hibl in BdA, but hubl in DbA "dim-witted (pl. com.)".

Apart from such variation in different tribal dialects, $u$ is regular in humr "red (pl. com.)", xuḍ "green (pl. com.)" and șufr "yellow (pl. com.)" in all dialects. Other recorded forms pl. com. are turš "deaf” (TyA), humg "stupid, silly" and xurs "dumb" (both HwA and TyA).

The short vowel in the imperfect of the verbs "eat" and "take" is $i$ in all dialects discussed here: $y \bar{a} k i l$ and $y \bar{a} x i d$. Imperatives of these verbs tend to have $u$ in the velarized forms of the sg. masc.: $x u \underline{d}$ and $k u l$ (velarization is 
indicated here with a subscript dot in $\underline{d}$ and $l){ }^{22}$ In the other forms $u$ is dropped, but velarization remains, as in (sg. fem.) $x \underline{d i y, ~ k l i y, ~(p l . ~ m a s c .) ~}$ $x \underline{d u w}, k l u w$ and (pl. fem.) $x d i n k$ lin. When such forms are preceded by a consonant, an anaptyctic vowel with a phonetic value near I.P.A. [v] is regular: yā nās uklúw "eat, people!" and yā hrayym uklín "eat, women!" (examples from TAȘ).

Like in other dialects of Sinai, medial geminate verbs tend to show $i$ in neutral environments, and $u$ elsewhere. Some of many examples are (for

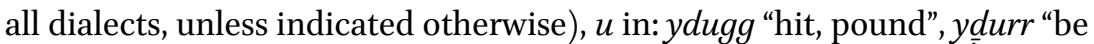
harmful to", yxudd "churn", ykudd "bite", ymuṣs "suck", yșubb "pour", ytubb "find, encounter; go to", yxušš "enter", yțušs "throw", yhuțt "place", yrudd "be related to; answer", ytuxx "shoot, fire", yluxx "be soaked in", yrušš "sprinkle", yğukk "churn, shake" and ykutt ykitt "go downstream in a wadi" (HwA, BdA, but ykitt in TAṢ). ${ }^{23}$

$i$ is heard in: yšidd "pull, tighten", yfikk "loosen", yliff "go around, turn", ymidd "stretch out", ytiff "spit", yširr "let dry (of dates) in a mašarrạ", yriff "flutter (of tent cloth)", yğiff "dry", ytimm "take place", yhimm "be important for".

\subsubsection{Morphological conditioning of the short high vowel}

Since a separate phoneme $/ \mathrm{k} /$ is not found in group I, exceptions like those noted for groups VI-VIII (and in group II) ${ }^{24}$ are not found in group I.

\subsubsection{Allophones of short vowels}

Allophones of short vowels $i, u$ and $a$ are like those described for group I in De Jong 2000:74-76, which are in turn also like those in group VI.

\subsection{Allophones of /i/}

Allophones of /i/ are like those described for group VI.

1.2.3.4.2. Allophones of $/ u$ /

Allophones of / $\mathrm{u} /$ are like those described for group VI.

${ }^{22}$ A supra-segmental feature like velarization could also have been indicated in $x$ or $k$, e.g. $x u \underline{d}$ and $k u l$, or throughout, e.g. $x \underline{u} \underline{\underline{d}}$ and $k u \underline{u}$, but since velarization spreads, marking it in one location may be sufficient.

${ }^{23}$ Again we see variation of the high vowel in the contiguity of $k$, see remark in fn 18 , p. 30 above.

${ }^{24}$ See De Jong 2000:253. 


\subsection{Allophones of $/ a /$}

\subsection{1. /a/ in non-raised positions}

Allophones of /a/ in non-raised positions are like those described for group VI.

1.2.3.4.3.2. Raising of $\left({ }^{*}\right) / \mathrm{a} /$ preceding long stressed vowels

Although raising of $a$ in the pattern $\mathrm{CaCīC}$ has been characterized as regular and therefore morphophonemic in dialects of group I of the north, such raising is optional in most southern group I dialects, except in HwA, where it is also concluded to be morphophonemic. In DbA raising of $a$ tends to be inhibited by preceding $h$, , $x$ or $\dot{g}$ (with preceding $h$ was not recorded in DbA).

Except when $a$ is preceded by ', such raising is not inhibited by phonetic factors in the other southern group I dialects. Examples recorded are (illustrating all dialects, except ḤA and DbA): șarimih șirimih "bridle", al'Arī̌s al'Irīš "name of the town al-Arish", xalìğ xilìğ "gulf", 'arīs 'irīs "bridegroom", rahïl "travelers", dagìg digìg "flour", rafig rifig "companion", rahịf "thin", galìd $\sim$ gilì $\underline{\underline{d}}$ "thick", ragīg "thin", xafif $\sim$ xifif "light" and also ganíy "rich".

Forms only recorded with raised $a$ are: gibïlah "tribe", kițir "much,

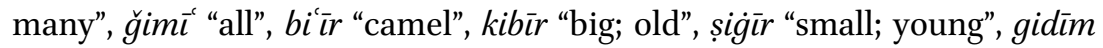
"old", 'irìs "bridegroom", 'iǧìn "dough", hizīn "sad", dixīl "guest taking refuge", šigìg "brother", širîf "honourable", rig̀if "loaf of flat round bread", bixil "stingy", 'Ilíy "male given name 'Aliy" and țiríy "moist, soft".

In most group I dialects of central and southern Sinai preceding hamzah blocks such raising, e.g. 'așil "thoroughbred" and 'atim "orphan" and also in verb forms (')ağı̆b "I bring", (')ašll "I carry", (')aǧîk "I come to you", (')arìd "I want" and (")abi "I sell" (see however remarks in 3.1.1.8. and 3.2.1.2.). Forms with the $b$-imperfect are treated similarly, e.g. babi , barid (raising of $a$ in mediae $y \bar{a}$ verbs of the type (b)ibi $\bar{\imath}^{-}$or (b)iríd for the 1st p. com. sg. is rare in the dialects discussed here, see also remarks in 3.2.1.2.).

- No instances were recorded of raised $a$ preceding stressed CCī, examples are: batțīx "watermelon", baddī "improvisor of rhyme", xarrīğ "alumnus", sakkinah "knife", garnit "octopus", sab'in "seventy", xamsin "fifty", Katrīn "(St.) Catherine", kabrit "matches", xanzìr "extra growth of twigs (to be removed) on lower stem of the grafted almond plant (lit. pig)”, ğarğı̌rih "watercress (n.u.) (?)" and many more.

- Instances of raising of $a$ preceding stressed Cē: in TyA, HwA and DbA one will hear e.g. 'ilēha 'alēha "on him"). Such raising in the suffixed 
preposition 'ala (e.g. 'alēh > 'ilēh) was not observed in TAṢ, TAN, ǦrA, MlA or BdA.

In verb forms we find optional raising in ḤA, TyA, ǦrA like mašēt $\sim$ mišèt "I walked" ( mišìt in HWwA), lagēt ligèt "I found" ( ligīt in HwA, TyA), fadèt fidèt "I sacrificed", though in MlA, TAṢ and BdA such raising was absent; forms there are e.g. mašèt, fadèt (ligìt only appears as $i$-type). Notice that in verb forms of the $a$-type imperfect raising of $a$ may take place when it precedes $\bar{e}$, but not in forms with diphthongs (i.e. when it precedes ay), so e.g. ramayt "I threw", dawayt "I went home before sunset".

- raising of $a$ preceding CCē is not current in MlA, TAṢ, TAN (though once suwwēt), BdA or TyA. Forms with raised $a$, though optionally so, like middèt, šiddèt etc. are however current in ĞrA, Hwa and somewhat less so in DbA.

- raising of $a$ preceding stressed Cā is regular in all dialects discussed here, but optional, e.g.: Tayāha Tiyāha "name of tribe Tayāha", Ğamāl Ǧimāl "Ğamāl ("Abd anNāșir)", ribā' "camel in its sixth year", ${ }^{25}$ gināh "small irrigation canal", ğarādil ǧirādil "buckets", bahāyim bihāyim "cattle (pl.)", gazāzih gizāzih "bottle", Sawārkih Suwārkih "name of tribe Sawārkah".

- raising of $a$ preceding stressed CCā is optional: fissāy "expert farter", gișṣāṣ "tracker", billāṣ "thief; extortionist", biṛ̂ād "teapot", tillāğih "fridge" and wiğ ān "suffering pain", milyān "full", hiğǧān "camel rider". Such raising was heard mainly in BdA, HwA, ĞrA and TyA, but was found to be much less current in MlA, TAN, TAS and DbA.

N.B. sg. fem. forms of colours and physical defects have short stressed final $-a ́\left({ }^{\prime}\right)$ (if not raised).

- raising of $a$ preceding stressed $\bar{u}$ is optional: gumūs $\sim \dot{g} a m \bar{u} s$ "food dip", $x u r u \bar{f} \sim x a r \bar{f} f$ "lamb", ǧunūb ğanūb "south" and yuhūd yahūd "Jews". With initial hamzah such raising remains absent (contrast with groups VI-VIII): (')abuuyy "my father" and (')axūy "my brother", and ist p. sg. com. imperfect forms of mediae $w \bar{a} w$ verbs (')agüm "I get up", (')agūl "I say" (see remark * below).

- raising of $a$ preceding stressed $a$ : (all dialects have a CaCáC stress-type) ǧimál "camel", libán "milk", šiǧár "trees", (a gahawah-form) šihár "month", sibág "race", mi áh "with him" and verb forms mišá" "he walked", kitáb "he wrote" and (gahawah-form) yixázin "he stores". Here

\footnotetext{
${ }^{25}$ See Stewart 1990:255 (glossary).
} 
too preceding hamzah prevents such raising, e.g. (')adáb "good manners", a verb form (')axád "he took" (TyA) and gahawah-forms like (')ahál "people", (')a áma "blind, (')a áạrağ "limping, lame" and (')axádar "green".

- raising of $a$ preceding stressed $u$ does not occur when *hamzah precedes the a: (')axušš "I enter", (')ahuutt "I place" (in contrast to such forms as uxušs etc., heard mainly in groups VI-VIII).

- raising of $a$ preceding stressed $i$ does not occur when hamzah precedes the $a$ : (')ašidd "I pull tight", (')amidd "I stretch out" (in contrast to such forms as išidd and imidd etc. heard in groups VI-VIII).

Stress in perfect forms of verbal measures $n-1$ and 1-t is ánwikal, áttifag, etc. (see 3.2.3.1. and 3.2.3.3.). The article is stressed in a sequence álCvCv(+) (see 2.1.1.1.), e.g. álğimal "the camel", álbușal "the onions".

Like in groups VI-VIII, when $a$ follows stressed $i$ in closed syllable, it is raised, as in yíndirib "he is beaten", yittifig "he agrees". ${ }^{26}$

1.2.3.4.3.3. Raising of the feminine morpheme $(\mathrm{T})$

The $a$ of the fem. morpheme is regularly raised in neutral environments and reaches a phonetic value near I.P.A. [ $\left.\mathrm{I}^{\mathrm{h}}\right]$.

Such raising is usually found in pausal positions, but also, though less regularly so, sentence-medially. Examples are: ğibál al'Iğmih ba'ád atTìh "The "Iğmah mountain lies behind the Tīh", (first word in) kilmih magyūlah "a spoken word", ba'ád kididy aǵațīiha b almallih xäliṣ "after that I cover it completely with hot sand", ${ }^{27}$ títil' allibbih $w$ lannha è e mistawyih tamām attamām "you take out the libbih and there it is what? Perfectly cooked".

In velarized environments such raising does not take place, e.g. šurțah "police", gilìidah šwayyih "a little thick", (second word in) kilmih magyūlah "a spoken word", algișsah "the story", baxūrah "incense", xüxah (velarized throughout) "peach", 'aḍah "bone", māsk alxūṣah f-ìdī "holding the knife in my hand".

Raising is not inhibited by the pharyngeals 'and $h$, e.g. ma tukfurha 'ašān mā ti'affan itxallha fäthih "don't close it (i.e. the bottle), so that it doesn't spoil, you leave it open".

\footnotetext{
${ }^{26}$ And also like in groups VI-VIII, in the verb forms yíndirib and yittifig, the raised $a$ will again 'reappear' as $a$ when in closed syllables, e.g. yindárbuw and yittáfguw, see also 3.2.3.1.1.

${ }^{27}$ mallih is the hot sand under the glowing embers in which the loaf of bread (libbih) is baked. A libbih is a thick round of dough baked in hot sand and embers. This type of bread is also prepared by men when they are travelling.
} 


\subsubsection{Prosodic lengthening of short vowels}

To express extra emphasis, such as on long durations of time, long distances or great quantities, speakers often prosodically lengthen short vowels. Examples are: iw minnih äh? iysawwlūh yōm yabra:'d fi māiun nad̄iff "and after that what? they carefully pour it into a bottle (through a funnel) when it (slowly) cools off in a clean container", mahál mā biyğ́y mațár wala kān ligīt alhamād hāda axaḍ:r "barren, no rain comes (to it) nor did I ever see (lit. find) this flat stony land ${ }^{28}$ green".

\subsubsection{Long vowels and diphthongs}

\subsubsection{Monophthongization of diphthongs *ay and *aw}

Like in group VI, in positions not influenced by velarization, or preceded by $\mathrm{X}$, older diphthongs * $a y$ and * $a w$ have in most cases become monophthongal $\bar{e}$ and $\bar{o}$ with realizations near I.P.A. [e:] and [o:].

Examples listed for group VI for *ay may also be heard in group I. Some additional examples are: ǧěšna "our army", šèn "bad, ugly", swēkin "(dim. of ) living", asSwēs "Suez", zèt "oil" and examples for $\bar{o}$ listed for group VI may also be heard in group I, nō "type, sort", ğō "husband", gōltak "what you said (lit. your saying)", lōnah "its (sg. masc.) colour", gōm "enemy tribe", gōz "sandy hill, dune", and $\overline{l o} z$ "almonds".

When *ay and *aw are preceded by $\mathrm{X}$ or velarized consonants, they have not been monophthongized, but have remained diphthongal.

Examples are (for ay) "ayn "eye", 'ayš "food", xayr "goodness", xayl "horses", hayt "walls", șayd "hunting", dayf "guest", and examples of verbs are hatțayna "we placed", xaḍdayna "we churned", ištarayna "we bought", dallayt "I stayed" and (for aw) hawl "year", 'Awdih "given name 'Awdah", xawf "fear", șawt "sound; voice". ${ }^{29}$

There is a tendency to prosodically lengthen the first element of the diphthong ay (which has an I.P.A. value between $[\mathrm{a}]$ and $[\varepsilon]$ ), especially in positions with primary stress. Forms with such lengthened diphthongs were heard mainly in TAȘ, TAN, ĞrA and BdA. Examples are 'aryš "food", 'a:yn "eye", 'a:yb "disgrace", xa:yt "thread", xa:ynih "severe cold (as a disease)", ha:yl "strength", șa:yf "summer", șa:yd "hunting”, Fra:yğ "male given

\footnotetext{
${ }^{28}$ Stewart 1990:232 (glossary) lists hamādih "flat barren stony land". For further references, see ibid.

${ }^{29}$ Shawarbah 2007:422-423 describes a situation for TyA of the Negev where monophthongization of *ay (as $\bar{e}$ or $\bar{l}$ ) and *aw (as $\bar{o})$ is general and not conditioned by phonetic environment.
} 
name Frayğ". Similar lengthening of aw was heard in tga:wțir "you go" and bya:wtuw "they travel (on foot?)".

In some cases monophthongization in neutral environments has not taken place, mawğūd "present (adj.)", aw'a "watch out!"3o and also šawlíy "left-handed (sg. fem.)" and also verb forms like awrid "I water" and awgaf "I stand up" and ğawna "they came to us". The advantage is that the arrangement of root consonants in a morphological pattern like $\mathrm{aC}_{1} \mathrm{C}_{2} \mathrm{aC}_{3}$ (as in awgaf instead of ōgaf, compare e.g. ašrab "I drink) has remained transparent.

The suffixed preposition lay "to me", bay "with me" are better interpreted as lay $+y$ and bay $+y$. In analogy to these forms, one will also hear fay "in me" in all dialects ( $\sim$ fin̄ in in ĞA).

\subsubsection{Isolating long vowels $/ \bar{\imath} /, / \bar{u} /, / \bar{a} /, / \bar{e} /$ and $/ \bar{o} /$ as phonemes}

In many dialects of group I the phonetic difference between $/ \overline{\mathrm{e}} /$ and $/ \overline{\mathbf{l}} /$ in neutral environments is often minimal, and in some lexemes the phonemes overlap. Such overlapping results from the higher realisation of $/ \overline{\mathrm{e}} /$, rather than from a lower realisation of /ī/. Examples are sif "sword", ši $\bar{x}$ "sheikh", bìt "house", itnīn "two", sanatīn "two years", zìn "good", dִ 'ayfin iftittāt $(<$ ftētāt) "tiny children". In such examples the $\bar{e}$ is not quite full $\bar{\imath}$, but it is very near [i:].

A few instances of such overlapping were heard in MlA, TyA, HwA, DbA and ĞrA but none were heard in TAN, TAS and BdA. ${ }^{31}$ Possible minimal pairs to isolate the five long vowels are (see also De Jong 2000:79):

dèr "monastery" — dìr "turn (trans.)!"—dūr "turn (intrans.)!"-dōr "floor (in a building)"—dār "house"

ǧibih/-ah "bring it!"—ǧēbih/-ah "his pocket"—ǧābih/-ah "he brought it", gōm "enemy tribe"—gūm "get up!"

\subsubsection{Allophones of $\overline{\mathrm{a}}$}

In the dialect of the Tarābīn of group I, $\bar{a}$ in neutral surroundings is realized near I.P.A. [ $\varepsilon^{*}$ ], but this is the case usually only when $i$ follows (within morpheme boundaries) in the next syllable (like e.g. ' $\ddot{a} r i f$ "knowing" and mizäri "fields for agriculture", but rāayib "curdled (of milk)"), or 'vanished' $i$ disappeared from a preceding syllable, e.g. drās "threshing". In other

\footnotetext{
$3^{30}$ In HwA, ASA and HnA aw'a is conjugated: aw'a tans!, aw'iy tansiy!, etc. "don't you forget!". In the other dialects it was left unconjugated for number and gender, e.g. aw'a tansin "don't you (pl. fem.) forget".

${ }^{31}$ My Tuṛbāniy informant claimed such overlapping to be a feature of northeastern (of Sinai) dialects, e.g. Rmēlāt and Sawārkah. See also MAP 5 in De Jong 200o:659 (appendix).
} 
(non-velarized) environments the phonetic value is slightly lower, nearer to $[æ:], 3^{2}$ as in for instance in šāy "my tea". Thus also the phonetic difference in $/ \bar{a} /$ in the examples $s \bar{a} l$ (near I.P.A. [æ:]) "he carried" and šāyil (nearer to I.P.A. [ $\varepsilon:])$ "carrying". 33

When velarization is involved, /āa is backed as I.P.A. [a:] as in $d \bar{a} r$

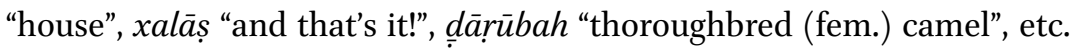

Minimal pairs, or near minimal pairs like ǧărı̄ "my neighbour" and ǧă "running" thus become possible. Similarly dārī "my house" and dëriy "knowing" (both with [a:] and [ع:] resp.), but the question remains which phonemes are actually isolated. ${ }^{34}$

\subsubsection{Reflexes of final ${ }^{*}-\bar{a}\left({ }^{\prime}\right)$}

Like in dialects of group I in the north, the reflex of final ${ }^{*} \bar{a}$ in neutral environments is often - $i y .{ }^{35}$ Some examples found in all dialects discussed here are: štiy / ášštiy "(the) winter", ši / áli šiy "(the) evening”, hniy "here", griy "villages", ${ }^{36}$ miy / álmiy "(the) water". Colours are: sawdíy or sōdíy "black (sg. fem.)", (a gahawah-form) šaḥabíy "sand-coloured”, hamšíy "a darker shade than šaḥabiy (sg. fem.)". Physical defects: 'arǧ́y "limping (sg. fem.)", hamgíy "stupid (sg. fem.)”, xarsíy “dumb, mute (sg. fem.)”, hawlíy "cross-eyed (sg. fem.)", šadfı́y "left-handed (sg. fem.)", 'amyíy "blind (sg. fem.)" and a diminutive form gray 'y "little bald (dim., sg. fem.)".

Raising was also heard in the forms 'ilyiy (compare CA 'ulyā) "upper grinding stone of a hand mill" and dinyiy "world", at Trayyíy "the Pleiades" (in TAȘ, but in BdA ațTrayyih), Ğawzíy "Gemini" in BdA and giniy "singing" in TyA.

In the perfect verb form $\check{g} a^{\prime}$ "he came" such raising is absent (contrast the DwA form ğiy, see De Jong 2000:416). Raising is also absent in the pron. suffix of the ist p. pl. com. -na "our; us", e.g. $w$ imaggid f-alwādiy w aššāyib, Aḷ̣āh yaṛ̂amih, [mā] 'indina ḥmār nāgl igrayybih fi ḍahárih ilná' "and he was going in the wadi, and the old man-God rest his soul-

\footnotetext{
$3^{2}$ Similar remarks on the phonetic quality of /ā/ were made for nTA in De Jong 2000:69 (there abbreviated as TA).

33 Shawarbah 2007:423-424 reports a high degree of imālah for medial $\bar{a}$ in specified neutral environments in the speech of the Qdīrāt sub-confederation of the Tiyāha of the Negev, e.g. wēdiy "wadi", Sēlim "male name Sālim", 'ēyiš "alive” and hềmiy "hot", etc.

34 See also remarks in De Jong 2000:65-66.

35 Such extreme imālah is also reported for TyA of the Negev, see Shawarbah 2007:424.

${ }^{36}$ griy (as a pl. of garyih) was recorded in HwA. However, Blanc 1970:125 [14] gives gíriy as a pl. for garyih and glosses griy as "hospitality". If the ancestral form would be *qurā (i.e. like in Classical Arabic), the pl. reflex griy instead of gíriy makes better sense. See also fn 144, p. 111 for griy in the meaning of "proper food served to a respected guest".
} 
(and) we did not have a donkey, was carrying a small waterskin on his back to us" (TyA).

In MlA and TyA final ${ }^{*}-\bar{a}$ of the pron. suffix of the 3 rd p. sg. fem. is raised, e.g. rabbayttiy ${ }^{37} w$ māt abūhiy $w$ hì mā rab'anat, wala hatt-áddriy ğa' 'alēhiy. iw fi ğizittiy...ma iț...yam'ațawhiy mn ihníy min-hāda. $w$ iykāwnūhiy là tğiy 'indī "I raised her and her father died before she was (even) 40 days old, and I even stopped breast feeding her (lit. 'nor did the milk come to her', i.e. because of the shock suffered by the mother caused by her husband's death). And after her wedding... snatched (lit. snatching)...they snatched (lit. imperfect: they snatch) her away from here, from here. And they had to fight her so she would not come (back) to me" (TyA) and itgūm ițța "imhiy ${ }^{38}$ b xūxah ... itğīb min ġușn alxūxah w itraggidhiy fihiy..." you then go and graft it with a peach tree... you get one of the twigs of the peach tree and you tuck it (sg. fem.) into it (sg. fem.)"39 (MlA). The form $y k \bar{a} w n u \overline{h i y}$ in the former example also shows that preceding $\bar{u}$ does not inhibit raising of the final $a$ in $-h a .^{40}$

In the other dialects (TAN, TAṢ, HwA, ĞrA, DbA and BdA) raising of * $-\bar{a}$ in this pronominal suffix is absent. Instead, a glottal catch, especially in pause, often accompanies the final (short) - $a$, e.g. $b$ addastah bağì bha' \# "by the dozen I get it (sg. fem.)" (TAṢ),ya'niy kān aḥna mnazzmīnha' ... ifwāğ 'a talat t-iyyām.. "that is, we used to organize it (sg. fem.) ... in heats over three days..." (talking about camel racing) (HwA).

When back spirants $h, x, \dot{g}$ or velarized consonants directly precede final ${ }^{*}-\bar{a}$, it is not raised, but in most cases has a $-a^{\prime}$ (with glottal stop, also in sandhi, and usually stressed) reflex. Examples are: mín-ihniy bnáxațir ${ }^{11}$ aššaț... 'ala zzamil [...] iw binğíb 'alēhin idrá' "from here we go to the market on the coast... on camels [...] and we bring sorghum on them (i.e. on their backs)" (HwA), kān 'indak șafráa ... áșșafrà hēdiy mānì 'ārifha biygūluw 'alēha ēš... "if you have jaundice... this jaundice I don't know (it) what they call it...". Other examples are: bē $\underline{d}^{\prime 42}$ "white (sg. fem.)",

\footnotetext{
37 Assimilated rabbayt + hiy, see 2.5. of this chapter.

${ }^{8}$ Assimilated $t+t a^{\text {" }}$ imhiy, see 2.5 . of this chapter.

39 raggad, yraggid would literally mean "cause to lie down/sleep", but here it refers to inserting (i.e. grafting) the twig into the incision in the stem and then cover it (usually with tape). Compare to "abdecken (bei Tomatenanbau, d.h. die Pflanze in eine Grube drücken und mit Erde überdecken)” in Behnstedt and Woidich 1994:168.

${ }^{40}$ Contrast with remarks on group I dialects in northern Sinai in De Jong 2000:166.

${ }^{41}$ For the verb xatar, yaxațir see Stewart 1990:283 (glossary): "to go to get supplies of corn and the like".

${ }_{42}$ In HwA and DbA reduction of $\bar{e}$ in this form was observed: bidán.
} 
zargá' zirgá' "blue" (in all dialects) ${ }^{43}$ (often as a euphemism for "black"), $x a d r a ́$ ' "green (sg. fem.)", 'awráa "one-eyed (sg. fem.)", gar 'á "bald (sg. fem.)" (but notice raising - since here further spread of velarization to the right is blocked by $y$-in the diminutive form gray ' $(y) .^{44}$

N.B. In MlA some instances of the sg. fem. were recorded with long final $-\bar{a}$, șafrā, zargā, xadrā and also d̦aḩa "morning".

When historical $a$ in open syllable directly precedes, raising of final *-a $\left({ }^{\prime}\right)$ remains absent, e.g. gifá' "neck", aná "I", gațáa "cover, lid", gadá" "lunch", 'ašá "dinner", dawá" "medicine", samá "sky", sawá "together", țaná "young boy".

In a form like raxá' "abundance", daháa' "morning" there is a combination of inhibiting factors preventing such raising (historical $a$ in open syllable preceding and $X$ preceding in combination with the spread of velarization).

When $a$ in preceding open syllable is not historical, but a gahawahvowel, such raising of final ${ }^{*}-\bar{a}\left({ }^{\prime}\right)$ is not inhibited, e.g. šahabíy "sandcoloured (sg. fem.)", kahalíy "variety of blueweed".

In TAS a phonemic difference in stress was noticed in the pair of adjectives hawlíy and háwliy: saxalah hawlíy "a cross-eyed (sg. fem.) lamb"gídiy háwliy "a one-year-old billy goat".

Like in other dialects of group I (see De Jong 2000:82), a short (underlying) $a$ in open syllable directly preceding will prevent such raising (provided this $a$ is not a gahawah-vowel), e.g. 'ašá "dinner", gadá' "lunch", nidá' "moistness, dew", gifá' "nape of the neck", 45 aná' "I" and also in velarized forms like tarará "moist ground", waráa "behind", ḍaráa "windscreen", gaḍán "law".

Final - $a$ in verb forms of the perfect of tertiae infirmae is not raised, e.g. fadá' "he sacrificed", mašá "he walked" and also velarized forms like ramá" "he threw", wațá' "he went to buy".

When the preceding $a$ is a gahawah-vowel, raising in neutral environments is not prevented, e.g. šahabíy "sand-coloured (sg. fem.)", kahalíy "variety of blueweed".

These reflexes of final ${ }^{*}-\bar{a}$, whether raised or not, are usually stressed, even when a heavy sequence precedes within morpheme boundaries, e.g.

\footnotetext{
43 Contrast zargíy in D̦A, see Blanc 1970:124 [13].

${ }^{44}$ In TyA of the Negev the un-raised stressed endings are also short and are cut off with a glottal stop, e.g. bidá' "white (fem.)" and 'orá' "one-eyed (fem.)", see Shawarbah 2007:422, 425 and remark on p. 418.

45 The vowel $i$ in the forms nidá and gifá' is raised (underlying) $a$.
} 
sōdíy or sawdíy "black (sg. fem.)", 'arǧíy "limping (sg. fem.)" and xậdrá" "green (sg. fem.)", tarmá "gap-toothed (sg. fem.)".

When the preceding heavy sequence contains the article, stress on the article is regular, e.g. ášštiy "the winter", álifiy $(a l+f \dot{y} y)$ "the viper", álġada" "the lunch", ánnida' "the moistness, dew" and gillt álhaya' "impudence".

N.B. "here" is hniy in all dialects (although in MlA hāna) and K-form hina may be heard in all dialects.

The forms with final -iy also occur sentence-medial. When suffixed, however, long $\bar{a}$ will 'reappear'. An illustrative example is in Bailey 2004:173 (entries 449 and 450, in my own transcription) wāğib al-ḥisníy 'ala griy wa driy (3 instances of raising) "he who's received benefaction must feed and shelter", but no raising in (two) suffixed forms in man ad'a li hisnāh yāxid garāh "he who's invited his benefactor will feed him". ${ }^{6}$

\subsubsection{Allophones of long vowels $\overline{\mathrm{e}}, \overline{\mathrm{i}}, \overline{\mathrm{o}}$, and $\overline{\mathrm{u}}$}

\subsection{Lowering effect of preceding emphatics on $\overline{\mathrm{l}}$ and $\overline{\mathrm{u}}$}

Primary and secondary emphatics will lower the phonetic value of following $\bar{\imath}$ and $\bar{u}$ towards (but not completely) (resp.) I.P.A. [e:] and [o:].

\subsection{Off-glide in $\overline{\mathrm{e}}$ and $\overline{\mathrm{i}}$}

Off-glides in $/ \overline{\mathrm{e}} /$ and $/ \overline{\mathbf{l}} /$ have been described for group I in De Jong 2000:85-86.

\subsection{Off-glide in $\overline{\mathrm{o}}$ and $\overline{\mathrm{u}}$}

Off-glides in $/ \overline{\mathrm{o}} /$ and $/ \overline{\mathrm{u}} /$ have been described for group I in De Jong 2000:86.

\subsubsection{Diphthongs}

Dialects of group I have four diphthongs: $a y, a w, i y$ and $u w$. Although the transcription of poems recorded from the Tīhiy poet "Tayāhā" (Husayn bin 'Īd bin Ḥamad bin Miṣlị̣ bin 'Āmir at-Tayāhā) and the Tuṛbāniy poet "Unayz" ('Unayz Aḅuw Sālim Swaylim al-'Urḍī) in Holes and Abu Athera $2009^{47}$ does not reflect dipthongal reflexes of *ay and * $a w$ when preceded

\footnotetext{
${ }^{46}$ Such reappearance of $\bar{a}$ in suffixed forms is also reported for TyA of the Negev, e.g. mi ziy, but mi zāna "our goats", see Shawarbah 2007:424.

${ }_{47}$ See pp. 47-62 for "Unayz" and pp. 67-81 for "Tayāhā". Examples in 'Unayz's poetry are: $\dot{g} \bar{e}$ (p. 53, l. 6), 'ébin (p. 53, l. 8), raḍēna (p. 56, l. 10), 'èn (p. 57, 1. 21), hōol (p. 6o, l. 19), hẹt (p. 61, l.4), gēebat (p. 61, l. 9) though gaḍdaynāhin (p. 54). In Tayāhā's poetry: al-guṣēma (p. 69, l. 5), fir'ōn (p. 69, l. 13), xēš (p. 72, l. 11), 'ōn (p. 77, l. 5), 'ènah (p. 79, l. 3), dèef (p. 79, l. 10), xēr (ibid.), ġēnah (p. 80, l.11), but also d̦allaw (p. 80, l. 21).
} 
by $\mathrm{X}$ or in velarized environments, ${ }^{48}$ my own findings for the dialects TyA and TAN described here are quite conclusive: in such positions reflexes tend to be diphthongal in these dialects of group I.99

1.2.4.6.1. Reflexes of *ay and *aw

1.2.4.6.1.1. Reflexes of *ay and *aw in neutral environments

In positions not preceded by X (i.e. back spirants $h,{ }^{\prime}, x, \dot{g}$ or $h$ ) or velarized consonants *ay and *aw have usually become $\bar{e}$ and $\bar{o}$, cf. 1.2.4.1.

In final positions, verbal endings ay and aw have also remained diphthongal, as in e.g. tansay "you (sg. fem.) forget", yansaw "they forget", harataw "they ploughed" and also ğaw "they came"..$^{\circ}$

In some cases monophthongization in neutral environments has not taken place, which has preserved morphological transparancy, e.g. taybis "drying (transitive verbal noun of measure 2 verb root $y-b-s)$ ", sawdíy $(\sim$ sōdíy) "black (sg. fem.)", mawğūd "present", and also initial sequences of prima $w \bar{a} w$ verbs often show diphthongs, e.g. awgaf "I stand up", nawrid "we give water", although such forms co-occur with monophthongized forms (in this case $\bar{o} g a f$ and nōrid). The prima $y \bar{a}$ ' verb (perfect) yibis "dry (intrans.)" also shows a diphthong in the imperfect yaybas, although the form with the monophthong yēbas also occurs.

1.2.4.6.1.2. Reflexes of *ay and *aw in non-neutral environments

1.2.4.6.1.2.1. Reflexes of *ay and *aw preceded by X

Reflexes of *ay and *aw preceded by $\mathrm{X}$ have remained diphthongal. Phonetic values range between [ai] and [ei] for *ay and between [au] and [ou] for "aw. Some examples are: (for ay) xayl "horses", gayt "rain", Ahaywāt "name of tribe (dim.)", 'ayb "disgrace" and min yōm țulü iShayl, iyxallattamir hayl "when the rising of Canopus ${ }^{51}$ (is there), it causes the dates to fall" (recorded in BdA), (for aw) hawğal "wooden threshing board", hawlíy "cross-eyed", hawl "year", 'awrá "one-eyed (sg. fem.)", xawf "fear" (an

\footnotetext{
${ }_{48}$ Also for TyA of the Negev unconditional monophthongization of *ay and *aw (> $\bar{e}$ or $\bar{\imath}$ and $\bar{o}$ resp.) is reported, see Shawarbah 2007:422-423.

${ }^{49}$ One of my TAN informants is actually a son of the late 'Nēz.

${ }^{50}$ Although I recorded a few instances of endings - $i y$ and $-u w$ in TAN and TyA in $a$-type imperfects (as in e.g. tášśrabiy and yášşrabuw), in the majority of possible cases the endings are in conformity with the rule formulated for group I, e.g. tášrabay and yášrabaw.

${ }^{51}$ Canopus (Ar. Suhayl) is visible just above the horizon in the southern sky around mid-October. See also the proverb in Bailey 2004:75: suhayl yixalli ar-ruțab hayl (in my own transcription this would be iShayl iyxall-árrțab hayl) "Canopus makes the ripe dates fall". Dates are said to be ripe for harvest as early as July in Nwēbi', then two months later in Fērāan, another month later in Rạas Șadr and again a month later in the Delta.
} 
example of $\dot{g}$ preceding $a w$ was not recorded). Examples of verb forms are yadbahaw ['yeðbeћau] "they slaughter", tázráaw ['tezrefau] "you (pl. masc.) grow (crops)".

1.2.4.6.1.2.2. Diphthongs *ay and *aw preceded by velarized consonants Reflexes of *ay and *aw preceded by velarized consonants have remained diphthongal. The phonetic value of the first element of the diphthongs tends to be slightly raised and is higher than when preceded by X: [ $\mathrm{\varepsilon i}]$ and [ou]. Examples listed in De Jong 2000:87-88 may serve to illustrate the situation in the group I dialects discussed here as well: (for ay) t'ayr IPA [t'eir] "birds", dayf [đzif] "guest", șayf [scif] "summer" and (for aw) șawm [soum] "fasting", țawr [ $\mathrm{t}^{?}$ our] "overhanging cliff".

Other diphthongs were heard in tawr "bull" and tawb "garment", where velarization has spread backwards (i.e. from right to left) through the word.

\subsection{Diphthongs -iy and -uw}

\subsection{Reflexes of final ${ }^{*}-\bar{\iota}$ and ${ }^{*}-\bar{u}$}

Like in other dialects of Sinai, the diphthongs $i y$ and $u w$ occur in a variety of positions.

Unlike the situation in group VI, $i$-type perfect forms of the tertia $y \vec{a}$ verbs pattern 3 rd p. sg. masc. CiCiy (underlying $\mid$ CaCiy $\mid$ ) commonly occur in group I. Examples are: ligíy "he found", fihiy "he was surprised", diríy (b) "he became aware (of)", nisíy "he forgot", gilíy "it became expensive".

Final -iy may also reflect older final * $-\vec{a}$, as in miy "water", in the saying alhisniy tnazzl algidir 'an algidir, lit. "benefaction removes one cooking pot (over a fire) (to make place) for another", ${ }^{2}$ (reflecting the sg. fem. pattern *CaCCā' for physical defects) 'arğíy "limping (sg. fem.)", hablíy "simple-minded (sg. fem.)", 'amyíy "blind" and the sg. fem. pattern for colours (also *CaCCā') sawdíy "black", šahabíy "sand-coloured". -iy may also reflect ${ }^{*}-\bar{a}$, as in hniy "here", mi ziy "goats". ${ }^{54}$ In groups VI-VIII the reflex for ${ }^{*}-\bar{a}\left({ }^{\prime}\right)$ is often $-i^{\prime}$, except in patterns for sg. fem. forms for colour or physical defects. The regular reflex then, like in group I, is -íy.

${ }^{52}$ A saying expressing the right of a host to come to someone else who has a fire, to cook food there for his guests; the man with the fire then as a deed of benefaction will remove his own pot to make place for the pot of the man acting as a host. See also Bailey 2004:164 (saying 419). In a more general sense the saying may also call for a special favour for those who have special obligations (like having to receive a guest).

${ }^{53}$ Final stressed $-i y$ for ${ }^{*}-\bar{a}$ is regular in group I. In the dialect of Biliy, however, the same $-i \bar{r}$ reflex was recorded for ${ }^{*}-\bar{a}$ and also ${ }^{*}-\vec{a}$, see De Jong $2000: 89$.

${ }^{54}$ See also Stewart 1990:248 (glossary), root $m{ }^{-}-z$. 
Like in group VI, final -iy may reflect final * $-\vec{\imath}$ in biríy "innocent", final *-`y in șibíy "boy", ganíy "rich", țiríy "moist; soft", *-ay' in šíy "thing” and the nisbah ending for the sg. masc., e.g. 'Abbädiy "(member) of the 'Abābdah". ${ }^{55}$

Instances of final (but unstressed) -iy sequences created by anaptyxis are: hákiy \# "telling" and ǧídiy \# "billy goat" (the morphological bases are haky and ǧidy resp.).

Instances of final $-u w$ or $-i w$ sequences created by word-final anaptyxis are: baduw \# "Bedouin (pl.)", hiluw \# "sweet; beautiful".

Examples of diphthongs created by word-medial anaptyxis are: biyšū $f$ "he sees", káwiyha "its (sg. fem.) cauterization" and aliwlād "the boys".

For remarks on diphthongal endings in $a$ - and $i$-type perfects of tertiae infirmae see 3.2.2.5.1.

The adverb "here" is in most dialects hniy, which may derive directly from $\operatorname{hun} \bar{a}\left({ }^{\prime}\right)$ or $\operatorname{hin} \bar{a}\left({ }^{\prime}\right)$.

Final -iy reflects final *- $\vec{\imath}$ in biríy "innocent", final *- $\bar{l} y$ in nibiy "Prophet", șibíy "boy", giwíy "strong”, final *-ay' in šiy "thing” and the nisbah-ending for the sg. masc., e.g. Su'üdiy "Saudi".

\subsubsection{Prosodic lengthening of long vowels and diphthongs}

Long vowels may be lengthened: (expressing a long duration of time) $w$ iytaxălațaw w yal'aba:w lamma yítilfuw "and they mingle and play (a long time) until they grow tired", (expressing an extreme degree) alihrayyim

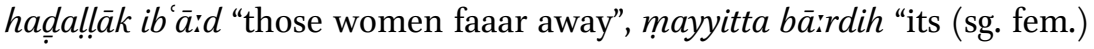
water is (extremely) cold".

The first element of a diphthong is also often lengthened. This occurs mainly in TAN, TAȘ, HwA, ĞrA and BdA (much less regularly in the other dialects) and predominantly so in monosyllabics, e.g. 'a:yš "bread; food", haryt "walls", 'a:yn "eye", xa:yt "thread". Such lengthening does not appear to be related to extra emphasis.

${ }_{55}$ The 'Abābdah are an Arabic speaking (though originally speakers of Beja, a Cushitic language) African tribe living in the eastern desert of Egypt (and across the border in northeastern Sudan), to the south of the Ma'āzah. 


\section{Stress AND Phonotactics}

\subsection{Stress}

\subsubsection{Rules for word-stress}

Stress in group I is of the máktabah-type. Rule order is the same as in group VI: elision — stress-anaptyxis. ${ }^{5^{6}}$

Verbal gahawah-forms of the $i$-type imperfect, like yáhalbuw "they milk", receive special treatment (see 2.1.2.4.).

The stress rules for central and southern group I dialects are like those described for group I in De Jong 2000:91-92. The rules can be summerized as follows:

1) Speech pause \# does not have the function of a consonant for the stress rule (contrast \# for anaptyxis rule below in 2.3.)

2) The domain of stress is formed by

a.) the last three syllables of a word, including the article $a l$ - and the verbal an-prefix (and the suffixes), the vowel preceding the $t$-infix (of measure 1- $t$ ) if these are part of the last three syllables.

b.) or the last four syllables, when there are no heavy sequences

3) Stress is placed according to the criterion of quantity, i.e. vowels of heavy sequences are stressed.

4) The following types of 'heavy' sequences occur: vCC $(C)$ and $\bar{v} C(C)$ (including $\overline{\mathrm{v}}(\mathrm{h})$ ).

5) The vowel of the first heavy sequence from the right is stressed (see examples in 2.1.1.1.)

6) a) In the absence of a heavy syllable, stress the vowel in the second syllable from the left (all dialects except TAȘ), or

b) In the absence of a heavy sequence, stress the vowel in the first syllable from the left (TAṢ).

\footnotetext{
${ }^{56}$ The same rule order is reported for TyA of Negev in Shawarbah 2007:425. Stress in Negev TyA can be characterized as: fa'ál, fi'llffu'úl/fa'il or fa'úl, fa'álah/-ih, fa'álatih, fa'à(')/ $f^{\prime \prime}$ 'ly, y'f 'iy/yáf'a (tertiae inf.), álfáal (stressed article), ánfáal, yinfa il (surface form yínfí il), anfáálat (verb measure $n$-1), áfta'al, yifta il (surface form yifti il), afta álat (verb measure $1-t)$.
} 
2.1.1.1. Stress in words with heavy sequences

Examples of stress in words with 'heavy' sequences are:

ášštiy "the winter", ál'aša' "the dinner, álif iy "the viper" (first $i$ is anaptyctic), șalät áli šiy (first $i$ is anaptyctic) "evening prayer", áli lab (first $i$ is anaptyctic) "the tins", mádrasah "school", áštagal "he worked", áttafag "he agreed", ángasal "he was washed", álbaṣal "the onions", álwalad "the boy/ son", darábt "I hit (perfect)", țilína "we rose", darábtih "I hit (perfect) him", waládkiy "your (sg. fem.) son", zēnin (i stressed) "good (pl.masc.)".

For forms like líbsitih "she wore it", libístih "I wore it" and šírbitih "she drank it", širíbtih "I drank it" recorded in ĞrA, see remarks in 2.4.4.

2.1.1.2. Examples of stress in words without heavy sequences

2.1.1.2.1. Stress in $\operatorname{c\nu } C \nu C(v)$

Examples of stress in $(\mathrm{C}) \mathrm{v}_{1} \mathrm{Cv}(\mathrm{C})^{57}$ are:

(') $v_{1}$ CvC: in all dialects: abár "needles", ahál "people, family", akál "he ate" (the latter only in DbA, TyA, HwA; kal in TAṢ, TAN, BdA, MlA, ĞrA), ("I come" is ağíy in all dialects of group I).

$\mathrm{Cv}_{1} \mathrm{Cv}($ (): 'ašá "dinner", mašá" "he walked”, dawá' "medicine”, hayá" "shame, bashfulness".

$\mathrm{Cv}$ CvC: hanáš "spider", malág "hard flat rock (on which no footprints show)", gatás "he dived"; wagáf "he stood up", warág "paper" and șibíy "boy", biríy "innocent", țiríy "moist; soft" ("he comes" is yǧiy) and gahawahforms șahán "plate", šahár "month" and ba ád "after".

2.1.1.2.2. Stress in $(C) v C v C v(C)$ and $(C) v C v C v C v(C)$

In the following sequences stress is placed thus:

$(\mathrm{C}) \mathrm{v}_{1} \operatorname{CvCv}(\mathrm{C})$ : stress in TAS is only on the initial syllable: $x a ́ s ̌ a b a h ~ " p i e c e$ of firewood", fárašat "she spread out", (and gahawah-forms) gáhawah "coffee", áxaḍ "green”, áhariț "I plough", á arag "I sweat”, táhariț "he ploughs", yá arag "he sweats", dárabaw "they beat (perf.)". Also when $(\mathrm{C})(\mathrm{v}) \mathrm{C}$ precedes a sequence $(\mathrm{C}) \mathrm{v}_{1} \mathrm{CvCv}(\mathrm{C})$ stress is on the first open syllable from the left: inwákalat "she was eaten", ištáġalat "she worked", ittáfagaw "they

${ }^{57}$ When $\mathrm{v}_{1}$ in this pattern is not preceded by $\mathrm{C}$, it is underlying $|\mathrm{a}|$. 
agreed", al'árabiy "Arabic", albádawiy "the Bedouin", and also (i)byáhafruw "they dig" (for such gahawah-forms of $i$-type imperfects with vowel-initial endings see remark in 2.1.2.4. below) and aláhamar "the red" and aláxadar "the green"..$^{8}$

Stress in TAN, ĞrA, TyA, HwA, DbA and BdA (for remark on MlA see *1 below) is on the second syllable: xašábah, farášat, darábaw, Tawárah or (with raised pre-stress a) Tuwárah "Tawarah (tribes)", akálat "she ate" (the latter only in DbA, TyA, HwA) and (gahawah-forms) gaháwah, axádar, ahárit, a'árag, taháriț, ya árag

When $(\mathrm{C})(\mathrm{v}) \mathrm{C}$ precedes a sequence $(\mathrm{C}) \mathrm{v}_{1} \mathrm{CvCv}(\mathrm{C})$ in these dialects (but see remark ${ }^{* 2}$ on TyA below) stress is also on the second open syllable from the left: algaháwah "the coffee", annaháásal "the (big black) ant", ingalábat "she overturned", ixtaláfat "she was different", ištaǵálat "she worked", aššağárah "the tree; bush", alwarágah "the paper (n.u.)", azza'átar "the thyme", annaxálah "the palm tree", ištagálaw "they worked", indarában "they (fem.) were beaten", azzalámah "the man", indarábat "she was beaten", assabágah "the race", a ğabátih "she pleased him", but also (gahawah-forms) alaxádar "the green" and alahámar "the red"59 and also azZagárạ "Wādiy Zagaarah (a tributary of Wādiy Dahab)".

When the heavy sequence preceding $(\mathrm{C}) \mathrm{vCvCv}(\mathrm{C})$ is created by a long vowel, stress is usually also on the penultimate syllable, e.g. kāwanátih "she fought him" (recorded in TyA, HwwA, BdA, ĞrA), but kāwanatih in DbA and also mgābalatak "the meeting with you" (the latter two stressed on long $\bar{a})$ in BdA.

(C) $v \operatorname{CvCvCv}(\mathrm{C})$ : stress in TAN, TyA, HwA, DbA and BdA is on the third syllable from the right: ragábatih, naxálatih, yaáragaw, ya'áragan, yahártuw, etc.

Stress in such sequences in TAS and MlA is on the fourth syllable from the right: rágabatah, náxalatah, yáaragaw, yá aragan, yáhartuw, etc. (for such gahawah-forms of $i$-type imperfects with vowel-initial endings see remark in 2.1.2.4. below) (for a remark on ĞrA see ${ }^{* 3}$ below).

In forms which become like a $\operatorname{CvCvCvCv}(C)$ ('surface') sequence as a result of bukara-insertion (see 2.2.2.1.), the bukara-vowel is ignored for the placement of stress, e.g. (bukara-vowel underlined) zág aratatat "she ululated".

\footnotetext{
${ }^{8}$ The latter two of which are-in terms of stress assignment-best interpreted as al'axadar and al'ahamar.

59 See preceding fn.
} 
${ }^{*}$ In MlA stress varies in $((\mathrm{C})(\mathrm{v}) \mathrm{C})(\mathrm{C}) \mathrm{vCvCv}(\mathrm{C})$; both $(a l)$ gașálah and $(a l)$ gásalah, (al)gaháwah and (al)gáhawah, sákanaw and sakánaw "they settled", etc. can be heard. Similar variation occurs in TyA, but only when $(\mathrm{C})(\mathrm{v}) \mathrm{C}$ precedes a sequence $(\mathrm{C}) \mathrm{v}_{1} \mathrm{CvCv}(\mathrm{C})$ : aššáğarah "the tree; bush" algáșalah "the twig", mintáa amah "grafted (sg. fem.)", but also maṣlahátak "your interest".60

*2 TyA however shows variation, since also forms with stress on the first open syllable from the left were recorded, like azzálamah "the man", ingálabat "she overturned", ingáta'an "they (pl. fem.) were cut off", inháśaraw "they were crammed together".

*3 Stress in ĞrA is placed thus: ragábatih, farášatih, naxálatak, naxálatih, but in elicited verb forms the gahawah-vowel was ignored and stress was placed accordingly: yáaragaw "they sweat", táaragan "you (pl. fem.) sweat", tá aragay "you (sg. fem. sweat)" (i.e. stress is placed as if forms are ya'ragaw, ta'ragan, ta'ragay resp., which are therefore concluded to be the underlying base forms).

\subsubsection{Exceptions to the stress rule}

2.1.2.1. Stress on reflexes of ${ }^{*}-\bar{a}$ and $^{*}$-à

Reflexes of ${ }^{*}-\vec{a}^{3}$ in the sg. fem. of colours and physical defects, whether raised or not, will be stressed, although they have been reduced to short vowels, e.g. xadrá(') "green (sg. fem.)", șafrá(') "yellow (sg. fem.)", beẹáa(') "white (sg. fem.)", gar'á(') "bald (sg. fem.)", 'awrá(') “one-eyed (sg. fem.)".

These reflexes are also stressed when they have been raised (to final -iy, see 1.2.4.4.), e.g. sōdíy sawdíy "black (sg. fem.)", šadf'í "left-handed (sg. fem.)", hawlíy "cross-eyed (sg. fem.)" and also with a gahawah-form šahabíy "sand-coloured (sg. fem.) (i.e. yellowish light brown)".

Notice that stress in forms like 'ašá', dawá', pronominal aná' and also a verb form mašá etc. is in conformity with the stress rules, and also when the article precedes and receives stress, this is according to stress rules, e.g. ál'aša', áddawa' and also miy "water", štiy "winter", šiy "evening" and álmiy "the water", ášštiy "the winter" and șalāt áli šìy (where the first $i$ is anaptyctic) "the evening prayer".

Reflexes of $-\bar{a}$ in pronominal suffixes, whether raised or not, will not be stressed (unless they are part of the only syllable available for stress, e.g.

\footnotetext{
${ }^{60}$ Such variation in stress is also present in dialects spoken nearby, such as those of the northern Tarāāin, Sawārkah and Rmēlāt, see De Jong 2000:664 (map 15).
} 
lná" "to us"), e.g. 'indina(') "with us", yğina(') "he comes to us" and mínha(') or mínhiy "from her".

The pair saxalah hawlíy "a cross-eyed (sg. fem.) lamb"-ǧídiy háwliy "one-year-old billy goat" could be used to show phonemicity of stress (recorded in TAṢ).

\subsubsection{Stress on final nominal *-iy reflexes in *CaCiy}

In group I, reflexes of the pattern *CaCiy are CaCiy or (after raising the short vowel $a$ ) CiCiy and are stressed on the ultimate, which is in conformity with the rules formulated in 2.1.1.2., e.g. wiliy "holy man", nabíy nibiy "prophet", șibíy "boy".

2.1.2.3. Stress in $\mathrm{al}+{ }^{*} \mathrm{CaC} \overline{\mathrm{y}}$

When the article precedes a CaCiy sequence it is stressed, e.g. ánnibiy or ánnibiy "the Prophet", áșșabiy or áșșibiy "the boy" and álwiliy "the holy man".

\subsubsection{Stress in suffixed gahawah-forms}

Examples of stress in gahawah-forms (see also 2.1.1.2.2.) are: ba'ádhuṃ "each other", naxálha "her datepalm".

For assignment of stress in $i$ - and $u$-type gahawah-imperfects the elision of the high vowel, made possible by the insertion of a gahawah-vowel, is ignored, e.g.yáḥalbin "they (fem.) milk", táhartuw "you (pl. masc.) plough", táxabțah "you beat it" (these latter three in TAṢ and MlA) or yahálbin, tahártuw, taxábțah (other dialects).

Resyllabication of sequences CaCaCatv > CaCCitv is not a characteristic of group I dialects.

\subsubsection{Stress in $v C C I C v$}

A short high vowel is not dropped from a sequence $\mathrm{vC}_{\mathrm{a}} \mathrm{C}_{\mathrm{a}} \mathrm{IC} \mathrm{V}$ and stress is placed according to rules in 2.1.1.2., e.g. biyhálliluw "they make heaps" and biyğaffifühin "they dry them (fem.)" and sadditī "my dam". The geminate is in these cases reduced. ${ }^{61}$

An exception to this exception recorded in TAN and TAS is sg. fem. m'ayyyih, pl. masc. m'ayyyin and pl. fem. m'ayyyāt (sg. masc. m'ayyiy) (i.e. the forms are not $\cdot m^{\prime}$ ayyiyih, $\cdot m^{\prime}$ ayyiyin and $\cdot m^{\prime}$ ayyiyàt $)$ for "feeble, sapless (esp. as a result of too much food or drink)".

For active participles of the verb ta 'aknan "be irritated", see 2.4.4.

\footnotetext{
${ }^{61}$ The same is reported for TyA of the Negev, see Shawarbah 2007:421.
} 


\subsubsection{Stress units}

2.1.3.1. Stress in combinations with preposition min and negated personal pronominals

Like in group VI, the preposition min may form one stress unit with the following word, as in mín-tahat "from below", mín-kidiy "from this", mínihniy "from here", mín-ihnuh "from there", mín-wara" "from behind".

In negated pronominals stress is on the first syllable: māni, minta, mintiy, mihnna, mintuw, mintin mūhū, mīha (also mīhì), mūhum, mīhin or māhin (in forms like mühúmmịa and mìhinna stress is on the second syllable).

\subsubsection{Enclitically suffixed prepositions $\mathrm{l}$ and $\mathrm{b}$}

2.1.3.2.1. Enclisis of the suffixed preposition 1

Enclitic suffixation of the suffixed preposition $l$ is less regular than in group VII, but does occur. An example (in ĞrA) is 'ala hittah ygūl-ilhá', iygūl-ilh-Aṃm Sa'ìd "to an area he calls, he calls (it) Aṃm Sa'īd". Notice that in case of enclitic suffixing the shorter form lha is used instead of the independant form lēha.

2.1.3.2.2. Enclisis of the suffixed preposition $\mathrm{b}$

Enclitic suffixing of suffixed preposition $b$ was not recorded.

\subsection{Phonotactics}

\subsubsection{The gahawah-syndrome}

2.2.1.1. The gahawah-syndrome: a-insertion in *aXC sequences

The gahawah-syndrome is active in all dialects discussed here. Some of many examples are: d̦ahár "back", saxálah "lamb", šaharayn "two months", yahalbūha "they milk her", Zagárah "name of a tributary wadi (coming from the west) of Wādiy Dahab some $10 \mathrm{~km}$ northwest of the town Dahab", aháwal "cross-eyed", šaḥabíy "sand-coloured", tahát "under".

\subsubsection{Morphological categories showing variation}

The gahawah-syndrome is active in forms of the past participle (i.e. where $\mathrm{C}_{1}=\mathrm{X}: \operatorname{maXC}_{2} \overline{\mathrm{u}} \mathrm{C}_{3}$ ) like ma arūf "known", ma azül "separated, isolated", ma agūul "reasonable", maharūt "ploughed", maḥarūg "burnt", mahațūt "placed" and maxarūm "pierced", but also maxtūt "mixed", maxșūṣ "special", mahyūn "insulted".

Exceptions are also found with the pattern $\operatorname{maXC}_{2} \mathrm{vC}_{3}(\mathrm{ah})$ : magarib "time of sunset", mahawiy "treated by a hāwiy (i.e. a snake charmer)", maxazan "storage place", but also (a loan) mahrağān "festival". 
Although derived measures are usually unaffected by the gahawahsyndrome, some verbal nouns of measure 2 do show gahawah-vowels, like in DbA tahagig (< tahgig) "allotment of shares of food (higgih) during the annual visit to a sheikh's tomb (zwārah)" was recorded, in MlA tağarīb "going north", ${ }^{62}$ in ĞrA tahawišs "collecting", ta a ašīb "removing weeds", tahabǐs fahám "making (by controlled burning) of charcoal". But forms without gahawah-vowels were also recorded, e.g. tahwīlna "our transfer", ta 'dīb "punishment" and taḥbǐs faháam (in TAȘ).

2.2.1.3. Morphological categories in which the gahawah-syndrome is not active The gahawah-syndrome is not active in derived verbal measures (for exceptions in verbal nouns of measure 2, see remark in the preceding paragraph 2.2.1.2. above). Examples are like those listed for group VI.

The examples of elatives listed for TwA, HnA and 'LA are also found in our group I dialects discussed here: ahsan "better/best", a hla "more/more beautiful, sweeter/sweetest", ag்lab "more/most" (and also a loan aǵlabiyyah

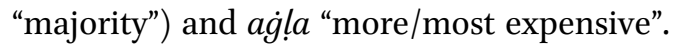

In loans (from Standard Arabic or Cairene) the gahawah-syndrome is usually absent, e.g. bahs "research" ${ }^{\text {"63 }}$ and ahlan! "welcome!" and also ya niy "that is; it means", and ya mal ${ }^{64}$ "he makes".

Like in group VII, the fem. morpheme in construct state becomes -at when it follows $\mathrm{XaC}$ (also where $a$ is a gahawah-vowel), so that the sequence CaXaCat is the result. When such a sequence is directly suffixed with a vowel-initial suffix, the resulting CaXaCatv sequence is not resyllabified (contrast MzA of group VI). Examples are naxalati "my palm tree" and gáhawatak (TAS and MlA) or gaháwatak "your coffee" (other southern group I dialects).

2.2.2. Articulatory delay in the realization of alveolar sonorants (liquids $l, r$ and $n$ )

2.2.2.1. Articulatory delay in the realization of $\mathrm{r}$ : the bukara-syndrome Examples of bukara-vowels are (underlined): hiğigin "his lap", yašaraban "they (fem.) drink", zağarațat "she ululated", katuruw w5 "they became many".

\footnotetext{
${ }^{62}$ On the system of orientation of tribes in the north of Sinai, see De Jong 2000:469, fn 48.

${ }^{6}$ bahs instead of MSA baht $\underline{t}: s$ for $\underline{t}$ is an indication that the loan came via a sedentary dialect such as Cairene, which lacks interdentals in its phoneme inventory.

${ }^{64}$ See remark in fn 51, p. 137.

${ }^{65}$ Since $a$ of the first syllable only appears in closed syllables (e.g. kutúr, but katrit), the underlined $u$ is here interpreted as a vowel created by the bukara-syndrome, rather than a vowel whose elision is inhibited by it.
} 
Examples of the bukara-syndrome inhibiting the elision of a preceding high vowel are alikbār tafātír aliṣ̂gār "old people are the records of young people" ${ }^{66}$ and $y k a s s \underline{i}$ albikāriğ "he smashes the coffee pots".

Examples of the 'greater' or 'expanded' bukara-syndrome creating vowels: Șadir alHayțān "Ṣadr al-Hayțān; name of the mountain range between Rāa Șadr and Nixl”.

The form núbudur al'ayš "we sow the (seeds for making) bread" is comparable to the form yúdukur ánnibiy discussed in De Jong 2000:114. The application of rules is as follows (here the high vowel eligible for elision is in bold print; the anaptyctic is underlined; the bukara-vowel is bold and underlined):

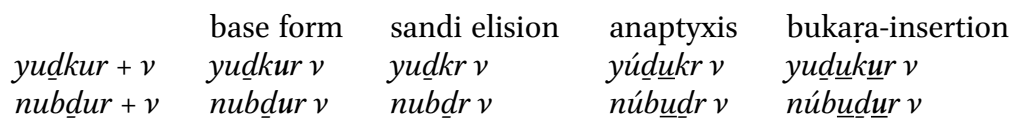

N.B. Since the bukara-rule is a late phonetic surface rule, the vowels produced by it are inconsequential for the placement of stress (i.e. the stress rule is applied before the bukara-rule), e.g. zágarațan "they (fem.) ululated", also in dialects that would otherwise stress CaváCaCv(C), as in e.g. ragábatak "your neck" (see remark in 2.1.1.2.2.).

\subsubsection{Influence of 1}

Like $r, l$ may also be involved in inhibiting elision of the short vowel. Examples are (preserved vowels underlined) min agdam gibāyil alliy hinnih ... alliy hummma Badārah "of the oldest tribes, which are... who are Badārah", nizill alxawāğih "the foreigner got out (of the car)" and min awwil al'umr "from the beginning of (his) life".

Examples of 'expanded' or 'greater' bukara-vowels preceding $l$ in sandhi (where the vowel is not a cluster-resolving anaptyctic as described in 2.3.2.) are ('greater' bukara-vowels underlined): aṣil alwādiy fì imlūhịh bardak "because there is also salinity (of the soil) in the wadi", arramil assạxin "the hot sand".

2.2.2.2.1. The high vowel preceding $\mathrm{l}$ in *'ibil and *raǧil

The forms bil "camels" and álbil "the camels" and bilha "her camels" were recorded several times in HwA (not in the other dialects).

\footnotetext{
${ }^{66}$ tafātir, cf. MSA daftar, dafātir. The saying stresses the importance of oral tradition: young people should use the experience of older people by consulting them. More or less like the African (Senegalese?) saying "when an old man dies, a library burns down".
} 
Like in group VII, răăgil, mainly in in the exclamation ya rāăil can be heard regularly. In one instance (in TAȘ) a woman was addressed with the fem. form rāğlih: tab w Alḷahiy yā rāğlih, úgu'diy 'indihin "okay, by God, woman, (go) stay with them (i.e. your children)".

rağil for was recorded a few times, but the current word for "man" is rağğăl (or, with a raised vowel $a$, riğğăl, pl. rğga $l$ ).

2.2.2.3. Articulatory delay in the realization of $\mathrm{n}$

A short high vowel $i$ in open syllable in sandhi is often not elided, due to a delay in the realization of $n$, e.g. ba'ağin aná "I knead", biyšüfin al'ayš "they (fem.) see the bread". The (relatively) high sonority of $n$ may also create a preceding vowel as in assamin aššḩhiy "the white wormwood ghee".

Articulatory delay in ( fōgna >) fōgəna "above us" was also recorded several times.

\subsubsection{Articulatory delay of 'ayn following geminates}

Instances of articulatory delay of 'ayn following geminates were not noticed.

\subsection{Anaptyxis}

Rules formulated for group VI are also valid for group I dialects.

\subsubsection{Word-medial anaptyxis}

Word-medial anaptyxis takes place like in group VI.

\subsubsection{Anaptyxis in sandhi}

2.3.2.1. Anaptyxis in clusters resulting from 'colliding' morphological base forms

In group I dialects sandhi clusters of four consonants caused by the collision of morphological base forms are resolved through anaptyxis like in group VI.

\subsubsection{Anaptyxis in \#CC and CC\#}

When speech pause directly precedes or follows CC, the resulting cluster \#CC or CC\# is resolved like in group VI.

2.3.2.3. Consonant clusters resulting from I-elision in sandhi, with subsequent anaptyxis

One example of clusters in sandhi after I-elision, eliminated by anaptyxis (the intermediate form with cluster is marked here with a preceding *): 
(base forms, high vowel eligible for elision underlined) mihnit alhurmah >

(after elision of high vowel, cluster in bold print)

* mihnt alhurmah >

(after stress and anaptyxis, anaptyctic underlined: surface forms)

mihint alhurmah "the woman's job".

2.3.2.4. Resyllabication of word-medial CVCCICV, and of CVCCIC VC sequences in sandhi

Like in group VI, the resyllabication of a word-medial sequence CVCCICV > CVCICCV (e.g. yiktibuw > yikitbuw) is compulsary, while resyllabication of a sandhi sequence CVCCIC VC > CVCICC VC (e.g. mihnit alhurmah > mihint alhurmah) is optional (see 2.3.2.3.).

\subsubsection{Exceptions to the anaptyxis rule}

\subsubsection{Unresolved consonant clusters}

Not all clusters are eliminated. Especially clusters of which the first consonant is nasal or a liquid followed by a voiceless second consonant are left intact, ${ }^{67}$ e.g.: sa'altha "I asked her", ta'allamtha "I learned them (pl. fem.)", bintha "her daughter", aftakart \# "I thought".

Clusters may be left unresolved in sandhi as well, e.g. ištaġalt fi Šarm aššèx "I worked in Šarm ašŠex", gult 'anha "I said about her" and "ind ba'adhum "with each other", gàmat albint mahha "the girl got up with her", șirt baxlaț "I started to be confused".

When assimilation between the first and second consonant takes place, the cluster will remain intact as well, e.g. (in sandhi) istafatt kițir "I gained a lot" (< istafadt).

2.3.3.2. The role of sonority of consonants involved in unresolved clusters See remarks in De Jong 2000:125-126.

\subsubsection{Some special cases with regard to anaptyxis}

\subsection{Consonant clusters with initial geminates}

When the first two consonants of a three-consonant cluster form a geminate, this geminate is usually (partially) reduced, e.g. (word-medial) widdna "we want, need", gillt al ilm "lack of science" and lih aḍ $\underline{d} w \bar{e} w$ ' $\bar{d} d$ "so it (sg. masc.) had the little light". Examples of such reduction listed for group VI may be heard in group I as well.

\footnotetext{
${ }^{67}$ For similar phonetic conditioning, see De Jong 2000:123-128.
} 


\subsection{Preposition 'ind $+C$}

The suffixed preposition 'ind takes vowel-initial allomorphs of the pronominal suffixes, e.g. 'indaha "with her", 'indak "with you (sg. masc.)", "indikiy "with you (sg. fem.)", 'induhuw "with them (pl. masc.)", 'indihin "with them (pl. fem.)", 'indukuw "with you (pl. masc.)", 'indikin "with you (pl. fem.)" and "indina "with us".

Clusters in sandhi are left intact, however, e.g.: 'ind 'ammih "with his uncle".

2.3.3.3.3. The 2nd p. sg. masc. and fem. pronominal suffixes in consonant clusters

The 2nd p. sg. masc. pronominal suffixes C- $a k / \overline{\mathrm{v}}-k$ behave predictably in group I.

\subsubsection{Phonetic quality of the anaptyctic}

\subsubsection{Phonetic quality of word-medial anaptyctics}

The phonetic quality of the word-medial anaptyctic vowel is a lax and centralized [1], towards [ə], in front environments and a lax and centralized $[\mathrm{v}]$, towards a moderately rounded [ə], in back environments. ${ }^{68}$

2.3.4.1.1. Phonetic quality of word-medial anaptyxis in clusters form "colliding" base forms

The situation is like in group VI (and also group I in De Jong 2000:128).

2.3.4.1.2. Phonetic quality of anaptyctics in clusters after I-elision

The situation is like in group VI (and also group I in De Jong 2000:129).

2.3.4.1.3. Anaptyctics in clusters resulting from elision of $\mathrm{i}$ from $T$ The situation is like in group VI.

\subsubsection{Phonetic quality of anaptyctics in sandhi}

2.3.4.2.1. Phonetic quality of word-initial anaptyctics in sandhi

Word-initial anaptyctic vowels tend to have a phonetic value near a lax and centralized [1].

Examples listed for group VI (and also for group I in De Jong 2000:130) also illustrate the situation in TwA and HnA.

Imperatives of the verbs (a)xad "take" and (a)kal "eat" are $x \underline{u} \underline{u}, x \underline{d} \underline{d} y$, $x \underline{d}$ duw, $x \underline{d}$ in and $k u b$, klíy, klúw, klín. ${ }^{69}$ When a speech pause precedes, the

\footnotetext{
68 This is the same as described for group I in De Jong 2000:128.

${ }^{69}$ All these imperative forms show considerable velarization.
} 
anaptyctic vowel resolving an initial cluster will be near I.P.A. [v], e.g. \# uklíy, \# uklúw, \# uklín (not recorded in MlA).

\subsection{Phonetic quality of word-final anaptyctics}

Anaptyctic vowels resolving word-final clusters have a phonetic quality near I.P.A. [v] in labial and/or velarized environments. Anaptyctics in neutral environments will be near (centralized) [1]. Examples for group VI (and those listed for group I in De Jong 2000:130-131) can also be heard in group I dialects discussed here.

\subsubsection{Stressed original anaptyctics}

The reflex of the pattern $\mathrm{CICaC}$ (i.e. ${ }^{*} \mathrm{CuCaC}$ or ${ }^{*} \mathrm{CiCaC}$ ) is $\mathrm{CCaC}$. Stress is then placed in conformity with rules described in 2.1.1. When a consonant or speech pause precedes, the cluster \# CC or C CC will often be resolved by an anaptyctic (indicated here as o): \# agráb, álagrab "waterskins", \# əḥgán, álahggan "injections", \# əwráś, áləwraš "workshops". But when assimilation precedes, a resulting geminate will be reduced, and anaptyxis will not take place, e.g. \# așwar, áșșwar (pronounced áșwar) "pictures", \# anxár, ánnxar (pronounced ánxar) "noses". These anaptyctic vowels are not stressed in the group I dialects discussed here.

Plurals include: sṣiy, ála șì "sticks", hșiy, álahssily "stones", but there are no anaptyctic vowels in forms with an assimilated preceding article like $(a l+$ rhiy $>)$ árrhiy "hand mills", and also $(a l+l$ hiy $>)$ állhiy "beards".

N.B. Of these dialects some have short forms like lha' or lhiy, Iná' etc., or longer forms like lèha, lèna etc. Forms of the suffixed preposition / with initial stressed $i$ - were not recorded in these group I dialects in the centre and south of Sinai (for more remarks on suffixed prepositions see 3.1.16.).

\subsection{Elision of Short Vowels}

All group I dialects are 'différentiels' in terms of short vowel elision. ${ }^{7^{0}}$ The rule for elision is like that given for group VI.

The rules of morphophonemic elision are compulsary.

\subsubsection{Morphophonemic I-elision}

Rules given for group VI are valid here as well.

\footnotetext{
$7^{0}$ The same is reported for TyA of the Negev, see Shawarbah 2007:421.
} 


\subsubsection{I-elision in sandhi}

Like in group VI, morphophonemic elisions of short high vowels $i$ and $u$ in group I are compulsary, but comparable elisions in sandhi are optional.

\subsubsection{Cyclic anaptyxis rule in sandhi}

The optional I-elision rule in sandhi may be applied after the execution of the anaptyxis rule, e.g. (the cluster is underlined and in bold print, the anaptyctic vowels are in bold print and the high vowel eligible for sandhielision is underlined):

yrawwih + lhin > yrawwih lhin > yrawwih ilhin > yrawwh ilhin "he goes to them (fem.)".

In this first example the cluster $h l h$ is resolved, after which the high vowel $i$ preceding it lands in open syllable (thus becoming eligible for elision) and is dropped.

Like in group VI, the I-elision rule may also be re-applied after execu-

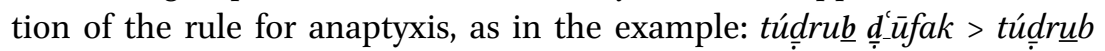

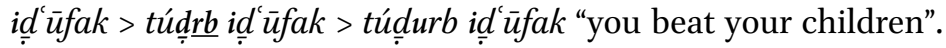

In this second example the cluster $b \underline{d}^{c}$ is resolved, after which the high vowel $u$ preceding $b$ is in open syllable (thus becoming eligible for elision) and is dropped, creating a new cluster $\underset{\underline{d}}{d r} b$, which is then eliminated by insertion of another anaptyctic vowel, in this case $u$.

\subsubsection{Exceptions to the I-elision rule}

When $\mathrm{C}_{\mathrm{a}}$ and $\mathrm{C}_{\mathrm{b}}$ in $\mathrm{C}_{\mathrm{a}} \mathrm{C}_{\mathrm{a}} \mathrm{IC}_{\mathrm{b}}$ are phonetically close or identical, the short high vowel $I$ is not dropped. Examples are (a suffixed noun) sadditi "my dam (where crops are grown)", (a verb form) yhálliluw "they make heaps" and (participles) mballilih, mballilīn and mballilät "having made wet".

Also in sandhi this type of elision does not take place, e.g. šiddit alharāarah "the intensity of the heat" (with clearly audible reduction of the geminate $d d$ ).

Like in TwA, HmA and HnA of group VI, elision of the high vowel does not take place in the act. participles (sg. fem.) mta'ákninih, (pl. masc.) mta'akninin and (pl. fem.) mta'akninät "irritated". This was the case in TAṢ, HwA, DbA, but in ĞrA direct elicitation produced the forms mta'aknin, mta'akinnih, mta'akinnin, mta'akinnāt (the forms were not recorded in the other dialects). 
As another exception to this I-elision rule, forms recorded in ĞrA like (preserved high vowel is underlined) líbsitih or lábsitih "she wore it" and šírbitih or šárbitih "she drank it" should be mentioned; the forms recorded were not (after elision and subsequent anaptyxis; anaptyctics in bold print) líbistih or lábistih and šíribtih or šáribtih, wich one might have expected.

Such forms were however recorded in TAȘ, so that stress may be interpreted to have acquired a phonemic function: širibtah "she drank it" as opposed to širíbtah "I drank it" (see remarks in 3.2.1.1.).

\subsection{Assimilation}

Three types of contact asimilations of consonants can be identified:

- regressive partial or total,

- progressive partial or total and

- reciprocal total.

The $l$ of the article only rarely assimilates to a following $\check{g}$, as in e.g. $a \check{g} \check{g} a m r$ "the live embers". Assimilation of $l$ to initial $k$ was not recorded. For examples of these types of assimilation, see De Jong 2000:136-137. In addition to examples listed there, an example of progressive total assimilation recorded in TyA is:

$\underline{t}+h>\underline{t} \underline{t}$ as in bnaharițticy (< bnaharițiy) "we plough it".

The type of metathesis of hissing sounds recorded in groups VI and VII (see 2.5. in the relevant chapters) was not heard in these southern and central group I dialects. Instead, forms like șāğ "iron baking sheet", sĭǧih "game of sĭğah", siǧn "prison" and tasğı̆l "recording", etc. are current.

In these central and southern group I dialects šams is current for "sun" and šă̌ar for "trees".

\section{Morphology}

\subsection{Nominal Morphology}

3.1.1. Raising of a

3.1.1.1. Raising of a in $C_{1} a C_{2} i C_{3}(a h)$

Raising of $a$ in the nominal pattern $\mathrm{C}_{1} \mathrm{aC}_{2} \mathrm{IC}_{3}(\mathrm{ah})$ occurs regularly, but is optional in southern group I dialects (except in HwA, see remark below). Such raising is only inhibited by preceding ' and is less regular when $\mathrm{X}$ 
precedes or follows $a$, although it may take place in such positions (especially when following ', see examples below). The resulting high 'surface' vowel $i$ is not elided. ${ }^{71}$ In HwA instances of non-raising were so few that morphological restructuring may be concluded. In DbA raising is mainly absent when ', $\dot{g}, h$ or $x$ precedes, e.g. 'adìm "enormous", galied "fat, bulky", garīb "strange", xalițah "mixture", hagigiy "real" (instances with preceding $h$ were not recorded). For examples see 1.2.3.4.3.2. of this chapter.

3.1.1.1.2. Raising of a in *CaCīy $\left(C_{3}=y\right)$

Raising of $a$ preceding ${ }^{*} \mathrm{CaCiy}\left(\mathrm{C}_{3}=\mathrm{y}\right)$ occurs often, but variation is still heard as well, e.g. biríy "innocent", (reflecting final *-iy) in șibiy "boy", ganíy "rich", țiríy "moist; soft", nibíy nábíy "Prophet", guwíy "strong", wilíy waliy "saint", 'Ilíy Alíy "male given name".

\subsubsection{Raising of a in open syllable preceding stressed í}

For raising of $a$ in open syllable preceding stressed $i$ in verb forms (with underlying $\mathrm{C}_{1} \mathrm{aC}_{2} \mathrm{iC}_{3}$ pattern for the $i$-type perfect), see 3.2.2.1.

3.1.1.3. Raising of a in $\operatorname{CaCCiC}(-a h)$

The short vowel $a$ preceding stressed CCĩ is not raised. Examples are: batțīx "watermelon", baddī "improvisor of rhyme", xarrīğ "alumnus", sakkinah "knife", garnit "octopus", sab ìn "seventy", xamsin "fifty", Katrīn "(St.) Catherine", kabrit "matches". Also in verbal nouns of measure 2 such raising is absent, e.g. $\operatorname{targ}^{-c}$ "grafting", tašğ wah-form like tagarïb "going north" (see for other examples 2.2.1.2. above).

\subsubsection{Raising of a in $\mathrm{CaCC} \overline{\mathrm{C}} \mathrm{C}$}

Raising of $a$ preceding stressed CCā is optional: gișsāạs "tracker", billās "thief; extortionist", fissāy "expert farter", birrrād "teapot", țillāğih "fridge" and wiğ àn "suffering pain", milyān malyān "full", galțān giltțān "mistaken", Silmān "male given name Salmān", mirḍān "ill", fihyān "surprised", kislān "lazy", hiğǧān "camel rider", siyyāl sayyāl "acacia trees (coll.)", but also "ațšān "thirsty", 'ațlān "broken, not functioning" and bakkākah "lighter"..$^{2}$ Although such raising was heard in all dialects, it is less current in TAN and TAS.

N.B. sg. fem. forms of colours and physical defects have short stressed final $-\dot{a}\left({ }^{\prime}\right)$ (if not raised) (except in MlA, where long final $-\bar{a}$ is also heard).

${ }^{71}$ This situation is the same as what has been described for group II in the north, see De Jong 2000:272-273.

$7^{2}$ The word bakkākah is used in TyA; in most dialects of Sinai the word for "lighter" is giddāhahah. 
The $a$ in closed syllable may then be raised, but this is optional, e.g. himrá" "red (sg. fem.)", himgá "stupid (sg. fem.)", but also zargá' "black; blue (sg. fem.)", șafrá' "yellow", etc.

Like in group VI, raising of $a$ in the pattern for sg. fem. for colours and physical defects may only take place when final $-\bar{a}\left({ }^{\prime}\right)$ has not been raised to -íy.

3.1.1.5. Raising of a in ... CaCāC...

Raising of $a$ preceding Cā is extremely current, but is concluded to be optional, since it is often absent in more careful speech.

Some of many examples are: matān mitān, "when?" (in HüA), gibāyil "tribes", zimān "before in olden times", gizāyiz "bottles", bikāriğ "coffee pots", Tiyāha "name of a tribe Tayāha", ǧināyin "gardens".

In labial environments, raising may also be towards $[\mathrm{u}]$, as in muwārik "cushions supporting the camel rider's leg" (pl. of mèrakah or mōrakah, see also remarks in 1.2.4.1. and in fn 101, p. 83) and zuwāyir "annual visits to sheikhs' tombs (pl. of zwārah)", Șuwālḥih "name of the tribe Șawālḥah".

Examples without raising are: talātīn "thirty", nahār "day", tamām "excellent", Badāṛah "name of a tribe", tafātir "records", ganāt asSwēs "Suez Canal", šamāl "north".

Also in group I, raising is less regular when $l$ or $r$ follows $a$, or X precedes, e.g. kalām "speaking", țalātah "three", xalāṣ "ready", salām "peace", Garārših "name of a tribe", farāṣ̌̄ "thin loaves of bread baked on a șāğ", marāğ h. "swings (three legs) for the goat skin (used to churn butter)", halāl "small cattle", axawāt "sisters", 'ašān "because", hayātak "your life", hamādih "flat barren land", garāàir "large sack (pl. of ġarārah)",73 Also when 'precedes, raising remains absent, e.g. (')așāyil "thoroughbreds", (')asāsih "his origin".

3.1.1.6. Raising of a in ... CaCá...

$a$ in open syllable preceding stressed $a$ is often (but optionally so) raised (like in group VI), e.g. (raising towards I.P.A. [I]) ğimál "camel", risán "halter", libán "milk", sibágah "race" (sábagah in TAṢ), šiǧárah "tree" (šáǧarah in TAȘ), a verb form misák "he took" and (towards [v] in labial and/or velarized environment) muțár "rain", duwá" "medicine". And also in gahawah-forms such raising may take place, e.g. tihát "under", šihár "month" and in verb forms like yi árif "he knows".

\footnotetext{
${ }^{73}$ ġarāyir: see ġarāra in Behnstedt and Woidich 1994:334-335 (glossary).
} 
Such raising is generally absent when the $a$ is preceded by ${ }^{*}$, e.g. (')abár "needles" and (")axád "he took".

Also, when $a$ is followed by $l$, such raising tends to remain absent, e.g. galám "pen", malág "hard flat ground (like rock, in which traces are invisible)", zalámah "man”, or when X precedes, e.g. haǧár "rock, stone”, ganám "goats and sheep", xašáb "firewood", etc. (see De Jong 2000:145-147).

3.1.1.7. Raising of a in open syllable preceding stressed $A$

To summarize the $a$-raising rules in one optional rule we can write: ${ }^{74}$

$$
\begin{array}{ll} 
& \mathrm{a}>\mathrm{I} / \mathrm{C}_{\mathrm{a}}-\mathrm{C}_{\mathrm{b}} \mathrm{A} \\
\mathrm{C}_{\mathrm{a} \neq{ }^{*} \text { or } \mathrm{X}} & \mathrm{A}=\text { stressed } a \text { or } \bar{a} \\
\mathrm{C}_{\mathrm{b}} \neq l & \mathrm{I}=\text { high vowel } i \text { or } u
\end{array}
$$

N.B. Raising of $a$ may also take place when stress on A is secondary, e.g. fássibag "in the race", verb forms ánkital "he was beaten", ástuwat "it (sg. fem.) became ripe/cooked" and muwālìd "births", muwāzin "weighing scales (pl. of mizānn)".

\subsubsection{Raising of a in $\mathrm{CaCu} C(a h)$}

Raising of $a$ preceding $\bar{u}$ is optional, e.g. gumūs $\sim \dot{g} a m \bar{u} s$ "food dip", xurūf xarūf "lamb", ğunūb ğanūb "south" and yuhūd yahūd "Jews", ḍurūbah d darūbah "beautiful young camel", ${ }^{75}$ 'urūs 'arūs "bride", 'uğūz 'aǧūz "old lady". With initial hamzah such raising is absent in most dialects (contrast with groups VI-VIII): abūy "my father" and axūy "my brother", and ist p. sg. com. imperfect forms of mediae $w \bar{a} w$ verbs agūm "I get up", agūl "I say" (see remark * below). However, in dialects indicated below, isolated instances of such raising were heard when *hamzah preceded, as in $u b u \bar{u} h \sim a b u \bar{u} h$ "father" (TAN), uxūk axūk "your brother", ugūm agūm "I rise" (both HwA), Such raising with preceding *hamzah was not heard in TAȘ, ĞrA, BdA, DbA or MlA.

Underlying $\mathrm{Ca} C \overline{\mathrm{Cu}} \mathrm{C}$ with reduced $\bar{a}$; ma ūn "container", babūr "tractor", ganūn "law", ba ū $\underline{d}$ dah "mosquitos". In one instance in TyA raising in babūr yielded bubūr.

The gahawah-vowel in open syllable preceding $C \bar{u}$ is not raised, e.g. mahațūt "placed", ma agūd "tied", mahabūs "locked up", maxanūg "constricted; suffocated".

\footnotetext{
${ }^{74}$ See also De Jong 2000:147.

${ }^{75}$ darūbah $\sim$ durūbah is used to refer to a recently acquired beautiful camel or car. It can aliso be used to refer to one's recent bride, e.g. durūbtī.
} 
3.1.1.9. Raising of a in open syllable preceding stressed $u$

Unstressed $a$ in open syllable preceding stressed $u$ (in the following syllable) is regularly raised, e.g. kubúr "he grew", kutúr "he became many", tuxún "he became thick", gulúd "he became fat".

The raised $a$ has remained underlying $\mid$ a $\mid$ however. It (as a surface $u$ ) is therefore not dropped in unstressed open syllables. In addition, in many dialects the vowel 're-surfaces' as $a$ in closed syllables, e.g. kabrit "she grew", $\dot{g}$ al $\underline{\text { dit }}$ "she became fat". ${ }^{6}$

3.1.1.10. a-raising rules combined

Like in dialects of group I in the north (see De Jong 2000:150), we can combine the rules for raising of $a$ preceding a long stressed high vowel:

$$
\mathrm{a}>\mathrm{I} / \mathrm{C}_{\mathrm{a}}-\mathrm{C}_{\mathrm{b}} \overline{\mathrm{I}} \mathrm{C}
$$

$\overline{\mathrm{I}} \quad=$ long vowel $\bar{u}$ or $\bar{\imath}$

I $\quad=$ short high vowel $u$ if $\overline{\mathrm{I}}$ is $\bar{u}$; short high vowel $i$ if $\overline{\mathrm{I}}$ is $\bar{\imath}$

$\mathrm{C}_{\mathrm{a}} \neq$ * $^{\prime}$ (hamzah)

$\mathrm{C}_{\mathrm{b}}^{\mathrm{a}}=$ consonant capable of carrying velarization in case of raising to $u$

Notice that, like in group I dialects of the north (see De Jong 2000:150), the provision of $\mathrm{C}_{\mathrm{a}} \neq{ }^{* \prime}$ is made for the group I dialects described here, i.e. preceding “*hamzah” inhibits such raising. However, in TAN and HwA a few forms were recorded which did show such raising: $u b \bar{u} h \sim a b \bar{u} h$ and ugūl agūl "I say".

\subsubsection{Reflexes of ${ }^{*} \mathrm{C}_{1} a C_{2} C_{3}(a h)$}

For reflexes of $\mathrm{CaCC}(-\mathrm{ah})$ the following forms were recorded (in all dialects, unless indicated otherwise): badw "Bedouin", tahát "under", fahám "charcoal", wah̆dih (but wiḥdih in ĞrA) "one (sg. fem.)", nahyih "direction", șa áb "difficult", šakl "shape", șáḥan "dish, plate", ǧidy "billy goat" (TAṢ, ḤwA, DbA, MlA, ĞrA), ğady (BdA), șadr "chest", (")akl (TAṢ, TAN, DbA, MlA), waḳl "food" (BdA), kirš (TAȘ) "(fat) belly", kalb "dog”, ǧidd "grandfather" and ğifn "eyelid" (TAȘ).

${ }^{76}$ Direct elicitation, however, yielded forms like tuxnit "she became thick" in ĞrA, $\dot{g}$ uldin "they (f.) became fat"; here the $a$ did not 'resurface', although the vowel is still to be regarded as underlying $|a|$, since it is not dropped in open unstressed syllables, e.g. also in these dialects the 3 rd p. sg. masc. forms are tuxún (not •txun) and $\dot{g} u l u \underline{d}$ (not $\bullet \dot{g} l u \underline{d}$ ). 


\subsubsection{Reflexes of ${ }^{*} \mathrm{CaCiC}(\mathrm{ah})$}

In all dialects, unless indicated otherwise: wirk "thigh" (TAȘ), kitf "shoulder" (HwA, ĞrA, TAS and TyA; other dialects not recorded), kilmih "word", šrkih "company".

xášin in TyA, xišsin in TAṢ

\subsubsection{Reflexes of $C_{1} u C_{2} C_{3}(a h)$}

Some reflexes of $\mathrm{C}_{1} \mathrm{uC}_{2} \mathrm{C}_{3}(\mathrm{ah})$ are (in all dialects, unless indicated otherwise): bunn "coffee beans", rizz "rice", kull "all; every", amm (all except $\mathrm{BdA} ; 7^{77} \sim$ umm in ĞrA), ummm "mother" (BdA), uxt "sister", Ğim ih "male given name" (not recorded in TAN, DbA, BdA), muddih "period", hurmah "woman", zibdih "butter", rukbah "knee" (HwA, TyA, TAȘ, ĞrA, TAN, not recorded in other dialects), hinnih "they (fem.)", šuggah "a woven length of a tent (about $1 \mathrm{~m}$. wide)" (TAȘ, MlA, BdA, TyA, Ḥ̂, not recorded in other dialects).

\subsubsection{Absence of I in open syllables preceding stress}

As is the case in all dialects of Sinai, a high vowel I (i.e. $i$ or $u$ ) in open initial syllables of the type $\mathrm{CIC}(+\mathrm{V})$ preceding stress (on $\mathrm{V}$ ) is dropped.

When $\mathrm{V}$ is a long vowel, an initial CC cluster is the result, e.g.: snin "years", 'yūn "eyes" and ǧnēh "pound (money)", ğbāl "mountains", drās "threshing".

Also when $\mathrm{V}$ is a short vowel, an initial cluster CC will result, e.g. rkab "knees", šnat "suitcases", grab "watersacks (goat skins)" and also in diminutives (see 3.1.6. below) like gșayyir "short" ("guṣayyir), bwēt "little house/ tent" ("buwayt).

Exceptions to such elisions are (often loans from MSA, probably via a dialect such as Cairene Arabic), e.g.: nizām "system" (all dialects), șinā ìy "artificial” (TAȘ), tiğārah "trade" (MIA), ğirāḥah "surgery" (MIA), (2 instances in) zurūf ḥukūmiyyah "government circumstances" (TyA), bidāyt albațtīx "the beginning of the watermelon (i.e. the season for growing watermelon)" (TyA), 'umūman "in general" TyA) and turās "legacy" (ḤA).

Notice that in the instances nizām and zurüf the sibilant $z$ is heard instead of more typically Bedouin $\underline{\underline{d}}$. In the example turās we have sibilant

77 Also aṃm in TyA of the Negev, see Shawarbah 2007:330. 
$s$ instead of more typically Bedouin $\underline{t}$ (compare MSA turāt $\underline{t}$ ). These are additional indications that we are dealing with loans.

Other instances of non-elision include: tulüḥhin "their (fem.) rising (of stars)" (BdA) and all dialects have gizāzih (after raising of $a$ in the first syllable of gazazzah) for "bottle".

Verb forms listed for group VI are also current in our group I dialects and the verb "come" has the imperfect form yğiy "he comes".

\subsubsection{Diminutive patterns}

The usual diminutives expressing 'littleness', 'shortness', 'narrowness' etc. were also recorded in our group I dialects (see examples listed in 3.1.6. for group VI) and also hrayyim is current. In addition, many diminutive forms were heard, and especially in the speech of an elderly woman of the Tayāha, e.g. $\underline{d}^{\prime} a y f i n ~ i f t e \bar{t} a \bar{t}$ "tiny children", swēkin "living (more or less)", wlēdī "my little son", gray'íy "bald (sg. fem.)".

Another diminutive pattern heard in $\mathrm{TyA}$ is $\mathrm{C}_{1} \mathrm{C}_{2}$ ayC $_{3} \mathrm{u} \mathrm{C}_{3}$ (i.e. $\mathrm{C}_{3}$ is reduplicated) in bațtix iṣgayrür "small watermellons". ${ }^{8}$ The same pattern is used in TAS as in (after reduction of the diphthong) șgarürah, șgarūrīn, s.garūrāt and also graybūb "nearish". Another diminutive heard in TAȘ is

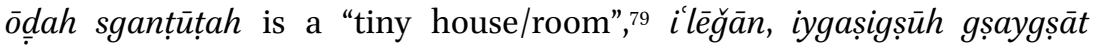
iṣgayyrāt "they cut it up into little pieces".

A lexical item coined on the $\mathrm{CaCCu} C(-a h)$ pattern in karrūusah "wheel chair" (TyA).

The hypochoristic - $\bar{a} n$ suffix, which was recorded in some of the dialects of group I in the north ${ }^{80}$ was also heard in TAN, but not in the other dialects. Examples in TAN are: hniyyān "here" and kidiyyān "thus" and alternatively hniyyāniy and kididyyāniy (see 3.1.15.1.). ${ }^{81}$

\subsubsection{Pattern $a C_{1} C_{2} a C_{3}$}

The pattern used for colours and physical (and sometimes mental) defects is (for sg. masc.) $\mathrm{aC}_{1} \mathrm{C}_{2} \mathrm{aC}_{3}$ (e.g. abyad ) and $\mathrm{aC}_{1} \mathrm{aC}_{2} \mathrm{aC}_{3}$ (e.g. áhamar, stressed

\footnotetext{
${ }^{78}$ Diminutive patterns are reported to be very common in TyA of the Negev, see Shawarbah 2007:427.

$79 \bar{o} \underline{d}$ ah is also used for "small (stone) house".

${ }^{80}$ See De Jong 2000:153. It thus appears to be mainly in use among tribes of the eastern central and northern Sinai.

${ }^{81}$ The $-\bar{a} n$ suffix is also heard in TyA of the Negev, see Shawarbah 2007:427-428.
} 
on the first syllable) where $C_{1}=X$. Other examples are like those listed for group VI.

The sg. fem. forms have a $\mathrm{C}_{1} \mathrm{aC}_{2} \mathrm{C}_{3}$ á pattern, with a final ${ }^{*} \bar{a}$ that has been shortened and which is often in pause followed by an unreleased glottal stop (e.g. be déá, hamráa; in MlA some forms were recorded with long final $-\bar{a}){ }^{82}$ There is an additional $a$ following $\mathrm{C}_{2}$ when it is $\mathrm{X}$ and final ${ }^{*}-\bar{a}$ is raised to -íy when $\mathrm{C}_{3}$ is neutral (e.g. šaḥabíy). Other examples are like those listed for group VI.

In the pl. com. forms for colours and physical defects all dialects show $\mathrm{C}_{1} \mathrm{IC}_{2} \mathrm{C}_{3}$ as the pattern, i.e. $\mathrm{C}_{1} \mathrm{iC}_{2} \mathrm{C}_{3}$ or $\mathrm{C}_{1} \mathrm{uC}_{2} \mathrm{C}_{3}$ (see 1.2.3.2.). Plural forms for "black" and "white" are sūd $\left(\mathrm{C}_{2}=w \bar{a} w\right)$ and bị $\underline{\underline{d}}\left(\mathrm{C}_{2}=y \bar{a}\right)$.

3.1.8. The elative patterns $a C_{1} C_{2} a C_{3} a C_{1} a C_{2} C_{3}$ and $a C_{1} C_{2} a$

Elative patterns in group I are like in group VI: $\mathrm{aC}_{1} \mathrm{C}_{2} \mathrm{aC}_{3}$, e.g. aktar "more; most", $\mathrm{aC}_{1} \mathrm{aC}_{2} \mathrm{C}_{3}$, e.g. aga!l "less; least" and $\mathrm{aC}_{1} \mathrm{C}_{2} \mathrm{a}$ (without gahawah-vowel), e.g. ahla "sweeter; sweetest".

\subsubsection{Initial a}

\subsubsection{The article and the relative pronoun}

The article is al-in all dialects of group I and the relative pronoun is alliy. ${ }^{83}$ The article is a stressable unit (see 2.1.1.).

Examples are: yōm iyțịh álmațar [...] biyḥuțtuw bdāarhum "when the rain falls, they plant their seeds".

The relative pronoun is alliy. Examples are: alliy byašrab imn alhāmid $h \bar{a} \underline{d} a w$ alliy biyfitt minnih "there are those ${ }^{84}$ who drink from this sour (milk) and there are those who make fattah with it".

The vowel in the preposition $f i$ is often dropped when it collides with $a$ - of the article, as in e.g. f-ášštiy "in the winter" and f-álğibal "in the desert (lit. the mountains)" and also with unstressed $a$ of the article, as in f-alwādiy "in the wadi".

Prepositioned $h a$ - was heard used predominantly in adverbial halhin "now".

\footnotetext{
${ }^{82}$ Like in the dialect of the Dawāgirah, see De Jong 2000:446 and 661 (map 9).

${ }^{8}$ Holes and Abu Athera 2009:214 also report al- and alliy as the current forms in their corpus of Bedouin poetry; the exception is their poet Šbaylāt (of Baniy Hasan in northern Jordan), who uses il- and illi thus "aligning himself [...] with the 'sedentary' dialects".

${ }^{84}$ alliy is often elliptically used for something like fih (min an-)nās alliy...
} 
Only in a few instances $h a$ - was used in its 'specifying' function: $f i$ haddikmih 'a țūl là šilēhāt wala ġayrih f-áddkam "there are no chalets in (i.e. near) that hill or anything (at all) in the hills" (HwA), šuft miy...tâfị fi ha-lgid $\underline{d} \bar{f} f$ "I saw water... overflowing in this ferry boat" (TyA).

Much more current in HwA, however, is postpositioned ha, e.g. alliy 'āwiz iy... iynawwi' f-álbil ássibag imn ássibag ha biywaddīh imn álǧimal $h a$ "there are those who want to vary in (sending) camels from one race to this other race (and) who will send from these camels" (for more detail, see 3.1.13.2.).

\subsubsection{Other instances of initial a}

Other instances of initial $a$ - are: amm (except uṃm in BdA and amm $~$ uṃm in ĞrA) "mother", uxt "sister" in all dialects, ạ̣na is "we" in HwA and $a h n n a \sim i h ̣ n a$ in ĞrA (in the other dialects only ịnna) and the pl. for (")ibrah "needles is (")abár. In all dialects pl. forms of the type CCaC are current, e.g. șwar "pictures" and grab "waterskins".

$y \bar{a}$ yummma is used in many group I dialects (also those that have amm for "mother") for "oh mother".

\subsubsection{The feminine morpheme $(T)$ in genitive construction}

$\mathrm{T}$ in genitive construction is treated like in the dialect of the Samā'nah of group II in the north; ${ }^{85}$ the vowel of T in construct state will be $a$, whenever $a$ precedes in open syllable. Otherwise, the T-vowel will be $i$ in construct state when a consonant precedes, or absent when a long vowel precedes. $^{86}$

3.1.10.1. T in genitive construction preceded by a in open syllable Like in group VI, the feminine morpheme $-a h \sim-i h$ in construct state becomes -at when aC directly precedes. Examples of aCT + suffix: (dual) sanatēn "two years" and ragabatih "his neck" (for stress, see 2.1.1.2.2.).

Notice that resyllabication of a (nominal or verbal) CaCaCTv sequence does not take place in group I dialects (contrast MzA of group VI), e.g. darabatih "she hit him" and ragabatih "his neck".

\footnotetext{
${ }^{85}$ See De Jong 2000:279-281.

${ }^{86}$ In TyA of the Negev $\mathrm{T}>-a t$ when historical aC directly precedes, otherwise $>-t$ or $-i t$, see Shawarbah 2007:424.
} 
3.1.10.2. The rule for $T$ not directly preceded by aC or $\bar{v}$

Like in group VI when not preceded by aC, the fem. morpheme -ah becomes -it (or $-t$ when a long vowel $\overline{\mathrm{v}}$ directly precedes, see 3.1.10.4.) in construct state.

The $i$ of the ending -it may then be subject to the rule for high vowel elision, after which resulting clusters are often eliminated by insertion of an anaptyctic. Examples listed for group VI may also illustrate the situation in our southern group I dialects discussed here.

3.1.10.3. T preceded by the gahawah-vowel a

Forms in which a gahawah-vowel $a$ directly precedes $\mathrm{T}$ in open syllable are treated the same way as forms in which such a preceding $a$ is 'historical'. Examples are: gahawati "my coffee", gahawatah "his coffee" and gahawatak "your coffee" (for stress in these forms see 2.1.1.2.2.) (treatment of T preceded by the gahawah-vowel $a$ could not be checked in MlA). ${ }^{87}$

\subsubsection{T following ā}

T preceded by $\bar{a}$ yields - $\bar{h}$, e.g. hamāh "mother-in-law" and when in construction, $\mathrm{T}>-t$, as in hamātak "your mother-in-law".

3.1.10.5. Nominal ending -it in construction vs. verbal $3 r d p$. sg. perf. ending -at The high vowel $i$ of the nominal ending -it is dropped when it is in open unstressed syllable, e.g. nägtah "his she-camel".

The low vowel $a$ in verbal forms of the 3 rd p. sg. perf. is not dropped, e.g. lāgatah "she found him".

\subsubsection{Genitive marker}

The genitive marker is šug̣! for sg. masc., šug lah (sg. fem.), šug̣tı̄n (pl. masc.) and šug̣ $\grave{a} t$ (pl. fem.) in our group I dialects discussed here; $h a g g(a h)$ is not used. Sometimes the K-form $b t \bar{a} c$ is used.

Paradigms in these dialects are:

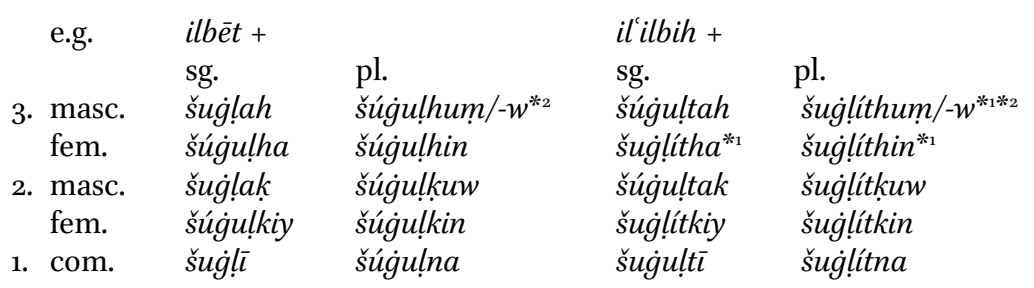

\footnotetext{
${ }^{87}$ In TyA of the Negev T preceded by gahawah-vowel $a>-i t$, e.g. ra'áwit ganám "grazing small cattle", see Shawarbah 2007:244.
} 
${ }^{*_{1}} t+h$ will often assimilate to $t t$, e.g. šug

$*_{2}$ For a remark on the suffix -huw, see 3.1.12.2.

A preference for the construct state instead of indirect annexation could not be concluded from the available data.

\subsubsection{Personal pronominals}

3.1.12.1. Independent pronominals

In group I dialects of the central and southern Sinai the following independent pronominals are used: $:^{88}$

\begin{tabular}{|c|c|c|}
\hline & sg. & pl. \\
\hline & $h \bar{u}$ & $\operatorname{hum}(m a) / h u w w a^{* 1}$ \\
\hline & $h \bar{\imath}$ & $\operatorname{hin}(n a)$ \\
\hline masc. & $\operatorname{int}(i h)$ & intuw \\
\hline $\begin{array}{l}\text { fem. } \\
\text { com. }\end{array}$ & $\begin{array}{l}\text { intiy } \\
\text { aná }\end{array}$ & $\begin{array}{l}\text { intin } \\
\text { ihna }{ }^{*_{2}}\end{array}$ \\
\hline
\end{tabular}

*1 $_{1}$ huwwa was also heard used for the pl. masc. in TAN, MlA, but not in the other dialects of group I discussed here. ${ }^{89}$

*2 In HwA aḥna; in ĞrA iḥna aḥna.

Negated $^{90}$ (in all forms stress is on the first syllable, except in mūhúmịa and mihínna $)^{* 1}$ :

\begin{tabular}{|c|c|c|}
\hline & & \\
\hline & $m \bar{u} h \bar{u}^{*_{2}}$ & $m u ̄ h u m(m a)^{*}$ \\
\hline & mìhì & $\operatorname{minin}(n a)^{*_{5}}$ \\
\hline 2. masc. & $\operatorname{mint}(i h)$ & mintuw \\
\hline $\begin{array}{l}\text { fem. } \\
\text { com. }\end{array}$ & 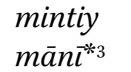 & $\begin{array}{l}\text { mintin } \\
\text { mahna }\end{array}$ \\
\hline
\end{tabular}

*1 In ĞrA direct elicitation yielded 'double' forms like aná mān̄̄, int(ih) mint(ih), intiy mintiy, hū mūhū. Such double forms are also often used in the other dialects.

${ }^{* 2} m \bar{u} h \bar{u} \sim m a \bar{h} \bar{u}$ in HwA

\footnotetext{
${ }^{88}$ Independent pronominals in TyA of the Negev are: anā(h), intih (int), intiy, $h \bar{u}(h), h \bar{\imath}$ (h), áhna, íntuw, íntin, húm(mah) and hin(nih), see Shawarbah 2007:426.

${ }^{89}$ For possible origins of the forms (possessive/object) -huw and the subj. (independent) pronominal huwwa, see De Jong 2000:163 (remark ${ }^{*}$ 2)) and NOTE in 3.1.12.2. of chapter I.

${ }^{90}$ In poetry recorded by Holes and Abu Athera (2009:225) the negation is commonly $m \bar{a}+$ pronoun $(+b i)$.
} 
*3 māna in HwA

${ }^{*}$ mūhuwwa or māhuwwa was not recorded in TAN or MlA

*5 māhin was also heard in BdA

*6 miḥna in DbA, BdA, ĞrA

3.1.12.2. Pronominal suffixes

In group I the following pronominal suffixes are used:
$\begin{array}{lll} & \text { sg. } & \text { pl. } \\ \text { 3. masc. } & \mathrm{C}-a h / \mathrm{C}-i h^{* 1}, \overline{\mathrm{v}}-(h) & - \text { hum }^{* 6}\end{array}$
fem. $\quad-h a^{*_{2}} \quad-h$ in
2. masc. C-ak, $\overline{\mathrm{v}}-k^{* 3} \quad-k u w^{* 7}$
fem. $\quad-k i y^{* 4} \quad-k i n$

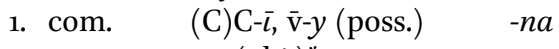 $-n \bar{\imath}(\mathrm{obj} .)^{*_{5}}$

Assimilation of initial $h$ to preceding voiceless consonants is current in our group I dialects, e.g. simitta "I heard her", tbuxxxa "you spray it (sg. fem.)", hisssa "her noise". ${ }^{11}$

For allomorphs used in combination with the preposition 'ind, see below 3.1.16.

${ }^{*}$ Group I, has with - $a h /-i h$, contrasting with $-u(h)$ of groups VI-VIII.

$*_{2}$-ha -hiy in MlA and in TyA (-hiy is predominant in the latter)..$^{92}$ The pron. suffix -hiy was also heard in group I dialects in the north of Sinai. The (partial) phonetic conditioning effective in group I dialects of the north (i.e. directly preceding $\bar{u}$ calling for the appearence of $-h a$ there instead of -hiy), ${ }^{93}$ is concluded not to be operative in MlA and TyA. Examples in MlA are: iw minnih biyța "mūhiy, iw yagța'aw w iygușșūhiy "and then they graft it (sg. fem.), and they cut and clip it (sg. fem.)" and abūhiy "her father".

*3 Contrast C- $a k$ and $\overline{\mathrm{v}}-k$ with heavily velarized $-{ }^{u} k /-u k$ of groups VI-VIII.

*4 Invariable -kiy is characteristic of group I, see also De Jong 2000:164. Contrast with $-k$ and $-i k$ of groups VI-VIII.

$*_{5}$ Suffixes $-\bar{\imath}$ and $-n \bar{\imath}$ for the 1 st p. sg. com. are stressed, but unstressed $-i$ and $-n i$ also occur.

\footnotetext{
${ }^{91}$ The spelling with 3 identical consonants is for reasons of morphological transparency. These forms are not different from tbuxxa and hissa.

${ }_{92}$ For -ha or -hiy among sub-confederations of Tiyāha in Negev see Shawarbah 2007:426.

${ }_{93}$ See De Jong 2000:164-166 and 674 (appendix), map 35 .
} 
*6 -huw -hum in HwA, MlA, ĞrA and TAN. Also a lengthened suffix -huwwa was also heard (in TAN). Such forms were also heard in group VI (see also De Jong 2000: 169, remark *3) ).

${ }^{*} 7-k u m$ is reported in poetry texts (by a speaker of TAN) recorded in Holes and Abu Athera 2009:234 as an alternative form (in a more formal register) for $-k u(w)$ in two poems addressed to the late King Hussein of Jordan, "perhaps as a token of respect for the king".

3.1.12.3. Pronominal suffixes and negation

In group I the negation is formed with single (preceding) $m \bar{a}$, which leaves pronominal suffixes unaffected.

\subsubsection{Demonstratives}

\subsubsection{Near and far deixis}

Demonstratives in TAS and TAN are:

Near deixis ${ }^{* 1}$

sg.

masc. $\quad h \bar{a} \underline{d} a^{*_{2}}$

fem. hẹ diy
Far deixis

pl. sg. com. hā $\bar{d} \bar{o} l^{* 3}$ pl. com. hōdallāk $k(a h)$

$*_{1}$ The same forms were heard in TAN.

$*_{2}$ Unvelarized $h \bar{a} \underline{d} a$ is sporadic in TAS, but $h \bar{a} \underline{d} a \sim h \bar{a} \underline{d} a$ in TAN.

* hōdal was also elicited in TAS, but did not occur in spontaneous speech.

$*_{4}$ The same forms were heard in TAN.

“There... is/are!” hayhū ğa', hayhī ǧat, hayhuṃ ğaw, hayhin ğan.

Demonstratives in TyA are:

Near deixis

sg.

masc. hā $\underline{d} a \sim h \bar{a} \underline{d} a$

fem. hèdiy

Far deixis*

masc. $\quad$ sg. $\quad h \bar{a} \underline{d} \bar{a} k(a h)$

fem. hē $\underline{d} \bar{k}(i h)$ pl.

com. hā $\underline{d a} \underline{l} \sim$ hàdō $\underline{l} \sim$ hōdal

pl.

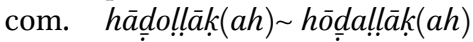

* Forms without initial $h \bar{a}-, h \bar{e}$ - or $h \bar{o}$ - are rare.

During direct elicitation, the existence of forms like hēhū or hayhū in TyA was denied. Instead, forms like ar ih ğa' "there he has come", árihhịy ğat 
"there she has come!", annās árịḥum ğaw "there the people have come!" were said to be current (see 4.8.1.).

Demonstratives in HwA are:

\begin{tabular}{|c|c|c|c|c|c|}
\hline Near de & & & & Far deixis* & \\
\hline & sg. & & pl. & & pl. \\
\hline $\begin{array}{l}\text { nasc. } \\
\text { em. }\end{array}$ & $\begin{array}{l}\text { hāda } \\
\text { hédidy* }\end{array}$ & com. & hāḍa! (ḷah) & $\begin{array}{l}\text { hād } \underline{d a} k(a h) \\
h \bar{e} \bar{d} \bar{i} k(i h)\end{array}$ & 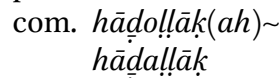 \\
\hline
\end{tabular}

* hādiy was heard three times, but with an exceptionally high $\bar{a}$, (slightly higher than I.P.A. $\left[\varepsilon^{\star}\right]$, but not fully $\left.[\mathrm{e}:]\right)$.

As a feature considered (by several informants of different tribes) to be very typical of HwA, Hwēṭiy speakers often use postpositioned ha (undifferentiated for gender and number). Examples are: $w$ alliy 'àwiz yašrab minnih $\bar{a}$... alhâmid ha "and there are those who want to drink from it, what... (from) this sour (milk)" (for a remark on the elliptic use of alliy, see fn 84, p. 235). Another example is așșjayyrāt ha "these young ones (pl. fem.) (in ref. to camels)". ${ }^{94}$

"There he/she/they is/are (litt. has/have come)!" is hayhū ğa', hayhī ğat, hayhum ğaw and hayhin ğan.

Demonstratives in DbA are:

Near deixis

$\begin{array}{lll} & \text { sg. } & \text { pl. } \\ \text { masc. } & h \bar{a} \underline{d} a \sim h \bar{a} \underline{d} a & \text { com. } h \bar{a} \underline{d} a !(! l a h)^{*} \\ \text { fem. } & h \bar{e} \underline{d} i y & \end{array}$

* Notice the same demonstrative for the pl. com. in HwA (see above).

Far deixis*

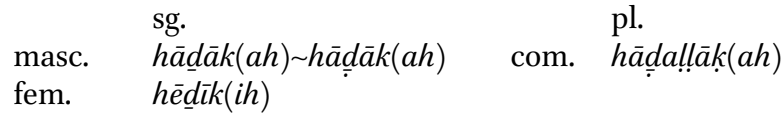

hayhü..."there he..." was recorded once.

${ }^{94}$ For a discussion on attributive $h \bar{a}$, see Fischer 1959:56. 
Demonstratives in MlA are:

Near deixis

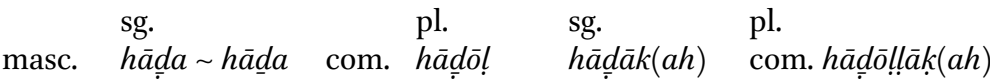

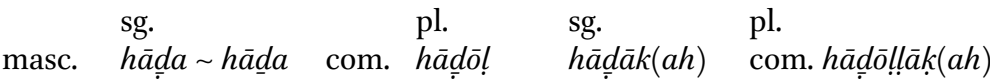

Far deixis*

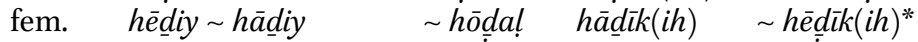

* hēdīkt alhìn was recorded three times for "now, at this moment".

The system of demonstratives in $\mathrm{BdA}$ is clearly mixed; $h \bar{a}$ - or $h \bar{e}$ - initial demonstratives for near deixis only occur in the singular, while the only pl. form dillih must be due to contact with (one of the) dialects of the bordering tribes Șawālḥah (group VII) and 'Lēgāt (group VIII).

Demonstratives in BdA are:

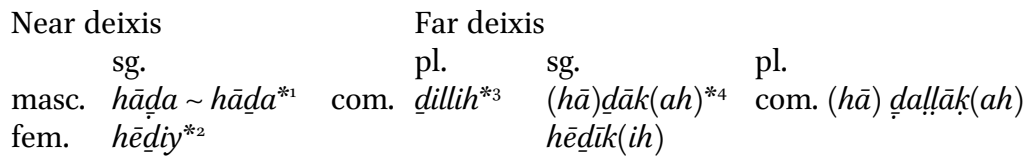

*1 Sentence-final $d i$ was recorded twice.

$*_{2}$ Sentence-final diy was recorded three times and also hädiy was heard twice.

*3 $h \bar{a}$-initial demonstratives for pl. com. were not recorded, whereas dillih was recorded five times. ${ }^{95}$

*4 hā $\underline{d} \bar{a} k$ was recorded twice, and once $\underline{d} \bar{a} k a h$.

ar ih was recorded for "there he is!"

Demonstratives in ĞrA are:
Near deixis
Far deixis
sg.
pl.
sg.
pl.
masc. hād
fem. he ${ }^{d} i y^{* 1}$ hèdīk(ih)
${ }^{*}$ diy was recorded three times.
${ }^{*}$ In one instance a separate demonstrative for the pl. fem. was recorded during direct elicitation: alihrayyim hāḍan "these women". This dem. was however not heard in spontaneous text.

\footnotetext{
95 For a demonstrative dillā in combination with a noun in older texts (Nuzhat an-nufūs),
} see Zack 2009:103. 
"There he/she/they is/are (lit. has/have come)" is hēhū ğa', hēhì ğat, hēhuṃma ğaw and hēhinnah ğan. Alternatively ir + pron. suffix is used: ír 'ih ğa', írịhha ğat, írị̣hum ğaw and írịhhin ğan (see 4.8.1.).

3.1.13.2. Specifying ha-

Specifying ${ }^{96} h a$ - is quite regularly used in southern group I dialects. Examples are binfitt halfattih 'a țūl "we immediately make this fattah" (DbA), bitğťbha min hassūg "you get it (sg. fem.) from the (lit. this) market" (MlA), $w$ alliy msawwiy...mițārah f-alblād-bingūl 'àlēha mițāạahhalmițārah hêdiy byilihgūha ttibin..."and there are those who have made... an underground grain storage in the ground-we call it (sg. fem.) a mitmārah — this mitmārah they add the straw to it (sg. fem.)" (HwA), and in all dialects halhin is current for "now".

\subsubsection{Interrogatives}

Interrogatives recorded in southern group I dialects for

1) “who?", 2 ) “what?", 3 ) “why?”, 4) “when?”, 5) “where?”, 6) “which?”, 7) "how?", 8) "how much?", 9) "how many/much?":

in HwA and DbA: 1) min, 2) wiš, ēš / èh, 3) lēh, 4) matān / mitān, wagtēh, 5) $w \bar{e} n, 6) y \bar{a} t+$ sg., 7) kèf, 8) kam + sg., 9) kutrayh, gaddèh.

in TAS (marked with * were also recorded in TAN): 1) $\left.\min ^{*}, 2\right) \bar{e} \bar{s}^{*} / \bar{e} h^{*}$,

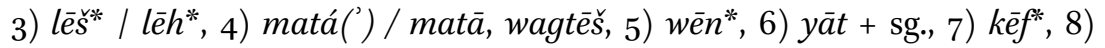
$k^{*}{ }^{*}+$ sg., 9) gaddēš / giddēš.

in ĞrA: 1) min, 2) èh, ēš (the latter much less), 3) lēh, 4) matā / mitā, 5) wèn, 6) yāt + sg., 7) kēf, 8) kām ${ }^{*_{1}}+$ sg., 9) kutrayh, gaddēh.

${ }^{* 1} k \bar{a} m$ (with long $\bar{a}$ ) was elicited, kam (with short vowel) was not recorded.

in TyA: 1) min, 2) ayš ( ēš ( $\bar{e} h, 3)(\bar{e} s ̌, 4)$ ?, 5) wēn, 6) yāt + sg., 7) kēf, 8) kam + sg., 9) kutray̌̌.

in BdA: 1) min, 2) èšs ( $\bar{e} h, 3)$ lès / lēh, 4) matā, 5) wēn, 6) yāt + sg., 7) kēef, 8) kam + sg., 9) kutray̌̌, gaddēš.

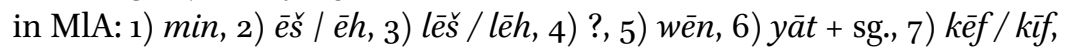
8) kam + sg., 9)?

\footnotetext{
${ }^{96}$ See Blau 196o:20 and Grotzfeld 1964:46-47.
} 
3.1.15. Adverbs

3.1.15.1. Adverbs: "there", "over there (far away)", "here”, "thus”, "now", "still", "afterwards, after that"

Adverbs recorded are:

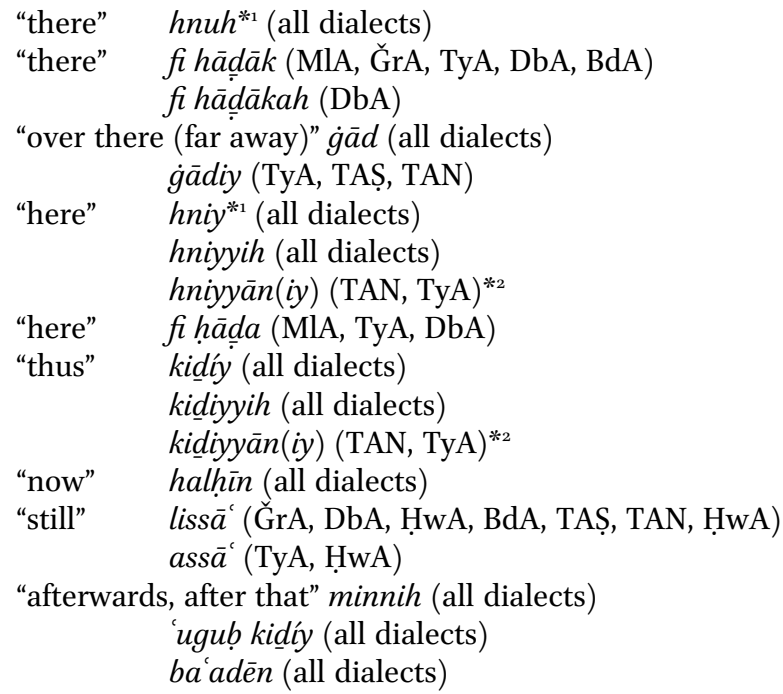

*1 mín-ihniy "from here; this way", mín-ihnuh "from there" are treated as one unit for stress assignment.

$*_{2}$ The hypochoristic - $\bar{a} n(i y)$ suffix is typical for group I dialects in the (north-)east of Sinai. It was also recorded in the dialects of the Sawārkah, Rmēlāt and Ahaywāt, see De Jong 2000:153. ${ }^{97}$

The connector 'uguḅ ma ('ug̣ + ma) is sometimes shortened to 'ugma, e.g. 'ugṃa haláfaw 'alēhum addīn "after they had sworn an oath on their religion to them" (BdA).

3.1.15.2. "maybe"

For "maybe" direct elicitation in TAS yielded forms based on the root $x$-w- $f$ (e.g. xōfallah) and k-w-d (e.g. kūd). xōfallah / xawfallah / (sometimes reduced as) $x \bar{a} f a ! l l a h$ is used to refer to undesired possibilities, while kūd refers to desired possibilities. ${ }^{98} k \bar{u} d$ may also be suffixed, examples are: álğimal kūdinnah zèn "maybe (let's hope) the camels are good", arrağāğĭl

97 See also Brockelmann 1966 (Vol. I):394.

$9^{8}$ See also Holes and Abu Athera 2009:226 and De Jong 2000:177-178. 
kūdinhum tayybìn "maybe (let's hope) they are good men" and alihrayyim küdinhin tayybāt "maybe (let's hope) they are good women".

Forms elicited for (variations on) xawf are: xawfallah (inkin) mintin tayybāt "perhaps you (pl. fem.) are no good". $x \bar{a} f$ (velarized) may also be suffixed, e.g. xăfinnah mūhū tayyib "perhaps he is no good", xăfinkin mintin tayybät "perhaps you (pl. fem.) are no good" and an unsuffixed form $x \bar{a} f i n,{ }^{99}$ as in $x \bar{a} f i n m \bar{a}$ nalgāha "perhaps we won't find it (sg. fem.)".

3.1.15.3. balhayl "very, extremely"

balhayl for "very, extremely" was recorded twice, but only in MlA: $(A)$ iw tākil...(X) hăăğih ... (A) hăăghah hilwah xāliṣ ... (X) balhäyl! w Allah balhayl ... "(A) and you eat...(X) A thing...(A) something very tasty... (X) Very! By God, very (tasty)..."

3.1.15.4. bišwēš "slowly, carefully"

The adverb bišwēš was not recorded in any of the group I dialects discussed here.

3.1.15.5. min xawf "lest"

min xawf in the sense of "lest" (see De Jong 2000:179) was not recorded.

3.1.16. Prepositions + pers. pronominal suffixes

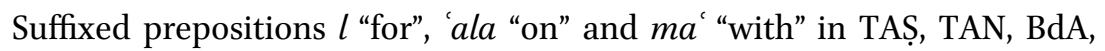
MlA, ĞrA, TyA, ḤA and DbA (unless explicitely stated otherwise) ${ }^{100}$ are:

\begin{tabular}{|c|c|c|c|c|c|c|}
\hline \multirow{7}{*}{$\begin{array}{l}\text { 3. masc. } \\
\text { fem. } \\
\text { 2. masc. } \\
\text { fem. } \\
\text { 1. com. }\end{array}$} & \multicolumn{2}{|l|}{$l_{+}^{* *_{1}}$} & \multicolumn{2}{|l|}{ 'ala+ ${ }^{* 6}$} & \multicolumn{2}{|l|}{$m a^{c}+{ }^{* 10}$} \\
\hline & & pl. & sg. & pl. & & pl. \\
\hline & lah/lih ${ }^{*_{2}}$ & lēhum ${ }^{* 5}$ & 'aláh ${ }^{*_{7}}$ & 'alēhum ${ }^{*_{5}}$ & ma'áh & mahhumum ${ }^{* 5}$ \\
\hline & lēha $a^{* 3}$ & lēhin & 'alēha*8 & 'alēhin & $m a h h a^{* 8}$ & mahhin \\
\hline & $l a k^{* 4}$ & lēkuw & ‘alák ${ }^{* 9}$ & 'alēkuw & mäák & mäkuw \\
\hline & lēkiy & lēkin & 'alēkiy & 'alēkin & makiy & makin \\
\hline & $\operatorname{lay}(y)$ & lèna & 'aláy $(y)$ & 'alēna & mááy & maina \\
\hline
\end{tabular}

${ }^{*}$ For the paradigm of $l+$ in TAN, TyA, DbA and HwA see below. The independent preposition is $l \sim l i$.

For an alternative paradigm in $\mathrm{BdA}$, see below.

$*_{2}$ The vowel in TAṢ and ĞrA is usually $a$, in BdA $i$. In MlA lah $\sim$ lēh.

*3 The suffix -ha -hiy in MlA.

${ }^{99}$ The form $x \bar{a}$ fin is reminiscent of the form xaftin reported in Stewart 1990:103 (text 32), l. 87 (+ fn).

${ }_{100}$ TAS was taken here as a starting point, and deviations in other dialects are described in notes. 
$*_{4}$ In MlA lak $\sim \bar{e} k$.

$*_{5}$-huw in ĞrA. In HwA, MlA and TAN -hum $\sim-h u w(w a)$.

*6 In TyA, DbA and HwA raising of the $a$ of the first syllable is regular, but only when preceding $\bar{e}$. So: 'ilèk, 'ilēhum etc., ${ }^{101}$ but usually absence of raising in 'aláy. The independent preposition is 'ala ' $a$.

*7 In TAN, BdA, MlA 'alēh. In TyA, HwA and DbA 'ilēh 'alēh. In ĞrA 'alíh.

*8 In TyA -hiy. Shawarbah 2007:419 reports for TyA of the Negev the form like maḥhiy "with her" as well.

*9 In TAN, BdA, MlA 'alēk. In HwA and DbA 'ilēk.

${ }^{*}{ }_{10}$ For the paradigm in TAN, see below.

The vowel of the first syllable is $i$ in BdA, also in closed (and stressed) syllables: miáh, miḥha etc. Raising of $a$ in open unstressed syllable occurs regularly in other dialects, e.g. mi áh (but $a$ in stressed closed syllable, e.g. mákuw).

The prep. $l+$ in TAN, TyA, DbA, HwA (and as alternative in $\mathrm{BdA})$ :

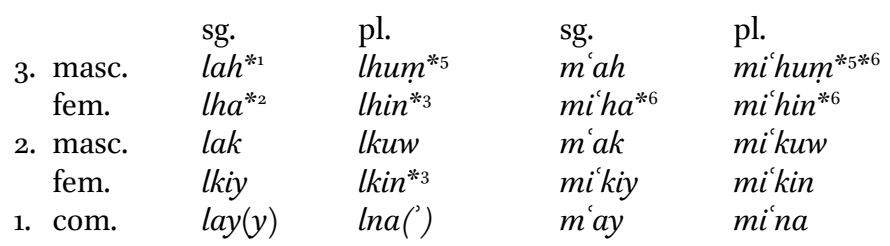

*1 In TyA lih.

*2 In TyA lhiy.

*3 In HwA lhin and lkin lhinnih and lkinnih.

*4 The independent preposition is $m^{\prime}$, e.g.: tāxd im ák libbtak $f$ ǧébtak...f-idak "you take your libbah (a thick round loaf of bread baked in hot sand) with you in your pocket... in your hand".

*5 In HwA and TAN -hum -huw(wa).

*6 ' $+h$ often assimilates to ḥh: miḥha, miḥhum, miḥhin.

${ }^{101}$ Notice that such raising remains absent when the short $a$ is the product of reduction of $\bar{a}$ in pre-stress position, as in mag'ad šasēh (< šāsēh) "a construction of piled rock with an old Ford chassis serving as a roof used as magcad in Malbad (Ğarāğrah)" (ĞrA). 
Suffixed prepositions $f i$ "in", min "from" and wara "behind" in TAȘ, TAN, BdA, MlA, ĞrA, TyA, HwA and DbA (unless explicitely stated otherwise) are:

\begin{tabular}{|c|c|c|c|c|c|c|}
\hline & $f i+$ & & $\min +$ & & wara+ & \\
\hline & sg. & pl. & & pl. & sg. & pl. \\
\hline $\begin{array}{l}\text { 3. masc. } \\
\text { fem. }\end{array}$ & $\begin{array}{l}f a h^{* 1} \\
\text { fih }^{* 2}\end{array}$ & $\begin{array}{l}\text { fihum }^{* 5} \\
\text { fihin }\end{array}$ & $\begin{array}{l}\text { minnih } \\
\operatorname{minh}^{*_{2}}\end{array}$ & $\begin{array}{l}\text { minhum }{ }^{* 5} \\
\text { minhin }\end{array}$ & $\begin{array}{l}\text { warāh } \\
\text { warāha }{ }^{* 2}\end{array}$ & $\begin{array}{l}\text { warāhump }{ }_{5} \\
\text { warāhin }\end{array}$ \\
\hline 2. masc. & $f a k^{* 3}$ & fikuw & minnak & minkuw & warāk & warākuw \\
\hline fem. & fikiy & fikin & minkiy & minkin & warākiy & warākin \\
\hline 1. com. & $\operatorname{fay}(y)^{*_{4}}$ & fina & minnī & minna & warāy & warāna \\
\hline
\end{tabular}

${ }^{*}$ fih (with short $i$ ) in MlA, fih (with long $\bar{\iota}$ ) in TAN, BdA, ĞrA, TyA, HwA and DbA. In all dialects: $f$ ih (with long $\bar{\iota}$ ) is used for "there is/are".

$*_{2}$-hiy in TyA.

*3 fik in TAN, BdA, ĞrA, TyA, HwA and DbA.

${ }^{*}$ finī in ĞrA.

*5 -huw in ĞrA and -hum -huw in HwA and TAN.

Suffixed prepositions "ind "with", hawāla "around" and fōg/fawg "over" in TAṢ, TAN, BdA, MlA, ĞrA, TyA, ḤA and DbA (unless explicitely stated otherwise) are:

\begin{tabular}{|c|c|c|c|c|}
\hline & 'ind+ & & hawālat*3 & \\
\hline & & pl. & sg. & pl. \\
\hline 3. masc. & indah & induhum ${ }^{* 2}$ & hawaläh ${ }^{* 4}$ & hawalāhuṃ \\
\hline fem. & 'indaha ${ }^{* 1}$ & 'indihin & hawalāha ${ }^{* 1}$ & hawalāhin \\
\hline 2. masc. & ‘ndak & ‘indukuw & hawalāk & hawalākuw \\
\hline fem. & 'indikiy & indikin & hawalākiy & hawaläkin \\
\hline 1. com. & ind $\bar{\imath}$ & indina & havaläy & hawalāna \\
\hline
\end{tabular}

\begin{tabular}{|c|c|c|}
\hline & $f o ̄ g+{ }^{*} 5$ & \\
\hline & sg. & pl. \\
\hline 3. masc. & fögah & fōghum ${ }^{* 2}$ \\
\hline fem. & fōgha & fōghin \\
\hline 2. masc. & fōgak & fōgkuw \\
\hline fem. & fögkiy & fögkin \\
\hline 1. com. & $f \bar{o} g \bar{\imath}$ & fōgna \\
\hline
\end{tabular}

$*_{1}$-hiy in TyA.

*2 -huw in ĞrA and -hum -huw in HwA and TAN.

*3 This prep. was not recorded with suffixes in BdA, ĞrA and MlA.

$*_{4}$ An alternative hawālah was recorded in TAS and hawēlah in TAN.

$*_{5}$ In HwA the preposition is diphthongal: fawgah, fawgha, etc. 
An interesting grammaticalisation recorded in DbA is byākluw min iğnūbāha "they eat from all sides (around them)".

Suffixed prepositions are negated with single preceding $m \bar{a}$, e.g. $m \bar{a}$ 'indī "not with me", mā fōgak "not above you".

\subsubsection{Numerals and counted plurals}

\subsubsection{Cardinal numbers 1-10}

Independent cardinal numbers are (forms that precede counted nouns

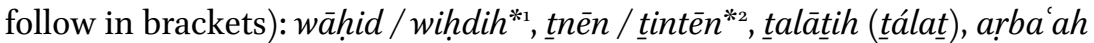
(arba'), xamsih (xams), sittih (sitt), sab ih (sab'), tamānyih (tamán), tis ì (tis'), 'ašarah ('ašár).

${ }^{* 1}$ wăhid and wihdih may follow the counted noun as adjectives for extra emphasis, e.g. walad wāhid "one boy" and bint wiḥdih "one girl".

*2 tnèn and tintēn may follow the counted dual form of the noun as adjectives for extra emphasis, e.g. waladèn ițnèn "two boys" and ìdāy attintèn "my two hands" and riğlāa attintèn "my two legs" (TyA, TAṢ, ĞrA, Ḥ̂A). The form adāy "my hands" was recorded in DbA. Direct elicitation in HwA yielded $\bar{\imath} d \bar{a} n \bar{\imath}$ instead of $\bar{\imath} d \bar{a} y$ for "my hands". ${ }^{102}$

Some plural forms of nouns are counted with proclitic $t$ - (a remnant of the fem. morpheme in construct state), e.g. arba' t-infār "four people", xamis t-iyyām "five days".

\subsubsection{Ordinal numbers 1-10}

Only three ordinals were recorded: awwil, țāniy, țālit.

3.1.17.3. Numerals: 11 and up

Numerals 11-19 recorded are: hdā̄̌ar, tnāšar / itnāšar, țalattāšar, aṛa tāšar, xamistāšar, sittāšar, saba'tāšar, țamantāšar, tisi tāšar in all dialects.

In HwA and BdA these forms ending in -āšar co-occurred with forms

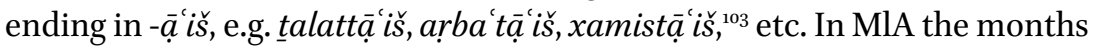
of November and December were referred to as šahár iḥdạciš and šahár itnậ ì̌ (resp.).

\footnotetext{
${ }^{102}$ This is perhaps a hybrid form of $\bar{\imath} d \bar{a} y$ "my hands" (like in other dialects) and ad $\bar{a} n \bar{\imath}$ "my ears", or the pl. ìdān was directly suffixed with the pron.: idāni "my hands".

${ }^{103}$ In the forms ending in -āšar velarization is indicated in $r$, in the forms ending in $-\bar{a} \cdot \dot{i}$, it is indicated in the long: $\bar{a}$.
} 
Numerals 20-90:

'išrìn, țalātīin, arba'ìn, xamsīn, sittīn, sab'ìn, țamānīn, tis'ìn.

Numerals 100-900:

miyyih, mìytēn, tulitmiyyih, rubi miyyih, xumismiyyih, suttmiyyih, subi miyyih, tuminmiyyih, tusi miyyih.

Numerals 1,000-10,000:

alf, alfēn, țalat $t$-ālāf, xamis $t$-ālāf, arba' $t$-ālāf, sitt $t$-ālāf, sabi' $t$-ālāf, taman $t$-āläf, tisi' $t$-ālā $f$, 'ašar $t$-ālāaf.

Long $\bar{a}$ of the first syllable is usually reduced to short $a$, e.g. talat t-alāf "three thousand".

Numerals 11,000-1,000,000:

ḥdāšar alf, mīt alf, miyytēn alf, milyōn / malyōn (and țalaț malāyīn).

Some plurals recorded with proclitic $t$ - are: tisi $t$-ālāf "nine thousand", 'ašar t-iyyām "ten days", sitt t-ušhur "six months", ${ }^{104}$ sabi t-infār "seven persons".

Months are usually referred to by numbers, e.g. šahár wāhid "January", f-awwil iḥd $\bar{a}$ iš "in the beginning of November".

\subsubsection{The dual}

Suffixing -èn (or -ayn) to the sg. form of a noun forms the dual, e.g. raffayn "two tent sections", šaharayn "two months", yōmēn "two days", šwālēn "two (large) sacks".

Older forms of the dual (? $)^{105}$ are used in expressions for body parts, e.g. TAṢ and TyA forms riğlāa "my (two) legs", ìdāy "my hands" (unsuffixed pl. forms are riğlān and $\bar{\imath} d \bar{a} n)$.

Forms recorded in HwA are: ìd "hand", ìdān "hands", ìdāha "her hands", idāhin "their (fem.) hands", but ìdāni "my hands". A form heard in ĞrA is idāhuw "their hands".

${ }^{104}$ sitt $t$-ušhur is actually pronounced like sitt ušhur (reduced $t t t>t t$ ). The proclitic $t$ - is concluded from other forms, like xamis t-ušhur "five months" and taman $t$-ušhur "eight months".

${ }^{105}$ It is not certain that these forms in final $-\bar{a} n$, and suffixed as $-\bar{a}+$, are older dual forms (see also remarks in De Jong 2000:187 (+ fn 341); one could also imagine a perhaps more

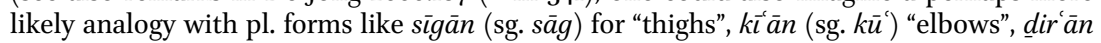
(sg. $\underline{d} r \bar{a})^{c}$ "forearms". 
Plural forms in BdA and DbA are with initial $a-$ : adēk "your hands", adēhum "their hands", adēhin "their (fem.) hands" and "my hands" in DbA is adāy, but was recorded as adayy in BdA.

Forms recorded in MlA are only sg.: ìd "hand" and $\bar{\imath} d \bar{\imath}$ "my hand". Forms in TAN are $\bar{\imath} d a k$ and $\bar{\imath} d a h$, and pl. forms ìdēh "his hands" and riğlēh "his legs".

These forms are also used as plurals—not only as duals—as is clear from recorded instances like $y \bar{a} k l u w ~ b$ id $\bar{a} h u w$ "they eat with their hands" and biygușșinhin, iw byudufrinnah dafar ... 'al-ìdāhin ... ášša ar hāda "they (fem.) shave them (fem., i.e. the goats), and they (fem.) plait it (sg. masc.) into a saddle girth ... this hair" and ib riğlāhin ibyídirsin "they (fem.) thresh with their (fem., i.e. animals) feet".

\subsection{Verbal Morphology}

\subsubsection{Regular verbs}

\subsubsection{Regular verbs perfect}

For measure 1 the two principal underlying pattterns for the perfect are (i-type) $\mathrm{C}_{1} \mathrm{aC}_{2} \mathrm{iC}_{3}$ and (a-type) $\mathrm{C}_{1} \mathrm{aC}_{2} \mathrm{aC}_{3}\left(\right.$ for $\mathrm{C}_{1} \mathrm{aC}_{2} \mathrm{uC}_{3}$ see 3.2.1.3.).

The paradigms in TyA are:

\begin{tabular}{|c|c|c|c|c|}
\hline & perfect "c & $k^{n * 1}$ & perfect "si & \\
\hline & sg. & pl. & sg. & pl. \\
\hline 3. masc. & širibt ${ }^{* 1}$ & širibna*1 & ga'ád & $g a^{\prime} a ́ d a w^{* 4}$ \\
\hline fem. & širibt ${ }^{*_{1}}$ & širibtuw $^{*_{1}}$ & $g a^{\prime a ́ d a t}{ }^{*}{ }_{4}$ & ga'ádan ${ }^{*}$ \\
\hline 2. masc. & širibtiy ${ }^{*_{1}}$ & širibtin $^{*_{1}}$ & $g a^{\prime} a d t^{*_{5}}$ & ga'adtuw ${ }^{*_{5}}$ \\
\hline fem. & širíb & šarbuw $w^{* 2}$ & ga'adtiy ${ }^{*}$ & ga $^{\prime}$ dtin $^{* 5}$ \\
\hline 1. com. & šarbit ${ }^{* 2}$ & šarbin $^{* 2}$ & ga'adt*5 & ga'adna \\
\hline
\end{tabular}

$*_{1}$ The short vowel $i$ of the open and unstressed first syllable is underlying $|\mathrm{a}|$ and is therefore not elided in these group I dialects (i.e. forms are not •šrib, •šribt, etc.) (cf. the verb gulúd in 3.2.1.3.).

${ }^{*}$ Notice that the underlying $a$ 'reappears' in closed syllables. This is not the case in TAȘ, ĞrA, MlA; forms there are širbit, širbuw and širbin. Other examples are: tilfuw "they grew old", wigfit "she stood".

Like in TyA, the $a$ does 'reappear' in HwA: 'argit "she sweated", yabsuw "they dried", waslit "she arrived, reached"; DbA: fahyit "she was surprised" and daryit "she became aware"; BdA: nasyit "she forgot", garmit "she was fined"; TAN: fahmit "she understood" (cf. the verb gulúd in 3.2.1.3.). 
${ }^{*}$ Raising of $a$ in open syllable preceding stress is regular, but optional, e.g. fitáh "he opened".

*4 Stress is CáCaCv in TAṢ. The other group I dialects discussed here (including TAN!) stress $\mathrm{CaCáCv}$ (but MlA shows variation in this respect, see remarks in 2.1.1.2.2.).

$*_{5}$ The consonant cluster $d t$ assimilates to $t t$.

In TAṢ suffixed forms only distinguished by stress are: širíbtah "I drank it (sg. masc.)" (< širibt $+a h)$ and širibtah "she drank it (sg. masc.)" $(<$ širbit $+a h)$.

In ĞrA, however, the high vowel of the verbal ending is not elided (and hence no subsequent anaptyxis takes place): hì líbsitih "she wore it", $h \bar{\imath}$ š́rbitih "she drank it", hì lígyitih "she found it", but aná libistih "I wore it". No such forms were recorded in MlA.

\subsubsection{Regular verbs imperfect}

Like in most dialects of Sinai, the imperfect is characterized by vowel harmony in the verbal prefixes, and like in group VI, this vowel harmony is also found in the 1st. p. sg. com. of $i$ - and $u$-type imperfects of some of the group I dialects discussed here: ĞrA, BdA and in some instances also in TAN (e.g. lēš inzil? "why should I dismount?"). The other group I dialects (TAS, TyA, DbA, HwA and also the large majority of forms in TAN) have initial $a$ - in all vowel types, see also De Jong 2000:299.

There are three imperfect patterns: $\mathrm{yaC}_{1} \mathrm{C}_{2} \mathrm{CaC}_{3}, \mathrm{yuC}_{1} \mathrm{C}_{2} \mathrm{CuC}_{3}$ and $\mathrm{yiC}_{1} \mathrm{C}_{2} \mathrm{iC}_{3}$.

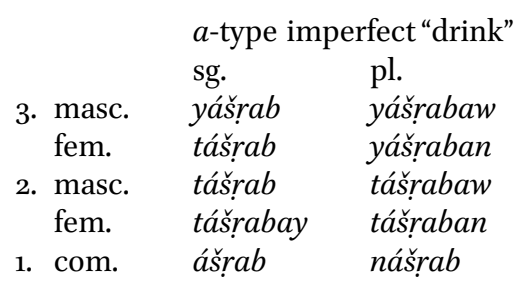

Paradigms for $i$ - and $u$-type imperfects are like those listed for group VI with differences in initial vowels in the 1st p. sg. com. as described above here (i.e. aktib and $a \underline{d} r u b$ or $i k t i b$ and $u d r u b)$.

Measure 1 verbs $i$-type (e.g. yaharit $)$ and $a$-type (e.g. ya'arag) with $\mathrm{C}_{1}=$ $\mathrm{X}$ have the following paradigms. 


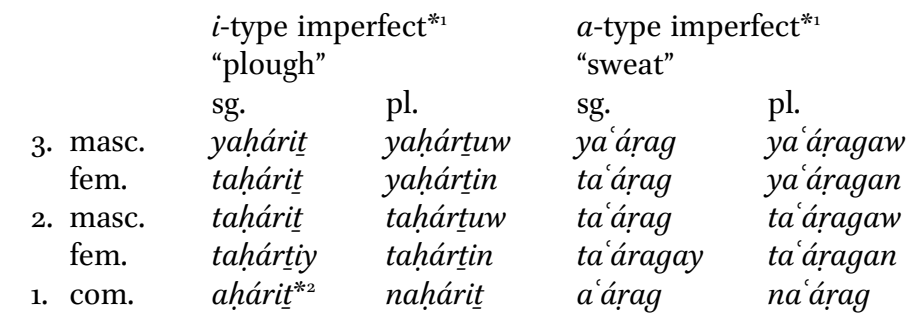

${ }^{* 1}$ For stress in these forms see 2.1.1. and 2.1.2.4.

*2 Notice that in gahawah-verb forms the initial vowel does not harmonize with the base vowel of an $i$-type imperfect.

For the morphological status of the $i$, and reasons for not indicating its elision (i.e. the forms are not written here as e.g. yahárț), see remarks in De Jong 2000:94, fn 94).

Perfects and participles of these verbs harát and 'iríg are like those of ga'ád and širíb (see 3.2.1.1.).

3.2.1.3. Reflexes of older ${ }^{*} C_{1} a C_{2} u C_{3},{ }^{*} y a C_{1} C_{2} u C_{3}$

The verb "grow fat" as example of an 'Eigenschafts' verb-type elicited in HwA, BdA, TAṢ:

"grow fat"

\begin{tabular}{|c|c|c|c|c|}
\hline \multirow{4}{*}{$\begin{array}{l}\text { 3. masc. } \\
\text { fem. }\end{array}$} & \multicolumn{2}{|c|}{$u$-type perfect ${ }^{*_{1}}$} & \multicolumn{2}{|c|}{$u$-type imperfect*3 } \\
\hline & sg. & pl. & sg. & pl. \\
\hline & $\dot{g} u l u ́ d \underline{d}$ & $\dot{g} a l \underline{\underline{d}} u w^{* 2}$ & yag்álud & yaġálḍuw \\
\hline & $\dot{g} a l d \underline{i} t^{* 2}$ & galdidin ${ }^{* 2}$ & taġáluḍ & yagáádịin \\
\hline 2. masc. & $\dot{g} u \dot{u} d \underline{d} t$ & $\dot{g} u l u d \underline{d} t u w$ & taġálud & taǵáld̄ $u w$ \\
\hline com. & $\begin{array}{l}\dot{g} u l u d \underline{\underline{d}} t i y \\
\dot{q} u l u d t\end{array}$ & $\begin{array}{l}\dot{g} u l u \underline{d} t i n \\
\dot{q} u l u d n a\end{array}$ & $\begin{array}{l}\text { taǵáldìy } \\
\text { à́álúd*4 }\end{array}$ & $\begin{array}{l}\text { tagááldin } \\
\text { nagáálud }\end{array}$ \\
\hline & gutuạt & gutuạna & agaluạ & nagaluḍ \\
\hline
\end{tabular}

$*_{1}$ In unstressed open syllables the surface $u$ (of the first syllable) is not dropped (i.e. forms are not $\bullet \dot{g} l u \underline{d}, \cdot \dot{g} l u \underline{d} t$, etc.) and is therefore to be interpreted as being underlying $|\mathrm{a}|$ (cf. the verb širíb in 3.2.1.1.).

*2 Notice that the underlying $|\mathrm{a}|$ of the pattern 'reappears' in closed syllables. This is not the case in TAṢ, ĞrA, MlA; forms recorded there are $\dot{g} u l \underline{d} i t, \dot{g} u l \underline{d} u w$ and $\dot{g} u l \underline{d} i n$. For TAN I have extrapolated 'reappearance' of $a$ here based on its 'reappearance' in the $i$-type perfect (compare širíb $*_{2}$ in 3.2.1.1.).

*3 Due to the relatively high sonority of the preceding $l$, the high vowel $u$ is usually dropped when $\underline{\underline{d}}$ is word-final, e.g. yagáld \# and taǵáld \#. See also remarks ${ }^{*_{1}}$ and ${ }^{*_{2}}$ in 3.2.1.2. on ordering the gahawah-rule and the rule for high vowel elision in the imperfect. 
*4 Like in ahárit (see 3.2.1.2. above) the initial vowel does not harmonize with the base vowel.

For the imperfect this paradigm with gahawah-forms was elicited in HwA. In other dialects a paradigm like that of yuḍub (i.e. yugilud, etc.) is current.

\subsubsection{Regular verbs participles}

Like in group VI, active participles are formed with the patterns $\mathrm{C}_{1} \overline{\mathrm{a}} \mathrm{C}_{2} \mathrm{iC}$, $\mathrm{C}_{1} \bar{a} \mathrm{C}_{2} \mathrm{C}_{3} \mathrm{ah}$ /-ih (sg. fem.), $\mathrm{C}_{1} \overline{\mathrm{a}} \mathrm{C}_{2} \mathrm{C}_{3} \mathrm{in}$ (pl. masc.), $\mathrm{C}_{1} \overline{\mathrm{a}} \mathrm{C}_{2} \mathrm{C}_{3} \mathrm{a} \mathrm{t}$ (pl. fem.).

When the sg. fem. participle is suffixed with an object, it is in construct state with this suffix. Examples are: rāayidtih "she wants/loves him”, šāribtih "having drunk (sg. fem.) it (sg. masc.)" (both ḤA), šārbitha "having drunk (sg. fem.) it (sg. fem.)" (TAȘ).

\subsubsection{Regular verbs imperatives}

Imperatives of regular verbs are like in other dialects of group $\mathrm{I}^{106}$ e.g. ášrab, ášrabay, ášṛabaw, ášraban "drink!", úg'ud, úgu'diy, úgu'duw, úgu'din "sit down!" and ímsik, ímiskiy, ímiskuw, ímiskin "grab, take hold!".

\subsubsection{Irregular and other verbs}

\subsubsection{Verbs $C_{1}=w$ (primae wāw)}

In group I dialects discussed here there is a mild preference for monophtongs in $i$-type imperfects, while $a$-type imperfects more often have diphthongs, e.g. warád, yōrid "give water", wazán, yōzin "weigh", waṣál, yawșal "arrive", but forms like yawrid and yōṣal were also heard. ${ }^{107}$

\begin{tabular}{lll}
\multicolumn{4}{c}{ a-type imperfect with wäw* "arrive } \\
& sg. & pl. \\
3. masc. & yawșal & yawșalaw \\
fem. & tawșal & yawșalan \\
2. masc. & tawșal & tawșalaw \\
fem. & tawșalay & tawșalan \\
1. com. & awșal & nawșal
\end{tabular}

${ }^{106}$ See De Jong 2000:192.

${ }^{107}$ Holes and Abu Athera 2009:212 recorded initial $y \bar{a}$ - in poetry from south Jordan and Sinai. Two instances of forms with initial short vowel (yaga and tigif), typical of dialects on the periphery of the Syrian desert, were also recorded. These prefixes (i.e. $y \bar{a}$ - etc.) were also reported for the dialect of the Ḥwētât in southern Jordan, see Palva 1984-86:30o. 
* In HwA two parallel imperfect paradigms were recorded for the $\mathrm{C}_{1}=$ wāw verb warad "give water": one without wāw (yirid), and one with incorporated $w \bar{a} w(y \bar{o} r i d)$ :

The $i$-type imperfect has the following paradigm:

\begin{tabular}{lllll}
\multicolumn{3}{c}{ "water" } & & \\
\multicolumn{2}{c}{ imperfect without $w \bar{a} w^{* 1}$} & \multicolumn{2}{l}{ imperfect with $w \bar{a} w^{* 2}$} \\
& sg. & pl. & sg. & pl. \\
3. masc. & yiríd & yarduw & yōrid & yōrduw \\
fem. & tiríd & yardin & tōrid & yōrdin \\
2. masc. & tiríd & tarduw & tōrid & tōrduw \\
fem. & tardiy & tardin & tōrdiy & tōrdin \\
1. com. & (')aríd & niríd & orid & nōrid
\end{tabular}

$*_{1}$ Notice that the vowel of the first syllable is underlying $|a|$ : it is raised to $i$ in open unstressed syllable (except when ' precedes), but appears as $a$ in closed (and stressed) syllables. Compare this to the perfect paradigms of širíb (see 3.2.1.1.) and giulúd (see 3.2.1.3.).

Similar paradigms in HwA were recorded for yigíf (paradigm like yiríd above) yawgaf (paradigm like yawșal above).

$*_{2}$ In ĞrA the imperfect of this verb is with incorporated $w \bar{a} w$. The tendency during elicitation was to monophthongize $a w>\bar{o}$ in closed syllables, but to maintain diphthongs in open syllables, e.g. yōrduw "they give water", but yawrid "he gives water" (the paradigm for the perfect warád is like ga'ád, see 3.2.1.1.)

Other primae $w \bar{a} w$ verbs are: wağa , yōği "hurt", walá, yawliy "come near", waká, yōkiy "tie closed", wațá, yawțiy "go shopping".

Verbs with the pattern yiwCiC or yiwCaC (like those current in e.g. Cairene Arabic) were not recorded in these dialects.

Imperatives of the verb wi iy, yaw'a "pay attention" (root $\left.w^{\prime}-y\right)$ are $a w^{\prime} a$, aw'ay, aw'aw and aw'an in HwA, DbA, e.g. aw'an rüskin "mind (pl. fem.) your (pl. fem.) heads!". Forms recorded in TAȘ, TyA were recorded with base vowels dropped: $a w^{\prime} a, a w^{\prime} i y, a w^{\prime}$ in and aw'uw, e.g. aw'a tans "don't you forget (sg. masc.)!" and aw in tansin “don't you forget (pl. fem.)!”.

In BdA and ĞrA the imperative of the sg. masc. was left unconjugated for grammatical number and gender and used as a general particle of warning (a similar particle was recorded in some dialects of group VII): aw'a rāsak, aw'a rāāskiy, aw'a rūskuw, aw'a rūskin for "mind your head(s)!" (BdA) and also aw'a tans, aw'a tansay, aw'a tansaw and aw'a tansan "don't 
forget!" (ĞrA). Other dialects have regular imperative forms like aw'an rüskin and aw'aw tansaw (Forms in MlA and TAN were not recorded).

Imperfect forms with base vowel $i$ in most dialects have $\bar{o}$ as in $y \bar{o} \bar{g} i$ " it hurts", yōkiy "he ties closed", yōrid "he waters" yōzin "he weighs", yōgid "he lights" (recorded in MlA, BdA, TAN and HwA). Some dialects (also) have diphthongs in these $i$-type imperfects, like yowluw "they come near", yawtuw "they go shopping" (both MlA), yawrid and yawgid (both TAȘ), yawkiy "he ties closed" but yōkiha "he ties it (sg. fem.) closed (both BdA) and diphthongs in a-type imperfects yawșal "he arrives", yawșaf "he describes" and yawğa " (all three TAȘ), yowgaf or yawgaf "he stands" (HwA and TAȘ). Sometimes such verbal imperfects are without wāw, e.g. agif "I stand", tigif "you stand" (both ḦwA).

Participles:

Active participles have a $\mathrm{C}_{1} \overline{\mathrm{a}} \mathrm{C}_{2} \mathrm{iC}_{3}$ pattern, e.g. wärid, wārdih, wārdīn, wārdāt "having watered".

$\operatorname{maC}_{1} \mathrm{C}_{2} \overline{\mathrm{u}} \mathrm{C}_{3}$ is the pattern for the past participle, as in mawğ $\bar{u} d(-a h,-\bar{i} n$, $-\bar{a} t)$ "present" for the root $w-\breve{g}^{\prime} d$ in all dialects except HwA, where twice māğ $\bar{u} d$ was recorded. Roni Henkin lists a form maylüd co-occurring with mawlüd, see Henkin 2008:362 for tribes in the Negev (see also fn 101, p. 83).

3.2.2.2. Verbs $C_{1}=\mathrm{y}$ (primae yä)

In TyA, HwA, TAS and ĞrA the diphthong of the first syllable in the imperfect is left intact (perfect) yibis, (imperfect) yaybas (not recorded in the other dialects).

Notice that, like in the verb siríb (see 3.2.1.1.), the vowel of the first syllable of the perfect is underlying $|\mathrm{a}|$, so that it 'reappears' in closed syllables (in those dialects that also have šarbit): yibis "it (sg. masc.) dried", but yabsit "it (sg. fem.) dried".

3.2.2.3. Verbs $C_{1}={ }^{* \prime}$ (primae hamzah)

The verb "eat" has the following paradigms:

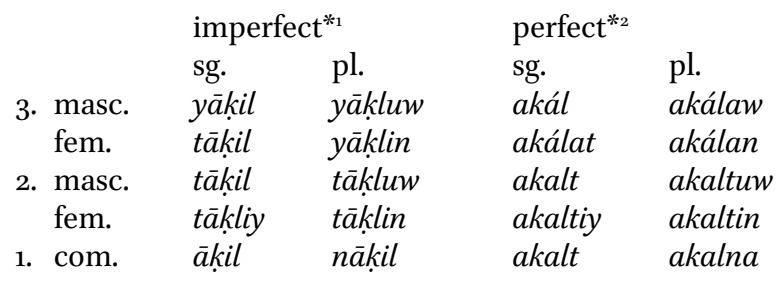

${ }^{* 1}$ The long vowel $\bar{a}$ is clearly lower than in the present participle (without velarization) $m a \bar{k} k i l$, but velarization in the imperfect (as indicated here in $k$ ) 
is only limited in most dialects. Velarization is clearly stronger in BdA. Such velarization could perhaps be described as 'phantom' velarization..$^{108}$

All dialects discussed here have the imperfect vowel $i$ in the imperfect. $*_{2}$ The perfect is without initial $a$ - in TAṢ, ĞrA, MlA (TAN is uncertain). Stress is then kalát, kaláw and kalán.

The paradigms for the verb "take" ('- $x-\underline{-}-\underline{d})$ are comparable (in the perfect $\underline{d}+t$ usually assimilates to $>t t$, e.g. axattuw).

Present participles are with initial $m$-: mākil, māklih, mäklīn, māklāt.

Past participles are: $m \bar{a} x \bar{u} \underline{d},-a h,-\bar{n} n,-\bar{a} t$ (all forms are velarized).

Imperatives are: $k$ ul, kliy, kluw, klin

The verbal noun is (")akl "eating" (also "food"), but wakl was recorded in BdA. The passive verb "be eaten" is ánwakal, yinwikil.

3.2.2.4. Verbs $C_{2}=\mathrm{w}$ or y (mediae infirmae)

3.2.2.4.1. Verbs $C_{2}=\mathrm{w}$ or y (mediae infirmae) perfect and imperfect In group I dialects the perfect and imperfect paradigms are:

\begin{tabular}{|c|c|c|c|c|}
\hline \multirow{2}{*}{ "say" } & \multicolumn{2}{|l|}{ perfect } & \multicolumn{2}{|c|}{ imperfect $^{* 2}$} \\
\hline & sg. & pl. & sg. & pl. \\
\hline 3. masc. & $g \bar{a} l$ & $g \bar{a} ! a w^{*_{1}}$ & ygūl & ygūluw \\
\hline fem. & gālat & gāḷan & $\operatorname{tgūl}$ & ygūlin \\
\hline 2. masc. & gult & gultuw & $\operatorname{tg} \bar{u} l^{* 3}$ & tgūluw \\
\hline $\begin{array}{l}\text { fem. } \\
\text { com. }\end{array}$ & $\begin{array}{l}\text { gultiy } \\
\text { qult }\end{array}$ & $\begin{array}{l}\text { gultin } \\
\text { gulna }\end{array}$ & $\begin{array}{l}\text { tgūliy } \\
\text { agūul* }{ }^{*}{ }_{4}\end{array}$ & $\begin{array}{l}\text { tgūlin } \\
\text { naūl }\end{array}$ \\
\hline & & & & \\
\hline
\end{tabular}

${ }^{*}$ In TAS and ĞrA the ending -aw varies with - $u w$. In the other dialects the ending is regularly $-a w$.

${ }^{*}$ Media yă verbs (with long base vowel $\bar{\iota}$ ) have the same endings.

${ }^{*}{ }_{3}$ Notice that shortened base vowels in the 2nd p. sg. masc. imperfect (like e.g. tanam, tugul and tišil) were not recorded in these group I dialects.

*4 See remarks in 3.2.1.2. on vowel harmony of the initial vowel of the sg. com. $(u g \bar{u} l)$ in ĞrA and BdA.

For media yā' verbs (with long base vowel $\bar{a}$ ) HwA, BdA, ĞrA, TyA and TAS have the same endings, but forms in DbA were recorded with vowel harmony: tnāmay, ynāmaw, ynāman, tnāmaw and tnāman. Situation in MlA and TAN is unknown (see also remark * in 3.2.2.4.2. below).

${ }_{108}$ 'Phantom' velarization is here meant to indicate the effect of velarization present in these forms, while the cause of this velarization (originally the vowel $u$ in the imperfect) is no longer present, since the vowel $u$ has been replaced by $i$. Compare this to velarization left behind by $u$ in forms (e.g. rkab "knees", grab "waterskins"), even after its total disappearence; the effect of the so-called vanished $u$, as described in Blanc 1970:128 [17]. 
The verb šâf, yšū $f$ was recorded in all dialects with short vowel $u$ only: šuft "I saw".

Verbs $\mathrm{C}_{2}=y$ are like in group VI as well, e.g. šāl, y̌̌̌l (and šilt) (for a remark on originally measure 4 verb $r \bar{a} d$, yrìd, see 3.2.3.7.2. of this chapter).

3.2.2.4.2. Verbs $C_{2}=\mathrm{w}$ or $\mathrm{y}$ (mediae infirmae) imperatives

Short base vowels in the sg. masc. imperative in mediae infirmae verbs are rare; I have heard it in $\mathrm{BdA}$ in imperatives gum "get up!" and nam "go to sleep!", but other imperatives in BdA all had long base vowels, e.g. gūl "say!", šll "carry, take away!", although there are also isolated instances of gul "say!".

Regular imperatives have long base vowels:

\begin{tabular}{|c|c|c|c|c|c|c|}
\hline & long $\bar{u}$ & & long $\bar{\imath}$ & & long $\bar{a}$ & \\
\hline & & & sg. & pl. & sg. & \\
\hline hasc. & $g \bar{u} l$ & gūluw & šil & šilluw & $n \bar{a} m$ & nāmuw \\
\hline & gūliy & gūlin & šlliy & šillin & nāmiy* & nāmin* \\
\hline
\end{tabular}

* These endings without vowel harmony were heard in HwA, BdA, TyA, TAS and ĞrA. In DbA the endings were heard with vowel harmony: nāmay, nāmaw, nāman (not recorded in TAN and MlA).

Imperatives used with the verb ǧāb, yğ̄̌b "bring" are: hāt, hātiy, hātuw, hātin.

N.B. Often the diphthong $i y$ is reduced to $i$ in forms like biygūl, biyš̌l > bigūl, bišll.

3.2.2.4.3. Verbs $C_{2}=\mathrm{w}$ or y (mediae infirmae) participles

Present participles are like in other groups, e.g. gāyil, gāylih, gāylīn, gāylāt.

Past participles are magyū $l,-a h,-\bar{\imath} n,-\bar{a} t$, but more current is mingāl, -ah, -in, $-\bar{a} t$.

3.2.2.5. Verbs $C_{3}=\mathrm{y}$ (tertiae infirmae)

3.2.2.5.1. Verbs $C_{3}=\mathrm{y}$ (tertiae infirmae) perfect

Like in the other groups of the south of Sinai, $a$-type and $i$-type perfects of tertiae infirmae verbs have often become mixed.

Unmixed paradigms in TAS for the $a$ - and $i$-type perfects are:

perfect

\begin{tabular}{|c|c|c|c|c|}
\hline & "walk"*1 & & "find"* & \\
\hline & & pl. & sg. & pl. \\
\hline 3. masc. & mašá(') & mašáw & ligíy & ligyuw \\
\hline fem. & mašát & mašán & ligyit & ligyin \\
\hline 2. masc. & mašēt & mašētuw & ligìt & ligìtuw \\
\hline fem. & mašētiy & mašētin & ligītiy & ligītin \\
\hline 1. com. & mašèt & mašēna & ligìt & ligina \\
\hline
\end{tabular}


* $_{1}$ Raising of $a$ in open pre-stress syllable is current in the $a$-type perfect, e.g. mišá(') and mišèt.

The same paradigm was recorded in ĞrA, BdA, though in the latter the 3rd p. sg. fem. was produced as mášyit.

In DbA and HwA the verb has two parallel conjugations: both as $a$-type

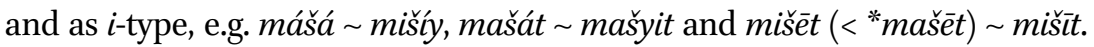
*2 The same paradigm was recorded in ĞrA

In $\mathrm{BdA}$ the 3 rd p. sg. masc. is also ligíy, but the underlying $|\mathrm{a}|$ of the first syllable 'reappears' when the syllable is closed: lagyit, lagyuw and lagyin. In the rest of the paradigm the verb is treated like an $a$-type perfect: ligèt $(<$ lagèt), etc.

In DbA and HwA the verb has two parallel conjugations: ${ }^{109}$ both as $a$-type and as i-type, e.g. ligá $\sim$ ligíy, ligát $\sim$ lagyit and ligēt $\sim$ ligìt.

The perfect paradigm for "forget" recorded in TAS is mixed: (sg.) nasá("), nasát, nasìt, nasìtiy, nasìt and (pl.) nasáw, nasán, nasìtuw, nasìtin, nasìna. In these forms $a$ of the open first syllable is usually raised to $i$, as in e.g. nisit.

DbA has two parallel conjugations: nasá(') nisíy, the conjugation elicited for "forget" in HwA is unmixed $i$-type: nisíy, nasyit, nisit, etc.

Material for MlA and TAN was limited, but the same mixed paradigms appear to be in use there.

3.2.2.5.2. Verbs $C_{3}=\mathrm{y}$ (tertiae infirmae) imperfect

Paradigms for the imperfect in TAS are:

\begin{tabular}{|c|c|c|c|c|}
\hline \multirow{5}{*}{$\begin{array}{l}\text { 3. masc. } \\
\text { fem. }\end{array}$} & \multicolumn{2}{|l|}{ “find"*1 } & \multicolumn{2}{|l|}{ "walk" } \\
\hline & sg. & pl. & sg. & pl. \\
\hline & yalga & yalguw ${ }^{* 3}$ & yimšiy & yimšuw \\
\hline & talga & yalgan $^{* 3}$ & timšiy & yimšin \\
\hline & talga ${ }^{*_{2}}$ & talguw ${ }^{*} 3$ & timšiy $^{*_{2}}$ & timšuw \\
\hline fem. & talgiy ${ }^{* 3}$ & talgan $^{* 3}$ & timšiy & timšin \\
\hline
\end{tabular}

* $_{1}$ The type of raising of final - $a$ (e.g. yansi') heard in group VI is not current here.

$*_{2}$ Apocopated imperfects for the 2nd p. sg. masc. are current only in BdA and TyA (where both full forms and apocopated forms may be heard used

${ }^{109}$ 'Parallel' should not be understood here as two conjugations that are kept separate, either by individual speakers or in different contexts. On the contrary: forms from either paradigm appear to be used at random. The topic certainly deserves more space than can be afforded here. On 'parallel forms', see fn 5 , p. 117 in this volume. 
side by side). Only few instances were heard in ĞrA, DbA and TAN, and none in TAS, HwA and MlA.

*3 Notice that in the $a$-type the final base vowel - $a$ is dropped in the endings of the 2nd p. sg. fem. and the 3 rd and 2 nd pl. masc. forms, but not in 3rd and 2 nd pl. fem. forms.

${ }^{*} 4$ See remarks in 3.2.1.2. on possible vowel harmony of the initial vowel of the sg. com. (imšiy) in ĞrA and BdA.

Endings with base vowel (i.e. -ay, -an and -aw, as in talgay, t/yalgan and t/yalgaw) were heard in TAN, HwA, DbA and BdA. In ĞrA and TyA these co-occurred with endings without the base vowel. Material is too limited for conclusions on MlA; only one relevant form was recorded there: talgūhuw "you'll find them".

3.2.2.5.3. Verbs $C_{3}=\mathrm{y}($ tertiae infirmae) imperatives

Dialects where apocopated imperfects are current (mainly in TyA and BdA, but also in ĞrA, DbA and TAN, see remark ${ }^{* 2}$ in 3.2.2.5.2.), may also use apocopated imperatives for the sg. masc.

3.2.2.5.4. Verbs $C_{3}=\mathrm{y}$ (tertiae infirmae) participles

Active participles have the patterns $C_{1} \bar{a} C_{2} i y, C_{1} \bar{a} C_{2} y i h, C_{1} \bar{a} C_{2} y \overline{i n}$ and $\mathrm{C}_{1} \overline{\mathrm{a}} \mathrm{C}_{2} \mathrm{yāt}$. E.g. nāsiy, nāsyih, nāsyīn, nāsyāt "having forgotten".

3.2.2.5.5. Verbs $C_{3}=\mathrm{y}$ (tertiae infirmae) verbal nouns

A verbal noun of a verb $\mathrm{C}_{3}=y$ (tertiae infirmae) is mašy.

3.2.2.6. The verb "come"

3.2.2.6.1. The verb "come" perfect and imperfect

The verb "come" was recorded in all group I dialects as:

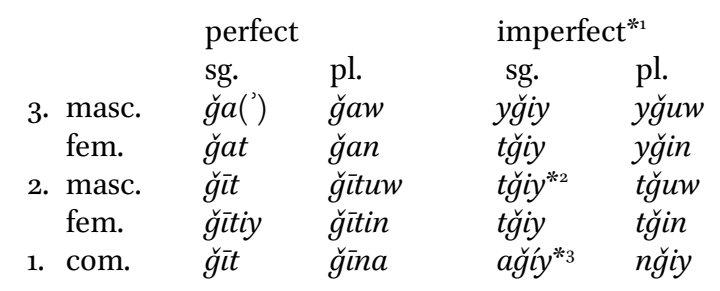

${ }^{*}$ In ĞrA forms with initial $t$ - often showed a following vowel as well: tiğ́y

$\sim$ tǧiy, tiğúw tğuw and tiǧín tǧin. 
$*_{2}$ The apocopated form in BdA and TyA is tiğ.

*3 Informants of ĞrA and BdA did not produce a form iğı́y here (contrast with remarks on vowel harmony in 3.2.1.2.).

3.2.2.6.2. The verb "come" imperatives

Imperatives used with the verb "come" in ĞrA, BdA and TyA are: $t a \bar{a} l$, ta'äliy, ta'äluw and ta'älin. The same forms are used in TAṢ, but there the pl. fem. shows vowel harmony: ta'älan.

In HwA the sg. masc is $t a^{\prime} \bar{a}\left({ }^{\prime}\right)$ and in DbA ta' $\bar{a} l$. In both HwA, DbA the endings of the other forms also show vowel harmony: ta'älay, ta'älaw and ta'àlan.

Material for MlA and TAN is too limited for conclusions.

3.2.2.6.3. The verb "come" participles

Participles of the verb "come" are: ǧāy, ğāyih, ğāàin, ğāyāt.

3.2.2.7. Verbs $C_{2}=C_{3}$ (mediae geminatae)

3.2.2.7.1. Verbs $C_{2}=C_{3}$ (mediae geminatae) perfect and imperfect.

Paradigms for mediae geminatae verbs are:

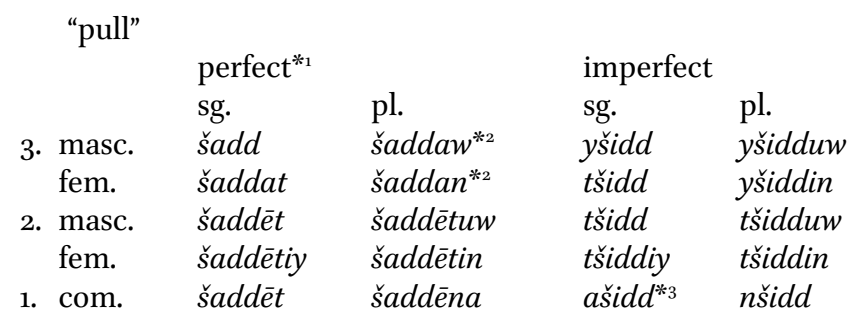

$*_{1}$ Raising of $a$ preceding a syllable with $\bar{e}$ may occur in HwA, DbA and ĞrA (e.g. šiddēt), but it is much less regular than in the other dialects, see also remark in $3 \cdot 2 \cdot 3 \cdot 5 \cdot 2$.

When the geminate is velarized, the $\bar{e}$ of the ending is diphthongal ay. E.g. hattayt "I placed" and hatțaytuw "you (pl. masc.) placed" (notice that $a$ is not raised, so not •hițtayt or •hutțayt, or something similar).

$*_{2}$ Notice vowel harmony in the 3 rd p. pl. endings in BdA, HwA, DbA, ĞrA, MlA and TAN.

In TAS and TyA, however, both - aw and -uw were heard as endings of the 3rd p. pl. masc., e.g. hatțaw hațtuw "they placed". In TAS froms with the ending - $u w$ are most commonly heard.

*3 In ĞrA and BdA also forms with vowel harmony were recorded, e.g. aná biḥibb "I love", bišidd "I pull" ( ahibb and ašidd), and also a form buțuxx "I shoot" in TAN, cf. remarks in 3.2.1.2. 
3.2.2.7.2. Verbs $C_{2}=C_{3}$ (mediae geminatae) imperatives

Imperatives of mediae geminate verbs are e.g. limm, limmiy, limmuw, limmin "gather!" and with base vowel u: xušš, xuššiy, xuššuw, xuššin "enter!".

3.2.2.7.3. Verbs $C_{2}=C_{3}$ (mediae geminatae)

Active participles geminate verbs are e.g.: lāmm, lāmmih, lāmmīn, lāmmāt "having gathered".

Passive participles may be subject to the gahawah-rule when $C_{1}=X$, e.g. mahatūṭ "placed" (see 2.2.1.2.).

\subsubsection{Derived measures}

3.2.3.1. Measure n-1

\subsection{Measure n-1 sound roots}

Like in group VI (but contrast VII and VIII), The vowel in the preformative of measure $n-1$ is stressable in the perfect and in the imperfect (see 2.1.1.). The underlying patterns are: $\operatorname{anC}_{1} \mathrm{aC}_{2} \mathrm{aC}_{3}, y_{1} \mathrm{CaC}_{2} \mathrm{iC}$. The $a$ in the imperfect is raised to $i$ in open syllables, but 'reappears' in closed syllables. Paradigms are:

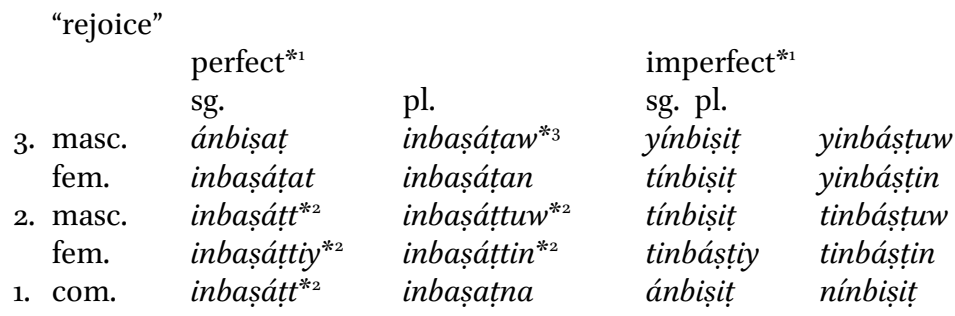

$*_{1}$ For stress in these paradigms, see 2.1.1.

$*_{2} t+t$ assimilates to $t \underline{t}$.

*3 Vowel harmony is absent in the ending - uw in TAS. In TyA -uw cooccurs with -aw and in other dialects the ending is -aw.

3.2.3.1.2. Measure n-1 $C_{2}=C_{3}$ (mediae geminatae)

Patterns for perfect and imperfect of measure $n-1$ of medial geminate verbs are: (i) $\mathrm{nC}_{1} \mathrm{aC}_{2} \mathrm{C}_{2}$ and yinC $\mathrm{aC}_{2} \mathrm{C}_{2}$, e.g. indabb, yindabb (miy) "be filled (with water)".

\subsection{Measure $\mathrm{n}-1 C_{2}=\mathrm{y}$ or $\mathrm{w}$ (mediae infirmae)}

The patterns for perfect and imperfect of measure $n$-1 of medial weak verbs are: $\operatorname{inC}_{1} \bar{a} C_{3}$ and yinC $\mathrm{a}_{1} \mathrm{C}_{3}$. The paradigm for the perfect is: 


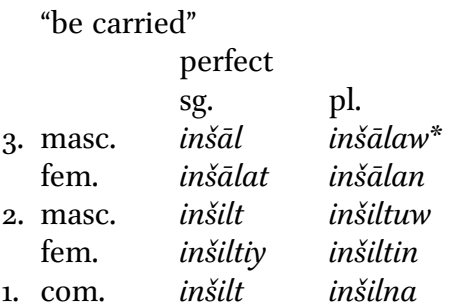

* In TAṢ both - uw and - aw were heard as endings

\subsection{Measure $\mathrm{n}-1 C_{2}=\mathrm{y}$ or $\mathrm{w}$ (mediae infirmae) participles}

Participles are shaped on the patterns $\operatorname{minC}_{1} \overline{\mathrm{a}} \mathrm{C}_{3},-\mathrm{ah} /$-ih, $-\overline{\mathrm{i}}$, -āt.

\subsubsection{Measure t-1}

Measure $t$-1 was recorded once in TAS in (the loan from presumably Cairene) yittākil "it (sg. masc.) is eaten", but the verb current in TAS for "be eaten" is (perf.) ánwakal, (imperf.) yínwikil. No other instances of measure $t$-1 were recorded in these group I dialects.

\subsubsection{Measure 1- $t$}

\subsection{Measure 1-t sound roots}

Underlying patterns for measure $1-t$ are: $\mathrm{aC}_{1} \operatorname{taC}_{2} \mathrm{aC}_{3} \mathrm{yiC}_{1} \operatorname{taC}_{2} \mathrm{iC}_{3}$. Like in measure $n-1, a>i$ is found in the unstressed syllables of the surface form for the imperfect (such raising is compulsary) and also in the perfect (where such raising is optional), e.g.: áštigal áštag்al, yíštigil "work", áttifag áttafag, yíttifig "agree" and ástuwa ástawa, yístiwiy "ripen; be cooked (of food)".

Notice, however, that although the morphophonemic base vowel $a$ 'reappears' in closed syllables when verbal suffixes follow, ${ }^{110}$ e.g. yíxtilif + verbal suffix -uw > yixtálfuw, no a 'reappears' in the example yítibir "he considers" + pron. obj. suffix -ih > yi tíbrih "he considers him" (recorded in TAN). ${ }^{11}$

\begin{tabular}{|c|c|c|c|c|}
\hline & perfect & & imperfect & \\
\hline \multirow{6}{*}{$\begin{array}{l}\text { 3. masc. } \\
\text { fem. } \\
\text { 2. masc. } \\
\text { fem. } \\
\text { 1. com. }\end{array}$} & sg. & pl. & sg. & pl. \\
\hline & áštara & áštaraw ${ }^{* 1}$ & yištiriy & yištáryuw ${ }^{* 3}$ \\
\hline & áštarat & áštaran & tístiriy & yištáryin ${ }^{* 3}$ \\
\hline & ištarayt & ištaraytuw & tíśtir & tištáryuw ${ }^{* 3}$ \\
\hline & ištaraytiy & ištaraytin & tištáryiy $^{* 3}$ & tištáryin $^{* 3}$ \\
\hline & ištarayt & ištarayna & áštiriy & níštiriy \\
\hline
\end{tabular}

\footnotetext{
${ }^{110}$ Similarly so in TyA of the Negev, e.g. yittafguw "they agree", see Shawarbah 2007:296.

${ }^{11}$ The fact that $a$ does not 'reappear' in this case suggests that the "reappearance" of $a$ is not a rule which is synchronically executed.
} 
${ }^{*}$ In TAS both - $u w$ and -aw were heard as endings

$*_{2}$ In BdA and TyA apocopated imperfects (like tiśtir) are possible. In other dialects the form is tístiriy.

*3 Notice that the base consonant $y$ is not dropped here. In DbA the forms

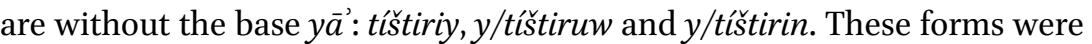
reported to be acceptable in ĞrA as well.

In HwA the base $y \vec{a}$ was dropped only in the end p. sg. fem.: tištiriy, but the $\mathrm{pl}$. forms were $y / t$ tistáryuw and $y /$ tištáryin.

The verb was not recorded in MlA and TAN.

Comparable forms occur with the verb ástuwa, yistiwiy: (e.g.) yistawyin "they (pl. fem.) ripen".

3.2.3.3.2. Measure 1-t $C_{2}=\mathrm{w}$ or y (mediae infirmae)

An example of a medial weak measure $1-t$ verb was not recorded (in the verb ástawa, yistiwiy the $w \bar{a} w$ is not a weak radical).

3.2.3.3.3. Measure 1-t $C_{2}=C_{3}$ (mediae geminatae)

An example of a medial geminate measure $1-t$ verb is iftakk, yiftakk "be solved (of a dispute/problem)".

3.2.3.3.4. Measure 1-t participles

Patterns for measure 1 - $t$ participles are $\mathrm{miC}_{1} \mathrm{tiC}_{2} \mathrm{iC}_{3}$ (underlying $\mathrm{miC}_{1} \mathrm{taC}_{2} \mathrm{iC}_{3}$ ), $\mathrm{miC}_{1} \mathrm{taC}_{2} \mathrm{C}_{3}$ ah/ih, $\mathrm{miC}_{1} \operatorname{taC}_{2} \mathrm{C}_{3} \mathrm{in}, \mathrm{miC}_{1} \operatorname{taC}_{2} \mathrm{C}_{3} \mathrm{a}$.

Examples are:

$\begin{array}{lllll}\text { sg. masc. } & \text { sg. fem. } & \text { pl. masc. } & \text { pl. fem. } & \text { translated } \\ \text { mixtilif } & \text { mixtalfih } & \text { mixtalfin } & \text { mixtalfät } & \text { "differing" } \\ \text { míštiriy } & \text { mištaryih } & \text { mištaryīn } & \text { mištaryāt } & \text { "having bought" } \\ \text { míttifig } & \text { mittafgih } & \text { mittafgin } & \text { mittafgāt } & \text { "agreed" }\end{array}$

Examples of participles of medial geminate and medial weak verbs are not available.

\subsubsection{Measure ista-}

\subsection{Measure ista-1 sound roots}

Like measure 2, measure ista-1 has alternating short vowels: $a$ in the perfect and $i$ in the imperfect. The paradigms are like those listed for group VI. An example is istahwan, yistahwin b "consider to be hayyin, i.e. unimportant". 


\subsection{Measure ista-1 $C_{2}=\mathrm{y}$ (mediae infirmae)}

A measure ista-1 $\mathrm{C}_{2}=y$ (media infirm) verb recorded in TAS is ista 'ā̌ (1st p. sg. com. ista $i s ̌ t), y i s t a ' i ̌ s(f i)$ "choose to live (in a certain place)".

\subsection{Measure ista-1 $C_{3}=y$ (tertiae infirmae)}

A measure ista-1 verbs $C_{3}=y$ (tertiae infirmae) is istawla, yistawliy. An example of a participle is kān mistawlinna "they occupied us (i.e. our land)".

3.2.3.4.4. Measure ista-1 verbs $C_{2}=C_{3}$ (mediae geminatae)

Patterns for medial geminate measure ista-1 verbs are: istaC $\mathrm{aC}_{2} \mathrm{C}_{2}$, yistaC $\mathrm{iC}_{2} \mathrm{C}_{2}$. Paradigms are:

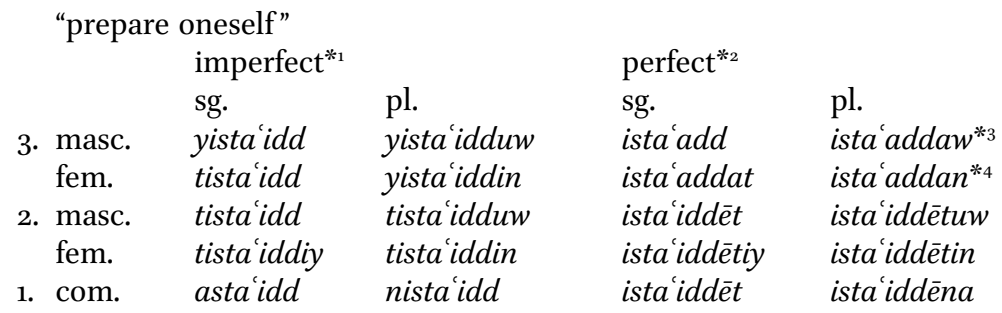

$*_{1}$ Raising of $a$ preceding stressed $i$ occurs, but is limited (perhaps under influence of following '). See remarks in 3.2.2.7.1. and 3.2.3.5.2.

$*_{2}$ Notice (optional) raising of $a$ to $i$ in positions preceding stressed $\bar{e}$.

*3 In TAS and TyA the ending was recorded as $-u w$.

*4 In TyA the ending was recorded as -in, in other dialects (incl. TAṢ) as -an.

3.2.3.4.5. Measure ista-1 participles

Participles of measure ista-1 verbs have the pattern mistaC $\mathrm{C}_{2} \mathrm{iC}_{3}$, e.g. mista ğil, mistá iğlih, mista iğlìn, mista iğlāt "in a hurry".

No instances were recorded of measure ista-1 verbs of medial weak roots.

For mediae geminatae the pattern is mistaC $\mathrm{iC}_{2} \mathrm{C}_{2}$ : mista idd, mista iddih, mista iddīn, mista iddāt "(having) prepared".

3.2.3.5. Measures 2 and $\mathrm{t}-2$

The patterns for measure 2 are: (perfect) $\mathrm{C}_{1} \mathrm{aC}_{2} \mathrm{C}_{2} \mathrm{aC}$, (imperfect) $\mathrm{yC}_{1} \mathrm{aC}_{2}$ $\mathrm{C}_{2} \mathrm{iC}_{3}$.

Measure $t$-2 has morphologically fixed $a$. The patterns are (perfect) taC $\mathrm{aC}_{2} \mathrm{C}_{2} \mathrm{aC}_{3}$, (imperfect) $\mathrm{ytaC}_{1} \mathrm{aC}_{2} \mathrm{C}_{2} \mathrm{aC}_{3}$. 


\subsection{Examples of measure 2 sound roots}

Like in other groups, the high vowel $i$ of imperfect measure 2 is elided in open syllables. The initial geminate of the resulting cluster may then be reduced. Examples of (compulsary) morphophonemic elisions are: itgallbih "you flip it (sg. masc.) over", biygammruw "they gather (harvest) with outstretched arms". ${ }^{112}$

Examples of (optional) sandhi elisions: nrawwh alMìdān "we go to alMīdān"113 and binrakkb alfrūd "we mount the ploughs". ${ }^{114}$

$r$ following the high vowel $i$ may inhibit its morpho-phonemic elision, e.g. biyfakkiruw ( $f$ ) "they look (at)" and in sandhi ydawwir aligșūr "he looks for the safe storages". ${ }^{115}$

When $\mathrm{C}_{2}=\mathrm{C}_{3}$, the elision of $i$ does not take place, but the geminate may be reduced, e.g. biyhálliluw "they make little heaps" and (in sandhi, same root, but different meaning) mḥallil ibnāklih yā rāāgll "(it's) ḥalāl, we eat it, oh man!".

The paradigms for measure 2 verbs are:

$\begin{array}{lllll}\text { "look" } & & & & \\ & \text { perfect } & & \text { imperfect } & \\ & \text { sg. } & \text { pl. } & \text { sg. } & \text { pl. } \\ \text { 3. masc. } & \text { fákkar } & \text { fákkaraw* } & \text { yfakkir } & \text { yfakkruw } \\ \text { fem. } & \text { fákkarat } & \text { fákkaran } & \text { tfakkir } & \text { yfakkrin } \\ \text { 2. masc. } & \text { fakkárt } & \text { fakkártuw* } & \text { tfakkir } & \text { tfakkruw } \\ \text { fem. } & \text { fakkártiy } & \text { fakkártin } & \text { tfakkriy } & \text { tfakkrin } \\ \text { 1. com. } & \text { fakkárt } & \text { fakkárna } & \text { afakkir } & \text { nfakkir }\end{array}$

* TAS and TyA have varying -uw and -aw endings in the 3 rd p. pl. masc. of the perfect, e.g. rawwahaw "they went" and karrabuw "they tied (ropes)". In TyA the -uw ending appeared during direct elicitation, but -aw came out in spontaneous texts.

\subsection{Measure 2 tertiae infirmae}

In the imperfect apocopated forms for the 2 nd p. sg. masc. may again be heard mainly in TyA and BdA, but also in: tsaww tsawwiy "you do", tfass $\sim$ ffassiy "you fart".

Paradigms for tertiae infirmae verbs are:

\footnotetext{
${ }^{112}$ A $\dot{g} i m r$ (pl. $\dot{g} m \bar{u} r$ ) is the quantity of harvest held in two arms.

${ }^{113}$ The meaning of the verb rawwah, yrawwih is "go", rather than its more specific meaning of "go home" (e.g. in Cairene Arabic, see Hinds and Badawi 1986).

${ }^{114}$ fard, pl. früd is the current word for "plough".

${ }_{115}$ For gaṣr, pl. gṣūr see fn 42, p. 47.
} 
"make, do"

$\begin{array}{lllll} & \text { perfect } & & \text { imperfect } & \\ & \text { sg. } & \text { pl. } & \text { sg. } & \text { pl. } \\ \text { 3. masc. } & \text { sawwa } & \text { sawwaw*2 } & \text { ysawwiy } & \text { ysawwuw } \\ \text { fem. } & \text { sawwat } & \text { sawwan } & \text { tsawwiy } & \text { ysawwin } \\ \text { 2. masc. } & \text { sawwēt } & \text { sawwētuw } & \text { tsaww/-iy*3 } & \text { tsawwuw } \\ \text { fem. } & \text { sawwētiy } & \text { sawwētin } & \text { tsawwiy } & \text { tsawwin } \\ \text { 1. com. } & \text { sawwèt } & \text { sawwēna } & \text { asawwiy } & \text { nsawwiy }\end{array}$

${ }^{*}$ Raising of $a$ preceding stressed $\bar{e}$ (> suwwèt) is a feature of ĞrA, HwA and somewhat less so of DbA. Such raising is much less, or not current in MIA, TAṢ, TAN, BdA or TyA (see 1.2.3.4.3.2. and 3.2.2.7.1.).

$*_{2}$ Here too the endings - aw and - $u w$ were both heard in TAS and TyA: sawwaw sawwuw "they made/did" (other dialects only sawwaw).

*3 Apocopated forms are regularly heard only in BdA and TyA.

\subsection{Examples of measure 2 primae hamzah}

Like in many other dialects, the verb "feed" is wakkal, ywakkil "give food" and wadda, ywaddiy is "bring, take to".

\subsection{Measure t-2 imperfect and perfect}

In measure $t-2$ the vowel $a$ is morphologically fixed for the perfect and imperfect. Patterns are $\operatorname{taC}_{1} \mathrm{aC}_{2} \mathrm{C}_{2} a \mathrm{C}_{3}, \mathrm{ytaC}_{1} \mathrm{aC}_{2} \mathrm{C}_{2} \mathrm{aC}$.

Like in group VI, the $t a$ - prefix in the perfect and imperfect of measure $t-2$ is stable and is only rarely reduced to $(i) t-{ }^{116}$

\begin{tabular}{|c|c|c|c|c|}
\hline & perfect & & imperfect $^{* 4}$ & \\
\hline & sg. & pl. & sg. & pl. \\
\hline 3. masc. & tag்adda & tag்addaw $w^{* 1}$ & ytag்adda & $y$ tag $a d d a w^{*_{1}}$ \\
\hline fem. & tag்addat & tag்addan $^{* 2}$ & tag்adda & ytagaddan ${ }^{*_{2}}$ \\
\hline 2. masc. & tag்addēt & tag்addētuw & tag்add $/-a^{*}$ & tag்addaw ${ }^{*_{1}}$ \\
\hline fem. & taǵaddētiy & taġaddētin & tagadday & tag்addan $^{* 2}$ \\
\hline 1. com. & taġaddēt & tag்addēna*3 & atag்adda & ntag்adda \\
\hline
\end{tabular}

$*_{1}$ The ending is $-u w \sim-a w$ in TAS and TyA.

$*_{2}$ The ending is -in in TAS and TyA.

*3 $a$ of the $t a$-prefix in the perfect may be raised, e.g. tigaddèt.

${ }^{*}$ Reduction of initial $t t a->t a$ - in the imperfect is regular.

*5 Apocopation is only regular in BdA and TyA.

${ }^{116}$ Like with measure $t-2$, reduction of $t a->t$ - in measure $t-3$ appears to be regular in TyA of the Negev, e.g. yiträfag "he is accompanied on his travel" (Shawarbah 2007:194), yitlägaw "they meet" (ibid.:296). 


\subsection{Measures 2 and $\mathrm{t}-2$ verbal nouns}

Verbal nouns for measure 2 have a $\operatorname{taC}_{1} \mathrm{C}_{2} \mathrm{iC}_{3}$ pattern, e.g. (MSA loan) tahrīb "smuggling", taybīs "drying (trans.)" and a gahawah-form taġaīb "going north"17 (for more examples see 2.2.1.2.).

Verbal nouns recorded for $t$-2 are tsubbug "racing (on camels)" (HwA) (see fn 126, p. 100) and tkissir "breaking into pieces" (ĞrA).

\subsection{Measures 2 and $\mathrm{t}-2$ participles}

Active participles of measure 2 have a $\mathrm{mC}_{1} \mathrm{aC}_{2} \mathrm{C}_{2} \mathrm{CC}_{3}(-\mathrm{ih} / \mathrm{h}$-ah, -īn, -āt) pattern. Passive participles have a $\mathrm{mC}_{1} \mathrm{aC}_{2} \mathrm{C}_{2} \mathrm{aC}_{3}(-\mathrm{ih} /-\mathrm{ah}$, -ìn, -ât $)$ pattern.

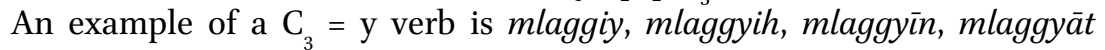
"going".

The $t a$ - preformative of measure $t-2$ is often reduced to $t$ - in participles, so that for $t$-2 active participles the pattern is $\operatorname{mitC}_{1} \mathrm{aC}_{2} \mathrm{C}_{2} \mathrm{iC}_{3}$ (-ih/-ah, -inn, -āt), e.g. mitrahhil "being on a trek', mitdakkir "remembering", mitkassir "having been broken into pieces", mitgaffil "not paying attention" and (for $\left.\mathrm{C}_{3}=\mathrm{y}\right)$ mitgaddiy "having eaten lunch". This is generally the case in TAS, ḦwA, MlA, ĞrA, DbA. On the other hand, also (but fewer) participles with the $t a$ - preformative were heard, e.g. mitamakkin, mita'akkid "convinced" and also mitáallim mit'allim "educated" (TAN, TyA) and in several dialects mta aknin "irritated" was elicited (data for BdA are insufficient for a conclusion).

\subsubsection{Measures 3 and $\mathrm{t}-3$}

Measure 3 has morphologically alternating vowels: $i$ in the imperfect and $a$ in the perfect. Patterns for measure 3 are: $\mathrm{C}_{1} \overline{\mathrm{C}}_{2} \mathrm{aC}_{3^{3}}, \mathrm{yC}_{1} \mathrm{aC}_{2} \mathrm{iC}_{3}$.

Measure $t-3$ has morphologically fixed $a$ in the perfect and imperfect, and like in measure $t$-2, reduction of the $t a$-preformative to $t$ - does occur, but such reduction is rare. Patterns for measure $t-3$ are: $\operatorname{taC}_{1} \mathrm{aC}_{2} \mathrm{aC}_{3}$, $\mathrm{ytaC}_{1} \mathrm{a}_{2} \mathrm{iC}_{3}$. Like in measure $t-2$, intital $t t$ - in the imperfect is reduced to $t$ - (see examples in 3.2.3.6.1.).

\subsection{Examples of measures 3 and $\mathrm{t}-3$}

Examples of measure 3 are: (imperfect) y'äwid "return", yräfig "be a travelling companion for (someone)", ylägiy "find", (perfect) sāfaraw "they (masc.) traveled", sāfaran "they (fem.) traveled", hărabaw "they fought a war against". Apocopation in 2nd p. sg. masc. imperfect of tertiae yă' verbs was again only noticed in TyA and BdA.

\footnotetext{
${ }^{117}$ For the system of orientation, see remarks in De Jong 2000:469, fn 48 .
} 
Examples of measures $t$-3: (imperfect) biytawāfagaw "they agree (with each other)", biytawā'adaw "they set a time (for a court session)", ${ }^{118}$ (perfect) tarāfagt "I was accompanied (on a trip)", talāgēna "we met each other", talägan "they (fem.) met each other", tahạrabaw "they fought a war (against each other)".

In TAS pl. endings for 3 rd p. masc. and fem. lacked vowel harmony in some cases, e.g. biytasābaguw "they race each other", biytarāafaguw "they accompany each other (as travelling companions)", talägin (< *ttalāgin) "they (fem.) meet each other", but talāgan "they (fem.) met each other".

3.2.3.6.2. Measures 3 and $\mathrm{t}-3$ participles

Active participles of measure 3 have the pattern $\mathrm{mC}_{1} \bar{a} \mathrm{C}_{2} \mathrm{iC}{ }_{3}(-\mathrm{ih} /$-ah, -inn, -āt), e.g. mwāfig "agreeing", mlāgyih "having found (sg. fem.)". mkāwnìn "fighting (pl. masc.)".

A passive participle (pattern $\mathrm{mC}_{1} \overline{\mathrm{a}} \mathrm{C}_{2} \mathrm{aC}$ ) is the origin for the loans mhầwalah "attempt" and msā'adah "help, assistence".

Like in measure $t$-2, active participles of measure $t$-3 often have a reduced preformative $(t a->(i) t-)$ in the pattern mitC $\bar{a}_{1} \mathrm{C}_{2} \mathrm{iC}_{3}(-\mathrm{ih} / \mathrm{ah},-\overline{\mathrm{n}}$, -āt) (see also remarks in 3.2.3.5.6.). Among the few instances of participles of measure $t-3$ recorded are: mitdāxlin "having sought refuge as daxīl (pl. duxala) with each other", mitwāsyih "flat, even".

\subsection{Measures 3 and $\mathrm{t}-3$ verbal nouns}

Verbal nouns for measure 3 recorded are mkāsaḥah "having sex" and a loan bala m'äxza "no offense intended". Verbal nouns of the type $\mathrm{tC}_{1} \overline{\mathrm{eC}}_{2} \mathrm{iC}_{3}$ were not recorded.

\subsubsection{Measure 4}

\subsection{Measure 4 sound roots perfect and imperfect}

Verbal measure 4 is active in group I. The patterns for this measure are (perfect) (') $\mathrm{aC}_{1} \mathrm{C}_{2} \mathrm{aC}$, (imperfect) $\mathrm{yiC}_{1} \mathrm{C}_{2} \mathrm{iC}$ and the active participle has a pattern $\operatorname{miC}_{1} \mathrm{C}_{2} \mathrm{iC}_{3}$ (-ih, -ìn, -āt).

Of many examples are: arkab, yirkib, active participle mirkib "cause (someone) to ride", asnad, yisnid was heard in MlA for "go to Palestine"120 and r $^{\prime}$ ad, yir id in DbA for "thunder".

The verb afțar, yifțir "have breakfast" is in most dialects of group I a measure 4, but in some cases (like in TyA) measure 1 may also be used:

${ }^{118}$ In TyA of the Negev such reduction of ta- > t- appears to be regular, see e.g. yitgahwa "he is served coffee or tea" (Shawarbah 2007:174), atxayyal "I imagine" (ibid.:330).

${ }^{119}$ bala m'äxza is probably a loan from MSA via Cairene Arabic, hence $z$ as a reflex for *d, see also fn 63 , p. 221 .

${ }^{120}$ Measure 2 for this root sannad, ysannid is current for "go upstream in a wadi" (being the opposite of the verb katt, ykutt (or ykitt) "go downstream in a wadi". 
fitir (and, remarkably so, with the 'reappearing' $a$ in closed syllables of the $i$-type perfect: fatrit), ${ }^{121}$ yifțir.

3.2.3.7.2. Measure ${ }_{4} C_{2}=\mathrm{w}$ or y (mediae infirmae) perfect and imperfect

The verb rād, yrīd "want" has become measure 1 in ḤwA, ĞrA, TAṢ, BdA with participles rāàid, rāaydih, rāàdīn, rāâdāt.

In TyA participles are mrìd, mrïdih, mrīdīn and mrìdāt, but verb forms are without initial $a$ : $r \bar{a} d, r \bar{a} d a t$ etc. (situation in MlA, DbA and TAN unknown).

\subsection{Measure ${ }_{4} C_{3}=\mathrm{y}$ (tertiae infirmae) perfect and imperfect}

In all group I dialects of southern Sinai the verb at ta, yiticy is verbal measure 4.

In DbA, HwA, ĞrA, TyA, BdA the verb dawá", yidwiy "return home before sunset (with small cattle)" is measure 1, the participles are then

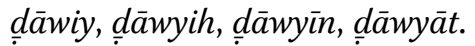

In the other tribal dialects TAS and HwA this verb is current as a measure 4. Participles are then miḍiwiy, mị̣iwyih, miḍiwyin, miḍiwyāt (situation in MlA unknown).

Another tertia yā' measure 4 verb is agra yigriy, with the participle migriy "serve a proper meal to a guest". ${ }^{122}$

Like in group VI, at ta, yiticy is a measure 4 verb in most dialects of group I. The perfect and imperfect paradigms for this verb are:

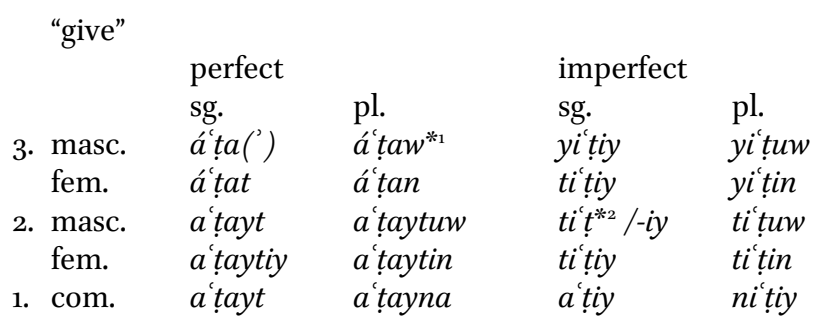

${ }^{*}$ Also in TAS the ending is - aw (but often - $u w$ elsewhere). ${ }^{123}$

$*_{2}$ Apocopated 2nd p. sg. masc. forms in the imperfect of measure 4 are heard in TyA and BdA.

${ }^{121}$ The term 'reappearing' could be a misnomer here, since there may never have been an original perfect form with $a$ in the first syllable. The $a$ only appears in closed syllables here because the entire measure 1 paradigm (compare simi ${ }^{\prime \prime}$ above in 3.2.1.1.) is applied to the root $f-t-r$.

${ }^{122}$ Cf. remarks in fn 144, p. 111.

${ }_{123}$ Such - aw endings appear to be phonetically conditioned in TAS (i.e. they appear following velarized consonants), at least more so than morphologically conditioned; $-u w$ endings also occur in tertiae $y \vec{a}$ ' verbs, provided the environment is neutral (i.e. no velarized consonant precedes). The ending - $u w$ does however occur in non neutral environments as well (see e.g. measure 9 verbs in 3.2.3.8.). 
When followed by a speech pause or a consonant an anaptyctic is inserted: $t t^{\prime} i$ it when followed by \# or C.

3.2.3.7.4. Measure ${ }_{4} C_{1}=\mathrm{w}$ (primae wāw) perfect and imperfect

$a w k a, y \bar{u} k i y$ "tie (closed) tightly" is a prima $w \bar{a} w /$ tertia $y \bar{a}$ ' measure 4 verb.

3.2.3.7.5. Measure ${ }_{4} C_{2}=C_{3}$ (mediae geminatae) perfect and imperfect

Verb forms of measure $4 \mathrm{C}_{2}=\mathrm{C}_{3}$ (mediae geminatae) were not recorded, or not recognized as such.

\subsection{Measure 4 imperatives}

Examples of imperatives for measure 4 sound roots are like imperatives for the $i$-type imperfect (see: 3.2.1.5.).

Imperatives of $\mathrm{C}_{3}=y$ roots are: for the sg. masc. (apocopated) it $(\sim$ it tiy) in TyA and BdA, but only it tiy was heard in the other dialects of group I. For sg. fem. it tiy, pl. masc. ițuw and pl. fem. ițin.

\subsection{Measure 4 participles}

The particples for sound roots have a $\mathrm{miC}_{1} \mathrm{C}_{2} \mathrm{iC}_{3}$ pattern, e.g. mifțir, mífțtrih, mifitrīn, mifitrāt "having eaten breakfast".

Participles of the prima $w \bar{a} w /$ tertia $y \bar{a}^{\prime}$ verb awka, yūkiy are (act. participles) mūkiy, mūkyih, mūkyìn and mūkyāt ${ }^{124}$ and (pass. part.) mawka, mawkayah, mawkayin, mawkayāt.

For mediae infirmae there are participles of the type $\mathrm{mC}_{1} \mathrm{i} \mathrm{C}_{3}$ (-ih, -inn, -āt) like mrìd "wanting" (in TyA, see 3.2.3.7.2.) and also annās țallaw mg்ììn "people appeared (while) running fast" (DbA).

\subsubsection{Measure 9}

Paradigms for measure 9 are:

"turn red"

\begin{tabular}{|c|c|c|c|c|}
\hline & sg. & pl. & sg. & pl. \\
\hline masc. & ihmarr & ihmmarrawaw & yihmaṛ & yihmarraw* \\
\hline & ihmarrat & iḥmarrạan & tihmaṛ̣ & yihmarran \\
\hline 2. masc. & ihmarrayt & iḥmarraytuw & tihmaṛ & tihmarraw* \\
\hline $\begin{array}{l}\text { fem. } \\
\text { 1. com. }\end{array}$ & $\begin{array}{l}\text { ihmarraytiy } \\
\text { ihmarrayt }\end{array}$ & $\begin{array}{l}\text { ihmarraytin } \\
\text { ihmarrayna }\end{array}$ & $\begin{array}{l}\text { tihmarriy } \\
\text { ahmarr }\end{array}$ & $\begin{array}{l}\text { tihmarran } \\
\text { nihmarr }\end{array}$ \\
\hline
\end{tabular}

* In TAS the endings are $-u w$.

Participles are mihmarr, $-a h,-\bar{\imath} n, \bar{a} t$

\footnotetext{
${ }^{124}$ Morphological $i+w>\bar{u}$, see De Jong 2000:90.
} 
An interesting measure 9 verb heard in HwA and TAS is ị̣laww, yiḥlaww "improve (intrans.)" (for a quadriliteral verb based on the root $h-l-w$ in BdA see 3.2.3.9. below.

\subsubsection{Quadriliteral verbs}

Like measure 2, quadriliteral verbs have morphologically alternating vowels in the imperfect (i) and perfect (a). The paradigms listed for group VI zagrat, yzagrit "ululate" are the same in group I.

The typically Bedouin verb type with inserted wāw between $\mathrm{C}_{1}$ and $\mathrm{C}_{2}$ $\mathrm{C}_{1} \overline{\mathrm{OC}}_{2} \mathrm{aC}_{3}, \mathrm{yC}_{1} \overline{\mathrm{o}} \mathrm{C}_{2} \mathrm{iC}_{3}$ may show a full diphthong like in gawțar, ygawțir (often so in DbA, HwA), a slightly diphthongal ow, e.g. gowtar, ygowțir (especially so in BdA, but also in other dialects) or monophthongal $\bar{o}$ (usually so in TAȘ, ĞrA, TyA, MlA and TAN). ${ }^{125}$ The paradigms for the verbs (including bukara-vowels, see 2.2.2.1.) are like those listed for group VI.

Quadriliteral verbs may also have a $t a$-preformative. The vowel of the perfect and imperfect is then fixed $a$. A quadriliteral verb with $\mathrm{C}_{4}=y$ is tagahwa, ytagahwa and has the paradigms:

\begin{tabular}{lllll}
\multicolumn{2}{l}{ "drink coffee/tea" } & & & \\
& perfect & & imperfect & \\
& sg. & pl. & sg. & pl. \\
3. masc. & tagahwa & tagahwaw* & ytagahwa & ytagahwaw* \\
fem. & tagahwat & tagahwan & tagahwa & ytagahwan \\
2. masc. & tagahwēt & tagahwētuw & tagahw/-a & tagahwaw* \\
fem. & tagahwētiy & tagahwētin & tagahwiy & tagahwan \\
1. com. & tagahwēt & tagahwēna & atagahwa & ntagahwa
\end{tabular}

* Endings - aw tend to be -uw in TAṢ.

An apocopated imperative for the sg. masc. is tagahw "drink tea / coffee!" (the final cluster $h w$ \# is then resolved: tagáhuw \#).

Participles are mtagahwiy, mtagáhiwyih, mtagahiwyīn, mtagahiwyāt.

Other examples (recorded in TAṢ): tagaḥraș, ytagaḥraṣ "wriggle the body to create a comfortable position to lie down (usually in pain)", tagarmas, ytagarmaṣ "wriggle the body, especially the shoulder, into soft sand to find a more comfortable position to sleep", tatawțh, ytatawtah "swing, sway (e.g. of a tree in the wind)". Another verb heard in TAS is karkam, ykarkim "add turmeric".

\footnotetext{
${ }^{125}$ Realizations listed here are how they were heard as predominent in the dialects mentioned (following in brackets).
} 
In BdA a quadriliteral ihlawla, yahlawliy expresses an increasing degree of acquiring a certain quality (here hilw "sweet; good; nice) "get better and better", e.g. algirbih ihlawlat "the watersack became better and better (as a result of it being used)".

\section{Remarks on Phraseology}

\subsection{Nunation}

Tanwīn is not a feature of any of the dialects of group I, but may be heard in poetry or sayings (and then has the shape $-i n$ ). ${ }^{126}$

Loans from MSA which show nunation are like those listed for other dialect groups, e.g.: tab 'an "of course", masalan "for instance", 'àmmatan "in general", dāyman (in ĞrA dìman was recorded) "always" (< MSA dāं iman), hăliyyan "currently", ahyānan "now and then", tagrīban "approximately".

\subsection{Negation}

A verb is usually negated with single $m \bar{a}+$ verb form. ${ }^{127}$ Examples are: albi ì hăda lah arba' t-iyyām mà warád "this camel had not drunk for four days", azzar'ah hāda mà biykallif ya'niy sbü' isbūayn "this work on the land does not take (more than) like one, two weeks" (ĞrA), albi r rān alimxawwarāt mā bništirīhin xalāṣ "the bastard camels, we don't buy them at all' (TyA). ${ }^{128}$

A negated suffixed preposition is $w$ inn mā finì lay hasyl "and suddenly there was no strength in me" (ĞrA). For the negation of 'existential' fih see 4.5. below.

\subsection{The b-imperfect}

Like almost everywhere in Sinai, ${ }^{129}$ the $b$-imperfect to express the habitual present tense is also current in group I. Some examples are: alkilmah he didy bit'assir 'alēh kibirih "this word has a great effect on him" (TyA), min tum-

${ }_{226}$ Tanwīn (ending -in) was noticed by Holes and Abu Athera 2009:214-219 to be "particularly common in the more traditional diction" in the poetry of the two Sinai poets recorded by them ('Unayz (TAN) and Tayāha (TyA)) and the Hwēțiy poet Barrāk of southern Jordan. Its use is optional and often for metrical reasons.

${ }^{127}$ Holes and Abu Athera (2009:225) found no instances in their corpus of poetry of verbal compound negation $m a \ldots \check{s}$.

${ }^{128}$ Compare xawwār "non-throroughbred camel", see Bailey 1991:436.

${ }^{129}$ The only exception to this rule is the dialect of the Dawāg̣ah, see De Jong 2000:478. 
mak ${ }^{130}$ ibtúnufxah "with (lit. from) your mouth you inflate it" (MlA), gult 'ğimalì mā biy'üz banzīn wala šiy' "I said 'my camel doesn't need petrol or anything'" $(\mathrm{BdA}) \cdot{ }^{1{ }^{1}}$

\subsection{Future Marker}

To express "volition" or "need" widd + pron. suffix may be used.

Examples of widd expressing futurity/volition are: asma', widd-axarrfak

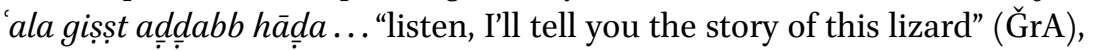
awșafnì addarib ... law widdì arawwih min sábagat il'Irīš fi IMìdān ... min indak min-ihniy... "describe the way to me... if I want to go from the race of al'Arīš at Mīdān ... ${ }^{132}$ from your place from here..." (TAṢ), widdhin...widdhin mákan...mákan, mā fì mákan mint mā tğīb wala hàăih ..."these things (lit. "they (pl. fem.)")...they need (spending of) money... money... if there is no money, you don't get anything" (MlA).

Examples of imperfect forms with prefixed $h a$ - to express futurity are: iw yōm tígilbih, hayșīr annā im tahát $w$ alxašin fōg "and when you flip it over, the soft (side) will be down and the coarse (side) will be up" (MlA), law kațárit lèha ...fa: algamih ... iddètha algamiḥ...hatțalli xišin "if you add more to it (fem.), then the wheat... if you've added wheat to it (fem.)...you'll take it out coarse" (ĞrA), miš hatá arfuw tištarkuw ma ba'aḍuw "you (pl.) won't be able to cooperate with each other" (TAṢ).

The future can also be expressed with the simple imperfect, as in $w$ Allah lhìn law tas'al nuṣs annās iygūl lakw Alllah mā-driy 'anha... "by God, if you now ask half the people they'll (lit. he'll) tell you 'by God, I don't know about it (sg. fem.)"' (BdA).

\section{5. fìh "there is / are"}

Examples of $f$ ih used to express existence or availability of something are $\bar{a}$ fìh garyah ísimha Mìdān ássibag hā Mīdān (where) this race (is held)" (see fn to 4.4.) (HwA), min hạ ḍa .. . 'arááb

130 "Mouth" is more regularly afám or áfam.

${ }^{13^{1}}$ Holes and Abu Athera (2009:212-213) report that in their Sinai poetry the $b$-imperfect is much less current than in casual speech, but does occur. The "dominant imperfect form [in their Sinai material] is $b i$-less". In their southern Jordanian material it is rare, but in the material from their northern Jordanian poet " $b i$-forms occur very frequently".

${ }^{132}$ An annual camel race is held on the plain of Mīdān in northern Sinai, some $22 \mathrm{~km}$ west of al'Arǐš, see map in De Jong 2000:654 (in appendix), location nr 26. 
ihníy w fih 'aráb zayy 'aráb iFrayğ... "from here... (there is) a family here and there are people like the family ${ }^{133}$ of Frayğ" (MlA).

The negation is usually ma fih, but sometimes (K-form) $m \bar{a}$ fiš may also be heard. An example is: hā $\underline{d} a$ șâfiy mā fih xarrāâf "this is a thoroughbred, there's no discussion (about it)" (both ĞrA).

Another current negation is māš, e.g. habbiț rāsak lā y̌̌ūfak alg̀azāl...alğazāl law țār xalāṣ almig̀rib biỵūḥ māš ġizlān "keep your head down, so the gazelle doesn't see you ... if the gazelle flees, that's it, at sunset time he goes away and there aren't any gazelles" (TAN).

\subsection{Some Conjunctions}

4.6.1. Conjunctions lamma and yōm

Like in many dialects of Sinai, conjunctions lamma and yōm, or variant forms based on these, are used for "when".

4.6.1.1. yōm

4.6.1.1.1. yōm used independently

An example of yōm used in the meaning of "when", e.g. garrib garrib yōm

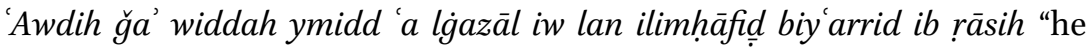
came $^{134}$ nearer and nearer, (and) when 'Awdah came to take aim at the gazelle, there the Governor suddenly rose with his head (becoming visible)" (TAN), ạ, háribt alWatyih lliy bèn ali 'Lēgāt iw bèn a...iw bèn

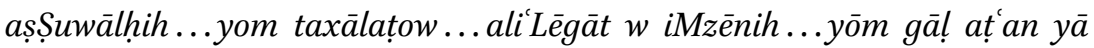
att $\bar{a} \bar{u}$ un "yes, the war at Watyah that took place between the 'Lēgāt and...the Șawālhahah... when they attacked each other...the 'Lēgāt and the Mzēnah... when he said 'let war break out!' (BdA). ${ }^{135}$

A variant of yom is yam, as in the example iw yam bahutt allibbih $w$ bažammirha, iw 'uguḅ ma-žammirha šwayyih kidíy, bahutț almallih "and when I put the libbah and roast it in hot embers, and after I have roasted it a little in embers like this, I put the hot sand" (HwA).

The $a$ in yam must be the product of reduction of the diphthong $a w$.

${ }^{133}$ For the different possible translations of 'arab (pl. 'urbān), see Stewart 1990:199 (glossary).

${ }^{134}$ garrib is an imperative form of the narrative style, see 4.14.1.

${ }_{135}$ at an $y \bar{a} t \bar{c}^{-} \bar{u}$ " lit. let the bubonic plague break out" is reported (oral communication in the field) to be the war cry of the great tribe of Harb, of whom the Mzēnah are said to be an offshoot, cf. Introduction, I. d. remark * 12 . 
4.6.1.1.2. yōm in combination with in

4.6.1.1.2.1. yōmin used independently

An example of yōmin used independently for "when" is iw yōmin tístiwiy...biyhutțin ilhá" assamin iw minnih byigilbūha "and when it becomes cooked... they add the ghee to it (sg. fem.) and then they stir it (sg. fem.)" (HwA).

4.6.1.1.2.2. yōmin + obj. suffix as subject of the clause

There is an example of yomin suffixed with an object suffix as subject; the subject is we: fiza'na ' $\bar{a} d$, iw yōminna fiza'na ... sawwēna ğina, iw limmēna lahámih kullah fi ga!̣b aššanțah "so we ran away, and when we ran away... we did [.] we came, and we gathered all his flesh in the bag" $(\mathrm{DbA}) \cdot{ }^{136}$

\subsection{3. $\min$ yōm}

An example of $\min y \overline{o m}$ (in) used for "as soon as" or "from the moment that": kēf bitsawwiy allibbih ... min yōm ma bta ağinha, lamma bitsațīha $w$ ithakhikha "how do you make libbah...from the moment that you knead it (fem.), until you slap it and scrape it"137 (TAṢ).

4.6.1.1.2.4. $\min$ yōm in combination with $m a$

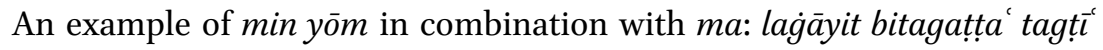
kidiy... lag்āyit ma yanšaf. lamma yanšaf. . yōm ma yanšaf binǧīb iš.... šwālät xayš ... šikāyir ${ }^{138}$ kidiy iw biyta'abba fihin "until it is cut to pieces like this ... until it dries. until it dries... when it has dried we bring a sack of cloth... bags like this and it is stuffed in them" (HwA).

4.6.1.2. lamma and lumma

lamma is often used for "when" and "until". Also a form like lam was recorded (a variant lum was not heard).

4.6.1.2.1. lamma "when" used independently

Of many examples of lamma used for "when" are: iw minnah tsawwiy fiha ěs lamma ț̣lliḥha? "and after that what do you do with it (fem.) when you

\footnotetext{
${ }^{136}$ The story is about a man who died after he had stepped on a land mine; some areas in Sinai are still extremely dangerous because of land mines from past military conflicts.

${ }^{137}$ The libbah is baked in hot embers in the sand. When it is ready, the cook will slap the loaf to clean it of sand and scratch and scrape it to remove other irregularities. The two quadriliteral verbs clearly express repetitive actions here.

${ }_{138}^{18}$ šārāh, šakāyir "gunny sack", see Wehr 1980.
} 
take it (fem.) out?" (TAṢ) and lamma tițliḥha w ilhá ēh? w ilhá bastawīk' ${ }^{139}$ "when you take it (fem.) out (then) it is what? Then it is (texture like) biscuit" (HwA) and rabbna lamma biyrìd azzalámah yíkirmih byíkirmih "When our Lord wishes to be generous to a man, he is" (BdA).

A form lam was also recorded several times, e.g. iw lam byațla a ašsi ìr gadd kididy, ibyanšaf, w ibyahașdūh "and when the barley has grown (lit. comes up) this high, it dries and they harvest it" (ĞrA).

4.6.1.2.2. lamma + in

Examples of lamman are few, and were only recorded in ĞrA and TAṢ: in ĞrA bindarrīh lamman laḡāyit itșìr gamih săfíy "we winnow it until it becomes pure (clean) wheat" and in TAS bass lamman intah lam hatțayt kidiy w šaddèt ibyínkirib. iw byurubtūh mín-tahat f-ánniga! "but when you, when you have placed it and pulled tight it is in distress. And they tie it to the nagal from below". ${ }^{140}$ The other dialects did not show instances of lamman or variations thereof.

4.6.1.2.3. lamma and lumma "until"

lamma and lumma maybe used in combination with lagāayit for "until", e.g. wähid min hiluw la hiluw lag̀āyit ... lamma biyṣī ... ğamal "one (grows) from beautiful to (more) beautiful until... it becomes... a (full grown) camel" (ĞrA) (for an example of lamman + la ġāyit see 4.6.1.2.2. above).

An example of lamma used as "until": tusxun lamma tigliy kidiy "you heat (it) until it boils" (BdA).

An example of luṃma recorded in TAṢ: kull hamāmih 'alēha šarák,

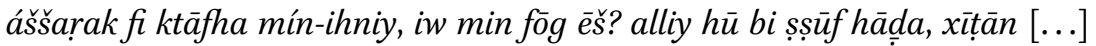
zayy kidigyih, luṃma ês?? ibyinzil așsagị 'a lhamammih 'a d̦aharha "there is a net on every pigeon, the net is under her shoulders here, and on top what? this (thing) with this wool, threads [...] like this, until what? (until) the falcon comes down on the pigeon, on its (fem.) back".

4.6.1.3. $\operatorname{lom}(+$ in $)$

lōm—but only in TyA and ĞrA—was also heard in the meaning of "when": ithutțha f-aššams. lōm itğ́y, linn hì rāaybih "you put it in the sun. When you come (back), there it (suddenly) is curdled (milk)" (ĞrA).

139 bastawīk is a metathesis of baskawìt "biscuit".

${ }^{140}$ The technique described here is used to lure precious falcons to a live pigeon tied to the claws of a nagal (a cheaper bird of prey). When the șagr strikes, its claws will be caught in the net in which the pigeon is tied. 
4.6.2. hatta

4.6.2.1. hatta "until", "so that"

hatta was usually recorded in the meaning of "even", e.g. w Allăhiy 'inna gatác alblād yā 'İd. hatta lbarid katalna f-allēl..."By God, the land has come to misery, oh 'Īd. Even the cold was too much to bear for us (lit. killed us) at night..." (TyA).

\subsection{Auxiliaries and Verbal Particles}

4.7.1. gām

Unconjugated gām used as a 'marker of consequent action' was not recorded in these dialects.

\subsection{2. ṛāḥ}

An example of the use of rāh used as an auxiliary recorded in ĞrA: kān

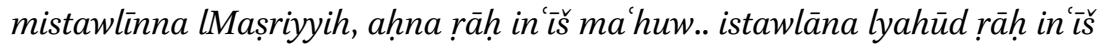
ma'huw "(when) the Egyptians occupied us we (then) lived with them ... when the Jews occupied us, we then (went and) lived with them". The material of the other dialects does not show such examples.

\subsubsection{Conditional particles}

\subsubsection{Variations on kān as a conditional particle}

4.7·3.1.1. in + kān

An example of in + kān "if": inkān fiha harig, bitḥukkha "if there are burnt spots on it (sg. fem.), you wipe it (off)" (HwA).

4.7·3.1.2. Suffixed inkān

An instance of suffixed inkān is: țab lēš sawwa fihin zayy kidily inkānnih zacim iw zèn kān... "okay, so why did he do that to them (fem.) if he was a general and a good man?" (TyA).

4.7·3.1.3. il + kān

Instances of $i l+k \bar{a} n$ were not recorded.

4.7·3.1.4. kān preceded by CA loans iz or iza

izkān ilhá masalan ilhá:... mațabb iddrās bi'ìd... biyšlluw 'a lbị̣̂ān "if there is for it (fem.), for instance there is for it (fem.) a threshing floor far away, they carry (it) on camels" (HwA). 
izkān lih țaláb, binğ̈̈bih lih ...māš țaláb, ibyitawakkal 'a-ḷah "if he has a wish, we get it for him... if there is no wish, he sets out on his journey" (TyA). ${ }^{141}$

kān may also be suffixed, as in izkānnih dayf gäliy bnadbah lih ...iw izkānnih dayf min iligrayybin hōdal bin'aššch "if he is a dear guest we slaughter for him... and if he is a guest of these relatives we give him a (regular) dinner" (TyA).

4.7.3.1.5. kān as an independent conditional

An example of kān used independently as conditional "if": kān ğìtnīf-allēl axarrfak rawāy-aktar "if you would have come to me in the evening I would have told you more stories" (BdA), (S) iw kān 'āyz itsawwha

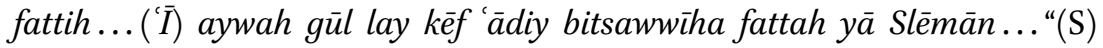

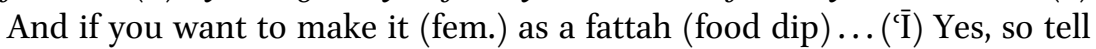
me then how you make it a fattah, oh Slēmān" (DbA).

4.7.3.1.6. kān, inkān or ilkān introducing alternatives

kān may introduce alternatives, like in šüfühum kān ali Lègāt walla șṢawālhih "go see (pl. masc.) them (to see if they are) 'Lēgāt or Șawālḥah" (BdA). Another example is yōm táhaṣdih bitdawwir lak hitt-alliy fìh ... iğbāl fìh malág ... táligha ${ }^{142} \bar{e} h$ ? mitwāsyih. bitgūm itkawwmah kullah fōg ba'aḍah. iw minnih bitğìb álğimal, kān 'indak bi rạan ikțār walla bi rēn... "when you harvest it, you look (for yourself) a piece (of land) in which there is ... desert (land) with hard ground ... you'll find it (sg. fem.) what? Flat. You (then) start piling everything on top of each other. And then you get the camel, whether you have many camels or (just) two" (ĞrA).

4.7.3.2. Absence of a conditional particle

Examples of conditional clauses not introduced by a particle are: 'indak bahāyim ibtafza 'itğîb l add dayf gadá" "if you have cattle you run and bring lunch for the guest", widdhin mákan ... mákan, mā fíh mákan mint mā tğìb wala hăğih ..."they (pl. fem.) need (spending of) money ... money... if there is no money, you don't get anything" and an example of both an introduced and an un-introduced conditional clause is (talking about a loaf of bread baked in sand) inkān fiha harig, bitḥukkha ... ib xūṣah ...mō fiha harig hì bitnaffidha-nta lak b ayyi hāăgh kidíy "if it is burnt, you scrape it ... with a knife... (if) it is not burnt, you clean it (sg. fem.) for yourself with anything like...".

\footnotetext{
${ }^{141}$ tawakkal, ytawakkal '-Allah lit. "put one's trust in God" is the current phrase used for "set out on a journey".

${ }^{142}$ táligha: talg (apocopated talga) + ha; the short vowel $i$ is an anaptyctic vowel.
} 


\subsection{Presentative Particles}

4.8.1. ir ${ }^{\mathrm{c}}$ or $\mathrm{ar}^{\mathrm{c}}$

Examples of presentatives ir or ar are: ar $^{`}$ ¿̇hum $^{143}$ all-akbar minnī mūhum 'ärfinhin "see those, who are older than I am, don't know them (fem.)". Forms with apocopation are: $\operatorname{ar}$ ' ih ğa' "there he is (lit. has come)!", árihhum ğaw "there they are (lit. have come)!", árihhịy ğat "there she is (lit. has come)!" (TyA). Forms with ar + were also heard in TAṢ and in ĞrA írịhuww "there they (masc.) are!" and irihhin "there they (fem.) are!".

\subsection{2. hē + suffix}

The presentative particle $h \bar{e}$ followed by a personal pronominal to draw the listeners attention to something or someone is current, e.g. (recorded in ĞrA) hēhū ğa"! "there he is!", hēhi ğat "there she is!", hēhuṃṃa ğaw "there they (masc.) are!", hèhinnah ğan "there they (fem.) are!".

In TAṢ forms with $h \bar{a}+$ were recorded, e.g. hāhi $\underline{d}$-almišiklih "there's the problem!", but also with initial hay +, as in hayhū ğa', hayhī ǧat, hayhum ğaw, hayhin ğan. Such initial hay + was also heard in DbA and HwA.

\subsubsection{Particle wlin $\sim$ wilin, win}

Like other examples for listed for other groups, a development introduced by the particle wlin $(w+$ lin) need not be unexpected or sudden, but is rather the intended result of an earlier action, as is clear in the first two examples cited here: wagit ma țāb alğurun biyxallūh mṣallab, iwlinn al'ayš wahád $w$ attibin wahád "when the (threshing on the) threshing floor has been good, he leaves it in a pile, ${ }^{144}$ and there's the yield ${ }^{145}$ by itself (on one side) and the straw by itself (on the other side)" (HwA). Another example is mumkin itbarrkih min awwil marrah yōm itğiy tawgaf, iw linnih yubruk "you can let it kneel from the first time when you come and stand still, and then it kneels" (TyA).

${ }^{143}$ Notice that ari 'hum is not an apocopated imperative. The question is also whether full grammaticalization as a particle has actually taken place. Since these recorded examples were directed to one male interlocutor, it cannot be concluded whether or not it (i.e. ir iy or ariy or its apocopated pendant) would be conjugated for number and/or gender.

${ }^{144}$ mșallab was glossed to me as "in a pile", but perhaps its meaning is closer to "having been separated into grains of wheat" and is thus related to șaliba: șalïbit ruzz "Reiskörner (grains of rice)", see Behnstedt and Woidich 1994:206.

${ }_{145}$ 'ayš is often used in the general meaning of "food". Here the reference is clearly to the yield of the harvest. 
An example with both wlā and wlin is: $w$ ihniyyih $w$ lā wāhid ligitih $w$ ba adèn iw linnih biyțālib fay wlin biygūl lay ġār itsūg alğìrih inta ğìt dāṛ̂̀... "and here there was (suddenly) someone I ran into (lit. I found) and after that (and) there he was making claims against me saying to me 'you have to pay the truce payment, you were trespassing on my property (lit. house)' " (ĞrA). Another example is iwlin mā fìh 'aša' "and there's (suddenly) no dinner" (TAN).

An example of suffixed winn is: iw ğina, $w$ Allăhiy $w$ innah lğaww zēn "and we came, by God, and (suddenly) the weather was fine" (DbA).

A variant wlan was also recorded, as in iw lan ilimhääld biy'arrid ib rāsih "there suddenly the Governor rose with his head (becoming visible)" (TAN).

\subsubsection{Particle wlā +}

An example of the presentative particle $w l \bar{a}$ is $w$ lā wăhid ligìtih "and (suddenly) there was someone I ran into to" (see preceding paragraph 4.8.3.). ${ }^{146}$

\section{9. gayr}

$\dot{g} \bar{a} r(<\dot{g} a y r)$ may be used (in all dialects discussed here) preceding imperfect forms to express the necessity of the action, e.g. albu'rān $\dot{g} \bar{a} r$ ibyitațabba'an. yainiy lbi īr iw hū ès, min fōg ássinah ibtabda mi áh taṭbì itțabbi albi ìr "the camels need to be trained. That is, the camel when it's what? Over a year (old) you start training with it, you train the camel" (TAȘ) and another example alliy 'âwiz iy...iynawwi' f-álbil ássibag imn ássibag ha biywaddīh imn álğimal ha ... masalan imșayyiṭ alğamal ațtāniy imșayyit... ġär yițlig 'alèha minnih masalan "if he wants to diversify the camels (for) the race and this (other) race, he'll take him from this camel... (there is) for instance a good reputation, the other camel has a good reputation, he then needs to let her be covered by him, for instance..." (TyA).

A particle irkān (presumably < * $\dot{g} a y r k \bar{a} n$ ) "need be, be only" was heard in TAṢ: alhīn intuw sūgkuw ...ì țalabātkuw rkān alMasūrah "now, you, your market ... and your shopping goods are only from alMāsūrah" and in BdA hāda-rkān māk macák yúkutlak áḍ̂dama fíh "(in) this (place) you need to have water with you, otherwise thirst will kill you there (lit. in it)".

${ }^{146}$ This presentative was also heard by Holes and Abu Athera (2009:227) in the poetry of the Hwētịy poet Barrāk of southern Jordan. 


\subsection{Intensifying Particle la}

The particle la intensifying the 1 st p. sg. com. was not recorded in these southern group I dialects. There is an example however in which la intensifies: hāda la rasmiy Tìhiy... "he’s really oficially a Tīhiy" (BdA).

\subsection{1. bidd or widd + pron. suffix}

To express "want" or "need" speakers of group I dialects use suffixed widd. Examples for "need" or "want" are: widdī-yyāk itxarrifni "I want you to tell me" (TAȘ) and alblād bass lissā" widdha takrìm "but the land still needs to

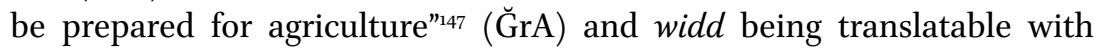
"want" or "in order to" in garrib garrib yōm 'Awdih ğa' widdah ymidd 'a

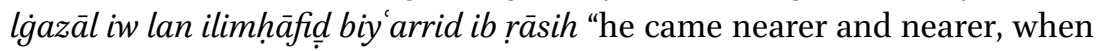
'Awdah came he wanted to (or: in order to) take aim at the gazelle, there suddenly the Governor stuck his head out (becoming visible)" (TAN).

Examples of widd used to express futurity rather than wish are: $m \bar{u} h \bar{u}$ 'ārif zayy intih... (interviewee) lā hāda 'ād widd-agūl lak, șalliy 'á-nnibiy "he doesn't know (about it) like you... (interviewee) No, this I'll tell you then, pray for the Prophet...", ${ }^{148}$ widd-agül lak 'ala ttamir "I'll tell you about the dates" (both examples BdA).

An example of widd expressing necessity from the viewpoint of the speaker is: țayyib, halhịn widdak itgūl lay kēf biysawwuw ssamin aššịiy "okay, now you need to tell me how they make šịniy ghee” (TAṢ).

$$
\text { 4.12. ‘ } \bar{a} d
$$

The particle ' $\bar{a} d$ is extremely current to express "so, thus, then". Examples are: rāayib...biyhutțūha fi ssi in 'ād bitșìr èh? imsawwyīn rawāğìh l assi in ... "curdled milk... they put it in the goat skin so then it becomes what? They'll have made a tripod for the goat skin"149 (HwA), lagga yāt iblād, lagga 'ād itlāwah Șadir walla tlāwah Daháb? "to which (part of the) land did he go, did he go towards Șadr or towards Dahab?" (TAȘ) and iw bingayyil wē:n iw bingayyil nușș alblādāt 'àdiy ana w Alḷāh zamān ... iyyām harib... "and where do we rest during the heat of the day? And so we'd

\footnotetext{
${ }^{147}$ A karm (pl. krūm) is a private orchard or garden in which people grow their agricultural products.

${ }_{148}$ The phrase sall(iy) 'á-nnibiy is often used to draw the attention of those present to what one has to say.

149 For an illustration of such a tripod from which the goat skin is swung to churn butter, see Behnstedt and Woidich 1985:59.
} 
rest right in the middle of the lands during the heat of the day. By God, in the old days I... during the days of war..." (BdA).

$$
\text { 4.13. yabga }
$$

yabga may be heard sometimes meaning "so, then", as in yabga hā $\underline{\underline{d}} a$ wähid alhịn țilí... min alliy byafhamow "so this was then someone now... who came forth from those who have a sound understanding" (TAȘ) and wagit ma dannat allibbah taharkalat hassētha, yabga llibbah ástuwat "and when it has sounded (it produces a knocking sound) the libbah it moves a little when you touch it, then the libbah has become cooked" (HwA). álğimal byiddīha ğamal...yabga șārat fíha ǧimál..."the (male) camel gives her a camel... so then there has come a camel in her..." (BdA). Another example in ĞrA is kull biyrawwih bètih xalās ... yabga ... kull rawwah bètih, biydall al'arìs 'àd $w$ al'arūs gā'dīn ...yōm, yōmèn talätih 'ind ba'adhuw... "everybody goes to his home, that's it... so (after) everybody has gone home, the groom and bride stay... for a day, two, three days with each other..." In MlA metathesized yagba was recorded.

\subsection{Characteristics of the Narrative Style}

\subsubsection{Imperative of narration}

Some examples of the imperative of narration are: garrib yā mhâfid iw garrib iw garrib, iw 'Awdah m'ah iw garrib w úxumruw iw garrib ... alimhạäfị biy'arrid ib rāsih kidiyyān alġazāl šāfih šárad..."the Governor came nearer ${ }^{150}$ and nearer and nearer while 'Awdah was with him and he came nearer and they hid and he came nearer... the Governor sticks his head out like this (and then) the gazelle saw him and fled". Another example is wadd arrğăl iw hät arrǧăl "(many) men came and went (lit. send the men and bring the men)" (both examples TAN).

\subsection{2. kān as a temporal marker}

Unconjugated $k \bar{a} n$ is very frequently used as a marker to indicate the past, e.g. ya'niy kān ahna mnazzminhha' ... ifwāăg 'a talat t-iyyām ... "that is, we used to organize it (fem.)... in heats (held) over three days..." (HwA),

${ }^{150}$ The narrative imperative used directly addresses the Governor: (lit.) "Come nearer, oh Governor". 
inǧīblak karṛūsih walla ǧhāzāt? gult la inšūf aliǧhāzāt... law karṛūsah ${ }^{151}$ kān lagètnì l alhìn al'amaliyyah ta'bānih "shall we get you a wheel chair or artificial legs? I said 'No, let's see the artificial legs'... if (I would have taken) a wheel chair you would have found me... the whole business until now in poor condition" (TyA) and basma xarārîf zamān biygūl lak int tağawwaz $w$ int mintah 'ārifhiy, ${ }^{152}$ mā bitšūfha ġār kān bitǧ́y 'indak "I hear stories of old times that tell you you'd get married (to a girl) that you didn't know (lit. while you didn't know her), you'd not see her until she came to live with you (i.e. on the wedding day itself)" (TAȘ) and tab iw kān biybǐ ūh wēn? "Okay, and where would they sell it (sg. masc.)?" (TAȘ), iw kān alimhạfị iymī::l 'alá-lǧimal iw kā:in iyfassiy... "and the Governor bent (all the way) over to the side on the camel and farted..." (TAN) and ana mānī 'ārif, mā-na kān batașayyad ma' nās bass hū fi 'ēš? f-āxir așșayf "I don't know, I used not to go hunting with people, but it is when? At the end of the summer" (TAȘ).

$k \bar{a} n$ was much less frequently used as a verb and conjugated as such, but one such example is alḥurmah hādiy kānat zamān alliy biygūluw lēhiy Šexah bițtill lay "this woman whom they called Šēxah in the old days used to come and look in on me" (TyA) (bitțill< bitțill).

\subsubsection{Dativus ethicus}

Some instances of the ethic dative are:153 lamma biyšūfah șagị, biygūm ibyítilg lak ánniga! hā $\underline{d} a$ "when a falcon sees it, he'll then set the nagal free

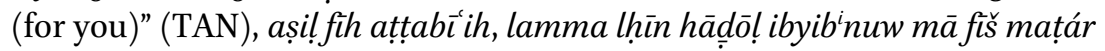
min xams isnīn, mūhum 'ārfin țabīit Sinah kēf, banaw lak fi hittah w xalāṣ "because there is nature, when these (people) are now building while there hasn't been rain for five years, they don't know (about) how the nature of Sinai is. They built (something) in a (certain) place (for you) and that's it" (TAṢ). ${ }^{154}$

\footnotetext{
${ }^{151}$ karrūsih, lit. "little chair" shaped on the dim. pattern $\mathrm{C}_{1} \mathrm{aC}_{2} \mathrm{C}_{2} \overline{\mathrm{u}} \mathrm{C}_{3}$ ah. The text was recorded from a man who had lost his legs after driving over a land mine. He lives in an area where a wheel chair would be useless, since there are no paved roads or paths.

${ }^{15^{2}}$ The interviewer, who is a Tựbāniy from Ṛās Șadr, here imitates a more north-eastern type of dialect by substituting - $h a$ with -hiy, the latter of which is also characteristic of TyA, but not of his own dialect (TAS).

${ }^{153}$ Holes and Abu Athera (2009:228) also report instances in the poetry of the Hwêtịy poet Barrāk from southern Jordan.

${ }^{154}$ In the past people have built in the wadi that runs straight through Dahab. When in 2004 a flood came, it washed away a MacDonald's restaurant, which had been built too near the $s \bar{e} l$ (actually, almost right in the middle of it).
} 


\subsection{Pluralis paucitatis}

For limited or countable numbers often the healthy plural form is used instead of the 'broken' plural. Some examples are: lugium min aḅuw rḥāyāt "a mine with disks" (broken pl. rhiy) ${ }^{155}$ (DbA), dawyāt "(types of) medicine(s)" (broken pl. ádiwyih) (TAȘ), arba sanawāt "four years" (broken pl. snīn) (MlA), talát marrāāt "three times" (TAN), ğhāzāt "artificial legs" (broken pl. áğihzih) (TyA).

\subsection{Concord}

An example of a limited number of men is (in the first part of the sentence reference is in the pl. masc.; in the second part the reference to the same men is in pl. fem.): ${ }^{156}$ biytsābagow lēhuw arba' huğğān mi ba'adhuw... xamsih, ibyiğrin lēhin itnēn kïlih talätah kïlih ... "four camel riders race (for themselves) each other...five, they (pl. fem.) run (for themselves) two kilometres, three kilometres" (ĞrA). another example is: hașa lbān, iw sukkur fiḍdiy, $w$ alhilbih ...('I) $w$ alhilbih ...(X) aywah ...hādōl tarayyag bìhin așșubuh 'á-xal-arrīg ...('I) 'á-xal-arrìg ...(X) aywah saba' t-iyyām ... min yōmin tibdiy fi hādōol lamma tōfihin ... ('I) tamām ... "rosemary, white (lit. silver) sugar and fenugreek... ('I) and fenugreek...(X) Yes, these you have for breakfast in the morning on an empty stomach...('I) On an empty stomach...(X) Yes, (for) seven days ... from the moment you start with these until you have finished them (fem.) completely..." (MlA). ${ }^{157}$

\section{A Sketchy Remark on Pitch}

The type of pitch heard in group I predominantly among older men in the north east could also be heard among older men in group I dialects discussed here.

${ }_{155}$ The disks of the landmine are metaphorically compared here to handmills used for grinding, which have a similar shape and size.

${ }^{156}$ Holes and Abu Athera 2009:222 remark that "plural and collective nouns referring to human beings of either gender [also] normally attract fem sing agreement, especially when the reference is generic". For further interesting observations on 'agreement', see ibid. 220-223.

${ }^{157}$ For the verb awfa, yūfiy (or yōfiy) "achieve in full", see De Jong 2000:219, fn 430. 


\section{CONCLUSIONS}

\section{Comparing Dialects}

\section{a. Methods of Comparing Dialects}

To present an overall picture, a number of maps have been added in the appendix, which show a number of features of the dialects spoken in the area. To facilitate direct comparison, data used in maps in De Jong 2000, which cover the dialects of the northern Sinai littoral, have also been incorporated in these maps. A total of 13 maps have been added, which illustrate dialect features not used in De Jong 2000. In these additional maps dialect features are set as criteria for comparison to show differences between dialects spoken by tribes in the centre and south of Sinai; setting the same features as criteria for a comparison to be illustrated in maps would not have yielded very significant results in De Jong 2000, but these criteria do offer new perspectives when the entire area of Sinai is represented in a map.

In De Jong 2000 the northern Sinai littoral was shown to be an area of transition. This transition is between a largely Bedouin type of dialect (labelled group I), spoken by the majority of the Sinai tribes, and which has also been referred to as Negev Arabic (described in Blanc 1970) on the one hand, and the sedentary dialect of the eastern part of the Šarqiyyah province in the Nile Delta of Egypt.

Dialects in De Jong 2000 were compared using the 'step method'. Since the dialects form a geographical continuum, the linear nature of the comparison (i.e. only dialects bordering on each other were compared, mainly in a westeast (or vice versa) distribution) does not present a problem; after having made the comparison the continuum proved to be linguistic as well. ${ }^{1}$

However, since the dialects of central and southern Sinai do not form such a geographical continuum, a comparison using the step method becomes too two-dimensional, since more dimensions are needed to group dialects that do not lie along a more or less neat two-dimensional line.

\footnotetext{
${ }^{1}$ One of the reasons is that in the case of the Bedouin dialects of the northern Sinai littoral we saw - from east to west - a gradual disappearance of 'Bedouin' dialectal features, yielding to more sedentary features also found in the dialect of the eastern Nile Delta. The central and southern regions of Sinai do not form a continuum in the same or a comparable manner.
} 
For this reason the method of multi-dimensional scaling yields more reliable results for the grouping of dialects. All dialects (also the ones that do not geographically border on each other) are compared to each other on the basis of all features used as criteria for comparison. This means that also dialects that are far apart will receive a full comparison in this method, whereby the relative typological distance between these geographically far removed dialects can also be established. The advantage is clear: the fact that for instance TAN and TAS are clustered relatively near to each other may be interpreted as the result of a common history of these dialects; both are dialects of the same tribe (Tarāāinn), although today these two varieties are spoken at locations hundreds of kilometres apart. ${ }^{2}$

Another advantage of the multi-dimensional scaling method is that parallel forms are more easily fitted into the comparison; every feature receives its own column in wich every dialect is marked for the presence or absence of this feature. When two parallel possibilities exist, their presence in the same dialect will be marked in the two columns created to record these features.

To give an example: When dialect A shows the use of interdentals, in dialect $B$ interdentals have been replaced by stops, and in dialect $C$ both forms with interdentals and forms with stops (which were originally interdentals) occur, this will be marked as follows:

E.g. in dialect A we heard: axad, țār, $\underline{\underline{d}} a r b$, In dialect B: $a x a d, t a \bar{r}, \underline{d a r b}$ and in dialect C: axad $\sim$ axad, tāa $r \sim$ tār, $\underline{\text { darb }} \sim$ darb

$\begin{array}{lcc} & \underline{\mathrm{t}}, \underline{\mathrm{d}}, \mathrm{d} & \mathrm{t}, \mathrm{d}, \mathrm{d} \\ \text { dialect A } & + & - \\ \text { dialect B } & - & + \\ \text { dialect C } & + & +\end{array}$

The programmes Proxscal and Alscal will then plot dialect $\mathrm{C}$ exactly between dialects $\mathrm{A}$ and $\mathrm{B}$ ( $\mathrm{C}$ sharing characteristics with $\mathrm{A}$ inasmuch as it shares (other) characteristics with B). Distances between the different points in the plot represent differences between dialects; the greater the distance between two points, the greater the difference between the two dialects represented.

$\begin{array}{lll}\text { o } & \text { o } & \text { o } \\ \text { A } & \text { C } & \text { B }\end{array}$

\footnotetext{
${ }^{2}$ From Nwēbi (centre of TAN territory) to Rās Ṣadr (centre of TAS territory) is approximately 200 kilometres as the crow flies.
} 


\section{Remarks to the Maps IN the AppendiX}

The maps in the appendix are ordered (with a few minor modifications) in conformity with the numbering used in De Jong 2000 (Maps referred to there are indicated in italics and with 'in 2000'). Dialect features were used as criteria for comparison between dialects and the outcome of these comparisons between dialects is illustrated in maps in the appendix of De Jong 2000. When a comparison based on the same criteria yielded no differences inside central and/or southern Sinai, no map has been drawn for that feature in the appendix of the volume in hand. Such features are, however, briefly mentioned in the remarks following below, and have been treated in the relevant paragraphs of the respective descriptive chapters of this study.

When a map was drawn for De Jong 2000, and not for the study in hand, this should be taken to mean that difference(s) with respect to the feature discussed only shows up in the dialects of the northern region discussed in De Jong 2000. References to the paragraphs discussing such features follow the remark in brackets as: '(cf. + numbering)'.

\section{a. Criteria for Comparison from De Jong 2000 Producing Differences/ Similarities in Central and Southern Sinai}

Before going into the various differences that are found in dialects of central and southern Sinai, and the maps that illustrate these differences, first a number of characteristics ${ }^{3}$ shared by all dialects in the central and southern Sinai are listed here: ${ }^{4}$

$\mathrm{NB}$, in the text below:

- 'No map in this volume' means that the feature discussed is not illustrated in a map in the appendix of this volume, since no differences were found inside central and southern Sinai for that feature set as criterion for comparison.

3 The reasons for incorporating the features listed below as a basis for dialect comparison are given in footnotes to the text in De Jong 2000:37-47.

4 Since there is little point in producing maps that only illustrate shared characteristics throughout the area, such characteristics are listed here separately. For a comparable summary of shared characteristics of dialects in northern Sinai, see De Jong 2000:30-38. To facilitate comparison I have followed the same numbering here, but have had to rearrange the order of listing in a few cases. Where additions had to be made for central and southern Sinai (when differences not found in northern Sinai do occur in this area), this is specifically mentioned. 
- 'No map' means that neither in De Jong 2000, nor in the volume in hand a map has been produced, since the feature set as criterion does not produce a difference in the entire region of Sinai).

- 'New MAP (followed by a number from 75 to 87 )' means that an additional map appears in the appendix of this volume below (for a feature for which no map appeared in De Jong 200o). The new maps for additional features set as criteria for comparison have been numbered from MAP 75 to MAP 87 (the last map-MAP 88-shows the subdivision into dialect groups in the entire region of Sinai).

- 'MAP (followed by a number from 1 to 73)' means that both in De Jong 2000, as well as in the appendix in this volume a map has been produced to illustrate differences between dialects in the entire region of Sinai. The numbering of these maps is parallel to the numbering used in De Jong 2000.

- Features used in De Jong 2000 to establish relative 'Bedouinness' or 'Sedentariness' (in a linguistic sense) of dialects under discussion are marked '(B-S)'.

- For further remarks see 'Remarks to the maps in the appendix' below.

(the numbering/capital letters used here are in reference to the list in De Jong 2000:37-47).

2. and 3. All dialects in central and southern Sinai have three interdental reflexes $\underline{t}, \underline{d}$ for respectively ${ }^{*} \underline{t},{ }^{*} \underline{d}$ and $\underline{d}$ in which * ${ }^{*}$ and ${ }^{*} \underline{\underline{d}}$ have merged (additional difference for central and southern Sinai) (cf. 1.1.2. $)^{5}$ (B-S).

No MAP 2 in this volume (MAP 2 in 200o).

No MAP 3 in this volume (MAP 3 in 20oo).

A. Like in northern Sinai, all dialects in central and southern Sinai have affricate $\check{g}$ or fricative $\check{z}$ (or both in free variation) for * ${ }^{\circ}$ (no map, cf. 1.1.4.) (B-S).

B. Like in northern Sinai, all dialects in central and southern Sinai have a voiced (unaffricated) plosive reflex $g$ for ${ }^{*} \mathrm{q}$ (no map, cf. 1.1.3.) (B-S).

${ }^{5}$ In the north dialects were identified where $\underline{d}$ and $\underline{t}$ were disappearing (Axrasiy, AxA), or had already disappeared (Biyyāḍiy, BA), see De Jong 2000:331-332 and maps 2 and 3 (in ibid., appendix). 
C. Like in northern Sinai, none of the dialects in central and southern Sinai show affrication of *k or * $q$ (no map, cf. 1.1.3.) (B-S).

D. Like in northern Sinai, all dialects have three short vowel phonemes /i/, /u/ and /a/. The short high vowels $i$ and $u$ can be isolated through minimal pairs, but like in northern Sinai this phonemic opposition is limited (no map, cf. 1.2.3.2.) (B-S).

E. Like in northern Sinai, reduction of geminated $C_{2}\left(C_{a} C_{a}\right)$ when $C_{3}$ $\left(C_{b}\right)$ is followed by $V$, i.e. a cluster $\mathrm{C}_{a} \mathrm{C}_{a} \mathrm{C}_{b} \mathrm{~V}>\mathrm{C}_{\mathrm{a}} \mathrm{C}_{\mathrm{b}} \mathrm{V}$ : this reduction occurs regularly in all dialects of central and southern Sinai (no map, cf. 2.3.3.3.1.) (B-S).

F. See remark below.*

G. Like in northern Sinai, a preference for the construct state instead of direct annexation was not unequivocally apparent in central or southern Sinai. Instead, a comparison is made on the basis of the use of $b t \bar{a}$, šuğ l, hagg (MAP 29, cf. 3.1.11.) (B-S).

H. Like in northern Sinai, nunation (or tanwīn) is not current in any of the dialects of central and southern Sinai (no map, cf. 4.1.) (B-S).

I. Like in northern Sinai, the locative preposition $f \iota$ "in" occurs in all dialects of central and southern Sinai (no map, cf. 3.1.16.).

J. Like in northern Sinai, productivity of diminutive patterns is difficult to establish ${ }^{6}$ (no map, cf. 3.1.6.) (B-S).

K. Use of $m \bar{a} r$ / $m \bar{e} r$ "so, then, but", mār was heard only in MlA (no map) (B-S).

L. Use of interrogative 'alām + pron. suffix "why, what for?": like in northern Sinai, this interrogative has been recorded in several dialects, like the example 'alämuk y-Aḅuw Zēd? (GrA) "what's the matter with you, Abu Zayd" (no map, cf. 3.1.14.) (B-S).

*

F. Like in northern Sinai, the second pl. masc. pron. suffix -kuw is regular in groups I and VI, but in groups VII and VIII we have -kuw (or $-k u w) \sim-k u m$ (or -ḳum) (see new MAP 8o, 3.1.12.2.).

Of characteristics used for maps in De Jong 2000 (pp. 37-47, numbering of maps used there again runs parallel to numbering of maps presented here), the following remarks can be made for Bedouin dialects in the centre and south of Sinai.

\footnotetext{
${ }^{6}$ See remark in De Jong 2000:153, fn 237.
} 
1. $/ \mathrm{k} /$ and $/ \mathrm{k} /$ as separate phonemes in the phoneme inventory: not in group I, but both are present in phoneme inventories of groups VI-VIII (cf. 1.1.1. and 3.1.12.2.).

MAP 1 in this volume (MAP 1 in 20oo).

In northern Sinai only two tribal dialects ('AgA and SaA) showed the presence of $/ \mathrm{k} /$ as a separate phoneme. It was surmised then that this was in fact a feature more commonly present in dialects of southern Sinai. It was also reported in De Jong 200:246 that the Samānnah had migrated from the southern mountainous region of aț-Țur to the Gatyah oasis, where they reside today. This migration, as I was told one day by an older Smē'niy, would have taken place around the year 19oo. ${ }^{7}$

The assumption in De Jong 2000:283-285 of / $/$ / being a more typically southern Sinaitic feature can now indeed be corroborated; we see that the southern groups VI, VII and VIII all show this separate phoneme in their phoneme inventories. The MAP also shows that in 'AgA and $\mathrm{BdA}$ the $/ \mathrm{k} /$ in the pronominal suffix - $a$. was heard with a degree of velarization, in any case a higher degree of velarization than in (other) group I dialects. In 'AgA such velarization would be attributable $-k$, resulting in a compromise form by transferring its velarization onto the new pron. suffix - $a k$ (hence $-a k$ ). In BdA velarization may be due to dialect contact; the Badārah are surrounded by Șawālhạah, and-no longer being on the Tìh plateau, but to the south of the escarpment in the reddish sands of ar-Ramlah near Ğabal Hmayyir ${ }^{8}$ - have considerably less contact with other group I tribes like Tiyāha, Ḥwețāt and Tarābīn (of Nwēbic).

2. and 3. See remarks made above (no maps in this volume, cf. 1.1.2.) (both B-S).

4. Secondary velarization, or emphatization: several differences were recorded in the centre and south of Sinai (cf. 1.1.7.).

MAP 4 in this volume (MAP 4 in 200o) shows the degree of velarization generally present in the dialects compared here. To illustrate this for central and southern Sinai the pl. forms of kibìr and kititir are adduced.

7 Von Oppenheim 1943:164 mentions that (in my translation) "parts of the 'Olēkāt have settled in Upper Egypt [...] Nowadays they mostly call themselves 'Ogēlāt". These 'Ogēlāt may well be related to the 'Agāylah (i.e. speakers of 'AgA) whom we find today as neighbours of the Samā'nah in Bīr Gațah, see map in De Jong 2000:656.

${ }^{8}$ Geographical coordinates of their current abode are appr. 29.02.53 North and 33.33.39 East. The white rectangular shapes, already plainly visible from an elevation of 1,00o metres on Google Earth, are their tents, which are made of flour sacks (donated by USAID). 
These pl. forms can be velarized, as in $k b \bar{a} r$ and $k t a \bar{a} r$, or velarization lacks and $/ \bar{a} /$ is even realized relatively high (near IPA $[\varepsilon x])$, as in $k b \bar{a} r$ and $k t \underline{a} r$. In group VI realizations are $k b \bar{a} r$, but no velarization in $k \underline{t a ̈} r$.

5. Partial or complete monophthongization of older diphthongs *ay and *aw and possible phonemic overlapping of $/ \overline{\mathrm{e}} /$ and $/ \overline{\mathrm{i}} /$ (cf. 1.2.2.1. and 1.2.4.5.).

MAP 5 in this volume (MAP 5 in 200o) illustrates which dialects have phonetic overlapping of $/ \overline{\mathrm{e}} /$ and $/ \overline{\mathbf{1}} /$ (e.g. sêf $\sim \operatorname{sĭf}$ "sword", šêx $\sim \check{s} \bar{c} x$ "sheikh") and which dialects lack this feature.

6. Tendency to retain length of long vowels in unstressed positions. In dialects of central and southern Sinai shortening of long vowels in such positions is a feature of allegro speech (cf. 1.2.2.4.) (B-S).

No MAP 6 in this volume. MAP 6 in 2000 shows in which dialects shortening of long vowels in unstressed positions takes place. If such shortening occurs in central or southern Sinai dialects, it is a feature of allegro speech and thus clearly of a phonetic nature.

7. Raising of the short vowel $a$ in positions preceding A. (cf. 1.2.3.4.3.2., 3.1.1.5., 3.1.1.6. and 3.1.1.7.) (B-S).

MAP 7 in this volume (MAP 7 in 20oo) shows where short vowel $a$ in open syllable tends to be raised when directly preceding primarily stressed $\bar{a}$ or $a$ within word boundaries (e.g. katábt $>$ kitábt and bakāriğ > bikāriğ).

8. Raising of the feminine suffix (T) (often referred to as 'imälah of *ah). The map reflects a generalized situation (cf. 1.2.3.4.3.3.).

MAP 8 in this volume (MAP 8 in 200o) shows the different degrees of raising of the fem. morpheme -ah (either as a pausal feature or a sandhi feature).

9. Extreme raising of final ${ }^{*}-\bar{a}$ or ${ }^{*}-\vec{a}{ }^{3}>-i y$, or less extreme raising $>-i \overrightarrow{ }$ (MAP 9, cf. 1.2.4.4.) (B-S).

MAP 9 in this volume (MAP 9 in 20oo) illustrates the different reflexes of final $-\bar{a}\left({ }^{\prime}\right)$ in neutral (i.e. non-velarized) environments encountered in Sinai.

10. Absence of raising of final $-\bar{a}$ or $-\vec{a}$ (MAP 10, cf. 1.2.4.4.).

MAP 10 in this volume (MAP 10 in 200o) shows reflexes of final $-\bar{a}\left({ }^{\prime}\right)$ in non-raised positions.

11. Diphthongal reflexes of *ay and *aw (cf. 1.2.4.1., 1.2.4.6. and 1.2.4.7.). MAP 11 in this volume (MAP 11 in 2000) shows the reflexes of diphthongs *ay and *aw when directly preceded by back spirants $(\mathrm{X})$ or emphatics (M) present in Sinai dialects. 
12. Stress in mediae geminatae where the geminate is word-final. (cf. 2.1.1.).

No MAP 12 in this volume. MAP 12 in 2000 shows stress in forms with final geminates. In central and southern Sinai the vowel directly preceding a final geminate is invariably stressed (e.g. yhutt "he places", tšidd "you pull", tinhátț "it (sg. fem.) is placed", aššáț or iššáț "the coast") and thus the whole central and southern region shows no difference in this respect.

13. Stress in maCCaCah (cf. 2.1.1.1.).

No MAP 13 in this volume. MAP 13 in 2000 shows stress assignment in the pattern maCCaCah. All dialects in central and southern Sinai have the máCCaCah stress-type.

14. Stress in ${ }^{*} \mathrm{CaCvC}$ (i.e. surface forms $\mathrm{CvCaC}, \mathrm{CvCiC}$ or $\mathrm{CvCuC}$ ) (cf. 2.1.1.2.).

MAP 14 in this volume (MAP 14 in 20oo) illustrates stress assignment in patterns $\mathrm{CiCiC}$ (including $\mathrm{CuCuC}$; both being 'underlying' $\mathrm{CaCi} / \mathrm{uC}$ ) and $\mathrm{CaCaC}$.

15. Stress in ${ }^{*} \mathrm{CaCaCv}$ (cf. 2.1.1.2.1.).

MAP 15 in this volume (MAP 15 in 2000) shows stress assignment in the pattern $\mathrm{CaCaCv}$.

16. Stress in ${ }^{*} \mathrm{CaCaCaCv}$ (MAP 16, cf. 2.1.1.2.2., was 2.1.1.2.1.3. in De Jong 2000).

MAP 16 in this volume (MAP 16 in 200o) shows stress assignment in the pattern $\mathrm{CaCaCaCv}$.

17. Resyllabication of ${ }^{*} \mathrm{CaCaCV}$ sequences. Such resyllabication is not a feature of any of the dialects of central and southern Sinai, e.g. waragah "piece of paper", gahawah "coffee" (cf. 2.1.1.2.2., was 2.1.1.2.1.6. in De Jong 2000) (B-S).

No MAP 17 in this volume. MAP 17 in 2000 shows the presence/absence of the Nağdiy type of resyllabification: $\mathrm{CaCaCV}>\mathrm{CCvCV}$. This type of resyllabification was not heard in central or southern Sinai.

18. The article and preformatives of measures $n-1$ and 1- $t$ as stressable units (cf. 2.1.1.2.2.) (B-S).

MAP 18 in this volume (MAP 18 in 200o) shows stress assignment in verbal measures $n-1$ (of VII) and 1- $t$ (or VIII) and in sequences (with article) alCaCaC.

19. The gahawah-syndrome (cf. 2.2.1. and 2.2.1.3.) (B-S). No MAP 19 in this volume. MAP 19 in 2000 shows the spread of the gahawah-syndrome. The syndrome is active in all dialects of central and southern Sinai. 
20. Presence of initial CCV in a limited number of morphological patterns (cf. 2.3.5.) (B-S).

MAP 20 in this volume (MAP 20 in 200o) shows reflexes of the pattern ${ }^{*} \mathrm{CICaC}$.

21. Raising of $a$ in $\mathrm{CaC}_{1} \mathrm{iC}_{3}$ ah (cf. 1.2.3.4.3.2. and 3.1.1.1.).

MAP 21 in this volume (MAP 21 in 200o) shows raising (or absence of it) of short vowel $a$ in pre-stress open syllable in a sequence $\mathrm{CaCīC}(\mathrm{ah})$.

22. Raising of $a$ in ${ }^{*} \mathrm{CaCCa} C$ (cf. 1.2.3.4.3.2. and 3.1.1.4.).

MAP 22 in this volume (MAP 22 in 200o) shows raising (or absence of it) of short vowel $a$ in a pre-stress closed syllable in a sequence CaCCāC(ah).

23. Raising of $a$ in open syllable preceding $\bar{u}$ (cf. 1.2.3.4.3.2. and 3.1.1.8.). MAP 23 in this volume (MAP 23 in 200o) shows raising (or absence of it) of short vowel $a$ in pre-stress open syllable in a sequence $\mathrm{CaCūC}(\mathrm{ah})$.

24. The pattern for colours and physical defects (cf. 3.1.7.).

No MAP 24 in this volume. MAP 24 in 2000 shows reflexes of the pattern *aCCaC for colours and physical defects. In southern and central Sinai the current reflex for this pattern is aCCaC in all dialects.

25. The definite article and the relative pronoun (cf. 3.1.9.1.) (B-S).

MAP 25 in this volume (MAP 25 in 200o) shows the form of the article and the relative pronoun.

26. Occurrence of $/ \mathrm{a} /$ in the initial syllable of a number of irregular nouns (cf. 3.1.9.2.).

MAP 26 in this volume (MAP 26 in 20oo) is on the short initial vowels in the lexemes for "mother" and "sister".

27. Treatment of $\mathrm{T}$ (the feminine suffix morpheme) (cf. 3.1.10.).

MAP 27 in this volume (MAP 27 in 200o) shows the behaviour of the fem. morpheme $(\mathrm{T})$ in construct state.

28. Elision of the T-vowel in construct state (cf. 3.1.10.).

MAP 28 in this volume (MAP 28 in 20oo) is on the elision of the short vowel of the fem. morpheme (the T-vowel).

29. The genitive exponent (cf. 3.1.11.).

MAP 29 in this volume (MAP 29 in 20oo) shows the different genitive exponents used for the analytical genitive in Sinai dialects.

30. Gender distinction masc./fem. in 2nd and 3rd p. pl. (cf. 3.1.12., 3.2.1.1., 3.2.1.2.) (B-S).

No MAP 30 in this volume. MAP 30 in 2000 is on the absence or presence of gender distinction masc./fem. in plurals of personal pronominals, adjectives and verb forms. In all dialects of central and southern Sinai this distinction is made. 
31. The independent personal pronominals of the 3 rd p. sg. masc. and fem. (cf. 3.1.12.1.).

MAP 31 (MAP 31 in 20oo) is on the shapes of the pronominals for the 3rd p. masc. sg, and the 3 rd p. sg. fem. "he" and "she".

32. The 1st p. sg. com. pronominal (cf. 3.1.12.1.).

No MAP 32 in this volume. MAP 32 in 2000 is on the shape of the pers. pronominal for the ist person sg. com. "I". The form used in the entire central and southern Sinai is ana, stressed either on the first or on the second syllable (covered in MAP 14).

33. The ist p. pl. com. personal pronominal (cf. 3.1.12.1.). MAP 33 (MAP 33 in 200o) is on the shape of the pers. pronominal for the ist person pl. com. "we".

34. The pronominal suffix for the 3 rd p. sg. masc. (cf. 3.1.12.2.) (B-S). $\mathrm{MAP}_{34}\left(\mathrm{MAP}_{34}\right.$ in 20oo) is on the shape of the pronominal suffix (obj. or poss.) for the 3 rd person sg. masc. "him (obj.)" or "his (poss.)".

35. The pronominal suffix for the 3 rd p. sg. fem. (cf. 3.1.12.2.). MAP 35 (MAP 35 in 200o) is on the shape of the pronominal suffix (obj. or poss.) for the 3 rd person sg. fem. "her".

36. The pronominal suffix for the 2nd p. sg. masc. (cf. 3.1.12.2.). $\mathrm{MAP}_{3} 6\left(\mathrm{MAP}_{3} 6\right.$ in 20oo) is on the shape of the pronominal suffix (obj. or poss.) for the 2 nd person sg. masc. "you (obj.)" or "your (poss.)".

37. The pronominal suffix for the 2nd p. sg. fem. (cf. 3.1.12.2.). MAP 37 (MAP 37 in 20oo) is on the shape of the pronominal suffix (obj. or poss.) for the 2nd person sg. fem. "you (obj.)" or "your (poss.)".

38. The pronominal suffix for the 1st p. sg. com. (cf. 3.1.12.2.). No MAP 38 in this volume. MAP 38 in 2000 is on the shapes of the pronominal suffixes (obj. and poss.) for the 1st person sg. com. In all of central and southern Sinai "me (obj.)" or "my (poss.)" (stressed) $\bar{\imath}$ (possessive) and (stressed) $-n \bar{\imath}$ (object) (usually $\sim$ unstressed $-i$ and $-n i$ ).

39. Emphatization of $\underline{d}$ in demonstratives of near deixis if not followed by $-i$ (cf. 3.1.13.) (B-S).

MAP 39 (MAP 39 in 200o) gives the demonstratives for sg. masc. near deixis "this".

40. The sg. fem. demonstrative (cf. 3.1.13.).

MAP 40 (MAP 40 in 200o) gives the demonstratives for sg. fem. near deixis "this".

41. Gender distinction in pl. demonstratives (cf. 3.1.13.1.) (B-S).

No MAP 41 in this volume. MAP 41 in 2000 is on gender distinction in pl. demonstratives. In central and southern Sinai no such distinction is made, except in MzA, but material is insufficient for definitive conclu- 
sions. In MAP 32 the pl. com. forms of demonstratives are given for central and southern Sinai (information is incomplete for northern Sinai).

42. Interrogative "who?" (cf. 3.1.14.) (B-S).

MAP 42 (MAP 42 in 200o) compares the different shapes of the interrogative "who?".

43. Interrogative "where?" (cf. 3.1.14.) (B-S).

No MAP 43 in this volume. MAP 43 in 2000 is on the shapes of the interrogative "where?" In central and southern Sinai this interrogative is wēn in every dialect.

44. Interrogative "how?" (cf. 3.1.14.) (B-S).

No MAP 44 in this volume. MAP 44 in 2000 is on the different forms for the interrogative "how?" In central and southern Sinai the current form is kēf or kîf.

45. Adverb "there" (cf. 3.1.15.1.) (B-S).

MAP 45 (MAP 45 in 200o) gives forms used for the adverb "there".

46. Shape of the adverb "here" (cf. 3.1.15.1.) (B-S).

MAP 46 (MAP 46 in 20oo) gives forms used for the adverb "here".

47. The preposition l "to" + 3rd p. sg. masc. suffix (cf. 3.1.16.) (B-S).

MAP 47 (MAP 47 in 200o) compares the different varieties of the preposition "to" + 3rd person. sg. masc. suffix: "to him".

48. The preposition $m(a)^{c}$ "with" + 3rd p. sg. masc. suffix (cf. 3.1.16.). MAP 48 (MAP 48 in 200o) gives the different varieties of the preposition "with" + 3rd person sg. masc. suffix: "with him".

49. Numeral "one (fem.)" (cf. 3.1.17.).

No MAP 49 in this volume. MAP 49 in 2000 shows forms of the sg. fem. numeral "one", The form wihdih is current throughout central and southern Sinai.

50. The 3 rd p. pl. masc. verbal ending of $a$-type perfects (cf. 3.2.1.1.). MAP 50 (MAP 50 in 200o) is on presence/absence of vowel harmony in verbal endings of the 3 rd person pl. masc. perfect.

51. The 3 rd p. pl. fem. verbal ending of $a$-type perfects (cf. 3.2.1.1.). MAP $5^{1}$ (MAP $5^{1}$ in 200o) is on the presence/absence of vowel harmony in verbal endings of the 3 rd person pl. fem. $a$-type perfect.

52. The $i$-type perfect (cf. 2.1.1.2.2. and 3.2.1.1.).

MAP $5^{2}\left(M^{2} 5^{2}\right.$ in 2000$)$ is on the $i$-type perfect of verbs ${ }^{*} \mathrm{CaCiC}: 3^{\text {rd }}$ person sg. masc., 3 rd person sg. fem. and ist person sg. com.

53. Vowel harmony in the preformative of the imperfect of verbal measure 1. (cf. 3.2.1.2.) (B-S).

No MAP 53 in this volume. MAP 53 in 2000 is on the absence/presence of vowel harmony in the preformative of the $a$-type imperfect: 
yaCCaC or yiCCaC. All dialects of central and southern Sinai show such vowel harmony, e.g. yašrab "he drinks".

54. The 3 rd p. pl. masc. verbal endings of $a$-, $i$ - and $u$-types imperfects (cf. 3.2.1.2.).

MAP 54 (MAP 54 in 2000) is on the presence/absence of vowel harmony in verbal endings of the 3 rd person pl. masc. endings in $a^{-}, i^{-}$ and $u$-type imperfect.

55. The 3 rd p. pl. fem. verbal endings of $a$-, $i$ - and $u$-types imperfects (cf. 3.2.1.2.).

MAP 55 (MAP 55 in 200o) is on presence/absence of vowel harmony (i.e. low short vowel $a$ or high short vowel $i$ ) in verbal endings of the 3 rd person pl. fem. in $a$-, $i$ - and $u$-type imperfect.

56. Imperfect preformative of measure 1 primae $w \bar{a} w$ verbs (cf. 3.2.2.1.) (B-S).

No MAP 56 in this volume. MAP 56 in 2000 is on the vowel in the imperfect preformative of primae $w \bar{a} w$ measure 1 verbs. This vowel is not $i$ (as in e.g. yiwșal) in central or southern Sinai dialects, but $a$ as in yawșal, or $(a w>)$ monothongized to $\bar{o}(\sim \bar{u})$ as in yōṣal.

57. Perfect of primae hamzah verbs (cf. 3.2.2.3.).

MAP 57 (MAP 57 in 200o) shows the ( 3 rd person sg. masc.) perfect forms of primae hamzah measure 1 verbs: with or without initial $a$-.

58. Imperfect vowel in primae hamzah verbs (cf. 3.2.2.3.).

MAP 58 (MAP 58 in 200o) is on the vowel $i$ or $u$ in the (3rd person sg. masc.) imperfect forms of primae hamzah measure 1 verbs.

59. The active participle of primae hamzah measure 1 verbs (cf. 3.2.2.3.). No MAP 59 in this volume. MAP 59 in 2000 shows the forms of the active participle of primae hamzah measure 1 verbs. In central and southern Sinai these are with initial $m \bar{a}-:$ mākil, māxid.

6o. 3rd p. sg. masc. perfect of the verb "come" (cf. 3.2.2.6.1.).

No MAP 60 in this volume. MAP 60 in 2000 compares perfect forms of the verb "come": 3rd person sg. masc., 1st person sg. com., 3rd person pl. masc. and 3 rd person pl. fem. In none of the dialects of central and southern Sinai initial $i$ - or $\bar{\imath}$ - (i.e. iğa or ĭğa for "he came") is current.

61. Imperfect of the verb "come". (cf. 3.2.2.6.1.).

MAP 61 (MAP 61 in 200o) gives imperfect forms of the verb "come": 3 rd person sg. masc., 1st person sg. com.: with or without lengthened preformative vowel.

62. Measures n-1, 1-t and (a)sta-1 or (i)sta-1 (cf. 3.2.3.1.1. and 3.2.3.3.1.). MAP 62 (MAP 62 in 200o) is on occurrence of initial $a$ - in the preformatives of measures $n-1$ and $1-t$ perfect and on imperfect. 
63. Measure (a)sta-1 or (i)sta-1 perfect and imperfect (cf. 3.2.3.4.1.).

No MAP 63 in this volume. MAP 63 in 2000 is on measures (i)sta-1: perfect and imperfect. In all dialects of the central and southern Sinai the patterns $(\mathrm{i}) \mathrm{staC}_{1} \mathrm{C}_{2} \mathrm{aC}_{3}$, yistaC $\mathrm{C}_{2} \mathrm{iC} \mathrm{C}_{3}$ with morphologically alternating vowels $a$ and $i$ are current.

64. Measure $t a-2$ or (i)t-2 (cf. 3.2.3.5.4.).

No MAP 64 in this volume. MAP 64 in 2000 is on measures ta-2 or $t$-2: perfect and imperfect. In the entire central and southern Sinai reducing the preformative $t a$ - to $(i) t$ - may at times occur, but it is not current.

65. Frequency of use of measure 4 verbs (cf. 3.2.3.7.) (B-S).

No MAP 65 in this volume. MAP 65 in 2000 is on presence/ absence of measure 4 . In the entire central and southern Sinai an active verbal measure 4 is current.

66. Typical Bedouin verbs of the $\mathrm{C}_{1} \mathrm{awC}_{2} \mathrm{aC}_{3}, \mathrm{yC}_{1} \mathrm{awC}_{2} \mathrm{iC}_{3}$-type (cf. 3.2.3.9.) (B-S).

No MAP 66 in this volume. MAP 66 in 2000 is on the typically 'Bedouin' verb-type with inserted $w \bar{a} w \mathrm{C}_{1} \bar{o} \mathrm{C}_{2} \mathrm{aC}_{3}\left(\right.$ or $\left.\mathrm{C}_{1} \mathrm{awC}_{2} \mathrm{aC}_{3}\right), \mathrm{yC}_{1} \bar{o} \mathrm{C}_{2} \mathrm{iC}_{3}$ (or $\mathrm{yC}_{1} \mathrm{awC}_{2} \mathrm{iC}_{3}$ ). In the entire central and southern Sinai this verbtype occurs regularly.

67. The sg. fem. active participle + object suffix in construct state (cf. 3.2.1.4.) (B-S).

No MAP 67 in this volume. MAP 67 in 2000 is on sg. fem. act. participles followed by an obj. suffix: a construct state results, or does not. In all dialects of central and southern Sinai a contruct state will result, e.g. hì mrìdtah or rāyidtah "she wants him".

68. Negation: single $m \bar{a}$ or compound $m a \ldots . .+\check{s}$ (cf. 4.2.) (B-S).

MAP 68 (MAP 68 in 200o) is on verbal negation: is $m \bar{a}+$ verb form used, or compound $m \bar{a}+$ verb form $+\check{s}$ ?

69. Use of the $b$-imperfect for the habitual present tense (cf. 4.3.) (B-S).

No MAP 69 in this volume. MAP 69 in 2000 is on use of the $b$-imperfect. The $b$-imperfect is current in all dialects of central and southern Sinai.

70. Future particle ha- (cf. 4.4.).

No MAP 70 in this volume. MAP 70 in 2000 is on use of the future particle. The future particle $h a$ - may be heard in all dialects of central and southern Sinai.

71. Use of yōm(-in) or lōm(-in) "when" (cf. 4.6.) (B-S).

MAP 71 (MAP 71 in 200o) is on the occurrence of yōm, lōm for the conjunction "when". These forms are regular in all dialects of central and southern Sinai. 
72. Marker of consequent action (unconjugated) gām (cf. 4.7.1.). MAP 72 (MAP 72 in 20oo) is on the occurrence of $g \bar{a} m$ as a "marker of consequent action" for the conjunction "when". This gām is not regular in central or southern Sinai dialects; only in 'LA it was recorded a few times.

73. Use of widd or bidd (cf. 4.11.) (B-S).

MAP 73 (MAP 73 in 200o) is on the use of widd or bidd to express "want" or "need".

74. No MAP 74 in this volume. MAP 74 in 2000 shows the dialect groups identified in northern Sinai. A map showing dialect groups in the entire Sinai is MAP 88 in the appendix of the volume in hand.

\section{b. Added Criteria for Comparison of Dialects in Central and}

\section{Southern Sinai}

In addition to comparisons based on the 73 features listed above, a total of 13 features are added here to serve as criteria for comparison to further illustrate differences/similarities in dialects of central and southern Sinai. These features (numbered $75^{-87}$ ) are listed below:

75. Raising of $a$ in closed syllable preceding stressed $\bar{e}$ : lammèt $>$ limmèt, sawwèt > suwwèt (new MAP 75 in this volume, cf. 1.2.3.4.3.2., 3.2.3.5.2. and 3.2.2.7.1.).

76. Raising of $a$ in open syllable preceding stressed $\bar{e}$ : $m a s ̌ e \bar{t}>$ mišèt (new MAP 76 in this volume, cf. 1.2.3.4.3.2., 3.2.2.5.1.).

77. Mutual influence of hissing sounds: metathesis in forms like șâğ and siğih-šızih (new MAP 77 in this volume, cf. 2.5.).

78. The pl. masc. personal pronominal "they" (new MAP 78 in this volume, cf. 3.1.12.1.).

79. Negated personal pronominals "not he", "not she", "not you (sg. masc.)", "not I" (new MAP 79 in this volume, cf. 3.1.12.1.).

8o. The 2nd p. pl. masc. pronominal suffix (new MAP 80 in this volume, cf. 3.1.12.2.).

81. The pl. com. demonstrative "these" (new MAP 81 in this volume, cf. 3.1.13.1.).

82. Interrogative "when?" (new MAP 82 in this volume, cf. 3.1.14.).

83. Shape of the preposition 'ala "on" with 3 rd p. sg. masc. suffix (new MAP 83 in this volume, cf. 3.1.16.).

84. The 2nd p. sg. masc. imperfect of mediae geminatae verbs (new MAP 84 in this volume, cf. 3.2.2.4.1.). 
85. The sg. masc. imperative of mediae geminatae verbs (new MAP 85 in this volume, cf. 3.2.2.4.2.).

86. The 3 rd p. sg. masc. perfect of tertiae $y \bar{a}^{\prime}$ verbs (new MAP 86 in this volume, cf. 1.2.4.4., 3.2.2.5.1.).

87. The apocopated 2nd p. sg. masc. of tertiae infirmae imperfect (new MAP 87 in this volume, cf. $3 \cdot 2.2 \cdot 5 \cdot 1$.$) .$

\section{IsOGLOSSES}

\section{a. The Identified Isoglosses in Central and Southern Sinai}

Below follows a list of isoglosses which result from the comparison of dialects based on features treated in the maps in the appendix, which were set as criteria for this comparison. The numbering of the criteria corresponds with the numbering of the MAPS in the appendix. The numbering of the criteria (nrs 1-73) here again corresponds to the numbering used in De Jong 2000:600-601. ${ }^{9}$ In addition to these, criteria nrs $75^{-87}$ (in MAPS $75^{-87}$, see preceding paragraph) illustrate further differences between dialects in the centre and south of Sinai.

In some cases - mainly where new features were set as criteria for comparison within the centre and south of Sinai-the data for the dialects in this comparison were incomplete; the dialects discussed in De Jong 2000, which now border on our more northern dialects discussed here, were not compared before on the basis of the additional criteria introduced for the dialects discussed here.

The totals of differences listed below have been calculated as follows: a partial difference has been counted as half in the total; often parallel forms result from dialect contact, so that one form may be identical to a form heard in a neighbouring dialect, while parallel to this form (in the same meaning) another form was heard, which was not heard in the same neighbouring dialect.

In cases where the comparison was incomplete due to the lack of data in one (or both) of the dialects compared, the uncertain outcome has been counted as half as well. The total numbers of isoglosses were calculated to be drawn into MAP o in the appendix.

9 N.B. the numbering of the isogloss bundles here does not correspond to the numbering of isogloss bundles in De Jong 2000. 
The percentages listed below were however calculated on the basis of a corrected total; uncertain outcomes have been subtracted from the total of the 95 features serving as criteria for comparison. Isogloss bundle number -1- may serve as an example: we count 4 full differences and 5 partial differences. These add up to $(4+2.5=) 6.5$ differences. We also count seven uncertain differences. From the total of 95 we subtract this 7 , which brings the corrected total to 88 . We then calculate 6.5 as a percentage of 88: $(6.5: 88) * 100=7.386364$. This is rounded off to be $7.4 \%$. This means that $7.4 \%$ of a total of 88 features set as criteria for comparison between the two (geographically bordering) dialects yield differences. These percentages were calculated to be used in the 'step method' calculation.

\section{N.B.}

* The absolute numbers of isoglosses drawn into MAP $o$ as bundles cannot be compared to the absolute numbers forming isogloss bundles drawn in MAP o in De Jong 200o, since the two maps illustrate comparisons based on different totals of dialect features set as criteria for comparison.

* The numbers between hyphens refer to the numbering of isogloss bundles in MAP o in the appendix (these numbers are not related to the numbering of isogloss bundles in De Jong 2000). The numbers followed by a bracket ) refer to the numbering of the maps in the appendix in De Jong 2000 and in the appendix of this volume (but the maps numbered $75^{-8} 7$ only appear in the volume in hand).

-1- Isogloss bundle $\mathrm{nr}-1$ - distinguishes SA from MlA.

4 differences: 23$), 39), 48), 87$ )

7 uncertain differences: 4), 27), 37), 72), 77), 79), 82)

5 partial differences: 14), 45), 46), 47), 78)

Total 10 differences; percentage of corrected total $(=88) 7.4 \%$

-2- Isogloss bundle $\mathrm{nr}-2$ - distinguishes MlA from nTA.

2 differences: 16$), 58$ )

11 uncertain differences: 4), 23), 57), 72), 76), 77), 78), 79), 81), 82), 87)

5 partial differences: 14), 40), 45), 46), 47)

Total 10 differences; percentage of corrected total $(=84) 5.4 \%$ 
-3- Isogloss bundle $\mathrm{nr}-{ }^{-}$- distinguishes nTA from TyA.

5 differences: 21), 48), 52), 58), 83)

9 uncertain differences: 4), 27), 72), 76), 77), 79), 81), 82), 87)

4 partial differences: 14), 15), 23), 86)

Total 11,5 differences; percentage of corrected total $(=86) 8.1 \%$

-4- Isogloss bundle $\mathrm{nr}-4$ - distinguishes 'AyA from Aḥ.

4 differences: 16), 23), 52), 85)

9 uncertain differences: 4), 27), 57), 72), 76), 77), 79), 82), 87)

6 partial differences: 14), 15), 35), 46), 48), 58)

Total 11,5 differences; percentage of corrected total $(=86) 8.1 \%$

-5- Isogloss bundle $\mathrm{nr}-5^{-}$- distinguishes 'AyA from Ḥ̂.

7 (minus $1^{*}$ ) differences: 11), 16), 33), 39), 52), 75), 83)*

10 uncertain differences: 4), 27), 57), 72), 76), 77), 79), 81), 82), 87)

5 partial differences: 14$), 15), 35), 48), 58$ )

* The difference is in raising of a ('alēh > 'ilēh), which is already covered in MAP 76 ).

Total 13,5 differences; percentage of corrected total $(=85) 10 \%$

-6- Isogloss bundle $\mathrm{nr}$-6- distinguishes ḤwA from AḥA.

11 (minus $1^{*}$ ) differences: 11), 23), 33), 35), 39), 72), 75), 76), 82), 83)*, 85)

1 uncertain difference: 27 )

1 partial difference: 46 )

* The difference is in raising of a ('alēh > 'ilēh), which is already covered in MAP 76 ).

Total 10.5 differences; percentage of corrected total $(=94) 11.1 \%$

-7- Isogloss bundle $\mathrm{nr}-7-$ distinguishes ḤwA from TAṢ.

16 (minus 1*) differences: 5), 7), 15), 16), 21), 22), 33), 39), 52), 57), 71), 75), 76), 81), 82), 83)*

o uncertain differences

1 partial difference: 25 ) 
* The difference is in raising of $a$ ('alēh > 'ilēh in 83)), which is already covered in MAP 76).

Total 15,5 differences; percentage of corrected total (= 95) $16.3 \%$

-8- Isogloss bundle $\mathrm{nr}-8$ - distinguishes TyA from AḥA.

8 differences: 21), 23), 48), 72), 76), 81), 83), 87)

2 uncertain differences: 27), 82)

2 partial differences: 46 ), 86)

Total 10 differences; percentage of corrected total (= 93) 9.7\%

-9- Isogloss bundle $\mathrm{nr}$-9- distinguishes AhA from DbA.

8 differences: 21), 23), 48), 72), 76), 81), 83), 87)

2 uncertain differences: 27), 82)

2 partial differences: 46$), 86$ )

Total 10 differences; percentage of corrected total (= 93) 9.7\%

-10- Isogloss bundle $\mathrm{nr}-10-$ distinguishes DbA from TyA.

6 differences: 21), 35), 48), 75), 82), 87)

o uncertain differences

1 partial difference: 81 )

Total 6,5 differences; percentage of corrected total $(=95) 6.8 \%$

-11- Isogloss bundle nr -11- distinguishes TAṢ from ĞrA.

9 differences: 15), 16), 22), 71), 75), 76), 81), 83), 87)

o uncertain differences

3 partial differences: 7), 26), 33)

Total 10,5 differences; percentage of corrected total (= 95) $11 \%$

-12- Isogloss bundle $\mathrm{nr}-12-$ distinguishes ĞrA from Ḥ̂.

8 differences: 5), 21), 39), 52), 57), 82), 83), 87)

0 uncertain differences

3 partial differences: 25$), 26), 33$ )

Total 9,5 differences; percentage of corrected total $(=95) 10 \%$ 
-13- Isogloss bundle $\mathrm{nr}-13^{-}$distinguishes TAS from 'LA.

37 (minus $2^{*}$ ) differences: 1), 4), 9), 10), 11), 22), 23), 26), 31), 34), 35), $\left.\left.\left.\left.\left.\left.\left.\left.36), 37), 39), 40), 42), 46), 47)^{*}, 48\right), 50\right), 54\right), 55\right), 60\right), 61\right), 62\right), 71\right), 72$ ), $73), 75), 76), 77), 79), 80), 81), 82), 83)^{*}, 87$ )

o uncertain differences

5 partial differences: 7$), 8), 14), 45), 58)$

* The difference of the different 3 rd p. sg. masc. pron. suffix in 47) and 83) is already covered in MAP 34 .

Total 37,5 differences; percentage of corrected total (= 95) 39.5\%

-14- Isogloss bundle $\mathrm{nr}-14$ - distinguishes ĞrA from 'LA.

34 (minus $2^{*}$ ) differences: 1), 4), 7), 9), 10), 11), 15), 16), 23), 31), 34), $\left.\left.\left.\left.\left.\left.\left.35), 36), 37), 39), 40), 42), 46), 47)^{*}, 48\right), 50\right), 54\right), 55\right), 60\right), 61\right), 62\right), 72$ ), 73), 77), 79), 80), 81), 82, 83)*

o uncertain differences

6 partial differences: 8), 14), 26), 33), 45), 58)

* The difference of the different 3 rd p. sg. masc. pron. suffix in 47) and 83) is already covered in MAP 34 .

Total 35 differences; percentage of corrected total (= 95) 36.8\%

-15- Isogloss bundle $\mathrm{nr}-15^{-}$distinguishes HwA from TyA.

9 differences: 11), 21), 33), 35), 39), 48), 75), 82), 87)

o uncertain differences

2 partial differences: 81), 86)

Total 10 differences; percentage of corrected total $10 \%$

-16- Isogloss bundle $\mathrm{nr}-16-$ distinguishes 'LA from HwA.

40 (minus $1^{*}$ ) differences: 1), 4), 5), 7), 8), 9), 10), 11), 15), 21), 23), 26), $\left.\left.\left.\left.\left.31), 33), 34), 35), 36), 37), 40), 42), 46), 47)^{*}, 48\right), 50,52\right), 54\right), 55\right), 57\right)$, $60), 61), 62), 72), 73), 77), 79), 80), 81), 82), 83), 87$ )

o uncertain differences

6 partial differences: 14), 16), 25), 39), 45), 58)

* The difference of the different 3 rd p. sg. masc. pron. suffix in 47) is already covered in MAP 34 .

Total 42 differences; percentage of corrected total (= 95) $44.2 \%$ 
-17- Isogloss bundle nr -17- distinguishes HwA from BdA.

11 (minus $1^{*}$ ) differences: 21), 26), 33), 39), 75), 76), 81), 82), 83)* , 85), 87)

0 uncertain differences

2 partial differences: 42 ), 78 )

* The difference is in raising of $a$ ('alēh > 'ilēh in 83)), which is already covered in MAP 76 ).

Total 11 differences; percentage of corrected total (=95) 11.6\%

-18- Isogloss bundle $\mathrm{nr}-18$ - distinguishes BdA from TyA.

8 (minus $1^{*}$ ) differences: 11), 26), 35), 48), 76), 81), 83)*, 85)

0 uncertain differences

3 partial differences: 42 ), 78), 86)

* The difference is in raising of a ('alēh > 'ilēh in 83)), which is already covered in MAP 76).

Total 8,5 differences; percentage of corrected total $(=95) 8.9 \%$

-19- Isogloss bundle $\mathrm{nr}$-19- distinguishes AhA from TAN.

10 differences: 5), 11), 21), 22), 23), 35), 48), 72), 81), 85)

1 uncertain difference: 27 )

2 partial differences: 42), 78)

Total 11 differences; percentage of corrected total (= 94) 11.7\%

-20- Isogloss bundle $\mathrm{nr}-20$ - distinguishes 'LA from BdA.

39 (minus $1^{*}$ ) differences: 1), 4), 5), 7), 8), 9), 10, 11), 15), 16), 23), 31), $\left.\left.\left.\left.\left.\left.34), 35), 36), 37), 39), 40), 46), 47)^{*}, 48\right), 50\right), 5^{2}\right), 54\right), 55\right), 57\right), 60$ ), $61), 62), 72), 73), 75), 76), 77), 79), 80), 82), 83), 85$ )

0 uncertain differences

7 partial differences: 14), 25), 42), 45), 58), 78), 81)

* The difference of the different 3 rd p. sg. masc. pron. suffix in 47) is already covered in MAP 34 .

Total 41,5 differences; percentage of corrected total $(=95) 43.7 \%$

-21- Isogloss bundle $\mathrm{nr}-21$ - distinguishes TyA from TAN.

8 (minus $1^{*}$ ) differences: 5), 11), 22), 35), 76), 81), 83)*, 87)

$o$ uncertain differences 
4 partial differences: 42), 46), 78), 86)

* The difference is in raising of $a$ ('alēh > 'ilēh in 83)), which is already covered in MAP 76).

Total 9 differences; percentage of corrected total (= 95) 9.5\%

-22- Isogloss bundle $\mathrm{nr}-22$ - distinguishes 'LA from HัmA.

6 differences: 4), 31), 47), 6o), 72), 79)

o uncertain differences

8 partial differences: 14), 18), 45), 68), 81), 83), 84), 86)

Total 10 differences; percentage of corrected total $(=95) 10.5 \%$

-23- Isogloss bundle $\mathrm{nr}-23^{-}$distinguishes 'LA from ṢwA.

11 differences: 4), 18), 20), 37), 48), 68), 71), 72), 83), 84), 85)

o uncertain differences

8 partial differences: 7), 14), 25), 50), 54), 58), 79), 81)

Total 15 differences; percentage of corrected total $(=95) 15.8 \%$

-24- Isogloss bundle $\mathrm{nr}-24-$ distinguishes BdA from ȘwA.

46 (minus $2^{*_{1} *_{2}}$ ) differences: 1), 4), 5), 7), 8), 9), 10), 11), 14), 15), 16), 18), 20), 23), 25), 31), 34), 35), 36), 37), 39), 40), 46), 47) $\left.{ }^{*}, 48\right), 50,52$ ), $\left.\left.\left.\left.\left.\left.\left.\left.\left.\left.\left.\left.54), 55), 57), 5^{8}\right), 60\right), 61\right), 62\right), 68\right), 71\right), 73\right), 75\right), 76\right), 77\right), 79\right), 80\right), 82$ ), $\left.\left.83)^{* 2}, 84\right), 85\right)$

0 uncertain differences

3 partial differences: 42$), 45), 78$ )

$*_{1}$ The difference of the different 3 rd p. sg. masc. pron. suffix in 47) is already covered in MAP 34 .

$*_{2}$ The difference is in raising of $a$ ('alēh > 'ilēh in 83)), which is already covered in MAP 76 ).

Total 45,5 differences; percentage of corrected total (= 95) 47.9\%

-25- Isogloss bundle $\mathrm{nr}-25^{-}$distinguishes 'LA from GrA.

11 differences: 4), 18), 20), 22), 48), 68), 71), 72), 83), 84), 85)

o uncertain differences

10 partial differences: 14), 25), 37), 39), 40), 46), 50), 54), 58), 81)

Total 16 differences; percentage of corrected total $16.8 \%$ 
-26- Isogloss bundle $\mathrm{nr}-26$ - distinguishes ȘwA from GrA.

1 difference: 22 )

0 uncertain differences

5 partial differences: 7), 39), 40), 46), 79)

Total 3,5 differences; percentage of corrected total $(=95) 3.7 \%$

-27- Isogloss bundle $\mathrm{nr}-27-$ distinguishes ȘwA from MzA.

25 (minus $2^{*}$ ) differences: 4), 7), 8), 11), 14), 18), 20), 22), 26), 31), 48), $\left.\left.\left.\left.\left.\left.\left.\left.\left.\left.\left.\left.\left.5^{2}\right), 57\right), 58\right), 61\right), 62\right), 68\right), 71\right), 78\right), 79\right), 80\right), 82\right), 84\right)^{*}, 85\right)^{*}, 86$ )

0 uncertain differences

8 partial differences: 16), 25), 27), 28), 29), 42), 46), 81)

* The difference here is mainly in stress, which is already covered in MAP 14.

Total 27 differences; percentage of corrected total (= 95) $28.4 \%$

-28- Isogloss bundle $\mathrm{nr}-28$ - distinguishes MzA from TAN.

35 (minus $3^{*_{1} *_{2}}$ ) differences: 1 ), 4), 9), 10), 15), 16), 22), 23), 27), 34), $\left.\left.\left.\left.\left.\left.\left.\left.35), 36), 37), 39), 40), 46), 47)^{*}, 48\right)^{*}, 50\right), 52\right), 54\right), 55\right), 60\right), 61\right), 73\right)$, 75), 76), 77), 81), 82), 83) $\left.\left.\left.)^{* 2}, 84\right), 85\right), 86\right), 87$ )

0 uncertain differences

5 partial differences: 25), 28), 29), 45), 78)

$*_{1}$ The difference of the different 3 rd p. sg. masc. pron. suffix in 47) and 48 ) is already covered in MAP 34 .

$*_{2}$ The difference is in raising of $a$ ('alēh > ilēh in 83 ), which is already covered in MAP 76 ).

Total 34,5 differences; percentage of corrected total $(=95) 36.3 \%$

-29- Isogloss bundle $\mathrm{nr}-29$ - distinguishes GrA from MzA.

24 (minus $2^{*}$ ) differences: 4$\left.\left.\left.\left.\left.\left.\left.\left.\left.), 7\right), 8\right), 11\right), 14\right), 18\right), 20\right), 26\right), 31\right), 48\right), 5^{2}$ ), $\left.57), 58), 61), 62), 68), 71), 78), 79), 80), 82), 84)^{*}, 85\right)^{*}, 86$ )

0 uncertain differences

9 partial differences: 16), 25), 27), 28), 29), 39), 40), 42), 81)

* The difference here is mainly in stress, which is already covered in MAP 14.

Total 26,5 differences; percentage of corrected total $(=95) 27.9 \%$ 
-30- Isogloss bundle $\mathrm{nr}-30-$ distinguishes GrA from ǦbA.

1 difference: 79 )

o uncertain differences

7 partial differences: 29), 31) $\left.\left.\left.\left.{ }^{*}, 39\right), 40\right), 61\right), 82\right), 85$ )

* The difference is in frequency of occurrence of the forms discussed, therefore the difference is here concluded to be partial.

Total 4,5 differences; percentage of corrected total (= 95) 4.7\%

-31- Isogloss bundle $\mathrm{nr}-3^{1-}$ distinguishes ĞbA from MzA.

21 (minus $2 *^{*} *_{3}$ ) differences: 4), 7), 8), 11), 14), 18), 20), 26), 31) $\left.{ }^{*_{1}}, 48\right)$,

$\left.\left.\left.\left.\left.\left.\left.\left.\left.\left.5^{2}\right), 57\right), 5^{8}\right), 62\right), 68\right), 71\right), 78\right), 79\right), 80\right), 84\right)^{* 3}, 86$ )

0 uncertain differences

9 partial differences: 16), 25), 27), 28), 42), 61) $\left.\left.\left.{ }^{*_{2}}, 81\right), 82\right), 85\right)^{*_{2}}$

$*_{1}$ The difference is in frequency of occurrence of the forms discussed, but the difference is greater than in bundle $-30-$, therefore the difference is here not concluded to be partial.

$*_{2}$ The difference here is partly in stress, which is already covered in MAP 14.

$*_{3}$ The difference here is mainly in stress, which is already covered in MAP 14.

Total 23.5 differences; percentage of corrected total (= 95) $24.7 \%$

-32- Isogloss bundle $\mathrm{nr}-\mathbf{3 2}^{2-}$ distinguishes BWA from GrA.

27 differences: 4), 7), 8), 11), 14), 18), 20), 22), 26), 37), 39), 40), 46), $\left.\left.\left.\left.\left.\left.\left.\left.\left.\left.\left.\left.48), 5^{2}\right), 57\right), 58\right), 61\right), 62\right), 68\right), 71\right), 78\right), 80\right), 83\right), 84\right), 85\right), 86$ )

0 uncertain differences

10 partial differences: 10), 25), 29), 31) $\left.\left.\left.\left.\left.\left.{ }^{* 1}, 42\right), 73\right), 75\right), 77\right), 79\right)^{* 2}, 81\right), 82$ )

$*_{1}$ The difference is in frequency of occurrence of the forms discussed, therefore the difference is here concluded to be partial.

$*_{2}$ The difference is only in the negated 2 nd p. sg. masc. pronominal, therefore a partial difference is concluded.

Total 32 differences; percentage of corrected total (= 95) 33.7\%

-33- Isogloss bundle $\mathrm{nr}-33^{-}$distinguishes BWA from ĞbA.

27 differences: 4$\left.\left.\left.), 7), 8), 11), 14), 18), 20), 22), 26), 31)^{*}, 37\right), 46\right), 48\right)$, $\left.\left.\left.\left.\left.\left.\left.\left.\left.\left.\left.\left.\left.5^{2}\right), 57\right), 58\right), 61\right), 62\right), 68\right), 71\right), 78\right), 80\right), 82\right), 83\right), 84\right), 85\right), 86$ ) 
o uncertain differences

12 partial differences: 10), 25), 39), 40), 42), 49), 73), 75), 77), 79), $80), 81$ )

* The difference is in frequency of occurrence of the forms discussed, the difference is here concluded to be not partial, (contrast remark * below in $-34^{-}$).

Total 33 differences; percentage of corrected total $(=95) 34.7 \%$

-34- Isogloss bundle $\mathrm{nr}-34-$ distinguishes ASA from BwA. 26 differences: 4), 7), 8), 11), 14), 18), 20), 22), 26), 37), 46), 48), 52), 57), 61), 62), 63), 71), 78), 79), 80, 82), 83), 84), 85), 86)

o uncertain differences

11 partial differences: 10), 25), 31), 39$), 40), 42), 58), 73), 75), 77), 81$ )

* The difference is in frequency of occurrence of the forms discussed, therefore the difference is here concluded to be partial.

Total 31.5 differences; percentage of corrected total $(=95) 33.2 \%$

-35- Isogloss bundle $\mathrm{nr}-35^{-}$distinguishes ASA and ĞbA.

1 difference: 22 )

o uncertain differences

7 partial differences: 31$\left.\left.\left.\left.\left.)^{*}, 46\right), 58\right), 61\right), 79\right), 82\right), 85$ )

* The difference is in frequency of occurrence of the forms discussed, therefore the difference is here concluded to be partial.

Total 4.5 differences; percentage of corrected total $(=95)$ 4.7\%

-36- Isogloss bundle $\mathrm{nr}-36$ - distinguishes ASA from HnA.

2 differences: 21$), 48$ )

0 uncertain differences

3 partial differences: 45), 58), 71)

Total 3.5 differences; percentage of corrected total $(=95) 3.7 \%$

-37- Isogloss bundle $\mathrm{nr}$-37- distinguishes ASA from MzA. 23 (minus $3^{*_{2}}$ ) differences: 4 ), 7), 8), 11), 14), 18), 20), 22), 26), 48), 52), $\left.\left.\left.\left.\left.\left.\left.\left.\left.\left.57), 61)^{* 2}, 62\right), 68\right), 71\right), 78\right), 79\right), 80\right), 82\right), 84\right)^{* 2}, 85\right)^{* 2}, 86\right)$

o uncertain differences 
10 partial differences: 16$\left.\left.\left.\left.), 25), 27), 28), 31)^{*_{1}}, 42\right), 45\right), 46\right), 58\right), 81$

$*_{1}$ The difference is in frequency of occurrence of the forms discussed, therefore the difference is here concluded to be partial.

$*_{2}$ The difference here is in stress, which is already covered in MAP 14 .

Total 25 differences; percentage of corrected total (= 95) $26.3 \%$

-38- Isogloss bundle $\mathrm{nr}-38-$ distinguishes ḤmA from ȘwA.

7 differences: 20), 47), 48), 60), 71), 81), 85)

0 uncertain differences

13 partial differences: 7), 18), 25), 31)*, 37), 50), 54), 58), 68), 79), 83), 84), 86)

* The difference is in frequency of occurrence of the forms discussed, therefore the difference is here concluded to be partial.

Total 13.5 differences; percentage of corrected total (= 95) 14.2\%

Finally, to have an idea of the typological distance between the dialects of the Mzēnah and the Baniy Wāșil, ${ }^{10}$ we compare these dialects on the basis of the same criteria:

-39- Isogloss bundle $\mathrm{nr}-39$ - is 'virtual' and distinguishes BWA from MzA.

9 differences: 37), 39), 40), 46), 79), 82), 83), 84), 85)

0 uncertain differences

9 partial differences: 10), 16), 22), 27), 28), 73), 75), 77), 81)

Total 13.5 differences; percentage of corrected total (= 95) 14.2\%

\section{b. The Step Method to Calculate Relative Typological Distances between Dialects}

The comparisons are made using a total of 95 criteria (73 in maps in De Jong 2000, criteria A, B, C, D, E, F, G, H, and I (see De Jong 2000:37-38)

${ }^{10}$ Since the Awlād Sa îd (who live more inland in the high mountains towards the east than indicated on the map, see fn 1, p. 115) are not physically located between the two dīrahs of the Mzēnah and Baniy Wāșil, the dīrahs of the latter two tribes in actual fact border on each other. 
and 13 criteria represented by maps $75^{-87}$ added in the appendix of this volume):

Score card:

Below the isogloss bundles between dialects have been ranked from low to high.

\begin{tabular}{|c|c|c|c|c|c|c|}
\hline \multirow{2}{*}{$\begin{array}{l}\text { isogloss } \\
\text { bundle } \\
\text { number } \\
-36-\end{array}$} & \multirow{2}{*}{$\begin{array}{c}\text { between } \\
\text { dialects }\end{array}$} & \multirow{2}{*}{$\begin{array}{r}\text { of groups } \\
\text { VII-VII }\end{array}$} & \multirow{2}{*}{$\begin{array}{c}\begin{array}{c}\text { number of } \\
\text { isoglosses } \\
\text { of total incl } \\
\text { uncertain }\end{array} \\
3.5\end{array}$} & \multicolumn{2}{|c|}{$\begin{array}{l}\text { subtract from } 95 \text { for } \\
\text { uncertain }\end{array}$} & \multirow{2}{*}{$\begin{array}{c}\text { percentage } \\
\text { of corrected } \\
\text { total }\end{array}$} \\
\hline & & & & & $(3.5 / 95)$ & \\
\hline$-26-$ & (ȘwA-GrA) & VII-VII & $3 \cdot 5$ & & $(3.5 / 95)$ & $3 \cdot 7 \%$ \\
\hline$-35^{-}$ & (ASA-ǦbA) & VII-VII & 4.5 & & $(4.5 / 95)$ & $4.7 \%$ \\
\hline$-30-$ & (GrA-ǦbA) & VII-VII & $4 \cdot 5$ & & $(4.5 / 95)$ & $4 \cdot 7 \%$ \\
\hline$-2-$ & (MlA-nTA) & I-I & 10 & 11 & $(4.5 / 84)$ & $5 \cdot 4 \%$ \\
\hline$-10-$ & (DbA-TyA) & I-I & 6.5 & & $(6.5 / 95)$ & $6.8 \%$ \\
\hline$-1-$ & (SA-MlA) & I-I & 10 & 7 & $(6.5 / 88)$ & $7 \cdot 4 \%$ \\
\hline$-4-$ & ('AyA-AhA) & I-I & 11.5 & 9 & $(7 / 86)$ & $8.1 \%$ \\
\hline$-3-$ & (nTA-TyA) & I-I & 13.5 & 9 & $(8 / 86)$ & $8.1 \%$ \\
\hline$-18-$ & (BdA-TyA) & I-I & 8.5 & & $(8.5 / 95)$ & $8.9 \%$ \\
\hline$-21-$ & (TyA-TAN) & I-I & 9 & & $(9 / 95)$ & $9 \cdot 5 \%$ \\
\hline$-8-$ & (TyA-AhA) & I-I & 10 & 2 & $(9 / 93)$ & $9 \cdot 7 \%$ \\
\hline$-9-$ & $(\mathrm{A} h \mathrm{~A}-\mathrm{DbA})$ & I-I & 10 & 3 & $(9 / 93)$ & $9 \cdot 7 \%$ \\
\hline$-5^{-}$ & ('AyA-HwA) & I-I & $13 \cdot 5$ & 10 & $(8.5 / 85)$ & $10 \%$ \\
\hline$-12-$ & (ǦrA-HwA) & $\mathrm{I}-\mathrm{I}$ & $9 \cdot 5$ & & $(9.5 / 95)$ & $10 \%$ \\
\hline$-22-$ & ('LA-HmA) & VIII-VII & 10 & & $(10 / 95)$ & $10.5 \%$ \\
\hline$-15^{-}$ & (HwA-TyA) & I-I & 10 & & $(10 / 95)$ & $10.5 \%$ \\
\hline$-11-$ & (TAȘ-ǦrA) & I-I & 10.5 & & $(10.5 / 95)$ & $11 \%$ \\
\hline$-6-$ & (HwA-Aḥ) & I-I & 10.5 & 1 & $(10.5 / 94)$ & $11.1 \%$ \\
\hline$-17-$ & (HwA-BdA) & I-I & 11 & & $(11 / 95)$ & $11.6 \%$ \\
\hline$-19-$ & $(\mathrm{AhA}-\mathrm{TAN})$ & $\mathrm{I}-\mathrm{I}$ & 11 & 1 & $(11 / 94)$ & $11.7 \%$ \\
\hline$-39^{-*}$ & (BWA-MzA) & VI-VI & $13 \cdot 5$ & & $(13.5 / 95)$ & $14.2 \%$ \\
\hline$-3^{8-}$ & (HmA-ȘwA) & VII-VII & $13 \cdot 5$ & & $(13.5 / 95)$ & $14.2 \%$ \\
\hline$-23^{-}$ & ('LA-ȘwA) & VIII-VII & 15 & & $(15 / 95)$ & $15.8 \%$ \\
\hline$-7-$ & (HwA-TAȘ) & I-I & $15 \cdot 5$ & & $(15 \cdot 5 / 95)$ & $16.3 \%$ \\
\hline$-25^{-}$ & ('LA-GrA) & VIII-VII & 16 & & $(16 / 95)$ & $16.8 \%$ \\
\hline$-31-$ & (ǦbA-MzA) & VII-VI & 23.5 & & $(23.5 / 95)$ & $24.7 \%$ \\
\hline$-37^{-}$ & (MzA-ASA) & VI-VII & 25 & & $(25 / 95)$ & $26.3 \%$ \\
\hline$-29-$ & $(\mathrm{GrA}-\mathrm{MzA})$ & VII-VI & 26.5 & & $(26.5 / 95)$ & $27.9 \%$ \\
\hline$-27-$ & (ṢwA-MzA) & VII-VI & 27 & & $(27 / 95)$ & $28.4 \%$ \\
\hline
\end{tabular}


Table (cont.)

\begin{tabular}{|c|c|c|c|c|c|}
\hline $\begin{array}{l}\text { isogloss } \\
\text { bundle } \\
\text { number }\end{array}$ & $\begin{array}{c}\text { between } \\
\text { dialects }\end{array}$ & of groups & $\begin{array}{c}\text { number of } \\
\text { isoglosses } \\
\text { of total incl } \\
\text { uncertain }\end{array}$ & $\begin{array}{l}\text { subtract from } 95 \text { for } \\
\text { uncertain }\end{array}$ & $\begin{array}{l}\text { percentage } \\
\text { of corrected } \\
\text { total }\end{array}$ \\
\hline$-34-$ & (ASA-BWA) & VII-VI & 31.5 & $(31.5 / 95)$ & $33.2 \%$ \\
\hline$-32-$ & (BWA-GrA) & VI-VII & 32 & $(32 / 95)$ & $33 \cdot 7 \%$ \\
\hline$-33^{-}$ & (BWA-ǦbA) & VI-VII & 33 & $(32 / 95)$ & $34.7 \%$ \\
\hline$-28-$ & (MzA-TAN) & VI-I & 34.5 & $(34.5 / 95)$ & $36.3 \%$ \\
\hline$-14-$ & (ĞrA-'LA) & I-VIII & 35 & $(35 / 95)$ & $36.8 \%$ \\
\hline$-13^{-}$ & (TAȘ-LA) & I-VIII & 37.5 & $(37.5 / 95)$ & $39.5 \%$ \\
\hline$-20-$ & ('LA-BdA) & VIII-I & 41.5 & $(41.5 / 95)$ & $43.7 \%$ \\
\hline$-16-$ & ('LA-HwA) & VIII-I & 42 & $(42 / 95)$ & $44.2 \%$ \\
\hline$-24-$ & (BdA-Ṣw) & I-VII & 45.5 & $(45 \cdot 5 / 95)$ & $47.9 \%$ \\
\hline
\end{tabular}

* isogloss bundle -39- is 'virtual' in the map (but 'real' on the ground), see remarks above and in fn 1, p. 115 .

Our figured calculations using the step method show a few results that do not appear to be in concord with earlier results in De Jong 2000: the subdivision into groups is not as clear-cut here in terms of percentages as it was in De Jong 2000. The reason appears to be that in De Jong 2000 we were looking at dialects that form a geographical continuum, which makes the comparison between the groups largely uni-directional (i.e. east-west or west-east, depending on preference).

Our dialects in the centre and south of Sinai do not form a comparable continuum, which makes the comparison between more than two groups (I, VI, VII and VIII) multi-directional. Such a garbled picture is also the result of a comparison between dialects of tribes that-even within certain identified groups-have arrived at different times and have over these different periods of time influenced each other to a lesser or greater degree. In addition, the comparison is between dialects of tribes, who can vary greatly with regard to numbers of members.

To give an example: the tribe Hamāḍah is considerably smaller (in terms of numbers of members) than the neighbouring tribes of 'Lēgāt and Șawālhah. ḤmA still shows a number of features which are reminiscent of the group I-type, and presumably this dialect type is much nearer to the original HmA-type than the group to which it has now been assigned (i.e. group VII). 
The reason to assign $\mathrm{HmA}$ to group VII is that $\mathrm{HmA}$ can be concluded to be developing into the direction of this group; 'originally' group I features are being replaced by group VII features, as is to be concluded from the variation that occurs. For this reason, HmA and 'LA have been assigned to different groups, even though the MDS plots and the step method both show relative typological proximity. The choice to isolate 'LA as a group by itself is thus partly subjectively inspired, and it is not being fully illustrated by the quantifying methods applied here. The only exception is the dendrogram (see p. 375 in the appendix), where 'LA is clearly branched separately, although inside group VI, for instance, the two dialects assigned to the same group (MzA and BWA) branch at exactly the same height. The subjective argument for the decision to nevertheless assign 'LA to a separate group is in the type of characteristics that distinguish 'LA from HmA (see next paragraph). In any case, $\mathrm{HmA}$ is not a proto-typical representative of group VII."

\section{c. A Continuum: From Group VII Through Group VIII Towards Group I}

One may conclude a continuum (albeit on a much smaller scale than the situation on the northern littoral), which is best illustrated in the Alscal (Euclidean Binary, see p. 374) MDS plot: from the typically southern dialect type of group VII ( $\mathrm{HmA}$ is here excluded from VII for not being prototypical, see remark in the preceding paragraph), the continuum moves through HmA, via 'LA to group I, for although there is always the question of relative 'typological weight', some differences in features set as criteria in a comparison tend to be more illustrative than differences found in other features, especially when seen in combination with features present in other groups. One could say that in this sense, although 'LA and HmA show relatively few differences, in cases where they do, 'LA tends to 'lean towards' group I, while HimA tends to 'lean towards' group VII.

To give an example: in 2.1.1.2.1. some imperative forms present in TwA and 'LA are cited. We see here that 'LA leans towards group I with its imperative forms kul, gūl, gūm, šul and nām (without a stressed initial vowel), whereas ȚwA dialects generally do show such vowels, e.g. (TwA) úkul "eat!", úgum "stand up!", išil "carry!" and ánam "go to sleep!".

${ }^{11}$ To cite a parallel with biology: if we were to discuss 'birds' in general, we would probably choose to be talking about proto-typical examples like a sparrow, a robin or a canary, rather than an ostridge or a penguin, see Aitchison 1987:51-62. 
Another example is the difference between velarization in the pl. forms of kibir and kitīir (kbār and ktǟr in 'LA), but lack of velarization in both forms in TwA ( $k b \overline{\ddot{a} r}$ and $k \underline{\underline{a}} \overline{\ddot{r}}$ ), and 'LA thus takes up an intermediate position between groups VII and I (the latter having $k b \bar{a} r$ and $k \underline{t} \bar{a} r$ ).

Another illustration of 'LA occupying such an intermediate position between groups VII and I is placement of stress in CvCvC (see 3.2.2.4.1. and 3.2.2.4.2.). Group I dialects surrounding ' $\mathrm{LA}$ all have CaCáC or CiCíC, while group VII will stress CáCaC and CíCiC, but in 'LA both possibilities exist as parallel options. This shows that the situation in HmA is in these respects more in conformity with the situation in (other) group VII dialects, than it is with the situation in 'LA, or even group I for that matter. The situation in 'LA would then be an indication of influences from surrounding group I dialects, if it is not an original feature of 'LA itself.

There is also the example of a stressable article in the sequence alCa$\mathrm{CaC}$ (see 2.1.1.): in 'LA, like in group $\mathrm{I}$, álCaCaC is the rule, whereas in group VII (excluding HmA) ilCáCaC is regular. HmA takes up an intermediate position here, allowing both possibilities as parallel options.

If we combine stressability of the vowel of the article with stress in the perfect on the initial vowel of the $n-1$ and $1-t$ measures of verbs (see 1.2.3.4.3.2., 3.2.3.1.1. and 3.2.3.3.1.), we see that group I will stress both (e.g. álbaṣal and ánwakal), group VII will stress neither (in group VII ilbáșal and inwákal), while 'LA will stress the article, but not the initial vowel in preformatives of the perfect of $n$-1 or 1-t measures (álbașal, but inwákal and ittáfag).

In the negation of verb forms (see 4.2.), we see that 'LA uses the single $m \bar{a}+$ verb form, which is like the situation in group I. TwA dialects other than HmA will use compound $m \bar{a} / m a+$ verb form $+-s(i)$. HmA in this case takes up the intermediate position allowing both possibilities as parallel options (without any apparent differences in meaning, such as is the case in some dialects where the single negation with $m \bar{a}$ is used when extra emphasis is intended).

Finally, both 'LA and HmA take up an intermediate position between groups VII and I in the allomorphs of the 2nd p. sg. fem. pronominal suffix (see 3.1.12.2.); where group I has invariable -kiy and group VII has $\overline{\mathrm{v}}-k$, vC- $k$ or CC-ik, both 'LA and HmA have $-i k$ when not directly preceded by $\overline{\mathrm{V}}$, but -kiy when $\overline{\mathrm{v}}$ directly precedes (i.e. a situation comparable to the allomorphs current in Cairene Arabic, where we have similarly conditioned appearance of allomorphs $-i k$ and $-k i) .^{12}$

\footnotetext{
${ }^{12}$ Cf. Woidich 2006:40.
} 
Although both 'LA and HmA seem to take up an intermediate position between group VII and group I, I have chosen to group 'LA separately as group VIII, because the 2-dimensional MDS plots clearly position it between groups VII and I, while HmA is plotted considerably nearer to other group VII dialects, and is thus concluded to be more part of group VII than of group VIII. The dendrogram in the appendix illustrates the same.

In a similar manner the dialect of Baniy Wāșil has been developing from a presumed 'originally" group I-type towards the dialect-type of the Mzēnah. The assumption of BwA originally being a group I type of dialect appears to be supported by BWA's position on the Alscal Euclidean Binary MDS plot (see p. 374); of all dialects of groups VI, VII and VIII (spoken in the south of Sinai) BWA is located nearest to group I.

If we compare the results of the step method with the multi-dimensional scaling (MDS-) plots produced by Proxscal and Alscal in SPSS we see that these MDS plots provide a better overall picture of the total area.

\section{d. Multi-Dimensional Scaling}

In some cases 'virtual isoglosses' were introduced in the 'step method' to show relative typological distance between dialects that do not geographically directly border on each other-or only seemingly so, as is the case with MzA and BWA.

Since the Proxscal and Alscal programmes (a matrix in the SPSS used for the MDS method) compare all dialects on the basis of the same criteria, all such relative typological distances-also of dialects that do not border on each other and may geographically even be far removed from each other-will receive a graphic representation in the MDS plot generated (see figure 3 in the appendix for the colour version of this plot).

The advantage of this MDS approach over the step method is that relative proximity/distance of every dialect in relation to every other dialect in a larger geographical area is calculated, which is then represented in a plot. Especially in societies with collectives of individuals who are, or were until recently, inherently spatially dynamic (such as a society with (semi-) nomadic tribes), relative typological proximity of dialects that do not geographically directly border on each other is potentially more

\footnotetext{
${ }^{13}$ As I was told by several speakers of surrounding dialects. This is also supported by features (which are also present as parallel to other features in the dialect) still present in BWA. For features that BWA (but not MzA) has in common with group I, see the list in Conclusions, III. g. below. See also remark in fn 5, p. 117 in this volume.
} 
revealing than the same method being applied in inherently spatially static societies (such as is often the case with centuries old villages/towns, rural communities etc. in a more typically non-nomadic context, like for instance in Europe).

In nomadic societies-much more so than in a European contextsocial collectives like (even if they are only semi-nomadic) tribes travel around, and since much of dialect change originates from contact with speakers of other dialects, influences of dialects of speakers, that today geographically border on these collectives, may have been effective and thus mask an older version of the dialect of that same collective. However, proper interpretation of existing variation may provide insight into earlier stages of such a dialect, at least during the stages in which variation exists, and even after focussing has resulted in the disappearence of parallel forms, interdialect forms may provide such clues. ${ }^{14}$

An example to cite here is the parallel existence of ${ }^{u} k$ and $-a k$ pronominal suffixes for the 2nd p. sg. masc. in the dialect of older speakers of group II in the north. ${ }^{15}$ If we can take the older speaker's word for it—and

Object Points

Common Space

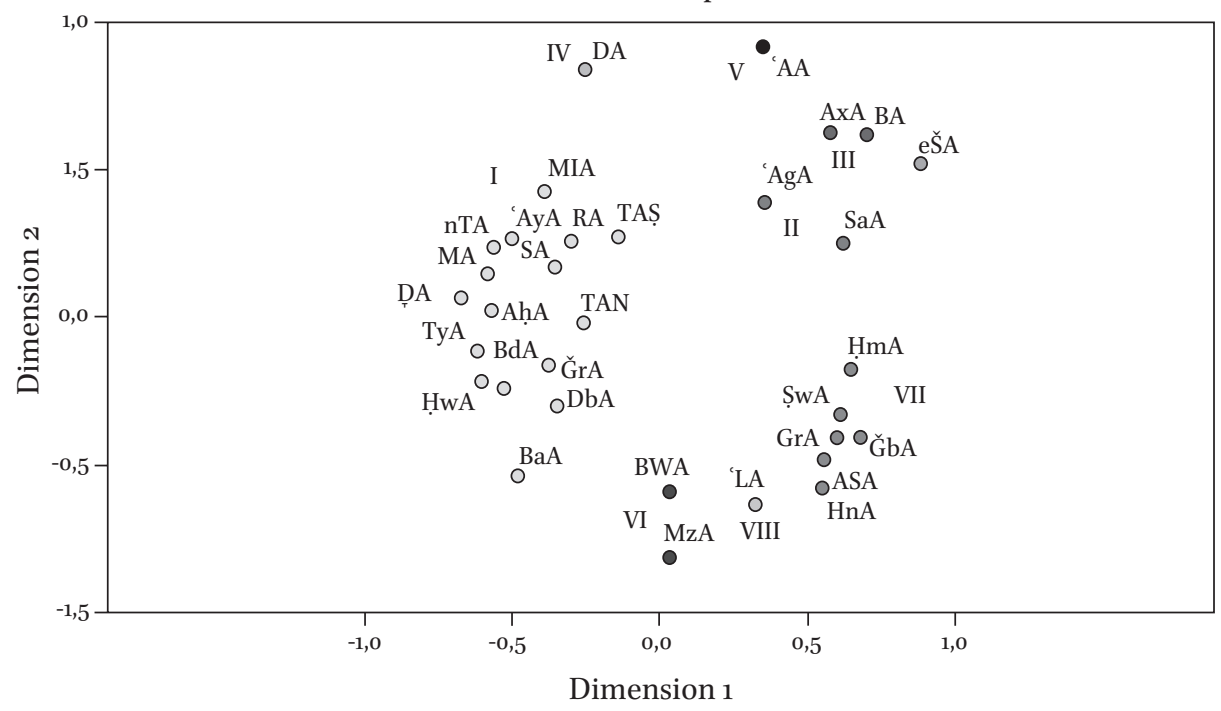

Proxscal-Euclidian Binary MDS plot of dialects of Sinai

${ }^{14}$ See Trudgill 1983:chapter 5 and also Woidich 1997.

${ }^{15}$ See De Jong 2000:288. 
I saw no reason to doubt him-the Samānnah lived in the area of aț-Tūr until the turn of the 19th-2oth century. Since dialects there all have $-{ }^{u} k$, a logical assumption would be that SaA too had ${ }^{u} k$ at the time they moved to the Gatyah oasis in the north. There they came into contact with speakers of Axrasiy (AxA) and Biyyādiy (BA), which resulted in the -ak suffix being introduced to speakers of $S a A .{ }^{16}$ The velarization present in the form $-{ }^{u} k$ was then transferred onto the $k$ of the $-a k$ suffix, resulting in the 'interdialect' form $-a k$. When both ${ }^{~}{ }^{k} k$ and were $-a k$ were used as parallel forms, "focussing" took place which produced -ak as the preferred form, while $-{ }^{-} k$ is (was?) only being used by older men ${ }^{17}$ and may thus be expected to eventually result in the disappearance of the latter form.

\section{e. 'Bedouinness'vs 'Sedentariness'}

In De Jong 2000:37-47 a total of 41 features are listed as criteria to establish relative 'bedouinness' or 'sedentariness' of dialects. These features are marked as 'B-S criteria' (these are also marked as such in the list in 'Conclusions II. a. Criteria for comparison from De Jong 2000 producing differences/similarities in central and southern Sinai' above). These B-S criteria are listed here with comments on the score of the three typological groups (VI, VII and VIII) discussed in the volume in hand (the numbering used is in reference to the list in De Jong 200o) (For B-S features used as criteria for comparison numbered from A) to L), see "II.a. Criteria for comparison from De Jong 2000 producing differences/similarities in central and southern Sinai" above):

2. All four groups (I, VI, VII and VIII) show interdental reflexes $\underline{t}$ for ${ }^{*} \underline{t}$ and $\underline{d}$ for * $\underline{d}$.

All dialects in central and southern Sinai score 1.

3. All four groups (I, VI, VII and VIII) show emphatic interdental $\underset{d}{d}$ for merged ${ }^{*} \underset{\sim}{d}$ and ${ }^{*} \underset{\text { en }}{ }$.

All dialects in central and southern Sinai score 1.

4. Secondary velarization: group I dialects in the centre (like in other group I dialects) show velarization in both $k b \bar{a} r$ and $k t a \bar{a} r$, groups VI and VIII only have velarization in $k b \bar{a} r$, but not in $k \underline{\underline{a}} \bar{a} r$, and group VII lacks velarization in both forms: $k b \bar{a} r$ and $k \underline{t} \ddot{a} r$.

\footnotetext{
${ }^{16}$ In some schools in the Gatyah oasis children from different tribes mix.

${ }^{17}$ And perhaps also by women, but there are no recordings of women speakers of this tribe to verify this.
} 
Score group I: 1; group VI: 0.5; group VII: 0 ; and group VIII: 0.5 .

6. All dialects have a tendency to retain length of long vowels in unstressed positions.

All dialects in central and southern Sinai score 1.

7. In all groups $a$ in open syllable preceding A (stressed $a$ or $\bar{a}$ ) is raised.

All dialects in central and southern Sinai score 1.

9. In group I dialects extreme raising of final * $-\bar{a}\left({ }^{\prime}\right)$ in neutral surroundings is current. In groups VI, VII and VIII final ${ }^{*}-\bar{a}$ is raised in a similar manner, but final $-\vec{a}$ tends to be reflected as $-i$.

Group I scores 1, groups VI, VII and VIII score 0.5 .

17. None of the dialects in the centre and south of Sinai show resyllabication of $\mathrm{CaCaCv}$ sequences.

All dialects in central and southern Sinai score 0.

18. In groups I and VI the definite article and preformatives of verbal measures $n-1$ and 1-t are stressable units (e.g. álwalad, ándarab, áttafag). In group VII the article is not stressed (e.g. ilwálad), although in HmA both stress-types are used (e.g. álwalad ilwálad). In group VIII the article is also a stressable unit (e.g. álwalad).

Preformatives of the perfect forms of measures $n-1$ and 1- $t$ are not stressed in groups VII and VIII (e.g. inḍárab, ittáfag).

Group I scores 1; group VI scores 1; group VII scores o (but HmA scores 0.25); group VIII scores 0.5 .

19. All dialects have an active gahawah-syndrome.

All dialects in central and southern Sinai score $\mathbf{1 .}$

20. Presence of initial CC in a limited number of morphological patterns:

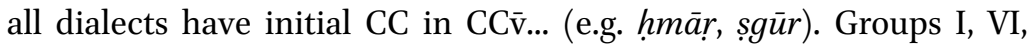
VIII and also ḦmA and (part of) ĞbA of group VII have initial CC in CCv ... (e.g. 'nab "grapes", grab "watersacks"). Other group VII dialects have however morphologically resolved the initial cluster in this pattern with an initial vowel (e.g. ánab, ágrab).

Groups I, VI, VIII and H.mA and ĞbA of VII score 1. Other dialects of group VII score 0.5 .

25. The initial vowel in the definite article and the relative pronoun: $a$ in group I (al- and alliy). In group VI and HmA of group VII $a l-\sim i l-$ and illiy. In group VII il- and illiy. In group VIII il- $\sim$ al- and alliy.

Group I scores 1. Group VI and HmA score 0.5, Group VII scores 0. Group VIII scores 0.5 .

30. All dialects have gender distinction in the 2 nd and 3 rd p. pl. of personal pronouns, adjectives and verbs. 
All dialects in central and southern Sinai score 1.

34. Shape of the personal pronominal suffix for the third p. sg. masc.: $-a h$ or -ih in group I. Groups VI, VII and VIII all have $-u(h)$.

Group I scores 1. Groups VI, VII and VIII score 0.

39. Emphatization of $\underline{d}$ in demonstratives $h \bar{a} \underline{d}+$, if not followed by $i$. Group I has $h \bar{a} \underline{d} a \sim h \bar{a} \underline{d} a$ (with the exception of HwA, where only $h \bar{a} \underline{d} a$ was heard). In groups VI, VII and VIII such velarization of $\underline{d}$ in this position is absent.

Group I scores 1. HwA, groups VI, VII and VIII score 0.

41. Gender distinction in pl. demonstratives: dialects in central and southern Sinai use pl. com. forms for pl. masc. and fem. (in MzA a pl. form used for the fem. was recorded, but the com. form was more current). All dialects in central and southern Sinai score o, except MzA, which scores 0.5 .

42. All dialects of group I have a short vowel in the interrogative min "who?". Groups VI, VII and VIII have a long vowel in min.

Group I scores 1. Other dialects in central and southern Sinai score o.

43. Initial consonant in the interrogative for "where?": all dialects of central and southern Sinai have initial $w$ in $w \bar{e} n$.

All dialects in central and southern Sinai score 1.

44. Interrogative for "how": all dialects have kêf or kîf. All dialects in central and southern Sinai score 1.

45. Adverb for "there": group I has hnuh. Group VI has hnuh hnōtiy or hnütiy, groups VII and VIII have hnōtiy or hnütiy. In all dialects the occasional K-form hnāk can be heard.

All dialects in central and southern Sinai score $1 .^{18}$

46. Adverb for "here": group I and BWA have hniy (or hniyyih, and in the central eastern Sinai hniyyān(iy)), groups VII and VIII and MzA have niha $\left({ }^{\prime}\right) \sim$ nihāniy. In all dialects the K-form hina (often in its adapted shape as hinih or hiniy).

All dialects in central and southern Sinai score $1 .^{19}$

47. Preposition $l+$ vowel-initial suffix: group I has lah or lih. Groups VI, VII and VIII have luh.

All dialects in central and southern Sinai score 1 (see remarks on the suffixes -uh or -ah / -ih below).

\footnotetext{
${ }^{18}$ Since the true 'sedentary' form (i.e. a form used in the Nile Delta and Cairo) is $h(i) n \bar{a} k$, I regard hnōtiy or hnütiy as 'Bedouin' in this context.

${ }_{19}$ Since the true 'sedentary' form (i.e. a form used in the Nile Delta and Cairo) is hína, I regard nihä(') or nihāniy as 'Bedouin' in this context.
} 
53. Vowel harmony in the imperfect prefix of verbal measure 1: yašrab, yiktib, yug'ud. All dialects in central and southern Sinai show such harmonized vowels.

All dialects in central and southern Sinai score 1.

56. Imperfect of primae $w \bar{a} w$ verbs: none of the Bedouin dialects of central and southern Sinai have a morphologically patterned diphthong $i w$. Forms are more typically yawșal or yōṣal "he arrives", and sometimes the $w \bar{a} w$ is dropped from the stem, like in talid "she gives birth".

All dialects in central and southern Sinai score 1.

65. Use of measure 4 verbs: all dialects use measure 4 verbs relatively frequently.

All dialects in central and southern Sinai score 1.

66. Typical "Bedouin" verb-type with inserted wāw, e.g. sōlaf, ysōlif "tell". In all dialects of central and southern Sinai this verb-type is current. All dialects in central and southern Sinai score 1.

67. The sg. fem. active participle + object suffix: in all dialects of central and southern Sinai a construct state is current.

All dialects in central and southern Sinai score 1.

68. Shape of the verbal negation: $m \bar{a}+$ verb or $m a+\operatorname{verb}+\check{s}(i)$. Group I, 'LA (group VIII) and BWA (of group VI) use the singular negation ( $m \bar{a}$ + verb form) almost exclusively. MzA (of group VI) uses both types of negation, and in group VII the compound negation is current $(m a+$ verb $+-\check{s})$.

Groups I, VIII ('LA) and BWA (of group VI) score 1. MzA (of group VI) scores 0.5 . Group VII scores 0.

69. The $b$-imperfect: in all dialects of central and southern Sinai the $b$-imperfect is current.

All dialects in central and southern Sinai score 0.

71. Use of $y \bar{o} m($ in $)$ or $\operatorname{lōm}$ (in) for "when". In all dialects yōm(in) or $\operatorname{lom}$ (in) is current.

All dialects in central and southern Sinai score 1.

73. Use of widd or bidd to express "want; need": group I uses widd. BWA (of group VI) and HmA (of group VII) use both. The other dialects of group VII, group VIII and MzA (of group VI) use bidd.

Group I scores 1. BWA (of group VI) and HimA (of group VII) score $\mathbf{0 . 5}$. MzA, dialects of group VII (except H.MA) and group VIII ('LA) score o.

When we count the 'Bedouin' features of dialects of the 30 listed here by adding up the 'scores' in the list above, we see the following in the totals: 
Group I scores highest ${ }^{20}$ with almost all dialects having 27 features as 'Bedouin'. Dialects of group VII score 18.5, except the dialect of the Hamāḍah, which scores 19.75 'Bedouin' features. The dialect of the 'Lēgāt (group VIII) scores 21 'Bedouin' features.

Although the dialects of groups VI, VII and VIII score less on Bedouin features (for the Negev dialect) than the group I dialects, if we compare the scores of VI, VII and VIII to scores of the dialects of the Biyyādiyyah and Axārsah in the north, we see that the dialects of groups VI, VII and VIII in the south still score considerably higher on Bedouin features than BA (scoring 8) and AxA (scoring 9). ${ }^{21}$

In reference to criteria listed above in 'Conclusions II. a. Criteria for comparison from De Jong 2000 producing differences/similarities in central and southern Sinai', the following remarks must be taken into account:

There may be reasons that certain typological differences between dialects in the central and southern area of Sinai are indeed also to be interpreted as forming part of a greater 'development' of dialects away from the Bedouin type towards a more sedentary type, but in this central and southern area of Sinai a direct and explicit geographical dimension-like the east-west dimension reflecting the 'Bedouin-less Bedouin' dimension in the north of Sinai ${ }^{22}$-is lacking. If certain differences are to be attributed at all to dialect contact of 'Bedouin' dialects with the more sedentary type, we would need to know more first of all about the dialects of related (sub-) groups of tribes in other areas such as the related tribal collectives (in many cases with identical names) in present-day Saudi Arabia or Jordan.

Secondly, we would need more historical data on the movement of tribes, or smaller collectives such as families, should we wish to measure with some acceptable accuracy the as yet unquantified influence on Bedouin dialects of speakers of sedentary dialects. To give an example: one

${ }^{20}$ This is not surprising, since the list was compiled to specifically illustrate the relative 'Bedouinness' of dialects in the north of Sinai as compared to the dialect of the Dullām in the Negev, which all belong to the same group I.

${ }^{21}$ BA and AxA are cited here as the clearest examples inside Sinai of Bedouin dialects which have acquired sedentary features through influence of dialect contact with sedentary dialects of the Nile Delta, see De Jong 2000:622-627. The numbers 7 and 8 cited here are the result of a count not made in De Jong 2000, but made here for the purpose of comparing groups VI, VII and VIII to group III in the north. Data on BA and AxA are in De Jong 2000:Chapter III.

${ }^{22}$ See remarks on this east-west dimension in the north of Sinai in De Jong 2000:622-627. 
could assume the personal pronominal suffix of the 3 rd p. sg. masc. $-a h$ or -ih to be representative of the 'Bedouin' type, and thus conclude the -uh suffix (like that recorded in the dialect of the Mzēnah of Sinai) to be more 'sedentary' (because it is identical with the $-u$ pronominal suffix found in the Nile Delta), but at the same time we do know that in many Bedouin dialects of the Arabian Peninsula - where influence of sedentary dialects, in any case of those spoken in the Nile Delta or Cairo, is highly unlikely-the suffix $-u(h)$ is current. ${ }^{23}$ In other words, if we do not know the 'original' form in dialects of related tribal collectives (like the Mzēnah in Saudi Arabia), a conclusion of sedentary influences being responsible for a change $-a h>-u h$ would be premature; ${ }^{24}$ dialects of groups VII and VIII could have come from the Egyptian mainland with the pron. suffix $-u(h)$ already in place, but they may also have settled in Sinai while (still) using $-a h$ or $-i h$, while only at a later stage copying the -uh suffix from the Mzēnah. On the other hand, a development mirroring this hypothetical development could have also taken place, i.e. the Mzēnah may have arrived in Sinai as $-a h \sim-i h$ speakers, and only later copied the $-u(h)$ from the other southern tribes.

Another example of a more typically 'sedentary' characteristic would be the absence of initial consonant clusters, ${ }^{25}$ such as in examples in TwwA (except part of ĞbA) išti "winter; rain”, ágrab "watersacks" (which in group I are more typically štiy and grab, see paragraphs 2.3 .5 . in the descriptive chapters). Although such stressed 'original' anaptyctics may

\footnotetext{
${ }^{23}$ It is not possible to decide here which form is more 'Bedouin' than the other. See, for instance, Prochazka 1988:126, where -u(h), -ah and -ih (and also other forms) are listed as occurring in the various dialects of Saudi Arabia.

${ }^{24}$ A suggestion once made to me that the speech of Egyptians among the Ğbāliyyah who were sent in the sixth century by emperor Justinian I to serve and protect St. Catherine's Monastery together with the Wallachians would have had a 'sedentary' influence on the speech of tribes in Sinai at that time must be dismissed as an anachronism; having been sent to Sinai before islam, it is highly unlikely that these Delta Egyptians came there as speakers of Arabic, let alone the Wallachians.

${ }^{25}$ See De Jong 2000:41 (criterion 20: presence of initial CCV in limited morphological patterns). To decide whether initial clusters are tolerated in patterns like CCūC or CCāC, one can add the definite article to such patterns in which the first $\mathrm{C}$ is a 'sunletter'. If assimilation takes place, as in e.g. $a l+s g \bar{u} r>a s s g$ ür "the falcons" and $a l+\operatorname{tra} \bar{b} b>a t t r \bar{a} b$ "the dust", one may conclude that initial CC in such morphophonemic patterns is tolerated.

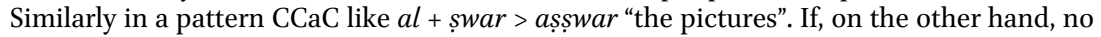
assimilation takes place, but an anaptyctic vowel separates the article and the first $\mathrm{C}$, like in e.g. (i) lisgū $r$, (i) litrāa b and (i) lișwar, we have to conclude morphophonemic base patterns $|\mathrm{iCCu} C|,|\mathrm{iCC} \overline{\mathrm{C}}|$ and $|\mathrm{iCCaC}|$. In the latter pattern the preceding (originally anaptyctic) $i$ is then usually stressed on the vowel of the newly available heavy sequence, as in ișwar, or with harmonized vowel áșwar "pictures".
} 
have been the result of dialect contact with sedentary dialects, in the case of Tuwara dialects it is very well possible that the development of incorporating anaptyctic vowels into the morphophonemic base (whereby they became stressable) is one that took place independently, if not altogether imported from other dialects from the Arabian Peninsula with which the tribes arrived in Sinai. In any case, in view of the lack of availability of historical data, we cannot definitively draw the conclusion that this feature is due to dialect contact with 'sedentary' dialects. ${ }^{26}$

One clear indication that the influence of sedentary dialects has been weaker at least than in the north, is the fact that dialects in central and southern Sinai without exception (still) have the full set of interdentals $(\underline{t}, \underline{d}$ and $\underline{d})$ in their phoneme inventories. We have seen that in the north the dialect of the Biyyādiyyah has lost 'neutral' interdentals $\underline{t}, \underline{d}$, and that the dialect of the Axārsah (both of group III) is in a process of losing $\underline{t}$ and $\underline{d}$, both dialects replacing these interdentals with stops $t$ and $d \cdot{ }^{27}$ Such a development has not taken place in central and southern Sinai, and this fact is one of the most telling ones illustrating that dialect contact of sedentary dialects with Bedouin dialects of groups VI, VII and VIII must have been less intense than the dialect contact between sedentary dialects and the dialects of group III in the north, of which many sedentary features are attributable to contact with Delta dialects such as that spoken in the eastern Šarqiyya.

On the other hand, since G.W. Murray 1935 reports that the 'Lēgāt and Șawālhah lived in the Šarqiyyah before they moved to Sinai almost seven centuries ago (see quote in Introduction, I. d., remark ${ }^{{ }^{*}}$ ), there is a chance that these tribes introduced sedentary features into the area, which were later through dialect contact copied into the dialects of other tribes already present in the area, or who arrived at a later time. Conversely, in this scenario, and with reference to a certain number of Bedouin features now present in the dialects of the Șawālḥah and 'Lēgāt, one could perhaps speak of re-bedouinization of these dialects; Bedouin features would then have been (re-)introduced into ȘWA and 'LA as a result of contact with speakers of Bedouin dialects. This hypothesis can however only be

\footnotetext{
${ }^{26}$ One could perhaps imagine 'sedentary' influence from speakers (of various dialects) of (mainland) Egyptian dialects in the town of at-Ṭūr, but then still we would need more data on the intensity of contact between these townspeople and Bedouin tribes in the area, and also on the dialect-type(s) spoken in aț-Țür if we want to arrive at some form of an acceptable conclusion.

${ }^{27}$ See also remarks in De Jong 200o:621-625.
} 
corroborated if we could somehow definitively establish the shape of an earlier type of eastern Šarqāwiy, which is not possible at this stage. We simply do not know the characteristics of the dialect-type (or even different types) - the degree of 'Bedouinness' or 'sedentariness' — spoken in this eastern Delta region in the fourteenth century.

What makes this scenario of 're-bedouinization' less likely, is that one would expect hypercorrections in the re-bedouinized dialects. An example of such hypercorrection would be, in case of a 're-split', an interdental reflex for originally plosives, like $\underline{t}$ for ${ }^{*} t$, or $\underline{d}$ for *d. I have seen no evidence of such or comparable hypercorrections.

It is more likely that these collectives (the 'Lēgāt and the Șawālhaha) kept speaking their own dialects during their stay in the eastern Delta, or at least their dialects were not extensively influenced by a sedentary type comparable to types heard in the Delta today, and that such 'rebedouinization' did not take place when they moved to Sinai. This situation would be comparable to the situation of the dialect spoken by the Rašāydah, who are known to have continued to speak their own Nağdiy dialect (in the privacy of their own homes, in any case) in Sudan and also in other areas, even though they have been away from their former abode in the Arabian Peninsula for almost two centuries (since the second half of the 19th century).

\section{f. The Locations of Isogloss Bundles in Central and Southern Sinai}

Isogloss bundles coincide with boundaries of tribal dirahs, simply because we have chosen geographical borders between the tribal areas (sg. dirah) of different tribes as the location to draw these isoglosses onto the map. To a degree, this is of course artificial, but experience has taught that often the speech of members of the same tribe in the same tribal area will not show very many differences..$^{28} \mathrm{I}$ did however notice some differences between members of the Ğbāliyyah who live near the monastery of St Catherine, and those who live some 40 kilometres away in Wādiy Fērān/ Wādiy aš-Šēx, in and near Mrēr and aț-Ṭarfa. ${ }^{29}$ Similarly, Mzēnah who live near the coast will use $\check{s} u \dot{g} !$ as the genitive exponent, whereas hagg appears to

\footnotetext{
${ }^{28}$ See also remarks in De Jong 2000:19.

${ }^{29}$ Hobbs 1995:140 reports that of the estimated 300 families (or 1,500 souls) of the Ğbāliyyah, around half live within a 5 kilometre radius fom the monastery, and the other half live in aț-Tarfa.
} 
be more current with Mzēniy speakers who live more inland, i.e. in the mountains (see 3.1.11.)..$^{0}$

Much clearer than in northern Sinai, some of the major isogloss bundles found in central/southern Sinai coincide with visible geological features of the landscape. From the fact that isoglosses in this study are drawn into maps to coincide with borders of tribal dīrahs, and borders of some of these dirahs coincide with features of the landcape,$^{31}$ the coincidence of isogloss bundles with natural features of the landscape will come as no surprise. In cases where such a natural feature of the landscape is an obstacle for the traveller, isoglosses may accumulate to form thicker bundles. This is no news, of course, since examples from Europe or elsewhere, like rivers (i.e. where they hinder traffic), swamps, mountain ranges, etc. are plentiful..$^{2}$

In Sinai, one of the clearest examples of such coincidence of isogloss bundles with a natural feature of the landscape is the southern escarpment of the Tìh plateau, ${ }^{33}$ which is also roughly the location of the major isogloss bundles (numbers -16-, -20- and -24- in MAP 88, see appendix) running more or less southeast-northwest through Sinai between dialects of group I (to the northeast) and dialects of group VII (SwA) and group VIII ('LA) (to the southwest). Although the dialect of the Badārah (assigned here to group I) is now spoken to the south of this escarpment as well, this tribe is originally from the Tìh plateau, where some of their families may still be found..$^{34}$ In figure 1 of the appendix the escarpment

$3^{30}$ Palva 1984-1986:307 remarks that hagg "is the genitive marker used by many dialects of the Arabian Peninsula".

${ }^{31}$ A practical way for tribes to decide on the border of their territories is to agree on features of the landscape to represent this border. An example is the "Fjord" on the coast of the Gulf of 'Aqabah (location appr. 29.25.50 North and 34.49.50 East, see Google Earth), which is accepted by Tarābīn and Ahaywāt to be the eastern end of the border between their dīrahs.

${ }^{32}$ In northern Sinai we identified an 'invisible obstacle' coinciding with such a major isogloss bundle: due to the lowly social status of the Dawāgrah major isogloss bundles coincide with the borders between their dīrah and the dirahs of neighbouring tribes, see De Jong 2000:653 (MAP oo in appendix), isogloss bundles numbers 6 and 8 .

33 The Tìh plateau is Eocene limestone, the high mountains to the south are part of a Precambrian Crystaline base, see webpage http://www.awayaway-sinai.net/main/about_ sinai.htm (accessed 10-18-2010).

${ }^{34}$ Oral communication from members of the Badārah in the field, and who now live in ar-Ramlah, the sandy area just to the south of this escarpment. Von Oppenheim 1943:152153 also mentions the Bedāra (in his transcription) as one of the oldest tribes in Sinai, living on Ğabal 'Iğmah, who were in a hilf (alliance) with the Tayāha in older times, after which they had 'Beziehungen' (relations) with the Țuwara ('Lēgāt) as well, and have 'now' (i.e. in his day) returned again to their old protectors the Tayāha. I had the impression during my visits that they had now returned to their earlier protectors the 'Lēgāt again. 
is visible in the map as the darker shade of grey between the brownish/ pink area to the south (the area aptly named ar-Ramlah, indicated on the map as Debbet er Ramleh) and the high granite mountains of aț-Tūr and the grey area to the north (limestone plateau of at-Tìh). This escarpment is very difficult to traverse. ${ }^{35}$

Another example is the isogloss bundle between the dialect of Tarābīn of Nwēbi ' and that of the Mzēnah ( $\mathrm{nr}-28$ - in MAP 88): although both tribes live on the sandy plain of Nwēbi in the Gulf of 'Aqabah of the mouth of Wādiy Watīr - the Tarābīn in the northern area and the Mzēnah in its southern area-farther inland the border is the mountain range of Ğabal Gunnah running more or less east-west, ${ }^{36}$ as I was told by my Tuṛāniy informant.

In Wādiy aš-Šēx the tribal border between the Mzēnah and Ğbāliyyah is the (nowadays) asfalt road that leads through Wādiy aš-Šēx (to Wādiy Fērān): at the stretch of this road to the west of at-Ṭarfa Mzēniy territory lies to the north and the territory to the south is claimed by the Ǧbāliyyyah.

The dialects of Baniy Wāșil and the Mzēnah show a number of important similarities. Since the Baniy Wāṣil are said to originally have been speakers of a group I-type of dialect ${ }^{37}$ - and if this is true - the dialect that they speak today must be the result of extensive influence from Mzēniy. On the map the territories of Baniy Wāșil and Mzēnah are separated by the territory of the Awlād Sa īd, which might prompt the question why their dialect (ASA) is not more like that of group VI (i.e. BWA and MzA), especially if dialect contact is assumed to be the cause of the development of older BWA towards the dialect type of MzA: how could this contact take place across an area inhabited by another tribe, and how can it be that the dialect of this separating tribe was not or at least much less influenced by MzA?

The answer is that the map in this case does not give a realistic picture of where members of the tribes actually live: the Awlād Sa îd live much farther inland (the mountainous area in and around Wādiy Șlāf; for the location see fn 2, p. 115 in Introduction to Chapter II), thus leaving the

\footnotetext{
35 For a map showing the passes leading down from the Tîh Plateau to the 'Dividing Valleys' (of which the ar-Ramlah area is a part), see Greenwood 1997:35 (Figure 3-6. The Dividing Valleys).

${ }^{36}$ This mountain is erroneously named Jabal Jannah on Google Earth, coordinates are appr. 28.52.30 North, 34.07.50 East.

${ }_{37}$ Oral information of sources in the field. See also a comparison of MzA and BWA below.
} 
sandy coastal plain near the town of at-Tūr, which they claim as their dīrah, deserted. The Baniy Wāṣil and Mzēnah can travel through this area freely, ${ }^{38}$ but simply will not settle in this empty land, which is also considered to be Sa îdiy territory.

Territorial disputes also occur from time to time. The latest (in 2008) large scale conflict was between 'Lēgāt and Taṛābīn, when the 'Lēgāt, supported in their territorial ambitions by the Ğarăğrah tried to move into Tựbāniy territory south of Ṛās Șadr. The Tarāāin did not sit idly and watch it occur, but instead rode out to defend their territorial claims in an armed conflict. The matter was settled later in a Bedouin court of justice. Not only were the 'Lēgāt sentenced in this Bedouin court of justice for their expansionist aspirations, the Ğarāğrah too were fined a substantial sum for choosing the 'Leggiy side in this dispute. ${ }^{39}$

\section{g. A 'Virtual' Isogloss Bundle, Number-39-: BWA and MzA}

To show the relative typological proximity of the dialects of the Baniy Wāṣil and Mzēnah, a 'virtual' isogloss bundle (number -39-) was drawn into the map (positioned in the Gulf of Suez).

A direct comparison through multi-dimensional scaling already shows their relative proximity. In terms of calculations done for the 'step method' this proximity is expressed as $13.4 \%$ of differences as the outcome of the total of comparisons.

We see that BWA is 'partially' or 'wholly' characterized by a number of features that are more of the group I type than of the MzA type. To list examples:

- Like in most group I dialects, raising of short $a$ in CaCCāC has not led to morphological restructuring (then > CICCāC), but is absent or rare (unlike the situation in surrounding dialects, where it is frequent and either optional or compulsary) (see MAP 22).

- The use of a sg. fem. pronominal suffix -kiy, either when following $\bar{v}$, or invariably so (i.e. preceded by any combination of vowels and/or consonants, like in group I) (see MAP 37).

${ }^{38}$ This is not to say that a tribe would otherwise normally deny a traveller passage through their dīrah. The point is that contact between Mzēnah and Awlād Sa îd and between Baniy Wāṣil and Awlād Sa îd is likely to be less frequent, and contact between the Mzēnah and Baniy Wāșil to be more frequent than the situation reflected by the map may suggest.

39 Oral communication from Turbāniy sources in the field. 
- BWA is the only dialect in the area which predominantly uses demonstrative forms with initial $h \bar{a}$-, like in group I (see MAPS 39 and 40).

- BWA is the only dialect in the area which uses the adverb hniy for "here" (see MAP 46).

- The system of negated personal pronominals is basically like in group I (see MAP 79).

- The interrogative "when" is like in group I matā, not like in the surrounding dialects (where one will hear (i)mtēh, mtēn, or mitēn) (see MAP 82).

- 2nd p. sg. masc. imperfect forms and sg. masc. imperatives of mediae infirmae verbs with shortened long vowels are not current (i.e. the situation is like in group I). In surrounding dialects such shortening of the long vowel occurs regularly (see MAPS 84 and 85).

Of the partial differences, it is striking that a form used parallel to a form also known in MzA is often of the type found in group I as well. Examples are:

- Like in group I, a reflex (with short vowel) -á (when preceded by an emphatic) is used as parallel to (with long vowel) $-\bar{a}\left({ }^{\prime}\right)$ (like in surrounding dialects) for *-a('), e.g. fid á" "free time", but $r h \bar{a}^{3}$ "hand mill".

- Like in group I, widd is used to express "want, need", parallel to bidd, the latter being current in surrounding dialects of group VII (see MAP 73).

- Like in group I, raising of $a$ in closed syllable preceding stressed $\bar{e}$ (e.g. lammèt > limmèt) is often absent, as opposed to the situation in surrounding dialects where such raising is current (see MAP 75).

- Like in group I, the baking sheet (for the preparation of bread) is called a șāg (as opposed to šāz in surrounding dialects). The game of siğih ( sìğih in group I), however, is referred to as šlzih, like in surrounding dialects.

- The demonstrative for the pl. com. "these" may be heard with initial $h \bar{a}$ - (i.e. $h \bar{a} \underline{d} i l)$, as opposed to surrounding dialects, where only forms without such initial $h \bar{a}$ - are current (this may be due to MzA, which has hädil as a parallel form as well, or may be due to forms in group I, where forms with initial $h \bar{a}$ - are predominant).

The combination of these features points toward an earlier group I type of dialect for BWA. This should be seen in combination with the fact that the Baniy Wāṣil were among the earliest tribes to arrive in Sinai (between 1oth and 13th centuries, and perhaps even earlier, see Bailey 1985:33-35, and remarks made above in the Introduction, I. d.). Chances that BWA 
acquired these group I features through dialect contact with one of the group I dialects are not great, since the dīrah of Baniy Wāṣil does not border on any of the group I dirah's (nor do I have evidence that it ever did).

The fact that BWA has been grouped together here with MzA to form group VI, is due to the features it shares with MzA. Notwithstanding the relic forms that are assumed to have their origin in its earlier group I-type, some of these features are truly unique for group VI (which makes their origin elsewhere in the region unlikely). E.g.

- The combination of (velarized) kbār and (unvelarized) kțär (like in $\mathrm{MzA}$ ) contrasting with (both velarized) kbār and ktāar in group I, and (both unvelarized) $k b \bar{a} r$ and $k \underline{\underline{a}} \vec{a} r$ in surrounding dialects (see MAP 4).

- Raising of $a$ in open syllable preceding stressed $a$ and also $\bar{a}$ is like in MzA.

- Initial (')a- in "mother": 'amm (like in MzA and group I) as opposed to 'umm in surrounding dialects (see MAP 26).

- The form of the preposition "with" + 3rd p. sg. masc. suffix is m 'uh "with him" and is identical to the form in MzA (and 'LA and HmA), but surrounding and group I dialects have different forms (see MAP 48).

- The 3 rd p. sg. fem. perfect of $i$-type is CiCCat like in MzA, but surrounding and group I dialects have other forms (see MAP $5^{2}$ ).

- The combination of 3 rd p. sg. masc. and ist p. sg. com. imperfect forms of "come" are yiğ́y and iǧíy is like in MzA, but forms differ from surrounding and group I dialects (see MAP 61).

- For the pl. masc. personal pronominal for "they" huwwa is current, like in MzA (but most group I dialects have hum (ṃa)) (see MAP 78).

- The reflex for final ${ }^{*}-\bar{a}$ in $a$-type tertiae infirmae $(y \bar{a})$ verbs is usually (stressed) -í, like in miší. ligí, nisí (see MAP 86).

The grouping of MzA and BWA together in the same group is also supported by the outcome of the plots generated by the SPSS programmes Proxscal and Alscal: the MDS plots (see pp. 373-374), the dendrogram (see p. 375), the multi-dimensional colour plot, and-although to a somewhat lesser extent - the percentages calculated using the step method (see Conclusions, III. b.). 


\section{Methods of Illustrating Dialect Differences}

\section{a. Some Remarks on Methods of Illustrating Typological Similarities/ Differences of Dialects}

One method of illustrating typological distances between dialects is to take the selection of features as they have been recorded in the data set. In this data set every dialect receives its own horizontal row and selected features are recorded in vertical columns. Presence of a feature is marked with the number " 1 ", absence of the feature with the number "o". When parallel forms have been recorded in one dialect, presence of these parallel forms will be marked " 1 " in an equal number of columns.

On the basis of this data set, a distance matrix is then calculated; for each pair of dialects a relative typological distance is calculated (see the distance matrix in the appendix p. 376) (for dialectometrical measurements of distances based on differences and similarities, see Chapter 11. 2. In Behnstedt and Woidich 2005).

Using the calculated distances from the distance matrix, dialects are then plotted into an imaginary three-dimensional cube.

To each of the three dimensions represented by axes $\mathrm{X}, \mathrm{Y}$ and $\mathrm{Z}$ one of the three basic colours red, green or blue is assigned.

Each axis is subdivided in values between zero and 255, in which zero represents o value for the basic colour, and 255 represents maximum value for that same basic colour on this axis. ${ }^{40}$

In this way every point inside the cube receives its own set of three coordinates, the combination of which is unique. Since these coordinates are represented by intensities of basic colours, different colours are produced according to the mix of the different values for these basic colours.

We then take these colours back to the geographical map, and paste them into the dirahs of the tribes whose dialects are represented by these colours. The result is a map in which typologically more similar dialects will show relatively similar colours, whereas more strongly differing dialects will receive more strongly differing colours on this map. An example of the situation in Sinai can be found on figure 8a in the Appendix.

\footnotetext{
${ }^{40}$ For an introduction to this method of multi-dimensional scaling, see the webpage (in Dutch) by Peter Kleiweg http://www.let.rug.nl/ kleiweg/Lo4/Tutorial/ti.html.nl (accessed 10-18-2010), which is part of the Linguistic Atlas of the Middle and South Atlantic States (LAMSAS) project at the University of Groningen (Netherlands).
} 
This map clearly shows the dialect groups as clusters in similar shades of colours:

group I is mainly different shades of light green (and greyish for TAS and TAN), group II is purplish red, group III is red/dark orange (with a similar shade for eŠA) group IV is light blue, group $\mathrm{V}$ is purple, group VI is sea green. group VII is purple/violet. group VIII is brownish / dark olive green.

When the three basic colours are assigned to different axes, naturally the colours will change. Examples are figures $8 \mathrm{~b}$ and $8 \mathrm{c}$ in the Appendix.

These maps also appear to corroborate claims of genealogical relatedness of some tribes. The dialects of TAS and TAN are spoken by two different branches of Tarābīn, who live approximately 200 kilometres apart. The fact that they are typologically near is clearly illustrated in the 2-dimensional MDS plots generated by Proxscal and Alscal (see pp. 373-374), where they have been plotted near each other. It is also illustrated by the 3 -dimensional colour MDS plot, where the two dialects receive very similar colour shades. The dialect of the northern branch of Tarāain (nTA) is however typologically further removed, which is also illustrated in the different plots.

In the same way, the proximity of the two dialects DbA and HwA seems to corroborate claims that the two tribes are genetically related, or in any case may have been part of the same confederation in earlier times; the Dbūr are said to have split off from the Hwētāt as a 'āylah. ${ }^{41}$

Compare these maps to map 88 of the appendix in which the differences have been interpreted and where every group is represented by one assigned colour.

Group I : yellow

Group IV : light blue

Group VII : light brown
Group II : orange

Group V : grey/blue

Group VIII : dark yellow
Group III : pink/light red Group VI : green

${ }^{41}$ Von Oppenheim 1943:154-155 already lists this collective (Debūr in his transcription) as a sub-tribe of the Hwēțāt, adding that they are "apparently a branch of the Debūr of Transjordan" (see ibid.:155, note 5). At-Tayyib 1997:107 also lists the Dubür as one of the branches of the Ḥwēțāt. 


\section{The dīrahs of the Hiwètāt and Ahaywāt}

Although interviews with Ḥwētāt were recorded in the area of Ğidy, I have not met with Hwētāt from the area more to the north in the triangular area drawn on the map between 'AyA and nTA territory. For the area of Ahaywāt to the south of this HwA area, I have spoken to some Ahaywiys who live near the road from Rạa Șadr to the main (west-east through central Sinai) road Mitla ${ }^{42}-$ Nixl, where some families of the Ahaywāt live, not far north of Qal'at alĞindiy. ${ }^{43}$

\section{b. Multi-Dimensional Scaling in a Two-Dimensional Map}

The MDS plots in the Appendix (pp. 373-374) show a number of interesting results. First of all, the plot supports the grouping of dialects and observations made earlier in De Jong 2000:44

- Balawiy Arabic (BaA) is shown to be nearest to (other) group I dialects, but its relative distance from these can still be interpreted as illustrative of the special place it occupies within this group. ${ }^{45}$

- To illustrate the relative typological proximity of group III dialects in the north to the dialect of the eastern Šarqiyyah (eŠA) in the Nile Delta, a 'virtual' isogloss bundle was introduced in De Jong 2000. ${ }^{46}$ The MDS plot also clearly shows this typological proximity.

- The MDS plot corroborates the separate typological status (as not being part of the northern Sinai dialect continuum) of Dwègriy (DA, group IV) and 'Arāyšiy ('AA, group V). The plot also shows that they are sufficiently far removed from other dialects to be considered as separate 'groups'.

- The MDS plot shows that groups I, II, III and eŠA (eastern Šarqāwiy) of the north are in a linear sequence ('west-east' from left to right in the MDS plot), which reflects the typological continuum they form (geographically running in the opposite direction of the MDS plot).

\footnotetext{
${ }^{42}$ Originally Uṃm It

${ }_{43}$ Qal'at al-Ǧindiy is located at appr. 29.51.04 North and 33.07.50 East, see Google Earth.

${ }_{44}$ Observations made here are really based on the comparison based on 95 features which were selected to serve as criteria. Other characteristics not represented in this comparison further illustrate the same results.

45 See remarks in De Jong 2000: $57-58$.

${ }_{46}$ There bundle number $-21-$, cf. remarks $611,615,619,622,625$.
} 


\section{c. Other Results of the MDS Plots}

- In De Jong ${ }^{2000^{47}}$ a remark from an older speaker of Smēniy (SaA of group II in the north) was quoted, in which he claimed that his tribe had until a hundred years earlier lived in at-Tūur, ${ }^{48}$ where they had owned datepalms. The MDS plot Proxscal Squared Euclidean clearly illustrates the dialect of the Hamādah (HmA of group VII) as being relatively nearest to that of the Samā nah. The MDS plot generated by Alscal (Euclidean Binary, see pp. 373-374) however does not produce the same result. I have no explanation for this difference between these two plots.

- The dialects of Baniy Wāșil and Mzēnah are plotted relatively near to each other. This is supported by the relatively limited number of isoglosses in the 'virtual' isogloss bundle introduced in the preceding pages, which also illustrates such relative typological proximity.

- The dialect of Baniy Wāșil (BWA), which was said by informants to have originally been of the group I-type, is plotted nearer to the group I dialects than any of the other non-group I dialects.

A problem with the outcome of the two-dimensional MDS plot Squared Euclidean Binary (see p. 373) generated by Proxscal is that the distance between e.g. BWA and ĞrA (of different groups: VI and I resp.) is plotted as shorter than the distance between, e.g., ĞrA and MlA, which are of the same group (both of group I), whereas dialects that are typologically more similar should be plotted nearer to each other than dialects that are less similar. The reason is that the number of dialects in group I to be incorporated in the plot is so great that it causes excessive stress, which results from 'cramming' hundreds of dimensions into a two-dimensional space. The result is that a less realistic representation like the one discussed here becomes unavoidable. To illustrate that it is stress that causes such distortion, all group I dialects causing such stress have been omitted from the MDS plot below, except ĞrA and MlA.

In this Proxscal MDS plot we see that the distance between ĞrA and MlA has been restored as being relatively shorter than the distance between ĞrA and BWA (dissimilarities are: BWA - MlA = 76, ĞrA - MlA

47 See p. 246. For illustration of similarities of these dialects cf. MAPS in the appendix of this volume.

${ }^{8}$ The name at-Ṭūr is generally used to refer to the high mountainous area in southern Sinai, roughly where the Tuwara tribes live. 


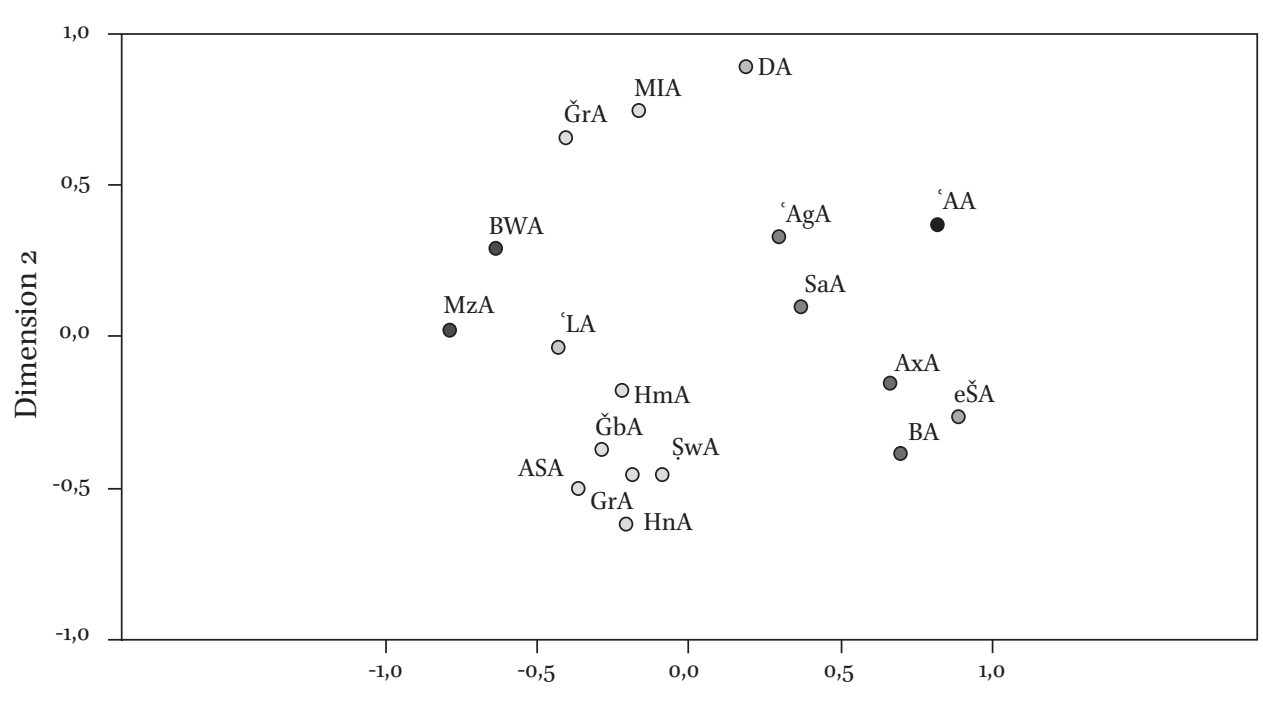

Dimension 1

$=44 ;$ ĞrA - BWA $=66 ;$ MlA - BWA $=76 ; 49$ binary Euclidean distances in the proximity matrix are: $\mathrm{BWA}-\mathrm{MlA}=8.718$; ĞrA $-\mathrm{MlA}=6.633$; ĞrA $\mathrm{BWA}=8.124$, see the proximity matrix on p. 376 ).

Excessive stress causing such distortions in these two-dimensional representations is less problematic ${ }^{50}$ in the MDS plot Euclidean Binary generated by Alscal of the SPSS (see p. 374).

Another interesting aspect of the different methods of multi-dimensional scaling is that these invariably lead the same grouping of dialects. Although different methods applied may inside the generated MDS plots lead to different positions of dialects (like 'AA and DA) that have relatively little in common with the other dialects spoken in Sinai, the different MDS plots do produce comparable clusters of typologically related groups of dialects (see also two other MDS plots and the dendrogram on p. 375).

In addition, we notice that the dialects of groups VI, VII and VIII are all plotted in the southeastern quadrant ${ }^{51}$ of the plot generated by Alscal (Euclidean Binary). The importance lies in the fact that, given the diverse

\footnotetext{
49 These numbers are only to be interpreted as distances relative to each other; the greater the number, the greater the distance.

$5^{\circ}$ By "less problematic" I mean that the resulting plot better represents my own subjective impressions of the typological distances of the groups involved.

${ }^{5^{1}}$ The fact that these three groups are plotted in this quadrant is coincidental to some degree, but the relative proximityof the three groups is not.
} 
origins of the tribal communties before they came to Sinai (and at different times in history), dialect contact is highly likely to have been the acting force in bringing these dialects typologically nearer to each other in a process of levelling. ${ }^{2}$ In this way the dialects of the different tribes have coalesced (though not entirely) to form a 'phylum', ${ }^{53}$ which now covers the southern tip of Sinai. Several processes of focusing must have taken place. One clear example is the spread of the ${ }^{-(u)} k$ (masc.) and ${ }^{-(i)} k$ (fem.) pronominal suffixes for the 2nd p. sg.; although the proposed development described above (cf. Chapter I, 3.1.12.2., NOTE) may be plausible, it is highly unlikely that the different different tribes who arrived in southern Sinai at different times in history all had these suffixes after having all gone through the same process of innovation (i.e. the reinterpretation of morpheme boundaries) independently and before their arrival in Sinai. A much more plausible scenario is that these suffixes originated in one of the dialects involved in dialect contact, after which they spread throughout the southern region. This development may be difficult to date, but we know that it must have taken place more than a century ago at least, because until ten years ago these suffixes were still present in the dialect of the Samānnah in the north, who had emigrated from southern Sinai towards the end of the nineteenth / beginning of the twentieth century (see De Jong 2000:246).

\section{d. Grouping Dialects Using a Dendrogram}

To arrive at a relatively logical grouping another tool used is a dendrogram ${ }^{54}$ (generated with the Hierarchical Cluster Analysis of the SPSS) to cluster the dialects of Sinai (including Negev Arabic, DA). It is important to remember that a dendrogram illustrates degrees of similarity (or dissimilarity), and

\footnotetext{
${ }^{52}$ See remarks in Trudgill 1986:39, where the relevance of the geographic parameter of diffusion models is stressed.

See also Palva 2008b:401 "[...] the Trawara tribes have lived in close alliance since the 17th century (Oppenheim 1943:156-157), and the earlier dialectal differences must have faded away long ago".

An alternative interpretation could be that these dialects were already much alike before the tribes came to Sinai, but given the heterogeneneous history reported for the different tribes in various sources, this is far less likely; in any case this alternative interpretation would fail to explain the current typological position of ĞbA, whose speakers must have come to Sinai in the fifth century CE as non-native speakers of Arabic (see also remarks in fn 24, p. 321).

${ }_{53}$ Other than a possible genetic relationship in the distant past, this term is not meant to suggest a relatively recent common ancestor.

${ }^{54}$ See also Behnstedt and Woidich 2005:129.
} 
that we should not conclude a genealogical relationship. A dendrogram generated for all dialects in Sinai is (grouping with Roman numbering was done by hand, see figure 6 in the appendix for the colour version):

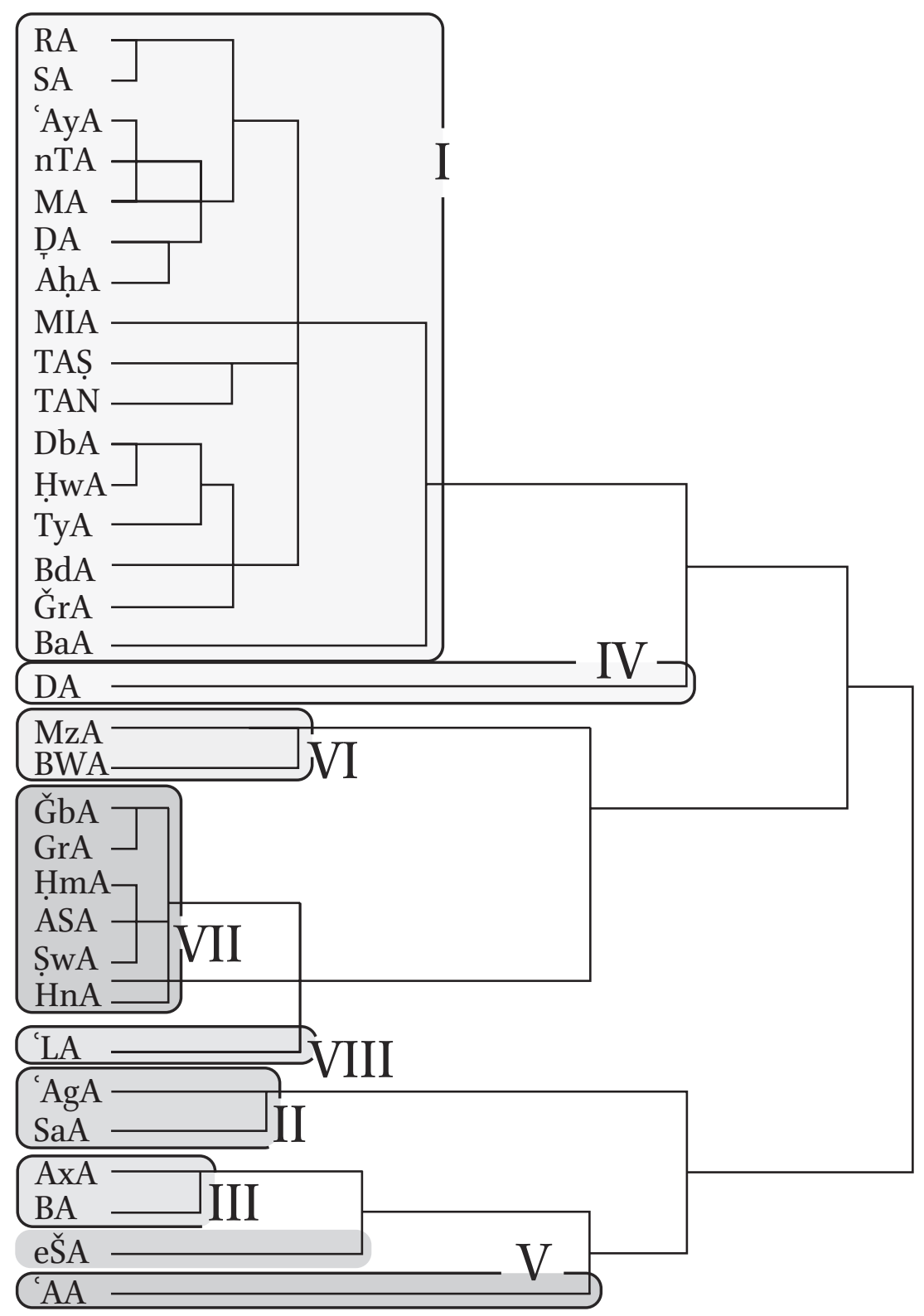

Dendrogram of dialects of Sinai 
We see here that the Group I dialects quite neatly cluster together, with BaA occupying a special place inside this group. BaA 'branches' at a lower level, farther to the right, than the other dialects (see remarks in De Jong 2000:57-58). Groups IV and V branch at a relatively low level as well (even farther to the right than $\mathrm{BaA}$ ), which supports the interpretation of these dialects as separate groups.

Clustering of the dialects that form groups II and III is also clear from this dendrogram. For remarks on decisions to group clusters of dialects in groups VI, VII and VIII in this manner, see remarks in Conclusions, III. c.

The dendrogram also shows that the dialect of the eastern Šarqiyya (eŠA) and the dialects of groups III (BA and AxA) and also V ('AA) are all on the same longer branch. This is due to the fact that these dialects are all more of the sedentary type (in comparison to the other dialects represented here in groups, which are more of the Bedouin type).

A plausible interpretation of the existing situation from a sociolinguistic perspective is that the different groups, in as far as dialects were not genealogically related, have developed from a diffuse situation (or situations, since the different tribes arrived at different times in history) towards a more homogeneous situation through dialect contact, in which certain original forms must have been lost due to processes of koineization through stages of levelling (simplification, reduction in irregularities, focusing, dropping minority and otherwise marked speech forms that exist parallel) and which resulted in a synchronically relatively stable dialect (see Trudgill 1986:107-108 and remarks in De Jong 2000:28-29).55

To conclude such a development becomes particularly plausible if we consider the case of the 2nd p. sg. masc. and fem. pronominal suffixes ${ }^{-}{ }^{u} k$ and ${ }^{i} k$ (resp.); a scenario in which different tribes of different origins arrived at different times in history, but were all already using these pron. suffixes is highly unlikely (see remarks in the preceding paragraph). We may not know where these suffixes originated, but we do know that they spread among this group with its heterogeneous background that currently exists in southern Sinai. Perhaps these suffixes were imported into the area by one of the tribes who arrived there, or perhaps these suffixes even came into being locally as 'interdialect forms' (see Trudgill 1986:62).

\footnotetext{
55 For processes of 'Konvergenz' leading to 'Nivellierung', bringing various dialects closer together, see Diem 1978.
} 


\section{e. What Informants Say}

In the course of this research several claims were heard made by informants concerning the relationships between the different tribes of Sinai. Although I have chosen not to use these comments for the typological classification and grouping, I consider them interesting enough to be mentioned here. Below is a list of these claims and in comments I have indicated how the results of the MDS plots and the dendrogram (in the appendix) might relate to these claims ${ }^{56}$ (the question of whether or not these statements are true is not investigated here). ${ }^{57}$

Remark: the Dbūr are said to be related to (i.e. they originally split off as a family from) the Hwētāt.

Comment: when we look at the MDS plots, we see that their dialects (DbA and HwA resp.) are indeed plotted closely together inside group I. The dendrogram shows the same.

Remark: the Ğarāğrah are said to be related to the Masāīì (in the northwest), who are in turn said to be related to the Ahaywāt (living around Nixl and Țāba).$^{8}$

Comment: the dialects of the Ahaywāt and Masāīd (AḥA and MA resp.) are indeed plotted closely together inside group I. The dialect of the Ğarāğrah (ĞrA), however, is not plotted very near to AhA and MA (resp.). The dendrogram shows the same.

Remark: the 'Lēgāt are said to be descendents of the neigbouring Ṣawālhah.

Comment: the MDS plots position their dialects relatively near each other. In the dendrogram these two dialects do not appear very near each other.

\footnotetext{
${ }^{56}$ There is of course also the chance that informants conclude a relationship based on features perceived to be similar in the dialects spoken by these tribes.

${ }^{57}$ One could even imagine that people 'invent' a genealogical relationship based on their perception of linguistic similarities with the dialect of another tribe, or simply because they for some reason like to be associated with another tribe or certain other tribes.

Much of the claims listed here can be checked against the information given in Introduction I. d. and in the relevant sources mentioned there.

${ }_{5}^{8}$ See also De Jong 2000:11.
} 
Remark: The Garāršah are said to be a section of the Șawālḥah (see also Bailey 1985:33).

Comment: the MDS plots and the dendrogram indeed cluster these two dialects relatively near each other.

Remark: the Tarābīn are said to be related to Biliy (in the north), but this is quite remote in the past. ${ }^{59}$

Comment: a relationship between (any branch of) the Tarābīn and Biliy - other than that they have been grouped together ${ }^{60}$ - is not evident from the MDS plots or the dendrogram.

Remark: the dialect of the Baniy Wāṣil was more like the dialect-type spoken by group I tribes, but it has changed under influence of dialects of 'other' (not further specified) tribes.

Comment: the MDS plots indeed show that Wāṣliy (BWA), as one of the dialects of the southern groups VI, VII and VIII, is typologically nearest to the group I-type dialects. The dendrogram does not show a direct connection.

In general, one could conclude that remarks made by informants are often on the mark, or quite near it. G.W. Murray's (1935:256-257) remark on Bedouin in southern Sinai that "among themselves, they can distinguish each tribe and subtribe by their looks and dialects..." is true for the entire region.

\section{A Comparison of the Dialect of the HWwēṭāt of Southern JoRDAN AND THE HWwêț̄itT OF SINAI}

Prompted by some additional remarks made by Professor Heikki Palva on the dialect of the Hwēțāt, which were partly in reaction to my own remarks on his description of their dialect as spoken by this tribe in southern Jordan, I feel encouraged to once again add a few of my observations.

\footnotetext{
59 Stewart (1991:106) reports that the Tarābīn were part of the Baniy 'Ațiyya.

${ }^{60}$ See also De Jong 2000:57-58, fn 3 on the special position of BaA inside group I.
} 
In this research it is assumed that members of the same tribe who live in the same dirah and are in regular contact with each other will also speak the same dialect. ${ }^{61}$

When members of the same tribe have been living in different locations, and have been relatively isolated from each other for longer periods of time, their dialects are bound to show differences, and one may expect that the longer the isolation has lasted, the more differences will have developed. ${ }^{62}$

The majority of those who identify themselves as Hwētāt are actually found in southern Jordan and in the adjacent far nortwestern corner (the northern Hiğāz) of Saudi Arabia. In older times many of the Hwēțāt settled on the Egyptian mainland, a large group of whom were found around Bilbēs in the eastern Nile Delta. The Hwẹtāt in Sinai are not very numerous, and a small settlement inhabited by them is Ğidy ${ }^{63}$ in the north of Sinai. The Hwêtạt of southern Jordan are said to be an amalgam of different groups of (semi-)sedentary population, many of whom are originally not of Bedouin stock. ${ }^{64}$

My earlier remarks concerned the typological status of the dialect of Hwêtạāt in Jordan, ${ }^{65}$ and whether perhaps their dialect formed part of a transition to a more Nağdiy type of dialect. The following is a comparison of Hwētiy spoken in Jordan (referred to here as HwJ) as described in Palva 1984-1986 (in this comparison the structure of this article is largely followed).

${ }^{61}$ This is a sociolinguistically inspired approach that has proven to be a very workable principle in the case of (sometimes still (semi-) nomadic) Bedouin tribes. There are exceptions, of course. See also remarks in De Jong 2000:19.

${ }_{62}$ Either as a result from autonomous developments inside the dialect itself, or as a result of change induced by contacts with speakers of other dialects.

${ }_{6}$ Since the area was said to be teeming with military (for the very strategic Ğidy pass about $20 \mathrm{~km}$ north of the Mitla pass), I had interviews there conducted for me by others. The approximate position of the village would be 30.12 North, 33.04 East, just to the northwest of Ğabal alĞidy, and to the north of Șadr alḤaytān, see Google Earth (where it is indicated as Gebel Heitan).

${ }^{64}$ Oral communication from a Hwēțiy šēx from al-Ǧafr interviewed in 2008 in al-Husayniyyah in southern Jordan. He told me that several families or clans had joined the tribe as duxala (Classical Arabic duxalä'), i.e. "people seeking refuge and protection".

See also remarks in Palva 2008b:402 "[the Hwēțāt] probably are descendants of an old local population (ahl ad-dìre) (Musil 1926:20), whose culture for centuries has fluctuated between seminomadism and semisedentarism".

${ }_{55}$ See De Jong 2000:627-630. 
I have added notes referring to Hwêțiy poetry as recorded in Holes and Abu Athera 2009 when forms appearing there are different from Palva's description or from my own findings. These poems will be referred to as 'Barrāk'. ${ }^{66}$ The abbreviation HwA is used her to refer to may own findings for the dialect of Hwêțāt in Sinai. For the sake of brevity, the emphasis in this comparison is on highlighting differences between HwA and HwJ, while briefly mentioning some similarities.

The texts of the poet Barrāk in Holes and Abu Athera 2009 are essentially the interpretation of the authors ${ }^{67}$ of written texts, and are not based on audio recordings. Apart from that, it is known that for poetry not every day spoken dialect is used, but a (higher) register considered to be more appropriate for this purpose. I shall therefore merely mention details of interest without drawing any conclusions from the Barrāk material.

\section{Phonetics}

The inventory of phonemes is almost identical (see Palva 1984-1986:296). One difference is that the affricate $g$ has a highly regular allophone (fricative) $\check{z}$ in HWA. In Barrāk transcription is with $\breve{g}$ throughout and is reported as "always realised as an alveolar affricate" (i.e. I.P.A. [d3]). ${ }^{68}$

A glottal stop often follows final stressed $-a$ in a pause (Barrāk:296): e.g. $\check{g} a^{3}$ "he came".

A similar situation in HwA, but 'is also often heard following unstressed final - $a$, e.g. áfda' "I sacrifice", tagádda' "he had lunch", biyrìdha' "he wants (i.e. loves) her" and ál 'aša' "the dinner".

Such glottalization is not indicated in Barrāk.

Lack of affrication in reflexes of *k and *q in ḤwJ: same in Ḥ̂A.

Three short vowel phonemes: /i/, /u/ and /a/ in ḤwJ: same in ḤwA.

66 "Barrāk" for the poet Barrāk Dāgiiš Ğāziy Aḅuw Tāyih al-Ḥuwayṭiy recorded in Holes and Abu Athera 2009:83-108. Some of his poems appear there in transcription. He is from al-Ğafr in southern Jordan (see ibid.:8), some $150 \mathrm{~km}$ northeast of 'Aqabah.

${ }_{7}$ For the notation in transcription the interpretation of Said Salman Abu Athera was taken as a starting point for the texts, which were only available on paper (the poet himself had passed away in 1999). Said is himself a Bedouin of the Tarābīn, born in the Gaza area, and was raised in Jordan (Clive Holes, personal communication). Chances are therefore considerable that in Barrāk's transcribed poems Said's own Turbāniy or perhaps (partly) Jordanian dialect shines through.

${ }^{68}$ See Holes and Abu Athera 2009:210. 
Five long vowel phonemes: $/ \overline{\mathbf{l}} /, / \overline{\mathrm{u}} /$ and $/ \overline{\mathrm{a}} /$, and $/ \overline{\mathrm{e}} /\left({ }^{*}\right.$ ay) and $/ \overline{\mathbf{o}} /\left({ }^{*}\right.$ aw $)$ in HwJ: same in HwA. No real overlap (or fluctuation) of $/ \overline{\mathrm{e}} /$ with $/ \overline{\mathbf{i}} /$ or $/ \overline{\mathbf{o}} /$ with $/ \overline{\mathrm{u}} /$. In HwA very high $/ \overline{\mathrm{e}} /$ was heard in the lexical items $z \bar{e} t$, seef and $b \bar{e} t$, but such high realisations (near I.P.A. [i:]) of / $\overline{\mathrm{e}} /$ were the exception, rather than the rule.

Palva (ibid.) reports $/ \overline{\mathrm{e}} /$ and $/ \overline{\mathrm{o}} /$ in all positions in HwJ, including those preceded by velarized consonants or X. In HwA, however, diphthongs have remained in such positions, e.g, 'ayn "eye", xaymih "tent", nușșayn "two halves", șayf "summer", dawayt "I went home before sunset", hawlíy "one-eyed (sg. fem.)", gawțar "he went". The diphthong in 'ayš "bread" was often realised lengthened: 'ayš in HwA.

In Barrāk only a few diphthongs occur, e.g. hawl (p. 93, l. 5), at-țbayg, (p. 96, 1. 37), taw in (p. 101, l. 4) but more regularly monophthongs are found following back spirants and velarized consonants, e.g.: hèel and xēel (p. 94, ll. 14 and 16) (but here perhaps to rhyme with sēl and mēl), hẹt (p. 95, l. 30), 'èn (p. 96, l. 43), țēr (p. 100, l. 29), ġèr (p. 100, 1. 32), bag்ètah (p. 101, l. 4) (here rhyming with nagètah and lagètah), șēf (p. 101, l. 5), a'tètah and na'étah (p. 102, ll. 20 and 21).

In terms of stress, the only diffence between HwJ and HwA appears to be that the former stresses $\mathrm{CáCaC}(\mathrm{v})$ (provided it is not $\mathrm{CaXaCv}),{ }^{69}$ while the latter clearly prefers stress $\mathrm{CaCáC}(\mathrm{v})$.

Examples for $\mathrm{CaCaC}$ from HwA are malág "hard soil/rock (i.e. where no foot prints will be visible)", libán "milk" and a gahawah-form dahár "back". HwA examples for CaCaCv are sibágah "race", zalámah "man", gaháwah "coffee”, hanákak "your mouth”, afámak "your mouth”, tahárid ('ala) "you go up (to)", na'árif "we know".

In HwJ we see forms like (following numbers refer to pages in Palva 2004) ritam "retem (firewood)" (203) and siǧar "trees" (203) (stressed, according

\footnotetext{
${ }^{69}$ This is how I interpret Palva's remarks, see 1984-1986:297. These remarks seem to be contradicted, however, by (verbal) forms listed on p. 299: k(i)tábat, $k(i) t a ́ b o w /-u$ and $k$ (i)tábin. Although Palva $(2004: 197,198)$ repairs the error of listing the forms ga'dat, ga'dow/-u and ga'din by replacing them with the forms ga'adat, ga'adow/-u and ga'adin, we are now faced with a new question: why is *katab + at stressed $k(i) t a ́ b a t$, whereas ga'ad $+a t$ is stressed, I assume, gáa adat? This assumption is not without ground: the form ga dat could not have been listed if the proper form is ga'ádat, since I find it hard to believe that a stressed vowel would have been heard as having been elided. The error of listing the form ga'dat could therefore only be made because the proper form is gáadat.

When gahawah-forms are involved, we do find a CaCáCv stress-type, e.g. ba áda (Palva 2004:201).
} 
to Palva's remarks, ritam and siğar),${ }^{70}$ which prompt the question whether these are perhaps relics of an older CaCáC stress-type (in which the vowel $a$ of the first syllable in neutral environments is often raised > CiCáC). In other words: are we dealing with a stress shift in Hwētị, and is its older stress-type then more like the present situation in HwA of Sinai? (for further remarks, see 'the verb' below)

Apart from stress in sequences mentioned above, stress in both HwA and HwJ can be characterized by the forms: álbil "the camels", álwalad "the boy", ángalab/yingilib (imperfect in HwJ would be yángalib) "be overturned", áttafag/yittifig (imperfect in HiwJ would be yáttafig) "agree", bintī "my daughter", darabatni "she hit me". As for forms in Barrāk, no conclusions can be drawn with regard to stress.

As for the Nağdiy type of resyllabication of $\mathrm{CaCaCV}$ sequences (> CCICV, or (gahawah-sequences) CaXaCV $>\mathrm{CxaCV}$ ), it is not a feature of HwA. As for HwJ, however, there are several instances of forms that have been subject to this rule. Palva appears to report free variation with respect to the application of this rule. ${ }^{72}$ Notice the following forms in Palva 2004. (Following bracketed numbers refer to the pages, the form in square brackets would be the HwA equivalent, which are not affected by the Nağdiy resyllabication rule). First of all, gahawah-forms appearing in HwJ which are also resyllabified in conformity with the Nağdiy resyllabification rule are (forms listed in square brackets are proper HwA forms):

ghawah (1984-1986:303) [gaháwah], yǵazu "they raid" (201) [yaǵázuw], 3 instances of nxabiz "we bake" (202) [naxábiz], 3 instances of n'ağin "we knead" (202) [na'áǵin], 2 instances of ng்azil "we spin", nǵázila "we spin it" (203) [naǵázil and naǵázlah] and nḥașid "we harvest" (204) [naḥáșid].

${ }^{70}$ I have not listed $\mathrm{CaCaC}$ forms preceded by the (stressed) article. Other forms in $\mathrm{HwJ}$ without such raising are balad (204), hağar (204, 205, 206), masak (206), walad (206), 'ašar (207), sana (207), nasab (207) and hașal (208). Interestingly, in the paradigms for kitab and sirib (see Palva 1984-1986:299), $i$ of the first syllable may only be dropped when it is in open syllable directly preceding a stressed syllable (forms cited are e.g. $s(i) r i b t i$ and $k(i)$ tábin). From this a conclusion that the second syllables in sirib and kitab are not stressed logically follows, and therefore these forms must be stressed kitab and šírib (since $k t a ́ b$ and 'šríb are not optional). For further implications, see remarks below in 'the verb'.

${ }^{71}$ For these imperfect forms of measures $n-1$ and $1-t$ in HwJ, see Palva 1984-1986:303.

${ }^{72}$ Listed verb forms with bracketed vowels, like $k(i)$ tabat and $y(a)^{\text {'arf }}$ (1984-1986:299), suggest free variation in the application of the Nağdi resyllabication rule and the forms yahkumu/ y hakmu (2004:207) also imply free variation in the application of the gahawahrule. For Nağdi resyllabification see Prochazka 1988:10-11 and Ingham 1986:276. 
But Palva also reports forms in HwJ which are not affected by Nağdiy resyllabification are: ba'áda (2004:201), hașalat (2004:205) šağara, šağarāt (2004:205), ga'adu (2004:205), haraka (2004:205), hağara (2004:206); darabat (2004:206), zalabāni (2004:206), yáhafru (2004:206), hafáraw (2004:206), hașalat (2004:207), sanawāt (2004:207, 208), 'ašara (2004:207), wahade (2004:207), 'agabe (2004:207, 208), madaniye (2004:207). Such forms are in terms of syllabication identical to comparable HwA forms.

In Barrāk instances of $\mathrm{CaCaCV}$ were not found.

gahawah-forms in Barrāk are: ar-ra'ad (p. 86, l. 11), wa l-wa'ad (p. 88, l. 4), and verb forms tahamdūh (p. 91, 1. 25), but there are also many forms which are not affected by the gahawah-syndrome (perhaps for metrical reasons), e.g. ša bah (p. 91, l. 27), ša b (p. 91, l. 28) and șa $b$ (p. 93, l. 8), an-naxlāt (p. 99, 1. 25) and verb forms yahfaḍōh (p. 91, 1. 20), yahkum (p. 91, 1. 28) and yax̌̌a (p. 95, 1. 23).

\section{Morphology}

Independent pronouns in HwA are aná, int $(a)$, intiy, hù, hī, aḥna, intuw, intin, hum (ṃa) and hin(na). For HwJ Palva reports ana, int, inti. hü, hì, ihna ( hinna), intu, intin, hum and hin. ${ }^{73}$

Also in Barrāk we find hinna (p. 95, l. 31).

\section{Pronominal suffixes}

C-ī / V-y (poss.) and -nī (obj.), C-ak / V-k, -kiy, C-ah or C-ih / V-(h), -ha( $\left.{ }^{\circ}\right)$, $-k u w$ / -kin, $-n a\left(^{\prime}\right)$. In HwJ the same suffixes are current, except the allomorph $-i$ of the 3 rd p. sg. masc. ${ }^{74}$

In Barrāk we find singular forms like (3rd p. sg. masc. -ah or -ih) ša ${ }^{\prime} b a h$ "his people" (p. 91, l. 27) and annās kullih "all people" (p. 85, l. 3) and (v + -h) yi țūh "they give him" (p. 89, l. 22); (3rd p. sg. fem. -ha) gașdha "her intent" or a long vowel at the end of a hemistich as in warāha "behind her" (p. 86, l. 7); (2nd p. sg. masc. -ak) ğěšak "your army" (p. 86, l. 6) or (v + -k) as in malfāk "your destination" (p. 93, l. 6); a short final vowel in (1st p. sg. com. -i) rizgi "my sustenance" (p. 101, l. 9), (v + -y) mabdāy "my principle" (p. 101, l. 6) and (obj. suff. -ni) talabni "he asked me" (p. 98, 1. 5). Plural

\footnotetext{
73 See Palva 1984-1986:297 and 2004:198. Palva also mentions that in pause, ana, $h \bar{u}$ and $h \bar{\iota}$ sometimes have an audible glottal stop following. In HwA I have only noticed this in the case of ana $^{\prime}$ \#, but then not only in pause.

${ }^{74}$ I follow a slightly different system of transcription in forms like -kuw and -kiy (Palva writes $-k u$ and $-k i$ ). I have not recorded (unstressed and short) $-i$ or $-n i$ for the 1st p. com. sg. in HwA, which Palva 1984-1986:197 gives for HwJ.
} 
forms are (3rd p. pl. masc.) ahalhum "their people" (p. 100, l. 33); (3rd p. pl. fem. -hin) la buddhin "they must"; (2nd p. pl. masc. -kum; -ku(w) was not recorded) ğihādkum "your fight" (p. 86, 1. 15); the 2nd p. pl. fem. was not found; (1st p. pl. com. -na) baladna "our land" (p. 89, l. 17).

Demonstrative pronouns in HwA are

Near deixis: hāda, hādiy ( fewer hēdiy), hadál (-lah),

Far deixis: hadāk, hadīk (-ih) ( fewer hēdīk (-ih)), hadallāk(-ah)

In $\mathrm{HwJ}$ the same forms were recorded. ${ }^{75}$

A feature considered very typical of HwA by other tribes is the postpositioned demonstrative ha, e.g. álwalad ha... "this boy". This feature was not reported for HwJ, nor were instances found in Barrāk.

\section{Interrogatives}

min is used for "who?" in both HwA and HwJ. ${ }^{76}$

For the interrogative "what?" $\bar{e} h$, much less regularly $\bar{e} s$ and sometimes wiš were heard in HwA. For HwJ Palva ${ }^{77}$ gives wuš, co-occurring with $\bar{e} \check{s}$ and K-form $\check{s} \bar{u}$ (with proclitic variants 'iš and $\check{s} u$ ).

"Which" is yāt in HwA, but ayy / ayya in HwJ..$^{8}$

The b-imperfect

For HwJ Palva reports that the $b$-imperfect is not current in HwJ. ${ }^{79}$ Barrāk shows no instances of the $b$-imperfect either. In HwA, however, it is as current as in other dialects of Sinai (except in that of the Dawāgrah).

Indefinite pronouns and the article ${ }^{80}$

HwJ wāhad-HwA wāhid "someone", both variants have šiy "something", kam "some", "all, every, whole" is kill in HwJ—kull in HwA, the article is alin both variants, and also often ('konkretisierendes') ${ }^{8_{1}}$ hal-. ${ }^{8_{2}}$ The relative pronoun is alli(y) in both, while halli is also reported for HwJ (the latter was not heard in HwA).

75 See Palva 1984-1986:298 and 2004:198.

${ }^{76}$ See Palva 1984-1986:298.

77 See Palva 1984-1986:298 and 2004:198.

${ }^{8}$ See Palva 1984-1986:298

${ }^{79}$ See Palva 1984-1986:307 and 2004:196

${ }^{80}$ For remarks on HwJ, see Palva 1984-1986:298

${ }^{81}$ See Blau 1960:20 and Grotzfeld 1964:46-47.

${ }^{82}$ For postpositioned ha in HwA, see remark in III, 3.1.9.1. 


\section{The verb in $H w A$ and $H w J$}

Perfect verb forms listed for HwJ reflect the $a$-type as $\mathrm{CiCaC}$ or $\mathrm{CaCaC}(<$ $\left.{ }^{*} \mathrm{CaCaC}\right)$ and the $i$-type as $\mathrm{CiCiC}$ or $\mathrm{CaCiC}\left(<{ }^{*} \mathrm{CaCiC}\right)$. Palva ${ }^{{ }_{3}}$ concludes that the vowel of the first syllable in both types depends on the phonetic surroundings. To summerize his point: if $a$ of the first syllable in ${ }^{*} \mathrm{CaCaC}$ was realized with a back allophone, it has remained $a$ (e.g. ga'ad), but if it was realized with a front allophone, it has become $i$ (e.g. kitab). In the older $i$-type $\left({ }^{*} \mathrm{CaCiC}\right)$ the same development is concluded, but an additional factor of vowel harmony is held responsible for this change. Examples cited are 'arif $\left(<{ }^{*} \mathrm{CaCiC}\right.$, in which $a$ is concluded to have been realized with a back allophone) and širib $\left(<{ }^{*} \mathrm{CaCiC}\right.$, where $a$ is concluded to have been realized with a front allophone).

Apart from the fact that it is difficult to imagine a back allophone for $a$ in 'arif (which would then have to be more or less like (the vowel in the first syllable) $a$ in e.g. darab, i.e. near I.P.A. [a]), ${ }^{84}$ there is a more plausible explanation.

A historically more plausible development to account for raising $a$ $>i$ in these patterns is to postulate a stress shift from $\mathrm{CvCv́C}$ to $\mathrm{Cv} \mathrm{CvC}$ (see also Grotzfeld 1969); patterns that are now stressed on the first syllable must have been stressed on the second syllable to allow the vowel $a$ in neutral surroundings to be raised to $i$. The scenario in which raising of short vowel $a>i$ in open syllable preceding a stressed syllable takes place is not unique in the area (see paragraphs 1.2.3.4.3.2. and 3.1.1.6. of preceding descriptive chapters), nor is stress of the CaCáC- or CiCíC-type (see paragraphs 2.1.1.2.1. of preceding descriptive chapters; HwA also has CaCáC and CiCíC, e.g. kitáb and širíb).

The implication is that Palva's suggestion of raising of $a$ in ${ }^{*} \mathrm{CaCiC}$ (> $\mathrm{CiCiC}$ ) in $\mathrm{HwJ}$ as the result of vowel harmony ${ }^{85}$ appears to be off the mark. After all, why would $a$ in ${ }^{*} \mathrm{CaCaC}$ be raised $(>\mathrm{CiCaC}$ ) if a mechanism of vowel harmony were operative ${ }^{86}$

$8_{3}$ See Palva 1984-1986:298-299.

${ }^{84}$ In fact, preceding ' or $h$ more typically result in an open front allophone near I.P.A. [a].

${ }_{5}$ As was assumed in Palva 1984-1986:298.

${ }^{86}$ Palva ibid. recognizes this, but does not elaborate. Also the fact that the vowel of the imperfect preformative does not harmonize with the stem vowel is an indication that vowel harmony (present in almost all dialects of Sinai, including HwA) is at least not a very productive rule in HwJ (see ibid.:299-301). Some examples of such lack of vowel harmony cited for HwJ are yag'ud, yaktib, yamši, yadri, etc. 
The more likely historical development is that after such raising ( $a$ $>i$ ) in neutral surroundings had become stable, resulting in CiCáC and CiCíC, ${ }^{87}$ stress shifted onto the first syllable, resulting in the forms that were recorded (e.g. kítab and širib).

The question remains then, why did stress shift? There is no easy answer, but chances are that HwJ has been influenced by a dialect-type which stresses Cv́CvC. The dialect-type could be a sedentary (rural or urban) type in southern Jordan, or perhaps even contact with speakers of a Nağdiy (i.e. a Bedouin type, but non-NWA) type of dialect; after all, the very same vowelling and stress-type are current in Nağdiy (e.g. the active (a-type) perfect forms kitab "he wrote", díbah "he slaughtered", but-due to lowering influences of contiguous $h$ and '-no raising in e.g. ( $a$-type perfect) hálab "he milked" and gá ad "he sat" ${ }^{88}$ and also (i-type perfect) "ášiǵ "he loved" $\left.{ }^{89}\right) .^{90}$

The confusing differences in stressing in forms like gá adat, but $k(i)$ tábat and (gahawah-forms) $y(a)^{\prime}$ 'árf and gháwah are already an indication that dialect contact may be have taken place (or is still operative); two systems for stressing sequences of the type $\mathrm{CaCaCv}(\mathrm{C})$ appear to be in use and exist side by side as parallel systems. And parallel forms, or parallel systems in this case, are often an indication of dialect contact..$^{91}$

In any case, the topic of stress shift deserves more attention than it can receive here.

Like in HwA, $a$ of the $i$-type perfect (underlying $|\mathrm{CaCiC}|$ ) in HwJ 'reappears' in closed syllables, e.g. šarbin "they (fem.) drank". A difference is the vowel of the 3 rd p. sg. fem. ending: šarbit in HwA, but šarbat in HwJ. ${ }^{92}$

${ }^{87}$ Such forms are not exceptional in the area, see map 14 in the appendix.

${ }^{88}$ See Prochazka 1988:28-29.

89 See ibid.:32.

90 If we look at stress systems current in some Nağdiy dialects (see Prochazka 1988:20-22), we see that there too a stress shift may have been involved in shaping forms that are heard today. If we take forms like (active) *katab "he wrote" and (internal passive) * kItib (in which $I=i$ or $u$ ) "it was written" as starting points, and we assume that both forms were stressed on the ultimate (katáb and kItíb), postulating stress on the ultimate syllable would not only account for raising of $a$ in katáb > kitáb, but also for the elision of the short high vowel $I$ from the open (first) syllable in $k I t i b>k t i b$. When stress then shifted, it could only do so in the active form (resulting in kitab, cf. ibid.:28), but stress could no longer shift in the internal passive form, since the vowel of the first syllable was no longer available after its elision, and stress had to remain where it was: ktíb (cf. ibid.:116). On stress shift in Arabic dialects, see also Grotzfeld 1969 .

${ }^{91}$ See Trudgill 1986:107-108 on the dynamics of dialect contact.

${ }^{2}$ See Palva 1984-1986:299. 
The vowel of in the 3 rd p. pl. fem. perfect ending in HwA colours with the base vowel: -an in the $a$-type perfect (e.g. katában) and -in in the $i$-type perfect (e.g. šarbin). In HwJ the situation is not clear, but Palvawith some hesitation-lists the forms with a fixed $i$ in this morpheme (k(i)tábin and šarbin).$^{93}$

Similar hesitation is apparent in the endings listed for the 3 rd p. pl. masc., for which Palva lists -ow/-u for both vowel-types of the perfect in HwJ (k(i)tábow/-u and šarbow/-u). In HwA vowel harmony produces -aw in the $a$-type (katábaw or kitábaw). The ending in the $i$-type (and also in the $u$-type) is $-u w$ (šarbuw).

Endings used in the imperfect for the 3 rd p. pl. masc. and fem. show the same differences. Examples for the fem. are byaṭanan iw biygáriblin "they (fem.) grind and sieve" in HwA, but in HwJ tákitbin / taktibin and tašrabin. Examples for the masc. are yíkitbuw and yašrabaw in HwA, but in HwJ forms are yákitbu / yaktibu and yašrabu, and fem. pl. forms are yákitbin / yaktibin and yašrabin. ${ }^{94}$

Barrāk lists some forms with the (more Nağdiy-like) pl. masc. ending -ūn, e.g. yišfün (p. 86, l. 6) and yirmūn (p. 86, l. 7), but there can be little doubt that this is due to the high register chosen for this poem. ${ }^{95}$ Other forms in Barrāk more strongly suggest a situation like in HwA, e.g. (perfect) iḥtāğaw (p. 95, 1. 21) and (imperfect) yaḍakaw (p. 91, 1. 21) and there are many instances where suffixation results in monophthongized -aw or $-o w>-\bar{o}$, as in (perfect) sawwōh (p. 90, l. 2) and (imperfect) yahfadōh (p. 91, 1. 20), while suffixation of $-u w$ results in $-\bar{u}$, as in (perfect) and (imperfect) ysammūh (p. 90, l. 1) and tahamdūh (p. 91, l. 25).

In poetry (Barrāk, pp. 93-97) many instances may be found of vowel harmony in the pl. fem. endings of perfect and imperfect: -an for the $a$-types and -in for the $i$-types, e.g. (perfect) bayyananni (p. 95, 1. 22) and imperfect (a-type) yarhalanni (p. 94, l. 18) and (i-type) yihtifinni (p. 94, l. 11). ${ }^{6}$

In HwA the vowel of the imperfect preformative colours with the stem vowel through vowel harmony, e.g. yiktib, yudrub and yarğa', while in Ḥw

\footnotetext{
93 See Palva 1984-1986:299.

94 Ibid.:299-300.

95 The poem was actually recited by the poet to king Husayn of Jordan, see ibid.:84-85.

${ }^{96}$ Endings there are actually -anni and -inni, instead of -an and -in; the additional -ni being a poetic device.
} 
the preformative is with fixed $a$, e.g. yaktib, yadrub and yarğa ${ }^{c} .{ }^{97}$ In Barrāk the system is basically like in HwA, e.g. yisfik (p. 86, l. 10), yihyi (p. 89, l. 25), yimši (p. 88, l. 8), yibnūh (p. 9o, l. 4), tunkus (p. 89, l. 15), yund̆ur (p. 89, l. 26), yudkur (p. 100, l. 34), tunșur (p. 91, 1l. 15, 16), yuțlub (p. 91, l. 23), nudukrah (p. 101, l. 9), yurzug (p. 101, l. 9) and also yasrax (p. 86, l. 14) and tarkab (p. 94, ll. 16, 17), but also (exceptions) ya izzhum (p. 89, l. 26) and tafrig (p. 96, l. 43).

Imperatives in HwA have initial vowels coloured by vowel harmony: ug $u d$, iktib and ašrab. In HwJ such colouring is absent from the $a$-type: ug'ud, iktib, but išrab. ${ }^{98}$

\section{Some weak verbs}

Primae wāw verbs in Ḥ̂A have incorporated wāw in the preformative, often monophthongal $\bar{o}$ in the $i$-type, as in yōrid, and diphthongal $a w$ in the $a$-type, as in yawșal. For some verbs another paradigm without incorporated wāw is also available, as in yigif and yiríd.

In HwJ the preformative contains long $\bar{a}$, as in yāgaf and yāsal. A shorter form la tiga was also recorded in HwJ ${ }^{99}$ Barrāk gives a form yāgafanni (for the -ni ending, see remark above) (p. 96, l. 33).

In tertiae yâ $a$-type imperfects in HwA the base vowel is not dropped when vowel-initial endings are appended, e.g. tansay, yansaw. In HwJ however the base vowel is dropped, e.g. tansi, yansu. ${ }^{100}$ In Barrāk we find forms like in HwA: yardaw (p. 88, 1. 10) and yitnāsōh (suffixed -aw or -ow $>-\bar{o})$ (p. 9o, l. 9).

The imperfect vowel in the primae hamzah verbs is $i$ in HwA, HwJ and Barrāk: yākil (p. 99, l. 25) and yāxid (p. 88, l. 11; p. 96, 1. 39).

The perfect forms are with initial $a$ - in both HwwA and Hww: akal, akalt, etc.

The verb "come"

In forms in HwA the vowel of consonant-initial imperfect preformatives has been dropped (and the final syllable is stressed): yğìy, tğiy, nği ty, tğuw,

\footnotetext{
${ }^{97}$ See Palva 1984-1986:299-301.

${ }_{98}^{8}$ Ibid.:300.

99 Ibid.

${ }^{100}$ Ibid.:301
} 
tğin, yğuw and yğin, but (1st p. com. sg.) ağíy. In Ḥw the vowel has not been dropped and is stressed (leaving the ending unstressed):yígi, tíği, etc.

Derived measures

In perfect and imperfect of measures $t a-2$ and $t a-3$, the $t a$-prefix is only rarely reduced to $(i) t$ - in HwA. Examples are tagadda, ytagadda and tasālam, ytasālam.

In HwJ reduction of $t a$ or $t a>t$ in the imperfect (but not in the perfect)

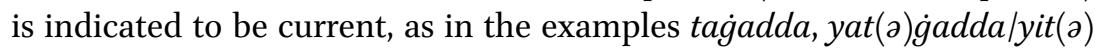
gadda and tasālam, yat(ə)sālam/ yit(ə)sālam. ${ }^{101}$ In Barrāk we find forms like iytarağğāh (p. 91, 1. 13), tabāšaraw (p. 91, 1. 21), tasallam (p. 98, 1. 8).

In measures $n-1$ and $1-t$ the first syllable in the perfect and imperfect is stressable in HwA and HwJ, but vowelling in the imperfect differs. Examples are ánfatah, yínfitị and ástawa, yístiwiy in ḤA, but ánfataḥ, yánfatị̣ and ástawa, yástawi in HwJ..$^{102}$ In Barrāk we find forms like ida nkasar (perhaps stressed id-ánkasar) (p. 88, l. 15), but also infağar (p. 91, 1. 22), ingalab (p. 95, 1. 27) yihtașilhā (with $a$ in the stem, but not in the preformative) (p. 89, 1. 21), yimtațilhä (ibid.) (p. 89, 1. 21), yihtifinni ${ }^{103}$ (p. 94, 1. 11).

\section{Nominal morphology}

The degree of raising of the fem. morpheme differs slightly: in HwA up to $\left[\mathrm{l}^{\mathrm{h}}\right]$ in neutral surroundings, but in HwJ mostly $[\varepsilon] .^{104}$ In Barrāk we see many examples where final $-i h$ is transcribed, e.g. the poem on pp. 98-100.

\section{Tanwin}

Tanwin is not a feature of HwA or HwJ, but in Barrāk's poems quite a number of instances of are found. The use of tanwīn (i.e. appending final -in) is however restricted to poetry and sayings and the like and is not current in every day speech.

\footnotetext{
${ }^{101}$ See Palva 1984-1986:302-303.

102 Ibid.:303.

${ }_{103}$ The final syllable is a poetic device; the poem rhymes in -ni.

104 See Palva 1984-1986:303.
} 


\section{Particles}

Some differences between adverbs in $\mathrm{HwA}$ and $\mathrm{HwJ}^{105}$ are:

\begin{tabular}{|c|c|c|}
\hline Hwa & HwJ & \\
\hline hniy(yih) & $\dot{h a ̄ n}$ & "here" \\
\hline hnuh & hināk & "there" \\
\hline kidíy(yih) & $h \bar{e} k$ & "thus, this way" \\
\hline lēh & $l \bar{e} s$ & "why?" \\
\hline mata & matān/mitān, wagtēh & “when?" \\
\hline kam & kam/kutrayh & "how many?" \\
\hline gaddēh & gaddēěs & "how much?" \\
\hline dāyman & daym & "always" \\
\hline 'a(la) țūl & duǵri & "straight" \\
\hline
\end{tabular}

Some differences in conjunctions

yōm is current for "when" in HwA and HwJ, but nhār was not recorded in HwA in the same meaning.

inkān is current for "if" in HwA and HwJ (and also Barrāk, e.g. p. 103, ll. 25 and 29), but (')ila was not recorded in HwA for "if" (but instances in Barrāk are, e.g., on p. 103, ll. 22 and 28), nor was suffixed kann- or kānn-. In Barrāk an instance of suffixed kann is kannak tidakkar "if you remember" (p. 102, 1. 15). ${ }^{106}$

For "until" lamma is current in both HwA and HwJ, but lamman and yāma were not recorded for "when" in HwA.

lākin and mār are used for "but, but then" in HọJ, but only bass was heard in HwA for "but".

Some differences in (suffixed) prepositions

Prepositions $m a$ " "with" and l "to" suffixed with the 1st p. sg. com. pronominal are ma'áy and lay in HwA. In HwJ forms are ma' $i$ and $l i$.

The shorter form ' $a$ for 'ala "on" may in HwA also be used in positions not directly followed by the article, e.g. 'a ğâl "aside" and 'a dahár álǧimal "on the back of the camel". In HwJ ' $a$ is only used when the article directly follows. ${ }^{107}$

mițl for "as, like" is used in HwJ, but in HwA zayy is current. miț also appears in Barrāk (p. 86, l. 11).

${ }^{105}$ Ibid.:304-305.

${ }^{106}$ A footnote explains tidakkar < titdakkar, but reduction of the initial geminate $t t$ as in ttidakkar is very well possible, see remark in fn 8o, p. 176 .

${ }^{107}$ See Palva 1984-1986:306. 
Differences between some irregular high-frequency nouns

Similarities in HwA and HwJ are for "father" (') $a b \underline{b}$ and (') $a b \bar{u}$ - in construct state; for "mother" (')aṃm; for "brother" (')axx and (')axu- in construct state. A difference is (')uxt in HwA, but (')axt in HwJ.

In HwA the pl. for "hand" ((')ìd) is (')ìdàn, in HwJ it is (')adèn. "Hands" suffixed in HwA is ìdān- (e.g. ìdān "my hands"), but in HọJ it is (')adé(e.g. (')adēk "your hands").

A similarity is (')afám for "mouth", e.g. (')afamī "my mouth" and (')afámak "your mouth".

A difference is "water": (')álma (with incorporated article!) in HwJ, but miy in HwA.

\section{The analytical genitive}

The analytical genitive is not frequent in HwJ. In HwA the analytical genitive with šugl is current. I have not come across instances in Barrāk.

\section{Negated pronominals}

In Ḥ̂A $m \bar{u} h \bar{u} \sim m \bar{a} h \bar{u}$ and $m \bar{\imath} h \bar{\imath}$ in Ḥ̂, HọJ has $m \bar{u} \sim m u h u$ and $m \bar{\imath} \sim$ $m i h i^{108}$ and in Barrāk we find ma hu (p. 98, l. 3) and ma hi (p. 89, 1. 22).

The comparison above shows that between these different branches of the same tribe (or tribal confederation) there are already many differences. The differences found-if there ever was a common starting point - must have arisen not only as a result of dialect contact with other tribes (or they are perhaps 'internally motivated'), but the development of differences may also have been facilitated by the very lack of contact between the different branches due to their geographical separation over a longer period of time ${ }^{109}$ (the Hwêțāt of Sinai are estimated to have arrived there in the $17^{\text {th }}$ century at the latest, see Introduction, I. c.); as the crow flies the distance between the dīrahs of the Hwẹtat of Sinai and southern Jordan is approximately $200 \mathrm{~km}$. Apart from that, regular contact between the two branches must have been severely hampered by the presence of new borders that came with the creation of the state of Israel in 1948.

Of the two varieties HwA is clearly of the group I type found in Sinai and the Negev (see also MDS plots and dendrogram in the appendix), while HwJ shows characteristics that are best attributed to contact with dialects which are more of the Nağdiy-type (see also remarks made in Palva 2008b:406).

\footnotetext{
108 Ibid. 307 .

${ }^{109}$ Due to the lack of contact, changes that appear in one variety cannot (any longer) be 'corrected' by speakers in another location of originally the same dialect.
} 


\section{Final Conclusions}

\section{a. The Position of Sinai Dialects in Northwest Arabian Arabic}

(the NWA-group)

The larger typological dialect group of Northwest Arabian dialects of Arabic (as was proposed in Palva 1991) was shown in De Jong 2000 to be present in northern Sinai (groups I, II and III), along the Mediterranean coast.

When we now check features of groups VI, VII and VIII against features listed as characteristic for NWA dialects in Palva 1991:154-165, we notice the following (only dialects of groups VI, VII and VIII are discussed here $\left.^{110}\right):{ }^{111}$

i Absence of tanwin and its residues: groups VI, VII and VIII conform (cf. 4.1.).

ii Absence of affricated variants of $/ \mathrm{g} /\left({ }^{*} \mathrm{q}\right)$ and $/ \mathrm{k} /\left({ }^{*} \mathrm{k}\right)$ : groups VI, VII and VIII conform (cf. 1.1.1., 1.1.3.).

iii Absence of final /n/ in the imperfect, 2nd p. sg. fem., 2nd p. pl. masc. and 3 rd p. pl. masc.: groups VI, VII and VIII conform (cf. 3.2.1.2.).

iv Pronominal suffix $-k u$ (-kuw in my own transcription) in the 2nd p. pl. masc.: groups VI, VII and VIII conform ( - -kum in VII and VIII) (cf. 3.1.12.2.).

v Use of locative preposition $f i$ : groups VI, VII and VIII conform (cf. 3.1.16.).

vi Interrogative $k \bar{e} f$ : groups VI, VII and VIII conform (cf. 3.1.14.).

vii Voiced reflex of $q \bar{a} f$ : groups VI, VII and VIII conform (cf. 1.1.1., 1.1.3.).

viii The gahawah-syndrome and the CVCaCV- > CCVCV- syllable structure: ${ }^{.12}$ groups VI, VII and VIII conform (cf. 2.2.1.1., 2.1.1.2.1.6. in De Jong 2000 and 2.1.1.2.2. in the vol. in hand).

${ }^{10}$ Since dialects of group I discussed in this volume are grouped together with other group I dialects described in De Jong 2000, whose NWA status has already been established there, the same NWA status of the group I dialects discussed in the volume in hand logically follows.

${ }^{111}$ The features are cited here as they were listed in Palva 1991. In a number of instances additional data have become available and appeared in De Jong 2000. The reader is referred to relevant paragraphs by the numbers following in brackets.

${ }^{112}$ This was rephrased as two separate criteria in De Jong 2000:48-50. The conclusion there was that resyllabication of $\mathrm{CaCaCV}$ sequences (> CCVCV) is not a feature of NWA 
ix Gender distinction in the end and $3 \mathrm{rd} \mathrm{p}$. pl. in personal pronouns, pronominal suffixes and finite verb forms: groups VI, VII and VIII conform (cf. 3.1.12.1., 3.1.12.2., 3.2.1.1., 3.2.1.2.).

$\mathrm{x}$ The definite article (')al- and the relative pronoun (')alli/halli: groups VI, VII and VIII conform only in part: al- il- and alliy illiy (cf. 3.1.9.1.).

xi A number of typical Bedouin lexical items (gōtar, sōlaf, țabb etc.): groups VI, VII and VIII conform (cf., e.g., 3.2.3.9.).

xii Occurrence of stressed variants $-\bar{\iota}$ and $-n \bar{\iota}$ of the pronominal suffix in 1st p. sg. com.: groups VI, VII and VIII conform (cf. 3.1.12.2.)

xiii Occurrence of /a/ in the initial syllable in verbal forms VII-X in the perfect, and the stability of this vowel, shown by stress on the initial syllable when in stressable position: group VI conforms, groups VII and VIII do not conform (cf. 3.2.3.1., 3.2.3.3., 3.2.3.4.).

xiv Occurrence of $/ \mathrm{a} /$ in the initial syllable in a number of irregular nouns ('amm, 'axt, 'axwān, 'adēn, 'afám): MzA of group VI and ĞbA of group VII conform in part. Other dialects do not conform (cf. 3.1.9.2.).

$\mathrm{xv}$ The invariable pronominal suffix - $k i$ of the 2 nd p. sg. fem.: groups VI, VII and VIII do not conform (cf. 3.1.12.2.).

On characteristics listed in Palva 1991, which are not shared by all NWA dialects, the following remarks are to be added:

xvi The use of $b$-imperfect: present in groups VI, VII and VIII (cf. 4.3.).

xvii Vowel harmony in the active imperfect of verbal form I: groups VI, VII and VIII conform (cf. 3.2.1.2.).

xviii Well-established monophthongs $/ \overline{\mathrm{o}} /$ and $/ \overline{\mathrm{e}} /$ vs. partial monophthongization of the older diphthongs, and $/ \overline{\mathrm{o}} / \sim / \overline{\mathrm{u}} /, / \overline{\mathrm{e}} / \sim / \overline{\mathrm{i}} /$ fluctuation: in group VI older diphthongs remain in certain environments, in groups VII and VIII monophthongization is not phonetically conditioned (cf. 1.2.4.).

xix The phonetically conditioned sg. fem. status absolotus marker allomorphs /-a/ and /-i/ in Sinai and the Negev, vs. a less strong 'imäla in the front allomorph in the dialects of the Hiwētāat and Baniy 'Ațiye

dialects, whereas sequences of the type $\operatorname{CICV}(\mathrm{C})$ (where $\mathrm{I}=i$ or $u$ ) have as a rule been resyllabified in NWA dialects, e.g. *'inab > nab "grapes", *turā $b>$ trāa $b$ "dust". 
(/-a/ and /-e/): group VI has [ $\left.\mathrm{I}^{\mathrm{h}}\right]$ in neutral enivironments, groups VII and VIII tend to have slightly lower 'imälah, between $\left[\mathrm{e}^{\mathrm{h}}\right]$ and $\left[\mathrm{l}^{\mathrm{h}}\right]$ (cf. 1.2.3.4.3.3.).

$\mathrm{xx}$ The pronominal suffixes of the 3 rd p. sg. masc. C-ih, fem. -hiy in the Negev, masc. C-ah, fem. - ha in Sinai, the Hwêțât and Bani 'Ațīye, masc. $-a h /-i h$, fem. - ha the Bdūl, masc. C-o, fem. -ha the N'ēmāt; groups VI, VII and VIII have masc. -uh and fem. -hal-hi(') (cf. 3.1.12.2.).

xxi Occurrence of several different plural forms of the demonstrative pronoun: most dialects in groups VI, VII and VIII show doubling of the $l$ (or !) in the pl. com. demonstrative, e.g. (hā) dill(-ih), dillēlih"13 (cf. 3.1.13.).

In addition to these features discussed with regard to NWA dialects in Palva 1991, it is important to note that all dialects of groups VI, VII and VIII (as well as southern dialects of group I) are 'différentiels' in terms of elision of short vowels; short high vowels $i$ and $u$ are dropped in eligible positions, while (underlying) short low vowel $a$ is not elided in comparable positions, e.g. širib (|šarib|) + -it > širbit, šarbit or šarbat, but katab + -at > kátabat or katábat kitábat (i.e. not *katbat).

Notwithstanding some differences between the dialects spoken in the central and southern regions of Sinai, there can be little doubt that these dialects are indeed a continuation of the NWA-group. There are some features of the southern Sinai dialects, however, that do not conform to the more typically NWA-type. The hypothesis of the presence of NWA Bedouin dialects throughout Sinai (with the exception of the dialect of the Dawāgirah and that of the town of al-'Arīšs, see De Jong chapters IV and V) is nevertheless corroborated.

At the same time the conclusion to be drawn with regard to the question how far the Negev-type stretches into Sinai is that this type is represented by the group I dialects identified, which then border on the southern dialects of groups VI, VII and VIII. For a large part the escarpment of the Tîh plateau is the geophysical obstacle where isoglosses accumulate to form the border between the Negev-type and the southern Sinai-type.

\footnotetext{
${ }^{13}$ This is characterized as "one of the most important peculiarities of the whole NWA group" (cf. Palva 1991:165). Some of the group I dialects (like TAS and TAN) may have forms without doubling for near deixis (e.g. hād $\bar{\alpha} l, h \bar{a} d \underline{d} a l$ or $h \bar{o} d a l)$ as current for near deixis, but all have doubling in forms for forms used for far deixis (e.g. hōạallāk(-ah) or hä dolḷăk(-ah)).
} 
An earlier hypothesis of the presence of a transitional area in Jordan, where a number of dialect characteristics reported for the Hwētāt and Bani 'Ațiyye (see Palva 1984-86) suggest influences from non-NWA dialects, was contradicted by Palva. The hypothesis was for the presence of a transition area between NWA and a more Nağdi-type of dialect(s) (see also the discussion above in Conclusions, V.). ${ }^{114}$

The question of whether or not dialects are "différentiels" or "nondifférentiels" — with NWA dialects being "différentiels" — was not the only indication that the dialects of the Hwēțāt and Bani 'Ațiyye have had influences from non-NWA (possibly Nağdi) type of dialects. ${ }^{115}$

Another important indication was the Nağdi-type of resyllabication $(\mathrm{CaCaCV}>\mathrm{CCvCV})$, that seems to be current in the dialects of the Bani 'Ațiyye and Hwēțāt in Jordan. ${ }^{116}$

In addition, it should be noted that the Hwẹtạat are much more a relatively recent amalgam of social entities of different backgrounds ${ }^{117}$ than other tribes - such as most tribes in Sinai-who usually have a more homogeneous background, at least in relatively recent history. Chances that (again, relatively) recent additions to this collective known as 'the Hwẹțāt' have until today preserved some of the features of their original dialects should not be excluded; it may also account for some of the contradictory findings reported for Jordanian 'Hwệțiy' in the available literature. Clearly, more research into the dialect situation in southern Jordan and its surroundings is needed to untangle this (seemingly?) contradictory information.

${ }^{114}$ Palva 2008b:407 erroneously quotes the conclusion in De Jong 2000:630 as (quoting from Palva 2008b) "[that] the existence of such a group [i.e. NWA] is questionable and deserves reconsideration". The passage referred to in De Jong 2000 actually reads: "Palva's conclusion that Hwētiy is part of his proposed NWA group deserves [therefore] reconsideration". In other words: the position of the dialects of the Hwẹtāāt and Bani 'Ațiyye as NWA-type of dialects deserved such reconsideration; the presence of an NWA-group is nowhere questioned in De Jong 2000, nor is it questioned here.

${ }^{115}$ Interestingly, at-Tayyib 1993:222 relates stories told by older tribesmen of the Bani 'Ațiyye of their origin in the eastern Nağd, from where they (then still known as Ma'āzah) migrated westward in the beginning of the fifth century Hiğrah (beginning of the eleventh century CE) to Taymä, after which they continued farther westward two centuries later (i.e. the beginning of the thirteenth century CE) to arrive near Tabūk (in present day Saudi Arabia, some 180 kilometres southeast of 'Aqabah). The Ma'āzah-or part of this collective-are today found in the eastern desert of Egypt (see map on p. 4 or p. 372).

${ }_{116}$ These and a number of other differences between Hwētiy as described by Palva and the Negev-type are listed in De Jong 2000:627-630.

${ }_{117}$ See remark ${ }^{* 11}$ in Introduction, I, d. 
Another answer to one of our earlier research questions is that the vowelless pronominal suffixes ${ }^{-}{ }^{u} k$ for the 2 nd p. sg. masc. and $-k$ for the sg. fem. are indeed a characteristic feature of the dialects spoken in the south of Sinai; these pron. suffixes are in regular use in groups VI, VII and VIII. The remark of the older speaker of the Samänah in the north, that his tribe had until the turn of the century (i.e. around $1900 \mathrm{CE}$ ) had their home in the region of at-Tür, may very well be true. If we combine the presence of the ${ }^{-}{ }^{u} k$ suffix in his speech $(\mathrm{SaA})$ with the presence of the pronominal suffix -kum $(\sim-k u w),{ }^{118}$ and also the verbal suffixes ending in - $m$ of the 2nd and 3 rd p. pl. masc. in the perfect and imperfect, ${ }^{119}$ and see that the combination of these characteristics is also found in 'LA and HmA, his remark acquires special significance. If linguistic evidence is anything to go by for conclusions on geographical origins of speakers, one would conclude that the Samānnah (and perhaps also the 'Agāylah) must have had their earlier abode in the region north of the lower end (not too far from the Gulf of Suez) of Wādiy Fērāan (i.e. the area around Wādiy Garandal and Wādiy Lihyān). Unfortunately, I could not find other indications that would support this conclusion.

Apart from the necessity of more research into the hypothesized border area between the NWA- and Nağdiy-groups of dialects, a remaining desideratum is a systematic survey of the dialects of the Hiğāa to establish how far-if at all - the North West Arabian dialect group reaches south along the Red Sea coast of western Saudi Arabia.

In the eastern desert of Egypt the dialect of the Ma āzah (which is hypothesized here to be part of the NWA group) borders on the dialect of the 'Abābdah (which can be seen as the northern extension of the Sudanese type of Arabic dialects, ${ }^{120}$ like that of the Šukriyyah ${ }^{121}$ ). Research into the dialect of the Ma āzah is needed to establish whether it is indeed the southwestern extremity of the NWA group on the Egyptian mainland. ${ }^{122}$

\footnotetext{
${ }^{118}$ See De Jong 2000:283-288.

${ }^{119}$ See De Jong 2000:298-299.

${ }^{120}$ As described in De Jong 2002, and see remarks in Woidich and Behnstedt 1980:176 (fn 1$)$.

${ }^{121}$ As described in Reichmuth 1983 .

${ }^{122}$ Although Hobbs 1989 is an excellent anthropological study on the Ma àzah, the transcription used there for Arabic is less suitable for linguistic interpretation of the features of their dialect.
} 


\section{BIBLIOGRAPHY}

Abul Fadl, Fahmi. 1961. Volkstümliche Texte in arabischen Bauerndialekten der ägyptischen Provinz Šarqiyya mit dialektgeographischen Untersuchungen zur Lautlehre. Munich: thesis.

Aitchison, Jean. 1987. An Introduction to the Mental Lexicon. Cambridge/Mass.: Basil Blackwell.

Aț-Ṭayyib, Muḥammad Sulaymān. 1993 (1st edition). mawsū'at al-qabā'il al-'arabìya, buhūt maydānìya wa-tārīxìya. Cairo: Dār al-Fikr al-'Arabī.

— 1997 (2nd edition). mawsūáat al-qabàil al-'arabīya, buḥūt maydānīya wa-tārīxīya. Cairo: Dār al-Fikr al-'Arabī.

Bailey, Clinton. 1984, "Bedouin Place-Names in Sinai". Palestine Exploration Quarterly $116: 42-57$.

- 1985 , "Dating the Arrival of the Bedouin Tribes in Sinai and the Negev". Journal of the Economic and Social History of the Orient, Vol. 28:20-49.

- 1991, Bedouin Poetry from Sinai and the Negev, Mirror of a Culture. Oxford: Clarendon Press.

- 2004. A Culture of Desert Survival, Bedouin Proverbs from Sinai and the Negev. New Haven: Yale University Press.

- 2009. Bedouin Law from Sinai and the Negev, Justice without Government. New Haven and London: Yale University Press.

Behnstedt, Peter and Manfred Woidich. 1985. Die ägyptisch-arabischen Dialekte, Band 1: Einleitung und Anmerkungen zu den Karten. Wiesbaden: Dr Ludwig Reichert Verlag.

—. 1994. Die ägyptisch-arabischen Dialekte, Band 4: Glossar Arabisch-Deutsch. Wiesbaden: Dr Ludwig Reichert Verlag.

—. 2005. Arabische Dialektgeographie, eine Einführung. Leiden, Boston: Brill.

Bergsträßer, Gotthelf. 1915. Sprachatlas von Syrien und Palästina. Leipzig.

Bernabela, Roy. 2009. BA-thesis on the dialect of the Ğbāliyyah (unpublished), University of Leiden.

Blanc, Haim. 1970. "The Arabic Dialect of the Negev Bedouins". Israel Academy of Sciences and Humanities, Proceedings, Vol. 4:112-150 (reprinted in Stewart 1990).

Brockelmann, Carl. 1966. Grundriss dervergleichenden Grammatik der semitischen Sprachen. I. Hildesheim: Georg Olms Verlagsbuchhandlung.

Cantineau, Jean. 1936. Études sur quelques parlers de nomades arabes d'Orient. Annales de l'Institut d'Études Orientales Alger 1:119-237. Algeria.

- 1946. Les Parlers arabes du Hōrān: Notions générales, grammaires. Paris: Klincksieck.

Diem, Werner. 1978. "Divergenz und Konvergenz im Arabischen". Arabica 25:128-147.

EALL. 2006, 2007, 2008, 2009 (four volumes + index vol.) Encyclopedia of Arabic Language and Linguistics. Kees Versteegh (gen. ed.), Mushira Eid, Alaa Elgibali, Manfred Woidich, Andrzej Zaborski (ass. eds). Leiden - Boston: Brill.

EEAA. 2003. "South Sinai Demographics and Population Projections (working paper)", South Sinai Environmental Action Plan. http://st-katherine.net/downloads/Demographics\% 20\&\%20Population.pdf (accessed 10-18-2010).

Fischer, Wolfdietrich. 1959. Die demonstrativen Bildungen der neuarabischen Dialekte. The Hague: Mouton \& Co.

—. 1967. "Silbenstruktur und Vokalismus im Arabischen". Zeitschrift der Deutschen Morgenländischen Gesellschaft 117:30-77

Greenwood, Ned. 1997. The Sinai: a Physical Geography. Austin: University of Texas Press.

Grotzfeld, Heinz. 1964. Laut- und Formenlehre des Damaszenisch-Arabischen. Wiesbaden: Deutsche Morgenländische Gesellschaft, Kommissionsverlag Franz Steiner GmbH. 
1969. "Zur Geschichte des Wortakzents in den arabischen Dialekten", Festgabe für Hans Wehr, zum 6o. Geburtstag am 5. Juli 1969 überreicht von seinen Schülern. Wolfdietrich Fischer (ed.). Wiesbaden: Harrassowitz:153-164.

Hava, J.G. 1982. Al-Faraid Arabic-English Dictionary. Beirut: Dār al-Mašriq.

Henkin, Roni. 2008. "Negev Arabic", Encyclopedia of Arabic Language and Linguistics (Vol. III). Kees Versteegh (gen. ed.), Mushira Eid, Alaa Elgibali, Manfred Woidich, Andrzej Zaborski (ass. eds). Leiden - Boston: Brill:360-369.

Hinds, Martin and Said Badawi. 1986. A Dictionary of Egyptian Arabic. Beirut: Librairie du Liban.

Hobbs, Joseph J. 1989. Bedouin Life in the Egyptian Wilderness. Cairo: American University in Cairo Press.

- 1995. Mount Sinai. Austin: University of Texas Press.

Holes, Clive and Said Salman Abu Athera. 2009. Poetry and Politics in Comtemporary Bedouin Society. Reading: Ithaca Press.

Hopkins, Simon. 1990. "The word gayr", in: Stewart 1990:297-300.

Ingham, Bruce. 1986. "Notes on the Dialect of the Āl Murra of Eastern and Southern Arabia". Bulletin of the School of Oriental and African Studies XLIX:271-291.

Jong, Rudolf E. de. 2000. A Grammar of the Bedouin Dialects of the Northern Sinai Littoral, Bridging the Linguistic Gap between the Eastern and Western Arab World. Leiden, Boston, Köln: Brill.

—. 2002. "Notes on the Dialect of the "Abābda". Sprich doch mit deinem Knechten Aramäisch, wir verstehen es, Festschrift für Otto Jastrow, W. Arnold and H. Bobzin (eds.). Wiesbaden: Harrassowitz:337-359.

Maiberger, Paul. 1984. Topographische und historische Untersuchungen zum Sinaiproblem. Worauf beruht die Identifizierung des Ğabal Mūsā mit dem Sinai? Orbis Biblicus et Orientalis 54. Freiburg: Universitätsverlag / Göttingen:Vandenhoeck \& Ruprecht.

Murray, George W. 1935. Sons of Ishmael. A Study of the Egyptian Bedouin. London: Routledge.

Nishio, Tetsuo. 1992. A Basic Vocabulary of the Bedouin Arabic Dialect of the Jbāli Tribe. Studia Sinaitica I. Tokyo: Institute for the Study of Languages and Cultures of Asia and Africa.

Oppenheim, Max Freiherr von. 1943. Die Beduinen, Band II, Die Beduinenstämme in Palästina, Transjordanien, Sinai, Hedjāz. Leipzig: Otto Harrassowitz.

Palva, Heikki. 1984-1986. "Characteristics of the Arabic Dialect of the Hwēțāt Tribe". Orientalia Suecana 33-35:295-312.

_ 1991. "Is there a North West Arabian Dialect Group?", in: M. Forstner (ed.) Festgabe für Hans-Rudolf Singer, zum 65. Geburtstag am 6. April 1990 überreicht von seinen Freunden und Kollegen, Part 1. Frankfurt: Peter Lang:151-166.

— . 2004. "Remarks of the Arabic Dialect of the Ḥwētāat Tribe". Jerusalem Studies in Arabic and Islam 29:195-209.

- 2008a. "Sedentary and Bedouin Dialects in Contact: Remarks on Karaki and Salți (Jordan)". Journal of Arabic and Islamic Studies 8:53-70.

- 2008b. "Northwest Arabian Arabic", Encyclopedia of Arabic Language and Linguistics (Vol. III). Kees Versteegh (gen. ed.), Mushira Eid, Alaa Elgibali, Manfred Woidich, Andrzej Zaborski (ass. eds). Leiden - Boston: Brill:400-408.

Prochazka, Theodor. 1988. Saudi Arabian Dialects. London: Kegan Paul International.

Reichmuth, Stefan. 1983. Der arabische Dialeckt der Šukriyya im Ostsudan, Studien zur Sprachwissenschaft, Band 2. Hildesheim: Georg Olms Verlag.

Rosenhouse, Judith. 2006. "Bedouin Arabic", Encyclopedia of Arabic Language and Linguistics (Vol. I). Kees Versteegh (gen. ed.), Mushira Eid, Alaa Elgibali, Manfred Woidich, Andrzej Zaborski (ass. eds). Leiden - Boston: Brill: 259-269.

Sarnowski, Andrea von. 2004. "Tourismusentwicklung im Südsinai", in: Meyer, G. (ed.): Die arabische Welt im Spiegel der Kulturgeographie. Mainz: 383-389. 
Shawarbah, Musa. 2007. The Bedouin Dialect of the Tiyāha in the Negev: Phonology, Morphology and Some Selected Syntactic Issues. Unpublished PhD-thesis (in Hebrew, summary in English) Hebrew University of Jerusalem.

Stanley, Arthur Penrhyn. 1856. Sinai and Palestine in Connection with their History. London: John Murray of Albemarle Street.

Stewart, Frank Henderson. 1987. "A Bedouin Narrative from Central Sinai". Zeitschrift für Arabische Linguistik 16:44-92.

. 1990. Texts in Sinai Bedouin Law, Part 2. The Texts in Arabic. Wiesbaden: Harrassowitz.

—. 1991. "Notes on the Arrival of the Bedouin Tribes in Sinai". Journal of the Economic and Social History of the Orient XXXIV, part I:97-110.

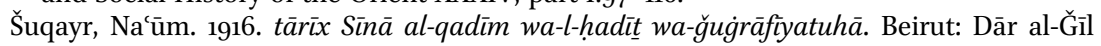
(reprint of 1916).

Wehr, Hans. 1980. A Dictionary of Modern Written Arabic, third printing (reprinted in Beirut, by special arrangement with Otto Harrassowitz). Beirut: Librairie du Liban.

Woidich, Manfred. 1997. "Egyptian Arabic and Dialect Mixing in Historical Perspective", Asma Afsaruddin and A.H. Mathias Zahniser (eds.), Humanism, Culture and Language in the Near East, Studies in Honor of Georg Krotkoff. Winona Lake, Indiana: Eisenbrauns:185-197.

- 2006. Das Kairenisch-Arabische, eine Grammatik. Wiesbaden: Harrassowitz Verlag. Woidich, Manfred and Peter Behnstedt. 1980. "Zum Sprachatlas von Ägypten”. Zeitschrift für Arabische Linguistik 5:176-192. 



\section{INDEX}

In terms of alphabetical order, indices in transcription are treated as if they were without diacritics. 'ayn precedes 'a', and hamzah precedes 'ayn. Forms with word-initial hamzah are listed under the following vowel. Where reference is to two or more of the descriptive chapters (multiple references), the Roman numbering (of the chapters) does not precede the numbering of the paragraphs referred to. Where reference is to only one of the descriptive chapters, the Roman numbering does precede the paragraph numbers. Such single references are listed following the multiple references. E.g., a multiple reference 1.2.3/4. refers to chapters I, II and III, paragraphs 1.2.3. and 1.2.4.

\section{'ād, 4.12}

'alām + suffix $\rightarrow$ interrogatives

$a:$ initial $\longrightarrow$ initial $a$

$a$-insertion $\rightarrow$ phonotactics,

gahawah-syndrome

$a$-raising $\rightarrow$ phonology, raising of $a$ accumulation of isoglosses, Conclusions,

III, $\mathrm{f}$.

adverbs, 3.1.15.

affricates $\rightarrow$ phonology

affrication of ${ }^{*} k$ and ${ }^{*} q$ : absence of-, 1.1.3.

allophones $\rightarrow$ phonology

alveolar stop: emphatic-/ț/, 1.1.5.

analogy: reasoning by-, I, 3.1.12.2., I, 3.1.16., II, 1.2.4.2.

analytical genitive $\rightarrow$ genitive marker

anaptyxis, 2.3 .

word medial一, 2.3.1.

in sandhi, 2.3.2.

in clusters resulting from "colliding" morphological base forms, 2.3.2.1.

in \# CC and CC \#, 2.3.2.2.

consonant clusters resulting from I-elision in sandhi, with consequent anaptyxis, 2.3.2.3.

resyllabication of word medial

CVCCICV, 2.3.2.4.

cyclic anaptyxis rule in sandhi, 2.4.3.

exceptions to the-rule, 2.3.3.

unresolved consonant clusters, 2.3.3.1.

some special cases with regard to

anaptyxis, $2 \cdot 3 \cdot 3 \cdot 3$

consonant clusters with initial

geminates, 2.3.3.3.1.

preposition 'ind $+\mathrm{C}, 2 \cdot 3 \cdot 3 \cdot 3 \cdot 2$.

the 2nd sg. masc. pron. suff. in

consonant clusters, $2 \cdot 3 \cdot 3 \cdot 3 \cdot 3$.

phonetic quality of the anaptyctic, 2.3.4. of word-medial anaptyctics, 2.3.4.1. in clusters form "colliding" base

forms, 2.3.4.1.1.

in clusters after I-elision, 2.3.4.1.2.

of anaptyctics in sandhi, 2.3.4.2.

of word-initial anaptyctics in sandhi, 2.3.4.2.1.

of word-final anaptyctics, $2 \cdot 3 \cdot 4 \cdot 2.2$.

stressed original anaptyctics, 2.3.5.

annexation, indirect- $\rightarrow$ genitive marker

direct-, 3.1.10/11.

apocopation, 3.2.2.5.1., 3.2.2.5.2., 3.2.2.5.3.,

3.2.3.5.4., 3.2.2.6.1., 3.2.3.3.1., 3.2.3.5.2.,

3.2.3.6.1., 3.2.3.7.3., 3.2.3.7.5., 3.2.3.7.5.,

$3 \cdot 2 \cdot 3 \cdot 9$.

apocopated imperfect, 3.2.2.5.2.

arrival: dating the - of Bedouin tribes

in central and southern Sinai,

Introduction, I.d.

article, 3.1.9.1.

articulatory delay $\rightarrow$ phonotactics

$a r^{\prime} \rightarrow$ presentative particles

assimilation, 2.5 .

auxiliaries, $4 \cdot 7$.

b-imperfect, $4 \cdot 3$.

backing environment $\rightarrow$ velarization

base: morphophonemic-, 1.2.4.6.2.1.,

2.3.2.1., 2.3.2.3., 2.3.4.1.1., Introduction

II, b., I, 1.2.4.4., 2.1.1.1., 2.1.2.1., 2.3.5.,

3.1.1.8., 3.1.5., 3.1.6., 3.2.2.3., II, 3.2.3.1.1., III,

2.1.1.2.2., 2.3.4.1.1., 3.2.3.3.1., Conclusions,

III, e.

bidd $\rightarrow$ widd + pron. suffix

bišwē̌s $\rightarrow$ "slowly, carefully"

$b t \bar{a}^{c} \rightarrow$ genitive marker

bukaṛa-syndrome, 2.2.2.1.

${ }^{*} \mathrm{C}_{1} \mathrm{aC}_{2} \mathrm{C}_{3}(\mathrm{ah})$
patterns 
${ }^{*} \mathrm{CaCiC}(\mathrm{ah}) \rightarrow$ reflexes of nominal patterns change: process(es) of-, I, 2.1.1.1.,

Conclusions, III d./e.

clusters of consonants $\rightarrow$ anaptyxis coincidence of isogloss bundles with tribal boundaries, Conclusions, II, f. colours, 3.1.7.

"come": the verb- $\rightarrow$ verbal morphology concord, 4.16.

conditional particles, $4 \cdot 7 \cdot 3$.

absence of conditional particle, 4.7.3.2.

in $+k \bar{a} n, 4 \cdot 7 \cdot 3.1 .1$.

suffixed inkān, 4.7.3.1.2.

$k \bar{a} n$ preceded by the CA loans $i z$ or iza, 4.7.3.1.4.

$k \bar{a} n$ as an independent conditional, $4 \cdot 7 \cdot 3 \cdot 1 \cdot 5$

kān, inkān or ilkān introducing alternatives, 4.7-3.1.6.

variations on $k \bar{a} n$ as a conditional particle, $4 \cdot 7 \cdot 3.1$.

conditioning: morphological_-of the short

high vowel $\rightarrow$ phonology

conjunctions, 4.6.

lamma and yōm, 4.6.1.

yōm, 4.6.1.1.

yōm used independently, 4.6.1.1.1.

yōm in combination with in,

4.6.1.1.2.

yōmin used independently,

4.6.1.1.2.1.

yomin + obj. suffix as subj. of the clause, 4.6.1.1.2.2.

min yōm, 4.6.1.1.2.3.

( $m$ in) $y \bar{o} m$ in combination with $m \bar{a}$, 4.6.1.1.2.4.

lamma, 4.6.1.2.

lamma "when" used independently, 4.6.1.2.1.

lamma + in, 4.6.1.2.2.

lamma "until", 4.6.1.2.3.

lōm $(+$ in $), 4.6 .1 .3$.

hatta, 4.6.2.

hatta "until", "so that", 4.6.2.1.

hatta + in, 4.6.2.2.

consequent action $\rightarrow$ verbal particles

consonants, 1.1.

construct state $\rightarrow$ genitive construction contact: (dialect)—, Introduction, I, e., III,

1.13.1., Conclusions, II, a., Conclusions,

III, a./d./e., Conclusions, IV, c.,

Conclusions, $\mathrm{V}$

continuum, Introduction, I, e.,

Introduction, III, a., Conclusions, I, a.,

Conclusions, III, b./c., Conclusions IV, b. convergence, Conclusions, IV.c.

criteria for comparison, Introduction, III,

a., Conclusions, I, a., Conclusions, II,

a./b., Conclusions, III, a./b./c./d./e.

${ }^{*} \mathrm{C}_{1} \mathrm{uC}_{2} \mathrm{C}_{3}(\mathrm{ah}) \rightarrow$ reflexes of nominal patterns

cyclicity of anaptyxis rule $\rightarrow$ anaptyxis

$\mathrm{d} \rightarrow$ reflex of $* \mathrm{~d}$ and $* \mathrm{~d}$

$\underline{\mathrm{d}} \rightarrow$ reflex of * $\mathrm{d}$ and $* \dot{\mathrm{d}}$

dative: ethical $\longrightarrow$ narrative style

defects: mental—, 3.1.7.

defects: physical-, 3.1.7.

deixis, 3.1.13.1.

delay: articulatory $-\rightarrow$ phonotactics

demonstratives, 3.1.13.

derived verbal measures, 3.2.3.

devoicing of final voiced stops, liquids and nasals in pause, 1.1.10., 2.5.

"différentiel", 2.4., $\rightarrow$ elision of short vowels diffuse situation(s): Conclusions, IV.d.

diminutive patterns, 3.1.6.

diphthongs, 1.2.4.

dissonorization $\rightarrow$ devoicing

distance: typological-, Introduction, I. a.,

Conclusions, III. a., b., d, IV, a., b., c.

distribution of Bedouin tribes in central and southern Sinai, Introduction, I, c., Appendix

doubling:

of $-n, 2.3 \cdot 3 \cdot 3 \cdot 3 ., 3.1 .16 ., 3 \cdot 2.2 .5 .1 ., 3.2 .2 .6 .1$. of non-final $l$ in pl. demonstratives, 3.1.13.1.

of $k$ in deictic forms, 3.1.13.1.

dual, 3.1.18.

'Eigenschafts' verb-type, 3.2.1.3.

ejective plosive $t^{\prime} \rightarrow$ glottalization

elative patterns $\mathrm{aC}_{1} \mathrm{C}_{2} \mathrm{aC}_{3}, \mathrm{aC}_{1} \mathrm{aC}_{2} \mathrm{C}_{3}$ and $\mathrm{aC}_{1} \mathrm{C}_{2} \mathrm{a}$, 3.1.8.

elision of short vowels, 2.4 .

morphophonemic I-elision, 2.4.1.

I-elision in sandhi, 2.4.2.

exceptions to the I-elision rule, 2.4.4.

ellipsis, III, 3.1.9.1., 3.1.13.1.

emphatic $/ \mathrm{t} / \rightarrow$ alveolar stop

emphatization $\rightarrow$ velarization

epenthesis $\rightarrow$ anaptyxis

ethical dative $\rightarrow$ narrative style

feminine morpheme or suffix $\rightarrow$ T-morpheme

fih "there is/are", 4.5.

fluctuation: phonetic $-\rightarrow$ overlapping

fricatives $\rightarrow$ phonology 
future marker, 4.4.

futurity $\rightarrow$ future marker; widd + pron. suffix

$\check{g} \rightarrow$ phonology: post alveolar affricate / $\breve{g} /$

gahawah-syndrome, 2.2.1.

$a$-insertion in *aXC, 2.2.1.1.

morphological categories showing variation, 2.2.1.2.

morphological categories in which the-is not active, 2.2.1.3.

$g \bar{a} m \rightarrow$ verbal particles

gayr, 4.9 .

gemination $\rightarrow$ doubling

genitive construction, 3.1.10/11.

genitive exponent $\rightarrow$ genitive marker

genitive marker, 3.1.11.

glottal stop (hamzah), 1.1.6.

glottalization of final ${ }^{*}-\bar{a}\left({ }^{\prime}\right) \rightarrow$ reflexes of final ${ }^{*}-\bar{a}\left({ }^{\prime}\right)$

glottalization of $t$, 1.1.5.

\section{hamzah $\rightarrow$ glottal stop}

haplology, 3.1.15.1., 3.2.3.5.4., $\rightarrow$ reduction of initial geminates

harmony: vowel-, 3.2.1.2., 3.2.1.5., 3.2.2.1., 3.2.3.1.3., 3.2.3.6.1., 3.2.3.7.3., I, 3.1.13.1., III, 3.2.1.3., 3.2.2.4.1./2., 3.2.2.5.2., 3.2.2.6.1./2., 3.2.2.7.1., 3.2.3.1.1.

hatta $(n) \rightarrow$ conjunctions

$h \bar{a} y \rightarrow$ presentative particles

heavy sequences $\rightarrow$ stress

I, 1.2.3.2.

I: absence of -in open syllables preceding stress, 3.1.5.

I-elision $\rightarrow$ elision

ilkān $\rightarrow$ conditional particles

imālah $\rightarrow$ raising of $a$, reflexes of final ${ }^{*}-\bar{a}\left({ }^{\prime}\right)$, T-morpheme

indirect annexation $\rightarrow$ genitive marker initial $a$, 3.1.9.

the article and relative pronoun, 3.1.9.1. other instances of initial $a, 3.1 .9 .2$.

inkān $\rightarrow$ conditional particles

insertion of $a \rightarrow$ gahawah-syndrome intensifying particle $l a, 4.10$.

interdental fricatives $/ \underline{t} /, / \underline{d} /$ and $/ \underline{d} /$, 1.1.2. interdialect form(s), Conclusions, III. d.

interrogatives, 3.1.14.

inventory of phonemes $\rightarrow$ phonology irregular verbs $\rightarrow$ verbal morphology ir ${ }^{\prime} \rightarrow$ presentative particles isolating phonemes $\rightarrow$ phonology $i z(a) k \bar{a} n \rightarrow$ conditional particles $j \rightarrow$ phonemes $(/ \check{\mathrm{g}} /)$

k, 1.1.1., 3.1.12.2.

K-form(s), I, 1.1.6., 1.2.4.4., 3.1.11., 3.1.15.1., II, 3.1.2., 3.1.11., 4.5.

$k \bar{a} n \rightarrow$ conditional particles, narrative style koineization, Conclusions, IV.d.

$k \bar{u} d \rightarrow$ "maybe"

labialization: (effects of $)-$, 2.3.2., 3.1.1.9.

$\operatorname{lamma}(n) \rightarrow$ conjunctions

lengthening: prosodic — of vowels and diphthongs, 1.2.3.5., 1.2.4.7.

levelling, Conclusions, IV.c./d. paradigmatic-, I, 3.1.16., 3.2.2.4.2., 3.2.2.5., III, 3.2.3.1.3.

liquids $l$ and $r$, 1.1.8., 2.2.2.

$\operatorname{loan}(\mathrm{s})$, 1.1.2., 2.2.1.3., 3.1.5., 3.2.3.6.2., 4.1., 4.7.3.1.4., I, 1.2.3.4.3.2., 1.2.4.1., 3.1.1.8., 3.2.2.1., 3.2.3.4.5., 3.2.3.5.5., II, 3.2.3.2., III, $3 \cdot 2 \cdot 3 \cdot 6 \cdot 3$.

$\operatorname{lom}($ in $) \rightarrow$ conjunctions

long vowels $\rightarrow$ phonology

"maybe", 3.1.15.2. xäfallah "maybe", 3.1.15.2.1.

kūd "maybe", 3.1.15.2.2.

measures: verbal $\longrightarrow$ verbal morphology mediae geminatae $\rightarrow$ verbal morphology mediae infirmae $\rightarrow$ verbal morphology

mental defects $\rightarrow$ defects

merging of *d and ${ }^{*} d$, 1.1.2.

minimal pairs $\rightarrow$ phonology

monophthongization, 1.2.4.1.

morphological restructuring $\rightarrow$

restructuring

morphology $\rightarrow$ nominal morphology,

verbal morphology

morphophonemic elision $\rightarrow$ elision

Nağdiy type of dialect(s), Conclusions, II, a., Conclusions, V, Conclusions, VI, a. narrative style: characteristics of the-, 4.14. imperative of narration, 4.14.1.

$k \bar{a} n$ as a temporal marker, 4.14.2. dativus ethicus, 4.14.3.

nasal $n, 2.2 .2 .3$.

necessity $\rightarrow$ widd + pron. suffix

negation, 4.2.

nominal morphology, 3.1.

raising of $a$, 3.1.1. in ${ }^{*} \mathrm{CaC} \mathrm{i} \mathrm{C}(\mathrm{ah})$, 3.1.1.1. in ${ }^{*} \mathrm{C}_{1} \mathrm{aC}^{\frac{3}{1}} \mathrm{C}_{3}(\mathrm{ah})\left(\mathrm{C}_{3} \neq y\right)$, 3.1.1.1.1. in ${ }^{*} \mathrm{C}_{1}^{1} \mathrm{aC}_{2}^{2} \mathrm{iC}_{3}^{3}(\mathrm{ah})\left(\mathrm{C}_{3}^{3}=y\right)$, 3.1.1.1.2. 
in open syllable preceding stressed $i$, 3.1.1.2.

in $\operatorname{CaCCīC}(a h)$, 3.1.1.3.

in $\mathrm{CaCCāC}(\mathrm{ah})$, 3.1.1.4.

in $\mathrm{CaC}_{2} \mathrm{C}_{2} \overline{\mathrm{a}}$, 3.1.1.4.1.

in $\mathrm{C}^{1} \mathrm{aC}^{2} \mathrm{C}^{2} \mathrm{an}$, 3.1.1.4.2.

in ... CaCắC..., 3.1.1.5.

in...CaCá ..., 3.1.1.6.

in open syllable preceding stressed

A, 3.1.1.7.

in $\mathrm{CaCu} C(\mathrm{ah})$, 3.1.1.8.

in open syllable preceding stressed ú, 3.1.1.9.

$a$-raising rules combined, 3.1.1.10.

reflexes of ${ }^{*} \mathrm{C}_{1} \mathrm{CC}_{2} \mathrm{C}_{3}(\mathrm{ah})$, 3.1.2.

reflexes of ${ }^{*} \mathrm{C}^{1} \mathrm{aC}_{2}^{2} \mathrm{iC}_{3}(\mathrm{ah})$, 3.1.3.

reflexes of ${ }^{*} \mathrm{C}_{1}^{1} \mathrm{uC}_{2} \mathrm{C}_{3}^{3}(\mathrm{ah})$, 3.1.4.

absence of short high vowels in open

syllables preceding stress, 3.1.5.

diminutive patterns, 3.1.6.

pattern $\mathrm{aC}_{1} \mathrm{C}_{2} \mathrm{aC}_{3}$, 3.1.7.

elative patterns of $\mathrm{aC}_{1} \mathrm{C}_{2} \mathrm{aC}_{3}, \mathrm{aC}_{1} \mathrm{aC}_{2} \mathrm{C}_{3}$ and $\mathrm{aC}_{1} \mathrm{C}_{2} \mathrm{a}, 3.1 .8$.

initial $a$, 3.1.9.

the article and the relative pronoun, 3.1.9.1.

other instances of initial $a, 3.1 .9 .2$.

the fem. suffix ( $\mathrm{T}$ ) in genitive

construction, 3.1.10.

$\mathrm{T}$ in genitive construction preceded by $a$ in open syllable, 3.1.10.1.

the rule for $\mathrm{T}$ not directly preceded by aC or $\bar{v}, 3.1 .10 .2$.

$\mathrm{T}$ preceded by gahawah-vowel $a$, 3.1.10.3.

T following $\bar{a}, 3 \cdot 1.10 .4$.

nominal ending -it in construction vs. verbal 3rd p. sg. perfect ending -at, 3.1.10.5.

genitive marker, 3.1.11.

personal pronominals, 3.1.12.

independent pronominals, 3.1.12.1.

pronominal suffixes, 3.1.12.2.(1./2.)

demonstratives, 3.1.13.

near and far deixis, 3.1.13.1.

specifying $h a-$, 3.1.13.2.

interrogatives, 3.1.14.

adverbs, 3.1.15.

adverbs "there", "over there (far

away)", "here", "thus", "now", "still",

"afterwards, after that", 3.1.15.1.

"maybe", 3.1.15.2.

xāfallah "maybe", 3.1.15.2.1.

kūd "maybe", 3.1.15.2.2. balhayl "very, extremely", 3.1.15.3.

bišwēš "slowly, carefully", 3.1.15.4.

min xawf "lest", 3.1.15.5.

prepositions + pers. pronominal

suffixes, 3.1.16.

numerals and counted plurals, 3.1.17.

cardinal numbers 1-10, 3.1.17.1.

ordinal numbers 1-10, 3.1.17.2.

numerals: 11 and up, 3.1.17.3.

the dual, 3.1.18.

North Arabian type of dialect $\rightarrow$ Nağdiy

numbers $\rightarrow$ numerals

numerals and counted plurals, 3.1.17.

cardinals 1-10, 3.1.17.1.

ordinals $1-10,3.1 .17 .2$.

numerals 11 and up, 3.1.17.3.

nunation, 4.1.

ordering of rules, 2.1.1., 2.3., 2.4., I, 3.1.15.1.,

II, 3.1.10.1., III, 3.2.1.3.

origins of Bedouin tribes in central and

southern Sinai, Introduction, I, a.,

Conclusions, V.

overlapping: phonetic - , 1.2.2.1.,

1.2.4.2., Conclusions, II, a., Conclusions, V.

parallel form(s), I, 3.1.9.1., 3.1.12.2., II, 1.1.3., 3.2.2.1., III, 3.2.2.5.1., Conclusions, I, a., Conclusions, III, a./c./d./g., Conclusions, IV, a., Conclusions, V.

partial isogloss(es), Conclusions, III, a./g. passive measure $\rightarrow$ measure $n-1$

pattern(s): morphological-, $\rightarrow$ reflexes of older * - $\rightarrow$ reflexes

pause

devoicing of final voiced stops,

liquids and nasals in-, 1.1.10.

diphthongization in-, 1.2.4.6.2.1.

glottalization in-, 1.1.6., 1.2.4.4.3.1., 1.2.4.4.6., 3.2.2.6.1.

raising in-, 1.2.3.4.3.3., 1.2.4.4., 3.1.13.1., Conclusions, II, a $\rightarrow$ phonology

'phantom' velarization $\rightarrow$ velarization

pharyngealization $\rightarrow$ velarization

phonemicity of stress, III 1.2.2.3., III 2.1.2.1.,

III 2.4.4.

phonemes $\rightarrow$ phonology

phonology, 1.

consonants, 1.1.

inventory of consonantal phonemes, 1.1.1.

interdental fricatives $/ \underline{t} /, / \underline{d} /$ and /d, 1.1.2.

velar stops $/ \mathrm{k} /$ and $/ \mathrm{g} /$, 1.1.3. 
post alveolar affricate / $\check{g} /$, 1.1.4.

emphatic alveolar stop /ț/, 1.1.5.

glottal stop (hamzah), 1.1.6.

secondary velarization, 1.1.7.

liquids $l$ and $r, 1.1 .8$.

nasal $n, 1.1 .9$.

devoicing of final of final voiced

stops, liquids and nasals in pause, 1.1.10.

vowels, 1.2.

inventory of vowel phonemes, 1.2.1.

long vowels, 1.2.2.

allophones of-, 1.2.2.1.

allophones of- $/ \overline{\mathrm{o}} /$ and $/ \overline{\mathrm{u}} /, \mathbf{1 . 2 . 2 . 2}$.

allophones of $-/ \bar{a} /, 1.2 .2 .3$.

shortening of-, 1.2.2.4.

short vowels, 1.2.3.

isolating phonemes $/ \mathrm{i} /, \mathrm{u} /$ and $/ \mathrm{a} /$, 1.2.3.1.

phonetic factors influencing the phonetic quality of I, 1.2.3.2.

morphological conditioning of the short high vowel, 1.2.3.3.

allophones of short vowels, 1.2.3.4.

of $/ \mathrm{i} /, \mathbf{1 . 2} \cdot 3 \cdot 4.1$.

of $/ \mathrm{u} /, 1.2 \cdot 3 \cdot 4.2$.

of $/ a /, 1.2 \cdot 3 \cdot 4 \cdot 3$.

/a/ in non-raised positions, 1.2.3.4.3.1.

raising of $\left({ }^{*}\right) / \mathrm{a} /$ in open syllable preceding long stressed vowels, 1.2.3.4.3.2.

raising of the feminine suffix $(\mathrm{T})$,

1.2.3.4.3.3., 1.2.4.4., 3.1.13.1.,

Conclusions, II, a

long vowels and diphthongs, 1.2.4. monophthongization of diphthongs *ay and *aw, 1.2.4.1.

isolating long vowels $/ \overline{\mathbf{l}} /, / \overline{\mathrm{u}} /, / \overline{\mathrm{a}} /, / \overline{\mathrm{e}} /$ and $/ \overline{0} /$ as phonemes, 1.2.4.2.

allophones of $/ \bar{a} /$, 1.2.4.3.

reflexes of final * $-\bar{a}\left({ }^{\prime}\right)$, 1.2.4.4.

raising of final ${ }^{*}-\bar{a}\left({ }^{\prime}\right), 1.2 .4 \cdot 4$.

when preceded by * $a$ in open

syllable, 1.2.4.4.3.

phonetic factors inhibiting raising of final * $-\bar{a}\left({ }^{\prime}\right), 1.2 .4 .4$.

raising of final * $-\bar{a}\left({ }^{\prime}\right)$ in neutral

positions, 1.2.4.4.

glottalization of non-raised reflexes

of final * $-\bar{a}\left({ }^{\prime}\right)$, 1.2.4.4.

other exceptions to raising of of final

*- $\bar{a}\left({ }^{\prime}\right), 1.2 .4 .4$.

suffixed older final of final * $-\bar{a}\left({ }^{\prime}\right)$, allophones of long vowel phonemes

$/ \overline{\mathrm{e}} /, / \overline{\mathbf{l}} /, / \overline{\mathrm{o}} /$ and $/ \overline{\mathrm{u}} /, \mathbf{1 . 2 . 4} \cdot 5$.

lowering effect of preceding emphatics on $/ \overline{\mathbf{l}} /$ and $/ \overline{\mathrm{u}} /$,

1.2.4.5.1.

off-glide in $/ \overline{\mathrm{e}} /$ and $/ \overline{\mathrm{i}} /, \mathbf{1 . 2 . 4 \cdot 5 \cdot 2}$.

off-glide in $/ \overline{\mathrm{o}} /$ and $/ \overline{\mathrm{u}} /, \mathbf{1 . 2 . 4 \cdot 5 \cdot 3}$.

diphthongs, 1.2.4.6.

reflexes of *ay and *aw, 1.2.4.6.1. in neutral environments, 1.2.4.6.1.1.

in non-neutral environments 1.2.4.6.1.2.

*ay and *aw preceded by $\mathrm{X}$, 1.2.4.6.1.2.1.

*ay and *aw preceded by M, 1.2.4.6.1.2.2

reduction of diphthongs ay and $a w, 1.2 .4 .6 .1 .2 .3$.

diphthongs $-i y$ and $-u w, 1.2 .4 .6 .2$. reflexes of final diphthongs *-1 and *-ū, 1.2.4.6.2.1.

prosodic lengthening of long vowels and diphthongs, 1.2.4.7.

phonotactics, 2.2.

the gahawah-syndrome, 2.2.1.

$a$-insertion in *aX sequences, 2.2.1.1.

morphological categories showing

variation, 2.2.1.2.

morphological categories in which

the-is not active, 2.2.1.3.

articulatory delay in the realization of alveolar sonorants (liquids $l, r$ and

$n), 2.2 .2$.

in the realization of $r, 2.2 .2 .1$.

influence of $l$, 2.2.2.2.

the high vowel preceding $l$ in *'ibil and *raǧil, 2.2.2.2.1.

in the realization of $n, 2.2 .2 .3$.

articulatory delay in the realization of "

following geminates, 2.2.3.

phylum, Conclusions, IV. c.

physical defects $\rightarrow$ defects

pitch, 5 .

pluralis paucitatis, $\mathbf{4 . 1 5}$.

plurals: counted $-\rightarrow$ numerals

post alveolar affricate / / $/$, 1.1.4.

prepositions + pers. pronominal suffixes, 3.1.16.

preposition 'ind + C, 2.3.3.3.2., 3.1.16., $\rightarrow$ anaptyxis

presentative particles, 4.8 .

ir' or $a r^{\prime}, 4.8 .1$.

hāy, 4.8.2. 


$$
\begin{aligned}
& \text { wlin } \sim \text { wilin, win, 4.8.3. } \\
& \text { wlä }+, 4.8 .4 \text {. } \\
& \text { primae hamzah, 2.3.5., } \rightarrow \text { verbal } \\
& \text { morphology } \\
& \text { primae } w \bar{a} w \rightarrow \text { verbal morphology }
\end{aligned}
$$
primae $y \vec{a} \rightarrow$ verbal morphology

pronominals, 3.1.12.

independent-, 3.1.12.1.

suffixed-, 3.1.12.2.

prosodic lengthening of vowels and diphthongs, 1.2.3.5., 1.2.4.7. prtototypes, Conclusions, III.c. purpose $\rightarrow$ widd + pron. suffix

*/q/ $\rightarrow$ phonology (phoneme /g/) quality: phonetic_-of I $\rightarrow$ phonology

rāḥ, 4.7.2., $\rightarrow$ verbal particles, future particle

raising of $a, 1.2 \cdot 3 \cdot 4 \cdot 3.2 ., 3.1 .1$.

raising $\rightarrow$ phonology, nominal morphology 'reappearance' of $a, 3.2 .1 .1 ., 3.2 .3 .1 .1$., $3 \cdot 2 \cdot 3 \cdot 3 \cdot 1 ., 3 \cdot 2 \cdot 3 \cdot 3 \cdot 4$.

'reappearance' of $\bar{a}, \mathbf{1 . 2 . 4} \cdot 4$.

reduction

of diphthongs, 1.2.4.6.1.2.3.

of geminated $\mathrm{C}_{2}, 2 \cdot 3 \cdot 3 \cdot 3 \cdot 1$.

of long vowels, 3.1.5.

of initial geminates, 3.1.5., 3.2.3.5.4., 3.2.3.6., 3.2.2.4.

reflexes

of *' (hamzah), 1.1.1/6.

of final *- $\bar{a}\left({ }^{\prime}\right), 1.2 .4 .4$.

of *ay and *aw, 1.2.4.6.1.

of $* \underline{d}, 1.1 .1 / 2$.

of ${ }^{*} d$ and ${ }^{*} d, 1.1 .1 / 2$.

of $* k$ and $* q, 1.1 .1 / 3$.

of ${ }^{*} r$, 1.1.1., 1.1.8.

of ${ }^{*} t, 1.1 .1 / 2$.

of ${ }^{*} t, 1.1 .1 / 7$.

of nominal pattern * $\mathrm{aC} \mathrm{C}_{2} \mathrm{aC}_{2}, 3.1 .7 / 8$.

of nominal pattern ${ }^{*} \mathrm{C}_{1}^{1} \mathrm{C}^{2} \mathrm{C}(\mathrm{ah}), 3.1 .2$.

of nominal pattern * CaCCāe $\left(\mathrm{C}_{1} \mathrm{C}_{2} \mathrm{C}_{2} \overline{\mathrm{a}} \mathrm{C}_{3}\right.$ or $\mathrm{CaC}_{2} \mathrm{C}$ ān), 3.1.1.4.1/2.

of nominal pattern ${ }^{*} \mathrm{CaCCīC}$, 3.1.1.3.

of nominal pattern ${ }^{*} \mathrm{CaCiC}(\mathrm{ah})$, 3.1.3.

of nominal pattern ${ }^{*} \mathrm{CaC}_{1} \mathrm{iC}(\mathrm{ah})$, 3.1.1.1.

of nominal pattern ${ }^{*} \mathrm{CaC}_{2} \overline{\mathrm{u}} \mathrm{C}_{3}(\mathrm{ah})$, 3.1.1.8.

of nominal pattern * $\mathrm{C}_{1}$ IC $\mathrm{a}_{2} \overline{\mathrm{a}}\left({ }^{\prime}\right)$, 1.2.4.4., 2.1.2.1., 2.3.5., 3.1.5.

of nominal pattern ${ }^{*} \mathrm{C}_{1} \mathrm{IC}_{2} \mathrm{aC}, 2.3 .4 / 5$., 3.1.5.

of nominal pattern ${ }^{*} \mathrm{C}_{1} \mathrm{uC}_{2} \mathrm{aC}_{3}(\mathrm{ah})$, 3.1.4. of verbal pattern ${ }^{*} \mathrm{C}_{1} \mathrm{aC}_{2} \mathrm{iC}, 3.2 .1 .1 ., \rightarrow$ verbal morphology

regular verbs $\rightarrow$ verbal morphology

relative pronoun, 3.1.9.1.

restructuring: morphological—, 1.2.4.4.,

3.1.1.1., 3.1.1.4.

resyllabication/resyllabification

in sandhi, 2.3.2.3/4., 3.1.12.2.1.

of the $\mathrm{CaCaCV}$ sequence, 2.1.1., 2.1.2.4., 2.2.1.3., 3.1.10.1., Conclusions, II.a., Conclusions, III.e., Conclusions, V.

of word-medial CVCCICV, 2.1.2.4., $\rightarrow$ anaptyxis

rule order $\rightarrow$ ordering of rules

sandhi

anaptyxis in $\rightarrow$ anaptyxis

elision in $-\rightarrow$ elision

sedentary dialectal characteristics, 4.3 .

shift: stress—, 3.1.5., 3.1.16., 2.1.3.2.1.,

Conclusions, $\mathrm{V}$.

short vowels, 1.2.3.2., 3.1.5., $\rightarrow$ phonology

short vowels: elision of $-\rightarrow$ elision

shortening of long vowels, 3.1.5., $\rightarrow$ reduction

"slowly, carefully" bišwēš, 3.1.15.4.

sonority, 2.2.2., 2.3.1., 2.3.3.2., $\rightarrow$ anaptyxis step method

stress, 2.1.

phonemicity of-, III 1.2.2.3., III 2.1.2.1., III 2.4.4.

rules for word-stress, 2.1.1.

in words with heavy sequences, 2.1.1.1. examples of - in words without heavy sequences, 2.1.1.2.

in $\mathrm{CvCvC}(\mathrm{v})(\mathrm{CaCaC}(\mathrm{v})$ and $\mathrm{CiCiC}$, 2.1.1.2.1.

in $(\mathrm{C}) \mathrm{vCvCvC}$ and $(\mathrm{C}) \mathrm{v} \operatorname{CvCvCv}(\mathrm{C})$, 2.1.1.2.2.

in $\mathrm{aCCaCaC}(\mathrm{v})$, 2.1.1.2.2.

in $\operatorname{aCCaCaCv}(\mathrm{C})$, 2.1.1.2.2.

exceptions to the stress rule, 2.1.2. on reflexes of ${ }^{*}-\bar{a}\left({ }^{\prime}\right), 2.1 .2 .1$.

on final nominal *-iy, 2.1.2.2.

on al/il + CaCīy, 2.1.2.3.

in suffixed gahawah-forms, 2.1.2.4.

in vCCICv, 2.1.2.5.

stress units, 2.1.3.

in combinations with preposition min, 2.1.3.1.

enclitically suffixed prepositions $l$ and $b, 2.1 .3 .2$.

enclisis of the suffixed preposition l, 2.1.3.2.1. 
enclisis of the suffixed preposition

$$
b, 2.1 .3 .2 .2 \text {. }
$$

stressed anaptyctics $\rightarrow$ anaptyxis

šug $l \rightarrow$ genitive marker

sunletters, 2.5 .

syllabication in sandhi, 2.3.2.3/4.

Systemzwang, 1.2.4.6.1.2.3.

\section{T-morpheme}

raising of, 1.2.3.4.3.3.

the fem. suffix (T) in genitive

construction, 3.1.10.

in genitive construction preceded by $a$ in open syllable, 3.1.10.1.

the rule for $\mathrm{T}$ not directly preceded by $\mathrm{aC}$ or $\overline{\mathrm{v}}$, 3.1.10.2.

$\mathrm{T}$ preceded by the gahawah-vowel $a$, 3.1.10.3.

$\mathrm{T}$ preceded by $\bar{a}, 3 \cdot 1.10 .4$.

nominal ending -it in construction vs. 3 rd p. sg. perfect ending - $a$, 3.1.10.5.

taba $\rightarrow$ genitive marker

tanwìn $\rightarrow$ nunation

tertiae infirmae $\rightarrow$ verbal morphology

typological distance, Introduction, I, a.,

Conclusions, III, a./b./d., Conclusions,

IV, a./b./c.

'vanished' $u$ or $i$, 1.1.8., 1.2.3.2., III, 1.2.4.3., $\rightarrow$ velarization

velar stops $/ \mathrm{k} /$ and $/ \mathrm{g} /$, 1.1.3.

velarization: (effects of ): (secondary) -

1.1.2., 1.1.7./8., 1.2.2.1./2./3., 1.2.3.2./3.,

1.2.3.4.3.3., 1.2.4.2./4., 1.2.4.5.1., 1.2.4.6.1.1.,

1.2.4.6.1.2.2., 2.3.4.2.1., 3.1.1.9./10., 3.1.12.2.,

3.1.13.1., 3.2.1.3., 3.2.2.1./3., 3.2.2.5.2.,

3.2.2.7.1., 3.2.3.8.

'phantom'-, III, 3.2.2.3., $\rightarrow$ vanished

verbal measures $\rightarrow$ verbal morphology

verbal morphology, 3.2.

regular verbs, 3.2.1.

perfect, 3.2.1.1.

imperfect, 3.2.1.2.

reflexes of older ${ }^{*} \mathrm{C}_{1} \mathrm{aC}_{2} \mathrm{uC}_{3}, \mathrm{yaC}_{1} \mathrm{C}_{2} \mathrm{uC}_{3}$, 3.2.1.3.

participles, 3.2.1.4.

imperatives 3.2.1.5.

irregular verbs, 3.2.2.

$\mathrm{C}_{1}=w$ (primae $\left.w \bar{a} w\right), 3 \cdot 2.2 .1$.

$\mathrm{C}_{1}^{1}=y($ primae $y \vec{a})$, 3.2.2.2.

$\mathrm{C}_{1}={ }^{*}$ (primae hamzah), 3.2.2.3.

$\mathrm{C}_{2}=w$ or $y$ (mediae infirmae), 3.2.2.4. perfect and imperfect, 3.2.2.4.1. imperatives, 3.2.2.4.2.

participles, 3.2.2.4.3.

$\mathrm{C}_{3}=y$ (tertiae infirmae), 3.2.2.5.

perfect, 3.2.2.5.1.

imperfect, 3.2.2.5.2.

imperatives, 3.2.2.5.3.

participles, 3.2.2.5.4.

verbal nouns, 3.2.2.5.5.

the verb "come", 3.2.2.6.

perfect and imperfect, 3.2.2.6.1.

imperatives, 3.2.2.6.2.

participles, 3.2.2.6.3.

$\mathrm{C}_{2}=\mathrm{C}_{3}$ (mediae geminatae), 3.2.2.7.

perfect and imperfect, 3.2.2.7.1.

imperatives, 3.2.2.7.2.

participles, 3.2.2.7.3.

derived measures, 3.2.3.

measure $n-1,3.2 .3 .1$.

sound roots, 3.2.3.1.1.

$\mathrm{C}_{2}=\mathrm{C}_{3}$ (mediae geminatae), 3.2.3.1.2.

$\mathrm{C}_{2}=y$ or $w$ (mediae infirmae), 3.2.3.1.3.

participles, 3.2.3.1.4.

measure $t$-1, 3.2.3.2.

measure $1-t, 3 \cdot 2 \cdot 3 \cdot 3$.

sound roots, 3.2.3.3.1.

$\mathrm{C}_{2}=y$ or $w$ (mediae infirmae),

3.2.3.3.2.

$\mathrm{C}_{2}=\mathrm{C}_{3}$ (mediae geminatae), 3.2.3.3.3.

participles, 3.2.3.3.4.

measure (a)sta-1/(i)sta-1, 3.2.3.4.

sound roots, 3.2.3.4.1.

$\mathrm{C}_{2}=y$ (mediae infirmae), 3.2.3.4.2.

$\mathrm{C}_{3}=y$ (tertiae infirmae), 3.2.3.4.3.

$\mathrm{C}_{2}^{3}=\mathrm{C}_{3}$ (mediae geminatae), 3.2.3.4.4.

participles, 3.2.3.4.5.

measures 2 and $t-2,3 \cdot 2 \cdot 3 \cdot 5$.

sound roots, 3.2.3.5.1.

tertiae infirmae, $3 \cdot 2 \cdot 3 \cdot 5 \cdot 2$.

primae hamzah, 3.2.3.5.3.

perfect and imperfect, 3.2.3.5.4.

verbal nouns, 3.2.3.5.5.

participles, 3.2.3.5.6.

measures 3 and $t-3,3 \cdot 2 \cdot 3 \cdot 6$.(1.)

participles 3.2.3.6.2.

verbal nouns, 3.2.3.6.3.

measure $4,3.2 .3 .7$.

sound roots perfect and imperfect, 3.2.3.7.1.

mediae infirmae $\left(\mathrm{C}_{2}=w\right.$ or $\left.y\right)$, 3.2.3.7.2.

tertiae infirmae $\left(\mathrm{C}_{3}={ }^{*} w\right.$ or $\left.y\right)$ perfect and imperfect, 3.2.3.7.3. 
primae $w \bar{a} w\left(\mathrm{C}_{1}=w\right)$ perfect and imperfect, 3.2.3.7.4.

mediae geminatae $\left(\mathrm{C}_{2}=\mathrm{C}_{3}\right)$ perfect and imperfect, 3.2.3.7.5.

imperatives, 3.2.3.7.6. participles, 3.2.3.7.7.

measure $9,3.2 .3 .8$.

quadriliteral verbs, 3.2.3.9.

verbal particles, 4.7 .

gām, 4.7.1.

rāạh, 4.7.2.

$b$ - $\rightarrow b$-imperfect

$h a-$ / ha- $\rightarrow$ future particle

"very, extremely" balhayl, 3.1.15.3.

'virtual' isogloss bundle(s), Conclusions,

III, a./g., Conclusions, IV, b./c.

volition $\rightarrow$ widd + pron. suffix vowel harmony $\rightarrow$ harmony vowels $\rightarrow$ phonology

"want" $\rightarrow$ widd + pron. suffix widd + pronominal suffix, 4.11. wilin $\rightarrow$ presentative particles win $\rightarrow$ presentative particles wlin $\rightarrow$ presentative particles word-stress $\rightarrow$ stress

$x a \overline{f a l l}$ ah $\rightarrow$ "maybe" xawf: $\min \rightarrow$ "lest"

yabga, 4.13.

yōm(in) $\rightarrow$ conjunctions

$\check{z} \rightarrow$ phonology: post alveolar affricate / $\check{g} /$ 
APPENDIX 



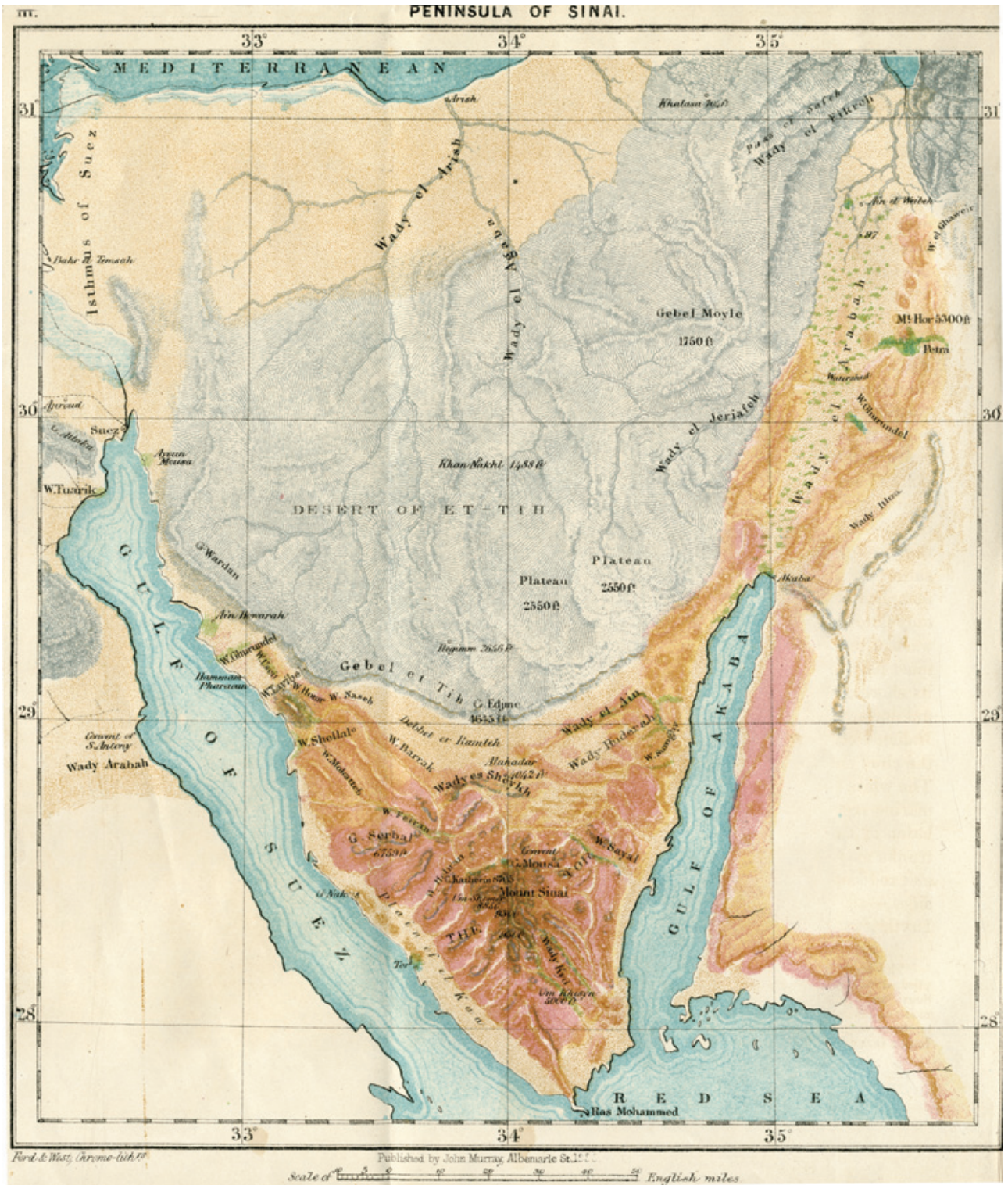

Figure 1. Peninsula of Sinai. From: Stanley, Arthur Penrhyn. 1856. Sinai and Palestine in Connection with their History. London: John Murray of Albemarle Street. Reproduced by courtesy of the Leiden University Library. 


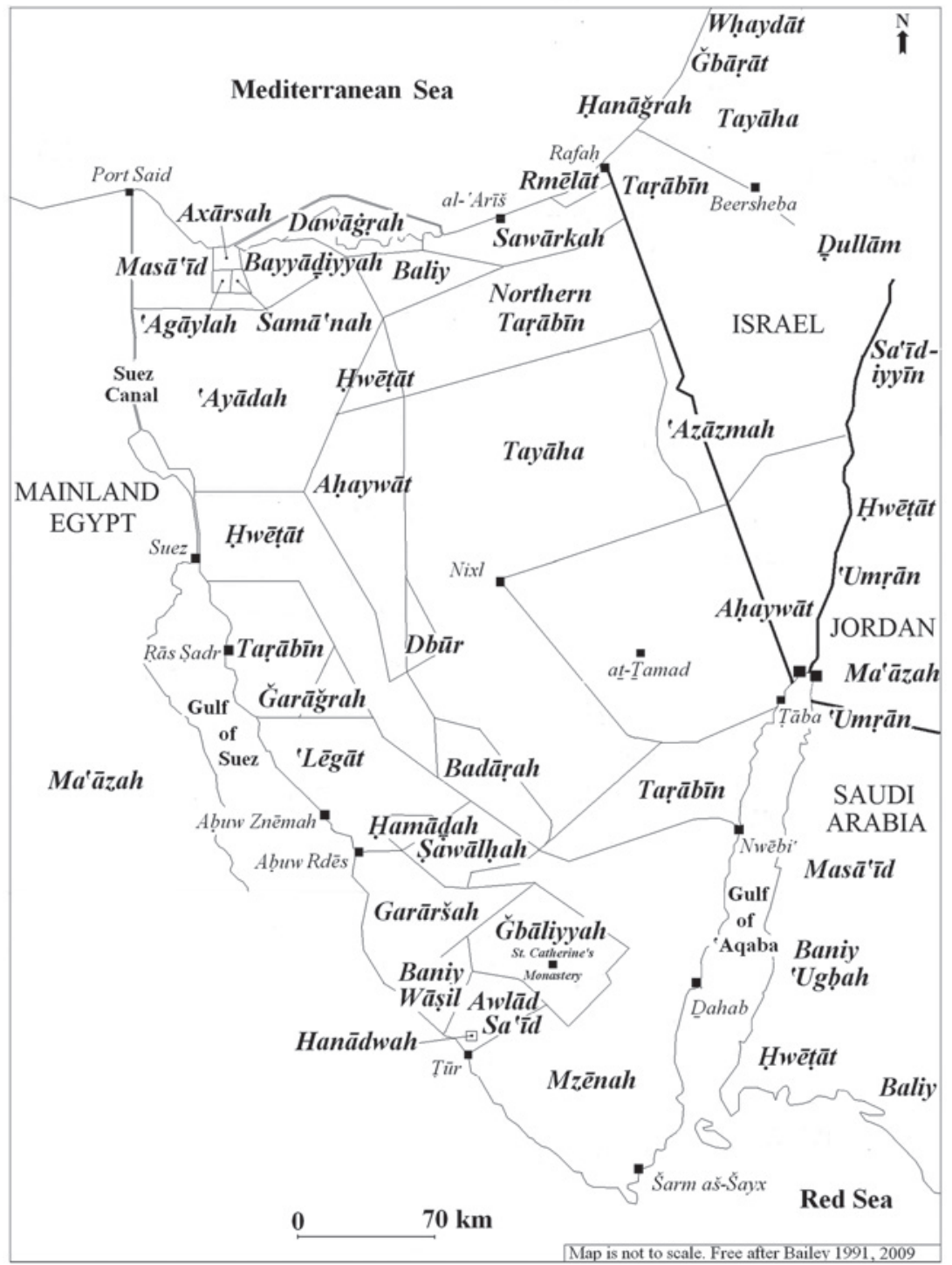

Figure 2. Approximate distribution of Bedouin tribes in Sinai and surrounding regions 
Object Points

Common Space

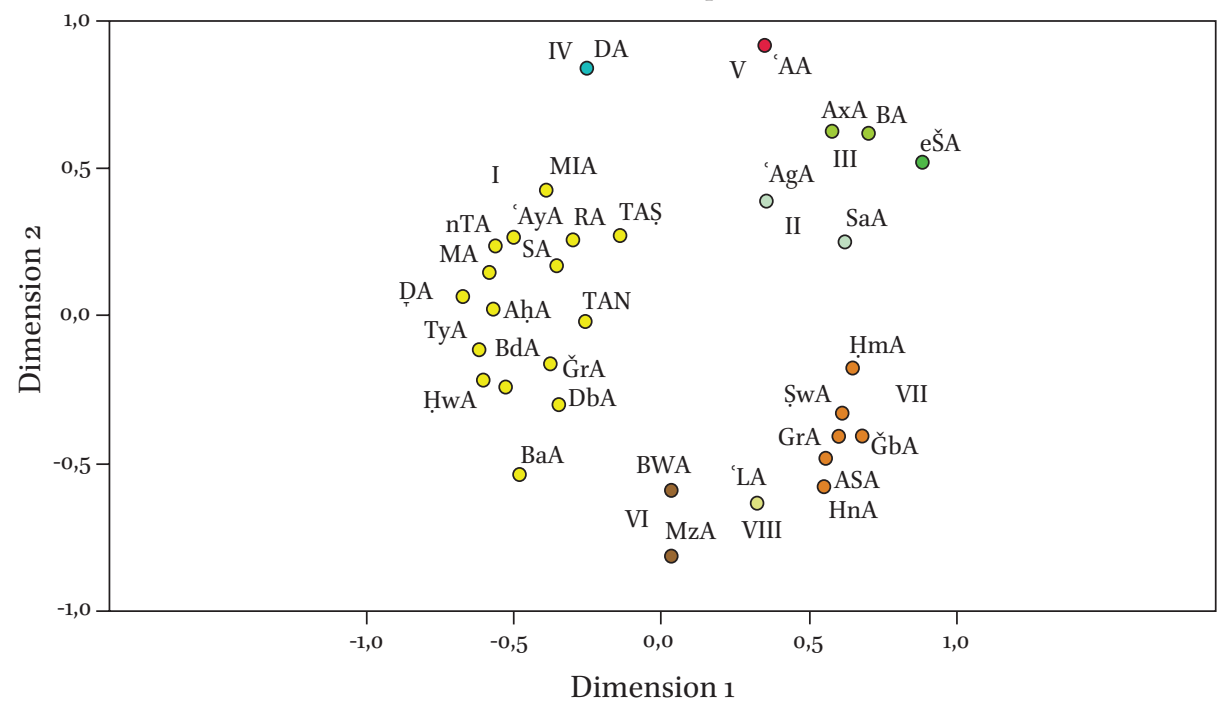

Figure 3. Proxscal—Euclidian Binary MDS plot of dialects of Sinai

Object Points

Common Space

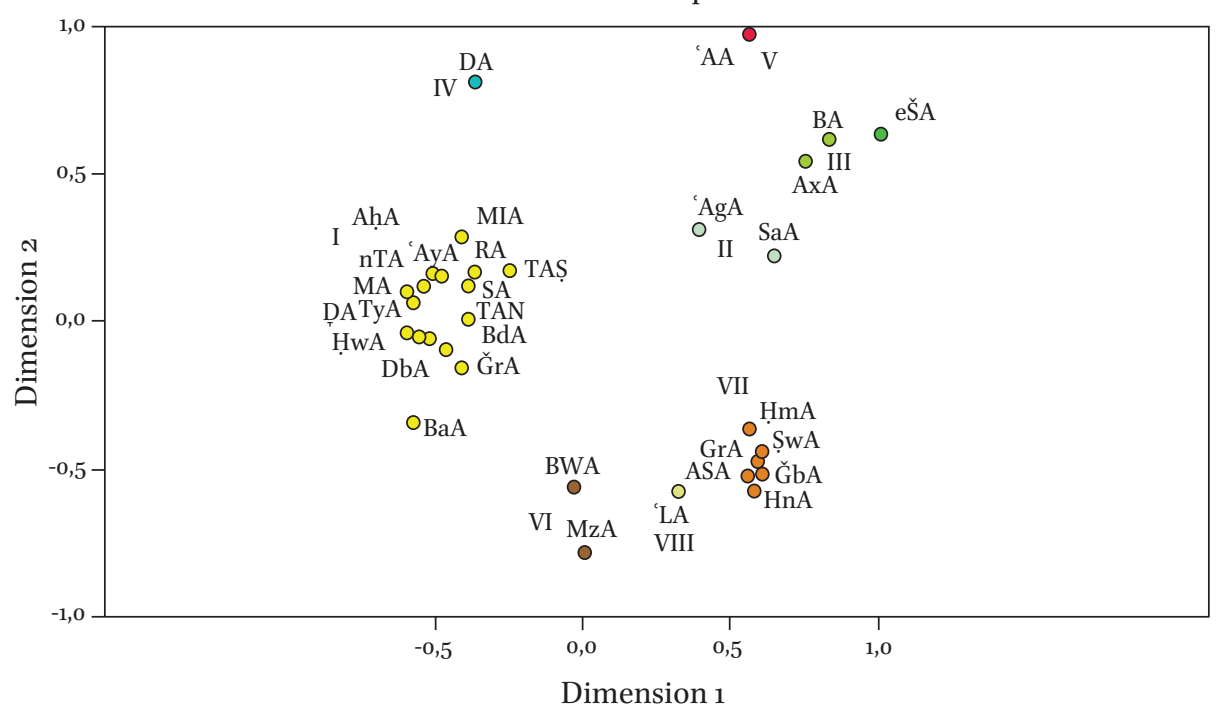

Figure 4. Proxscal—Squared Euclidian Binary MDS plot of dialects of Sinai 


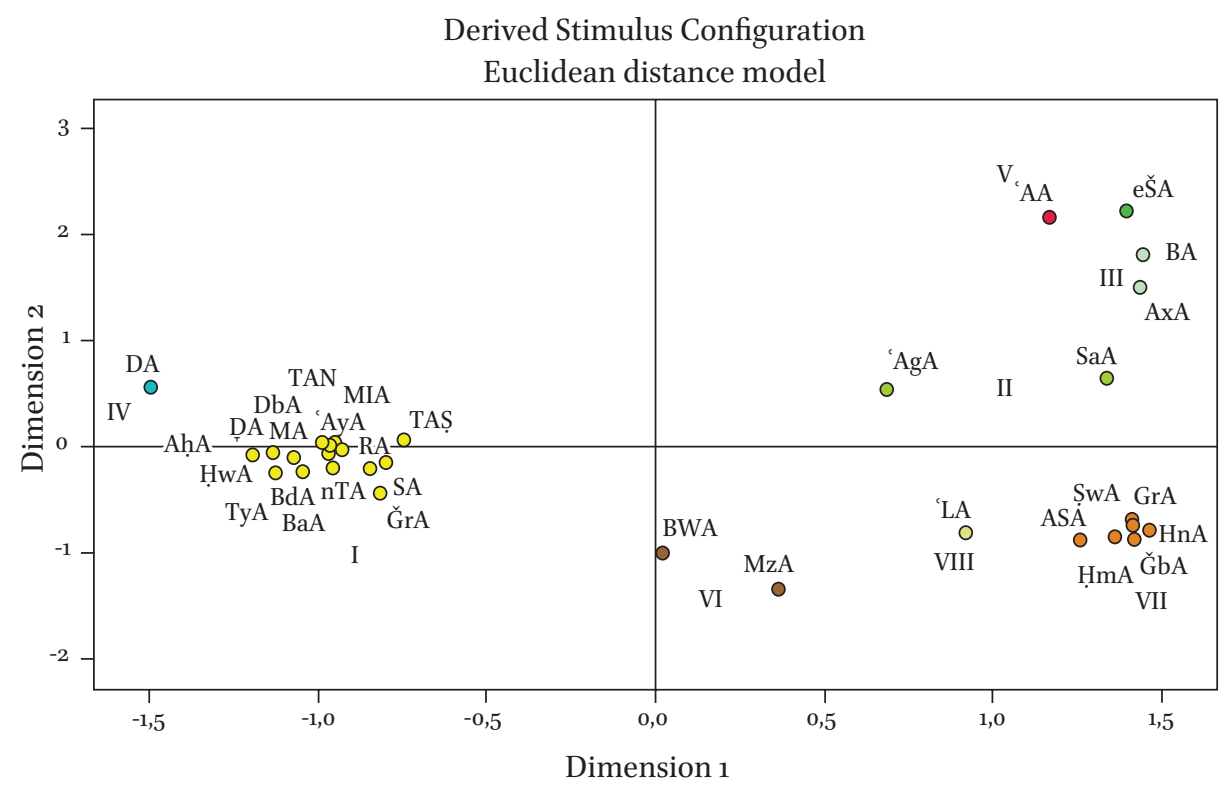

Figure 5. Alscal-Euclidian Binary MDS plot of dialects of Sinai 


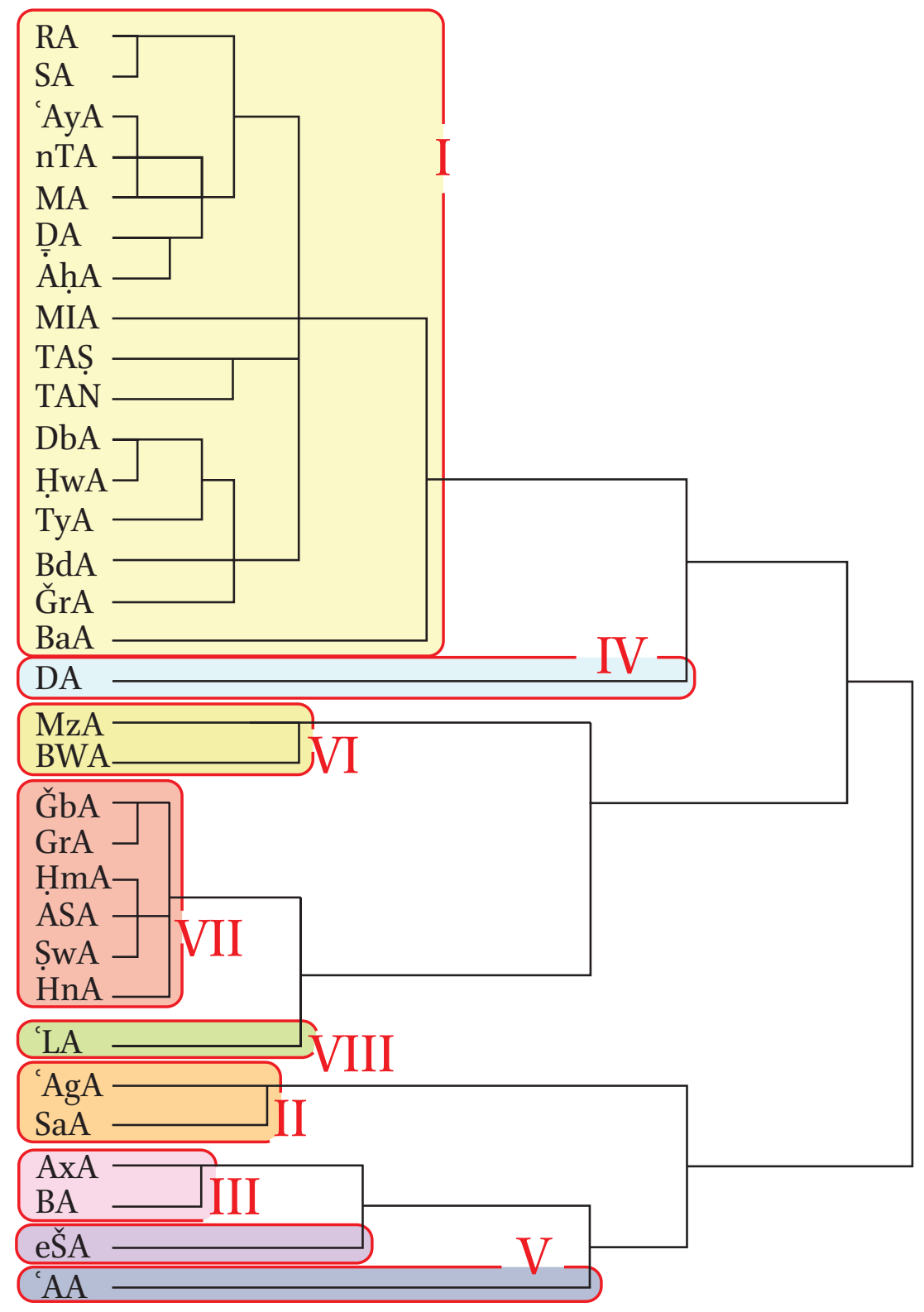

Figure 6. Dendrogram of dialects of Sinai 


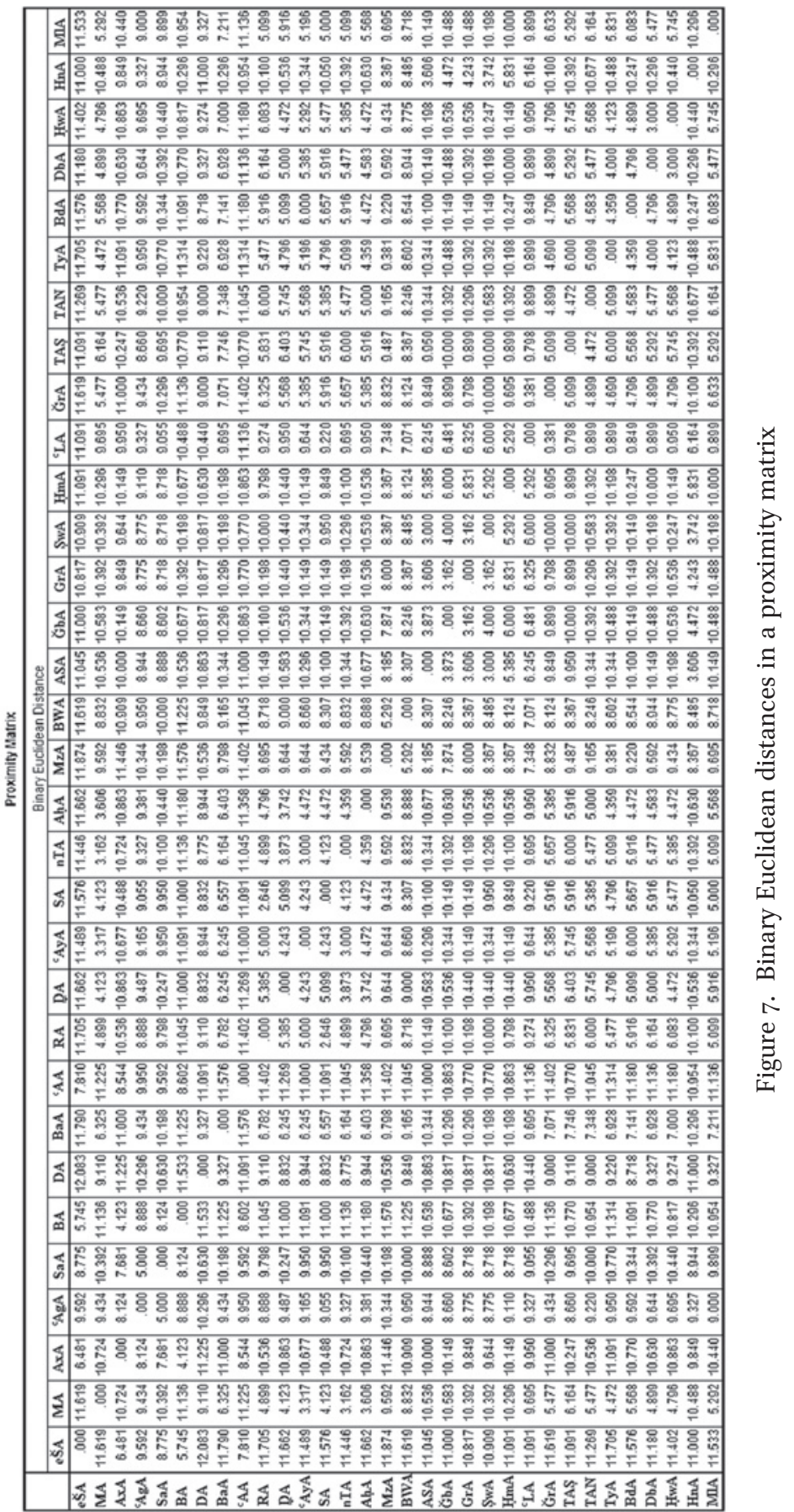




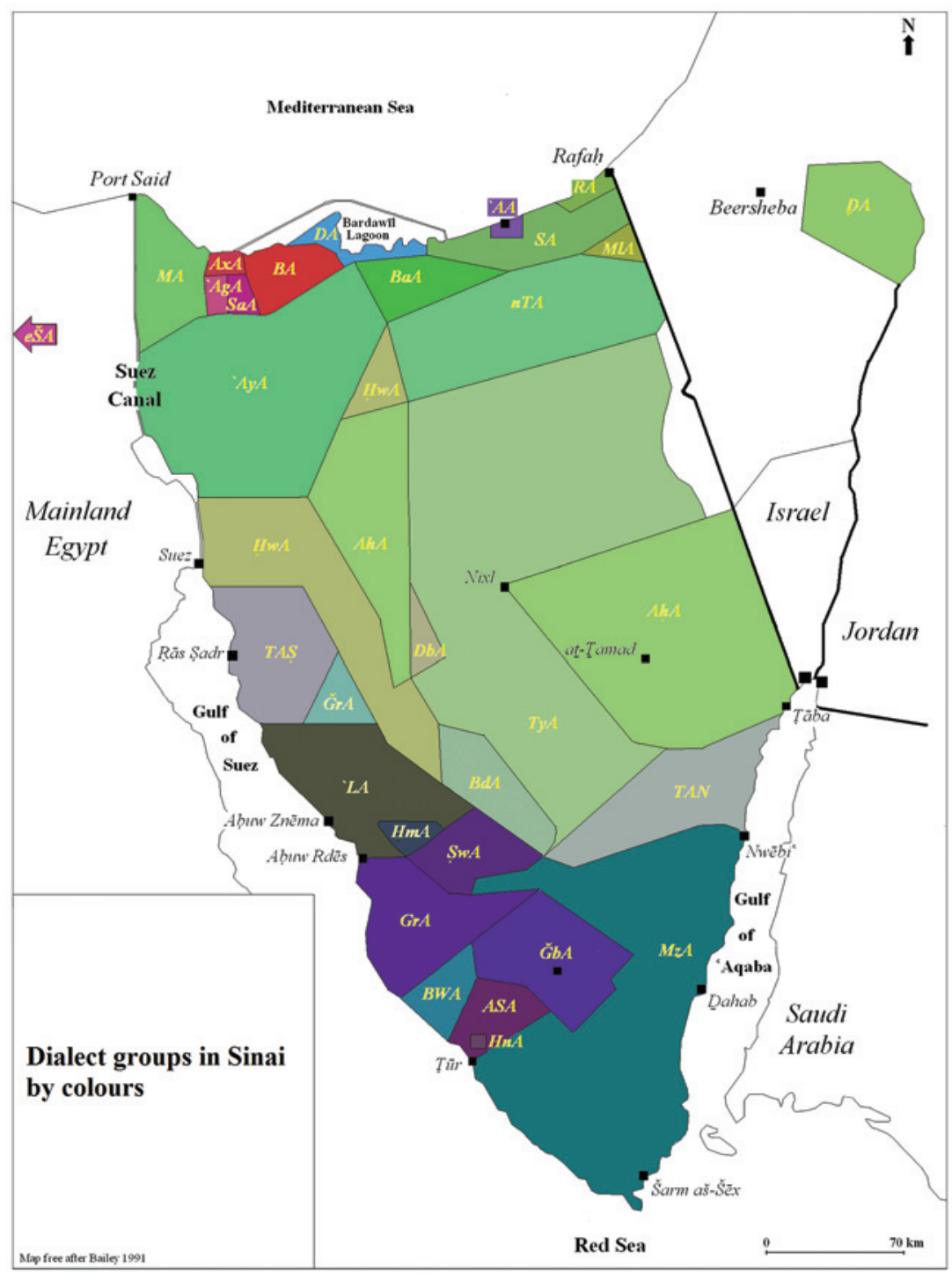

Figure 8a. Dialect groups as clusters in similar shades of colours 


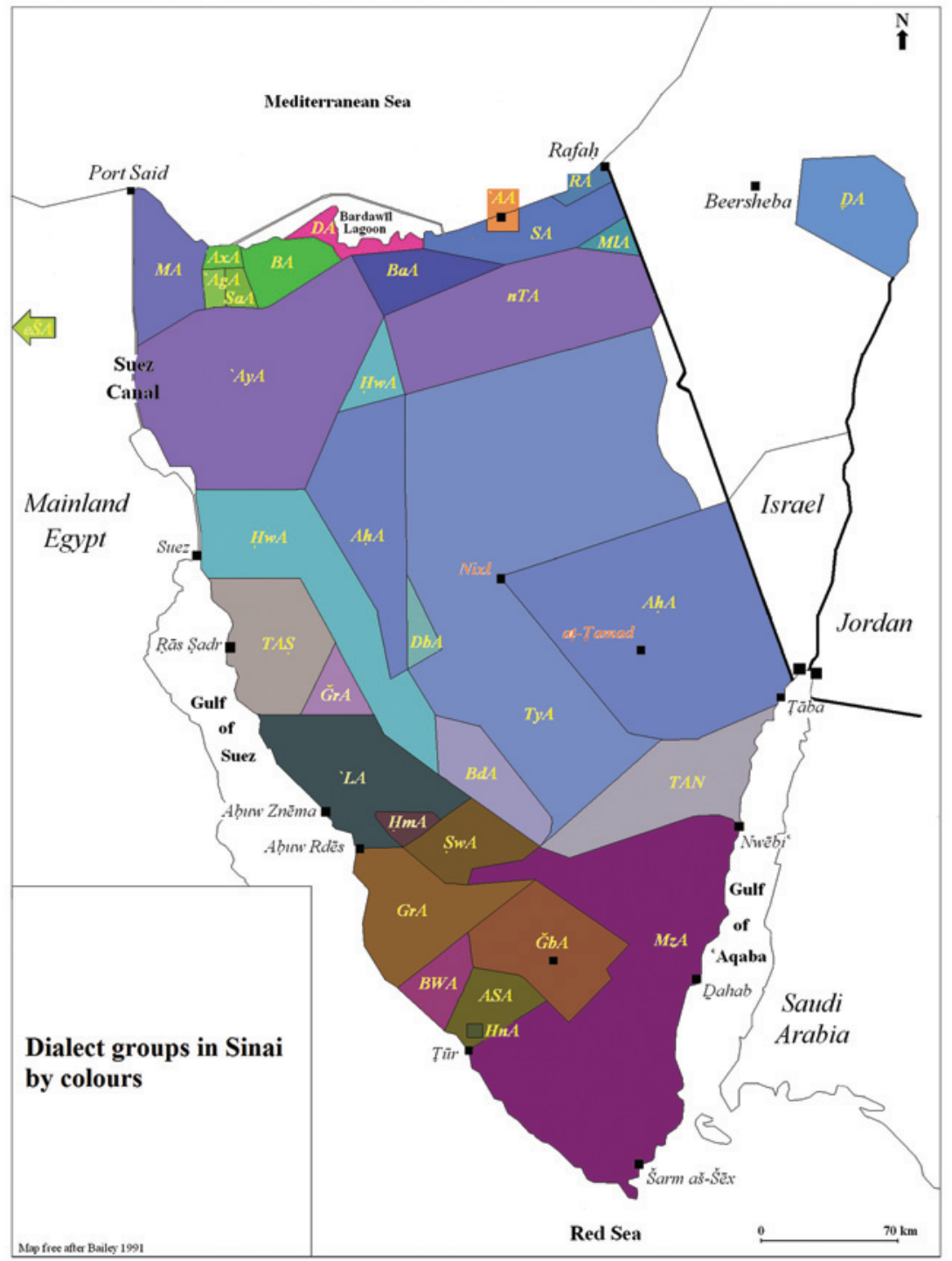

Figure 8b. Dialect groups as clusters in similar shades of colours 


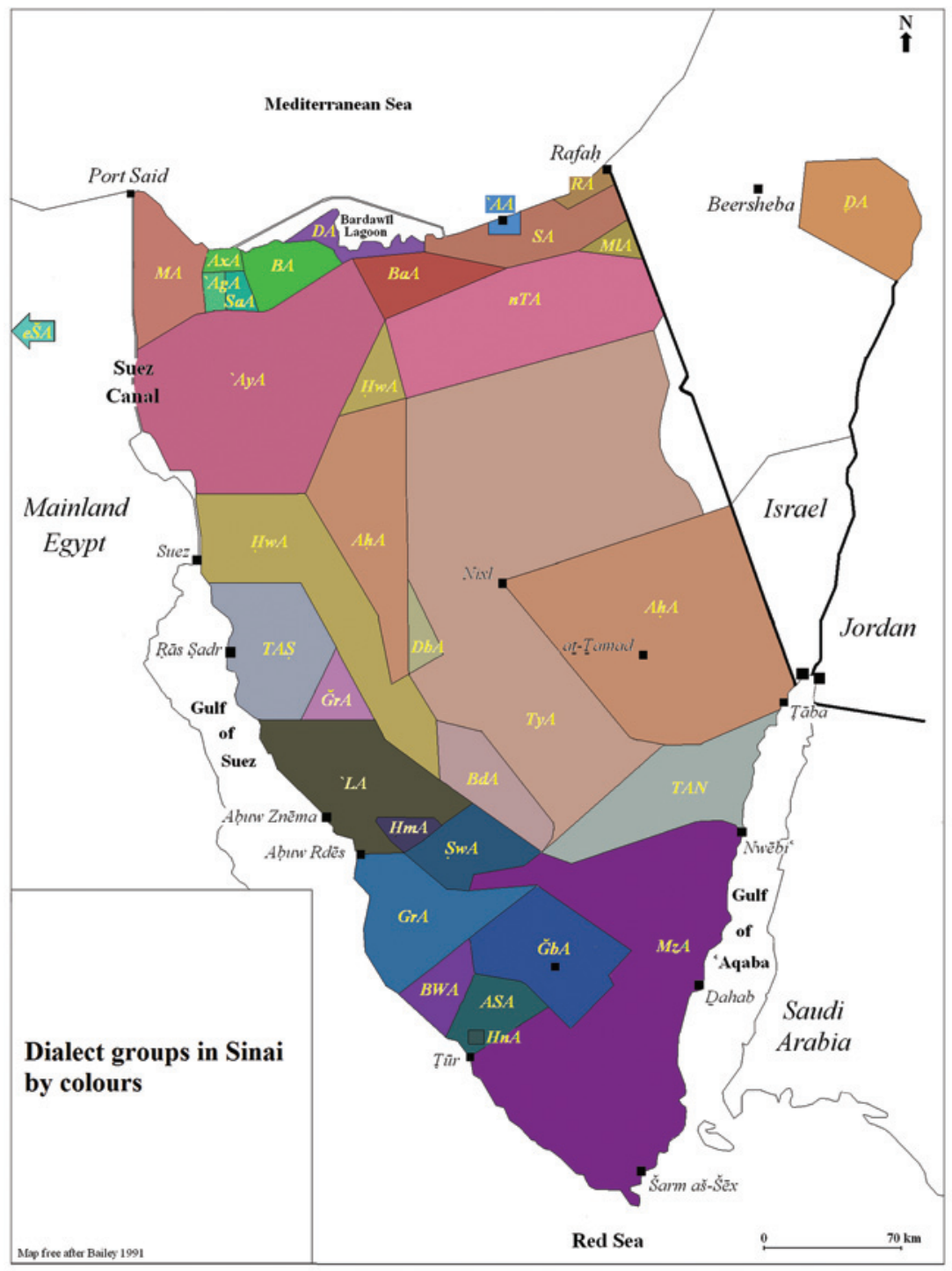

Figure 8c. Dialect groups as clusters in similar shades of colours 
For MAP o, see remarks in Conclusions, III. a. The identified isoglosses in central and southern Sinai.

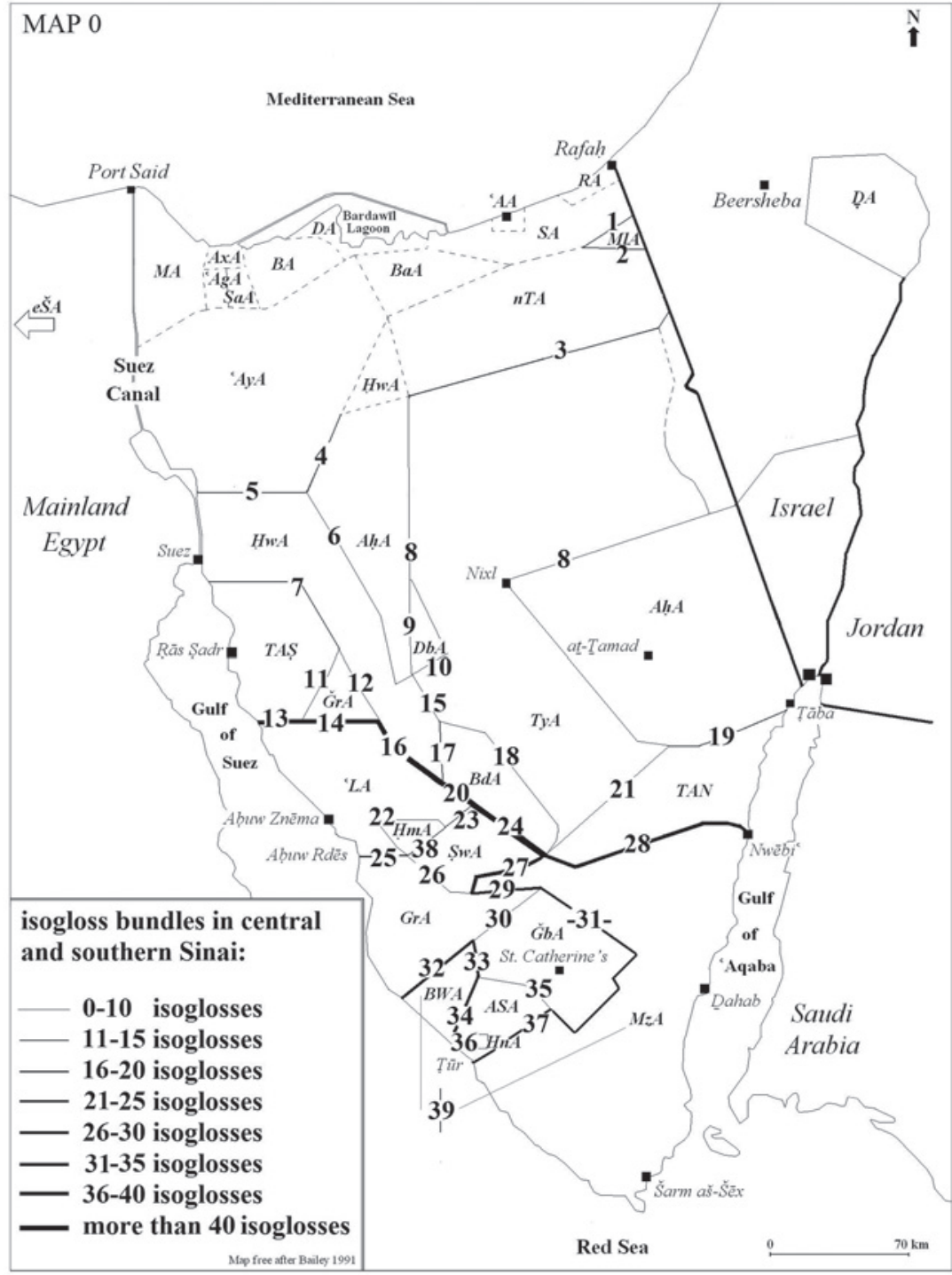

Map o. Isogloss bundles in central and southern Sinai 


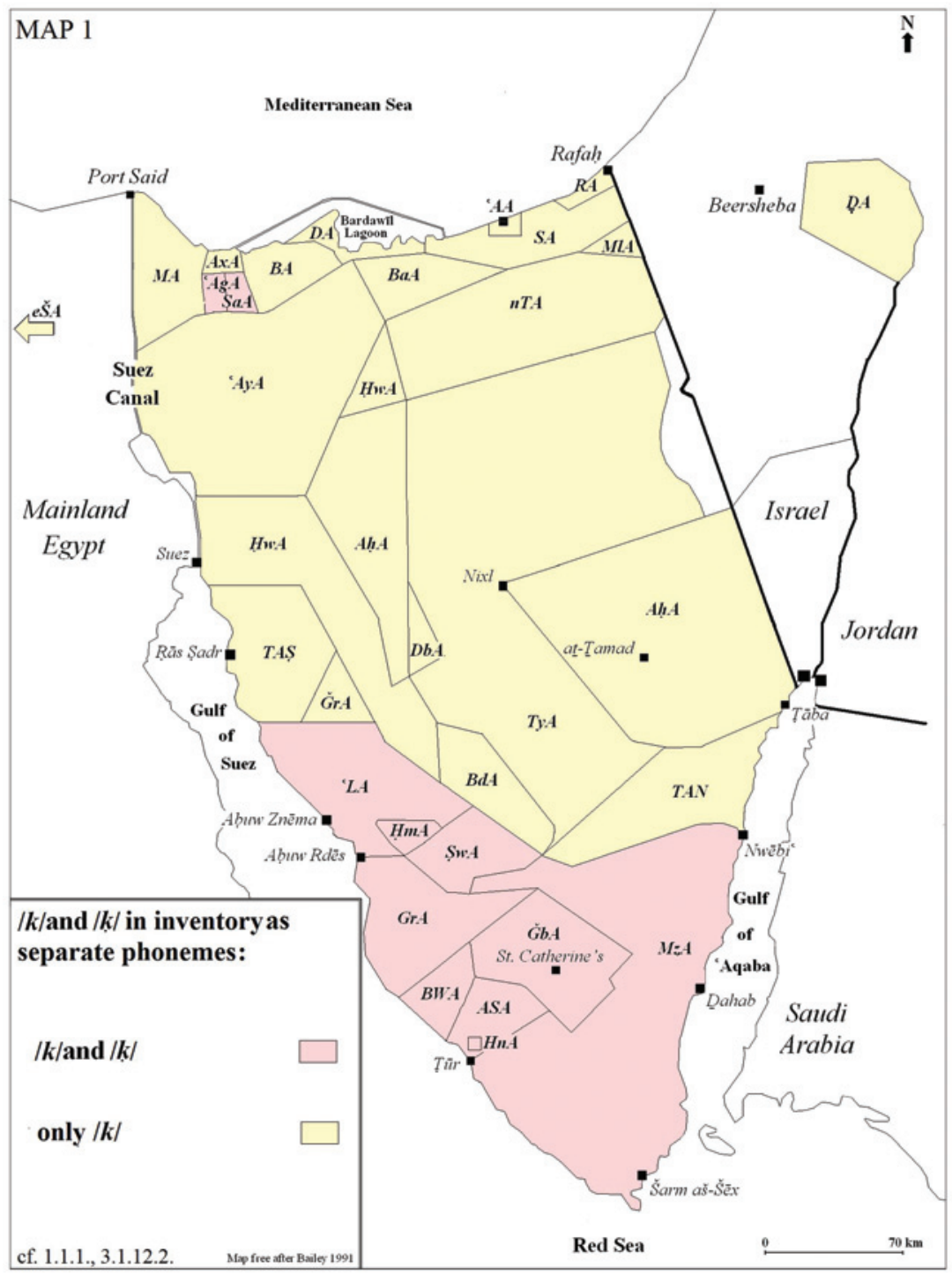

Map 1. $/ \mathrm{k} /$ and $/ \mathrm{k} /$ as separate phonemes in the phoneme inventory

For remarks on the absence of MAPS 2 and 3 see Conclusions II. a. Criteria for comparison from De Jong 2000 producing differences/similarities in central and southern Sinai. 


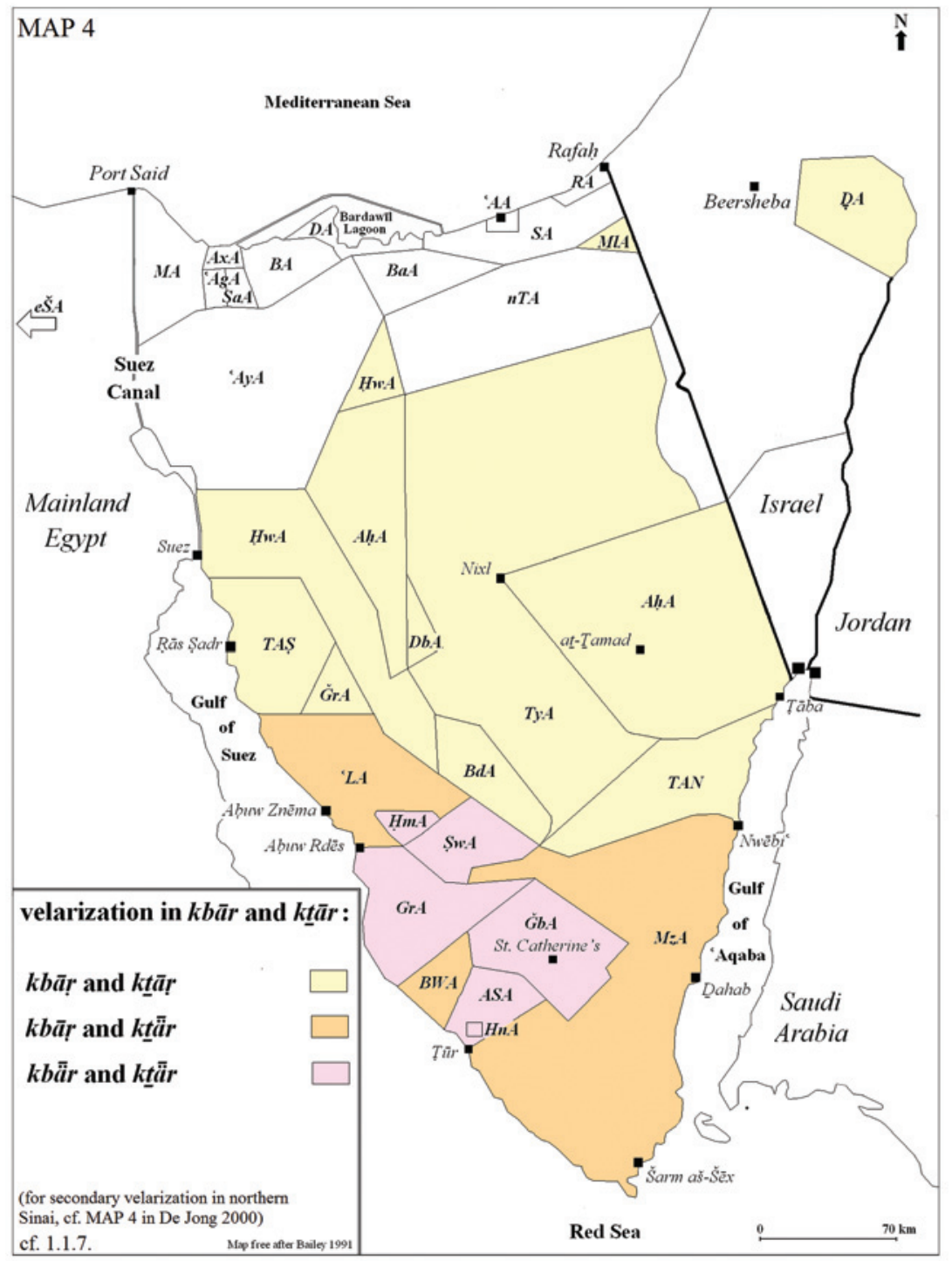

Map 4. Velarization in $k b \bar{a} r$ and $k \underline{t} a \bar{r} r$ 


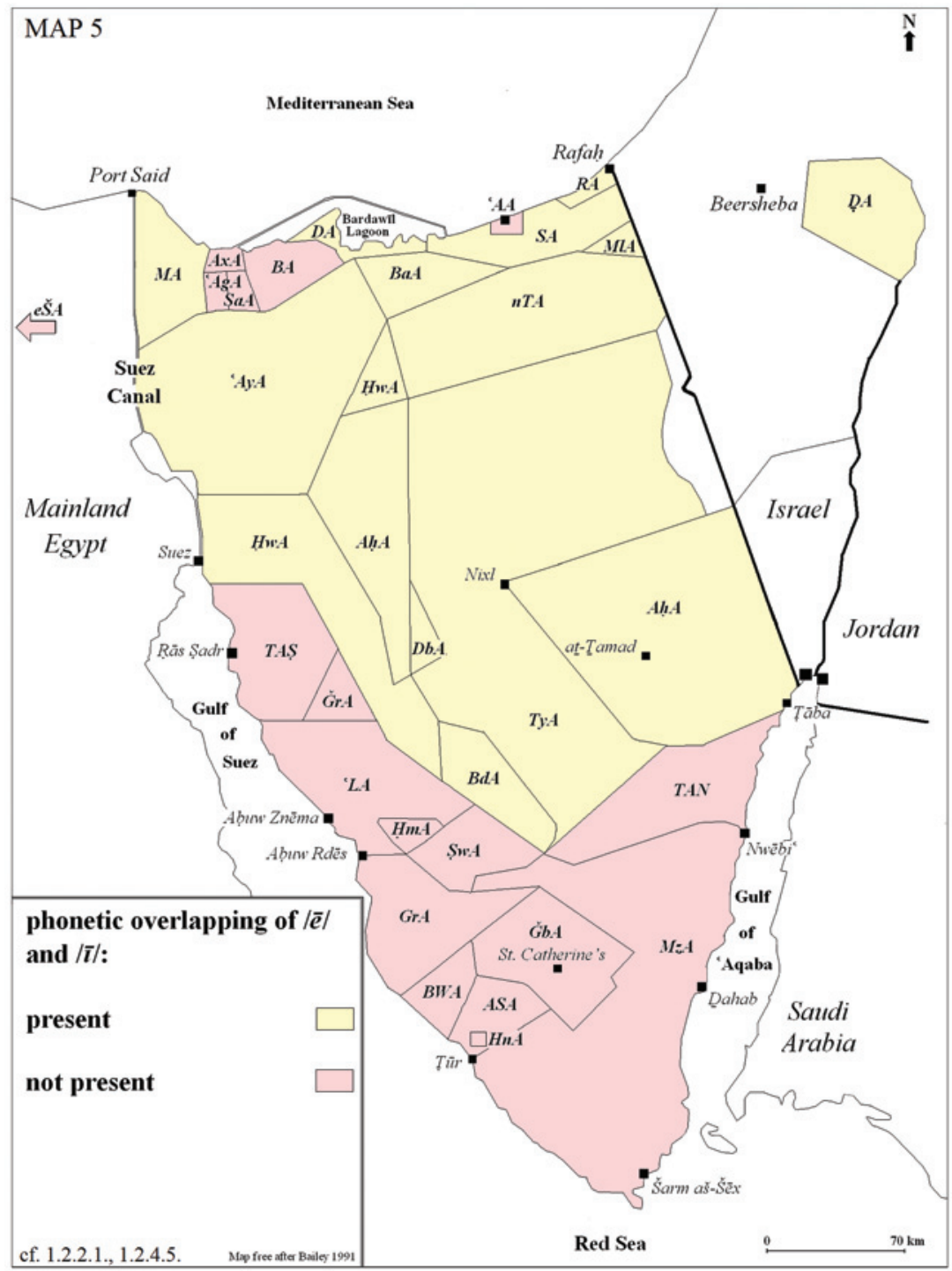

Map 5. Phonetic overlapping of $|\bar{e}|$ and $|\bar{\imath}|$

For remarks on the absence of MAP 6 see Conclusions II. a. Criteria for comparison from De Jong 2000 producing differences/similarities in central and southern Sinai. 


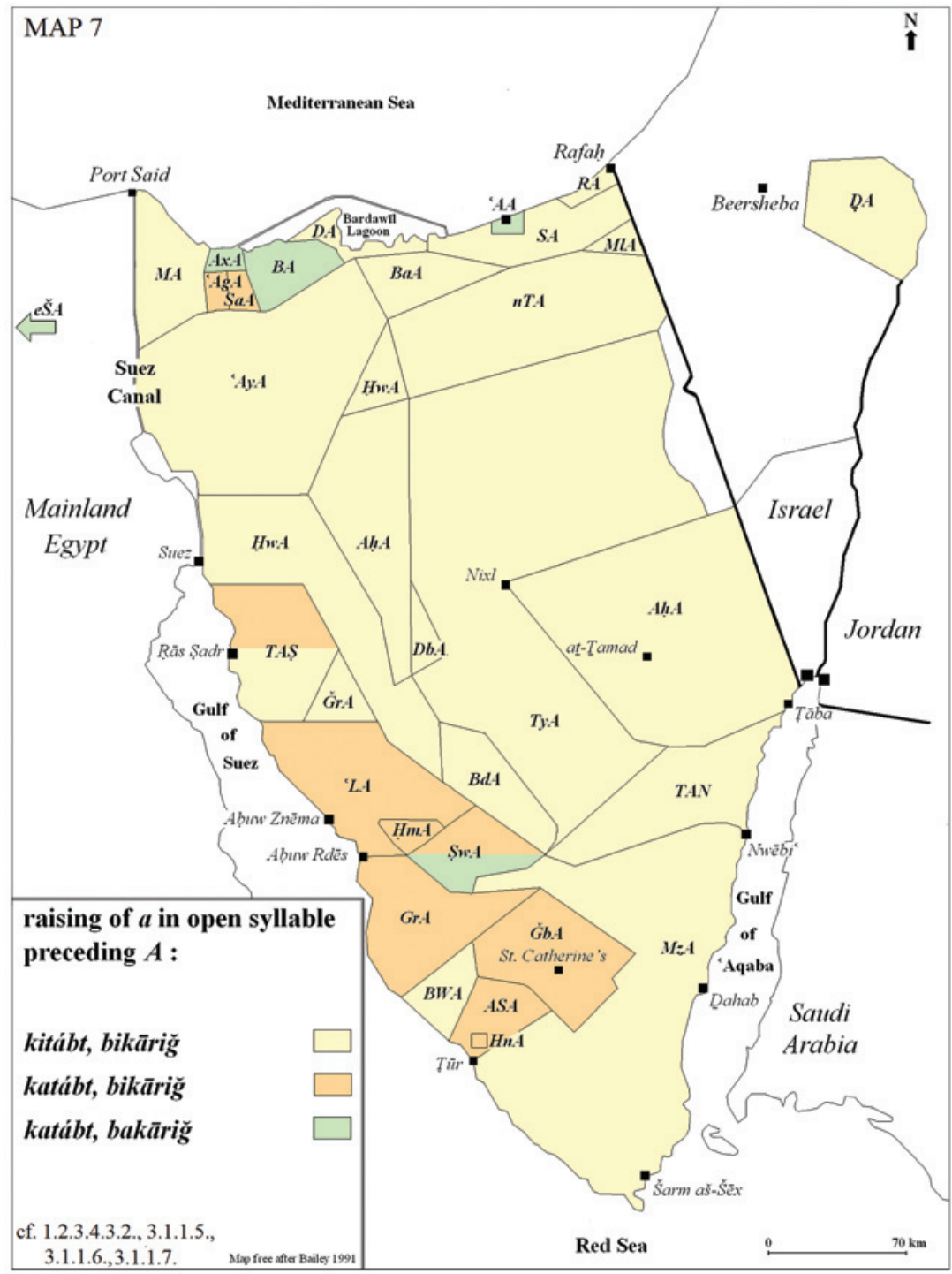

Map 7. Raising of $a$ in open syllable preceding $A$ 


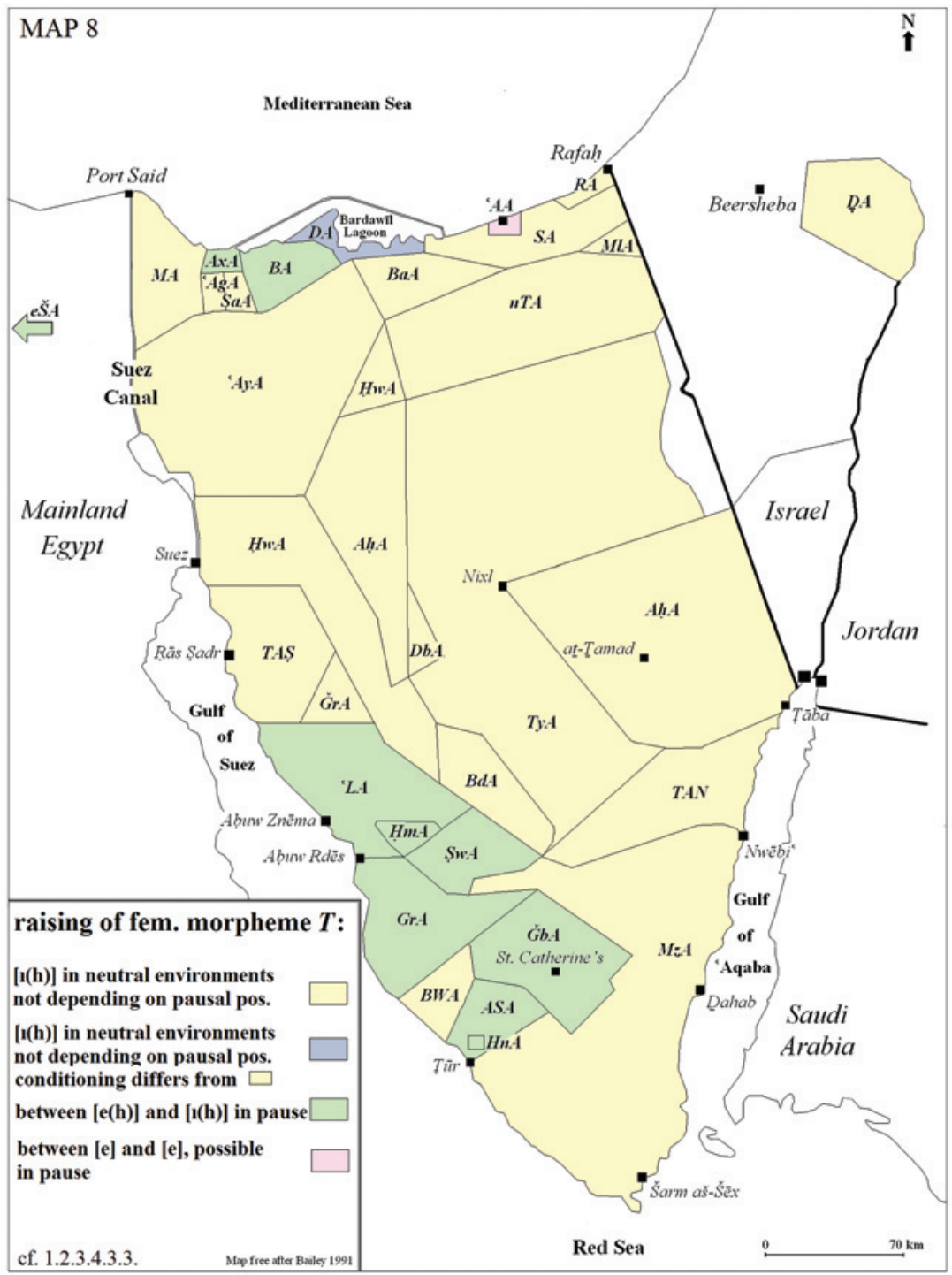

Map 8. Raising of fem. morpheme $T$ 


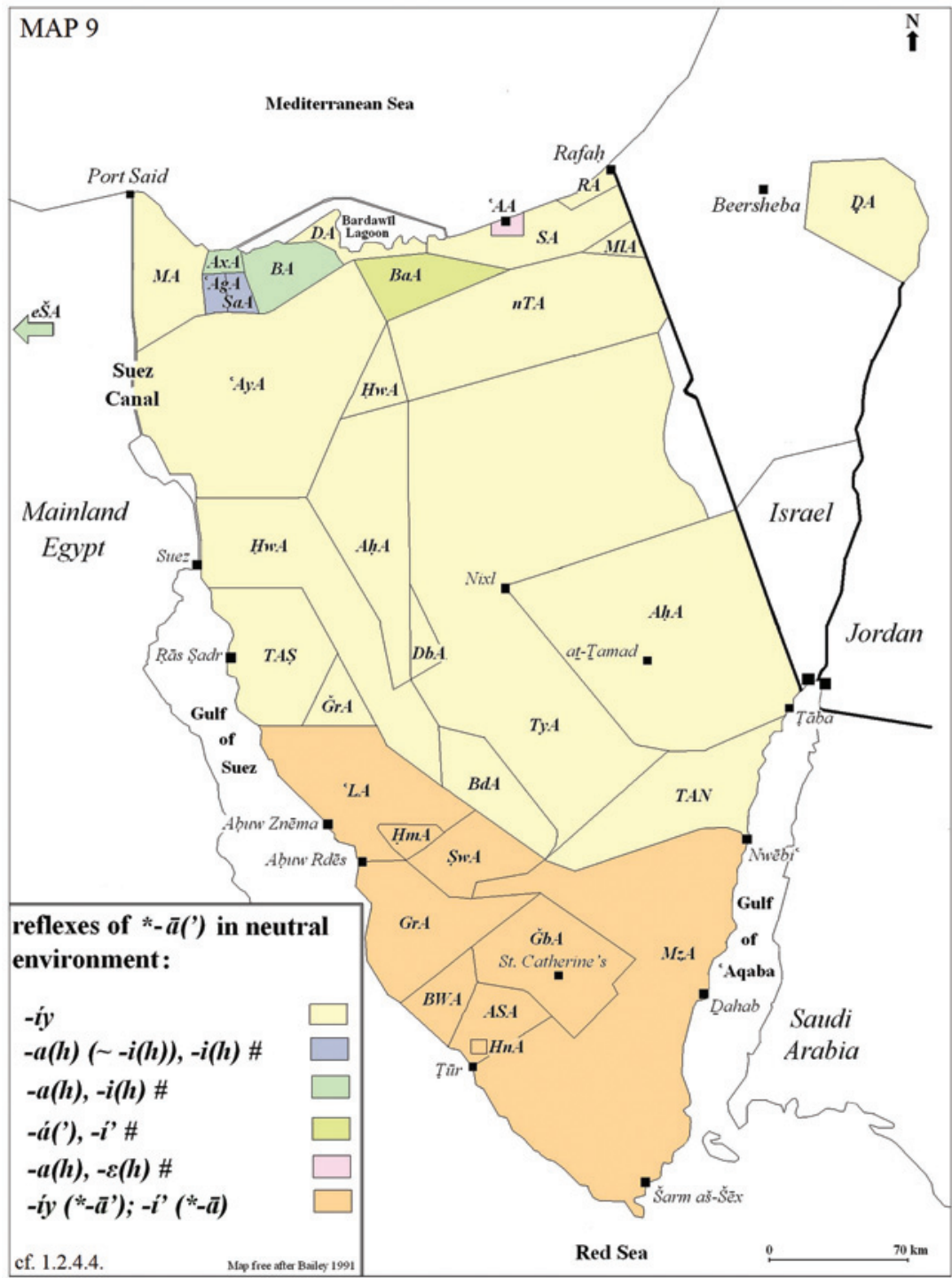

Map 9. Reflexes of $-\bar{a}\left({ }^{\prime}\right)$ in neutral environment 


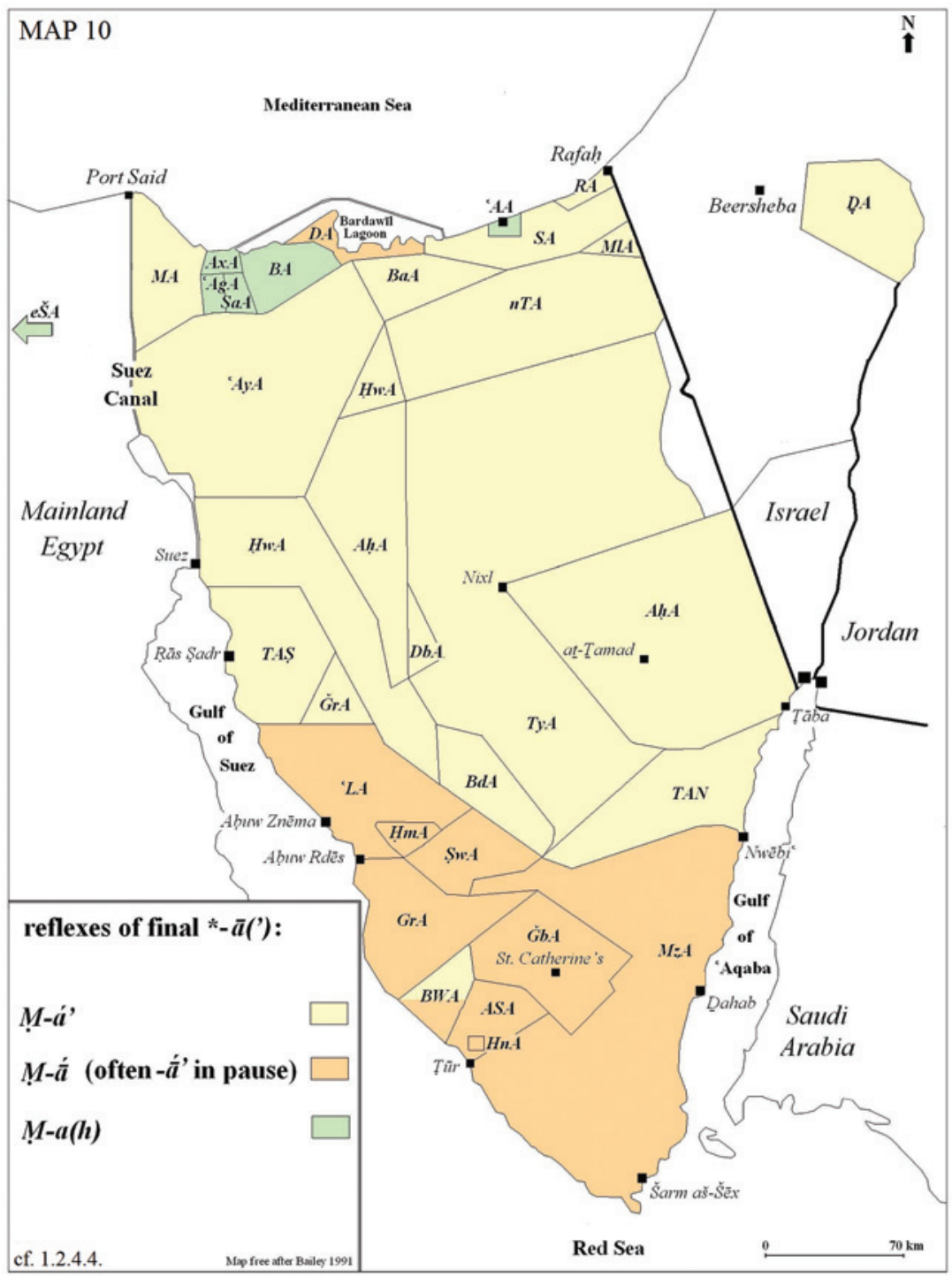

Map 10. Reflexes of final * $-\bar{a}\left({ }^{\prime}\right)$ 


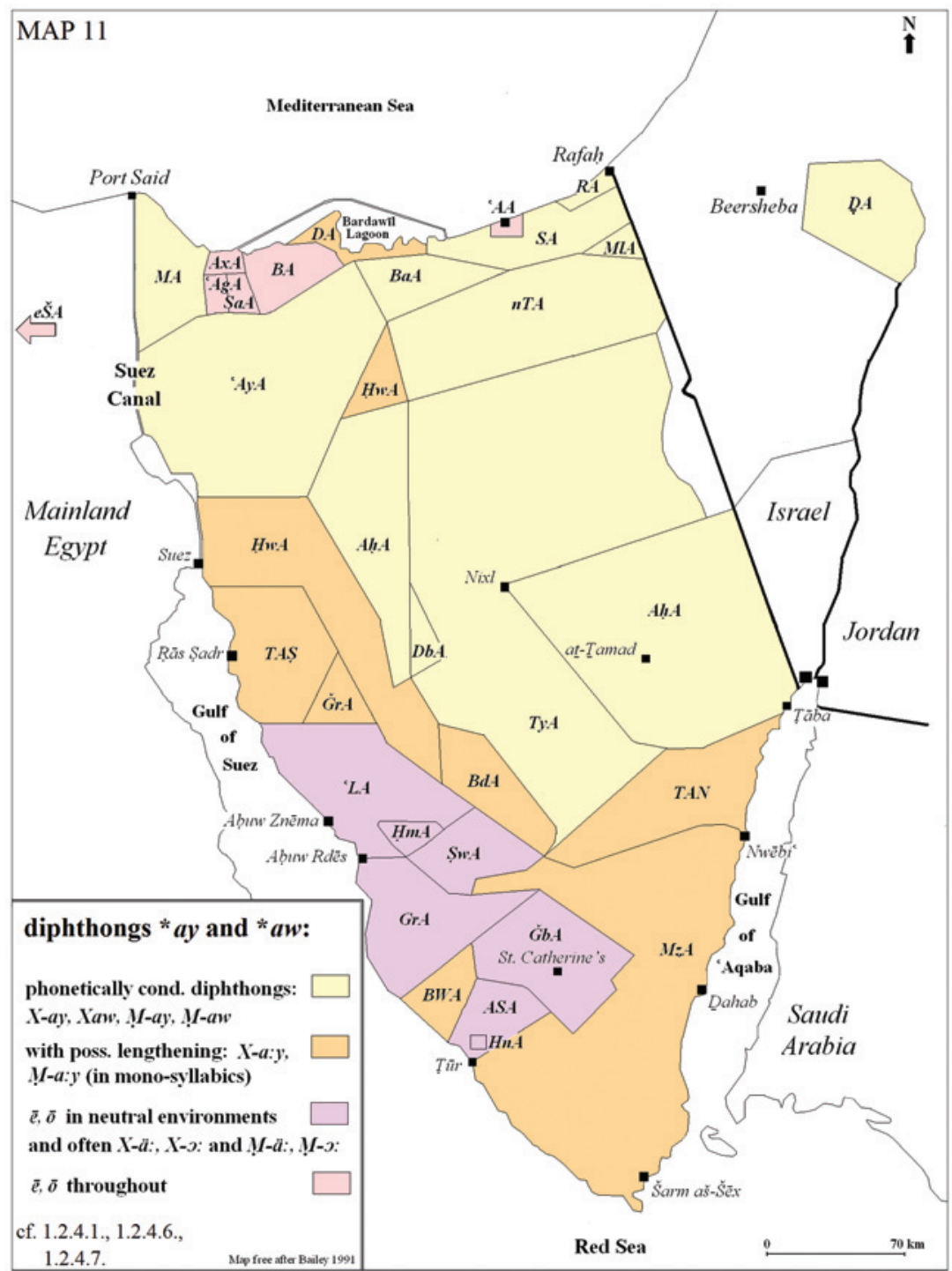

Map 11. Diphthongs *ay and *aw

For remarks on the absence of MAPS 12 and 13 see Conclusions II. a. Criteria for comparison from De Jong 2000 producing differences/similarities in central and southern Sinai. 


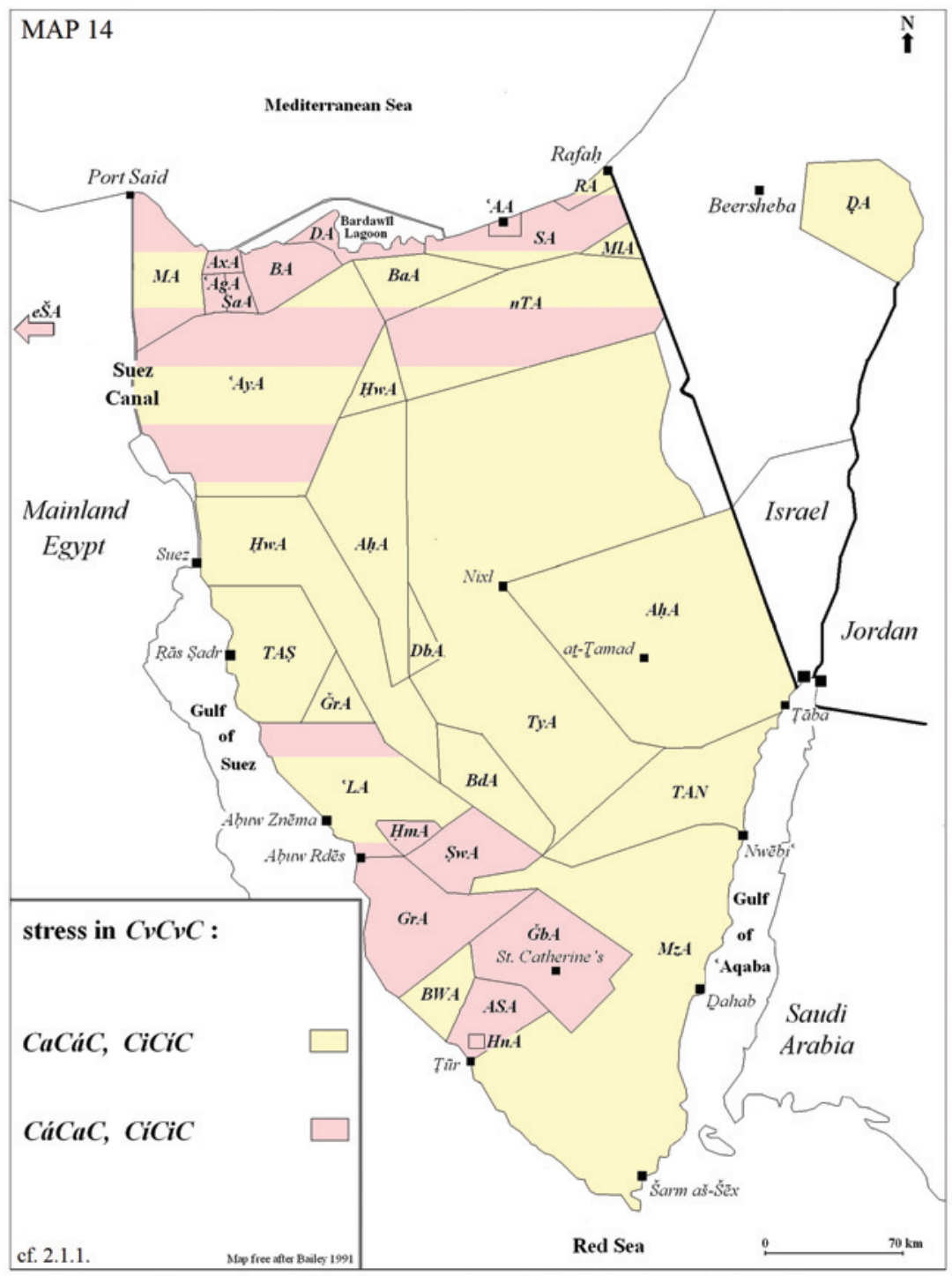

Map 14. Stress in $C \nu C \nu C$ 


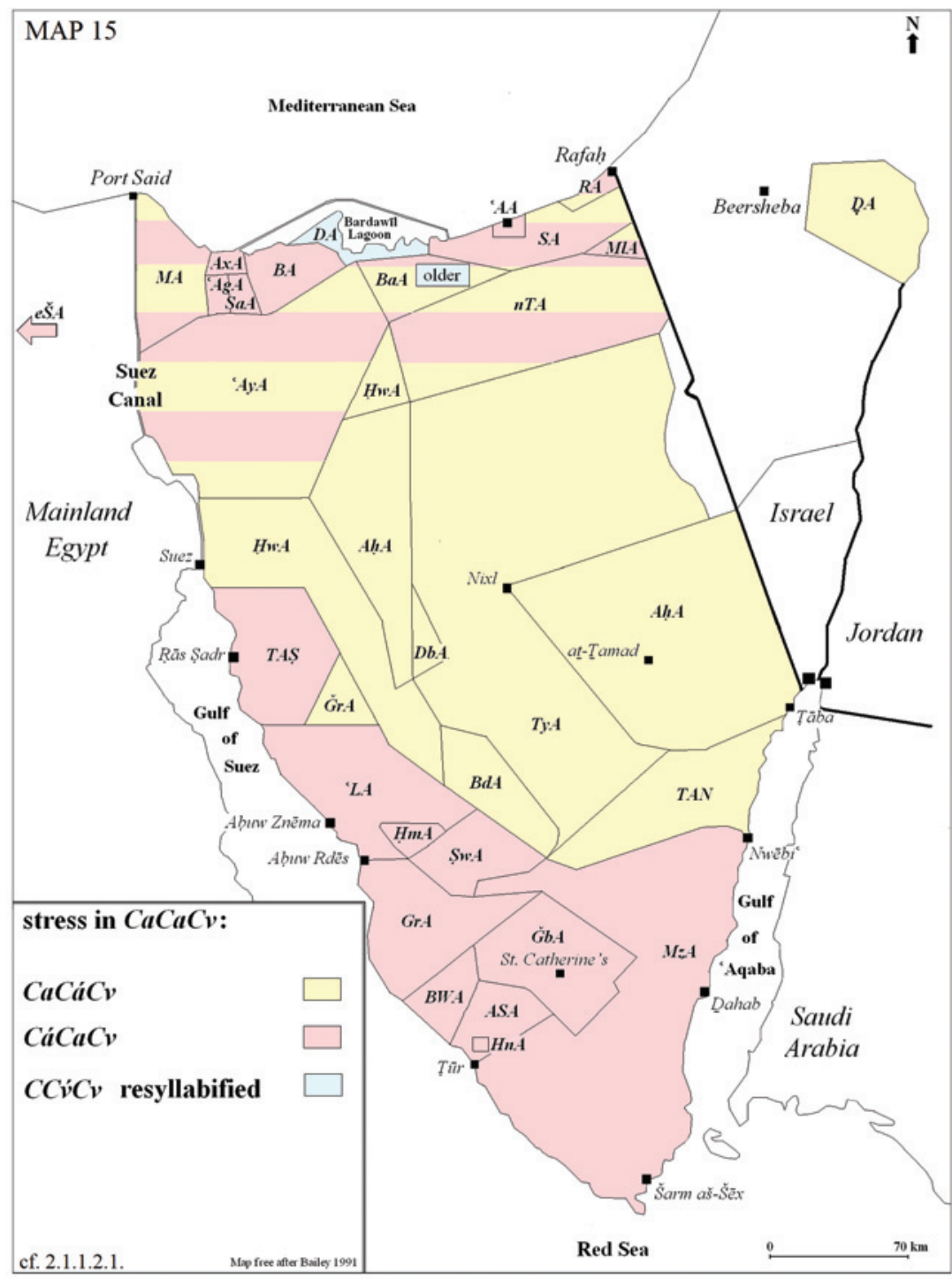

Map 15. Stress in $\mathrm{CaCaCv}$

For remarks on the absence of MAPS 16 and 17 see Conclusions II. a. Criteria for comparison from De Jong 2000 producing differences/similarities in central and southern Sinai. 


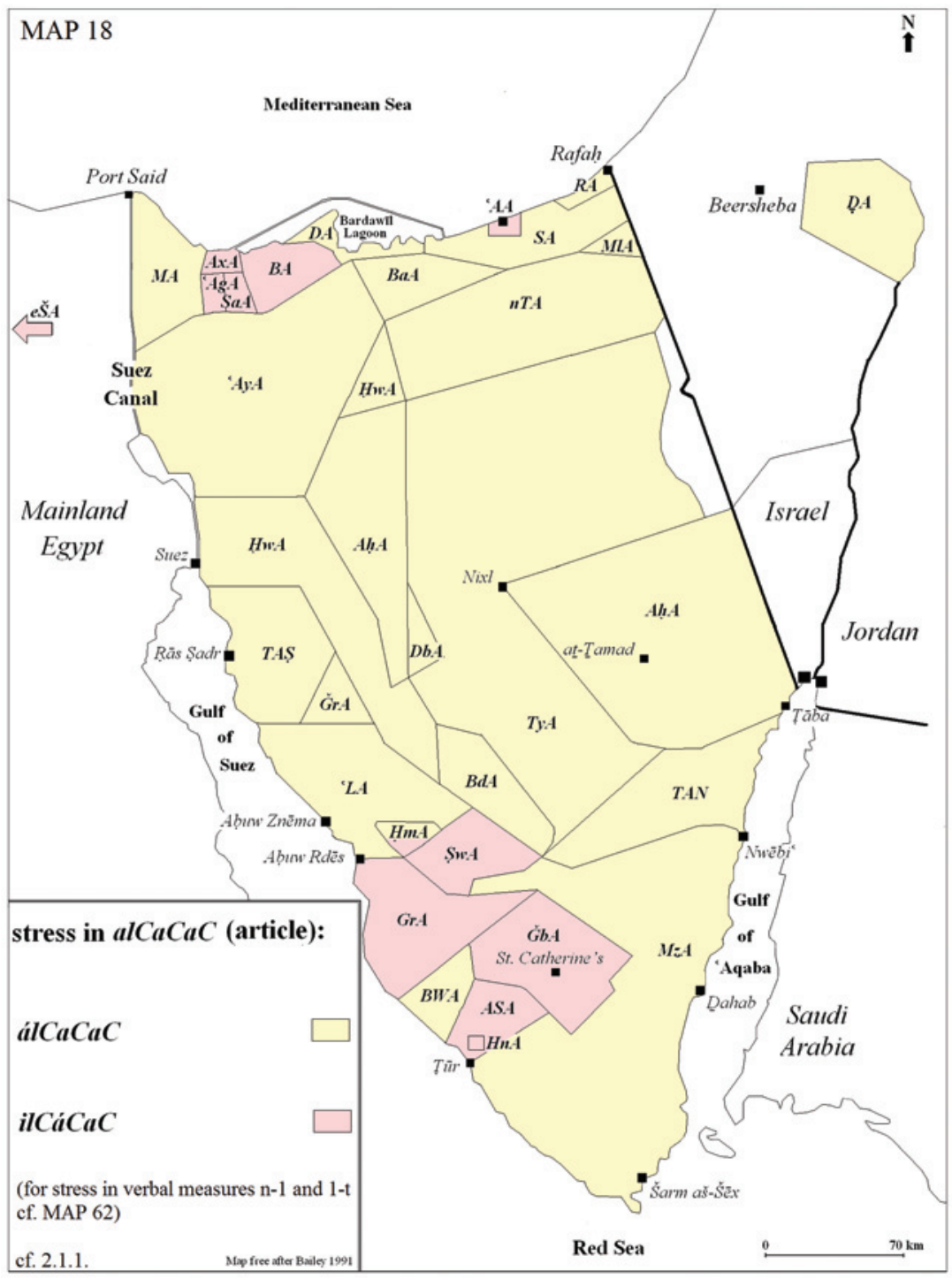

Map 18. Stress in alCaCac

For remarks on the absence of MAP 19 see Conclusions II. a. Criteria for comparison from De Jong 2000 producing differences/similarities in central and southern Sinai. 


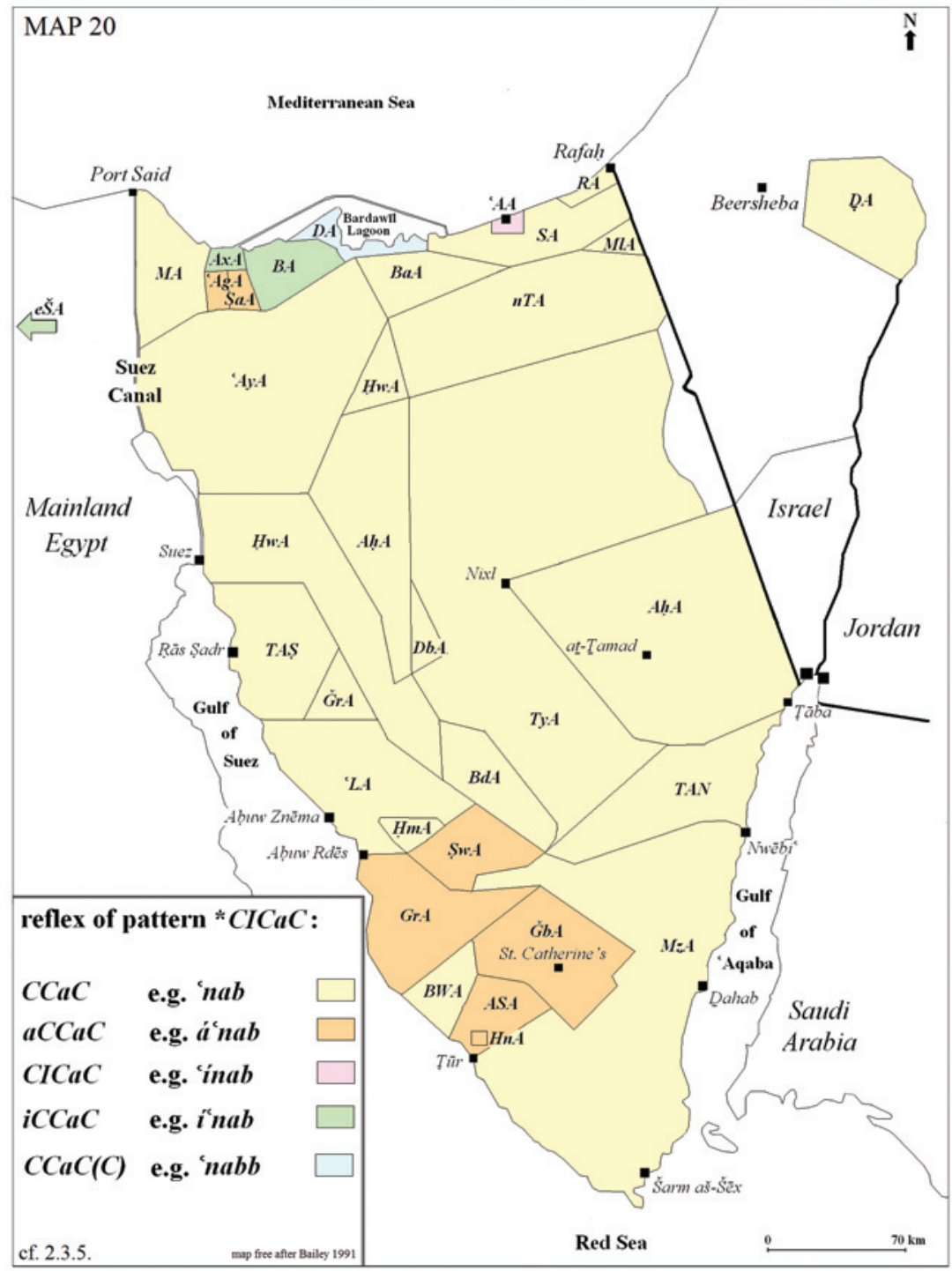

Map 20. Reflex of pattern ${ }^{*} \mathrm{CIC} a \mathrm{C}$ 


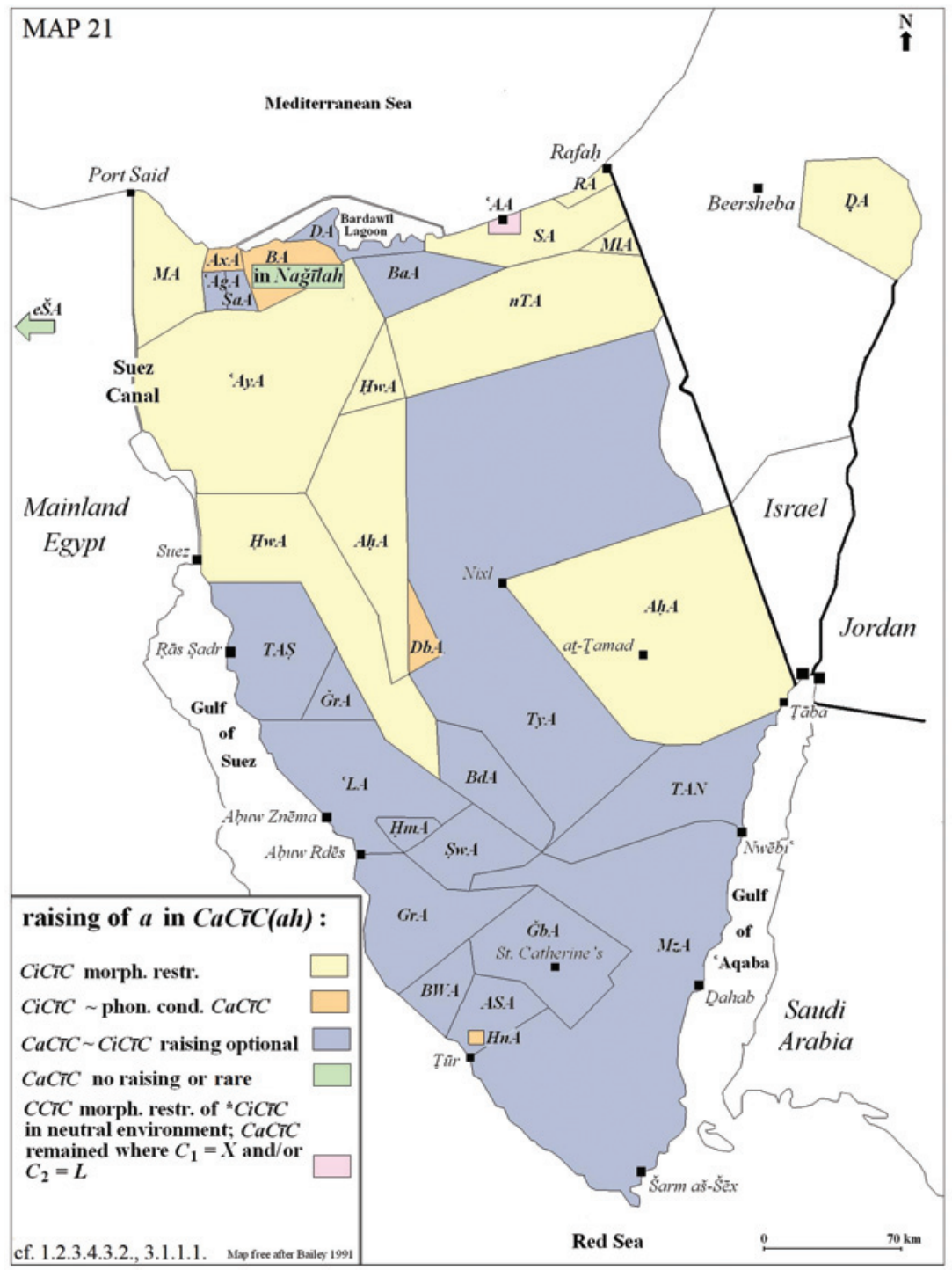

Map 21. Raising of $a$ in $\mathrm{CaC} \bar{\imath} C(a h)$ 


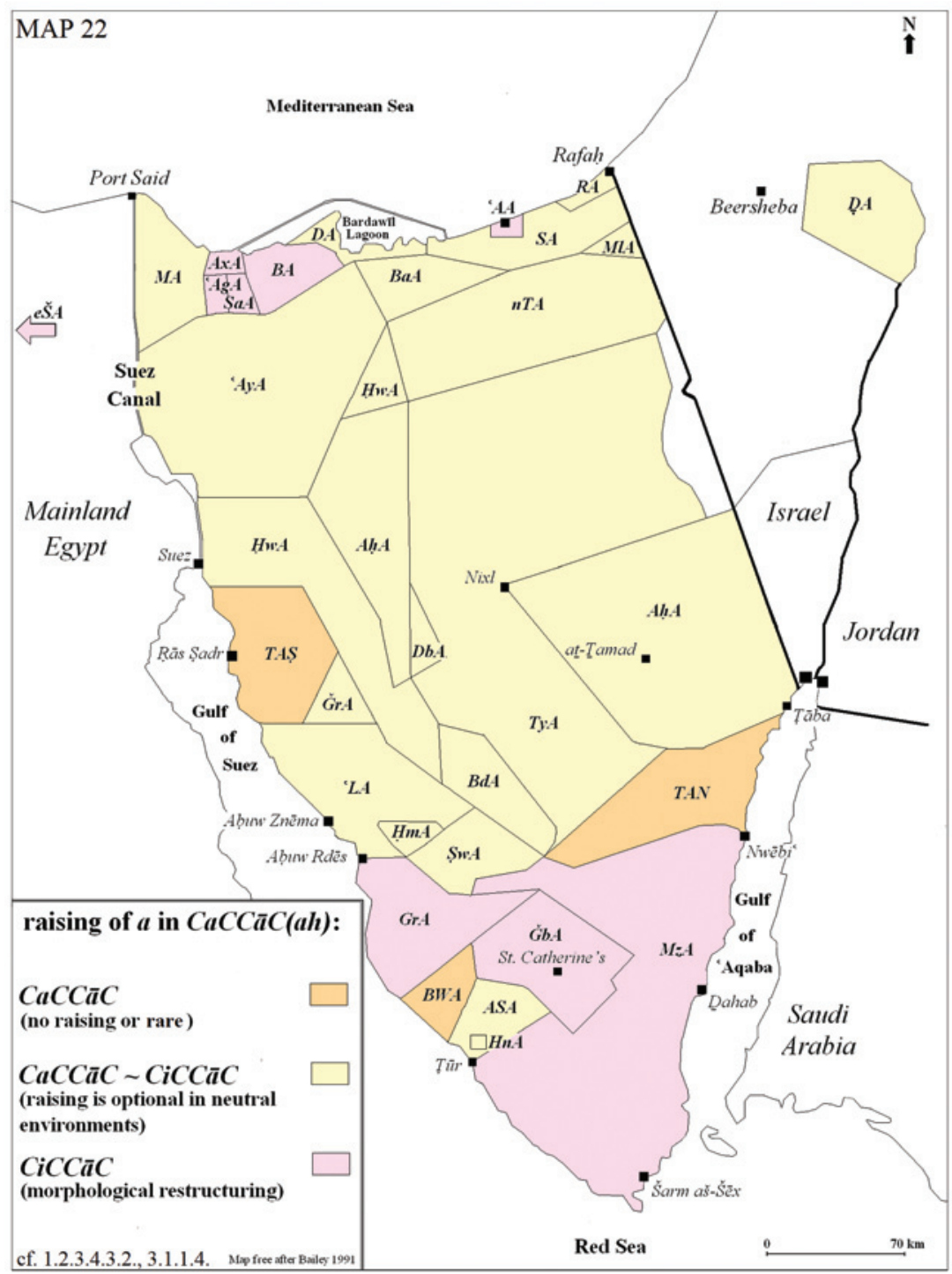

Map 22. Raising of a in $\operatorname{CaCC} \bar{c} C(a h)$ 


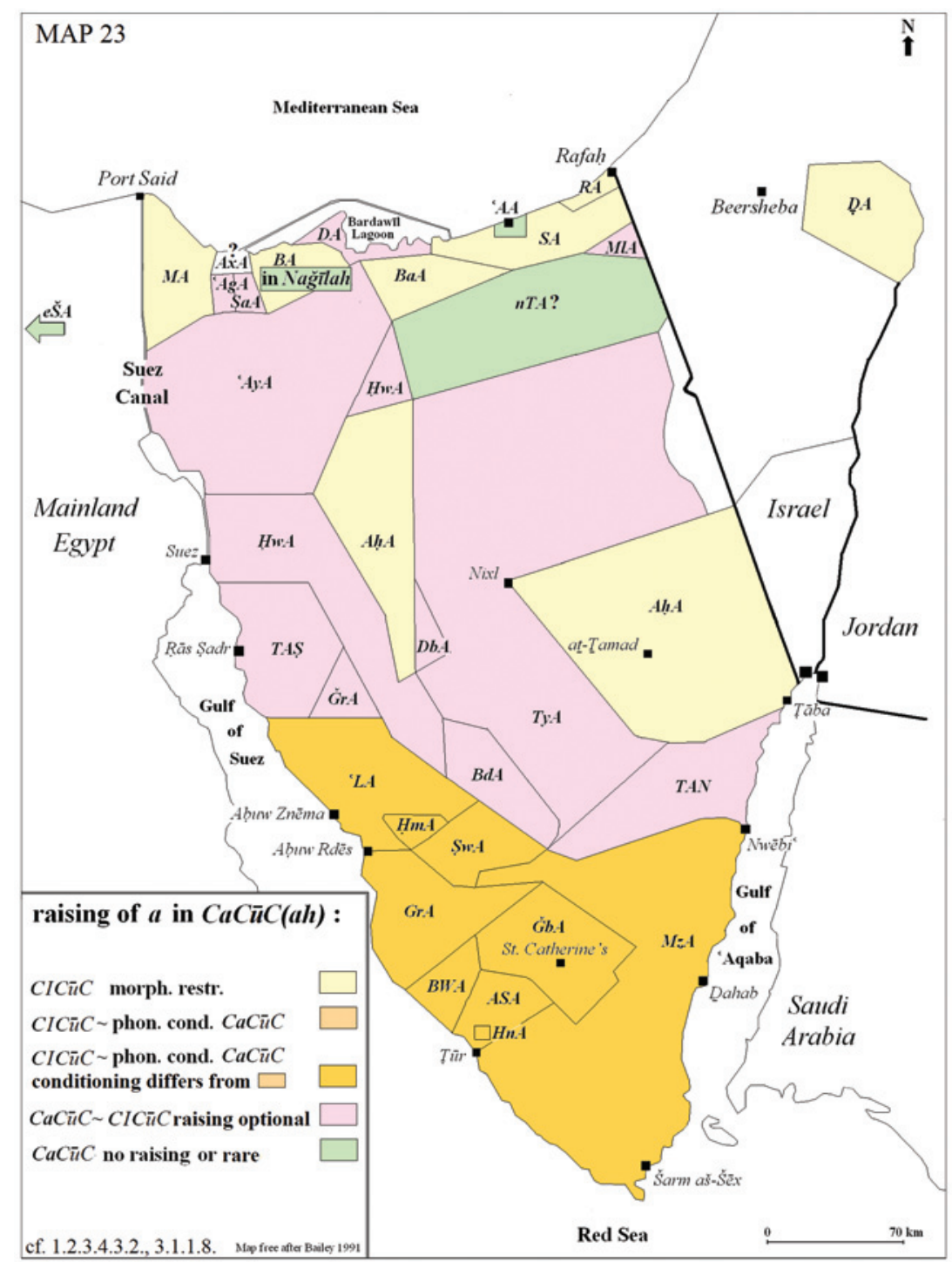

Map 23. Raising of $a$ in $\operatorname{CaC} \bar{u} C(a h)$

For remarks on the absence of MAP 24 see Conclusions II. a. Criteria for comparison from De Jong 2000 producing differences/similarities in central and southern Sinai. 


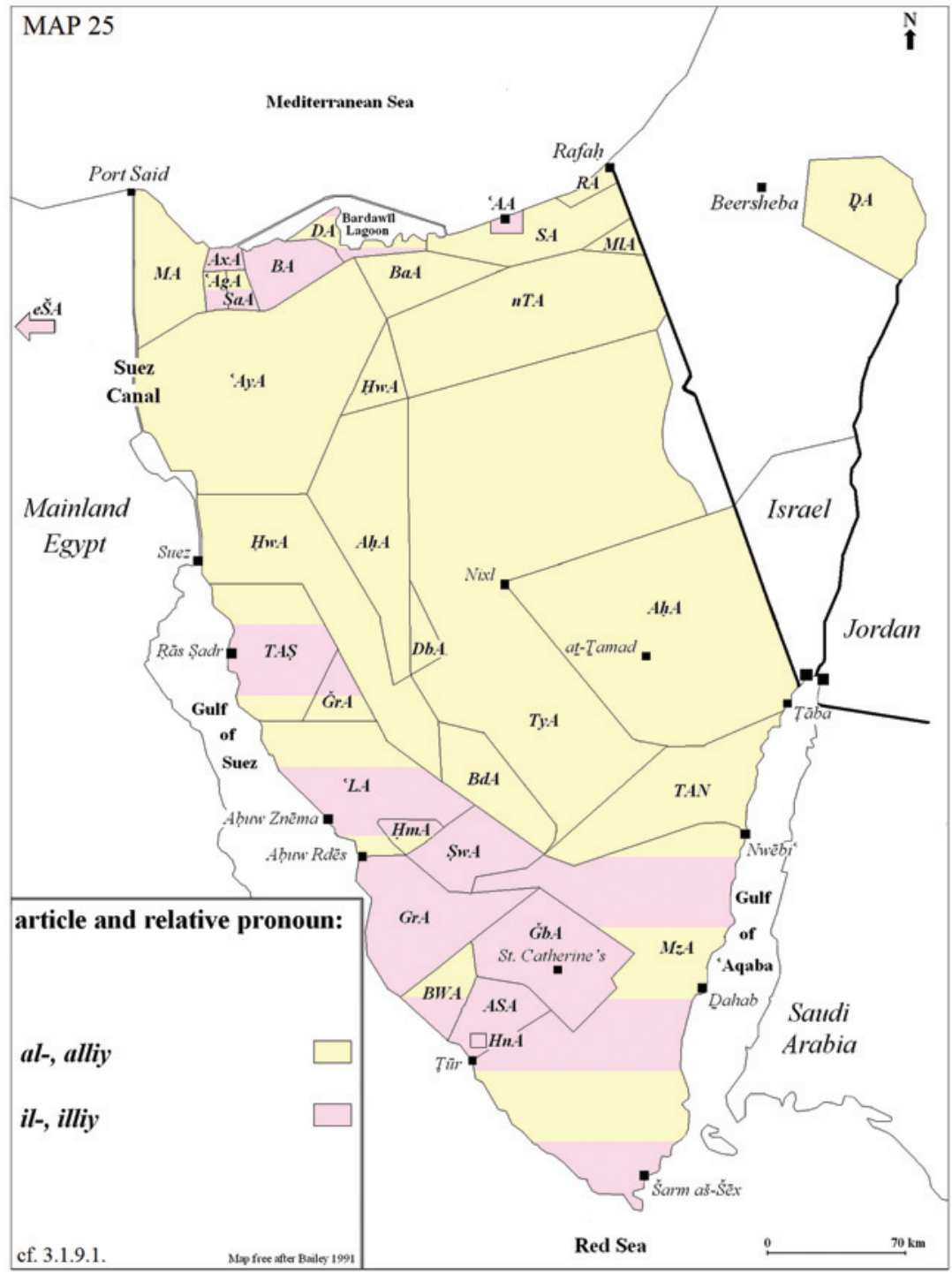

Map 25. Article and relative pronoun 


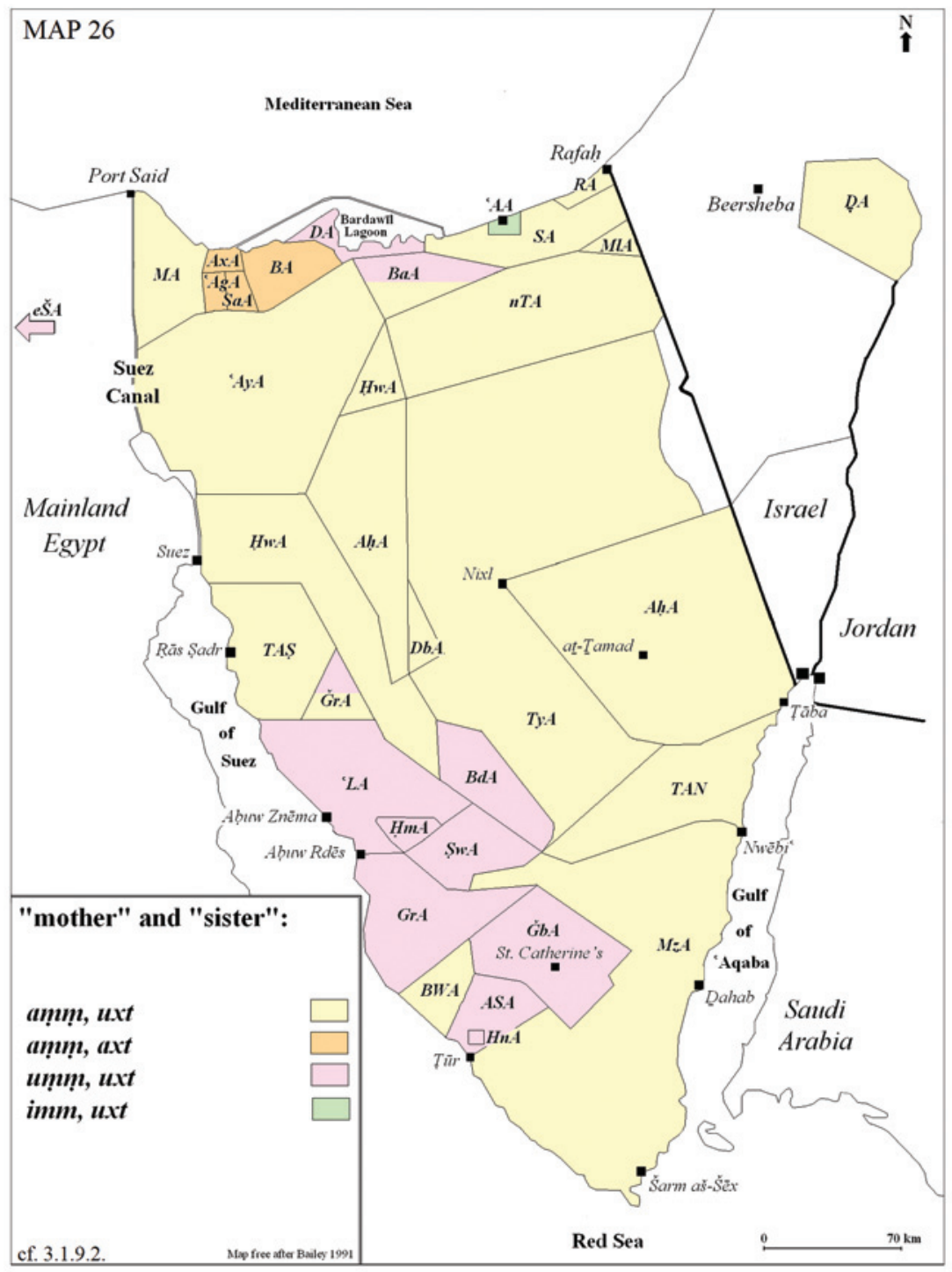

Map 26. "mother" and "sister" 


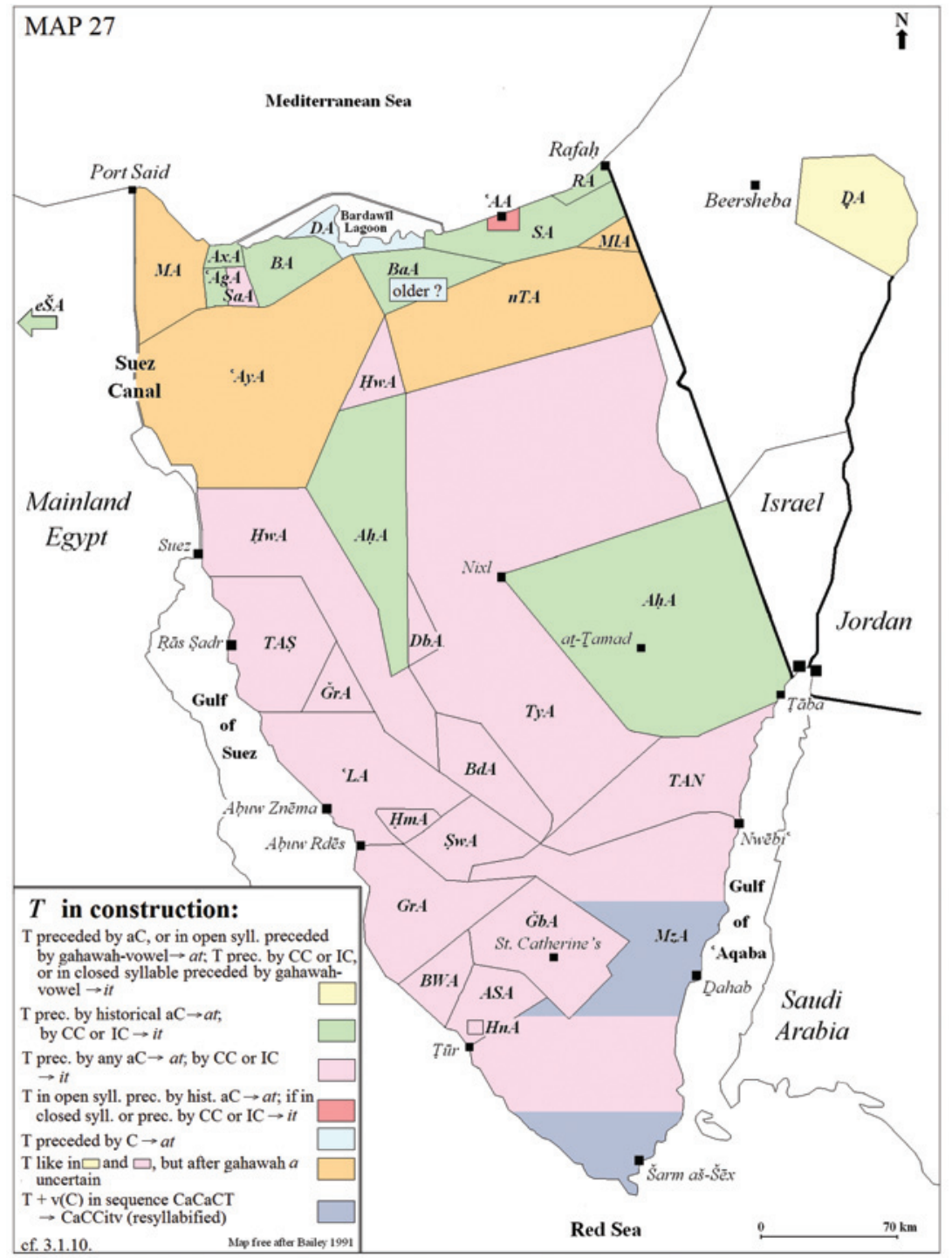

Map 27. $T$ in construction 


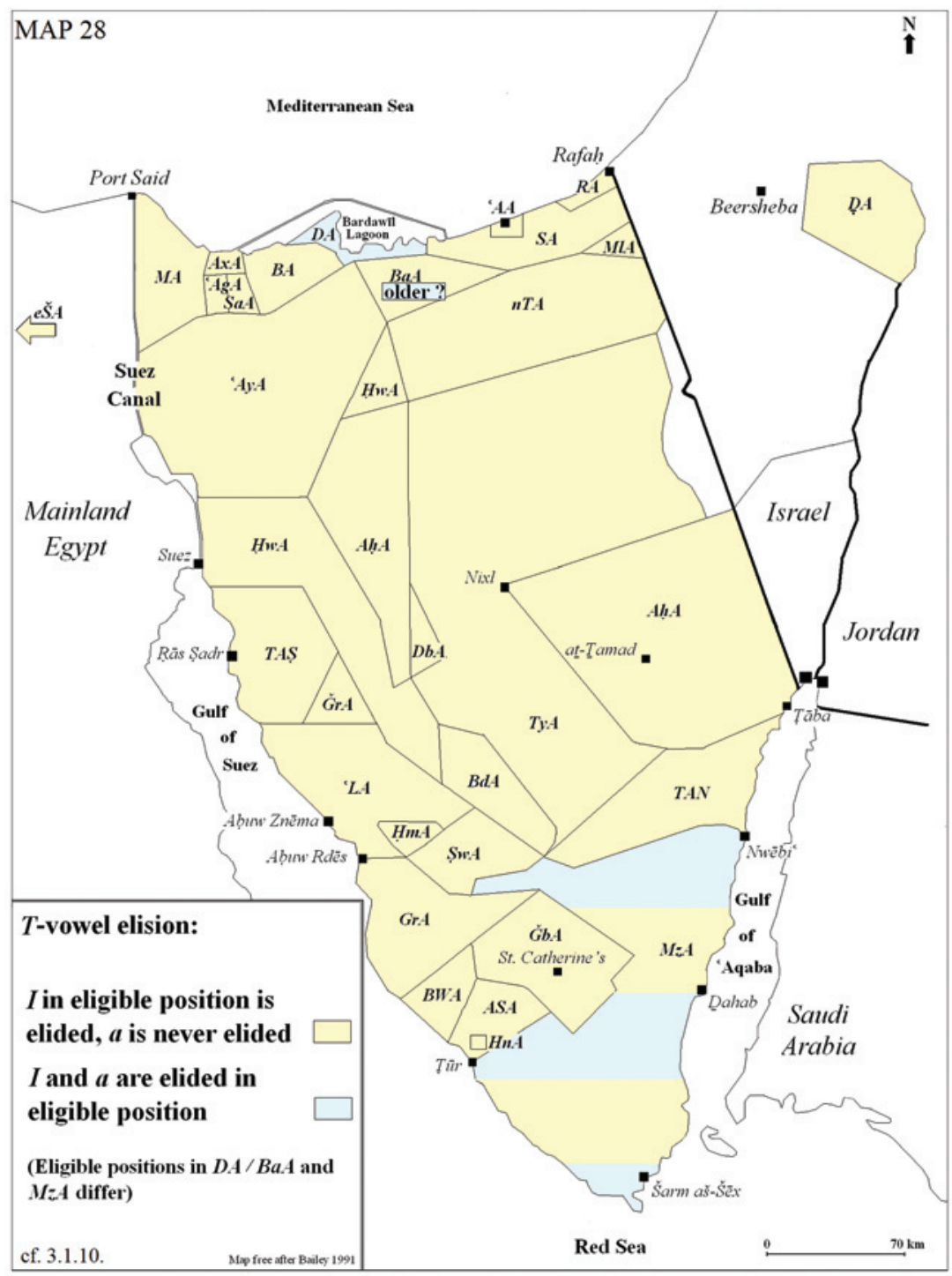

Map 28. $T$-vowel elision 


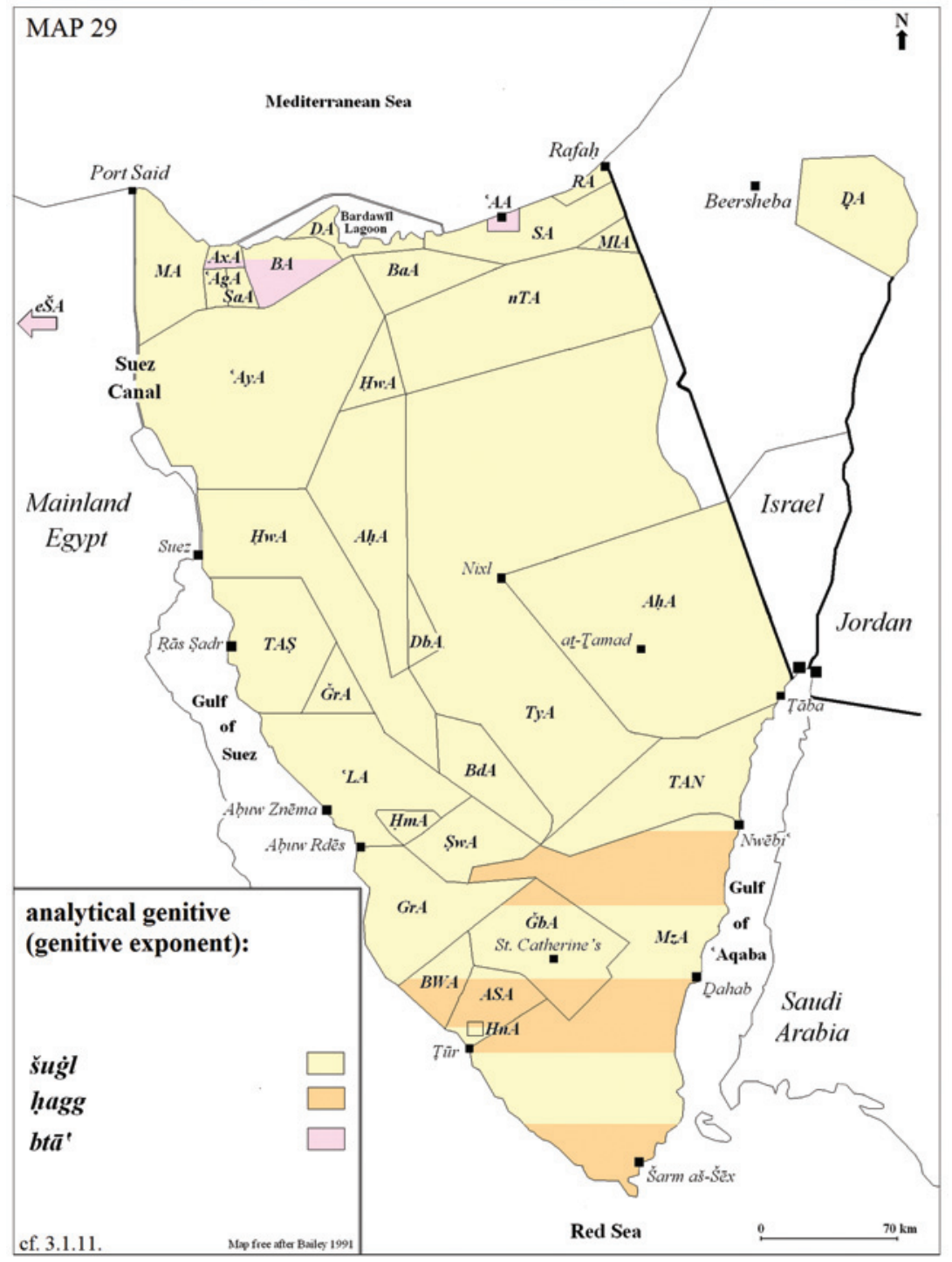

Map 29. Analytical genitive (genitive exponent)

For remarks on the absence of MAP 30 see Conclusions II. a. Criteria for comparison from De Jong 2000 producing differences/similarities in central and southern Sinai. 


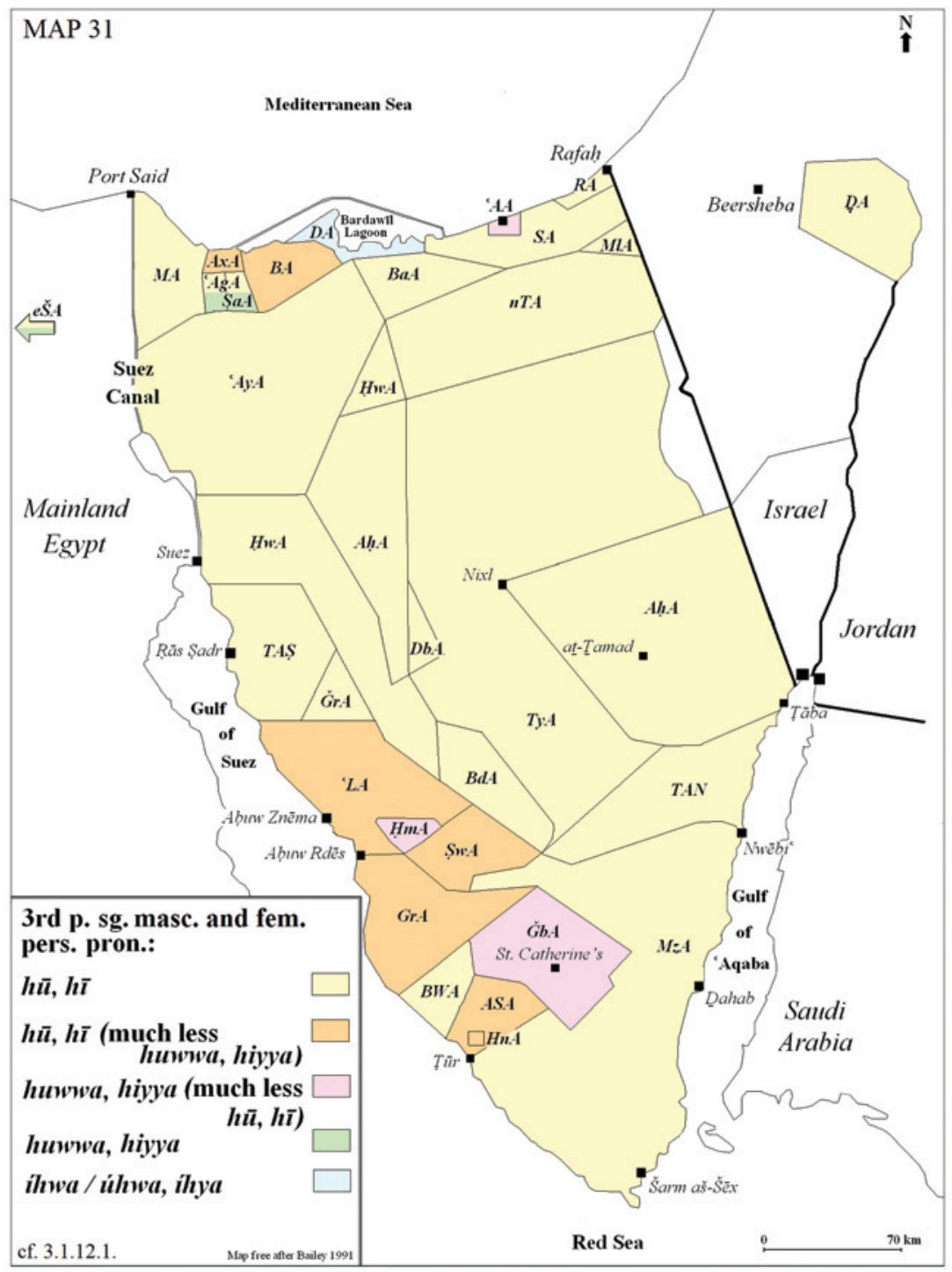

Map 31. The independent personal pronominals of the 3 rd p. sg. masc. and fem.

For remarks on the absence of MAPS 32 and 33 see Conclusions II. a. Criteria for comparison from De Jong 2000 producing differences/similarities in central and southern Sinai. 


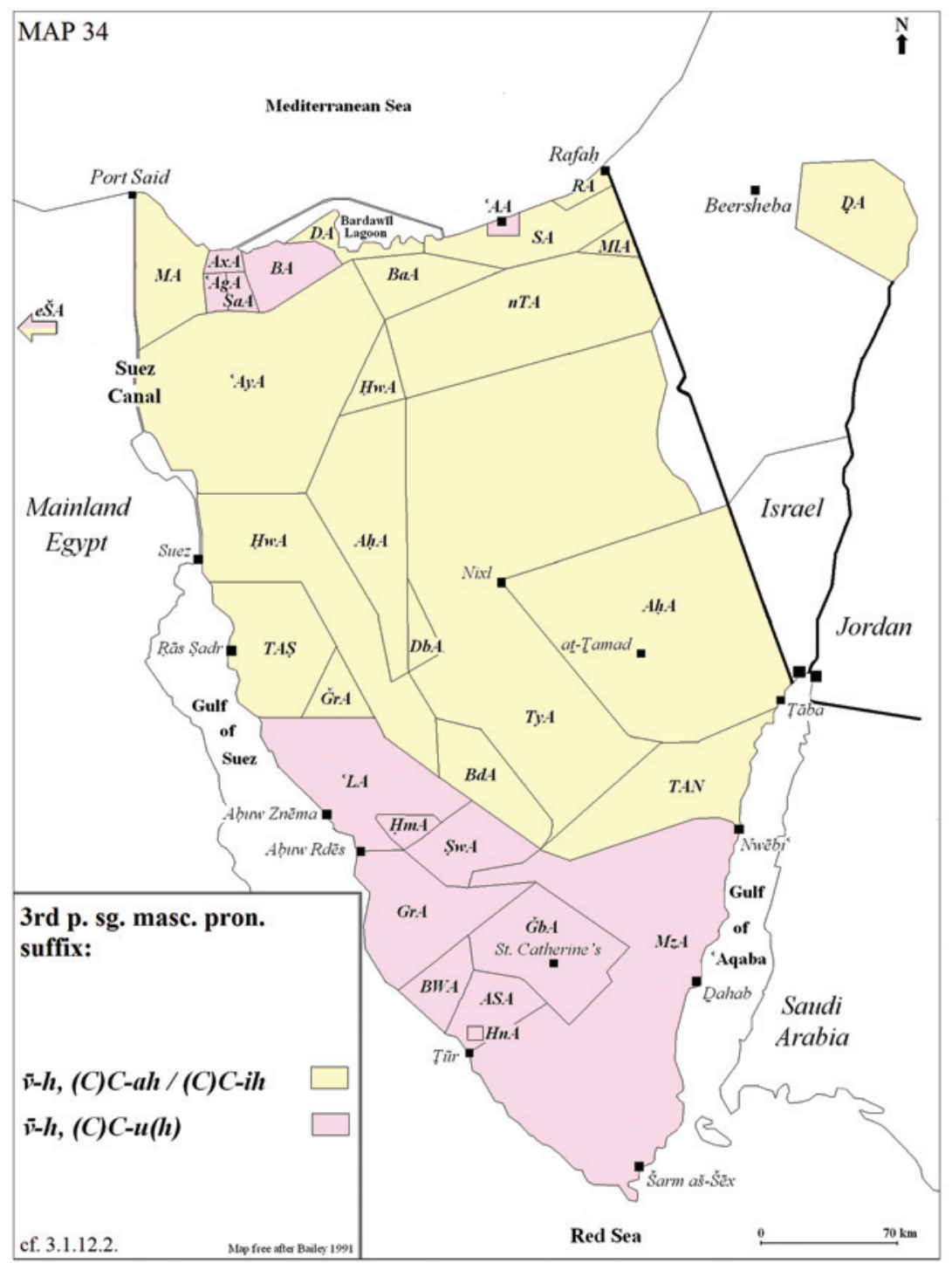

Map 34. 3rd p. sg. masc. pron. suffix 


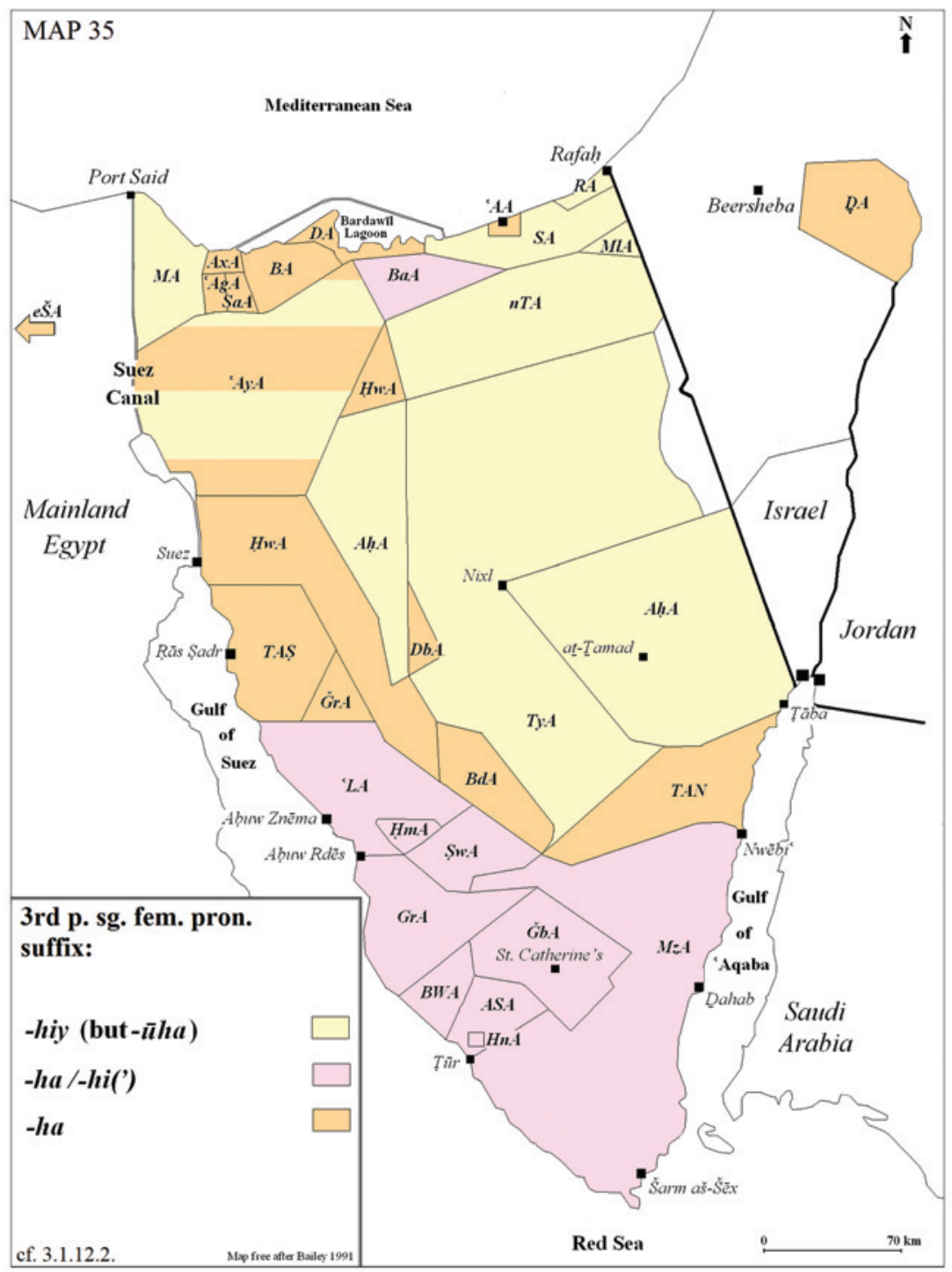

Map 35. 3rd p. sg. fem. pron. suffix 


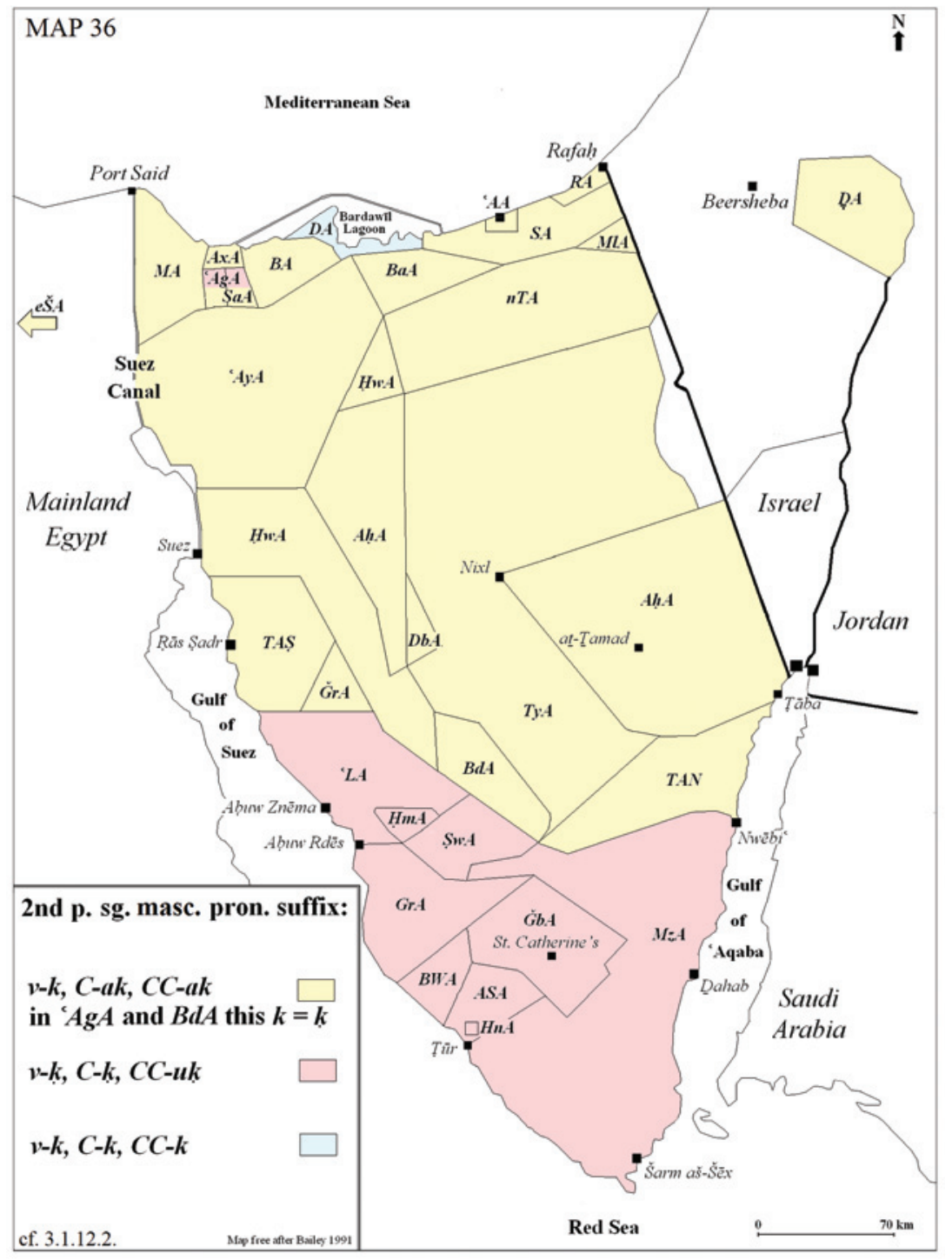

Map 36. 2nd p. sg. masc. pron. suffix 


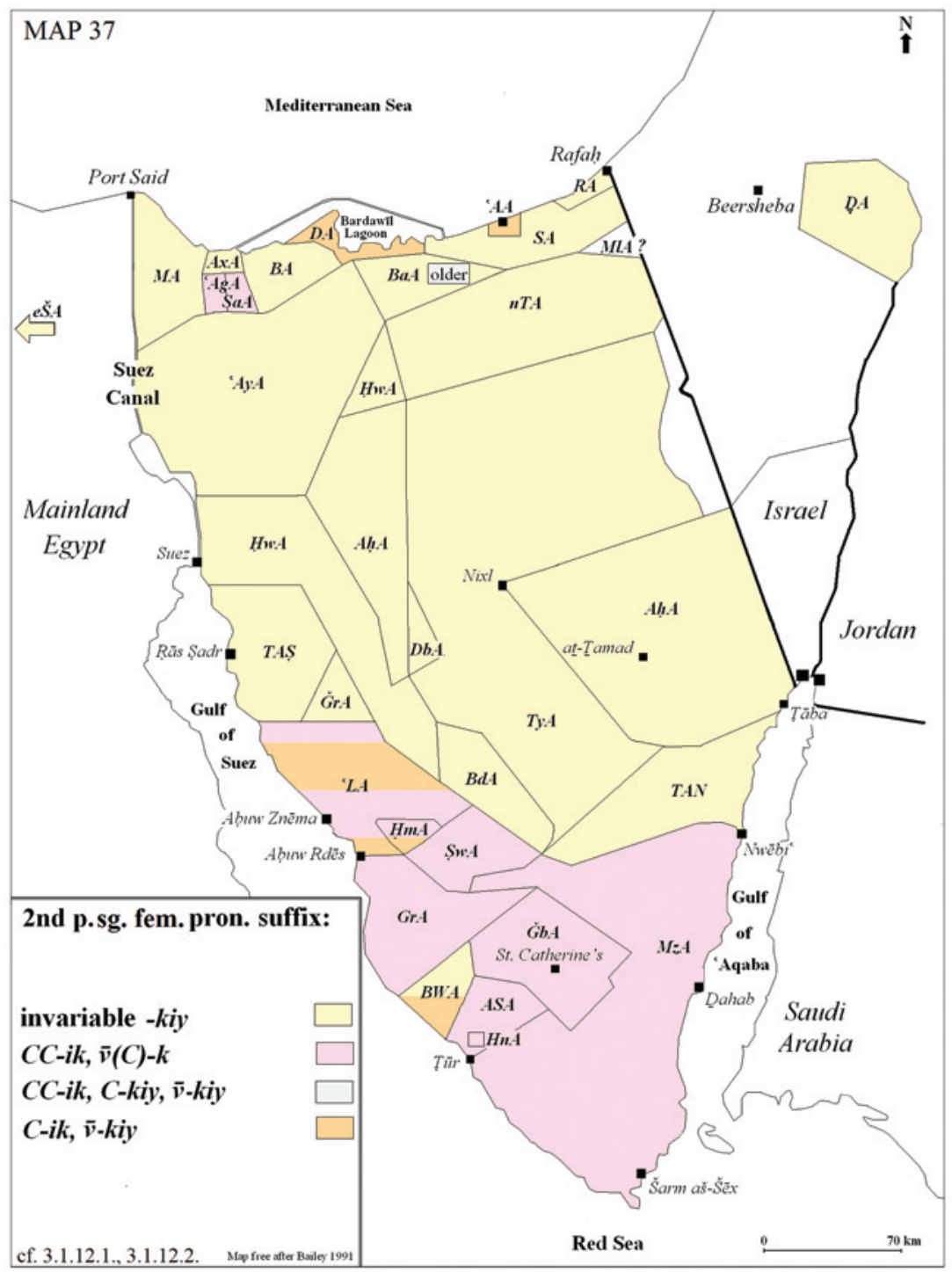

Map 37. 2nd p. sg. fem. pron. suffix

For remarks on the absence of MAP 38 see Conclusions II. a. Criteria for comparison from De Jong 2000 producing differences/similarities in central and southern Sinai. 


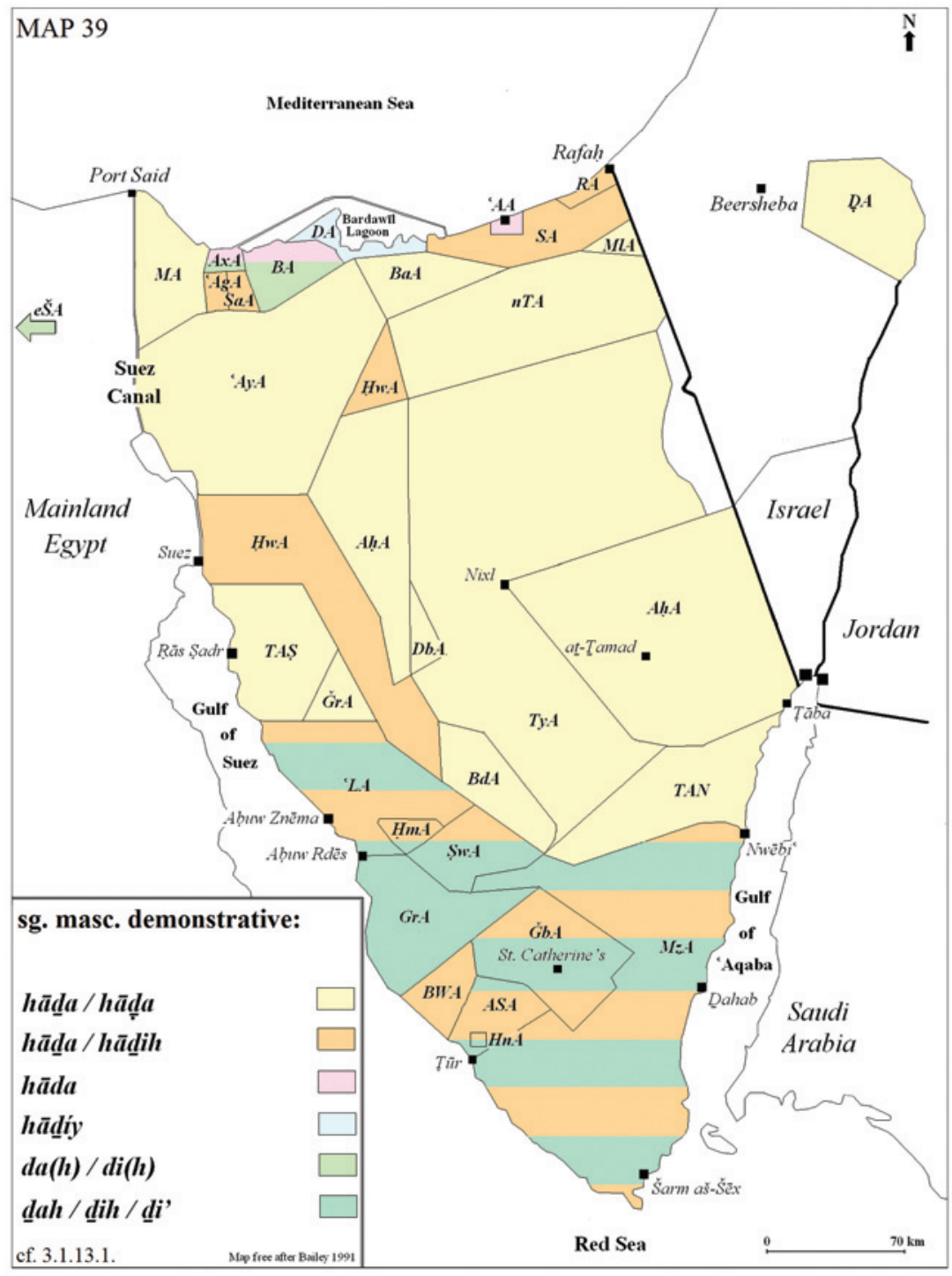

Map 39. sg. masc. demonstrative 


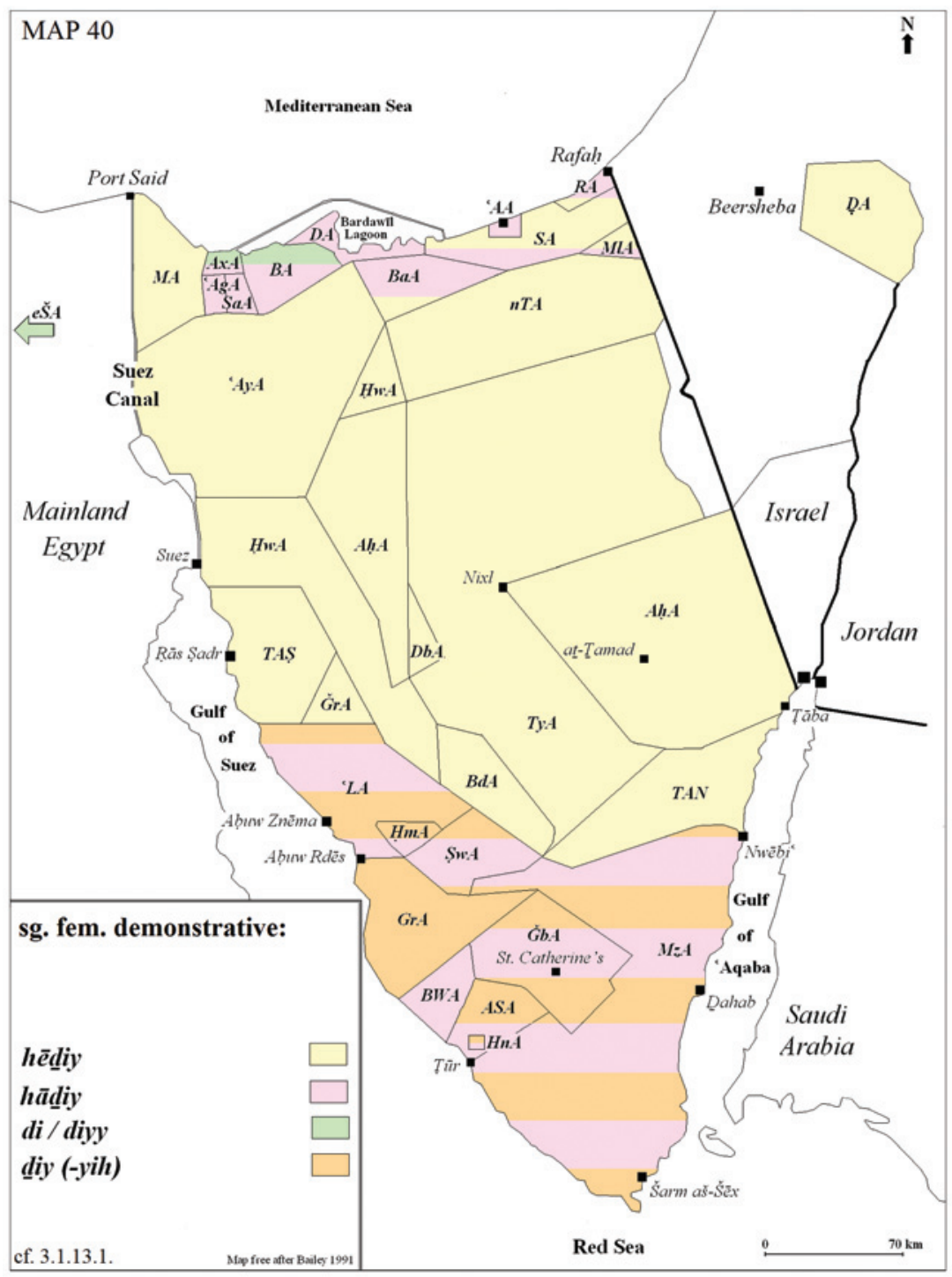

Map 40. sg. fem. demonstrative

For remarks on the absence of MAP 41 see Conclusions II. a. Criteria for comparison from De Jong 2000 producing differences/similarities in central and southern Sinai. 


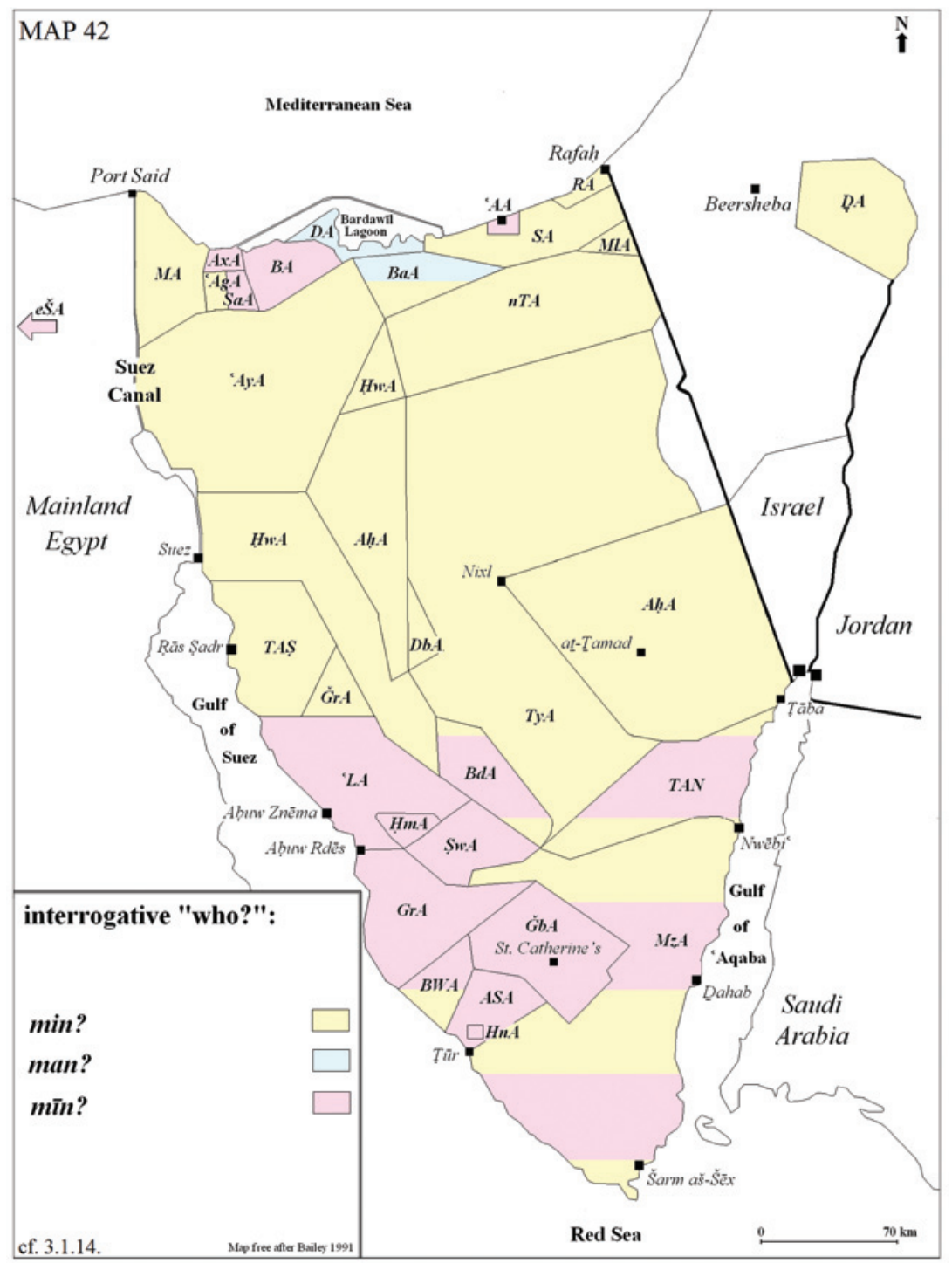

Map 42. Interrogative "who?"

For remarks on the absence of MAPS 43 and 44 see Conclusions II. a. Criteria for comparison from De Jong 2000 producing differences/similarities in central and southern Sinai. 


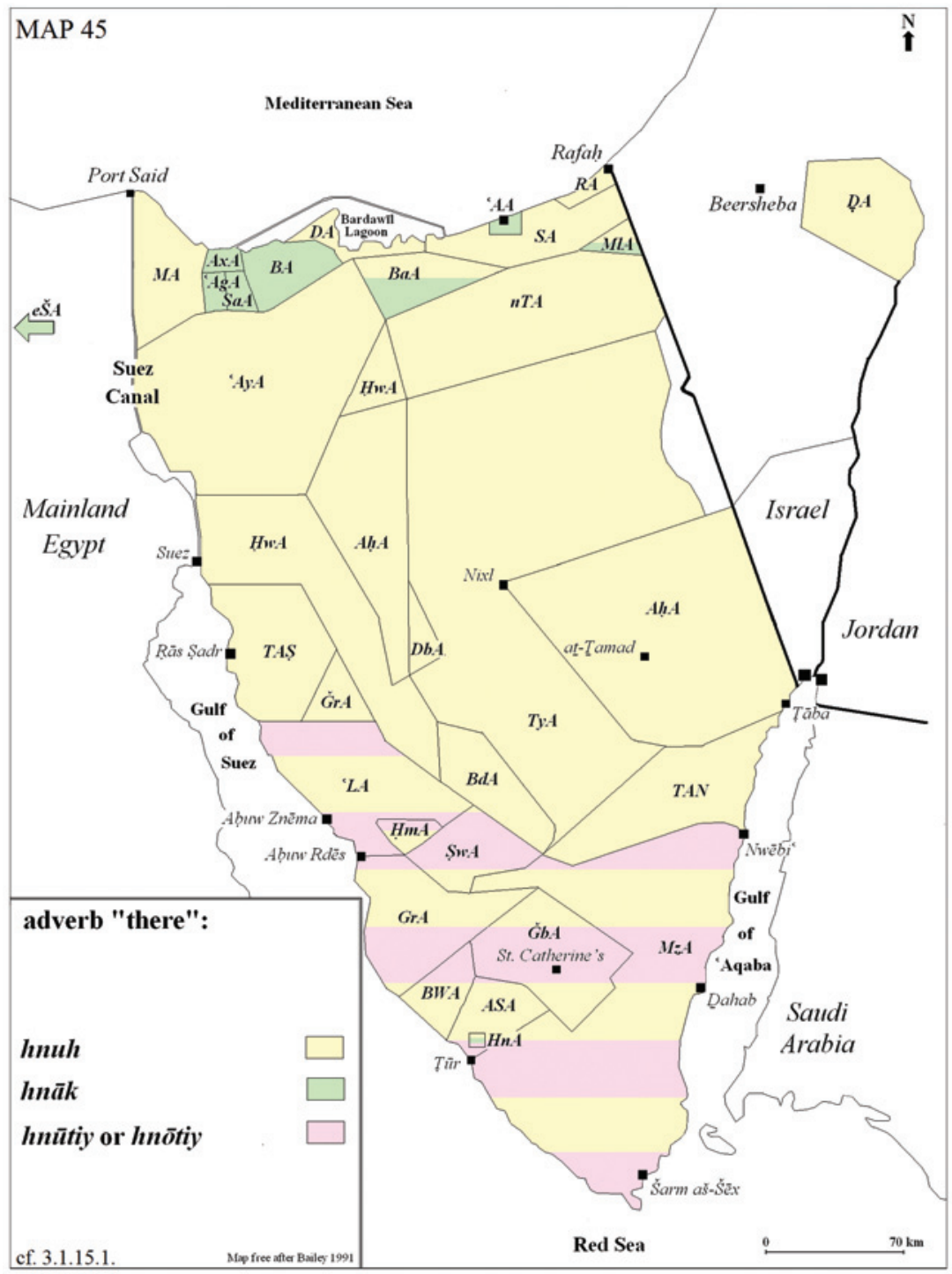

Map 45. Shape of the adverb "there" 


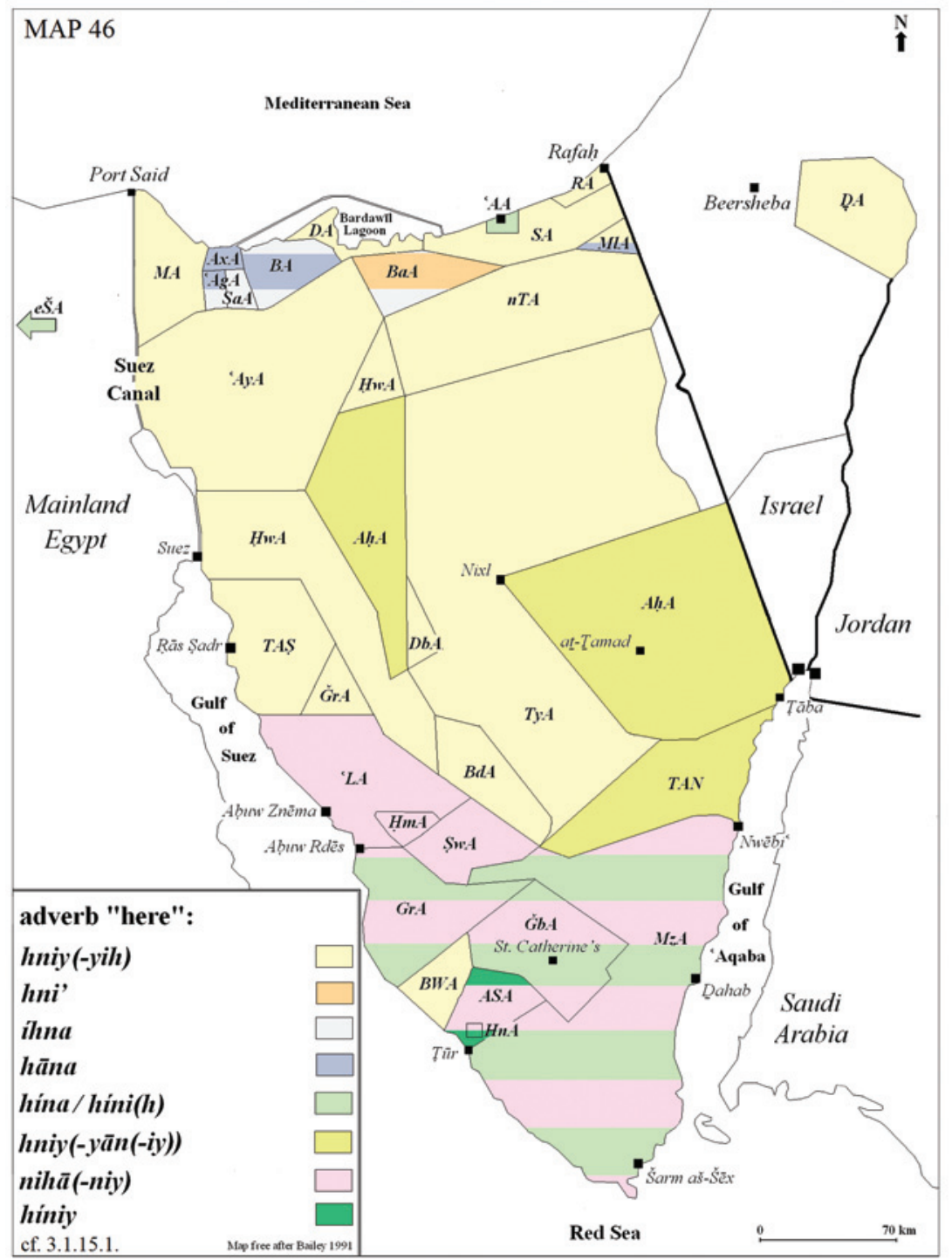

Map 46. Shape of the adverb "here" 


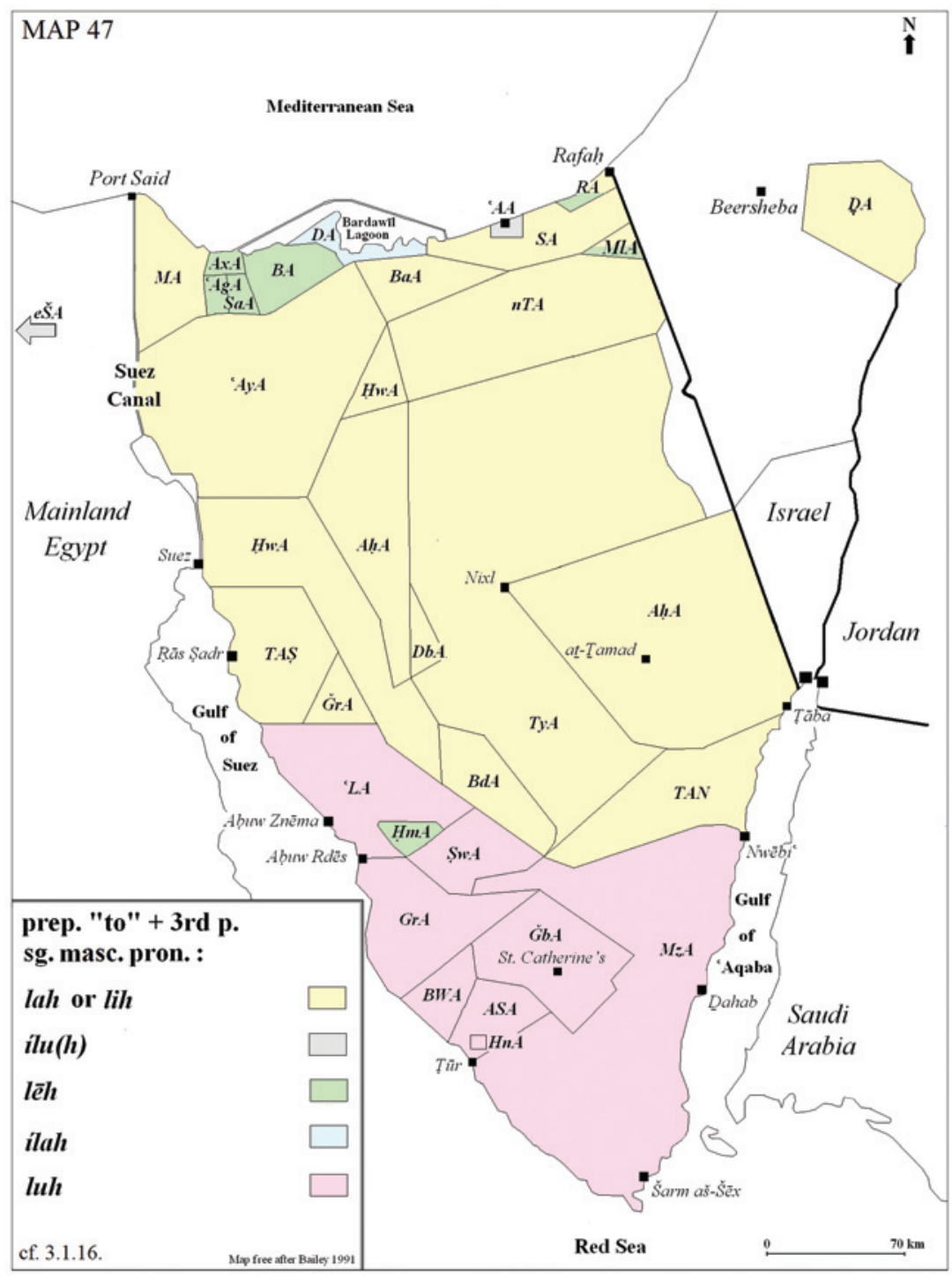

Map 47. The preposition "to" + 3rd p. sg. masc. pron 


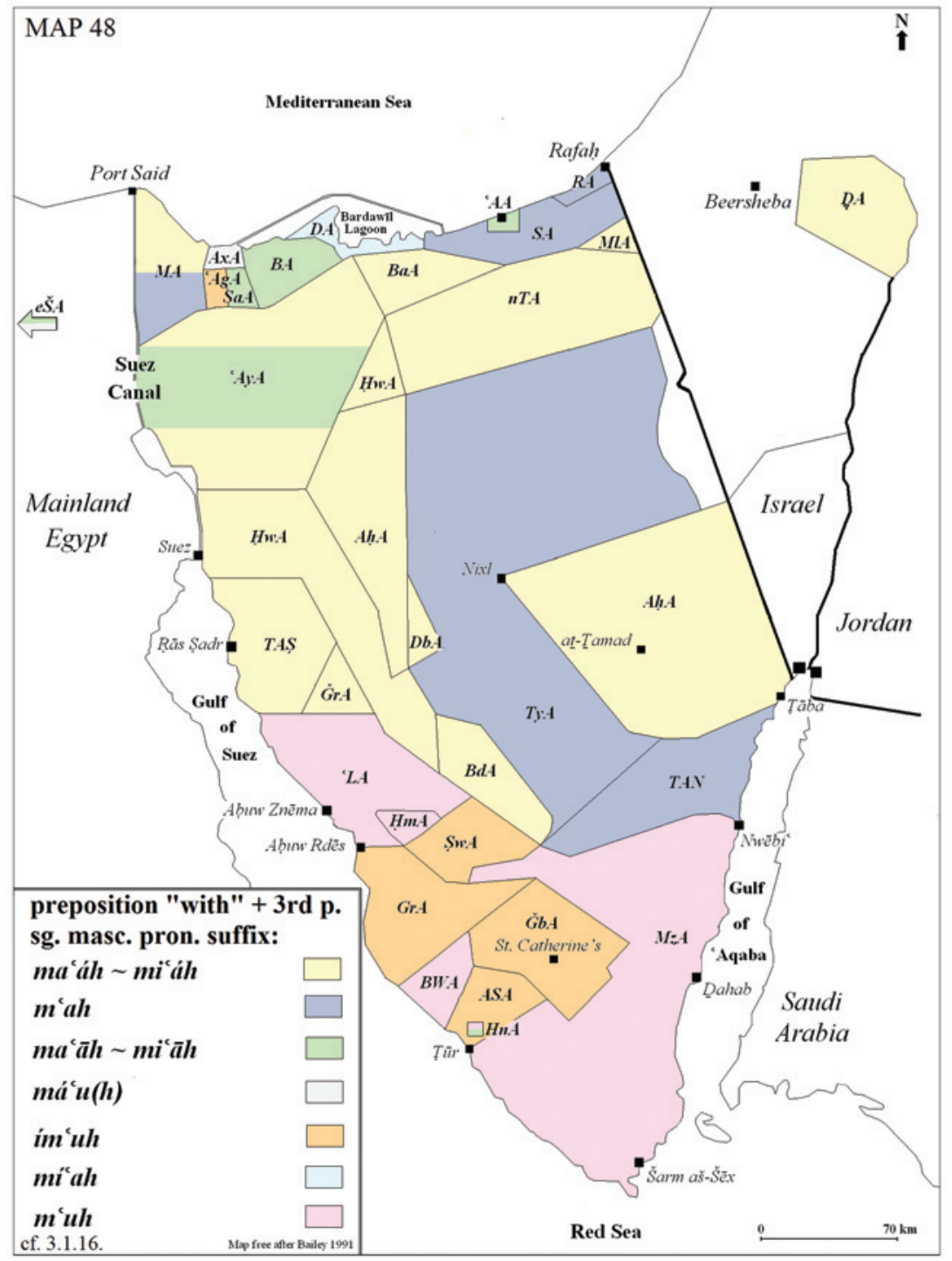

Map 48. The preposition "with" + 3rd p. sg. masc. suffix 


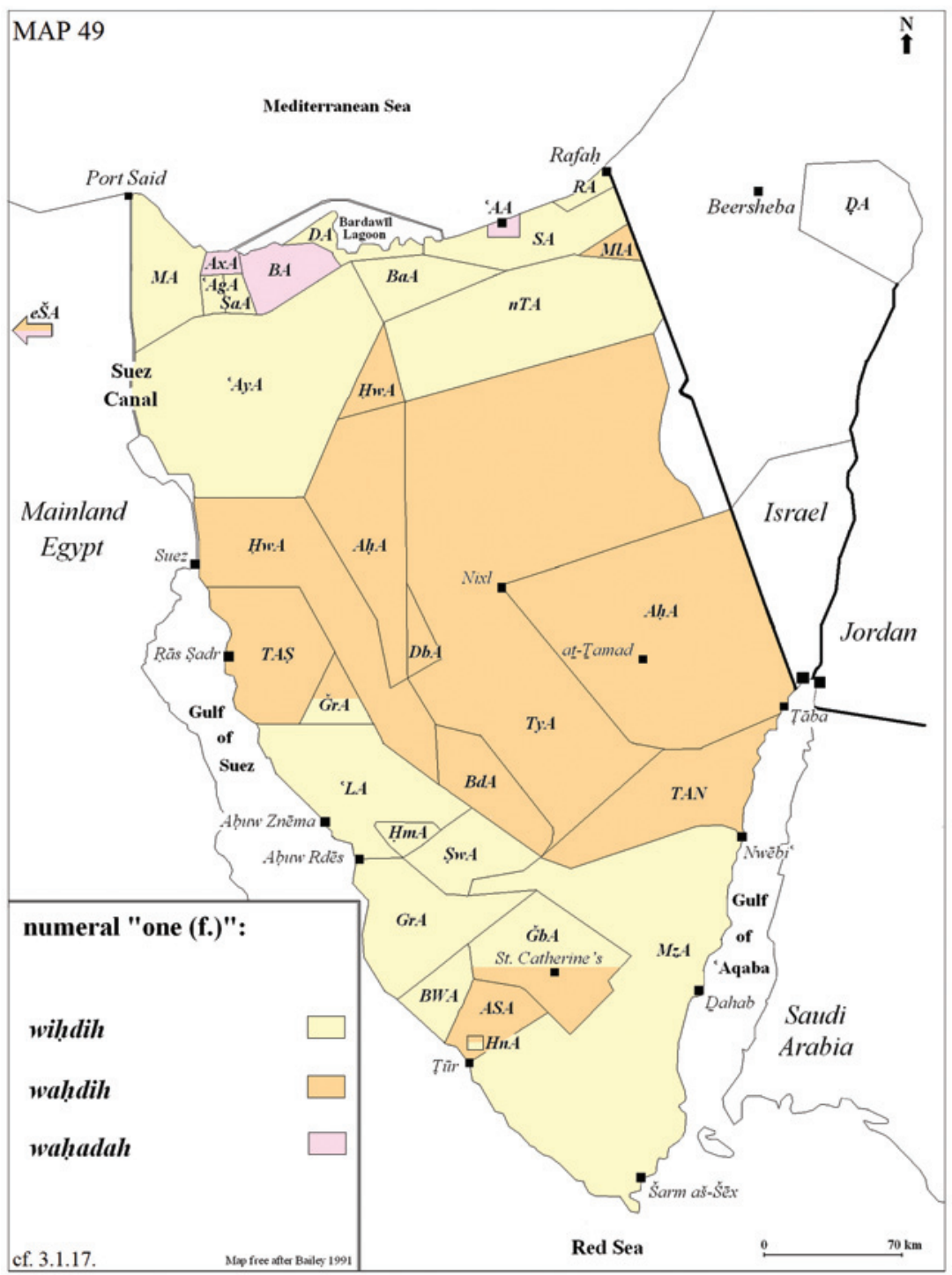

Map 49. Numeral "one (fem.)" 


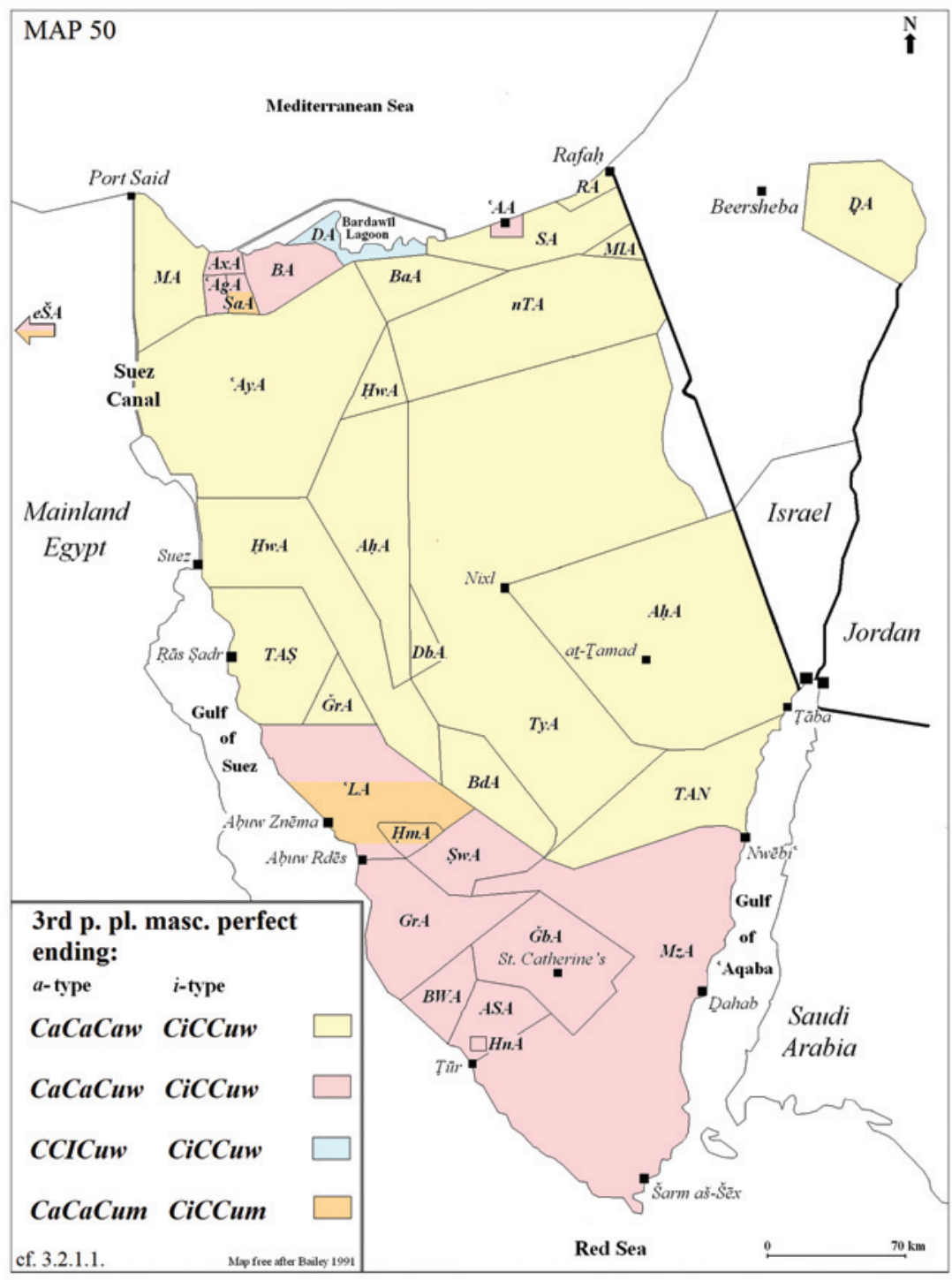

Map 50. 3rd p. pl. masc. perfect ending

For remarks on the absence of MAP $5^{1}$ see Conclusions II. a. Criteria for comparison from De Jong 2000 producing differences/similarities in central and southern Sinai. 


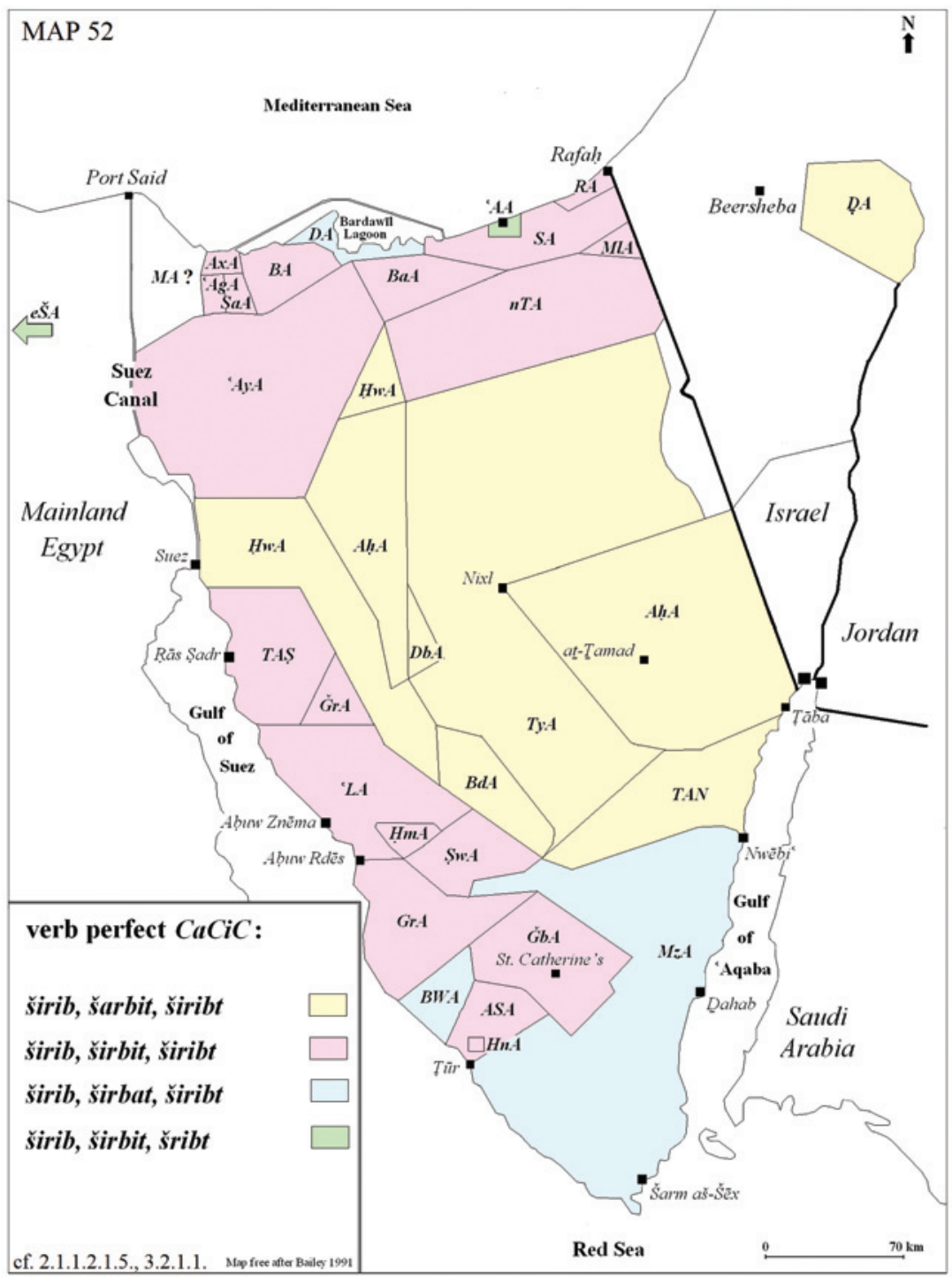

Map 52. Verb perfect $\mathrm{CaCiC}$

For remarks on the absence of MAP 53 see Conclusions II. a. Criteria for comparison from De Jong 2000 producing differences/similarities in central and southern Sinai. 


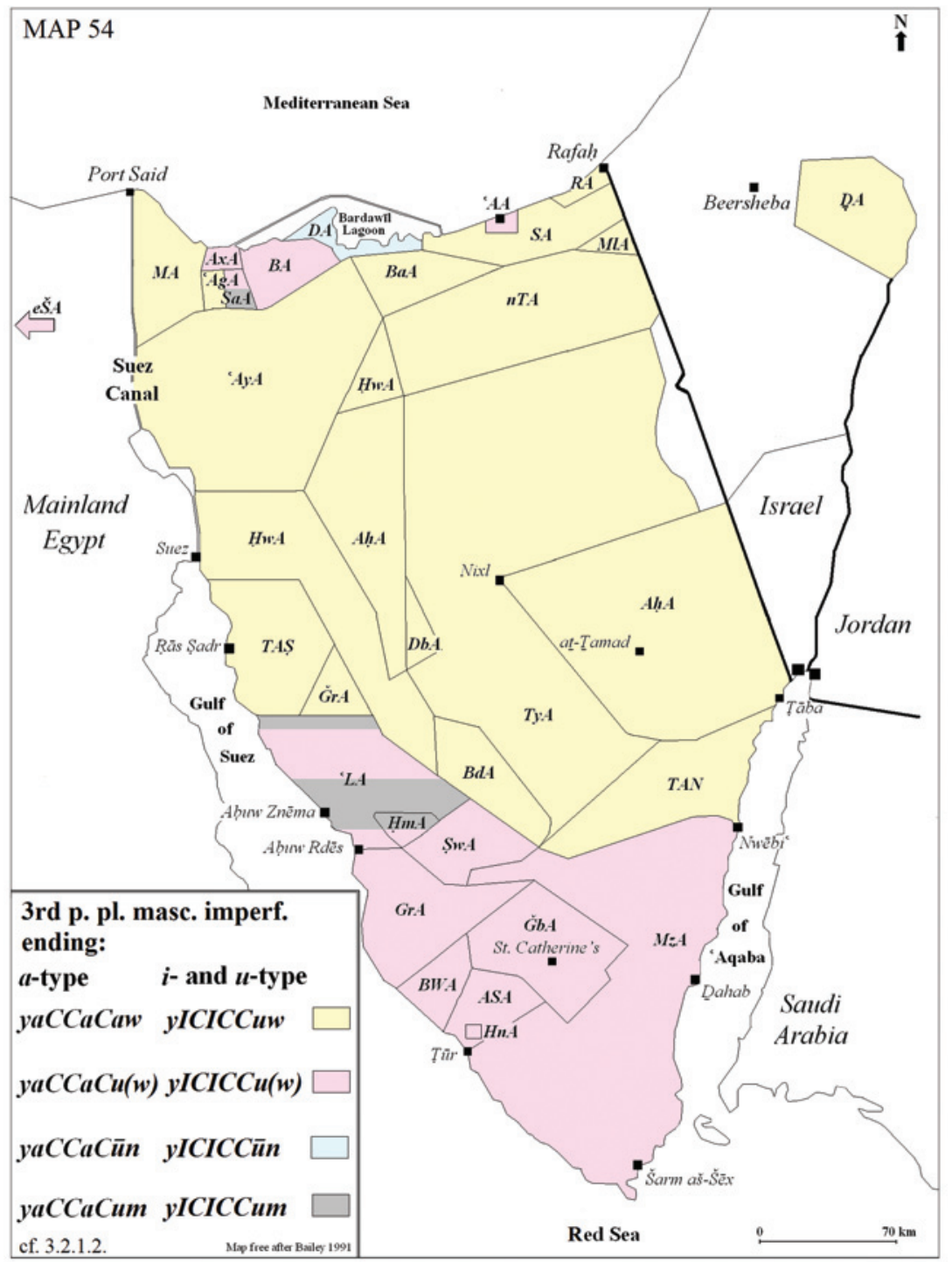

Map 54. 3rd p. pl. masc. imperf. ending 


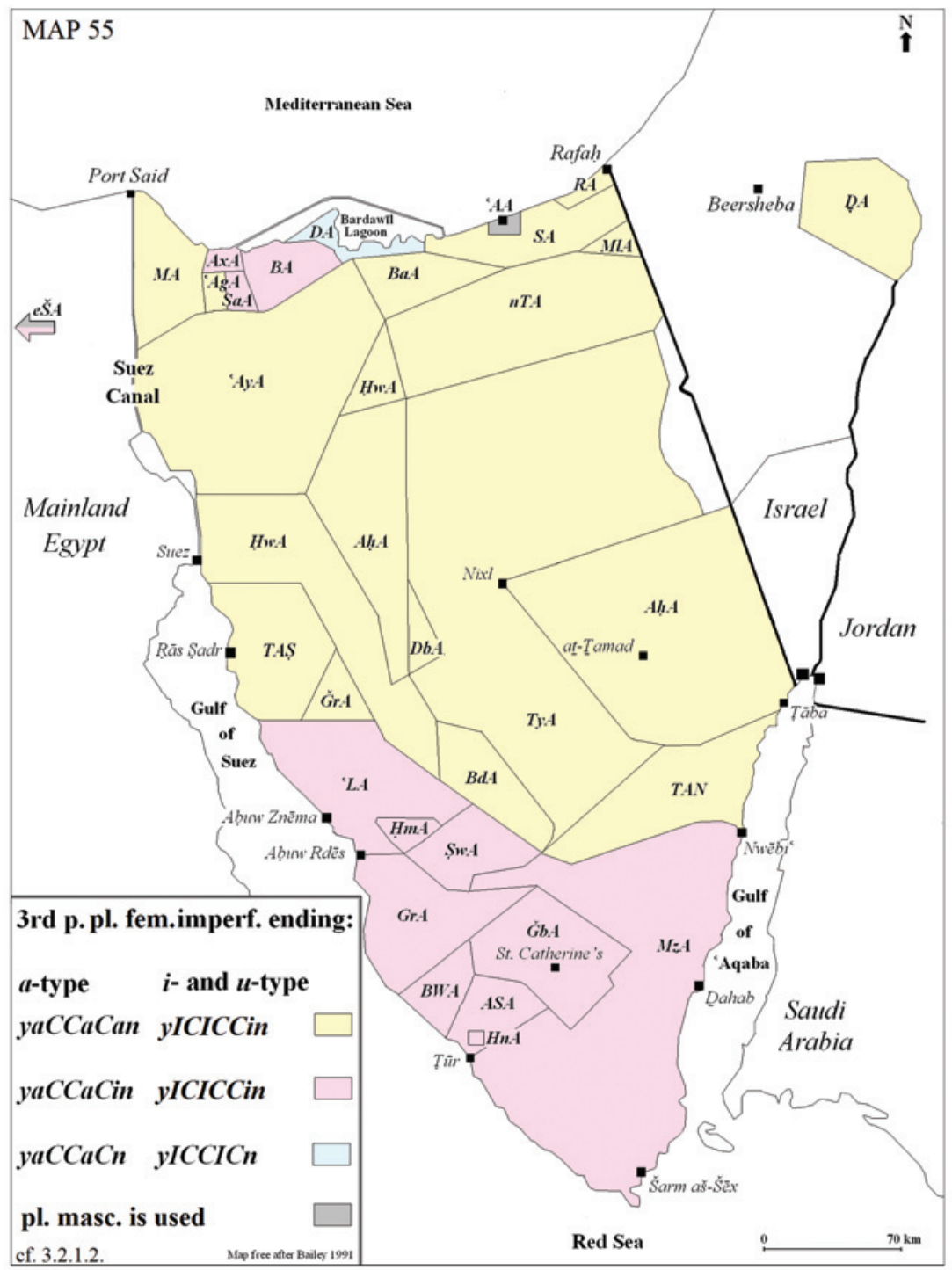

Map 55. 3rd p. pl. fem. imperf. ending

For remarks on the absence of MAP 56 see Conclusions II. a. Criteria for comparison from De Jong 2000 producing differences/similarities in central and southern Sinai. 


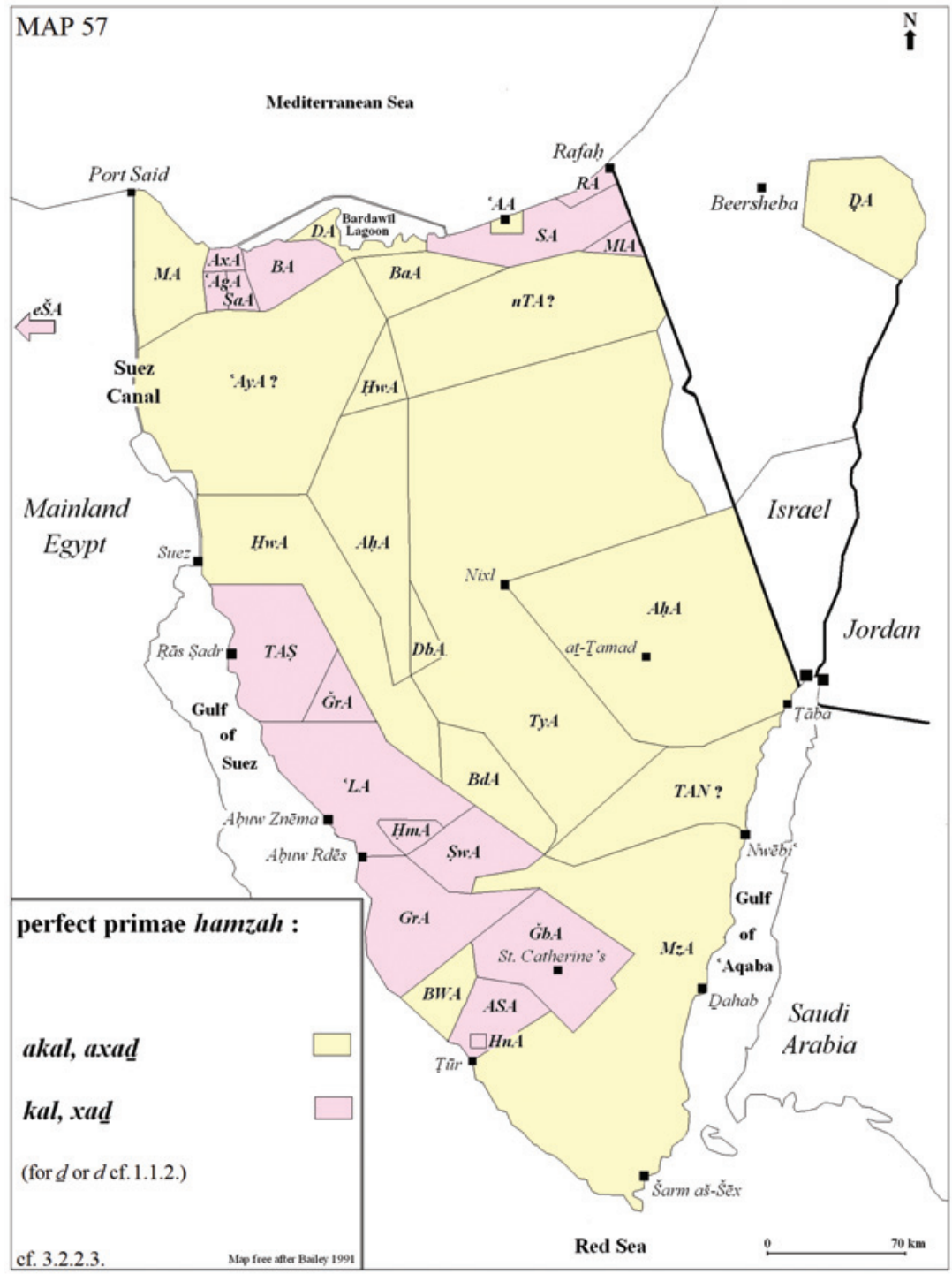

Map 57. Perfect of primae hamzah verbs 


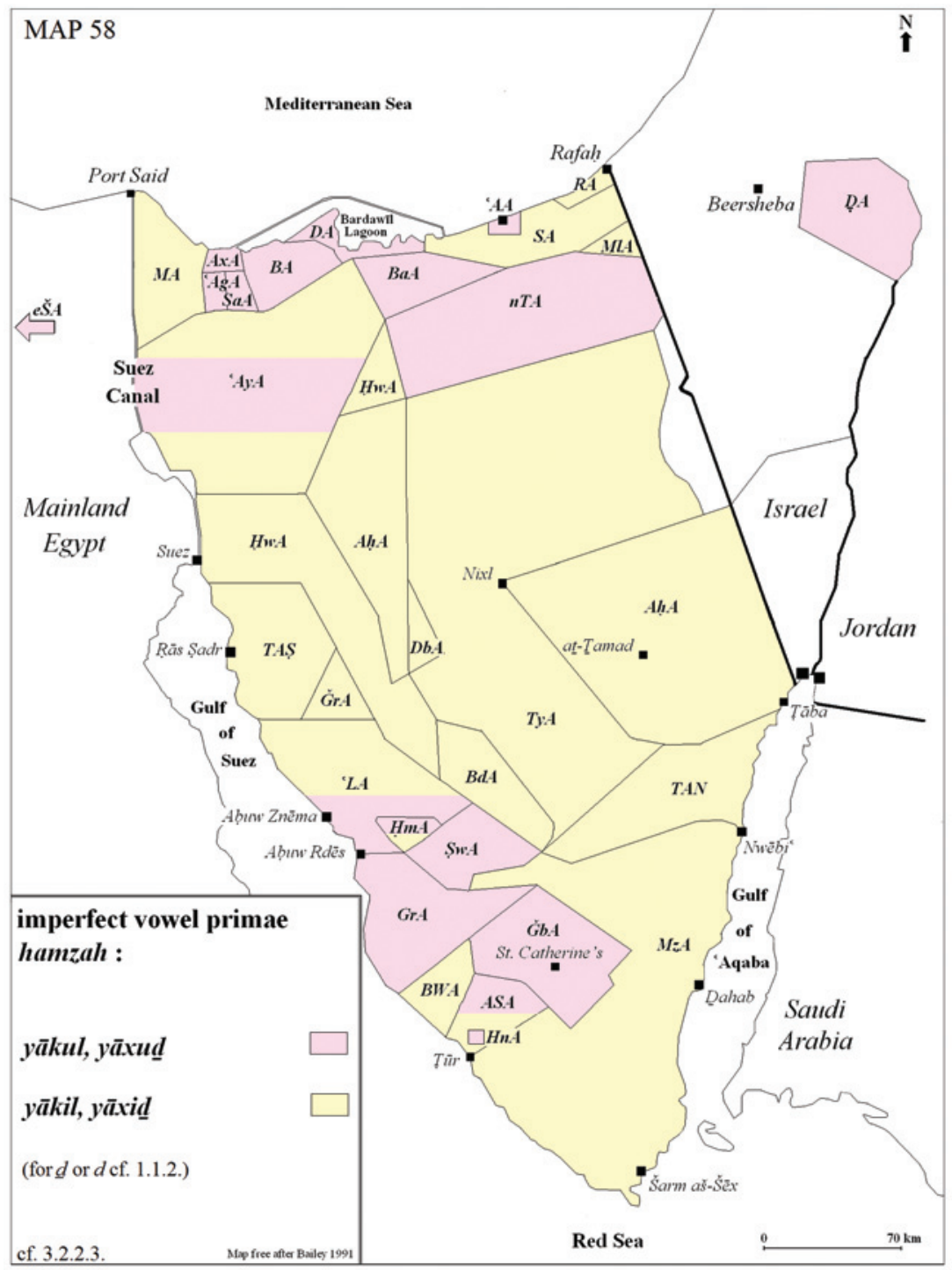

Map 58. Imperfect vowel primae hamzah verbs

For remarks on the absence of MAP 59 see Conclusions II. a. Criteria for comparison from De Jong 2000 producing differences/similarities in central and southern Sinai. 


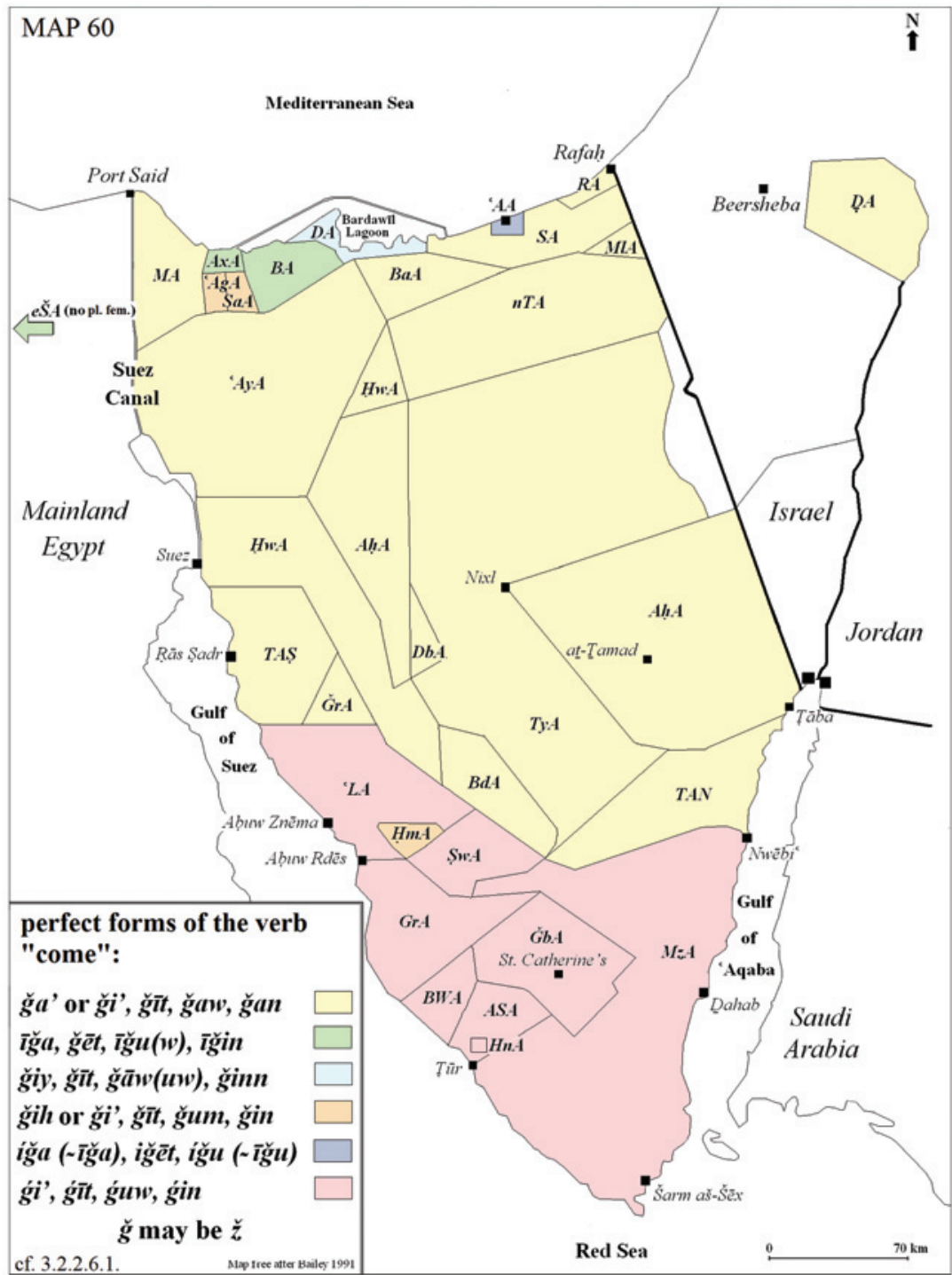

Map 6o. Perfect forms of the verb "come" 


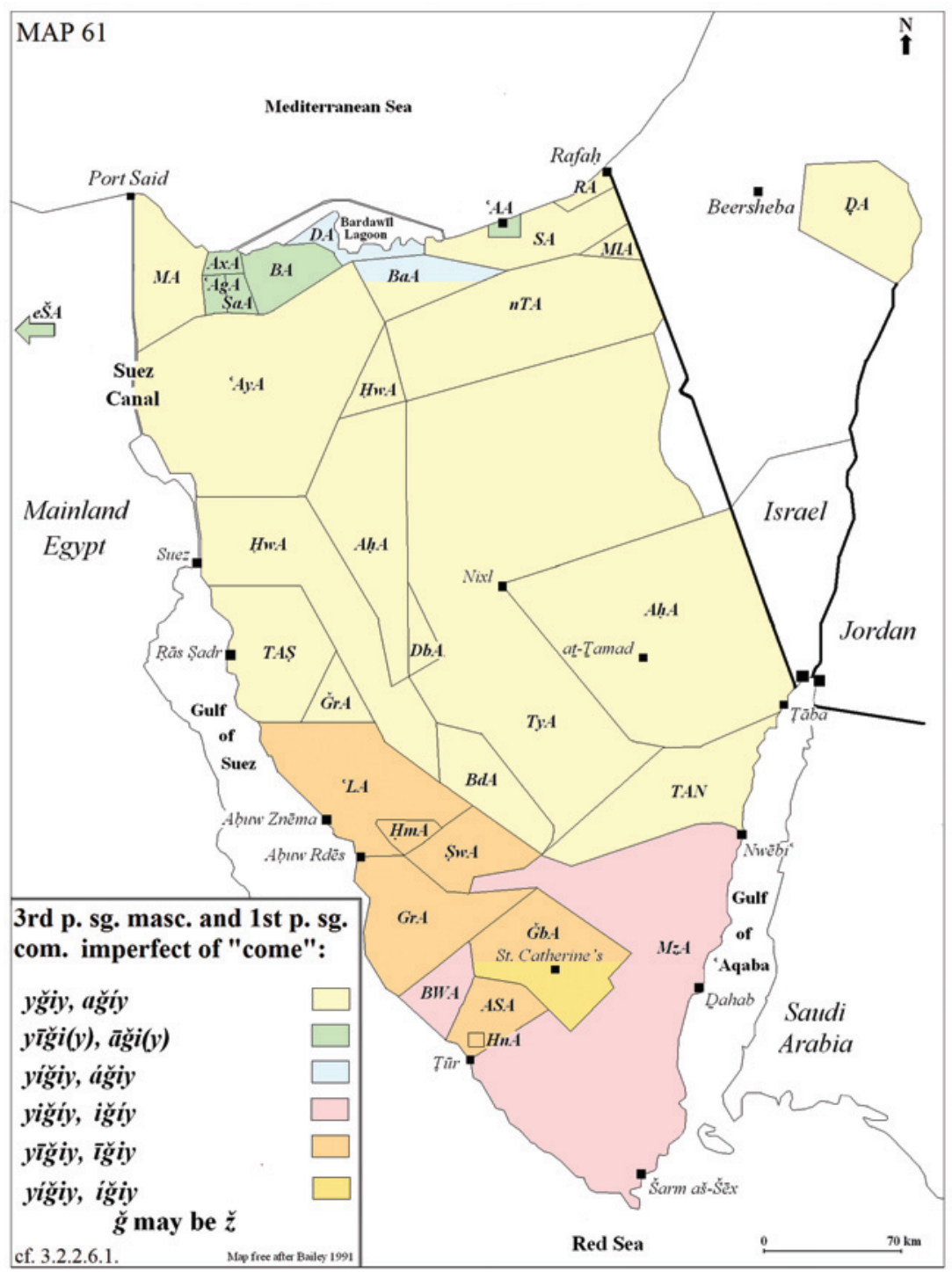

Map 61. 3rd p. sg. masc. and 1st p. sg. com. imperfect of "come" 


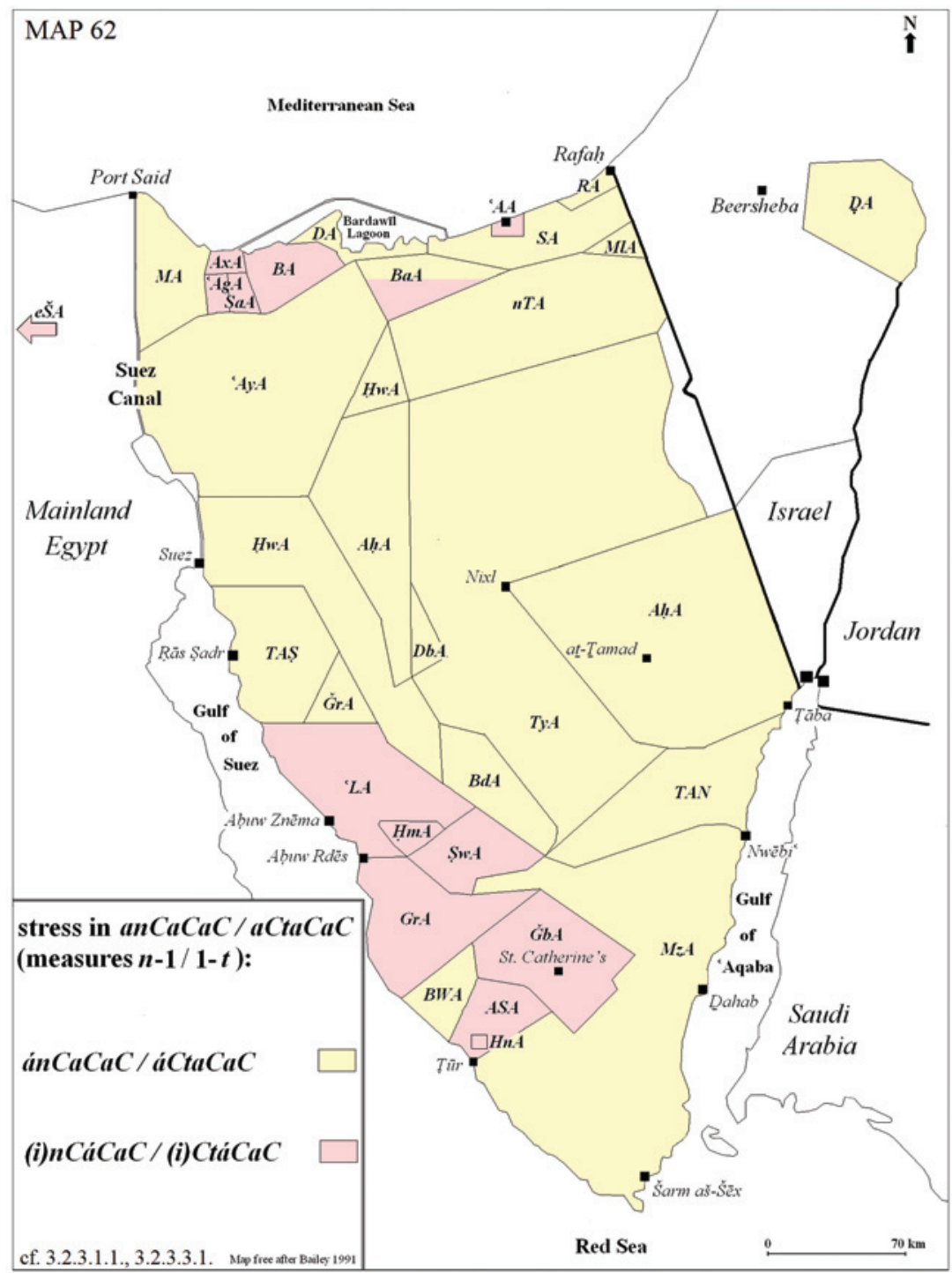

Map 62. Stress in anCaCaC / aCtaCaC (measures $n-1 / 1-t$ )

For remarks on the absence of MAPS $63,64,65,66$ and 67 see Conclusions II. a. Criteria for comparison from De Jong 2000 producing differences/similarities in central and southern Sinai. 


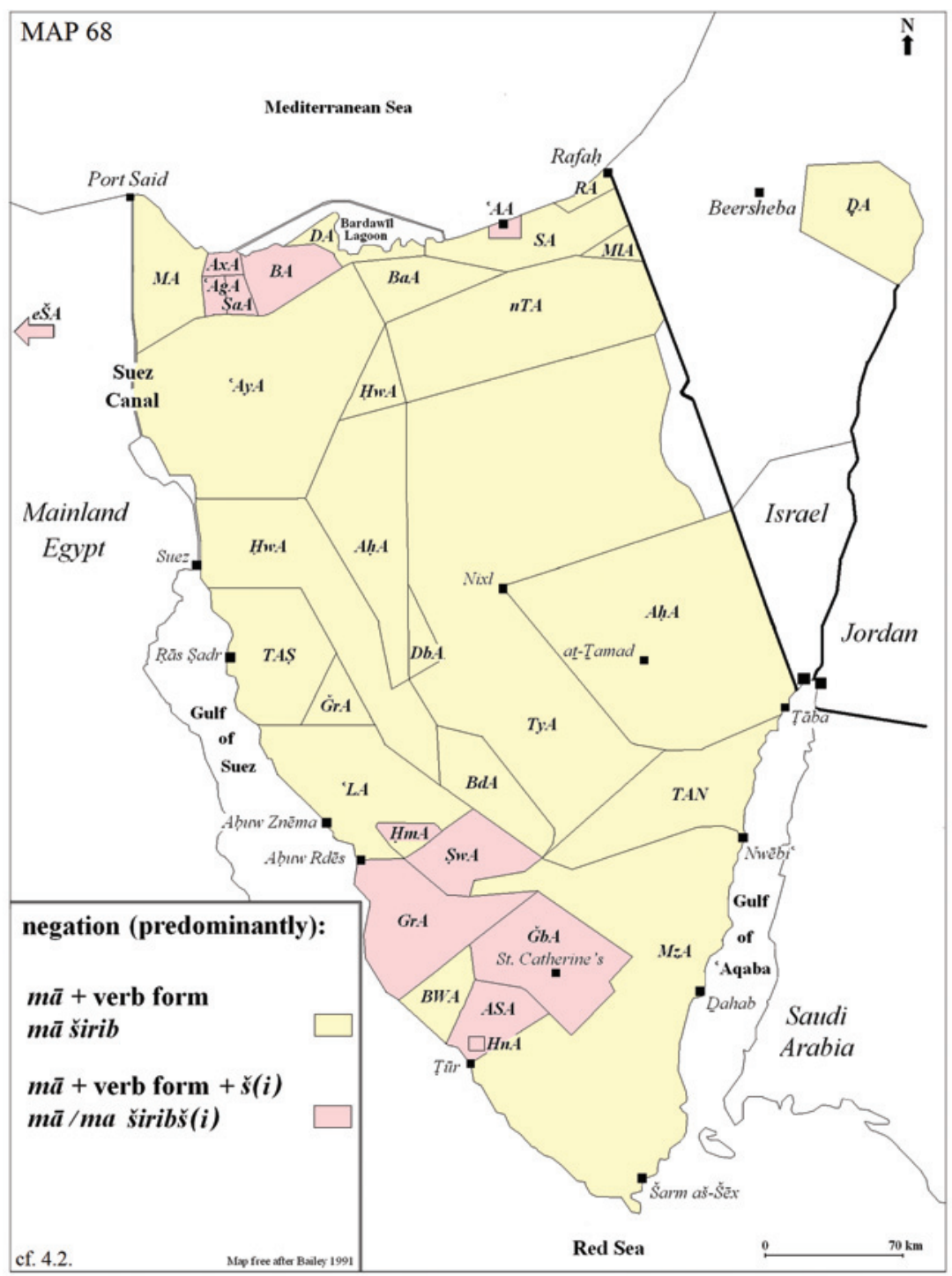

Map 68. Negation (predominantly)

For remarks on the absence of MAPS 69 and 70 see Conclusions II. a. Criteria for comparison from De Jong 2000 producing differences/similarities in central and southern Sinai. 


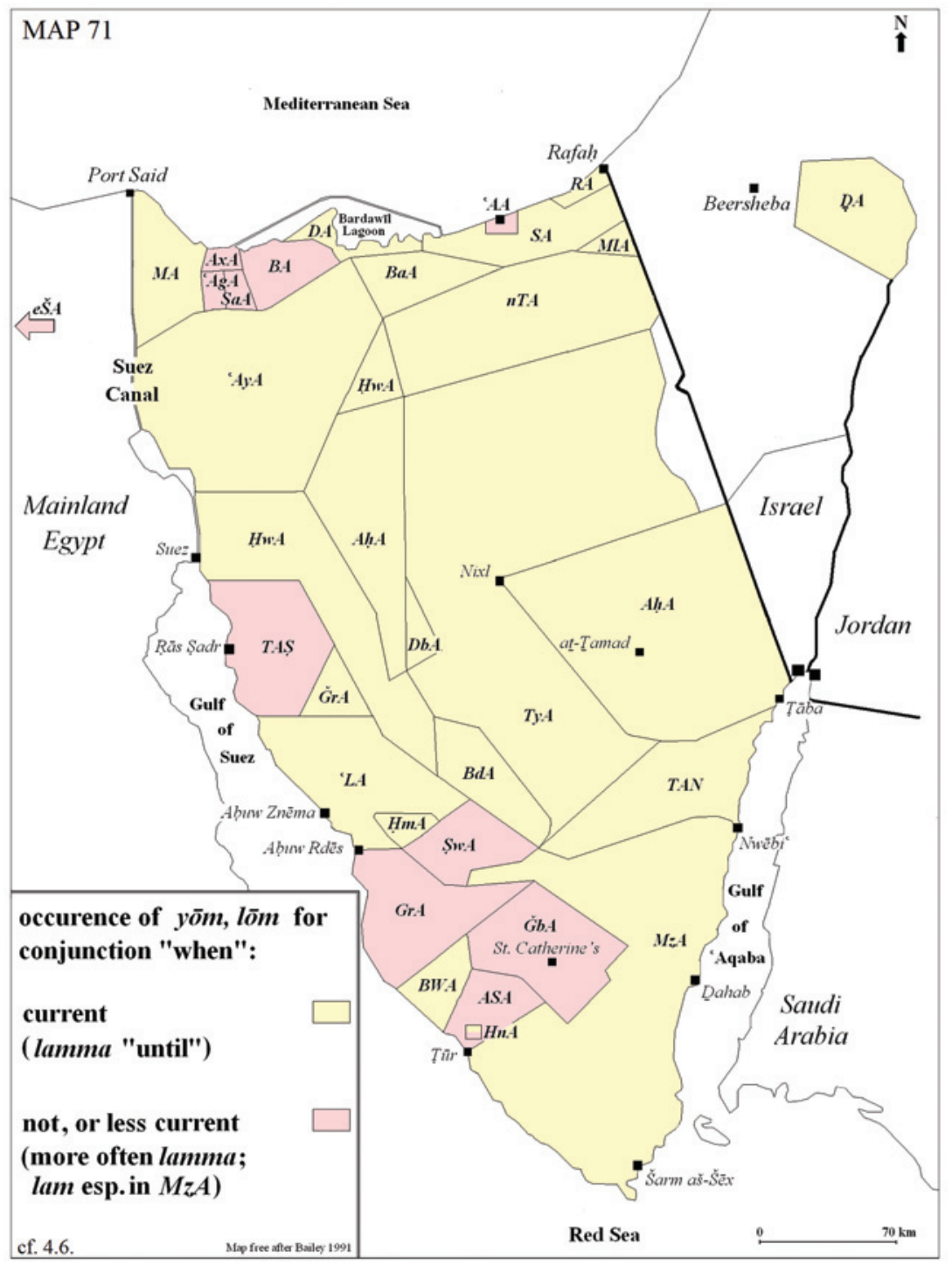

Map 71. Occurrence of $y \bar{o} m$, lōm for conjunction "when" 


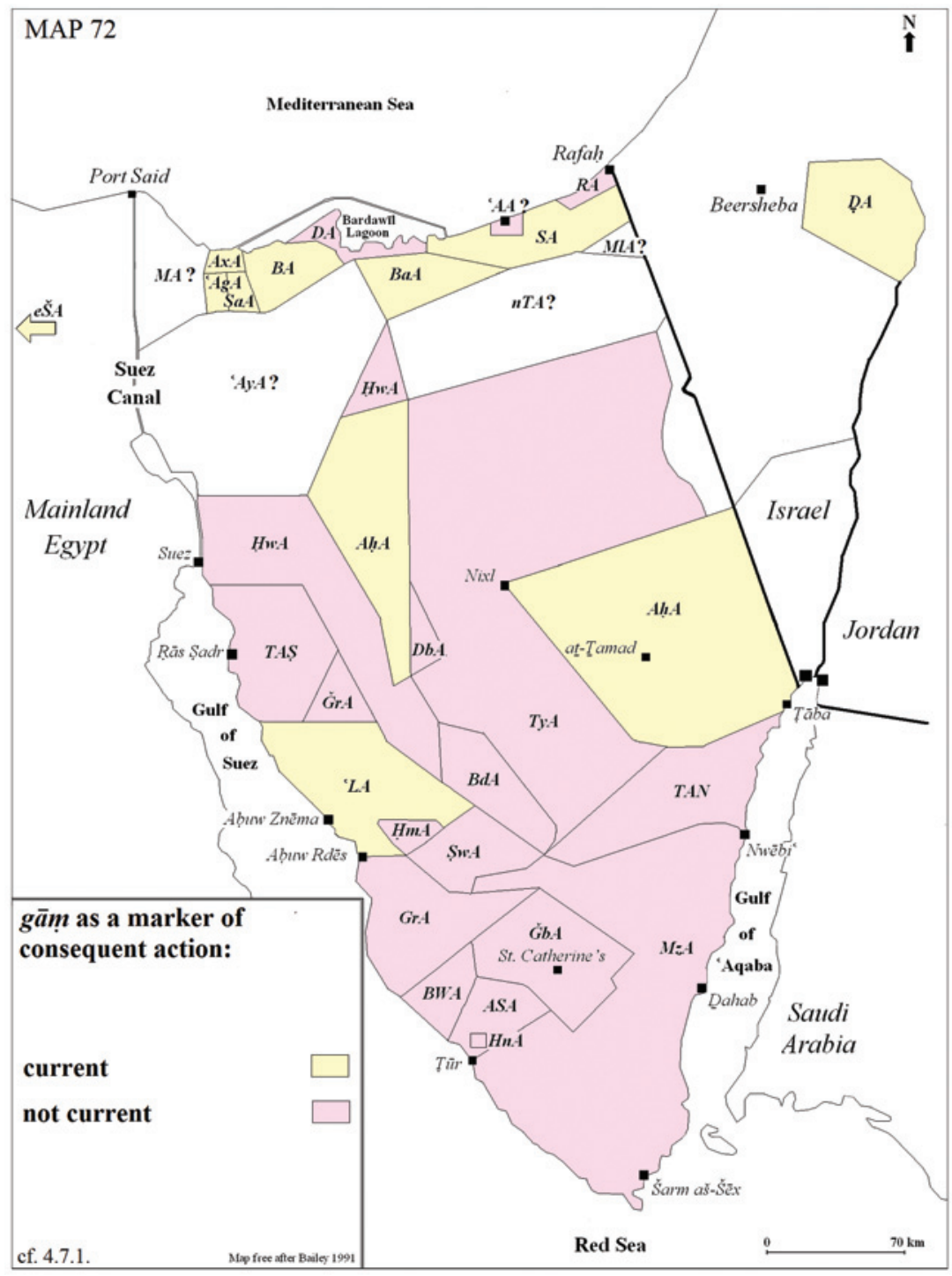

Map 72. Marker of consequent action (unconjugated) gām 


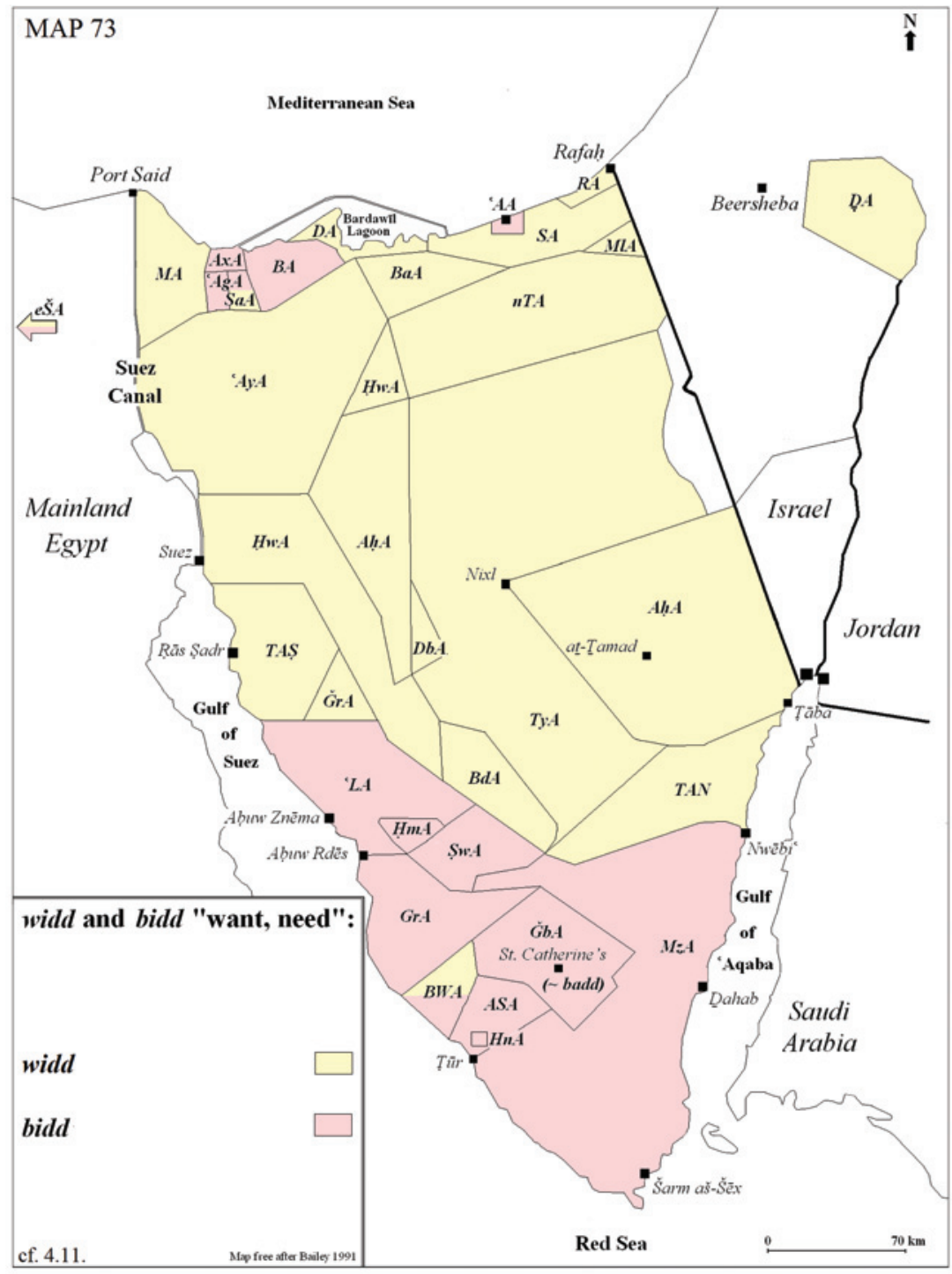

Map 73. Use of widd or bidd, "want, need"

For remarks on the absence of MAP 74 see Conclusions II. a. Criteria for comparison from De Jong 2000 producing differences/similarities in central and southern Sinai. 


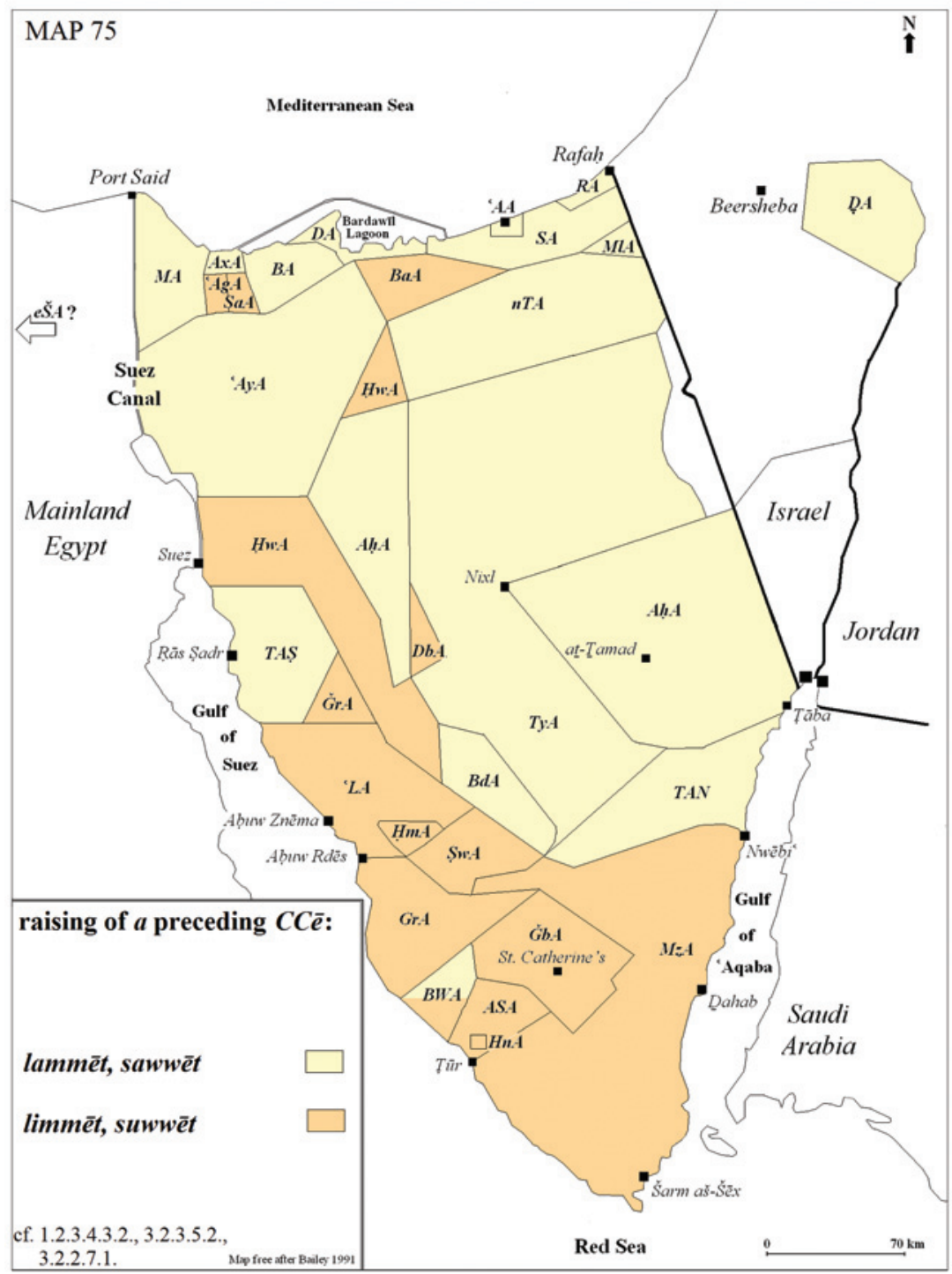

Map 75. Raising of $a$ preceding $C C \bar{e}$ 


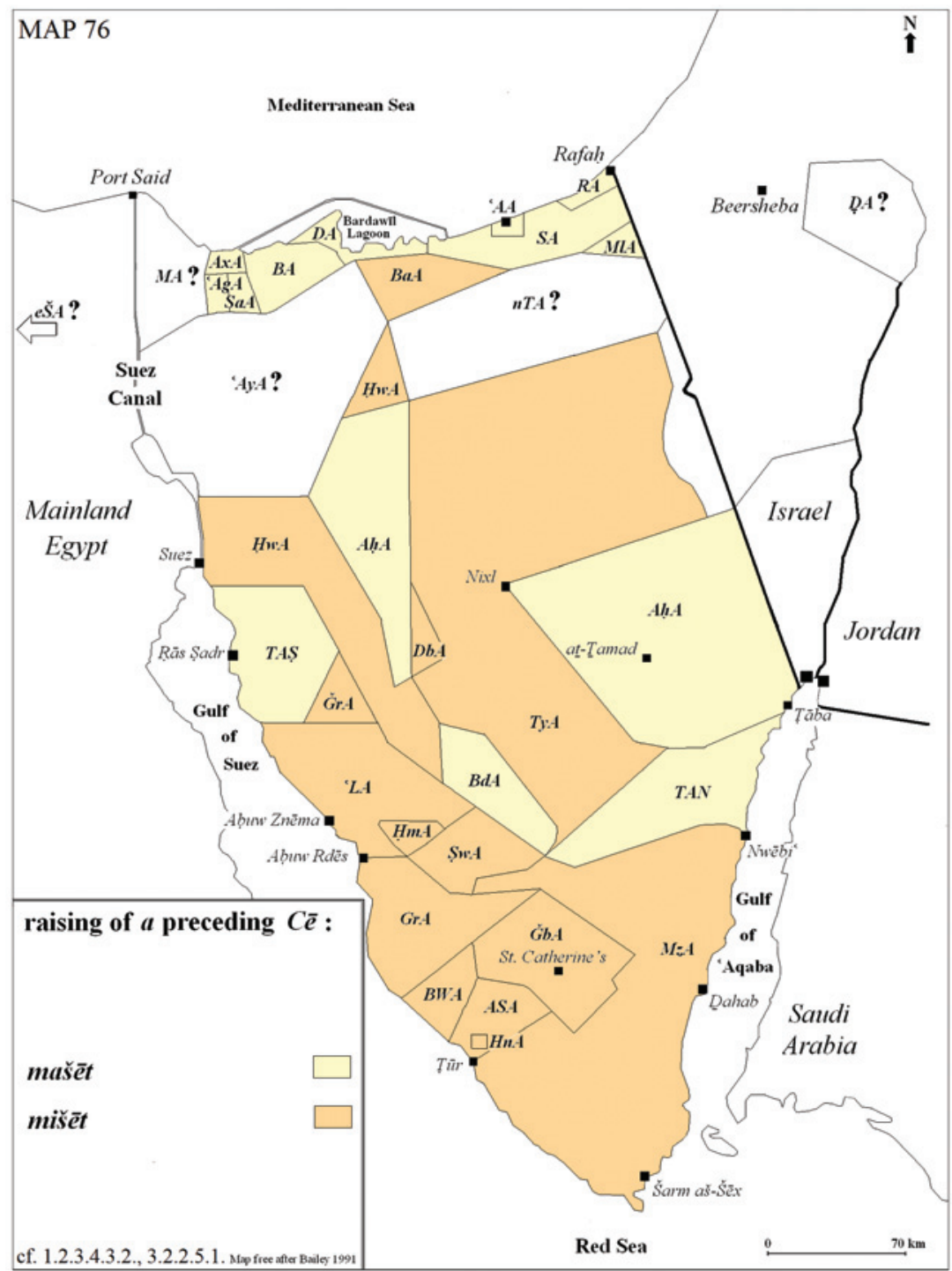

Map 76. Raising of $a$ preceding $C \bar{e}$ 


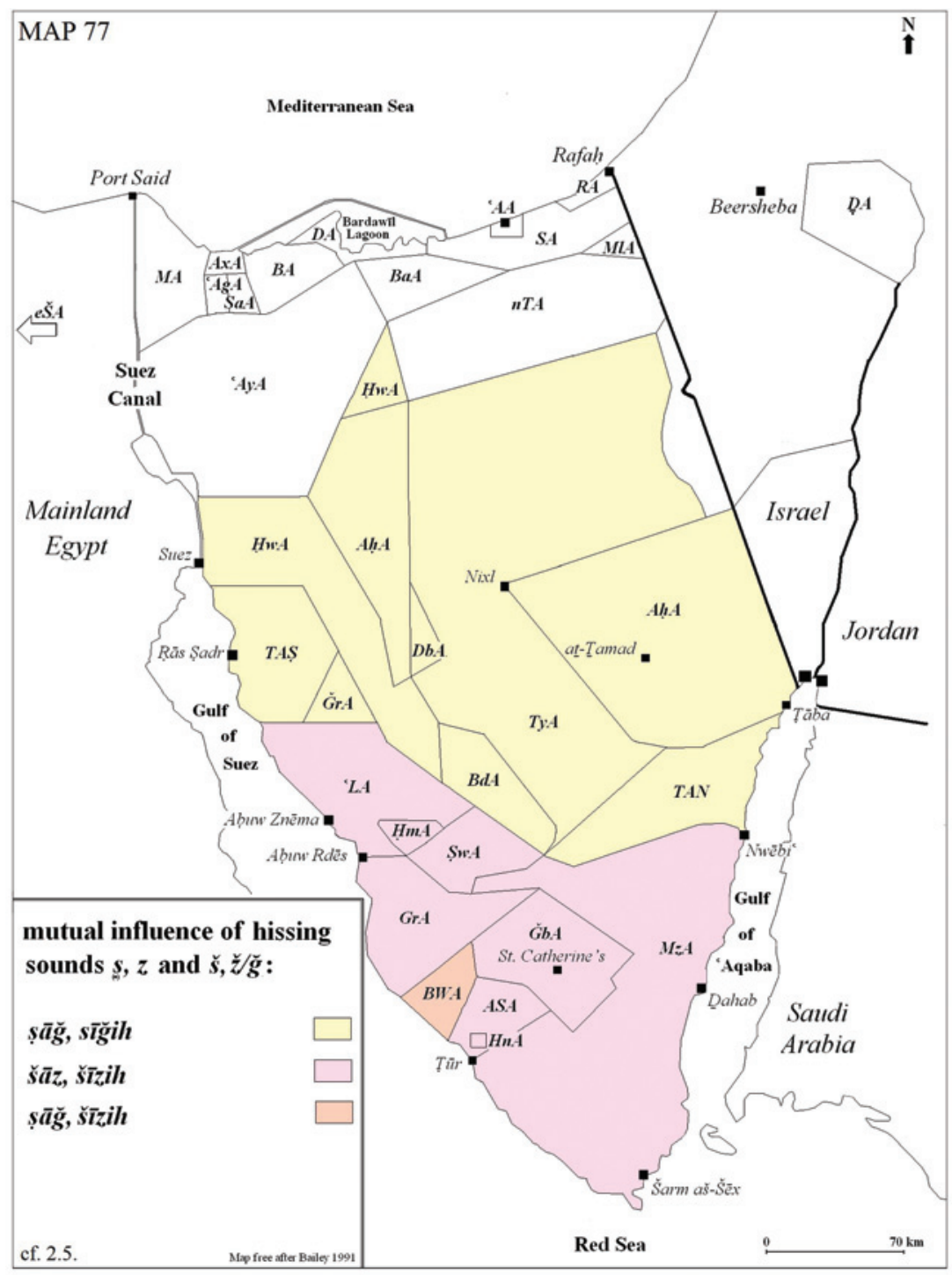

Map 77. Mutual influence of hissing sounds $s, z$ and $\check{s}, \check{z} / g ̆ g$ 


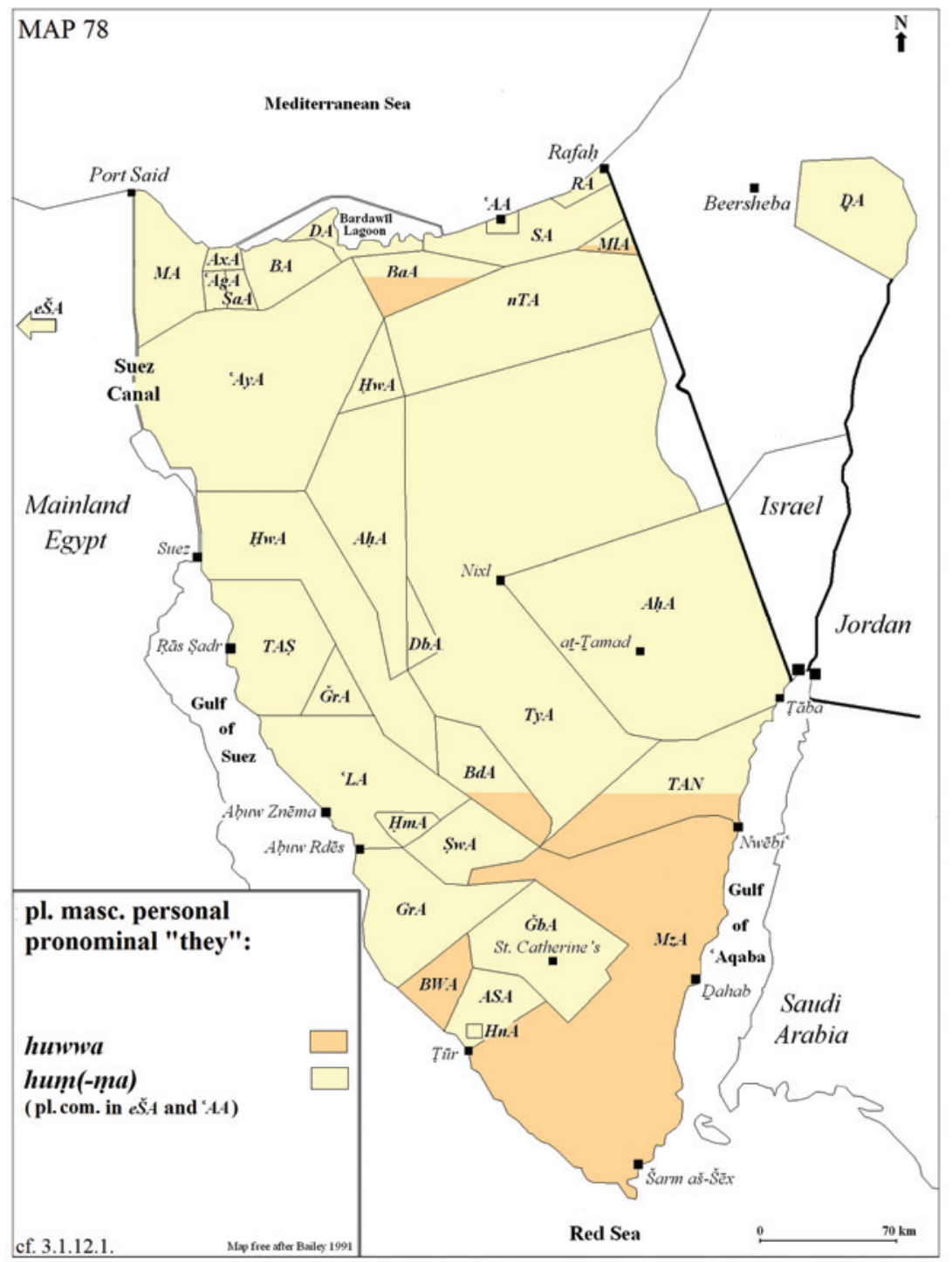

Map 78. The pl. masc. personal pronominal "they" 


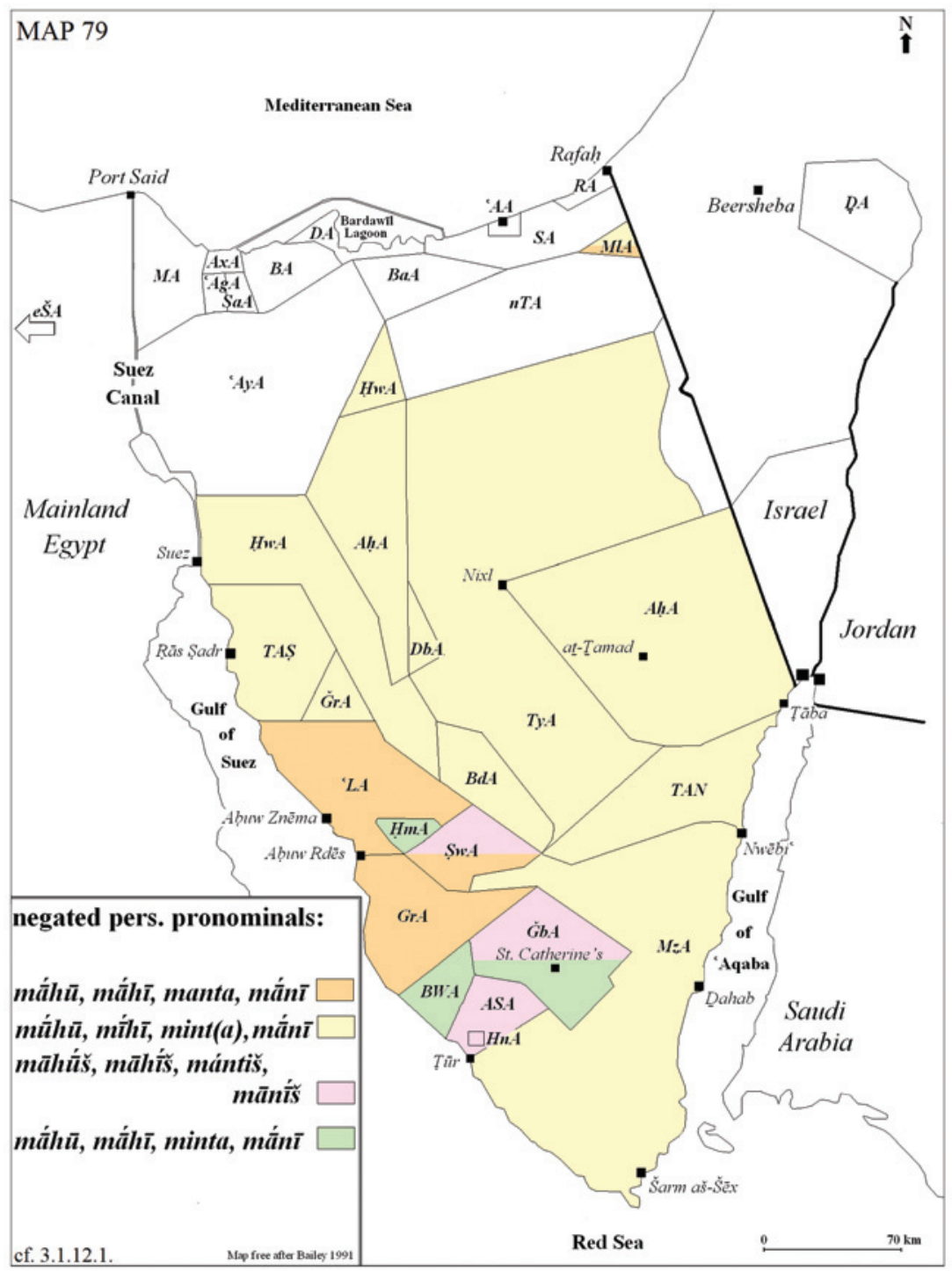

Map 79. Negated personal pronominals 


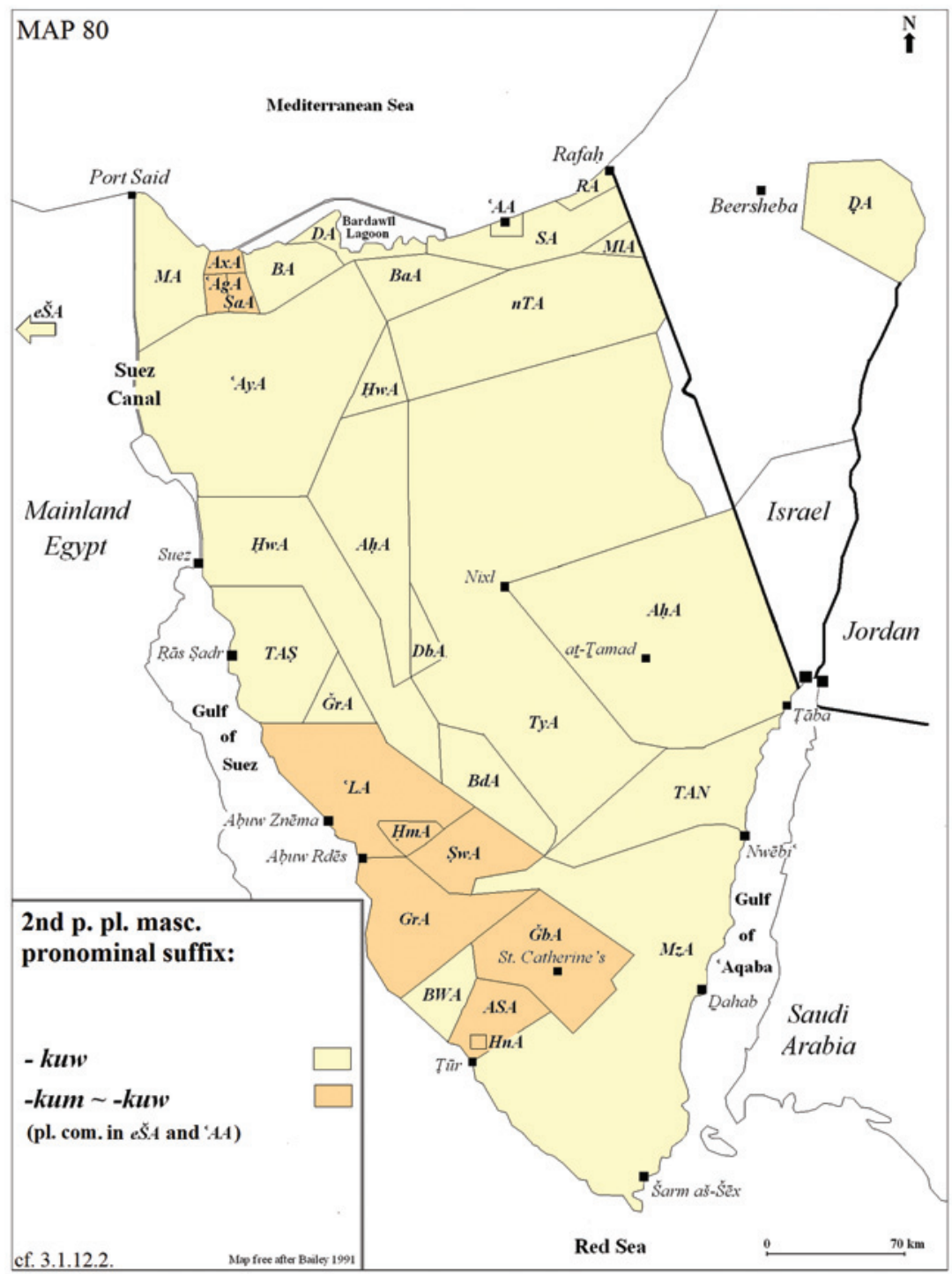

Map 80. 2nd p. pl. masc. pronominal suffix 


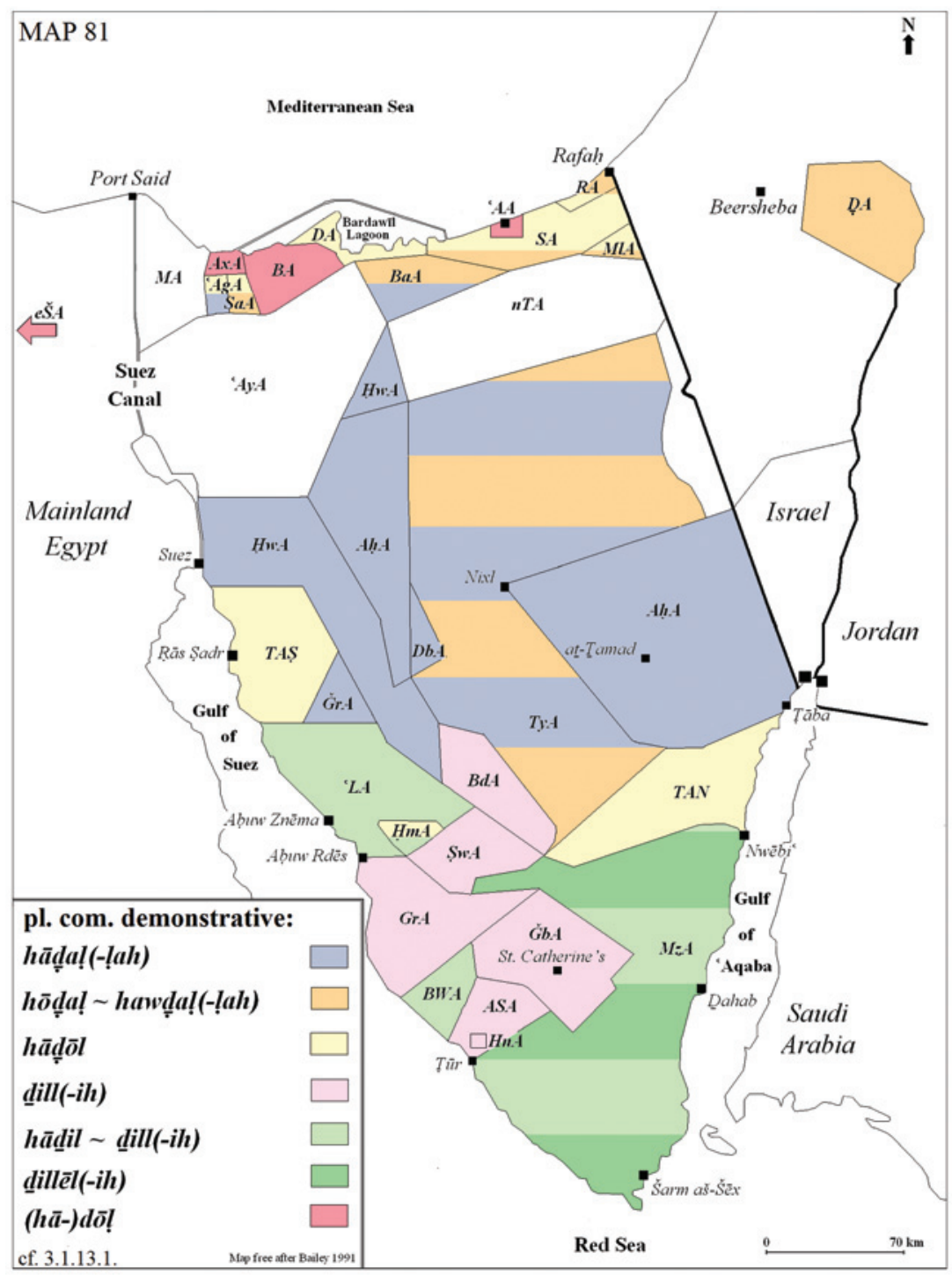

Map 81. Pl. com. demonstrative "these" 


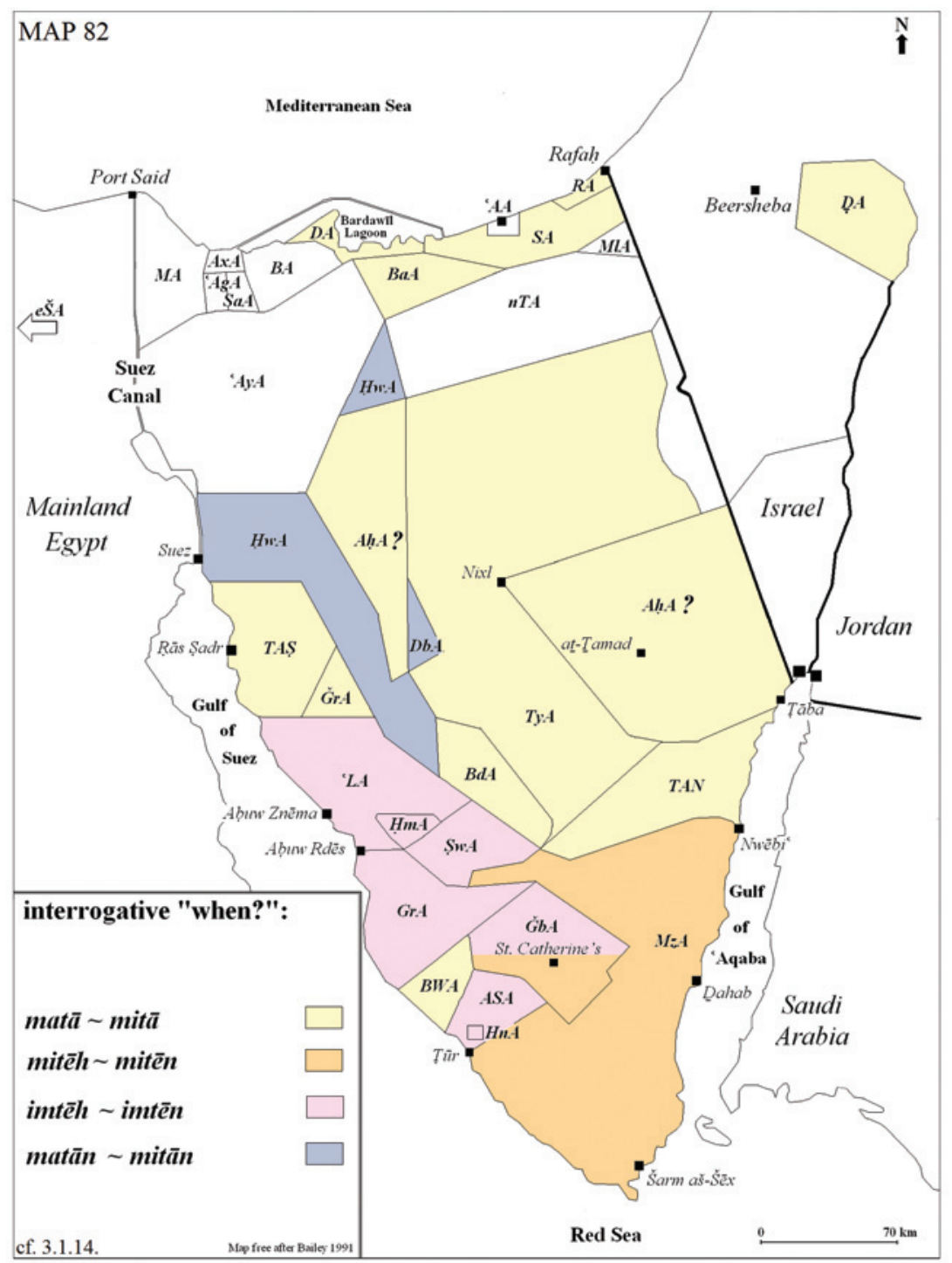

Map 82. Interrogative "when?" 


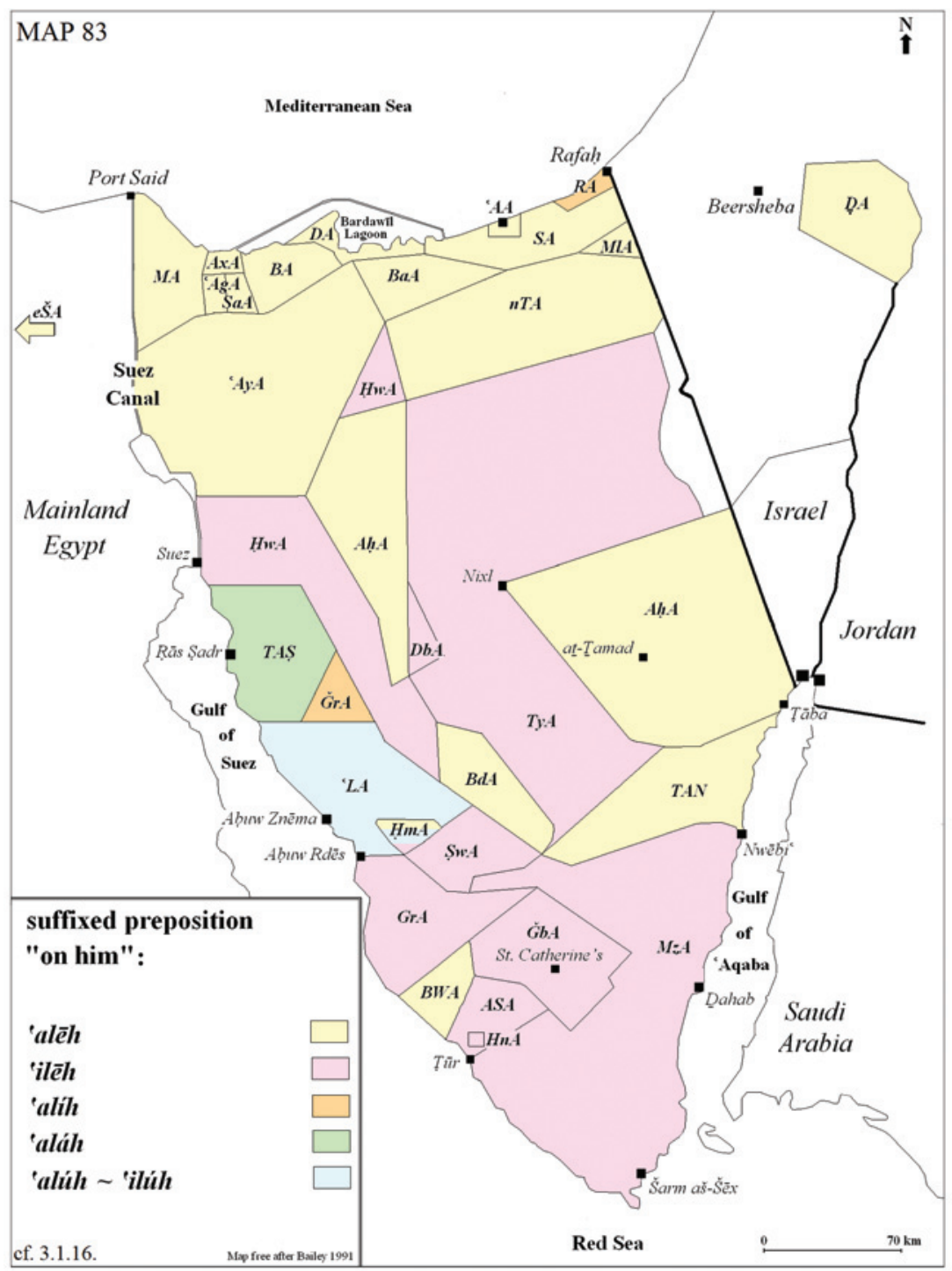

Map 83. Suffixed preposition "on him" 


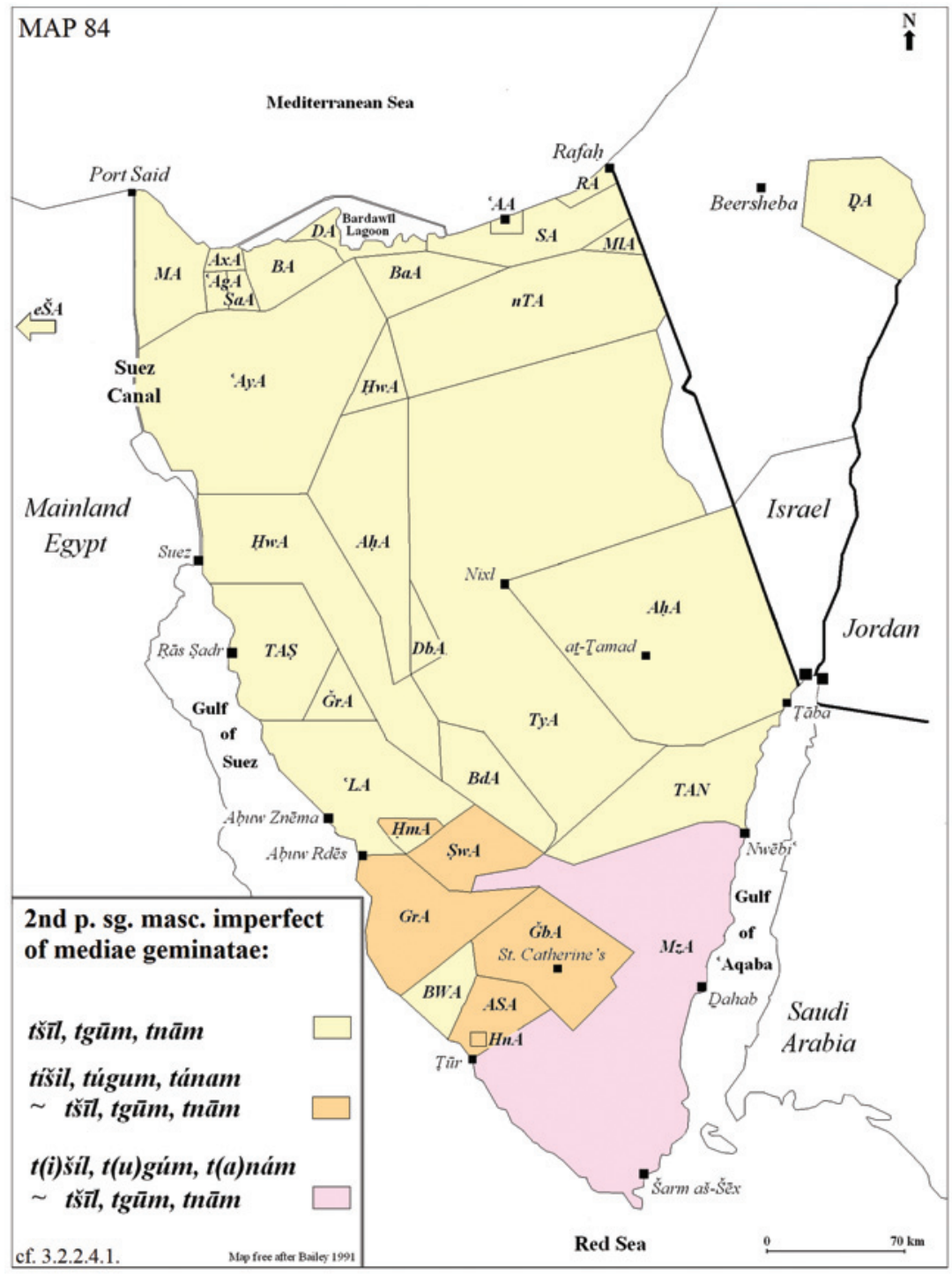

Map 84. 2nd p. sg. masc. imperfect of mediae geminatae 


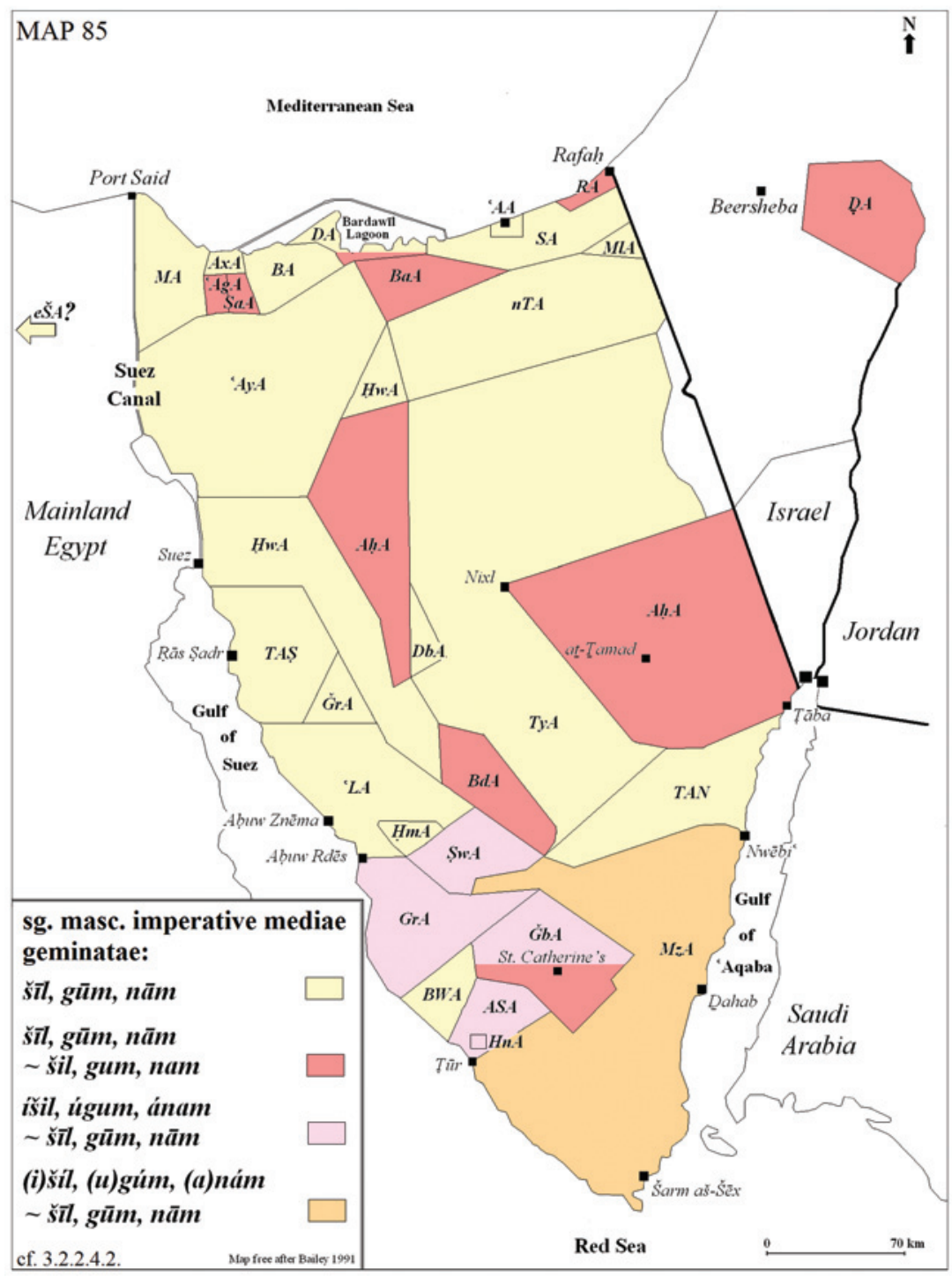

Map 85. Sg. masc. imperative of mediae geminatae verbs 


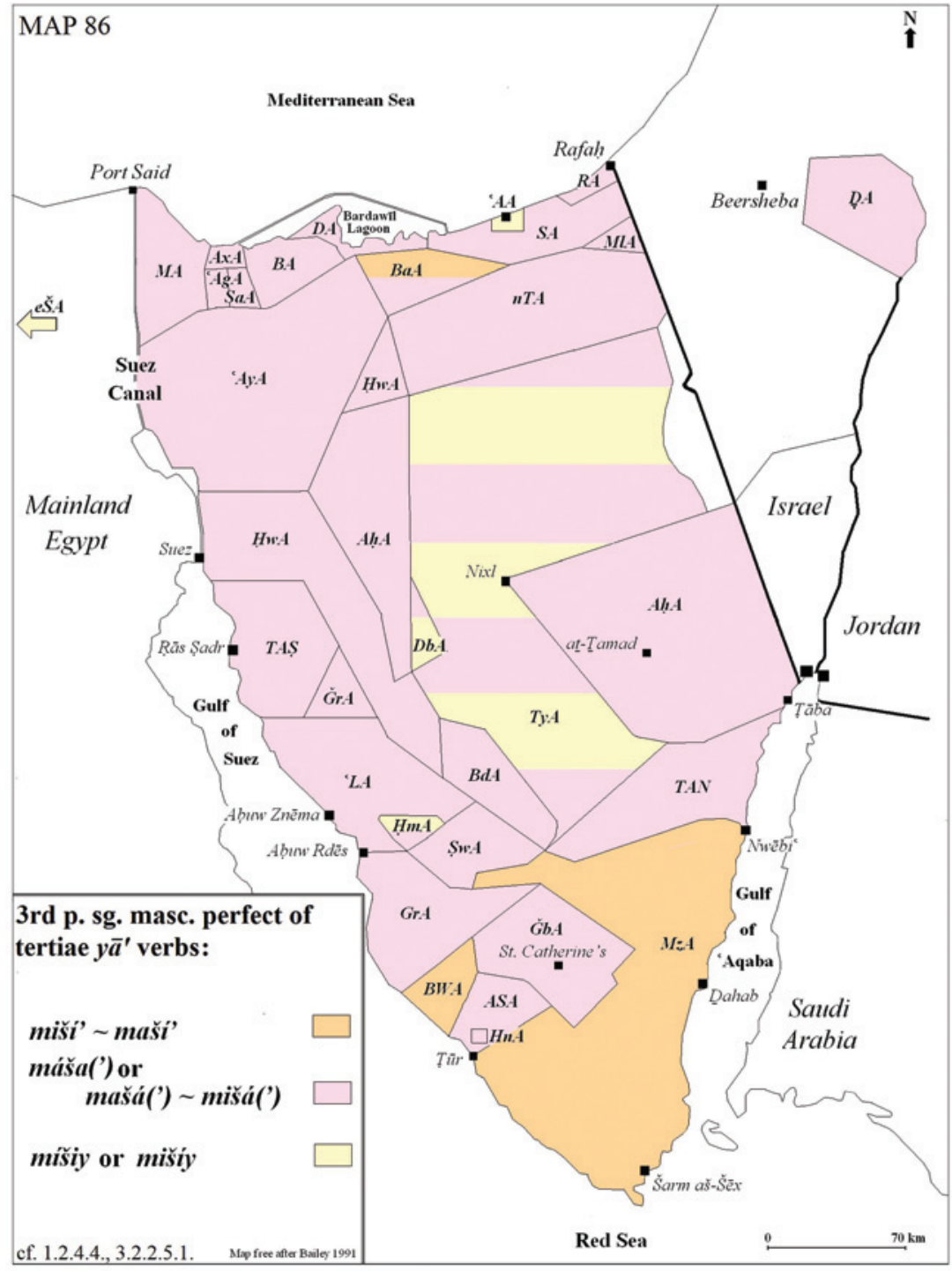

Map 86. 3rd p. sg. masc. perfect of tertiae $y \bar{a}^{3}$ verbs 


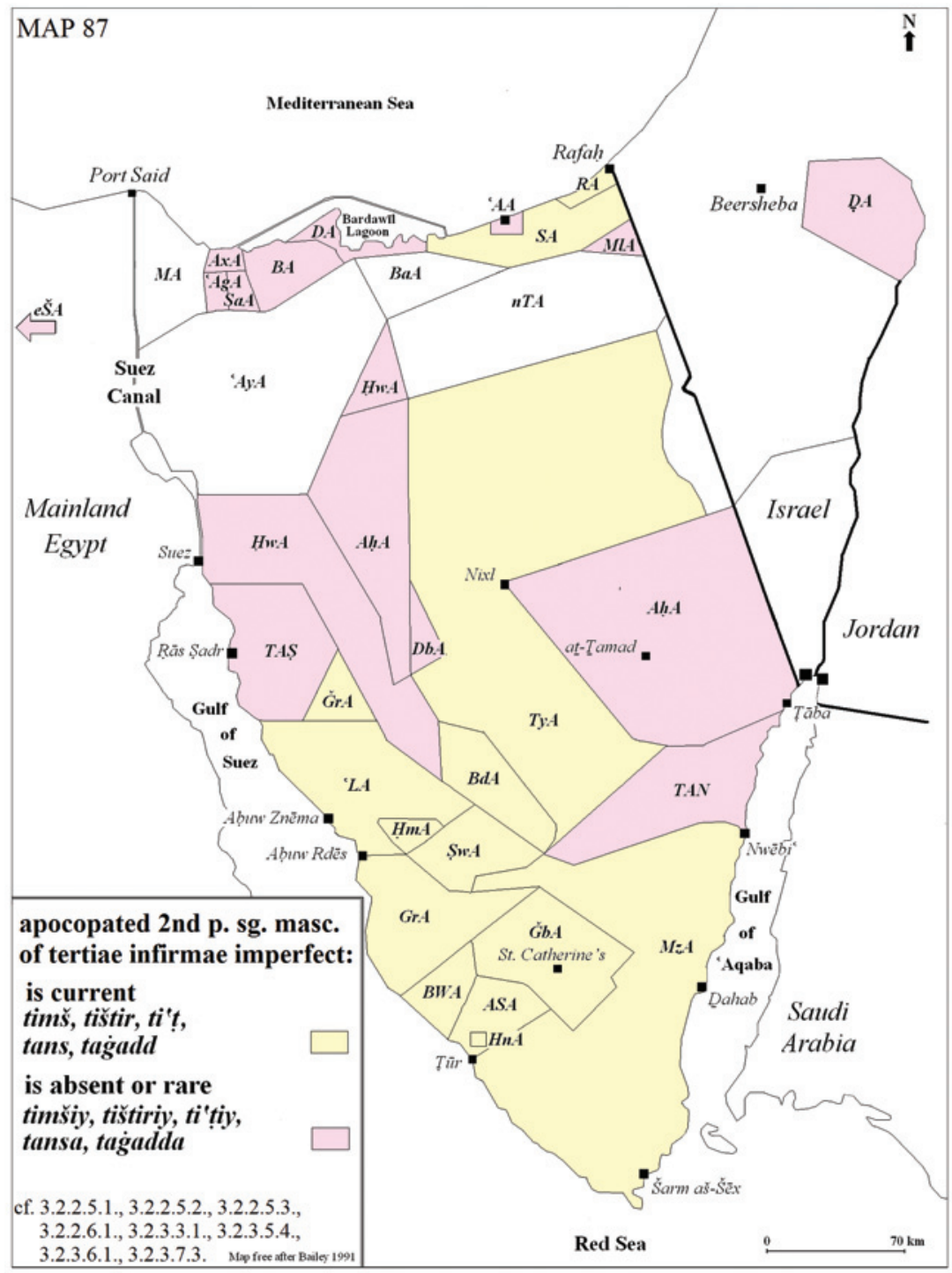

Map 87. The apocopated 2nd p. sg. masc. of tertiae infirmae imperfect 


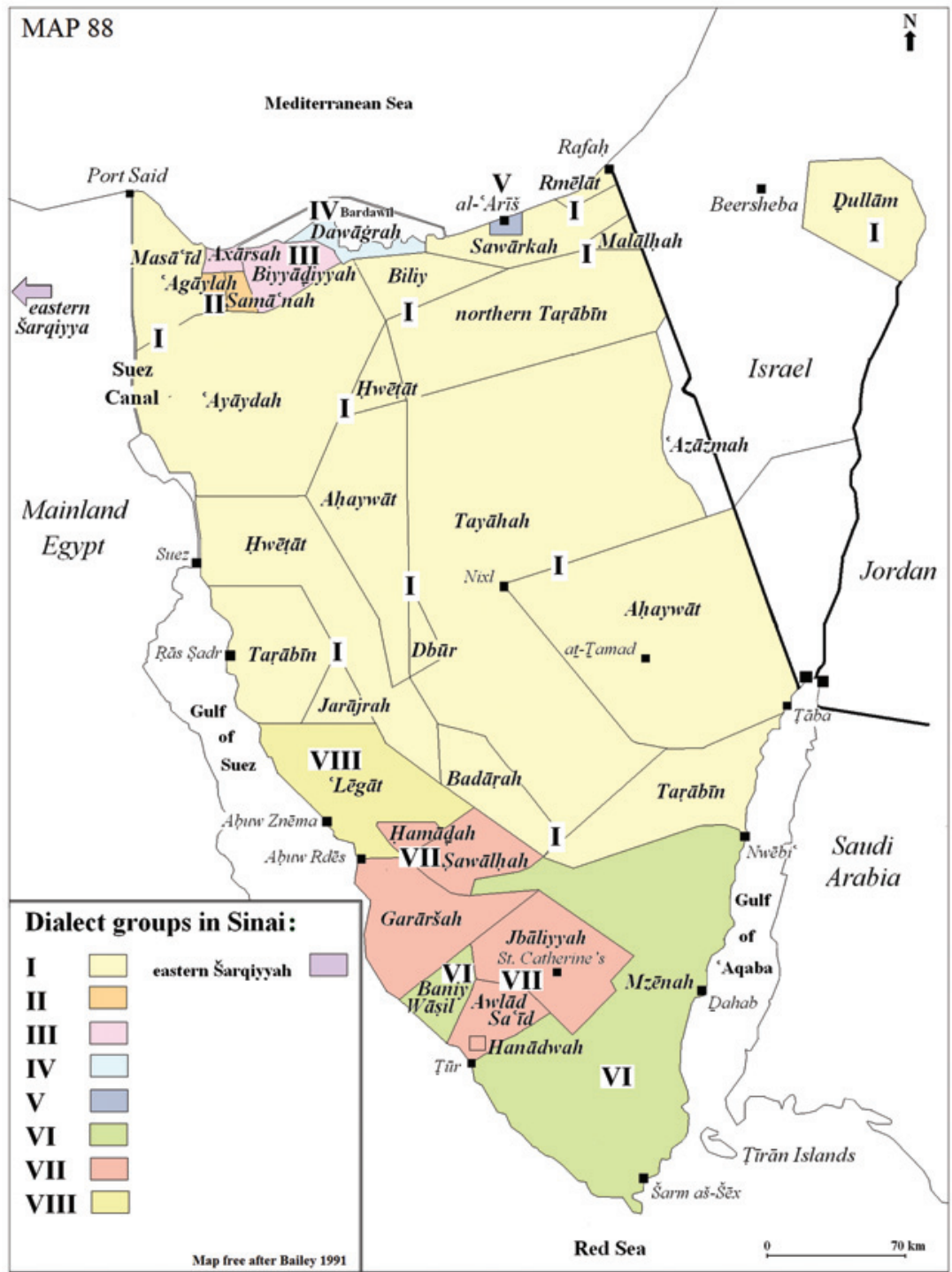

Map 88. Dialect groups in Sinai 